\title{
Contributory negligence: a historical and comparative study
}

Citation for published version (APA):

van Dongen, E. G. D. (2013). Contributory negligence: a historical and comparative study. [Doctoral Thesis, Maastricht University]. Universiteit Maastricht. https://doi.org/10.26481/dis.20130618ed

Document status and date:

Published: 01/01/2013

DOI:

10.26481/dis.20130618ed

Document Version:

Publisher's PDF, also known as Version of record

\section{Please check the document version of this publication:}

- A submitted manuscript is the version of the article upon submission and before peer-review. There can be important differences between the submitted version and the official published version of record.

People interested in the research are advised to contact the author for the final version of the publication, or visit the DOI to the publisher's website.

- The final author version and the galley proof are versions of the publication after peer review.

- The final published version features the final layout of the paper including the volume, issue and page numbers.

Link to publication

\footnotetext{
General rights rights.

- You may freely distribute the URL identifying the publication in the public portal. please follow below link for the End User Agreement:

www.umlib.nl/taverne-license

Take down policy

If you believe that this document breaches copyright please contact us at:

repository@maastrichtuniversity.nl

providing details and we will investigate your claim.
}

Copyright and moral rights for the publications made accessible in the public portal are retained by the authors and/or other copyright owners and it is a condition of accessing publications that users recognise and abide by the legal requirements associated with these

- Users may download and print one copy of any publication from the public portal for the purpose of private study or research.

- You may not further distribute the material or use it for any profit-making activity or commercial gain

If the publication is distributed under the terms of Article $25 \mathrm{fa}$ of the Dutch Copyright Act, indicated by the "Taverne" license above, 
Contributory Negligence 
Immagine di copertina:

Tratto dal documento: Ms. Torino BN, E.I.4, fo. 139v.

Collocazione documento: Biblioteca Nazionale Universitaria di Torino.

Gentilmente concesso dal Ministero per i Beni e le Attività Culturali.

Ogni riproduzione è vietata.

On the cover: Ms. Torino BN, E.I.4, fo. 139v.

Cover image rights Italian Ministry of Heritage and Culture, National University Library of Turin.

Reproduction of the cover image without permission of the library is prohibited.

(C) 2013 E.G.D. van Dongen

Cover design and lay-out by Canon Business Services.

Printed in the Netherlands by Canon Business Services.

This book is printed on cradle to cradle recycled paper.

A commercial edition of this dissertation is forthcoming.

All rights reserved. No part of this book may be reproduced or transmitted in any form or by any means, electronically or mechanically, including photocopying, recording by any information storage and retrieval system without permission from the author. 


\title{
Contributory Negligence \\ A Historical and Comparative Study
}

\author{
PROEFSCHRIFT
}

ter verkrijging van de graad van doctor aan de Universiteit Maastricht, op gezag van de Rector Magnificus, Prof. dr. L.L.G. Soete

volgens het besluit van het College van Decanen,

in het openbaar te verdedigen

op dinsdag 18 juni 2013 om 12.00 uur

door

Emanuel Gabriël Dominique van Dongen 
Promotores:

Prof. dr. C.H. van Rhee

Prof. dr. J. Hallebeek (Vrije Universiteit Amsterdam)

Beoordelingscommissie:

Prof. dr. A.M.J.A. Berkvens (voorzitter)

Prof. dr. N. Jansen (Westfälische Wilhelms-Universität Münster)

Prof. dr. R.C.H. Lesaffer (Universiteit van Tilburg)

Prof. dr. G.E. van Maanen

Prof. dr. J.M. Smits

Dit proefschrift is tot stand gekomen dankzij financiële steun van NWO. 




\section{CONTENTS}

Preface $\quad$...................................................................................... XIII

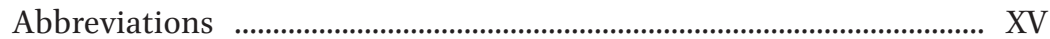

Chapter One Introduction .......................................................................... 1

$1.1 \quad$ The subject of this study ................................................................. 1

$1.2 \quad$ Methodology …………………………….......................................... 5

1.2.1 Central questions ............................................................... 5

1.2.2 Comparative legal history...................................................... 7

1.2.3 Definition of contributory negligence .................................. 7

1.2.4 Delineation of the study......................................................... 9

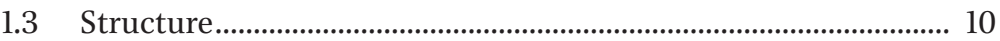

Chapter Two Roman Law in Antiquity ....................................................... 13

2.1 Introduction .............................................................................. 13

2.1.1 Subject and purpose of this chapter................................... 13

2.1.2 Structure and method ........................................................... 15

2.2 The origin of the regula of D. 50.17.203 ..................................... 16

2.2.1 The text of D. 50.17.203 ......................................................... 16

2.2.2 Translation of D. 50.17.203 ................................................ 18

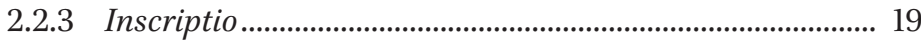

2.2.4 Exegesis according to (classical) Roman law .................... 21

2.3 Alfenus' reply in the case of the innkeeper ................................... 30

2.3.1 The text of D. 9.2.52.1 ...................................................... 30

2.3.2 Translation of D. 9.2.52.1 .............................................. 38

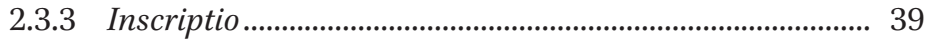

2.3.4 Exegesis according to (classical) Roman law................... 41

2.4 Ulpian's reply in the case of the javelin throwers ......................... 54

2.4.1 The text of D. 9.2.9.4 ....................................................... 54

2.4.2 Translation of D. 9.2.9.4 …................................................ 55

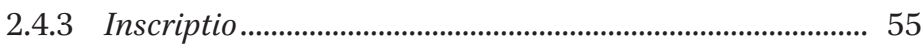

2.4.4 Exegesis according to classical Roman law ..................... 56

2.4.5 Post-classical development ................................................. 72 


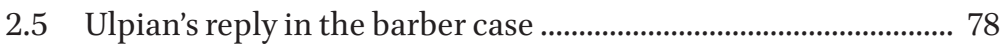

2.5.1 The text of D. 9.2.11pr. ........................................................... 78

2.5.2 Translation of D. 9.2.11pr.............................................. 80

2.5.3 Inscriptio ….......................................................................... 81

2.5.4 Exegesis according to classical Roman law ....................... 83

2.5.5 Post-classical development (Justinian law).................... 98

2.6 General treatment of all relevant cases in Justinian law............ 98

2.7 Concluding remarks ............................................................... 102

Chapter Three Medieval Ius Commune ..................................................... 105

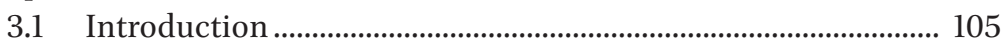

3.1.1 Subject and purpose of this chapter................................. 105

3.1.2 Structure and method ....................................................... 107

3.2 Medieval Roman legal scholarship ............................................. 109

3.2.1 Introduction ...................................................................... 109

3.2.2 Starting point 1: the doctrine of culpae compensatio ..... 111

3.2.2.1 The case of the javelin throwers.......................... 115

3.2.2.2 The case of the barber........................................ 123

3.2.2.3 The case of the shopkeeper.............................. 129

3.2.3 Starting point 2: the rule of D. 50.17.203 ...................... 139

3.2.4 Concluding remarks........................................................... 142

3.3 Canon law............................................................................. 146

3.3.1 Introduction ................................................................... 146

3.3.2 Negligence and causation in canon law........................... 147

3.3.3 Accidental homicide: early canonists ............................. 153

3.3.4 Accidental homicide: two cases from the Liber Extra... 156

3.3.4.1 The case of X 5.12.8 ............................................. 156

3.3.4.2 The case of X 5.12.9 ............................................. 163

3.3.5 Contributory negligence according to the law

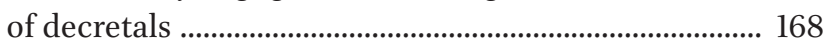

3.3.5.1 The case of X 5.16.6 ................................................ 168

3.3.5.2 Culpae compensatio ............................................ 173

3.3.6 The maxim of VI 5.12.86 ................................................. 175

3.4 Short comparative remarks........................................................... 177

3.4.1 Structure and purpose...................................................... 177

3.4.2 Byzantine law .............................................................. 178

3.4.3 Indigenous law ............................................................ 179

3.4.3.1 Examples following the all-or-nothing approach ........................................................... 179

3.4.3.2 Examples including a partition of damages.... 182

3.5 Concluding remarks ................................................................ 183 
Chapter Four Early Modern Period ........................................................ 189

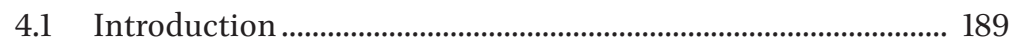

4.1.1 Subject and purpose of this chapter................................ 189

4.1.2 Method and structure ........................................................ 191

4.2 Legal humanism ...................................................................... 192

4.2.1 Introduction to the mos gallicus and mos italicus.......... 192

4.2.2 Humanistic thoughts based on the rule of D. 50.17.203.. 195

4.2.2.1 The origin of D. 50.1 7.203 _............................... 196

4.2.2.2 According to the humanists, did D. 50.17.203 really concern contributory negligence in classical Roman law? .......................................... 199

4.2.2.3 Examples of the application of D. 50.17.203 ..... 200

4.2.2.4 Preliminary conclusion..................................... 203

4.2.3 New insights as regards D. 9.2.52.1 ............................... 204

4.2.3.1 The case of D. 9.2.52.1 as an example of self-defence ..................................................... 204

4.2.3.2 The connection with D. 50.17.203.................. 205

4.2.3.3 Compensation of unlawful acts ..................... 206

4.2.4 New insights as regards the case of the javelin throwers...................................................................... 207

4.2.4.1 The link between D. 9.2.9.4 and D. 9.2.10 ...... 207

4.2.4.2 Solving D. 9.2.9.4 with a new criterion: (in) iustum?......................................................... 210

4.2.4.3 A case from practice: application of a iudicatio scheme................................................ 211

4.2.4.4 Contributory negligence as avoidability .......... 211

4.2.4.5 Faber's criterion of gravior culpa ...................... 212

4.2.4.6 Conclusion on the humanistic contribution to the development of the theory based on D. 9.2.9.4 ......................................................... 214

4.2.5 New insights as regards the case of the barber............... 214

4.2.5.1 A new approach to the actors in D. 9.2.11pr. .... 214

4.2.5.2 Application of the medieval doctrine of culpae compensatio? ......................................... 216

4.2.5.3 Influence of the mos italicus in the thinking of Suarez de Mendoza .............................................. 216

4.2.5.4 Application of the maior culpa doctrine to D. 9.2.11pr.? ...................................................... 217

4.2.5.5 Some concluding words on the theories developed by humanists based on D. 9.2.11pr..... 221 
4.3 A general introduction to the period of the Reception of Roman law ........................................................................ 222

4.3.1 Reception of the lex Aquilia.............................................. 222

4.3.2 Requirements for a succesful claim for damages.......... 224

4.3.3 Different types of damage.............................................. 226

4.4 Roman-Dutch law.................................................................. 227

4.4.1 Introduction ....................................................................... 227

4.4.2 Liability based on the lex Aquilia ................................... 228

4.4.2.1 New starting points for the theory of culpa maior ........................................................... 231

4.4.2.2 Criminal law...................................................... 233

4.4.2.3 Preliminary conclusion....................................... 240

4.4.3 Maritime collisions ........................................................... 241

4.4.3.1 Introduction to the topic ..................................... 241

4.4.3.2 Collision cases described by Grotius................ 242

4.4.3.3 Cases in which one ship was to blame............ 244

4.4.3.4 Accidental collision damage.............................. 245

4.4.3.5 Collision damage caused by the fault of both parties ......................................................... 250

4.4.3.6 Preliminary conclusion on collision cases..... 254

4.5 Usus modernus pandectarum..................................................... 255

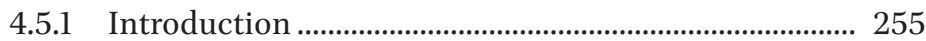

4.5.2 Usus modernus in Germany........................................... 258

4.5.2.1 Introduction..................................................... 258

4.5.2.2 Contributory negligence in theory and in practice: a problem of causality ....................... 260

4.5.2.3 Contributory negligence in theory and in practice: a problem of negligence ..................... 261

4.5.2.4 Solving cases of contributory negligence without replying upon the contributory negligence of the injured party ......................... 273

4.5.2.5 The criterion of the auctor rixae as an alternative way to solve the problem of contributory negligence ................................... 274

4.5.3 'Giurisprudenza pratica' in Italy ........................................ 281

4.6 The northern natural law school ................................................ 285

4.6.1 Introduction ..................................................................... 285

4.6.2 Scholars who followed the old approach....................... 286

4.6.2.1 Variant 1: the existence of contributory negligence leads to a denial of claim 
4.6.2.2 Variant 2: applying the doctrine of maior culpa

4.6.3 A new approach: Christian Wolff .................................... 295

4.7 Concluding remarks .................................................................... 298

4.7.1 The humanistic contribution.......................................... 298

4.7.2 Reception and usus modernus .......................................... 299

4.7.3 Collision cases................................................................. 301

4.7.4 Natural law/rationalism ............................................ 302

Chapter Five Modern and Contemporary Law .................................... 303

5.1 Introduction: content, method and structure............................ 303

5.2 Codifications around 1800 ........................................................ 308

5.3 Conservatism in nineteenth-century legal doctrine and the struggle of nineteenth-century judges .................................. 312

5.3.1 French exegetical school: faute de la victime .................. 312

5.3.1.1 Introduction ......................................................... 312

5.3.1.2 Faute commune ..................................................... 313

5.3.2 The revival of Roman law in nineteenth-century

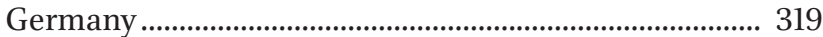

5.3.3 The situation in the Netherlands until 1916 .................. 324

5.4 Codifications around 1900 ........................................................... 331

5.4.1 The German drafts for codification ................................. 331

5.4.2 The solution of the German Bürgerliche Gesetzbuch (1900) 333

5.5 Modern contemporary solutions to the problem of contributory negligence.

5.5.1 The Netherlands .............................................................. 339

5.5.1.1 New directions in dutch case law and literature...................................................... 339

5.5.1.2 Recent codification: The Dutch Burgerlijk Wetboek of 1992..................................................... 343

5.5.2 France......................................................................... 348

5.5.2.1 Contemporary solution in France ..................... 348

5.5.2.2 Contributory negligence in the context of liability without fault ......................................... 351

5.6 Traffic accidents: rise and fall of the all-or-nothing approach?.................................................................................... 353

5.6.1 Traffic accidents: France ................................................ 353

5.6.2 Traffic accidents: Germany ............................................ 355 
5.6.3 Traffic accidents: The Netherlands ................................ 356

5.7 Contributory negligence after the damaging event ................. 358

5.8 Harmonisation: rules for the future? ........................................... 362

5.9 Concluding remarks ........................................................................ 367

5.9.1 The concept of contributory negligence in the nineteenth century........................................................... 367

5.9.2 The concept of contributory negligence in codes and in contemporary law ....................................................... 369

5.9.3 Contributory negligence after the damaging event ..... 372

Chapter Six Summary and Concluding Remarks ................................. 373

6.1 Introduction ............................................................................ 373

6.2 Roman law in Antiquity .............................................................. 374

6.3. Medieval ius commune .............................................................. 376

6.3.1 Medieval Roman legal scholarship ............................... 376

6.3.2 Medieval canon law .................................................... 377

6.3.3 Some final words on medieval ius commune.................. 378

6.4 The humanistic contribution......................................................... 379

6.5 Reception, Roman-Dutch law and usus modernus.................... 379

6.6 The northern natural law school ..................................................... 381

6.7 The concept of contributory negligence in the nineteenth century ................................................................... 382

6.8 The concept of contributory negligence in modern and contemporary law ...................................................................... 384

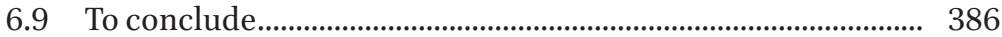

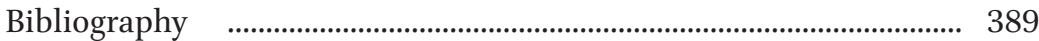

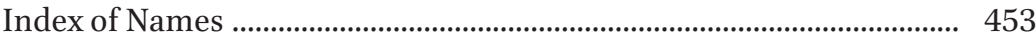

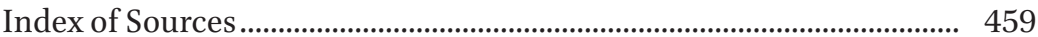

Index of Cases .................................................................................................... 473

Samenvatting en conclusies ........................................................................ 477

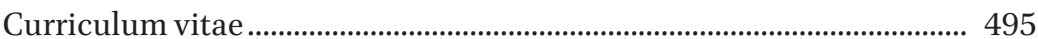


PREFACE

Now that my PhD thesis is finished, I wish to express my gratitude to several people who made this all possible. First and foremost to Prof. Paul Nève for recommending me to my later supervisor, Prof. Remco van Rhee. I am also grateful to the Faculty of Law of Maastricht University for making it possible to carry out this research. A word of thanks must be addressed to the Netherlands Organisation for Scientific Research (NWO) too, without whose financial support this project would not have been possible.

I owe my greatest debt and gratitude to my academic supervisors, Prof. Jan Hallebeek, VU University Amsterdam, and Prof. Remco van Rhee, Maastricht University. Their experience and detailed criticism have proved invaluable in writing this thesis. In addition to their good guidance, I also want to thank them for their hospitality and the pleasant meetings we had.

I wish to thank Dr. Olga Tellegen-Couperus for introducing me to the fields of Roman law and rhetoric during the final phase of my study of Dutch law at Tilburg University. I would like to thank Prof. Chris Coppens as well, who taught me history of canon law and introduced me to the study of medieval canon law manuscripts, and Prof. Randall Lesaffer, who guided me during my time as a student at the Research Master in Tilburg. I would like to thank all who helped me write the PhD proposal prior to this study and not least Prof. Hans Ankum who, from the start, shared his thoughts with me on this topic.

I would like to thank the members of my Assessment Committee, namely, Prof. Louis Bervens, Prof. Nils Jansen, Prof. Randall Lesaffer, Prof. Gerrit van Maanen, Prof. Jan Smits, for reading and commenting upon my thesis. I am also grateful for the diligent work of Randolph W. Davidson, lecturer in legal English in the Department of Law at the University of Pavia (Italy), in thoroughly revising the English language text of the manuscript. Furthermore, I would like to thank the Max Planck Institute for European Legal History (Frankfurt am Main) for giving me the opportunity to work in the institute and for awarding me a scholarship.

Thanks also to my (ex-)colleagues and friends at the Faculty of Law of Maastricht University with whom I really enjoyed working over the last years; the conversations and contact made the start of my job as well as the following years at the Faculty very pleasant. Furthermore, thank you Dr. Mariken Lenaerts 
and Jennifer Sellin, LLM, both for being my paranymphs as well as for being pleasant colleagues to share an office with. Although I cannot thank all of my colleagues who contributed to my $\mathrm{PhD}$ thesis, in particular I would like to mention the following: Prof. Hans Ankum for his detailed comments on chapter two of this thesis; Marie-Louise Schonewille, MSc, MA, Leo Nellissen, MA and Dr. Fokke Fernhout for helping me with various problems in ancient Latin and/ or Greek; Prof. Bernard Stolte and Dr. Hylkje de Jong for commenting upon and helping with the parts on Byzantine law; and Mieke de Leeuw, LLM, Josine Polak, MA and Gideon Bodden for reading and commenting upon parts of my thesis.

Finally, the last but not least person to be mentioned is Tamara. Her patience and support have proven to be of invaluable worth for me. She has witnessed the process of writing this $\mathrm{PhD}$ thesis from the start and always had faith that it would be okay in the end. Finally, I want to dedicate this work to Aldo, my father, who unfortunately could experience neither the beginning nor the end of my work on this thesis. I dedicate this work to his memory.

This thesis was completed on 20 February 2013; after this date only incidental changes were included. 


\section{ABBREVIATIONS}

1 Comp. Compilatio prima (Breviarium extravagantium)

3 Comp. Compilatio tertia

4 Comp. Compilatio quarta

5 Comp. Compilatio quinta

AA

aant.

(Juridisch studentenblad) Ars Aequi

Abt.

ABGB

ABL

Abs.

$\mathrm{AD}$

aantekening, note

Abteilung

Allgemeines bürgerliches Gesetzbuch (1811)

Collection Willem Matthias d'Ablaing (1851-1889)

ADB

al.

Absatz, paragraph

Anno Domini

Allgemeine Deutsche Biographie

ALR

paragraph

Am.J.Juris.

Allgemeines Landrecht für die preußischen Staaten (1794)

anast.

American Journal of Jurisprudence

Anm.

ANRW

Anastatic <reprint $>$

Anmerkung

Aufstieg und Niedergang der römischen Welt: Geschichte und Kultur derneueren Forschung

A-Rb.

Arrondissements-Rechtbank

$\operatorname{Art}(\mathrm{s}) \cdot / \operatorname{art}(\mathrm{s})$.

Article(s)

AtomG

auth.

Atomgesetz (German Atomic Energy Act)

authentica

AV\&S

Aansprakelijkheid, Verzekering en Schade

B.

Basilica

BC

Before Christ

Bd./Bde.

Band/Bände

Bed.

Bedenken

BIDR

Bulletino dell'Istituto di diritto romano

BS

Basilicorum libri LX, ed. Scheltema, Holwerda \& Van derWal, Groningen 1953, Series B (Scholia) 
BT

BGB

$\mathrm{BGH}$

$B G H Z$

Bull. Civ. II

BW (NBW)

c.

C. q. c.

C

C.

C-

$c a$.

cap.

CA

Cass.

Cass. ch. réun.

Cass. civ.

Cass. req.

Cass civ. 2e.

CC

CCC

col.

coll.

coll.

Coll.

controv.

cent.

$c f$.

$\mathrm{cm}$.

CMBC

co

cons.

Cons. Tub.

const.

$\mathrm{CPO}$

Crim.
Basilicorum libri LX, ed. Scheltema, Holwerda \& Van der Wal, Groningen 1953, Series A (Textus)

Bürgerliches Gesetzbuch (German Civil Code, 1900)

Bundesgerichtshof

Entscheidungen des Bundesgerichtshofes in Zivilsachen

Bulletin des arrêts de la Cour de cassation, 2ème Chambre civile

Burgerlijk Wetboek (new Dutch Civil Code)

canon/circa

Causa, quaestio, canon (second part of the Decretum

Gratiani)

Cour

Codex (534)

Case

circa

capitulum/caput

Cour d'appel

Cour de cassation

Cour de cassation (chambres réunies).

Cour de cassation, chambre civile

Cour de cassation, chambre des requêtes

Second civil chamber of the Cour de cassation

Code civil (1804)

Constitutio Criminalis Carolina (1532)

column

collatio

collected

Collatio legum Mosaicarum et Romanarum

controversia

century

compare

centimetre

Codex Maximilianeus Bavaricus Civilis (1756)

conclusio

consilium

Consilia Tubingensium

constitutio

Civilprozeßordnung (1879, since 1900: ZPO)

Chambre criminelle de la Cour de cassation 
D.

D. c.

D.

d.d.

DCFR

dec.

def.

dict.

disc.

disp.

diss.

D.P.

dub.

ECR

edn.

eds.

EEC

e.g.

etc.

et al.

esp.

ext.

f./ff.

fo.

FIRA
Digest (533)

Distinctio, canon (first part of the Decretum Gratiani)

RecueilDalloz

de dato

Draft Common Frame of Reference

decisio

definitio

dictum/dicta

discursus

disputatio

dissertation

Recueil Dalloz périodique

dubitatio

European Court Reports

edition

editors

European Economic Community

exempligratia, for example

et cetera

et alii, and others

especially

externus, foreign

and the following (page(s), paragraph(s), etc.)

folium

Fontes Iuris Romani Antejustiniani I-III, ed. Riccobono et al., Florence 1940-1943.

Gai.

Gaius

Gai. Inst.

Gh.

$G P B$

HR

i.a.

Iavol.

ibid.

i.c.

i.e.
Gaius, Institutiones

Gerechtshof

Groot-Placaet Boek

Hoge Raad (High Court, NL)

inter alia, among other things

Iavolenus

ibidem, in the same place

in casu, in this case

id est, that is to say 
in fin. in fine

Inst. $\quad$ Institutes (533)

IR. Informations Rapides

IURA Rivista internazionale di diritto romano e antico

Jurisclasseur périodique

$J d P$ Journal du Palais: Recueil le plus ancien et le plus complet de la jurisprudence française

jo. juncto, in conjunction with

JuS Juristische Schulung

JW Juristische Wochenschrift

Juristenzeitung

Ktg.

Kantongerecht

$K P$

Der Kleine Pauly

Law Libr. J.

Law Library Journal

LCL

Loeb Classical Library

lib., Liv.

liber/livre, book

loc.

locus

$L Q R$

The Law Quarterly Review

LuftVG

Luftverkehrsgesetz (German Air Traffic Act)

Med.

Meditatio

$\mathrm{MGH}$

Monumenta Germaniae Historica

m.m.v. met medewerking van, with the cooperation of

MRW

Motor-en Rijwielwet (Dutch MotorVehicles and Cyclists Act)

Ms. manuscript

Mss.* manuscripts

MünchKommentar Münchener Kommentarzum Bürgerlichen Gesetzbuch $M v A$ II Memorie van Antwoord (Memorandum of reply, NL) Tweede Kamer

n.

NBW

$N D B$

NJ

NJW

Nov.

$\operatorname{nr}(\mathrm{s})$. footnote Nieuw Burgerlijk Wetboek (New Dutch Civil Code) Neue Deutsche Biographie Nederlandse Jurisprudentie Neue Juristische Wochenschrift Novellae number(s) 


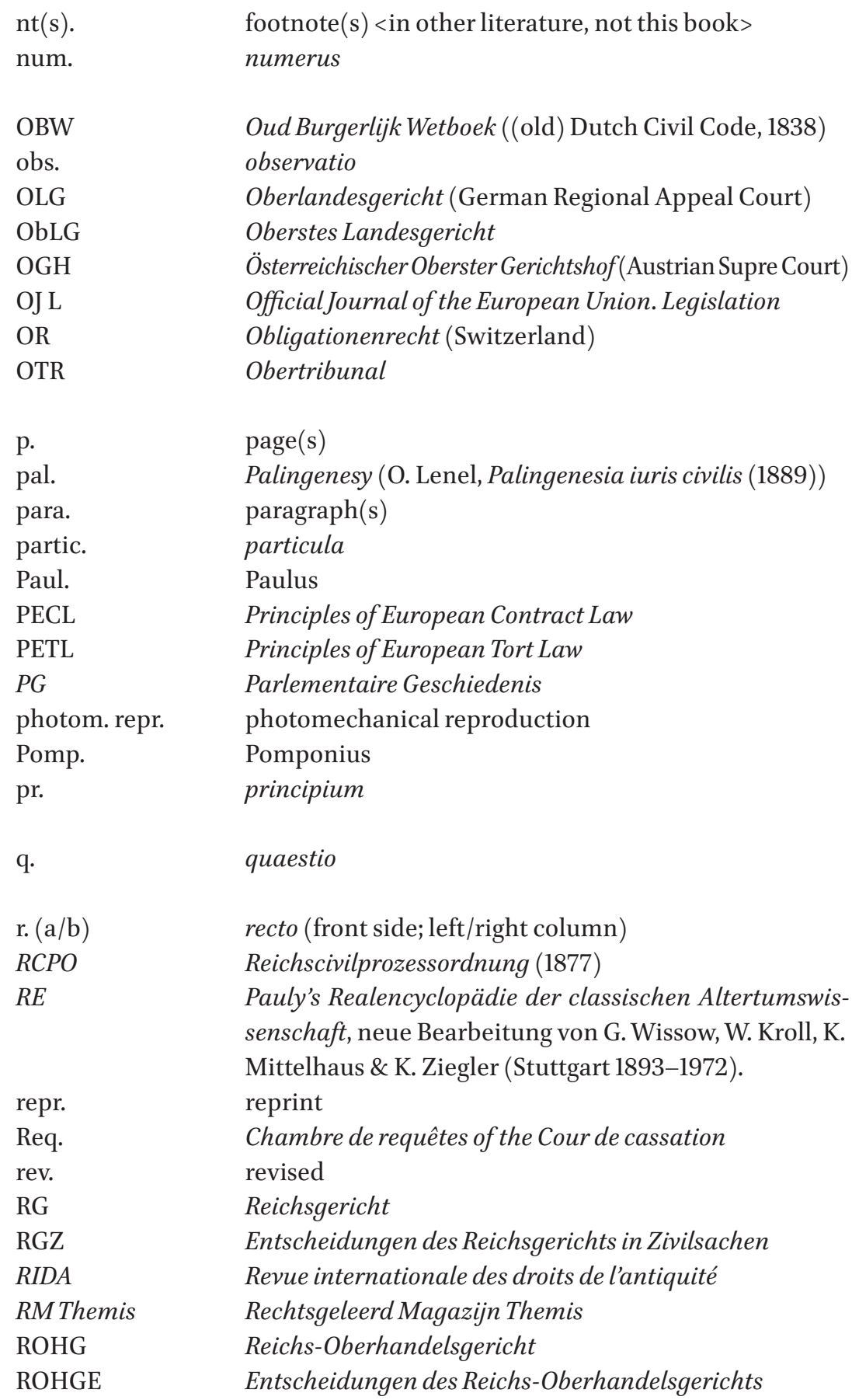


RSFSR

RTD Civ.

Rv

$R v d W$

R.W.

S.

sc.

Schw. (OR)

$S D H I$

sect.

SeuffA

Spec.

St.

StVG

s.v.

Tetr.

Th.

tit.

tom.

TPR

tract.

transl.

TvR

Ulp.

UNIDROIT PICC USSR

v. $(a / b)$

vers./uers.

VI

VIR

viz.

$\operatorname{vol}(\mathrm{s})$.

Vrb

vs.
Russian Soviet Federative Socialist Republic

Revue trimestrielle de droit civil

Wetboekvan Burgerlijke Rechtsvordering

Rechtspraakvan de Week

Rechtskundig Weekblad

Recueil Sirey

scilicet

Schweizerisches $<$ Obligationenrecht $>$

Studia et Documenta Historiae et Iuris

sectio, section

J.A. Seuffert, Archiv für Entscheidungen der obersten Gerichte specimen

Saint

Straßenverkehrsgesetz (German Road Traffic Act)

sub voce; below the word

Tetralogy

Theil

titulus

tomus

Tijdschrift voor Privaatrecht

tractatus

translation

Tijdschrift voor Rechtsgeschiedenis

Ulpian

UNIDROIT Principles of International Commercial Contracts Union of Soviet Socialist Republics

verso (back side; left/right column)

versiculus

Liber Sextus (1298)

Vocabularium Iurisprudentiae Romanae

videlicet, namely

volume(s)

Verzekeringsrechtelijke berichten

versus 
$W$.

WAM

WvK

WVW (1994)

$\mathrm{X}$

ZEUP

$\mathrm{ZPO}$

ZSSRA
Weekblad van het Regt

Wet aansprakelijkheidsverzekering motorrijtuigen (Motor Insurance Liability Act)

Weekblad voor Privaatrecht, Notariaat en Registratie Wetboek van Koophandel

Wegenverkeerswet (Road Traffic Act)

Liber Extra (Decretales Gregorii IX, 1234)

Zeitschrift für Europäisches Privatrecht

Zivilprozeßordnung (1900, between 1878-1900: CPO)

Zeitchrift der Savigny-Stiftung für Rechtsgeschichte.

Romanistische Abteilung

* As to the manuscripts, I adopted the abbreviations used by G. Dolezalek, Verzeichnis der Handschriften zum römischen Recht bis ı6oo, I-IV, Frankfurt am Main 1972 (now available online at http://manuscripts.rg.mpg.de); further information on the meaning of these abbreviations can be found in this work. 



\section{CHAPTER ONE}

\section{INTRODUCTION}

\subsection{THE SUBJECT OF THIS STUDY}

Often accidents occur not only through the fault of a wrongdoer but also (partly) by the conduct or activity of the injured party. In the latter case the question arises of how to deal with this contribution of the injured party (from a legal point of view). This contributory conduct of the injured party, often dealt with by the concept of contributory negligence, and its consequences for the delictual liability of the person who committed the unlawful act have been central issues in the study of private law throughout the centuries. This phenomenon of contributory negligence is of all periods and can occur in all legal orders. ${ }^{1}$ In addition, the defence of contributory negligence is of great importance in legal practice in various European countries and is particularly often raised in cases involving motorcar accidents. ${ }^{2}$ In the Netherlands, various scholars have argued that Article 6:101 of the (new) Dutch Burgerlijk Wetboek of 1992 that provides the most important rule on contributory negligence does not offer adequate guidance to solve issues of contributory negligence and liability. That point of view is affirmed by case law, from which it becomes clear that judges, if they are aware at all of the criteria for contributory negligence pursuant to Article 6:101 of the Burgerlijk Wetboek of 1992, do not succeed in working with the rule provided. As will become clear from this study, the Dutch Hoge Raad expressed the view that lower judges (should) distinguish between the (two) standards of this article (the primary apportionment made by a correlative balancing of causes, and secondarily an equitable adjustment of the outcome of the primary apportionment). ${ }^{3}$ One has to keep in mind that the question of contributory negligence is often one of the final issues to

1 In the same sense Looschelders 1999, p. 3f.

2 Magnus \& Martín-Casals 2004, p. 260. In some countries, however, the importance of contributory negligence, especially in the field of law, is being reduced; see Magnus \& MartínCasals 2004, p. 260.

3 See, e.g., HR, 13 January 2006, NJ 2006, 59. 
be considered in the rulings of judges, who mostly concentrate on the main question regarding the liability of the wrongdoer. It is also true that the debate between litigants does not usually offer a solid basis to judges upon which to make a coherent assessment on the issue of contributory negligence. ${ }^{4}$ The present research provides new historical and comparative perspectives ${ }^{5}$ to approach the issue of contributory negligence and in this way leads to a deeper knowledge of the phenomenon of contributory negligence.

Apart from the importance of a thorough study of the foundations of the concept of contributory negligence in the Netherlands, such a study is also - and possibly even more - important from an international, especially European, perspective. A short explanation is necessary to make this clear. Most Continental laws of delict have been influenced by Roman law (especially the lex Aquilia). As regards delictual liability, the ultimate origin of the contemporary provisions is sometimes considered to be provided by the Roman law of delicts. There are, however, important differences between the Roman law of delicts and our present-day delictual liability. This research focuses on some of these differences by tracing their historical origins, more specifically concerning contributory negligence. In so doing, it provides a historical background of this particular aspect of the law of obligations - offering a better insight into the reason behind certain rules on this matter - in order to facilitate and enrich the present European discussion in this area of study. The present research offers new perspectives regarding the issue of contributory negligence and (delictual) liability by investigating solutions that have been proposed by legal scholarship, legal practice and codifications throughout the centuries. These solutions have directly influenced our contemporary approach to this subject, which has been shaped by its long history and cannot be completely understood without knowledge of its historical development. Since the study of the history of contributory negligence with its alleged origins in Roman law (and if it were proven that the origins do not lie so much in Roman law, possibly in other legal systems) until the present day, linking past legal developments to contemporary law has not been fully undertaken yet, this research fills lacuna in our knowledge and supplies the necessary data for other researchers in this field in Europe. ${ }^{6}$

4 Keirse 2006, p. 185.

5 Another perspective could have been to study the conceptual and normative issues of the problem of contributory negligence - such research largely falls outside the scope of this study; some reflections on this topic can be found in Simons 1995a, p. 461ff.; 1995b, p. 1693ff.

6 One has to remember that 'the Roman law' does not exist. Roman law is not primarily meant as the law in a certain period of time, but rather as an element of the Roman(-canonical) tradition which underwent significant development throughout the centuries. 
Often scholars discuss (Justinianic) Roman law of the Corpus Iuris and then skip over almost all of the ensuing history, only picking up the discussion again with the nineteenth century codifications. However, and my study confirms this, the period in between is of major importance: ${ }^{7}$ not only because of the reception of Roman law in legal practice, but also because of the influence of this period of ius commune on later legal doctrine and codes throughout Europe. ${ }^{8}$

Although this study can be qualified as a dogmatic study, apart from the study of legal doctrine it also includes legal practice. The historical approach to the subject matter uncovers the origins of similarities and differences between the various European countries as regards the subject of contributory negligence. These are relevant in light of the attempts to harmonise private law within the entire European Union. Furthermore, legal history and comparative law are two sides of the same coin, ${ }^{9}$ and legal history can offer extensive information for practitioners of comparative law. My research will hopefully enable scholars practicing comparative law in the area of private law to obtain a more complete picture on the topic of contributory negligence.

Although, as described above, Roman law is one of the foundations of our contemporary continental private law systems, it is questionable whether this is also true for liability in the event of unlawful acts. The other pillars are canon law and indigenous law, the influence of which, as will be shown in this study, is possibly stronger compared to the influence of Roman law. One could question whether the sources of Roman law already addressed the issue of contributory negligence. By comparing and contrasting our contemporary ideas on specific subjects with provisions in Roman law, insights can be gained into shared problems and potential solutions. ${ }^{10}$ Unfortunately, Roman law is often used as a short reference, as a brief background before passing on to a more detailed exposition of present-day law. While legal scholars sometimes state that certain rules can be traced to Roman precedents, this tracing has to be performed with great care, since Roman sources are easily misread and sometimes rules are anachronistically read into these sources.

7 In the same sense already Ankum 1956/1957, p. 131.

8 In this study the influence of other systems such as canon law and indigenous law will also be discussed as far as necessary for the interaction with Roman law and for the understanding of the (Roman?) origins of later aspects of the doctrine of contributory negligence.

9 See also Heirbaut 2005, p. 136.

10 In the same sense Travis Laster 1996, p. 188. 
Furthermore, sometimes Roman law sources are used in order to support a contemporary rule and to show that the same result was reached in a society that is distant both in terms of time and of space. ${ }^{11}$ That is why the search for similarities must be performed with particular care. All these approaches are imprudent and result in incorrect information or at least in comparisons of rules of dissimilar nature. A deeper study, such as the present one, provides more valuable insights into the way the problem of contributory negligence has been dealt with throughout history.

Little secondary literature on the topic of the historical development of contributory negligence is available and the material that can be found is incomplete and contradictory. The topic of the historical roots of contributory negligence was first studied in a more or less comprehensive way in the modern monographic dogmatic study on contributory negligence by Kaser's student Peter Aumann in 1964, and this study has been partly complemented by an elaborate article by Klaus Luig in 1969. Although these scholarly publications presented extensive material, some aspects of the problem still remained unsolved. In his work, Aumann did not consider the Middle Ages or the early modern period; ${ }^{12}$ this omission was only partly filled by Luig. In my study, in addition to primary sources mentioned in the available secondary literature, an independent study of primary sources has been made, and the sources found were interpreted in order to obtain the proper perspective on these materials. The secondary literature has not only been supplemented but also corrected. Nevertheless, the work of the two scholars mentioned has given rise to discussions on the topic of contributory negligence, although there are still gaps in their research. The goal of my study is to fill that gap. As will be shown, the available research material is incomplete and, especially with regard to medieval ius commune, the historical context is not always fully taken into account, and of course it was impossible that later, contemporary developments were taken into account in these older studies. The overview of the later developments will also include various monographic studies written in more recent times on the topic of contributory negligence. The innovative features of the investigation consist in filling in the gap in the existing literature as regards the historical development of the doctrine of contributory negligence and in providing an outline of this aspect of delictual liability in Western legal scholarship, from Roman Antiquity until today.

11 See also Travis Laster 1996, p. 189.

12 An important fact is that Aumann revealed the new ideas of systematic rationalist natural law (Vernunftrecht) of Christian Wolff. Wolff's view will be elaborately discussed further in this study. 


\subsection{Methodology}

\subsubsection{Central questions}

This study seeks to address the following two central questions. Firstly, what was the historical development of the solutions provided for the problem of contributory negligence in the event of delictual liability? Secondly, what was the influence of solutions found in Roman law, canon law and indigenous law ${ }^{13}$ on later and present-day doctrines and on codes?

As to the effect of contributory negligence, theoretically two solutions appear possible: all-or-nothing or an apportionment of damages between wrongdoer and injured party. The first solution, 'all-or-nothing', could be substantiated with an explanation on the level of an imputation, one that ties up with the question whether the injured party's conduct was the last or decisive cause of the damage. Another possibility is to solve the problem by way of allocation of a loss, imputable to both parties, to just one of the parties. This possibility can be based just on the fact that the injured party has been contributorily negligent, or on a weighing of the extent of negligence of both parties or of the other circumstances of the case. ${ }^{14}$ With regard to an apportionment of damages, other solutions are also imaginable. Certain types of damages can be entirely allocated to the persons involved (possibly the direct damage to the wrongdoer and the consequential damage to the injured party) or the total damage can be partitioned between the persons concerned, in halves or according to a certain quota based on the concrete circumstances of the case. ${ }^{15}$ As will be discussed in this study, causation and negligence are most commonly used as criteria to come to such a partition. This main question, a historical and theoretical problem, and the theoretical solutions are in essence the same for all times. ${ }^{16}$

It is necessary to answer the first (central) question in order to provide an answer to the second (central) question, which can be regarded as pulling together various views and solutions provided in various periods in legal

13 Indigenous law is only discussed where the learned sources give an immediate reason to do so. In general the sources do not (or only to a limited extent) give reason for such a discussion; furthermore, an extensive study into indigenous law would have been too time-consuming and falls outside the scope of this study.

14 Jansen 2007, p. 663.

15 ibid

16 Looschelders 1999, p. 5, argued that the first solution means an unequal treatment of both parties: the negligence of the wrongdoer is only relevant when there is no contributory negligence of the injured party; the second solution means an equal treatment of the parties as each has to bear the damage to the degree to which he is responsible for it. I will come back to this matter in chapter five. 
history. This main query gives rise to several questions. Since it has not been possible to study all possible subquestions extensively, I have chosen to concentrate on the following. I will start with the views of classical Roman jurists as regards contributory negligence. These views are interesting from a comparative point of view, and furthermore the exegeses of the relevant texts in the context of classical Roman law are important because of the influence of this law on legal Humanism (e.g. the Dutch Elegant School). A treatment of the topic of contributory negligence in Justinian law follows; the rules contained in Justinian law were the starting point of later developments in European legal scholarship with regard to intellectual thinking about the effects of contributory negligence in cases of delictual liability. Therefore, this treatment is necessary in order to make it possible to understand later developments; it is crucial to obtaining a good understanding of the texts of the Corpus Iuris Civilis. ${ }^{17}$ These texts will therefore be discussed in chapter two in order to provide a basis for the following chapters to build upon.

With regard to the medieval period, in chapter three, the emphasis lies on the ius commune (Roman law and canon law). With regard to the early modern period (humanists, jurists of the usus modernus pandectarum, natural law scholars), in chapter four the emphasis lies on the development from the reception to the codifications. For each period I will show how cases in which the injured party's own act was considered to have contributed to the damage were solved dogmatically. What was the legal effect of the injured party's contribution to delictual liability? As regards the early modern period, I also include legal practice.

The study concludes in chapter five with the contemporary way in which jurists in European countries (particularly France, the German territories and the Netherlands) have dealt with the problem of contributory negligence. France and the German Empire were chosen to be studied because they produced influential codes of substantive (and procedural) civil law. Furthermore, the Netherlands was chosen as it has a very recent law provision on contributory negligence including a new, different element. In the discussion of these modern codifications (and of the preceding nineteenthcentury development), particular attention is given to the extent to which these legal systems have been influenced by ius commune approaches to contributory negligence, theories of Natural Law and the German Pandectists, and also to the extent to which these legal systems have developed their own unique approach to the concept of contributory negligence.

17 All translations of (Latin) texts into English are mine, unless explicitly stated otherwise. 
The answers to questions relating to this matter have allowed me to determine whether common (historical) foundations of liability law may be discerned as regards contributory negligence in Europe.

\subsubsection{Comparative legal history}

One of the methods used in this thesis is that of comparative legal history as a method of analysis in order to answer the central questions stated above. ${ }^{18}$ This study does not depart from the normative legal concept of contributory negligence as such, but from a perspective of a functional problem. This study seeks to compare the function of 'contributory negligence' in its attempt to solve a factual problem. At first the problem will be defined in general terms, the focus of the elaboration of the study being on the area of the law of delicts and on the solutions for the problem in the past (starting with classical Roman law and up to the present day). What was the legal effect of the contribution of the injured party to extra-contractual, i.e. delictual liability? ${ }^{19}$ One has to keep in mind that the 'law of delicts' does not concern criminal law but civil liability. In this study the factual problem, which will be used as a basis, is as follows:

Without the existence of a contractual relationship, two persons interact in such a way that one of them suffered loss as a result. In principle - the less complicated situation - the person who did not suffer damage is regarded as the wrongdoer. If the applicable requirements are fulfilled, he is liable for the damages suffered by the other party, i.e. the injured party. How does one solve the delictual cases in which the injured party's own act was considered to have contributed to the damage?

\subsubsection{Definition of contributory negligence}

In this study contributory negligence is assumed to be present if the person who suffered damage in one way or another contributed to his own harm (in a legally sufficient way). ${ }^{20}$ When studying the historical roots of the doctrine of contributory negligence, it is essential to be aware of the danger of anachronisms. Perhaps there was no such thing as 'contributory negligence' in (classical) Roman law, medieval ius commune or in later periods.

18 More specific methods, different for each period, will be used and discussed in the introductory part of the respective chapters.

19 The problem of contributory negligence in other areas, e.g. criminal law or contract law, is only dealt with when this is necessary for the essence of contributory negligence.

20 cf. Magnus \& Martín-Casals 2004, p. 259. 
In my study I used the term 'contributory negligence' as a classification concept, a concept that may not appear in the sources but that is used for better understanding of the sources. ${ }^{21}$ In other words, the term 'contributory negligence' may not be found, but the problem it intends to deal with can be found. Therefore, the term 'contributory negligence' is a useful tool to indicate comparable problems. Furthermore, I studied situations in which today we would assume contributory negligence and situations in which today the defence of contributory negligence would probably or possibly be raised.

The term 'contributory negligence' is traditionally used in common law, while in continental legal systems the broader term 'contributory fault' (including both negligent and intentional conduct) is more familiar. ${ }^{22}$ In this thesis these terms are used as synonyms, unless the contrary is explicitly stated. The term contributory negligence is also used for the sake of convenience for either traditional contributory negligence (leading to a complete bar to recovery) or the so-called comparative negligence (where the negligence of the injured party reduces - not necessarily bars - his ${ }^{23}$ right to claim recovery).$^{24}$ Therefore, contributory negligence is not used in the technical common law sense, but as a useful shorthand.

In principle, the term contributory negligence is used in a more restricted way than the expression 'fault of the victim': it excludes conduct that is merely contributory but not the sole cause. Although examples of this second category, i.e. conduct that is the sole cause of the victim's harm, will also be frequently mentioned in this study - especially to contrast these examples with the first category, i.e. the cases in which the conduct of the injured party is merely contributory to the victim's harm - that category does not represent the central subject matter of this study. The use of the term contributory negligence also excludes intentional rather than merely negligent conduct. If the conduct of the injured party was intentional, this will be explicitly stated and - if necessary - dealt with separately. Examples of these cases will be explicitly mentioned and clearly distinguished. Conduct of the victim occurring after the conduct of the wrongdoer will only be dealt with in the final chapter on contemporary law.

21 See Veen 1996, p. 10.

22 Van Gerven, Lever \& Larouche 2000, p. 689

23 In general, in this study the masculine form is used, which also refers to the feminine form. In case masculine or feminine forms are specifically meant, it is stated explicitly.

24 cf. also, e.g., Simons 1995a, p. 463; 1995b, p. 1697. 


\subsubsection{Delineation of the study}

It is impossible to write a comprehensive study on contributory negligence due to the immense mass of material on this topic. Therefore, following this broad outline of the subject of this study in the previous subsections, I will now explain more in detail how I delineated my study. First of all, two basic types of contributory negligence cases can be distinguished. Firstly, the case in which the injured contributes to the damage. In such cases an interaction between the injured and the wrongdoer always takes place. Secondly, the case in which contributory negligence is presumed, viz. the injured party has made no attempt to restrict the extent of the damage arising from his injury. In that case, the injured contributed to the increase of the damage. My study primarily deals with the former case, i.e. when the act of the injured party contributed to the occurrence of the damage. The latter case, i.e. when the act of the injured party contributed to the amount of loss, has not been the focus of attention in this study but - for the sake of completeness - has been briefly mentioned at the end of the study (see section 5.7).

As to the authors of the early modern period, a selection had to be made; a reproduction (and translation) of the precise argumentations found in early modern writings on the action to claim damages would not only have been impossible but is also pointless, since it would only constitute a long repetition of materials from the Corpus Iuris and writings of scholars. Only writings offering insight into the (new) ideas about contributory negligence or about the historical context of certain texts of the Corpus Iuris are included. The outline of the developments from the nineteenth century onwards is restricted to France, Germany (German territories) and the Netherlands. France and Germany are chosen as representative countries of major legal families in continental Europe. The Netherlands is mainly studied because of this country's very recent new Civil Code (the Burgerlijk Wetboek of 1992). In case of relevancy, reference is also made to other jurisdictions (England, Switzerland and Austria; see chapter five).

Contributory negligence has implications for the behaviour of people, for accident avoidance, i.e. it forces injured parties to take precautions for their own safety. ${ }^{25}$ Another remarkable theory, which must be demarked from my topic, and which is not extensively discussed as such, is the theory of the assumption of risk.

25 See, e.g., Travis Laster 1996, p. $190 f$. 
This theory refers to the situation when a plaintiff recognises a certain amount of risk of harm, but nevertheless chooses to proceed anyway. Also the topic of consent of the victim, although very interesting, is not extensively discussed in this study.

\subsection{Structure}

The study is subdivided into three main parts, each with its own methodological approach as already stated above. A more elaborate explanation on the methodology used can be found in the respective upcoming chapters.

In the first part, a coherent interpretation of relevant texts from classical Roman law is provided. Subject of the investigation is the way in which classical Roman jurists dealt with the question of contributory negligence. The research focuses on a number of casuistic texts from the Digest. A thorough analysis and exegesis of these texts in their palingenetic and socio-cultural context was necessary. From this elaborate study, it becomes clear that Roman legal sources may not be taken as support for a modern rule or to show that the same result was reached in such a distant society, separated by a very long period of time, unless the search for similarities is performed with utmost care. The way the Roman jurists worked with Roman law texts and the way in which medieval legal scholars worked with texts from the Corpus Iuris will be set off against each other. This gave me the possibility to show that contemporary scholars often interpret texts outside their contexts, and thus the perspective from which sources are interpreted has to be elucidated. ${ }^{26}$ The results of the first part of this study can be found in chapter two, which also includes a treatment of the problem of contributory negligence in Justinian law

The second part of the investigation concerns the development of the solutions to the problem of contributory negligence from the Middle Ages until the twentieth century. Unlike the first part, this second part focuses on the relevant texts as part of the Corpus Iuris Civilis, and - apart from some humanist authors - not so much on their original meaning in classical Roman law. Questions that are answered are: How were the relevant texts interpreted in medieval doctrine? To which other texts in the Corpus Iuris were they linked ${ }^{27}$ Which dogmatic rules were derived from these texts? In

26 To find (large amounts of) secondary literature, firstly the classical manuals on Roman private law and the fundamental commentaries on the Corpus Iuris were examined. In addition, the most important monographs on the lex Aquilia were consulted. By using the Bibliotheca iuris antiqui (BIA), important recent literature on the various texts has been traced.

27 As regards the contents of the texts of the littera vulgata, I used the edition of Kriegel (edn. 1844) unless text-critical discussion demanded otherwise, and as to the contents of the 
which way was legal practice influenced by the learned theories from the days of the reception of Roman law? This second part endeavours to clarify the meaning of the relevant texts in the tradition of ius commune. The period of the Glossators (1120-1260) is studied through an analysis of printed sources and a selection of manuscripts (see chapter three). The choice of manuscripts was pragmatic: it depended on the availability and the legibility of the manuscripts in question. Reading the manuscripts was necessary, considering the fact that the important Apparatus Maior to the Digest of Azo was unpublished in print. Furthermore, it was necessary to make clear the line of development in the pre-Accursian period. As regards the period of the Commentators, a selection of the most important writers was made. Commentaries on the most relevant texts in the Corpus Iuris have been studied as well as special treatises, court reports and consilia (see chapter three). As to the consilia, a study of a selection of indices to them has been made for the purpose of finding the relevant consilia which dealt with the problem of contributory negligence in delictual liability cases. Apart from references to consilia in early modern writings and contemporary secondary literature, not many relevant consilia have been found. This second part of the investigation consists of a study of primary sources. Subsequently, the reception in legal practice of Roman law as regards contributory negligence is studied, as well as the role of the writers of the usus modernus and of natural law in this respect (chapter four).

The third part of this study concludes with a discussion of the contemporary concept of contributory negligence, concentrating on the nineteenth- and twentieth-century doctrines, case law and codes in France, Germany and the Netherlands. The concept of contributory negligence in these three contemporary jurisdictions, firmly based on the tradition of the ius commune, allowed a discussion of the continuity and discontinuity in Western legal thought on this subject (see chapter five).

Glossa Ordinaria of Accursius I used the edition from Venice 1487-1489 (reprint Turin 1968/1969). The citation of texts follows the modern numbering system of Mommsen/Krüger. 



\section{CHAPTER TWO}

ROMAN LAW IN ANTIQUITY

\subsection{INTRODUCTION}

\subsubsection{Subject and purpose of this chapter}

It is commonly argued that until the nineteenth century the injured party could not recover damages in a legal procedure when his negligence contributed to the occurrence of the injury, unless the wrongdoer had acted intentionally. This idea should already have been present in Roman law, but one has argued that the foundation of this rule in Roman law was unclear. ${ }^{1}$ In this chapter clarity will be provided with regard to both aspects. While I will argue that the first statement should be regarded as oversimplified, even untrue, I will clarify whether the second statement is true, i.e. whether such a foundation indeed existed.

The main subject of this chapter is the role of the conduct of the injured party. Questions which will be dealt with are: what was the approach of legal practice of the Roman jurists dealing with what we would now call the 'contributory negligence' of the injured party? If this notion was recognised in legal practice, then what were the consequences of such 'contributory negligence'?

The purpose of this chapter is twofold. Firstly, a good understanding of the relevant texts of Justinian's legislation ${ }^{2}$ (later called the Corpus Iuris Civilis) is necessary in order to understand the later developments in the period of ius commune. Secondly, an exegesis of the relevant texts in the context of classical Roman law is important not so much because of the significance for the ius commune but because of the influence of this law on legal Humanism (e.g. the Dutch Elegant School). ${ }^{3}$

1 Smits 1997, p. 214f.

2 The number of differences between Justinian's legislation and modern codifications and their importance is so great that it is better to avoid the term codification; see Ankum 2001 (reprint 2007, p. 399ff.).

3 Besides, it is also important because of the influence of classical Roman law on modern scholarly (Romanistic) studies. 
With regard to classical Roman law, the main sources on the effect of contributory negligence of the injured party on the liability of the wrongdoer in Roman law (in Antiquity) can be found in the compilation of Justinian, more specifically in title D. 9.2 and also in one fragment of the last title of the Digest, namely, D. 50.17.203. The maxim of D. 50.17.203 is nearly always used as a relevant provision; however, in this chapter it will be argued that this text did not represent a general rule ${ }^{4}$ and that it was not generally applied in the classical period. With regard to classical Roman law, all the other fragments of the Digest have to be interpreted bearing this fact in mind; this situation changed in Justinian law. Many texts are linked to the subject of contributory negligence, and obviously not all of them can be discussed. ${ }^{5}$ After dealing with the above-mentioned text of D. 50.17.203, this chapter continues with three sections in which three important texts, namely, D. 9.2.9.4, D. 9.2.11pr. and D. 9.2.52.1, will be critically examined (sections $2.3,2.4$ and 2.5). This examination will start with an exegesis of D. 9.2.52.1 because this text includes the oldest legal reply (i.e. advice of Alfenus, a jurist from the late Republic), followed by two fragments by Ulpian viz. D. 9.2.9.4 and D. 9.2.11pr.

After the exegesis of these texts in classical Roman law, a comparison with the approach in Justinian law will be made. Justinian included the above-mentioned fragments by Alfenus and Ulpian in his Digest. He made these fragments as well as the text from the Institutiones (Inst. 4.3.4) all equally applicable, promulgating them as law. ${ }^{6}$ They have to be interpreted in connection with each other, being provisions of one and the same piece of legislation.

4 This was defended in earlier times, e.g. by Heilfron 1920, p. 245; Holdsworth 1937 (repr. 1966), p. 459; see also Looschelders 1999, p. 7.

5 Recently, Travis Laster wrote an article in which he discussed six cases in the Digest where the conduct of the victim was, according to his opinion, clearly relevant (Travis Laster 1996, p. 203). According to Travis Laster, the cases 'uniformly show that the victim's conduct was considered as one contingent fact in an overall contextual inquiry into blame'. The fragments I have chosen were selected based on the frequency of occurrence in Romanistic literature and on their influence later in ius commune. The cases of the bear pits (D. 9.2.28-29pr.) only very implicitly concern the contributory negligence of the injured party. The texts concern more the overall discussion of the blameworthiness of the defendant. Also in the case of the tree pruner (D. 9.2.31), the role of the victim's conduct is taken into account in the overall discussion of the blameworthiness of the tree pruner; this text will frequently be dealt with in this chapter because it could indeed be interpreted as considering contributory negligence. More information on this text will follow later. Because these two texts together with the cases of the javelin throwers all seem to illustrate a contextual fault-based inquiry (Travis Laster 1996, p. 203), I have chosen the most important one, D. 9.2.9.4, for an integral treatment in this chapter to show the way classical jurists treated this matter. The last case, which Travis Laster discussed and which I do not, D. 9.2.52.4, seems to have been considered more within the context of the distinction and the boundaries between culpa and casus.

6 As to the concept of contributory negligence of the injured, apart from fragments from the Institutes and Digest, also Codex title 3.35 could be relevant (De lege Aquilia), but, after closer examination, the respective texts appear not to be relevant for my topic. 
Therefore, in section 2.6, I will see whether there is sufficient coherence in the texts so that they are based on the same principle of law.

Finally, the fact that the concept of contributory negligence also developed in the Eastern Roman Empire merits attention to be paid also to Byzantine law. Moreover, Byzantine law will be included in the exegesis of the relevant texts in Antiquity, since it can be helpful when reconstructing classical Roman law. After Antiquity, the developments of legal scholarship in Eastern and Western Europe did not run parallel, due to the (temporary) interruption of the development of Roman law in Western Europe, only to be resumed with the Glossators. The theories of the Glossators with regard to the concept of contributory negligence will be expounded in the next chapter. ${ }^{7}$ The current chapter will end with some concluding observations in which the above questions will be answered (see section 2.7).

\subsubsection{Structure and method}

In the first four sections exegeses of fragments of the Digest will be presented. Apart from the specific fragments of the Digest, a text from another part of the Corpus Iuris Civilis is also relevant, namely, Inst. 4.3, as well as texts from two other sources, the Paraphrasis Institutionum of Theophilus and the Basilica. These texts will be discussed together with the corresponding relevant fragments in the Digest and Institutes.

The structure of these exegeses will be similar: after the text of the source is provided and a text-critical discussion based on a consultation of the text editions of the Digest of Mommsen and of Gebauer-Spangenberg is made, ${ }^{8}$

7 The 'new' scholia, which can give us insight into the way the law was interpreted in the 11th century in the East, and in this respect especially that of Hagiotheodoritès, therefore, do not fit within the scope of this study, and will as such not lead to new insights into the development of law in Western Europe. These scholia are, however, important for the development of the concept of contributory negligence in the sense that they can provide a better understanding of how legal problems were solved in Byzantine law. Being interesting from a comparative point of view, one of these scholia will be discussed in the next chapter.

8 The text-critical discussion will start with the edition of Mommsen. However, this edition is very much based on the littera Florentina and too little notice is given to the littera vulgata. Mommsen made a complete collation of only one manuscript, namely, Ms. Paris BN, lat. 4450, and only consulted other manuscripts of the Digestum Vetus when Ms. Paris BN, lat. 4450, and the littera Florentina disagreed; see Radding \& Ciaralli 2007, p. 173. On Ms. Paris BN, lat. 4450, see Radding \& Ciaralli 2007, p. 205ff. In order to compensate for this limitation, I used the edition of Kriegel (edn. 1844) as the first starting point for the littera vulgata, and I also consulted the edition of Gebauer- Spangenberg as well as several vulgate editions (e.g. Ms. Biblioteca Vaticana, vat. lat. 1406, fo. 80v, which has been qualified as the earliest manuscript of the vulgate tradition; see Radding \& Ciaralli 2007, p. 171, 197f.). For my text-critical reproduction, I discussed the main variants of the reading of the texts in these editions. 
a translation of the source is given, the inscriptio of the text is discussed, and an exegesis of the texts in their classical context follows, including a discussion of possible later interpolations. Finally, the post-classical development of the texts, in the context of Justinian law, is discussed.

Most importantly, in these exegeses, is the legal problem, i.e. the legal articulation of the actual conflict that gave rise to the legal dispute, which will be defined. Furthermore, the reply of the jurist or jurists involved will be discussed. Especially important for the discovery of the legal problem and the reply of the jurist(s) are the particular circumstances of the case, the claims of the plaintiff and the defence of the defendant. Reconstructing the case in this way often helps to understand the advice that jurists gave in a particular case. Then, the different interpretations in modern and present-day literature will be discussed and where these seem to be inaccurate, new ways to solve the problem will be provided.

\subsection{THE ORIGIN OF THE REGULA OF D. 50.17.203}

\subsubsection{The text of D. 50.17 .203}

As mentioned above, this subsection will start with the reading of D. 50.17.203, ${ }^{9}$ followed by a text-critical discussion.

Pomponius libro octavo ad Quintum Mucium. Quod quis ex culpa sua damnum sentit, non intellegitur damnum sentire.

The first peculiarity of this fragment is that the name of Pomponius is lacking in the oldest manuscript of the Digest, the littera Florentina (there is an empty space in place of his name).$^{10}$ However, Torelli seems to have filled in the empty space by printing the name of Pomponius in his edition of 1553, which was fully and directly based on the littera Florentina. ${ }^{11}$ Also the littera vulgata contains the name of Pomponius. ${ }^{12}$ Furthermore, there are no reasons to assume that someone

9 The readings of the Digest texts which are elaborately discussed in this chapter are taken from the editio maior (and the editio minor) of Mommsen \& Krüger.

10 Fo. 474r of the facsimile edition of the Florentina.

11 See edition of Torelli of 1553, III, p. 1665.

$12 c f$. edn. Kriegel 1844, p. 979. See also the critical edition of Gebauer-Spangenberg containing variants of the littera vulgata (Gebauer-Spangenberg 1776, p. 1144). In the edition of Gregorius Haloander (1501-1531), which incompletely and indirectly contains elements from the littera Florentina (see Feenstra 1974, p. 128), the inscriptio only contains IDEM (see edn. of 1550, fo. $1694 \mathrm{v})$. In the edition of Haloander, the inscriptiones of the previous phrases also contain the 
else wrote this fragment. Accordingly, it seems plausible and acceptable that this fragment was correctly ascribed to Pomponius by Mommsen.

The second peculiarity concerns an inserted word. In the littera Florentina a small 'si' is written between the lines. ${ }^{13}$ Probably, as Mommsen also stated in his editio maior, the first corrector of the littera Florentina $\left(\mathrm{F}^{2}\right)$ made an addition in the margin of the Florentine. He added 'si' (then the text reads quod si quis). Another manuscript, namely, a (vulgate) manuscript, collected by Thomas Rehdiger (15411576), part of the so-called (Codices) Rehdigerani, provides additional information on this point. The reading of D. 50.17.203 originally commenced with the words Quod si quis. ${ }^{14}$ The word si was deleted at a later moment by means of dots (sed vocula 'si' punctis est deleta). ${ }^{15}$ However, the insertion of 'si' seems to add to the fragment a meaning more general than would be justifiable for classical Roman law. ${ }^{16}$ As with si the phrase is more likely to be a general statement (if someone $\mathrm{X}$, then $\mathrm{Y}$ ), and without si the phrase could be considered as the end of a casuistic decision, the latter option is more plausible (as will also be discussed below).

A final problem concerns the second word damnum. In the littera Florentina and in the littera vulgata the second word damnum is clearly present. ${ }^{17}$ Mommsen suggested deleting this word. ${ }^{18}$ However, such a deletion seems to be unnecessary for classical Roman law, as will appear below.

word IDEM, and by looking back to the first different inscriptio one finds Iabolenus (D. 50.17.198). Therefore, one could conclude that the IDEM at D. 50.17.203, according to Haloander, has to refer to Iabolenus, and thus this has to be a mistake of Haloander's.

13 See fo. $474 \mathrm{r}$ of the facsimile edition of the Florentina.

14 See Ms. Wroclaw BU, Rehd. 289, fo. 285r.

15 Gebauer-Spangenberg 1776, p. 1144; differently, the littera vulgata cf. edn. Kriegel 1844, p. 979, which contains 'Quod quis'.

16 The placing of this text in Lenel's Palingenesia (see section 2.2.3, p. 19) does not give cause to consider D. 50.17.203 as a general rule. The formulation of D. 50.17.203 originates from a larger text and belongs to a reply to a concrete case rather than that is was meant as a general (didactical) rule. Also the Greek reading of the 'rule' of Pomponius in the Basilica in the title about 'various rules of old law', B. 2.3.203 [BT 66/16-17], cannot provide sufficient grounds for such an insertion. When comparing B. 2.3.203 with D. 50.17.203, one observes that the fragment was stated in a more general manner.

17 See fo. 474r of the facsimile edition of the Florentina (and similarly in the later edition of Torelli of 1553, III, p. 1665), and also the littera vulgata $c f$. edn. Kriegel 1844, p. 979.

18 Mommsen \& Krüger 1963b (editio maior), II, p. 969; also De Ligt/Sirks in: Spruit et al. 2001, p. 986, leave this word untranslated. 


\subsubsection{Translation of D. 50.17.203}

The following translation will be as literal (in order to remain faithful to the Latin text) and as grammatically acceptable as possible. As a result, the incompleteness of the fragment becomes visible, more specifically, the fact that the text was removed from its original context. The text of D. 50.17.203 could be translated in two different wpays: 'damage that someone suffers ...' or 'because someone who suffers damage ....' I think the first translation is less accurate, therefore, and for the reasons I will mention later on, I have chosen the second translation.

Pomponius in his eighth book on Quintus Mucius.

Because $^{19}$ the one, who suffers $\operatorname{loss}^{20}$ as a result of his own negligence $($ culpa $),{ }^{21}$ is not considered to suffer any loss.

19 'Quod' is translated differently by Scott 1973, p. 317 ('He who sustains any damage through his own fault ...') and De Ligt/Sirks in: Spruit et al. 2001, p. 986 ('Schade die iemand door eigen schuld lijdt ...'); and not translated by Watson 1985, who starts with 'If anyone ...', nor d'Ors et al. 1975, p. 882, who start with 'No se considera que ...'; different also Otto, Schilling \& Sintenis 1832 (reprint 1984), p. 1285, who did translate this word, but differently, namely, as 'wenn'.

$20 \mathrm{cf}$. Heumann \& Seckel 1907 (reprint 1958), p. 120, s.v. damnum, this fragment is classified under damnum iniuria, Sachbeschädigung, by which loss as the damage to an object is meant. On p. 534 it is written that sentire damnum has to be interpreted as 'Schaden leiden, davon betroffen werden'. The meaning of the term damnum will be further discussed below.

21 In this chapter, culpa is mostly translated as negligence, sometimes as fault; according to MacCormack 1974, p. 201ff., culpa (in the context of the lex Aquilia) has to be translated as fault. With the translations of the word culpa, no principal choice in this respect is made; with the translation into negligence, no necessary implicit principle of forseeability is meant (in classical Roman law); the choice is mostly made for linguistic reasons based on what is most suitable in each individual case. 


\subsubsection{Inscriptio}

The context of D. 50.17 .203

This fragment derives from Pomponius' commentary ${ }^{22}$ on Quintus Mucius Scaevola. ${ }^{23}$ Q. Mucius Scaevola ${ }^{24}$ (ca. 140-82 BC) became known mainly due to his Iuris civilis libriXVIII. This work contained a systematic treatise of the ius civile ${ }^{25}$ and was the only pre-classical work still read in the classical period. In the second century AD it was even commented on by Laelius Felix, Gaius and Pomponius. ${ }^{26}$ D. 50.17.203 concerns a commentary of Pomponius on Q. Mucius Scaevola's record of the ius civile, and, therefore, can be seen as a commentary on the ius civile. As is generally known, the ius civile at the time of Quintus Mucius is understood to have consisted of 'private' law as far as enclosed in laws (e.g. Lex XII Tabularum), senatus consulta and it also comprised the interpretation of all these legal sources by the jurists. At the time of Pomponius the imperial constitutions also became part of the ius civile. ${ }^{27}$ D. 50.17 .203 contains a fragment by Pomponius in the eighth book of his commentary on Q. Mucius Scaevola.

Lenel, in his Palingenesia, placed the fragment of D. 50.17.203 in the commentary of Pomponius on Quintus Mucius under the title De legatis. ${ }^{28}$ This fragment (pal. nr. 260) is the last fragment of liber VIII (De legatis 6), which part consists of nine Digest texts (in seven pal. numbers). Book eight (De legatis 6 ) is one of the parts about legacies (De legatis), De legatis consisting of seven parts in total (liber III [pal. nr. 228ff.] to liber IX). Unfortunately, Lenel's

22 In humanistic literature, there has been a discussion on the precise nature of Pomponius' commentaries on Q. Mucius. According to Jacobus Gothofredus, Pomponius wrote notae to the regulae of Q. Mucius Scaevola. See J. Gothofredus, Commentarius in titulum Pandectarum de diversis regulis iuris antiqui, col. 1221f., paragraph before the commentary on D. 50.17.203. However, the Dutchman (Frisian) Georgius d'Arnaud (1711-1740) argued that Pomponius shaped his commentaries as 'Readings (Lectiones) on Quintus Mucius'. See G. d'Arnaud, Variae conjecturarum, II.29, p. 400. Also Johannes Bachius (1721-1758) cited those writings as 'Q. Mucium Lectionum XXXIX'. See I.A. Bachius, Historiae Jurisprudentiae Romanae, III.2 sect. 5 § 13.

23 Already in the humanistic edition of Schulting-Smallenburg, three fragments of the same origin as D. 50.17.203 are mentioned, namely, D. 23.3.66, D. 29.2.77 and D. 31.45. With regard to the content of D. 50.17.203, reference is made to D. 43.16.9.1, which will be discussed by J. Gothofredus and Donellus in their commentaries on D. 50.17 .203 (see chapter four).

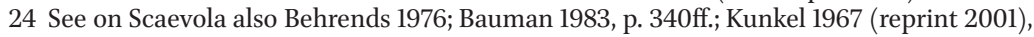
p. 18; Liebs 2002, p. 569ff.; also Kübler 1933 (RE 31), col. 442ff., which is about his life as a jurist.

25 Pomp. D. 1.2.2.41: 'Post hos Quintus Mucius Publiiflius pontifex maximus ius civile primum constituit generatim in libros decem et octo redigendo.'

26 Spruit 1994, p. 99; Liebs 2002, p. 571.

27 In the 2nd century AD, Gaius noted that the 'responses prudentium' were also part of the ius civile (Gai. Inst. 1.2).

28 Lenel, Palingenesia iuris civilis, II, col. 68 pal. nr. 6.260. 
reconstruction in his Palingenesia is the only indication available. ${ }^{29}$ Since there is no well-founded reason to take a different view, the best option seems to consider his indication as an assumption.

A legacy is a bequest in a will of certain goods or rights to another person or to persons other than the heir. In the classical period one could mainly distinguish two categories of legata: legatum pervindicationem and legatum per damnationem..$^{30}$ Later, the compilers of the Digest placed this fragment in the title De diversis regulis iuris antiqui (various rules of ancient law). ${ }^{31}$

\section{Sextus Pomponius}

The writer of this text, Sextus Pomponius, ${ }^{32}$ lived in the second century AD. In the absence of any other sources, his works provide the only information available about his life. Pomponius wrote his works during the reign of the emperors Hadrian, Antoninus Pius, Marcus Aurelius and Lucius Verus. He was probably born in about $110 \mathrm{AD}$ and died around $180 \mathrm{AD}$. From the complete 'silence of the sources', we may deduce that Pomponius did not exercise public functions and that the ius respondendi was not granted to him. ${ }^{33} \mathrm{We}$ do not know whether Pomponius belonged to one of the schools and, if he did, to which school he belonged (the Proculiani or the Sabiniani). ${ }^{34}$ The majority of present-day scholars seem to maintain that Pomponius was an adherent of the Sabinian school. ${ }^{35}$ However, a more correct view would be that there is no conclusive indication as to Pomponius' own preference for one school or the other. ${ }^{36}$

Pomponius wrote over three hundred papyrus rolls (libri). Fragments of his writings are indirectly handed down to us via the Digest, and they are possibly altered by interpolations. His now most famous work is the Enchiridium, a di-

29 Some humanists, namely Raevardus and Donellus, attempted to reconstruct by means of palingenesis the contextual origin of D. 50.17.203, which they also considered to be the law of legacies. However, they came to a conclusion different from mine as will be made clear in the discussion of their views in chapter four.

30 See on legatum: Voci 1967, p. 11f., 21ff.; Kaser 1971, p. 109ff., 740ff.; 1975, p. $549 \mathrm{ff}$.

31 Only then did the fragment become a maxim; see the end of this section.

32 On S. Pomponius, see, e.g., Wesenberg 1952 (RE 21), col. 2416ff.; Nörr 1976, p. 497-604; Liebs 1997a, p. 144-150; Kunkel 1967 (reprint 2001), p. 170f.

33 Ankum 1974, p. 1; see also Wesenberg 1952 (RE 21), col. 2417.

$34 c f$. Wesenberg 1952 ( $R E$ 21), col. 2417; Honoré 1962a, p. 21ff.; - In general, on the Sabiniani and Proculiani, see Liebs 1976; Falchi 1981 and recently Leesen 2009.

35 See references mentioned by Leesen 2009, p. 4 nt. 3. The opposite view is held by Baviera 1898, p. 27ff.; Honoré 1962a, p. 21ff., esp. 25f., argued that Pomponius was first educated at the Proculian law school, but later moved to the Sabinian school to teach.

36 Stolfi 1997, p. 7ff.; Leesen 2009, p. 4 nt. 3. 
dactical work, the more important because, besides the Institutes of Gaius, very few didactical works existed in the first two centuries of the Roman Empire. Also important are Pomponius' two commentaries on the ius civile (one ad Q. Mucium [lectionum] libri XXXIX and one ad Sabinum XXXVI), a commentary on the edict as well as monographs on stipulations, senatusconsulta and fideicommissa. ${ }^{37}$

\subsubsection{Exegesis according to (classical) Roman law}

\section{Introduction}

When Pomponius wrote the lines of D. 50.17.203, in later times adopted as a maxim, they probably formed an integral part of a larger text which is lost. The text may have been shortened by the compilers of Justinian, when including it in the Digest. ${ }^{38}$ After a study of this text one could come to the conclusion that identification of the details of the original context of the fragment is impossible. ${ }^{39}$ Also the reconstruction of Lenel (pal. nr. 260) seems to support that conclusion, but deeper investigation of D. 50.17.203 seems, nevertheless, appropriate.

One can assume that this fragment, like all regulae, originally referred to a concrete case. ${ }^{40}$ From Lenels' reconstruction it becomes clear that Pomponius' statement D. 50.17.203 belonged to the law of legacies. ${ }^{41}$ So, probably originally, i.e. when Pomponius wrote his commentary, it concerned a case of legacy. ${ }^{42}$ It is not clear whether the fragment is even much older, i.e. if it already derives from Quintus Mucius. ${ }^{43}$ In the event the fragment is indeed much older, Pomponius has cited Quintus Mucius, or he made the citation to comment on it, or he was just referring to the cited fragment. Possibly, the fragment originated

37 For a more detailed and precise overview on Pomponius' work, see Wesenberg 1952 (RE 21), col. 2417f.; Liebs 1997a, p. 145ff.; Wieacker, Wolff \& Manthe 2006, p. $108 f f$.

38 According to Jörs 1927, p. 119, the fragment is interpolated; see also Levy \& Rabel 1935, col. 600 .

39 Medicus 1962, p. 323; according to Buckland, McNair \& Lawson 1974, p. 372, the text is corrupt.

40 Lange 1955, p. 71; on the (development in the) meaning of the regulae (iuris), see, inter alia, Stein 1966; Schmidlin 1970; Pérez Simeón 2001, p. 380ff.; Nörr 2003, p. 775*ff.

41 Lenel, Palingenesia iuris civilis, II, col. 68 pal. nr. 6.260, categorised D. 50.17.203 under the eighth book of Pomponius' commentary on Quintus Mucius under the title De legatis 6; - Also Endemann 1893, p. 56; Pernice 1895, p. 98 nt. 1; Medicus 1962, p. 323 n. 13; Aumann 1964, p. 30f.; Wollschläger 1976, p. 119; Hausmaninger 1996a, p. 29; - Differently Deschizeaux 1934, p. 11, who argued that the rule of Pomponius is a remnant from the time in ancient Rome when liability was just penal, and the rule was applied in the sense that the punishment as serious as the talio was not applied when the victim also was at fault.

42 See Riezler 1941, p. 190; Genzmer 1942, p. 126.

43 See, for a positive answer, Arnò 1939/1940, p. 41. 
already from Republican times. However, it cannot be ascertained whether Q. Mucius Scaevola had already formulated it in the wording adopted by Pomponius. ${ }^{44}$ Possibly, the expression 'damnum sentire', common to Pomponius' style,$^{45}$ could indicate that this fragment was extracted from the commentary of Pomponius. ${ }^{46}$ In addition, the concise style (quod quis ...), the technique and the method of solving the problem by word interpretation could support such a conclusion. ${ }^{47}$

Despite the fact that there is no reference to a legacy in this text, it is plausible that such a reference to a legacy existed somewhere in the original context, i.e. when Pomponius added his statement or commentary. As stated earlier, the text contained a commentary of Pomponius, or maybe already of Q. Mucius, on a specific legal problem. The word 'Quod' also gives reason to presume that a part is missing before the word 'Quod'. It is impossible to restore the context of the text that preceded the fragment in Pomponius' time; some scholars believe that in the fragments handed down to us (in book eight) there is even too little support to come up with a solution as to the original context. ${ }^{48}$ However, the only possibility to confer a significant meaning to this fragment is to situate it in its original palingenetical (law of legacies) context. The later insertion of the word si in the text of D. 50.17.203 can be explained by the positioning of the text of D. 50.17.203 in the regulae iuris and by the purpose of that title. Justinian described the title de diversis regulis iuris antiqui as a consumation of the whole work, and that whatever is expressed is in the form of a regula (quaeque regulariter definita). ${ }^{49}$

\section{The problem in D. 50.17 .203}

The main problem the text obviously deals with is the meaning of the legal term damnum. The interpretation of damnum, as used by Pomponius or

44 According to Pernice 1895, p. 97f., this can, however, be assumed.

45 Kalb 1890, p. 1lf., 66; - More in general, already Petrus Burmann the Elder (16681741) remarked that the expression damnum sentire was familiar to jurists; see Burmann ad Quintilianus' Declamatio maior XIII.13, ad damnum intellegis, edn. 1720, p. 287.

46 Di Marzo 1961, p. 376; according to this author, the Quod quis ex culpa sua damnum sentit, non intellegitur damnum sentire was already in Quintus Mucius' time a principle with a widespread application: 'quando esteso fosse pur in quell'epoca il senso attribuito a sì fatto principio'.

47 Wollschläger 1976, p. 122 also mentioned the origin of a parallel problem of the societas (see D. 17.2.52.18); he added that the uncertain dating of the partitio legata (after $169 \mathrm{AD}$; see Stiegler 1968, col. 1037ff.) certainly left the possibility open that Quintus Mucius himself formulated the rule of partitio (this will be discussed below), so that it was Pomponius who limited the rule.

48 Also Medicus 1962, p. 323 nt. 13; Wollschläger 1976, p. 119.

49 Constitutio Tanta, 8; Stein 1966, p. $114 \mathrm{f}$. 
already by Quintus Mucius, would currently be classified as a restrictive interpretation. Roman jurists, however, treated declaratory, ${ }^{50}$ extensive and restrictive interpretation (as it would be referred to today) as an explanation of words and even what we today call analogy was treated as a way of explaining words. Roman jurists used essential descriptions containing the verbs esse, intellegi, videri and contineri, with which they always indicated these kinds of interpretations of legal notions. ${ }^{51}$ Already from the use of the verb intellegitur, one can conclude that an interpretation, in this case specifically of the word damnum, is concerned.

Some scholars argue that the first damnum is damnum in the sense of 'disadvantage', and that the second damnum is used in a more narrow sense, i.e. in the sense of an unknown norm, as commented upon here by the Roman jurist. ${ }^{52}$ Does the second damnum (in accusativus singularis) indeed differ from the first damnum? The second damnum is used in (direct) connection with sentire and has to be seen in this light as damnum sentire..$^{53}$ By sentire damnum, (financial) loss resulting from the damage of a corporeal object is meant. Elementary also is the connection with intellegitur: is the damage mentioned in the first words of D. 50.17.203, 'because someone who suffers a loss' (quod quis damnum sentit), also considered (intellegitur) as damage? The question is whether in this specific case, of which the details are unknown to us, the (financial) loss resulting from the damage of a (material) object could be explained as damnum in the legal sense. If someone suffered damnum in the legal sense, because of that fact, the injured party could justly take legal action (i.e. sue the wrongdoer before the praetor) on the ground of negligence (culpa). ${ }^{54}$

50 With declaratory interpretation 'einfache Wortauslegung' is meant; see Wesel 1967, p. 45.

51 See Wesel 1967, p. 42ff.

52 Wollschläger 1976, p. 119; according to Arangio-Ruiz 1958, p. 222 nt. 1, it is clear that the first damnum in D. 50.17.203 is used in the economical sense of disadvantage, the second damnum is used in the legal sense of harm/damage that can be compensated or repaired; therefore, the emendation of Mommsen, who cancels the second damnum, does not have to be accepted; also Arangio-Ruiz 1958, p. 222 nt. 1, argues that it is not permissible to cancel the second damnum.

53 See also VIR II, col. 13.

54 VIR I, col. 1078. 
Possibly, the second part of D. 50.17 .203 is a fiction. If the damage suffered was the consequence of one's own negligence, the damage caused to the harmed person was presumed not to be damnum. This linguistic use of intellegere is quite common in fragments by Pomponius. Also in D. 46.3.16 the verb intellegere is used as a fiction: someone, i.e. the debtor, is considered to have been released from his debt some time earlier, whereas in fact he was not.

However, considering the close connection in Roman times between rhetoric on the one hand, and law and politics on the other hand (see next section), and the acquaintance with rhetoric, a different interpretation is very well possible. It is plausible that when the jurist wrote the lines of D. 50.17.203, he considered the case to be a problem of definitio (whether the damage could be considered damnum) and argued his case on the basis of a locus a differentia (a distinction between what was damnum and what was not damnum based on the fact that the loss was incurred because of one's own negligence) ${ }^{55}$

In view of the original context, i.e. the original legal case in which Pomponius made his comment ( $c f$. pal.: De legatis), one can assume that the text was an interpretation of a rule of the law of legacies containing the word damnum. The rule had to contain the word damnum and had to leave room for interpretation. In addition, in the case Pomponius was replying to, he obviously aimed to interpret this notion in a way which allowed him to solve the problem that arose in that particular case. Otherwise, no question concerning this case would have been asked, or at least the jurist would not have replied in this way. There must have been a case concerning a legacy for which Pomponius found it necessary to define or interpret the legal term damnum more closely. Can we find fragments dealing with the law of legacies that include the word damnum and comment on it?

The casus of D. 50.17 .203

\section{The view of Aumann}

In recent history, two scholars have tried to elaborate a possible context. The first scholar, Aumann, provided two possibilities. The first possibility is that the text originally may have indicated that the invalidity of a legacy must not be considered to be to the disadvantage of the testator because the testator had the possibility to change his last will and make another effective legacy, ${ }^{56}$ which he apparently did not do, and, thus, was to be seen as his own negligence

55 On the locus a differentia, see Quintilianus, Institutio Oratoria, V.10.58-63.

56 Aumann 1964, p. 30. 
(culpa). This possibility is mentioned by Aumann; however, I cannot think of what kind of damnum Aumann had in mind here. To support his statement Aumann refers to Lenel's Palingenesia. Lenel located D. 50.17 .203 (pal.nr. 260) next to a number of other fragments on legata (pal. nr. 254-259). The fragments contain texts about the effectiveness of legacies as well as texts concerning the question whether the fulfilment of an obligation (Auflage) can be enforced. Does this possibility indeed make sense? A person would consult a jurist to receive advice on a specific (legal) problem, in this case that he had made a testamentary arrangement that would not become effective. Why would it not become effective? Is it plausible that the jurist replied that the damage was not considered damnum in the legal sense because the testator had the possibility to make another effective statement? It is not clear what the damage/loss in that case would be. It is more likely that the word damnum refers to damage of the legatee. In that case the second possibility provided by Aumann, as we will see, seems to make more sense.

The second explanation is that D. 50.17 .203 referred to the relationship between the legatee and the heir. It is possible that Pomponius discussed the legal consequences that occur when the legatee himself made it impossible for the heir to pay out the legacy. Let me explain this further: suppose D. 50.17.203 concerned a legatum per damnationem. An object is bequeathed to a legatee, but initially the heir acquires the ownership and becomes, as a debtor, obliged to transfer the object to the legatee (by traditio or mancipatio). The legatee has a legal claim on the heir. This type of legatum was connected with a personal actio ex testamento. Depending on the content, the formula of the legatum was a formula certa with quanti ea res est or a formula incerta with quidquid... dare facere oportet.$^{57}$ Accordingly, in case of a formula certa, it concerned a certain sum of money, a certain individual thing or a definite quantity. ${ }^{58}$ In case of a formula incerta, it concerned neither certa pecunia nor certa res or quantitas, but, for example, an obligation to do something. In any event, when the legatee himself made it impossible for the heir to pay out the legacy, the legatee was to blame and, therefore, seemed to be suffering no harm. ${ }^{59}$ An actio ex testamento was not given in such a case.

57 Kaser 1971, p. 109ff., p. 742ff. On the post-classical development of legatum, see Kaser 1975 , p. $549 f f$.

58 Lenel 1985, p. 232; Schulz 1992, p. 476 f.

59 Aumann 1964, p. 30. 
The view of Wollschläger

A different attempt to reconstruct the original case is provided by Christian Wollschläger. In his opinion, D. 50.17.203 most likely refers to a specific case, namely, a compensation for damages in a case of a legatum partitionis (an explanation of this legal concept will follow below).$^{60}$ Wollschläger refers to Aumann, who argued that in the original case upon which Pomponius most likely commented, the legatee himself could be blamed for the fact that he made the fulfilment of the legacy impossible. ${ }^{61}$ In such a case, an actio ex testamento would not be granted. The denial of a remedy to the legatee was obviously based on the idea that the legatee had not suffered damnum in the legal sense. One could, however, respond that by way of the regular actio certi ex testamento, the value of the object, the quanti ea res est could be claimed ${ }^{62}$ In the rarer cases of legacies of an incertum, with the actio directed at quidquid dare facere oportet, the judge had more discretion to assess the damages than in a case of a certum. In the sources this kind of condemnatio is always qualified as quod interest, ${ }^{63}$ but nowhere as damnum. ${ }^{64}$

Most likely the term damnum originally had a more specific meaning than just loss or damage (in the legal sense), namely, the total loss of a specific object. ${ }^{65}$ In a legal context, later this term was defined as any damage to property as determined in the third chapter of the lex Aquilia ${ }^{66}$ This fragment may have concerned an argument applied in the context of the law of legacies commented on by Quintus Mucius (second/first century BC) or a statement made by Mucius on which Pomponius (second century AD) commented. The damages resulting from the withholding of a legacy could not be called damnum, provided 'complete loss of a concrete object' was still the usual

60 Wollschläger 1976, p. 119; an explanation of partitio (legata) can be found in Kaser 1971, I, p. 745 .

61 Aumann 1964, p. 30.

62 Medicus 1962, p. 212; Kaser 1971, p. 743; Wollschläger 1976, p. 120.

63 For the sources, see Medicus 1962, p. 213 nt. 4, p. $221 \mathrm{ff}$.

64 Wollschläger 1976, p. 120; the word 'damnum' is missing in the fragments of the commentaries on Sabinus' commentary on the ius civile which were categorised by Lenel under 'Si ex testamento agatur'. See D. 42.2.8, which is part of the fourth book of the commentary of Paul on Sabinus; see Lenel, Palingenesia iuris civilis, II, pal. nr. 1674. See also D. 30.37 and D. 30.39 pr.- $\$ 6$, both part of the twenty-first book of Ulpian's commentary on Sabinus, which were categorised by Lenel under the subtitle 'Si ex testamento agatur?' (pal. nr. 2618f.). In a footnote to this subtitle, Lenel referred back to the commentary of Paul in book IV of his commentary on Sabinus). The word 'damnum' is also missing in the Roman law texts concerning the quidquidformula cited by Kaser 1950, p. 346f. (nt. 45).

65 Liebs 1968, p. 25lf. The meaning of damnum indicating the loss of a concrete object is still used by literary sources, such as Horatius. See Epistulae, I.17.57; I.7.88; Sermones, II.3.300; see for a more elaborated view on this topic Liebs 1968, p. $196 \mathrm{f}$.

66 See Liebs 1968, p. 189 ff., $251 f$. 
meaning in the time of Pomponius. In the event one assumes that the text concerned a legatum per damnationem, the legatee would not receive any object (from the inheritance). Accordingly, none of his property was damaged since no object was transferred to him and, thus, never became his property. ${ }^{67}$ In that case, the legatee still had not yet received any object belonging to the inheritance that could be taken away from him or be damaged. Therefore, the damage to which D. 50.17.203 refers must have occurred to the detriment of the heir who was still in possession of the object and for which the heir was responsible. ${ }^{68}$ The heir might have tried, unfairly, to shift the financial loss to the legatee by maintaining that he was not liable for the fact that the object was completely gone. To further concretise this possibility, another source, i.e. Gaius (second century AD), may provide the necessary information.

Investigating Gaius' Institutiones (ca. 160/161 AD), one notices that the word damnum only occurs in one actual case concerning the law of legacies. ${ }^{69}$ The relevant text is Gai. Inst. 2.254, in which a rule is given for the partition of an inheritance, namely, the partitio legata..$^{70} \mathrm{~A}$ legatum partitionis included the instruction to share the inheritance with the legatee in a certain proportion: My heir will share, split my inheritance with Titius (heres meus cum Titio hereditatem meam partitor, dividito $).{ }^{71}$ In the classical period it came to be understood as a legatum per damnationem of an incertum. ${ }^{72}$ The testamentary will containing a legatum partitionis granted part of the inheritance to the legatee. The partitio legata implied no real succession by two heirs, only a partition of the patrimony; in external relations, the heir remained the sole heir and the debts of the inheritance and all legal claims remained his. Only in their internal relation was a settlement made between the heir and the legatee. However, there was the problem of distribution of the profit and loss (lucrum and damnum) during the period after the acceptance of the inheritance until

67 This argumentation applies, unless the text nevertheless referred to a legatum per vindicationem.

68 Wollschläger 1976, p. 120.

69 All in all damnum is, in addition, (only) used in relation to the lex Aquilia (Gai. Inst. $3.210 \mathrm{ff}$.), the actio furti (Gai. Inst. 4.37ff.), the legis actio damni infecti (Gai. Inst. 4.31) and the societas (Gai. Inst. 3.149f.). See also Gai. Inst. 2.258 on hereditas damnosa.

70 See on the partitio (legata) Cicero, De legibus II.20.50; Cicero, Pro Cluentio VII.21; Cicero, Pro Caecina IV.12; Labeo-Iavol. D. 32.29.1; Iavolenus D. 28.6.39pr.; Gai. Inst. 2.254ff.; also the Laudatio Murdiae (1st cent. AD) in FIRA III, p. 218f.; Biondi 1955, p. 440ff.; Grosso 1962, p. 20 nt. 1, 272ff.; Metro 1963, p. 291ff.; Voci 1963, p. 343f.; Stiegler 1967, p. 357ff.; Stiegler 1968, cols. 10331049.

71 Ulpiani Epitome XXIV, 25 (edn. Avenarius 2005, p. 56f., with German translation: 'Mein Erbe soll mit Titius meinen Nachlaß teilen, aufteilen'; also FIRA II, p. 293 (PARTITOR); and Schulz 1926, p. 55 partito)).

72 Kaser 1971, p. 745. 
the partition actually occurred. ${ }^{73}$ Before splitting up the inheritance, the legatee was entitled to receive part of the profits from cashed claims (debts? payments?) and he was also liable for part of the expenses involved with obligations of the estate. Lucrum and damnum are adjusted as assets (activa) and liabilities (passiva), respectively, in the calculation of the patrimony to be split up..$^{74}$ With regard to the period after the partition, the parties stipulated verbal contracts (contractus verbis) in which they agreed that future claims and obligations would be settled mutually: stipulationes partis et pro parte (Gai. Inst. 2.257). The heir promised to give his part of the received assets/claims to the legatee, the legatee promised to cover part of the expenses (involved with debt fulfilments).$^{75}$ Gaius describes the purpose of such stipulations with the words: ut et lucrum et damnum hereditarium pro rata parte inter eos commune sit (Gai. Inst. 2.254). ${ }^{76}$

Quintus Mucius was acquainted with the partitio legata. ${ }^{77}$ In his Ius Civile he would have dealt with the just-mentioned rule that lucrum and damnum go on joint account. Obviously, there was a rule that if an heir had to incur certain expenses, he could recover a part of the expenses (damnum) from the legatee. However, such a rule would not apply in all cases, for then it would be too broadly formulated because it would allow the heir to proportionally shift a damnum, for which he himself was liable, to the legatee. ${ }^{78}$ Wollschläger gives an example of a trial in which someone pretended to have a claim on the inheritance, which claim in reality did not exist. If the heir in such a case lost the trial, as a consequence he would have to pay for a non-existing claim ( $c f$. D. 17.2.52.18). The payment could be qualified as damnum and become a reduction in the amount of the patrimony to be split up, or it would become part of the compensation the legatee promised to hand over. ${ }^{79}$ To avoid such a result, the principle had to be limited by an exception for damages that the heir himself was to blame for.

73 Wollschläger 1976, p. 121. From Cicero we know that Quintus Mucius did know the partitio legata; see Cicero, De legibus II.20.50; see also D. 32.29.1 where Labeo refers to Quintus Mucius; also Stiegler 1968, col. 1037ff. According to Wollschläger 1976, p. 121f., Quintus Mucius shall also have treated the fragment in his ius civile, in which lucrum and damnum originated in the same calculation; probably in the style of the law of the societas omnium bonorum.

74 Stiegler 1968, col. 1044f.

75 ibid., col. 1044.

76 According to Wollschläger 1976, p. 121, one can conclude that those stipulations were not used for the time before the distribution of the inheritance, and that, therefore, there was an independent rule provided by the ius civile. See also Stiegler 1968, col. 1044f.

77 See n. 73 above.

78 Wollschläger 1976, p. 122.

79 ibid. 
In that case the exception of D. 50.17.203 is relevant: one has to distribute the damnum, but not the above-mentioned damnum resulting from the (own) culpa of the heir. ${ }^{80}$

\section{A concretisation and a further elaboration on Aumann's theory}

Seen from the above perspective the first theory of Aumann seems unlikely, the second theory makes more sense. But from Aumann it is not quite clear what the legatee could have done to hamper the conveyance of the legacy. On the other hand, Wollschläger's theory seems possible, but is rather complicated.

Aumann's view on this text can also be concretised. In case of a legatum per damnationem, it could be that the legatee refused to accept the legacy. If one assumes that the case concerned a legatum of a certum, e.g. a horse, the heir had to feed and take care of the horse. If the legatee was not at home (deliberately) every time the heir tried to deliver the horse, the heir might consider the feeding and caring for the horse too costly or time-consuming and decide to sell or slaughter the horse. A second possibility is that there was a suspensive condition to the legacy the legatee refused to fulfil. An example of the last option would be a legacy of two slaves under the suspensive condition that one of them would be manumitted. If the legatee refused to fulfil the condition, he was not considered to suffer any damage (D. 50.17.203).

\section{Concluding remarks on D. 50.17 .203}

The conclusion is that D. 50.17.203 had no general validity in classical Roman times. However, with Justinian's Constitutio Tanta/ $\Delta \dot{\varepsilon} \delta \omega \varkappa \varepsilon \nu$ (533), the Institutes and the Digest acquired the status of individual constitutions enacted into law, and, thus, became equal in force. ${ }^{81}$ The compilers extracted D. 50.17.203 from its original context in Pomponius' work and designated it as a 'regula'. Because the compilers were the first to formulate the sentence as now known in the Digest, this sentence could become one of the bases for the later medieval

80 ibid.

81 Van der Wal \& Lokin 1985, p. 31f.; - The Codex (529), however, did not provide new authority and did not transform the constitutions into a new constitution of the year 529, but they remained separate enactments with their force of law; see also Lokin 1976, p. 34; Van der Wal \& Lokin 1985, p. 35; Radding \& Ciaralli 2007, p. 135. This is important because if it had become a new autonomous constitution, the relation between the constitutions would have changed as well as their interpretation; see Scheltema 1966, p. 346. Neither did the Codex repetitae praelectionis of 534 have the authority of an autonomous enactment. The constitutions continued to be in force as promulgated by earlier emperors and dated on previous times, what is important with regard to D. 1.4.4: lex posterior derogat legi priori. Apart from the applicability of this rule on the constitutions inside the Codex, it may also be applicable in case of an inconsistency between the three parts of the compilation of Justinian. On this topic also Van der Wal \& Lokin 1985, p. 35; - On the authority of the Institutes, Digest and Codex, see Scheltema 1966, p. $344 \mathrm{ff}$. 
theory of contributory negligence.$^{82}$ Because of the formulation as a regula, it was generally set up as an abstract principle, both valid for delictual ${ }^{83}$ and contractual remedies. ${ }^{84}$ Someone who suffered disadvantage resulting from his own negligence, in a legal sense was not considered to have suffered damage for which compensation could be claimed. Although in some cases the facts would give rise to compensation, the injured party would not be granted a remedy because of his contributory negligence. ${ }^{85}$

\subsection{Alfenus' reply in the CASE Of the inNKeEPer ${ }^{86}$}

\subsubsection{The text of D. 9.2.52.1}

\section{Alfenus libro secundo digestorum. ${ }^{87}$}

Tabernarius in semita noctu supra lapidem lucernam posuerat: quidam praeteriens eam sustulerat: tabernarius eum consecutus lucernam reposcebat et fugientem retinebat: ille flagello, quod in manu habebat, in quo dolor inerat, verberare tabernarium coeperat, ut se mitteret: ex eo maiore rixa facta tabernarius ei, qui lucernam sustulerat, oculum effoderat: consulebat, num damnum iniuria non videtur dedisse, quoniam prior flagello percussus esset. Respondi, nisi data opera effodisset oculum, non videri damnum iniuria fecisse, culpam enim penes eum, qui prior flagello percussit, residere: sed si ab eo non prior vapulasset, sed cum ei lucernam eripere vellet, rixatus esset, tabernarii culpa factum videri.

82 Luig 1969, p. 193.

83 Haymann 1921, p. 362; Cohen 1956, p. 323 n. 6. See also Arangio-Ruiz 1958, p. 222, who applies the maxim to the socii.

84 Aumann 1964, p. 31; for a more elaborated discussion on the application of D. 50.17.203 in different areas (of law), see Wollschläger 1976, p. 122ff; on 'contributory negligence' in other areas, see, e.g., Luig 1969, p. 195; Jansen 2007, p. 657 f.

85 Aumann 1964, p. 31.

86 This subsection, although slightly different, has already appeared in a Dutch version (see Van Dongen 2009).

87 Besides the editio maior (and editio minor) of Mommsen \& Krüger, see also Bremer 1985, p. $284 \mathrm{nr}$. 6; - It is remarkable that, instead of Alfenus whose name was attached to D. 9.2.52.1, the Basilica reads 'I $\alpha \beta 0 \lambda$ Évov (Iavolenus). 
Apart from some emendations of minor importance, ${ }^{88}$ three peculiarities can be distinguished in this text. The passer-by started beating the tabernarius ${ }^{89}$ with the flagellum, in which something painful was enclosed (in quo dolor inerat ${ }^{90}$ ). The first peculiarity concerns the word dolor. ${ }^{91}$ Mommsen follows the littera Florentina here. However, in the littera Florentina, the rendering of the word can cause some problems. Four characters, dolo, are written at the end of a line. Originally, the rest, the letter $r$, was written on the next line, so it became: rinerat. The ordinary corrector removed the character $r$ and added it to the word dolo.

$88 c f$. edn. Kriegel 1844, p. 196, the vulgate edition contained mitteret; some, however, such as the vulgate edition with the Accursian gloss (in edn. of 1487, fo. 167r) contain dimitteret. This latter reading is later followed in the edition of Haloander (edn. 1550, fo. 265v). In the primitiva scriptura of the littera Florentina, see fo. $154 \mathrm{r}$ of the facsimile edition, a second hand (the corrector ordinarius) had changed offoederat into effoderat. With regard to the word consulebat: a more recent emendation has been made into consulebatur, namely, by some manuscripts of the vulgate. This (first) emendation is provided by Paris BN, lat. 4450, fo. 97r, a manuscript of the Digestum vetus of the end of the 1lth or beginning of the 12th century (close in age to the older Ms. Biblioteca Vaticana, vat. lat. 1406), as well as by the emendation made in Ms. Padova, Bibl. Univ. 941, fo. 91v. This reading is also provided by Ms. Leipzig, Univ. bibl. 873, fo. 80v (the latter two manuscripts from the mid 12th century are later in date than that of Paris BN, lat. 4450, and cannot really help to unravel textual problems; conventions were already standardising the text by then, while copies made earlier were now rendered obsolete by an apparent abundance of manuscripts that met the new norms; see Radding \& Ciaralli 2007, p. 210). In the Florentina, someone has indeed written the characters 'UR' above/between the words consulebat and num. Instead of percussit the edn. of Haloander contains percussisset (edn. of 1550, fo. 265v).

89 The second time the word tabernarius appears in the littera Florentina, it is written as tauernarius. See fo. 154r of the Florentina. At first sight, it seems that the copyist initially intended to write something else but then wrote a 'u' over it. This reading is confirmed by the edition of Torelli of 1553, I, p. 217, the first edition fully and directly based on the littera Florentina, in which the second time the innkeeper appears in the text he is referred to as taUernarius. A more recent emendation seems to have been made to the original text (where a 'u' was written), namely, by the littera vulgata ( $c f$. edn. Kriegel, 1844, p. 196, which contains tabernarius). Also the critical edition of Gebauer-Spangenberg of 1776, p. 177, contains tabernarius. At the end of the text the littera Florentina contains tubernarii instead of tabernarii (it seems as though the copyist first wrote a different letter and afterwards wrote a ' $u$ ' over it). A more recent emendation has been made, namely, by the littera vulgata, into tabernarii; $c f$. edn. Kriegel 1844, p. 196.

90 According to Lenel in his Palingenesia, I, col. 39, Alfenus fragment 7, 'in quo-inerat' could be a (post-classical?, EvD) gloss. This view was also already held by Willem Bilderdijk (1756-1831); see also Van den Bergh 2002, p. 166; Van den Bergh/Stolte 1977, p. 247. In D. 47.10.5.1, Ofilius (also a disciple of S. Sulpicius Rufus') explains that the difference between hitting (pulsare) and beating (verberare) is that beating (verberare) also caused pain and hitting (pulsare) means inflicting blows without pain. In the event a form of verberare is used, possibly in quo dolor is indeed meant as a clarification, i.e. a gloss. To me it seems more a clarification than something really necessary for the comprehensibility of the text, factual as well as legal. Also Bilderdijk argued that the words seem to give an additional explanation on the word 'verberare', which is unnecessary because it is already obvious from D. 47.10.5.1 that 'verberare' leads to the infliction of pain. See W. Bilderdijk, Observationes et Emendationes, XXXVII (edn. 1819, p. 198). Also, in the Digest edition of Bonfante 'in quo-inerat' is considered a glossema (see also Von Lübtow 1971, p. 107); - This phrase has been extensively discussed by various scholars in the early modern period; see, e.g., A. Schulting-N. Smallenburg, Notae ad Digesta seu Pandectas, ad D. 9.2.52.1. This could be relevant: for the question of liability, the type of weapon used by one person to hit another makes a difference. These scholars approached the phrase in a philological way.

91 See on this topic also Van den Bergh \& Stolte 1977, p. $246 \mathrm{f}$. 
The vulgate reads dolor, ${ }^{92}$ and the Glossators apparently did not consider this problematic. An Accursian gloss simply reads: 'Note that (it is said that) there is pain in a whip because it causes pain to others. ${ }^{93}$ Therefore, for the Glossators it was nothing more than a notable turn of speech. ${ }^{94}$

Several humanists, however, followed and propagated the emendation dolon based on a scholion on Vergilius. ${ }^{95}$ Dolon (or dolo) is known as a whip and within the stick of this whip a dagger was hidden. ${ }^{96}$ The first humanist following this emendation was the Italian Philippus Beroaldus (1453-1505). ${ }^{97}$ The emendation was generally accepted after the French humanist Budaeus (1467-1540) endorsed it. ${ }^{98}$ Later, Haloander, Gothofredus and others followed the emendation dolo $(n) .{ }^{99}$ This emendation was no longer followed by Contius, Van Leeuwen and Gebauer, who preferred the reading of the littera Florentina again. ${ }^{100}$

Various explanations and reasons for the emendation into dolon are provided by the humanists and the scholars of the Dutch Elegant School based on legal arguments or on literary sources. To be able to make a good choice as to the plausibility of the emendation, a summary of the most relevant arguments and sources will be given below, starting with the reasons for the emendation based on literary sources.

92 See vulgate edition with the Accursian gloss (in edn. of 1487, fo. 167r); see also Van den Bergh \& Stolte 1977, p. 247. Differently, the edition of Kriegel 1844, p. 196, which contains the reading 'dolon'.

93 Gloss inerat ad D. 9.2.52.1.

94 Van den Bergh \& Stolte 1977, p. 247.

95 Differently Haloander, who is of the opinion that it has to be dolo (edn. of 1550, fo. 265v). Dolo could also already be found in the vulgate manuscript of the Digestum Vetus, Paris, Bibl. Nat., Lat. 4450, fo. 97r; see Liebs 2000, p. 525; Krampe 2002, p. 134. However, this conclusion seems to be premature. In the manuscript, dolor is written, but the copyist probably made an error because it seems that he corrected it and indicated that the ' $r$ ' had to be removed (two points, one above and one underneath the ' $r$ '). See Paris, Bibl. Nat., Lat. 4450, fo. 97r.

96 Already Servius (4th cent. AD), in his commentary to Aeneis VII.664; Gebauer/ Spangenberg 1776, p. 177f. Also Heumann \& Seckel 1907 (reprint 1958), p. 156, s.v. dolon classified D. 9.2.52.1, and only this text, under dolon ( $\delta \dot{\delta} \lambda \omega \nu)$. Their explanation: 'ein in einem Stoße verborgener Dolch, Stoßdegen'; according to VIR II, kol. 323, the meaning of dolo corresponds with that of pugio, which means dagger.

97 See Servius, Commentarius in Vergilii Aeneidos VII. 664 (edn. Beroaldus and Badius 1501, fo. $237 \mathrm{v}$.

98 Van den Bergh \& Stolte 1977, p. 247. See G. Budaeus, Annotationes, ex D. 9.2.52.1 (edn. 1557, p. 166); and see also after him, e.g., U. Zasius, Commentaria, ad D. 9.2: In eadem l[ege $] \S$ Tabernarius [D. 9.2.52.1], dicitur: Flagellum in quo dolor inerat: corrige, dolon; F. Hotman, Opera, ad Inst. 4.3 (col. 745): 'dolon (sic enim legendum puto, non dolor)'.

99 In Haloander the $n$ is missing so the reading was dolo; Van den Bergh/Stolte 1977, p. $246 \mathrm{ff}$.

100 See H. Brenkman, Apparatus on D. 9.2, note dolor (1) ad D. 9.2.52.1 (edn. Van den Bergh/Stolte 1977, p. 300f.); Van den Bergh/Stolte 1977, p. 247f.; nota in quo dolor in the edition of Gothofredus/van Leeuwen (edn. 1663, p. 177); Gebauer/Spangenberg 1776, p. 177. 
The word dolon is rather complicated, as is proven by various works of humanistic writers, because it has more than one meaning. ${ }^{101}$ The most important place where the word dolon is found, and this is already referred to by Beroaldus, is the commentary of Servius Honoratus Grammaticus (early fifth century) on Vergilius' Aeneis (VII. 664). Two different meanings of this word are provided: either a whip, with a dagger hidden in its stick; ${ }^{102}$ or, according to (Servius' record of) Varro, a large javelin with a very small sword. ${ }^{103}$ In particular, the first meaning (the leading view) has been extensively commented upon. In this view dolones are said to be hidden and deceptive: they contain an iron object, but appear to be made of wood. ${ }^{104}$ A Greek word (dolon) was used to express deception and this word had to be dolo, since the deception lay in the material of the object. ${ }^{105}$ Another source that affirms this meaning is Hesychius of Alexandria (fifth century AD), who explained dolones as daggers concealed in a wooden sheath. ${ }^{106}$ Also Isidorus of Sevilla (ca. 560-636) referred to sword-canes (dolones) as wooden sheaths in which a dagger is concealed with the appearance of a cane. Sword-canes are named after 'guile' (dolus), because they trick and deceive by having an iron blade hidden within under the guise of wood. Commonly, people called them by the Greek name $0 \xi \dot{\xi} \varsigma$, which means 'sharp. ${ }^{107}$ This view has been contested

101 See, e.g., G. Budaeus, Annotationes, ex D. 9.2.52.1.

102 The emendation dolon (dagger) was followed by various jurists of the Dutch Elegant School, e.g., E. Bronckhorst (1554-1627) and G. Noodt (dolo (n)), based on the first meaning of dolon provided in Servius' commentary on Vergilius' Aeneis VII.664. See, e.g., K.F. Walch in: EckhardWalch, Hermeneutica Juris, I.3 §104, p. 190; E. Bronckhorst, Commentarius, ad D. 50.17.203; G. Noodt, Ad legem Aquiliam liber singularis, c. XIX, p. 143; E. Otto, De vita ... P. Alfenus Varus, cap. 5 $\S 5$, p. 230f.; also nota in quo dolor in the edition of Gothofredus/van Leeuwen 1663, who referred

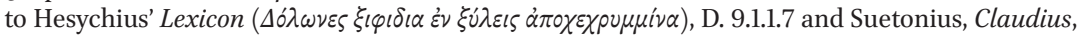
$\mathrm{XIII}<.1>$. It is interesting that the author of the gloss argues that also in D. 9.1.1.7 dolone has to be read instead of dolore. On this point see also W. Bilderijk, Observationes et Emendationes, XXXVII. A comparison with D. 9.1.1.7 has also been used by the Spaniard Gregorio Mayáns y Siscar (Gregorius Majansius; 1699-1781) as (part of) the basis to suggest the emendation of dolo $(n)$ in D. 9.2.52.1 instead of dolor; - See also Ammianus Marcellinus, Res gestae, XXX.1<.21, $\mathrm{EvD}>$ (found in the handwriting of Schulting in the edn. of the Corpus Iuris of Gothofredus/Van Leeuwen 1663 available in Leiden (759 A 35)), where dolon is used in the meaning of 'dagger'.

103 The fragment of Varro can also be found in the Grammaticae Romanae Fragmenta, repr. edn. 1969, nr. 425 (p. 360f.): dolo est - secundum Varronem ingens contus cum ferro brevissimo. Dolones autem a fallendo dicti sunt, quod decipiant ferro, cum speciem praeferant ligni. The edition continues with other references, namely, that of Servius' commentary on Vergilius, Aen., VII.664, Isidorus of Sevilla, Etymologiae, XVIII.9.4 and Aelius Donatus' commentary on Terentius' Eunuchus III.3.9, ad dolo malo omnia fieri haec. In the final reference, Donatus explained dolones as war spears (tela bellica); - Rich 1860, p. 247, formulated the meaning of dolon (or dolo) as follows: 'a long and strong stick, with a small sharp iron point at the extremity'.

104 See Servius, Commentarius in Vergilii Aeneidos VII.664 (edn. Beroaldus and Badius 1501, fo. 237v and Ramires et al. 2003, p. 90). See also Constanzo Landi, Exercitat., ex D. 9.2.52.1.

105 G. Budaeus, Annotationes ad D. 9.2; apparently an etymological connection was seen here (dolus-dolo), which is questionable.

106 See also the notae of Johannes Scheffer to Phaedrus, Fabulae Aesopiae, III.6.3, ad dolone; Conradus Rittershusius' comment to Phaedrus, Fabulae Aesopiae, III.6.3, ad dolone; C.G. Heyne in his critical apparatus ad Vergilius' Aeneis VII.664, ad dolone.

107 Isidorus of Sevilla, Etymologiae, XVIII.9. 
at a relatively late time, by Willem Bilderdijk (1756-1831) ${ }^{108}$ who rejected the emendation dolon. He argued that if this interpretation were true, the swordcane (dolon) could not be inside the whip, since it had to be understood that the dagger was concealed in the whip. However, it was not common usage to strike somebody with a dagger, and the text very clearly states that the passer-by beat (verberare) the other person with a whip. Bilderdijk argued that it was certainly not common to use a dagger in this way (for beating), nor to use the weapon for a purpose other than the usual one, nor to hide a dagger in a whip. Furthermore, it is not plausible that someone whose eye was knocked out in a fight having this weapon would refrain from using it according to its original purpose, in the way best fit for his defence. ${ }^{109}$

A third meaning of the word dolon based on (literary) sources is the use of dolon as a (short) sword. ${ }^{110}$ This sword would have been a short and curved one, a concealed short-sword, in Latin called 'sica', i.e. a dagger which one used to engird oneself. ${ }^{111}$ However, this meaning is contested by the German humanist Ulrich Zasius (1461-1535), ${ }^{112}$ who argued that it is wrong to call dolones swords (sicas), because, although commonly used in his time, dolones were whips, in which tenuous branches protected the sting. ${ }^{113}$

108 He is called 'a marginal figure of the Dutch Elegant School' by Van den Bergh 2002, p. 100; on Bilderdijk see also Van den Bergh 2002, p. 165ff.

109 W. Bilderdijk, Observationes et Emendationes, XXXVII (edn. 1819, p. 198f.).

110 See Suetonius, Claudius, XIII.1 (dolon as a sword-cane); and also Suetonius, Domitianus, XVII.1, where, based on the conjecture of the Renaissance lawyer Jacobus Ferrarius, dolonem is written; in this text a certain Stephanus wrapped up his left arm in woollen bandages, pretending he was injured, and concealed a dagger in these bandages (the translation by Rolfe 1979 is used); see also Phaedrus, Fabulae Aesopiae, III.6.3, where dolone is appropriately compared to the sting of a fly; - See also the later critical apparatus of G.A. Ruperti (1758-1839; edn. 1795, p. 203), to the word dolon in T.C. Silius Italicus, Punica III.250, referring to C. Dausque (1566-1644), Chr. Cellarius (1638-1707) and others who interpret the word dolon as pugio; see also the edition of Basilius Faber/Augustus Buchnerus/Cellarius 1692, col. 826, who referred to Donatus' commentary on Terentius' Eunuchus III.3.9; [Servius ad] Vergilius, Aeneis VII.664; Hesychius' Lexicon; Plutarchus, Tiberius Gracchus X.7 and Suetonius, Claudius, XIII.1.

111 See Plutarchus, Tiberius Gracchus X.7 and Th. Reinesius, Variarum lectionum III.17 (edn. 1640, p. 640). See also E. Otto, De vita ... P. Alfenus Varus, cap. 5 §5, p. $230 f$., who gave two interesting references, namely, to the word 'Dol(c)k' in the Otfired von Weißenburg' Evangelienbuch [III. c. 25 ] and the name of the title 'De dolg' in the Frisian Leges Frisionum [titulus 22], which means, however, 'on wounds' here.

112 On Zasius see, e.g., Wolf 1963, p. 59ff.; Stobbe 1965, II, p. 40f.; Stintzing 1978, I, p. $155 f f$.

113 See U. Zasius, Commentaria, ad D. 9.2, nr. 41. 
A fourth meaning of the term dolon is a small sail of a ship. ${ }^{114}$ If the vessel had three masts and consequently three sails, the dolon was the smallest of the three. ${ }^{115}$ Apparently, dolon was a mast with a sail of the same name, which subsequently served for manoeuvring before an action and for escaping after a defeat. ${ }^{116}$ In the context of Livy XXXVI.45.1, dolones had to mean something different, namely, the ends of the sail-yards covered with the sails or just the small sails. The word dolones probably comes from the verb 'to deceive', what was also the case in the events of $191 \mathrm{BC} .{ }^{117}$

The emendation dolon has been explained in history in various ways. Someone (incorrectly) restored an $\mathrm{R}$ instead of an $\mathrm{N}^{118}$ Formerly, the reading could have been dolon, but the $\mathrm{N}$ was partially consumed at the end of the line and thus

114 The meaning of dolon as a small sail of a ship (dolonibus meaning top-sails) can be found in Livy's description of the events of 190 BC (Ab urbe condita XXXVII.30.7), reference to this fragment of Livy is also made by Ramshorn 1841, p. 412, who explains dolon ( $\delta \dot{\delta} \lambda \omega \nu)$, under the heading of the word velum (the sail in general), as 'the small foresail, only used in favorable wind'; and in Livy's description of the events of 191 BC (Livius, Ab urbe condita XXXVI.45.1); see also Livius, $A b$ urbe condita XXXVI.44.2f.

115 See Pollux, Onomasticon, I.91 who argues that this mast was also called $\lambda$ ór $\alpha \sigma \sigma \varsigma ;$ see also Suidae Lexicon, ad $\Delta \dot{\delta} \lambda \omega \nu \varepsilon \varsigma: \tau \dot{\alpha} \mu \varkappa \rho \dot{\alpha} i \sigma \tau \dot{\alpha} \alpha$ (the small sails). A possible meaning of dolon could be a mast (spar) carrying a sail; see Liddell 1940, p. 443. This seems to be supported by the explanation given in the Lexicon, namely, as a 'flying jib'; more extensively in an earlier edition, Liddell 1883, p. 383: 'perhaps a top-sail, used when the wind was too strong for the greater square-sail, or when there was not time to hoist it'; Rich 1860, p. 247.

116 The use of dolons was also mentioned by Polybius, Historiae, XVI.15.2; Diodorus Siculus, Bibliotheca historica, XX.61.8. In an explanatory note of Geer in his English translation (1983), he explains that ' $\delta \dot{\delta} \lambda \omega \nu$ was either a light spear that could be rigged at the prow of the war ship, extending forward like a high bowsprit, or a square sail hung on a crossarm at the end of such a spear. We know of such rig only on Phoenician and Roman craft. Since it could be set up more quickly than the ordinary mast, which was stowed before the battle, it seems to have been used here often.' See on this topic also Torr 1964, esp. p. 87, who argued that Diodorus Siculus is perhaps misquoting his authorities, since at that time the ships might have used akatians. Finally, also Procopius (De bello Vandalico, I.17) mentioned dolons when describing Byzantine warships in $533 \mathrm{AD}$; he described dolons as small sails and distinguished them from large sails. Torr 1964, p. 87, argued that this fragment is an adaptation of Xenophon, Hellenica, VI.2.27. Furthermore, he argued that the name must have been obsolete for centuries, then revived as a classical term for the smaller sort of mast or sail; - Rich 1860, p. 247 described dolon as a small fore-sail on a ship with more than one mast, carried over the prow, and attached to the foremast (with reference to the explanation of dolo in Isidorus of Sevilla, Etymologiae, XIX.3.3); he refers to an (annexed) illustration of a ship, from a bas-relief of Villa Borghese.

117 In the events of $191 \mathrm{BC}$ as described by Livy, Polyxenidas raised his top-sails (dolonibus) and due to that was able to flee from his enemy and thus deceived him; see the comment of Marcellus Donatus as reproduced by A. Drakenborch in note ad sublatis dolonibus effuse fugere intendit ad Livium XXXVI.45.1

118 Meaning a whip, of which the stick contained a dagger; see the French scholar Pardulphus Prateius (Pardoux Duprat, ca. 1520 - ca. 1570), in his Jurisprudentiae Mediae, IV.XI. 
became an R. ${ }^{119}$ Also, several legal reasons for the emendation dolon have been stated by the humanists.

1. Hermann Cannegieter (1723-1804) provided a profound explanation of the multi-faceted concept of dolon. In addition, he also argued that verberare meant to hit with a dagger and pulsare to hit without a dagger. According to Cannegieter, dolones (pikes or sword-sticks) also cover whips, staves or even wooden sheaths, in which a spike is hidden under the disguise of a staff. ${ }^{120}$

2. According to Idzert Eekma (1785-1852), more cases could be found in Roman law in which dolor was written instead of $<$ the right word $>$ dolon, and one of them is D. 9.2.52.1. Pain (dolor), considered as animi adfectus, could not be contained in a whip; dolon, on the contrary, could be put in a whip: a wooden object could contain a little sword, and in the same way a dagger could be hidden in the stick of a whip. ${ }^{121}$

Finally, the humanist Antonius Faber (Antoine Favre, 1557-1624) believed the word dolor should not be read as 'dolor' as Accursius did, but as 'dolori. ${ }^{122}$ This interpretation is grammatically possible because the verb 'inerat' can go together well with a dativus. However, this view was not adopted by other humanists nor by modern scholars.

With regard to classical Roman law, 'dolor' seems to be the best word to use. It seems preferable to follow the littera Florentina, it being the most authentic manuscript and also because dolor in the sense of pain seems plausible.

The second problem concerns the word 'non' in the statement num damnum iniuria non videtur dedisse. ${ }^{123}$ In the littera Florentina, the word 'non' is placed between quotation marks. ${ }^{124}$ It is not clear what the meaning of these marks

119 See J.G. Marckart, Probabilia receptorum lectionem Juris Civilis, I, ad D. 9.2.52.1 (edn. 1737, p. 136ff.); see also H. Brenkman, Apparatus on D. 9.2, note dolor (1) ad D. 9.2.52.1 (edn. Van den Bergh/Stolte 1977, p. 300f.), concluding that although the littera Florentina contained the word dolor, it should, without any doubt, read 'dolon.'

120 H. Cannegieter, Commentarius ad Fragmenta veteris jurisprudentiae, p. 106f.; see also J. van der Linden, Adnotationes ad Voet's Commentarius ad D. 9.1, nr. 5 (edn. Gane 1955, p. 539).

121 I. Eekma, Dissertatio iuridica inauguralis, p. 74f.

122 A. Faber, Rationalia in Pandectas, ad D. 9.2.52.1.

123 A different possible reading is provided by Van de Water: 'consulebatur, damnum injuria num videtur dedisse'. According to Van de Water, the same reading should apply in, e.g., D. 40.1.6. See J. van de Water, Annotatio ad Pandectas, num damnum etc. ad D. 9.2.52.1 (handwriting in edn. Gothofredus/Van Leeuwen of 1663; I consulted a copy with signature 759 A 36 in the University Library of Leiden).

124 See fo. 154r of the facsimile edition of the Florentina; also the edition of Torelli, which 
is; I suppose the copyist doubted the appropriateness of this term. The littera vulgata ${ }^{125}$ also contains non but without quotation marks. ${ }^{126}$ Whatever the meaning of the quotation marks might have been, there seems to be no reason to delete the word non in this fragment. ${ }^{127}$ Already Johannes Marckart (1698-1757) argued that the question whether non had to be deleted or not and whether this question had to be read in an affirmative or in a negative way is of little importance. ${ }^{128}$ From a legal perspective, in my opinion he is right; however, from an argumentative perspective as well as a philological perspective the question remains interesting and relevant.

A third peculiarity concerns the word videtur. ${ }^{129}$ In the littera Florentina, the characters 'RE' have been written above videtur. ${ }^{130}$ Such a correction into uideretur was also made by a more recent (but medieval) emendation in the littera vulgata. ${ }^{131}$ However, other forms of the verb can also be found, e.g. in the manuscript Ms. Padova, Bibl. Univ. 941 in which the text reads uidebitur. ${ }^{132}$ Grammatically, videretur is preferable, because when a dependent clause is used, the verb has to be a subjunctive.

was based on the littera Florentina, contained the word non (see edn. of 1553, I, p. 217).

$125 c f$. edn. Kriegel 1844, p. 196.

126 Also in the later editions of Haloander (the first humanistic edition, I consulted the edn. of 1550, fo. 265v) and of Gebauer/Spangenberg 1776, p. 178. Despite the fact that Gebauer wrote that in the edn. of Haloander 'non' has disappeared, this was a mistake. See A. Augustinus, Emendationum I.2, who argued that a more recent author made an alteration to the littera Florentina and tried to excise the word 'non' by writing '[non]'

127 Already the edition of A. Schulting-N. Smallenburg, Notae ad Digesta seu Pandectas, ad D. 9.2.52.1, stated that the deletion of the word 'non' has to be considered less correct (minus recte). Various humanists were in favour of the reading with 'non' (as the littera Florentina): (of course) Torelli in this Digest edition (the 16th-cent. edn. (1553) of the manuscript of F), A. Augustinus, Emendationum I.2, whose argumentation is also repeated in H. Brenkman, Apparatus on D. 9.2, note non (3) ad D. 9.2.52.1 (edn. Van den Bergh/Stolte 1977, p. 301), S.R. Jauch, Meditationes criticae de Negationibus, p. 9f., I.G. Marckart, Probabilia receptorum lectionem Juris Civilis, I, ad D. 9.2.52.1, p. 138, and (implicitly) also I. Püttmann, Interpretationum et Observationum, cap. 7 §2, p. 31.

128 I.G. Marckart, Probabilia receptorum lectionem Juris Civilis, I, ad D. 9.2.52.1, edn. 1737, p. 138.

129 Also in Paris, Bibl. Nat., Lat. 4450, fo. 97r, 'non videtur dedisse' is written.

130 According to Huvelin 1912, p. 560, the original 'mistake' could easily be explained by a fault of the copyist; in Huvelin's opinion, one would need here an imperfect of the subjunctive.

$131 c f$. edn. Kriegel 1844, p. 196; also in A. Augustinus, Emendationes I. 2, edn. 1544, p. 16 and preferred by Gebauer/Spangenberg 1776, p. 178. Furthermore, H. Brenkman, Apparatus on D. 9.2, note non (3) ad D. 9.2.52.1 (edn. Van den Bergh/Stolte 1977, p. 301) noticed that (almost all) editions have the reading videretur instead of videtur, which is also the reading he himself preferred. Similarly with regard to D. 9.2.52.4, where the littera Florentina reads: 'quaerebatur, an potest', see fo. $154 \mathrm{v}$ of the facsimile edition of the Florentina (the edition of Haloander contained the word posset), and in the wording of D. 9.2.2.2 in the littera Florentina: 'an - continentur, quaeritur', see fo. 147v of the facsimile edition of the Florentina (the littera vulgata contained contineantur).

132 Ms. Padova, Bibl. Univ. 941, fo. 91v. 


\subsubsection{Translation of D. 9.2.52.1}

\section{Alfenus in the second book of his Digest}

An innkeeper had placed his lantern at night on a stone at a path; ${ }^{133}$ someone took it when passing by. The innkeeper pursued him, ${ }^{134}$ demanded the lantern back, and got hold of the person running away; he (i.e. the passer-by) started beating the innkeeper with a whip which he had in his hand, inside of which ${ }^{135}$ something painful ${ }^{136}$ was enclosed, ${ }^{137}$ so that he (i.e. the innkeeper) would let him go. From this encounter, a real brawl developed in which the innkeeper knocked out an eye of the man who had taken the lantern. He (i.e. the innkeeper) asked for advice as to whether the damage he had inflicted would not be considered unlawful (iniuria), bearing in mind he was hit with the whip first. I answered that unless he had intentionally knocked out the eye, he would not be considered to have caused the damage unlawfully (iniuria), as the culpa lay with the one ${ }^{138}$ who first struck with the whip; ${ }^{139}$ but if he had not been hit by him first, but he had started the brawl when he wanted to get the lantern from him, it seems to have happened as a result of the culpa of the innkeeper. ${ }^{140}$

133 The tabernarius did so outside his taberna. The taberna (shop) could be any kind of building which was fit for habitation, evidently because these were generally closed with boards; see Ulp. D. 50.16.183. Usually it was a place for trade or industry. Many examples can be found in Heumann \& Seckel 1907 (reprint 1958), p. 577, s.v. taberna; differently Huvelin 1912, p. 561, who, based on the circumstances of the adventure and also with reference to D. 23.2.43pr. and D. 33.7.13, translates taberna with taverne, cabaret and tabernarius with tavernier.

134 That is, the innkeeper ran after him to seize him (persequendo adprendere); see VIR I, col. 929.

135 Refers to flagello; see VIR III/1, col. 797.

136 Monro 1898, p. 75: 'a lash with which would inflict severe pain'; Thayer 1929, p. 47: 'in which there was a spike'; d'Ors et al. 1968, p. 394: 'aguijón'; Scott 1973, p. 345: 'and to which an iron was attached'; Otto, Schilling \& Sintenis 1839 (reprint 1984), p. 814: 'worin ein Dolch steckte'; Watson 1985: 'on which there was a spike'; Feenstra/Spruit in: Spruit et al. 1994, p. 741, translate this passage as 'waaraan een scherpe punt zat' and explains in a footnote that they had translated quo dolo inerat; Schipani 2005, p. 262: 'in cui era una punta'.

$137 c f$. Heumann \& Seckel 1907 (reprint 1958), p. 263, s.v. inesse: 'worin enthalten, begriffen sein'.

138 Heumann \& Seckel 1907 (reprint 1958), p. 416, s.v. penes: In übertragenen Sinne zur Bezeichnung der Person, auf der ein nachteiliger Umstand sitzen bleibt: culpam penes aliquem residere (D. 9.2.52.1).

139 This part of the argumentation ('I answered that unless he had intentionally knocked out the eye, he would not be considered to have caused the damage unlawfully (iniuria), as the culpa lay with the one who first struck with the whip') is missing in the text of the Basilica (B. 60.3.51.1), which simply states that the innkeeper was not responsible (on culpa as $\alpha i \tau i \alpha$, see Paschialidis 2008, esp. p. 360). The text of the Basilica continues by stating that if the tabernarius had not been hit first, but he had taken the lantern back, and given rise to a scuffle, he is to be held liable under the lex Aquilia. According to a short explanation in BS 3163/2 (scholion 1 ad B. 60.3.51), no actio legis Aquiliae could be brought against the shopkeeper, as the 'injured party' was the first who hit with the whip. See also Paschialidis 2008, p. 360, who argued that according to this scholion, the passer-by first hit the innkeeper, and that, thus, the incident is not attributable to the shopkeeper.

140 Different d'Ors et al. 1968, p. 394: 'el daño parecía hecho por culpa del posadero'. 


\subsubsection{Inscriptio}

The context of D. 9.2.52.1

This fragment derives from the second book of the Digesta ${ }^{141}$ of Alfenus (Varus). ${ }^{142}$ The Digesta (libri XL) of the (pre-classical) jurist Alfenus is the earliest work of a Roman jurist whose texts occur in the Digest of Justinian. ${ }^{143}$ However, the compilers of the Digest (of Justinian) did not have the original work of Alfenus at their disposal, but only an Epitoma by Julius Paulus, written in the second century (or the beginning of the third century) $\mathrm{AD},{ }^{144}$ and another Epitoma written by an anonymous jurist (probably in the first half of the second century). ${ }^{145}$

As almost six hundred years elapsed between the Digesta of Alfenus and the Digest of Justinian, it is uncertain to what extent it really provides information about the law of the late Republic. ${ }^{146}$ This uncertainty is further increased by the circumstance that the compilers did not have the original work of Alfenus at their disposal and by the fact that in post-classical times texts that were adopted in the Digest were sometimes modified or even interpolated by the compilers.

Neither the original Digest of Alfenus nor the original Epitomae survives to our day. Only the texts included in the Digest of Justinian can be the basis of a (certain) reconstruction of the Epitomae. The original work by Alfenus consisted of forty books; the Pauli Epitomae contained eight books and the anonymous Epitoma ten at the most. ${ }^{147}$ Only one hundred and four decisions of Alfenus survived in Justinian's Digest. ${ }^{148}$ The interpretation of these texts may provide some information about the Epitomae, but hardly about the original Digest of Alfenus. In his Palingenesia, Lenel placed D. 9.2.52.1 in book two of Alfenus Varus' Digesta (ab anonymo epitomata) under the title Ad legem Aquiliam. ${ }^{149}$ According to Lenel, this text, therefore, originally derives from the context of the lex Aquilia. The actio the plaintiff wanted to obtain was the actio legis Aquiliae. ${ }^{150}$ Based on this enactment the injured party, i.e. the one

141 On the tradition of this Digest, see also Roth 1999, p. $20 \mathrm{ff}$.

142 Assuming that the reading of the Basilica is incorrect. For the rest of my exegesis I assume that the text of D. 9.2.52.1 was not written by Iavolenus ( $c f$. the reading of Basilica:

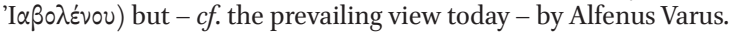

143 Wieacker 1988, p. 107f.

144 In any case before 211 AD; see Roth 1999, p. 185f., 202 and Liebs 2000, p. 522.

145 Roth 1999, p. 201f.; Tellegen-Couperus 2001, p. 382.

146 Tellegen-Couperus 2001, p. 382.

147 ibid., p. 384.

148 Roth 1999, p. 20.

149 Lenel, Palingenesia iuris civilis, I, col. 39, pal. nr. 7.

150 The dating of (the origin of) the lex Aquilia is not certain, but it probably dates from 286 or 287 BC; see, e.g., Kaser 1971, p. 161; Watson 1984, p. 234. 
who suffered damage to his property, could ask the praetor for an actio legis Aquiliae against the wrongdoer. Also the compilers of the Digest placed this fragment under the title Ad legem Aquiliam (D. 9.2).

\section{Alfenus}

The author of this text, Publius Alfenus Varus, ${ }^{151}$ lived during the late Republic and the beginning of the Principate. He was consul suffectus in 39 BC. According to Horace, Alfenus (vafer) remained a sutor (shoemaker) even after having tossed aside every tool of his art and after having closed his shop; ${ }^{152}$ this can be explained in the sense that a man may be actively engaged in one pursuit (being a consul suffectus) yet remain potentially the master of another (a shoemaker) ${ }^{153}$ From the commentary of Porphyrio on Horace, ${ }^{154}$ it appears that Alfenus Varus was born in Cremona and originally was a shoemaker or a son of a shoemaker. ${ }^{155}$ In addition to the meaning of the word sutor as a craftsman working with awl and pitched thread it can also mean a person belonging to the equites who is an entrepreneur and uses slaves to make shoes. ${ }^{156}$ Interpreting the word sutor here in the latter sense is more plausible as it is not likely that Octavian would have raised an actual shoemaker to the consulship. ${ }^{157}$ Besides, only if Alfenus (or already his father) ${ }^{158}$ owned a large-scale enterprise, would he have sufficient capacity to supply the means required in the social order for Alfenus to aspire to a state career and dedicate himself to jurisprudence. ${ }^{159}$

151 Klebs 1894 ( $R E$ 2), col. 1472f., Jörs 1894 ( $R E$ 2), col. 1473f.; Kunkel 1967 (reprint 2001), p. 29; Wieacker 1988, p. 607ff.; Behrends 1990, p. 607; Badian \& Honoré 2000; Liebs 2010, p. 32ff. On Alfenus, and on his Digesta, see Ferrini 1891, p. 1ff.; De Sarlo 1940; Roth 1999 and the literature mentioned therein and Liebs 2000, p. 519ff.; 2010, p. 32ff.; extensively, also Bauman 1985, p. 89-105.

152 Horatius, Sermones I.3.130ff.; the tradition of this text is not clear, another version, namely, according to the Codex Blandiniensis, is clausaque ustrina tonsor erat: this could be interpreted as a corpse washer or a funeral undertaker (libitinarius); see Liebs 2010, p. 34f. (with references) who discussed these possibilities profoundly.

153 See also Brewster 1917, p. 71. However, according to Frank 1920, p. 160, Horatius in Sermones I.3.130 cited the example of Alfenus - who was once a shoemaker and recently a consul - in pretended support of the Stoic paradox that the wise man alone is the universal expert; although Alfenus long ago closed his shop, he has never outgrown being a shoemaker.

154 Porphyrio, Commentum in Horati Sermones I.3.130ff.

155 Kunkel 1967 (reprint 2001), p. 29.

156 Klebs 1894 (RE 2), kol. 1472; Kunkel 1967 (reprint 2001), p. 29.

157 In the same sense Frank 1920, p. 620.

158 Frank 1920, p. 620, provided the possibility that the father of Alfenus was a colonial of the usual type found in the Po Valley, in which case he doubtless invested the surplus earnings of his farm in urban shops and factories.

159 Differently Liebs 2010, p. 35ff.; - Probably the jurist is also Alfenus Varus, who, in the year 41 BC together with Asinius Pollio and Cornelius Gallus, let the settlement of the veterans in Gallia Transpadana and kept Vergilius from being penalised (i.e. expropriated) in the distribution of lands after the victory at Philippi, when lands were being divided among the veterans by order of the triumvirate; Klebs 1894 (RE 2), kol. 1472. On this topic also Liebs 2010, p. 44ff. See Vita 
Probably P. Alfenus Varus, who was consul in the year 2 AD, was Alfenus' son. Alfenus Varus, born in Cremona, was the first from Gallia Cisalpina to gain a consulship under Augustus (27 BC - 14 AD).

Alfenus Varus was a student of Servius Sulpicius Rufus' (ca. 105-43 BC) and belonged to the last generation of pre-classical jurists. He was the first Roman jurist who, under the title of Digesta, wrote a casuistic work based on the praetorian edict in which he treated problems by means of concrete cases. ${ }^{160}$ Frequently, Alfenus gave appraisals to his teacher Servius Sulpicius Rufus. He often cited consultative opinions (responsa) of his teacher Servius along with his own. ${ }^{161}$ According to (the writings of) Aulus Gellius, one may assume that Alfenus wrote another work, the Coniectanea. ${ }^{162}$

\subsubsection{Exegesis according to (classical) Roman law}

\section{Introduction to the case of D. 9.2.52.1}

Before turning to the legal problem, some remarks have to be made as regards the facts of the case. Two persons are involved in the legal conflict: the innkeeper and (probably) the owner of the passer-by (assuming that the passer-by was a slave). The lantern was placed outside the shop of a shopkeeper or the inn of an innkeeper, ${ }^{163}$ beside the street. ${ }^{164}$ A taberna could be a shop for certain forms of retail. ${ }^{165}$ Nevertheless, one could also translate tabernarius as a keeper of a tavern or an innkeeper because this translation, among others, would be consistent with the normal language used from the second century BC onwards, when with tabernarius normally an innkeeper was meant. ${ }^{166}$ When one interprets tabernarius as keeper of a tavern, one should immediately realise that tabernarii were notorious people ${ }^{167}$ who belonged to the lower

\footnotetext{
Vergilii Donatiana in Brummer 1912, p. 17, and the translation of and commentary on Donatus' Vita Vergilii by D. Scott Wilson-Okamura 2008, which was based on Brummer's text.

160 Spruit 1995, p. 249.

161 On the discussion of the question whether the Digesta of Alfenus were only, or considerably, a collection of responsa of Servius, see Roth 1999, p. 21.

162 Noctes Atticae VII.5.1.

163 Several translations are possible. According to Heumann \& Seckel 1907 (reprint 1958), p. 577, s.v. tabernarius, tabernarius can mean (a) Besitzer einer Kaufbude, Krämer, or (b) Schankwirt.

164 Interesting is H. Brenkman, Apparatus on D. 9.2, note semita (c) ad D. 9.2.52.1 (edn. Van den Bergh/Stolte 1977, p. 300). Apparently, according to Brenkman, one has to consider the street as a rather narrow one, a half-road. He referred to Varro, De lingua Latina, V.35, who mentions that narrow streets were called semita, a 'by-path', or a semiter, a 'half-road' (see also the English translation by Kent 1938, p. 33).

165 Spruit 1995, p. 250. On taberna, see also VIR V, p. 933; Schneider 1932, col. 1863ff.; Wagner, 1982, p. 391ff.; Wacke 1989, p. 485.

166 Spruit 1995, p. 251; for further reasons, refer to this article, esp. p. 251-252.

167 See, e.g., C. 5.27.1pr.
} 
ranks of Roman society and to the infames personae. ${ }^{168}$ The translation as innkeeper does make more sense, as the lantern would be especially relevant in that case: at night, the visibility of an inn would be important to attrack potential customers. ${ }^{169}$

Some scholars assume that the passer-by did not have the intention to steal. ${ }^{170}$ Those scholars suggest that the passer-by, to some extent, was just a little drunk. ${ }^{171}$ So, a drunken prank ${ }^{172}$ or a case of practical jest is suggested and even a simple 'borrowing' of the lantern (assuming the innkeeper would not mind), ${ }^{173}$ or at any rate an act not constituting theft. ${ }^{174}$ In addition, secondary literature mentions that such an assumption has to be made, otherwise a problem would arise as regards the provision of the Twelve Tables on the fur nocturnus. ${ }^{175}$ If the tabernarius caught the thief in the act at night, he was allowed to kill him immediately. The fact that the passer-by started to use a weapon (a whip) only made it even more imperative to kill him. Because of the large possibility to do justice by his own hands, there would have been no reason to argue about the less serious injuries inflicted on the thief. ${ }^{176}$ However, in the meantime, the introduction of the actio furti manifesti by the praetors had put an end

168 See also literary sources such as Cicero, In Catilinam IV.17; Pro Flacco 18; for further sources, see Spruit 1995, p. 251. In this article, a sociological interpretation is given of D. 9.2.52.1 in which the social position of the persons and the (social) relations between the persons involved are used to interpret D. 9.2.52.1.

169 Although this also - in principle - applies to shops, it seems less likely that shops were open at night.

170 A different conclusion could be made based on the text of the Basilica B. 60.3.51. The content of the text of the Basilica is mainly identical to the fragment in the Digest, in D. 9.2.52.1 (except for the part that a part of Alfenus' argumentation is missing in B. 60.3.51). The fragment from the Basilica is more explicit, in the sense that it mentions the verb i $\pi \dot{\varepsilon} \kappa \lambda \varepsilon \psi \varepsilon$ instead of sustulerat in D. 9.2.52.1. Thereby, it explicitly states that the case concerns a passer-by who stole a lantern.

171 Spruit 1995, p. 247.

172 Watson 1984, p. 239; Travis Laster 1996, p. $217 \mathrm{ff}$.

173 Lawson 1968, p. 131; as Travis Laster 1996, p. 217 and Hausmaninger 1996b, p. 248 nt 71 rightly sate, this is disproved by his refusal to return it.

174 MacCormack 1975, p. 46; - According to Huvelin 1912, p. 571, the case did not give a hypothesis of theft because 'anciennement la soustraction ne rentrait pas dans la notion technique du furtum'; differently De Castillo Santana 1994, p. 52f., who argues that the verb residere indicates that there was a reference to theft in the fragment. The compilers would have deleted it to make it fit into the sedes materiae of the lex Aquilia.

175 See Lex XII Tabularum 8.12; 8.13; Ulp. Coll. 7.3.2; Ulp. D. 4.2.7.1; Gai. D. 47.2.55.2; Noctes Atticae XI.18. 6-8; Kaser 1972, p. 158 nt. 34; Spruit 1995, p. 247; on these matters also, Huvelin 1912, p. 569ff.; Del Portillo 1983, p. 163f.; Roth 1999, p. 105f.

176 Spruit 1995, p. 253;- According to Hausmaninger 1996b, p. 247, the dolo (Hausmaninger wished to emendate dolor into dolo), i.e. a dagger or a spike, which was inserted into a stick, was probably only stressed by the tabernarius in order to dramatise the danger threatening him; for the rest it did not really play a role in the discussion/dispute. 
to the archaic forms of permissible self-redress in theft, ${ }^{177}$ and, therefore, it is questionable whether such competence still existed. A second reason why one states that the passer-by could not be qualified as a thief is that it is not at all clear why the owner of the thief should ever have been allowed an Aquilian action in respect of an injury received in the course of a struggle with the innkeeper. ${ }^{178}$ Taking into consideration that the lantern probably was a very common thing of relatively low value, knocking out an eye was more serious than taking away a cheap lantern. In that case, the reaction of the innkeeper knocking out an eye is disproportionate, ${ }^{179}$ and would not be allowed.

Clearly, Alfenus was consulted by the innkeeper. ${ }^{180}$ The innkeeper asked whether the damage in this particular case had (not) unlawfully been inflicted. The fact that the passer-by took the lantern was not in question, but just the fight. ${ }^{181}$ The innkeeper thought (and hoped) that his action would not be seen as unlawful (iniuria), ${ }^{182}$ and he would not be at fault (culpa) because of the fact that he was hit first by the passer-by and only defended himself. Therefore, the theft was not the central problem, but only the knocking out of the eye.

Which specific actio was applicable in this case Alfenus does not tell us explicitly. However, because of the phrase damnum iniuria nonvidetur dedisse, it probably concerned the actio legis Aquiliae based on the third chapter of the lex Aquilia, and not - as has also been defended - the actio iniuriarum. ${ }^{183}$

177 Zimmermann 1996, p. 938, and see also already Kaser 1971, p. 616.

178 MacCormack 1975, p. 46.

179 Spruit 1995, p. 253; see p. 257ff. for the reason why it was the tabernarius who consulted the jurist; Cannata 1971, p. 71, considers the lantern to be a neutral object of public use.

180 Maybe the responsum is already of S. Sulpicius Rufus. One says that the form Respondi does not with certainty mean that it concerns a reply of Alfenus; on this topic, see Sanio 1858, p. 73ff.; Huvelin 1912, p. 562 nt.1; Schulz 1961, p. 108f., 255; Watson 1984, p. 240; Del Castillo Santana 1994 , p. 52.

181 As appears from these facts, in particular from the beating with this whip, a rather big fight originated, i.e. a real fight, not confined to an argument but the quarrellers came to blows. In the same sense already G. Noodt, Ad legem Aquiliam liber singularis, c. XIX, p. 143 (and also H. Brenkman, Apparatus on D. 9.2, note rixa (d) ad D. 9.2.52.1 (edn. Van den Bergh/Stolte 1977, p. 301), who shares Noodt's view on this point). Noodt mentioned some literary sources interesting in this respect. An almost similar case was mentioned by Suetonius in his commentary on the life of Nero; see Suetonius, Nero, XXVI.2, who stated that in quarrels there was often danger to life and limb for Nero, since in one case he was almost beaten to death by a man of the senatorial order, whose wife he had touched. That the fight must be interpreted in this way is also confirmed by the use of the word rixa by Juvenalis, Satires, III.287 and Tacitus, Historiae, I.64, in which they used the word rixa (brawl) in the same meaning.

182 In other words: has he inflicted unlawful damage at all? (cf. Von Lübtow 1971, p. 107: ob er überhaupt widerrechtlich Schaden zugefügt habe).

183 See Huvelin 1912, p. 565ff. who interprets the fragment from the perspective of the actio iniuriarum; this possibility is also suggested by Lawson 1968, p. 131, namely, that this was a case of iniuria, wedged in between cases of damnum; on this possibility, see also Pugsley 1968, p. 383 (nt. 50) and Krampe 2002, p. 137. 
Although Alfenus does not further specify the person of the passer-by, in particular did not say whether he was a slave, modern scholars often assume he was. ${ }^{184}$ In fact, it seems that we have to assume that the injured person was a slave ${ }^{185}$ or a son under paternal control (filius familias) because it is not plausible that (the pre-classical) Alfenus would allow an Aquilian action to a free person sui iuris for physical injuries suffered. ${ }^{186}$ Otherwise, this would be evidence of an actio utilis for negligent injury to a freeman as early as in the Republic. That Alfenus pronounced upon granting such an actio utilis ${ }^{187}$ is not likely, since there are hardly any traces to justify such a possibility in the Digest, apart from the two exceptional late-classical cases of the liber homo bona fide serviens (Ulp. D. 9.2.13pr.; application by analogy ${ }^{188}$ ) and the case of the apprentice of the shoemaker (Ulp. D. 9.2.5.3). ${ }^{189}$

\section{The reply of Alfenus}

Before pursuing the legal interpretation of this text, it is appropriate to focus more closely on the structure of this responsum of Alfenus. The master of the injured passer-by (assuming that the passer-by was a slave - as discussed above) brought a lawsuit against the innkeeper. The innkeeper asked Alfenus about the lawfulness of his act. The jurist gave a twofold answer.1) He answered that the damage was not inflicted unlawfully, unless the innkeeper knocked out the eye intentionally, ${ }^{190}$ because the culpa did not lie on his side but on the person who first struck with the whip (i.e. the passer-by). ${ }^{191} 2$ ) If the innkeeper

$184 c f$. Mommsen 1955, p. 830 nt. 7; Von Lübtow 1971, p. 107, 120, even presumed that the text had been changed and that Alfenus originally wrote servus praeteriens instead of quidam praeteriens (an interpolation).

185 Also Wieacker 1975, p. 357; Roth 1999, p. 104. Spruit 1995, p. 254f. believes that to contemporaries of Alfenus it was clear that the case was about a slave, also because there was no extension of the lex Aquilia to freemen in the time of Alfenus.

186 MacCormack 1975, p. 47; Roth 1999, p. 104; differently Del Portillo 1983, p. $163 f$.

187 See Huvelin 1912, p. 565f.; also Ulp. D. 9.2.5.3; differently Del Portillo 1983, p. 161ff.; - On this topic also Wittman 1972, esp. p. $98 \mathrm{ff}$.

188 A freeman, who did not know his status and served in good faith as someone else's slave, had been injured. The reason, therefore, probably was that since this person until then had been treated as a slave, it would have been inequitable to withhold from him the specific protection accorded to a slave; see Wittmann 1972, p. 104; Zimmermann 1996, p. 1017.

189 On this text, see, e.g., Del Portillo 1983, p. $160 \mathrm{ff}$.

190 On the words data opera, see, e.g., Schipani 1969, p. $172 f$.

191 Also the phrase culpam enim penes eum ... residere was suspected as being an interpolation; see Albertario 1923, p. 506 (nt. 4); differently Rodriguez-Ennes 1984, p. 93, who argued that this statement must be understood in such a way that the action must be brought against a person whose authorship is presumed, in the case of D. 9.2.52.1, because he was the one who first hit with the whip; Rotondi 1922, p. 489 criticised the meaning of residere as 'to remain, to stay', based on VIR V, col. 167. In the Vocabularium, one can see the unique use of residere, because D. 9.2.52.1 is the only case in which residere means neither to reside physically nor to remain, stay (dotem apud maritum, peculium); differently Huvelin 1912, p. 564 and Schipani 1969, p. 174. Also the reference to culpa in this phrase is suspected of being spurious. See Albertario 
had started the fight himself when trying to get the lantern back, he would have been at fault (culpa) and would, therefore, be liable for the damage.

Alfenus thus drew distinctions. It has been suggested that they are only hypothetical variations, which had nothing to do with legal practice and which were particularly well suited to explain difficult legal problems to law students. ${ }^{192}$ For such didactical purposes, however, no direct proof can be found in any other source. Furthermore, such a clear (implied) distinction between responsa collected for use in legal practice and responsa collected for didactical purposes was never made in the time of Alfenus. ${ }^{193}$

Other authors consider this second part of Alfenus' reply (sed si ... factum videri) an interpolation. ${ }^{194}$ This last sentence would be redundant and could be deleted without altering the sense of the decision. ${ }^{195}$ Besides, this phrase would solve a question the tabernarius had not asked because of the presumption that not the innkeeper but the adversary of the tabernarius had given the first blow (illeflagello ... tabernarium coeperat). Alfenus had to give an answer assuming that it was the passer-by who struck the first blow and not the tabernarius. Why, then, contemplate the inverse case, as if the tabernarius was the one who had taken the offensive? ${ }^{196}$

In my opinion, it is possible that this second part is not a hypothetical variation, but reflects an argument in favour of the passer-by assuming a different set of facts. Probably the passer-by argued that the facts were not as stated by the innkeeper and that it was not he, but the innkeeper who struck first and started the fight. ${ }^{197}$ Alfenus replied to the defence of the passer-by (that it was the innkeeper who started fighting) by stating that if this indeed had been the

1936, p. 87 nt. 1; Beinart 1953, p. 287 nt. 37; differently De Sarlo 1940, p. 124ff.; Visky 1949, p. 451ff.; MacCormack 1974, p. 223f.; Schipani 1969, p. 168ff.; Watson 1984, p. 239; Pugsley 1970, p. 427 suggests that the facts stated by Alfenus were used by the compilers 'as a peg on which to hang a discussion of their own'.

192 Roth 1999, p. 102ff., 203.

193 See Tellegen-Couperus 2001, p. 384, a responsum could be used as an argument in pleading a case as well as used as a decision for teaching purposes.

194 Huvelin 1912, p. 563; Riccobono 1913, p. 76 nt. 3; see also Lawson 1968, p. 130f.; Taubenschlag 1925, col. 2326f. and 2327: 'die Unterwerfung des damnum iniuria datum unter die Allgemeine Kategorie von der culpa ist erst ein Werk byzanistischen Jurisprudenz' (see, e.g., the interpolation in D. 9.2.52.1; see Rotondi 1922, p. 486, and also Bonfante 1946, p. 524); differently Roth 1999, p. 107.

195 Accordingly, Huvelin 1912, p. 563.

196 Therefore, this part of the decision should not belong to the original part of the responsum of Alfenus. See Huvelin 1912, p. 563; Del Portillo 1983, p. 160.

197 Tellegen-Couperus 2001, p. 384; the author adds another possibility, namely, that such 'variations' may also be arguments Alfenus used in order to make his decision more convincing. 
case, the innkeeper would have been liable. The outcome was not yet clarified and had to be assessed by the judge (iudex). So Alfenus argues both ways: firstly, according to the facts presented by the innkeeper and, secondly, as an alternative, according to the facts presented by the passer-by. ${ }^{198}$

Another remarkable part of Alfenus' reply is the phrase nisi data opera effodisset oculum. Possibly, these words were not included in the original responsum; they may have been added by the compilers, ${ }^{199}$ perhaps in order to give the phrase a broader meaning. They are part of the answer to num damnum ... percussus esset. The response, including the phrase nisi data opera effodisset oculum, however, would not represent a logical answer to the question whether the damage could be considered unlawful given the fact that the tabernarius was hit first by the passer-by. Besides, (only) based on the information of Alfenus, it is impossible to say whether the knocking out of the eye was done intentionally. Moreover, according to Huvelin (1873-1924), ${ }^{200}$ restrictive propositions in the Digest starting with nisi are often interpolated. ${ }^{201}$ Obviously, however, in Huvelin's time passages were more often and more easily suspected of being interpolated than today.

It would be too simple to state that all passages starting with nisi are interpolated. Also in this case this seems to go too far, since there are no solid arguments for assuming such an interpolation. Possibly the contrast between such a restriction and the rest of the responsum is an argument in favour of a later addition. While nisi ... oculum provokes the problem of the delictual intention, the rest of the text only concerns the priority of the aggression. ${ }^{202}$ At first sight, given the fact that Roman jurists did not write scholarly treatises, it does not seem plausible that num damnum ... percussus esset was originally part of the text. It is not necessary to provide an answer to the question posed by the tabernarius. Below, however, it will be argued that this addition was in fact necessary. When answering the question whether the tabernarius was at fault (culpa), Alfenus made use of an argumentum ab initio incremento summa, but he added a restriction that applied for the case in which the tabernarius acted intentionally. ${ }^{203}$

198 Also Krampe 2002, p. 139.

199 Huvelin 1912, p. 564; Del Portillo 1983, p. 160; differently De Castillo Santana 1994, p. 53 f.

200 P. Huvelin was a professor at the Faculté de Droit de l'Université de Lyon.

201 Eisele 1899, p. 296ff.; Huvelin 1912, p. 564; Appleton 1967, p. 52ff., 265ff.

202 Huvelin 1912, p. 564 nt. 3; Del Portillo 1983, p. 160.

203 Also Spruit 1995, p. 260 argues that the passage has to be seen as a restriction, namely, to the priority of the aggression as criterion to determine the culpa. 


\section{Various interpretations of D. 9.2.52.1: Introduction}

Before explaining my new theory, various interpretations of the meaning of D. 9.2.52.1 have to be discussed. When examining Digest texts in which the actio legis Aquiliae played a role, it is important to avoid interpretations of Roman law from a perspective determined by later developments (anachronistic interpretation). A requirement to succesfully apply for an actio legis Aquiliae (for damnum iniuria datum) was that the damnum had to be caused iniuria. With damnum in the third chapter of the lex Aquilia the loss inflicted on the victim of the delictual act is meant. It is often assumed that damnum refers to the actual damage done to the object concerned, in this case the knocked-out eye. However, it seems more precise to argue that damnum refers to the loss caused to the owner. ${ }^{204}$

The damnum had to be caused iniuria. Unfortunately, the meaning of iniuria is very complex, ${ }^{205}$ as is also the relation between iniuria and culpa. ${ }^{206}$ The majority view considers the concept of iniuria as evolving over time. ${ }^{207}$ Iniuria had the generic and most probably earlier meaning of unlawfulness (non iure), without justification. ${ }^{208}$ In relation to the lex Aquilia it can also mean culpa. ${ }^{209}$ The concept of culpa had a gradual influence, in time, on the concept iniuria. Eventually, culpa ousted the earlier concept to a certain degree, so that aspects of iniuria in many cases just became a 'pleading device' (the formula included the word iniuria so the jurists had to do this); it was, however, never completely suppressed, but rather submerged. Jurists thought more in terms of culpa and

204 See Daube 1948, esp. p. $98 \mathrm{ff}$.

205 Recently, on the meaning of iniuria in the lex Aquilia, Paschalidis 2008, p. 321ff. and on the meaning of iniuria and culpa in the lex Aquilia, Corbino 2009b, p. $77 \mathrm{ff}$., Cursi 2010, p. 45ff., $59 \mathrm{ff}$.

206 On this topic also Paschalidis 2008, p. 322ff.

207 On this view, see Travis Laster 1996, p. 195ff. A minority view (mainly defended by MacCormack) argues that iniuria always meant acting wrongfully in the general sense ('what is not right' in the positive sense of what is wrong), and that the terms dolus and culpa appeared merely to satisfy a semantic need for flexible terminology; see Travis Laster 1996, p. 195, 199f.; see also MacCormack 1981, p. 122f., 126.

208 According to De Robertis 2000, p. 91, during the Republic, iniuria indeed meant 'quod non iure fit'. See also Travis Laster 1996, p. 194ff., who argued that by the late Republic jurists were focusing on the concepts of dolus and culpa.

209 Beinart 1953, p. 281; - According to Parisi 1992, p. 60f., at a later stage, iniuria datum came to be interpreted as being given with culpa or dolus. He argued that, at this time, the notion of the individual's culpability was thus gradually added to the objective notion of iniuria as the basis of liability. Differently Pugsley 1982, p. 12, who argues that in D. 9.2.52.1 culpa is not said to be an interpretation of iniuria or to ground liability under the statute. According to Alfenus, statutory liability has been excluded except in cases of intentional wrongdoing. Culpa, therefore, must refer to an independent liability, the praetorian actio in factum. Alfenus thereby would have made a distinction between statutory liability for iniuria for intentional wrongdoing and praetorian liability for culpa. See also Ziliotto 2000, p. 37 nt. 5. 
dolus, even in the realm of what, strictly speaking, was unlawfulness. ${ }^{210}$ Also in D. 9.2.52.1 Alfenus seems to interpret iniuria in the sense of culpa, and made culpa (in the sense of fault) the basis of the test whether the innkeeper would be liable, determining the culpa by examining the circumstances of the case.

In that respect it is important to remember the penal character of the lex Aquilia in classical Roman law. Because of the penal character, ${ }^{211}$ and because of the wording of the actio legis Aquiliae, ${ }^{212}$ the only question was whether the defendant had to be punished or not. That is the central question, as it concerned a poena.

\section{Various interpretations of D. 9.2.52.1: self-defence}

In secondary literature, there are roughly two theories in which an attempt is made to explain Alfenus' responsum. Some authors interpret the text in such a way that the tabernarius invoked in his defence that he had legitimately acted in self-defence. ${ }^{213}$ Due to the act of self-defence, there would be no iniuria (in the sense of acting non iure), since the wrongfulness disappears. ${ }^{214}$ In that case the act is justified by a preceding, unjust act of aggression. ${ }^{215}$ However,

210 Beinart 1953, p. 285.

211 See, e.g., Wallinga 2009, p. 1386f., who reminds us of the fact that it was only since the medieval theory of restitution from moral theology that it became more obvious that someone who suffered damage may bring a claim against the culpable causer.

212 Recently, on the delictual origin, penal nature and the reipersecutory object of the actio damni iniuriae legis Aquiliae, see Sirks 2009, p. 303ff., and on the character of the actio legis Aquiliae, Ankum 1987-1988, p. 3ff. (reprint 2007, p. 99ff.); Wallinga 2009, p. 1385ff.; see also Cursi 2010, p. 67ff.

213 See, e.g., Grüber 1886, p. 170; Ruhm 1898, p. 27; Von Leyden 1902, p. 28; Van Nierop 1905 p. 5f; Coppa-Zuccari 1909, p. 30f.; Tassin 1912, p. 37f.; Garraud 1912, p. 327ff.; Rossi Masella 1951, p. 191; Hausmaninger 1996b, p. 248; Jansen 2004, p. 122; 2009, p. 236f.; Corbino 2008, p. 162f.; or on the possibility of an excess of self-defence, see Wacke 1989, p. 484ff. (Notwehrexcess); De Robertis 2000, p. 91: eccesso di reazione (e quindi esorbitante dai limiti del proprio diritto); Castresana 2001, p. 69f. also interesting is the view of Cannata who argued that the tabernarius had a causa giustificazione until the first outbreak of the brawl. If he had hit the fugitive intentionally, he would have no justification, just as in the case when he was not hit first, but, because he wanted the lantern back, started a fight; see Cannata 1995, p. 39, and Ziliotto 2000, p. 40f. nt. 13.

214 Demelius 1861, p. 61; Levison 1891, p. 43; Plog 1896, p. 59; Mommsen 1955, p. 78, p. 621 nt. 1, p. $830 \mathrm{nt}$. 7. So the tabernarius is a priori not liable; so there could be no compensation of the acts or of the culpae of the parties at all; also Van Nierop 1905, p. 6.

215 Interesting is BS 3163/3-5 (scholion 2 ad B. 60.3.51), where the final (Greek) phrase of 60.3.51.1 (But if the tabernarius had not been hit first, but wishing to take the lantern back gave rise to a scuffle, he would have been held liable under the lex Aquilia), is interpreted as follows. According to this scholion, it is lawful to repel violence with violence, as in D. 9.2.45.4. Here, the other person had not used violence on the tabernarius, but <only > took the lantern. Besides, it is permitted to him, to whom violence occurs, to protect himself against a beating, acting without the reason of revenge (apparently revenge would have been the case if the tabernarius had not been hit first, but wishing to take the lantern back initiated a scuffle). No such explanation is given in the text of a Byzantine work of the 10th century, a text of the Epitome legum 42.34, where it is only stated that the person who started the fight (who first hit the other) and suffered loss as a result of that (because the other hit him back quite hard) cannot take legal action; in Zachariae 
no foundation for this theory can be found in the text, ${ }^{216}$ nor is there any reference to any compulsion. Moreover, it is not necessary to consider the question of self-defence ${ }^{217}$ (as ground for exclusion of iniuria) because Alfenus ends with the question of culpa: did the innkeeper act culpably? This question is answered negatively, and since there was no culpa, the innkeeper did not act with iniuria. Therefore, the question whether his act was justified does not have to be dealt with.

\section{Various interpretations of D. 9.2.52.1: culpae compensatio}

Other authors consider D. 9.2.52.1 as an example of the idea of culpae compensatio. ${ }^{218}$ The rixa is provoked by the passer-by, i.e. by a hit, and in doing so, the passer-by acted culpably (with culpa). The negligence (culpa) of the tabernarius in knocking out the eye is compensated by this negligence (culpa) of the passer-by. However, when reading the text it is clear that there is no separate treatment of the culpability of the actions of both persons. Alfenus is not discussing any reciprocity of faults, and this was even impossible due to the formulary procedure. Only the culpa of the wrongdoer was relevant to be granted an actio based on the third chapter of the lex Aquilia. ${ }^{219}$ Alfenus seems

von Lingenthal's edition of the Epitome legum a reference is made to D. 9.2.52.1.

216 In the same sense Pernice 1895, p. 98 nt. 3; Aumann 1964, p. 8; Jansen 2004, p. 122; 2009, p. 237, argues that in the case where the innkeeper first hit the passer-by, the means (hitting someone leading to the loss of an eye) was not in proportion to the purpose (preventing damage to a relatively cheap object), and hitting was not the most appropriate means to achieve his goal; therefore, he would have acted with culpa. However, there is no textual basis for this interpretation. Furthermore, Jansen argued that in the event that damage occurred, the thief would not be free from responsability (because he took the lantern). This vision also seems to lack textual basis. Therefore, a set-off/balancing of respective negligent acts of two parties is not at stake. This will be discussed below.

217 See also Spruit 1995, p. 257; differently Van Warmelo 1967, p. 14; Wacke 1988, p. 530ff.; Travis Laster 1996, p. 218, called D. 9.2.52.1 an example of different social norms. Roman jurists appear to have accepted inebriation as an excuse for deviant behaviour, and they supported the immediate resort to a forceful self-help remedy. Because these examples of conduct were not blameworthy, the jurist could focus on the fight. This interpretation seems to read too much into the source.

218 Pernice 1867, p. 58-64; 1895, p. 98; Bekker 1871, p. 172f. nt. 14; Levison 1891, p. 41ff.; Rossi Masella 1951, p. 190; Von Lübtow 1971, p. 108, 136; Lawson 1968, p. 54; differently Von Leyden 1902, p. 28; Thayer 1929, p. 115f.

219 Also Spruit 1995, p. 256, argues that one does not have to argue in terms of culpae compensatio in this text. Such culpae compensatio was not possible in the formula procedure: the iudex had to condemn or absolve (tertium non datur); - Also Fried 1960, p. 148, who argues that the conclusion of culpa negligence is the last stage in injury for the Roman lawyer, and the application of the term is itself the verdict of guilty. Fried argues that it is absurd to speak of a culpa-compensation: there cannot be culpa in both parties because the notion of culpa refers to the legal imputability of blame, which by its nature can only attach to the defendant, if at all; The formula of the actio legis Aquiliae is, however, not passed on to us. Recently, on the formula of the actio legis Aquiliae, see Nörr 2009, p. 833ff. 
to have discussed this case as a whole, in which he constructed just one fault, i.e. the fault of the person who first hit the other. ${ }^{220}$

\section{A new perspective on D. 9.2.52.1}

Because these two, rather technical theories about the responsum of Alfenus are quite unsatisfactory, in order to correctly explain Alfenus' answer a totally different approach has to be chosen. Alfenus answered the question of iniuria by discussing the requirement of culpa. The requirement of culpa has to be considered by looking at the circumstances of the case. Apparently, the facts are not sufficient to provide a clear answer as to how the tabernarius knocked out the eye with the whip. Therefore, the case was decided by means of another criterion, namely, a criterion originating from Greek law: who struck first? ${ }^{221}$ Applied to this case this means that the tabernarius acted without culpa because he was not the person who struck first. A remarkable similarity can be noted here with a fragment from rhetoric, namely, Quintilianus, Institutio Oratoria, V.10.7172. In Roman times there was a close connection between rhetoric, on the one hand, and law and politics, on the other hand. ${ }^{222}$ Roman jurists were acquainted with rhetoric, it belonged to their education, and, therefore, knowledge about argumentation figures can be assumed. Rhetoric can, therefore, be used as an auxiliary resource to interpret this fragment by Alfenus.

Whenever a legal problem allowed more than one plausible interpretation, the jurist had to substantiate his decision persuasively. In rhetoric, the method for searching for true (or probable) arguments that make a case credible is called inventio. ${ }^{223}$ Thereby, it is essential to study the places of arguments (topoi,

220 Huvelin 1912, p. 567f.; according to Paschalidis 2008, p. 350, only if the thief had been at fault would the fault of the tabernarius not matter. And this, according to Paschalidis, is in tune with the lack of a doctrine of contributory negligence in Roman law. Furthermore, Paschalidis (2008, p. 350f.), interpreting D. 9.2.52.1 in Aristotelian terms, argued that the poking out of the eye was an unjust act, but that, nevertheless, no injustice was committed against the lantern thief. The two acts (taking away the lantern and striking the tabernarius with a whip), per se unjust, created a situation in which the tabernarius reacted and poked out the eye of the passer-by. The incident would not have taken place if it was not the passer-by's intention to fight, and thus, the incident was due to the own culpa of the passer-by. Paschialidis on p. 351 note 176, explains that the word culpa is not meant as negligence but as culpa in the meaning of the phrase 'Mea culpa, mea culpa, mea maxima culpa!' (Missale Romanum). This remark could be interesting, but is, in my opinion, not understandable without further explanation.

221 There are traces from Greek law, and from the Tetralogies of Antiphon in D. 9.2.52.1; see also Wollschläger 1976, p. 129f.; Castresana 2001, p. 75; - The killing of the person who struck first was without penalty already since the law of Drakon (see Sylloge I nr. 11l, 33 in Dittenberger 1915, p. 150), which can be reconstructed to that extent after Antiphon, Tetralogiae III.2.6; III.3.2; III.4.2 \& 4 and after Plato, Leges 869C; Dittenberger 1915, n. 17; Ruschenbusch 1960, p. 150; Latte 1968, p. 289; Maschke 1979, $78 \mathrm{ff}$.

222 See also Tellegen-Couperus 2003b, p. 12ff.

223 Saiz Noeda 2003, p. 97. 
loci). The status theory of Hermagoras of Temnos (second century BC) $)^{224}$ is important in this perspective because the theory of status has a central place in the search for arguments. The status theory of Quintilianus (and also of Cicero) is probably based on that of Hermagoras. ${ }^{225}$ This is a method to determine what is at issue in a case that results from rhetorical arguments. The term status refers to the nature of the quaestio that results from the confrontation between claim and defence. ${ }^{226}$ As the claim always has the same factual character, the status is determined by the changing contents of the defence. When a jurist had determined which status was at stake, he could find arguments for his point of view by consulting lists of topoi that were specifically relevant for the specific status. ${ }^{227}$ For a jurist to substantiate his decision persuasively, rhetoric and more specifically the topoi (or loci) were apposite methodological tools. ${ }^{228}$ In that respect Quintilianus is relevant. Marcus Fabius Quintilianus (first century AD) was an orator who wrote the Institutionis oratoriae libri XII (published in 94 or 95 AD). ${ }^{229}$ These twelve books on the education of the orator contain a full and systematic survey of the rhetorical insights that had been developed in the previous centuries, i.e. of the rhetorical system. ${ }^{230}$ In his Institutio Oratoria, as the work is generally called, he uses examples from practice to unfold his (rhetorical) theory. In this context the fifth book on the discovery of arguments is relevant (see below).

Firstly, Alfenus had to determine the status of the conflict. What was the quaestio resulting from the confrontation between the views of the plaintiff and the defendant? The master of the passer-by was of the opinion that the innkeeper unlawfully inflicted damage to his slave and because of that brought an actio legis Aquiliae against the innkeeper. The innkeeper denied that his act could be considered to have been performed with iniuria. The resulting quaestio is: did the innkeeper inflict damage with iniuria? The applicable status (according to the status theory of Hermagoras) is the status qualitatis because the case did not concern a dispute about the facts (the knocking out of the eye), nor a definition of the act, but about the quality: was the act unlawful? Thereafter, Alfenus would have looked at which topoi were specifically relevant for the status qualitatis. He could use these topoi to find arguments in support of the position of the person

224 See, e.g., Leeman \& Braet 1987, p. 76ff.; Wieacker 1988, I, p. $669 f f$.

225 See Cicero, Topica, 21.82; Quintilianus, Institutio Oratoria, III.5.10.

226 Leesen 2009, p. 35.

227 See Leesen 2006, p. 275, also Tellegen-Couperus \& Tellegen 2006, p. 384.

228 Also Leesen 2009, p. 28; see also p. 38f., where she referred to Cicero, Topica, 17.66 and 17.65, which texts confirm that jurists were acquainted with rhetoric and topoi.

229 On Quintilianus and his Institutio Oratoria, see, e.g., Tellegen-Couperus 2003b, p. 11ff., $17 \mathrm{ff}$. 230 Tellegen-Couperus 2003b, p. 11. 
who consulted him, the innkeeper. ${ }^{231}$ He found an argument in the gradual development of events in three moments: from a start, through an escalation, to a climax (argumentum ab initio incremento summa). This argument is described in Quintilianus, Institutio Oratoria, V.10.71-72:232

Ut sunt autem tria tempora, ita ordo rerum tribus momentis consertus est: habent enim omnia <initium>, incrementum, summam, ut iurgium, deinde <rixa, tum> caedes. Est ergo hic argumentorum quoque locus invicem probantium; nam et ex initiis summa colligitur, quale est: 'non possum togam praetextam sperare cum exordium pullum videam, et contra: 'non dominationis causa Sullam arma sumpsisse, argumentum est dictatura deposita.' Similiter ex incremento in utramque partem ducitur ratio cum in coniectura, tum etiam in tractatu aequitatis, an ad initium summa referenda sit, id est, an ei caedes inputanda sit a quo iurgium coepet.

Just as there are three divisions of Time, so the order of events is made up of three stages: everything has < a beginning, $>$ a development, and a culmination: quarrel, then < brawl, then $>$ murder. So here too is a Place for Arguments which support one another. (1) The culmination may be inferred from the beginning: 'I cannot hope for the toga with a purple edge when I see the weave begins so drab.' (2) The other way around: 'Sulla's resigning the dictatorship is a proof that he did not take up arms to set up a tyranny.' (3) We can similarly argue forwards or backwards from the development stage both in Conjecture and in questions of Equity: should the culmination be referred to the beginning, that is, should the murder be set to the account of the man who started the quarrel? ${ }^{233}$

Quintilian(us) uses this status theory in Institutio Oratoria V.10.71-72 and also Alfenus could have been guided by this doctrine (in D. 9.2.52.1). In both cases the status qualitatis was relevant. The last sentence in the text of Quintilian is extremely relevant in this context. Alfenus constructed his argumentation in a similar manner as Quintilian. The ordering of events by Alfenus is the same: beginning, culmination and climax. In Quintilian's fragment there was a quarrel, a brawl and then a murder; in Alfenus' text one reads that the passer-by hits the innkeeper, then the fight (rixa), and subsequently the knocking out of an eye of the passer-by. Such an orderly and gradual unfolding of events in three stages plays a main role in the finding of arguments that support each other. ${ }^{234}$ From the development stage one can argue both forwards and

231 It was not uncommon for a jurist to give advice that served the cause of the citizen who consulted him; see Cicero, De Oratore, I.239-240.

232 See also Quintilianus, Institutio Oratoria, V.10.94.

233 Text and translation from Russell 2001.

234 Saiz Noeda 2003, p. 109. 
backwards. Alfenus argued from the beginning to the end: the person who hit first had to be held responsible for the climax. Alfenus was of the opinion that, considering the circumstances of the case, among which particularly the fact that the passer-by had to be held responsible for his act (the start of the fight), no fault (culpa) could be attributed to the innkeeper and, therefore, he could not be considered to have inflicted damage unlawfully (iniuria).

This new perspective has the advantage that it does not use concepts from later legal doctrines (and thus is not anachronistic) but connects, maybe even better, and in any case more directly, to the sources. There was no technical theory at all behind the reply of Alfenus. The reply of Alfenus was one of a rhetorical nature. The question whether the tabernarius was at fault (culpa), was considered in the light of the status qualitatis and answered with the use of an argumentum ab initio incremento summa: in Alfenus' opinion the culmination in this case should indeed be referred to the beginning. Accordingly, (according to the facts as presented by the tabernarius) the passer-by was the person who struck first and not the tabernarius. Therefore, the damnum could not be qualified as unlawful (iniuria) because the culpa rested with the person who struck first. Thus, the person who started the fight was negligent (culpa). The tabernarius did not start the fight, could not be accused of negligence (culpa), and as a consequence was not liable and would not have to pay a poena.

\section{9.2.52.1 in Justinian law}

From the above discussion it appears that the Roman jurist did solve a situation which could be interpreted from a modern perspective as contributory negligence without knowing such a concept. This situation does not change for Justinian law. Nevertheless, some final remarks as regards the case of the innkeeper in Justinian law have to be made. ${ }^{235}$ Firstly, the discussion on the status of the person, whether the passer-by was a slave or a free man, lost its relevance. ${ }^{236}$ In Justinian law an actio legis Aquiliae utilis was generally applicable to injured free persons (D. 9.2.13pr.). Secondly, although the positioning of this text in title 9.2 confirms the applicability of the actio legis Aquiliae in D. 9.2.52.1. ${ }^{237}$, there is a difference as regards the amount of money the wrongdoer had

235 In Justinian law it is not self-evident that theories of Quintilian were meant to play a big role, so a dogmatic explanation of the compilation of Justinian is quite possible. Future investigation of the precise influence of the Institutio Oratoria seems necessary on this point.

236 Hausmaninger 1996a, p. 36 nt. 77, mentions the possibility that if Alfenus wrote servus, later someone, possibly Justinian, changed the word into quidam and by doing so made the case more general.

237 This is affirmed by the fact that this case, as well as the cases of the javelin thrower and barber can be found in the title about the lex Aquilia de damno in the Basilica. 
to pay. For the case in which a slave was injured, D. 9.2.27.5 was applicable, meaning that the wrongdoer had to pay what the slave was worth in the nearest thirty days. In the case where a free man was injured, however, D. 9.2.7pr. was applicable and the wrongdoer had to pay the father the amount of money corresponding to the value of the services of the son, which he lost because of the destruction of the son's eye, as well as all expenses incurred for medical treatment. Thirdly, one could question whether D.9.2.52.1 should be seen as an application of D. 50.17.203. This was probably not the case, as also appears from the scholia discussed above (see footnote 215), where the case of D. 9.2.52.1 was used in the discussion on selfdefence (this will also initially be the case with the Glossators; see next chapter).

\subsection{ULPIAN'S REPLY IN THE CASE OF THE JAVELIN THROWERS}

\subsubsection{The text of D. 9.2.9.4}

\section{Ulpianus libro octavo decimo ad edictum}

Sed si per lusum iaculantibus servus fuerit occisus, Aquiliae locus est: sed sicum alii in campo iacularentur, servus per eum locum transierit, Aquilia cessat, quia non debuit per campum iaculatorium iter intempestive facere. qui tamen data opera in eum iaculatus est, utique Aquilia tenebitur:

Unlike the littera Florentina, in certain manuscripts the word ' $a$ ' has been inserted before 'iaculantibus'. ${ }^{238}$ With regard to classical Roman law, it is unnecessary to emend the original text of the littera Florentina. It is not evident that the changes were part of the original text. With regard to the remaining text of the fragment, an extensive discussion is not necessary. ${ }^{239}$

238 Ms. Paris, Bibl. Nat., Lat. 4450, fo. 93r, the ' $a$ ' is even connected to iaculantibus; also in Ms. Biblioteca Vaticana, Barb. lat. 1459, fo. 88r; Ms. Padova, Bibl. Univ. 941, fo. 88r, Ms. Leipzig, Univ. bibl. 873 , fo. $76 \mathrm{v}$; see also the vulgate edition with the Accursian gloss (in edn. of 1487, fo. 162v), where - furthermore - the word ' $e t$ ' is inserted between the twice appearing words 'sed' and ' $s i$ '. These two insertions (of the word ' $a$ ' and of the word ' $e t$ ') were made neither in the vulgate edition $c f$. edn. of Kriegel 1844, p. 191, the Florentina (see fo. 148v of the facsimile edition of the Florentina) nor in the edition of Torelli (see edn. of 1553, I, p. 238). In the humanist edition of Haloander (edn. of 1550 , fo. 1550r), not only did he make both insertions, but he even reformulated the first phrase in the following way: Sed et si a iaculantibus per lusum servus fuerit occisus.

239 With regard to the word 'quia', it can be noticed that the littera Florentina first contained the word iulia, but that a second hand corrected it to quia. See fo. $148 \mathrm{v}$ of the facsimile edition of the Florentina. Instead of 'intempestive', the reading 'tempestive' was followed by the orginal text of Ms. Padova, Bibl. Univ. 941, fo. 88r (however, later it was emended into intempestive). This reading can also be found in Ms. Biblioteca Vaticana, vat. lat. 1406, (fo. 80v, EvD). The manuscript contains the reading intempestive. However, after consulting the original manuscript, I have to conclude that the character $\mathbf{i}$ was inserted at a later date, in a caroline hand, with a darker ink. Furthermore, Mommsen referred to the uncertain reading of Ms. Paris BN, lat. 4450 (fo. 93r, 


\subsubsection{Translation of D. 9.2.9.4}

\section{Ulpian in the eighteenth book of his commentary on the edict}

But if a slave were killed while persons threw javelins in a game, there is a place for the [lex] Aquilia $;^{240}$ but if when others were throwing javelins in a field ${ }^{241}$ a slave crossed the field, the [lex] Aquilia is not applicable, because he ought not to have passed at an inopportune time through a field of javelin throwers. Nevertheless, the person who intentionally threw a javelin at him will, in any case, be held (liable) under the [lex] Aquilia.

\subsubsection{Inscriptio}

\section{The context of D. 9.2.9.4}

This fragment is part of the eighteenth book of the commentary of Ulpian on the edict (of the praetor). Book eighteen was probably written during the sole reign of emperor Caracalla (211-217 AD). ${ }^{242}$ D. 9.2.9.4 is derived from the comment of Ulpian on the edict, which regarded the actio legis Aquiliae; an introduction to the lex Aquilia has already been provided in the preceding section. Since the fragment concerns the killing of a slave, the first chapter of the lex Aquilia is relevant. ${ }^{243}$ That this fragment originally concerned the lex Aquilia is endorsed by Lenel, who, in his Palingenesia, placed this fragment in book eighteen of Ulpian's commentary on the edict, in the part dealing with the first chapter of the title Ad legem Aquiliam. ${ }^{244}$ The compilers of the Digest incorporated this fragment in the title Ad legem Aquiliam. ${ }^{245}$

EvD). Indeed, the space between iter and (in)tempestive is less than in other spaces; however, the size of the character $(\tilde{l})$ is not smaller than the rest, and at first sight the handwriting does not seem different.

240 Of course the actio based on the lex Aquilia is meant (see also Watson, 1985, I, p. 280; Feenstra/Spruit in: Spruit et al. 1994, p. 715; Schipani 2005, p. 241). This is, however, not explicitly mentioned in the text, so it is not translated as such.

241 According to Heumann \& Seckel 1907 (reprint 1958), p. 242, s.v. iaculatorius campus this was an 'Übungsplatz für das Speerwerfen'; also Feenstra/Spruit in: Spruit et al. 1994, p. 715: 'oefenveld'; Otto, Schilling \& Sintenis 1839 (reprint 1984), p. 792, just added the words [dazu bestimmten]; Schipani 2005, p. 241 translates: 'in un campo di Marte'.

242 Honoré 2002, p. 176.

243 See Gai. D. 9.2.2pr.

244 Lenel, Palingenesia iuris civilis, II, col. 523f., pal. nr. 614.

245 According to Mommsen, this fragment fell into disuse when a similar one, i.e. Inst. 4.3.4, began to be read; see Mommsen \& Krüger 1963a, I, p. 157 ('interciderunt similia iis quae leguntur Inst. 4.3.4, talia fere: si miles, qui iaculis exercitatur in campo, ubi solent exercitari, transeuntem servum tuum traiecerit, nulla culpa eius intelligitur'); and it seems that Mommsen considered Inst. 4.3.4 as a need to give meaning to the phrase/the words (starting with) sed si cum alii. Mommsen \& Krüger 1962 (editio maior), I, p. 280 ('exciderunt similia iis quae leguntur Inst. 4.3.4, haec fere: si miles, qui iaculis exercitatur in campo, ubi solent exercitari, transeuntem servum tuum traiecerit, nulla culpa eius intellegitur: talia requirunt quae sequunturverba sed et alii'). 


\section{Domitius Ulpianus}

The fragment is written by the late-classical jurist Domitius Ulpianus ( $c a$. 170-223 AD). ${ }^{246}$ He originally came from Tyrus in Phoenicia, ${ }^{247}$ which area now belongs to Lebanon. Living in the same period as Paul and Papinian, he was probably born around the year $170 \mathrm{AD} .{ }^{248}$ Ulpian had an extensive political career; among other functions we can mention: procurator a libellis, praefectus annonae and praefectus praetorio. In $223 \mathrm{AD}$ he was murdered by his own praetorian guard, during the reign of Alexander Severus (222-235). This emperor was very well-disposed towards him, in contrast to his predecessor the emperor Elagabalus (218-222): the latter even dismissed Ulpian from his function as praefectus praetorio; later Alexander Severus appointed Ulpian as praefectus annonae and reappointed him later in his function as praefectus praetorio. ${ }^{249}$ During the reign of Alexander Severus, Ulpian's career reached its climax. Ulpian had tried to unite the law into two large commentaries (on the ius civile and the ius honorarium). The results of his work were remarkable: 83 books ad edictum, 51 books ad Sabinum, numerous monographs and two books of Responsa. ${ }^{250}$ Most likely he wrote the largest part of his extensive work during the reign of Caracalla (211-217) and the reign of Macrinus (217-218). ${ }^{251}$

\subsubsection{Exegesis according to classical Roman law}

Introduction: the case of D. 9.2.9.4

The facts of the following case are quite simple: persons are playing a game ${ }^{252}$ of javelin throwing. ${ }^{253}$ Blunt spear heads were generally used for practice, especially for distance throws. For target practice sharp javelins were used. ${ }^{254}$ Both pointed and blunt javelins were light objects. They were thrown by means

246 See Kunkel 1967 (reprint 2001), p. 245ff. On the person of Ulpian, see also Mayer-Maly 1961 (RE 17), col. 567ff., Crifò 1976, p. 708-789; Liebs 1997b, p. 175-187; Zwalve 1998, p. 83-114; Liebs in: Kunkel-Liebs 2001, p. XIII and Honoré 2002, esp. p. 1-36.

247 Ulp. D. 50.15.1pr.

248 Honoré 2002, p. 14.

249 Kunkel 1967 (reprint 2001), p. 246.

250 Tellegen-Couperus 2003a, p. 102.

251 Spruit 1994, p. 186.

252 Per lusum seems to be contrasted with in campo, and does mean that it was not a game in an official form. According to Monro 1898, p. 13, in campo probably implies military drill (cf. Inst. 4.3.4).

253 Zimmermann 1996, p. 1007, is speaking about a person who is throwing the javelin by way of sport (also Thayer 1929, p. 11; Wacke 1979, p. 275), but outside a proper sports field (he is held responsible under the lex Aquilia if he hits and kills a slave who happens to be passing by)

254 See Antiphon, Tetr. II.2, in which case a youth, who accidentally missed the mark, accidentally hit and killed another person; also Norman Gardiner 1907, p. 250. 
of an amentum. ${ }^{255}$ The amentum was a leather thong, a foot or eighteen inches long (i.e. $30.48 \mathrm{~cm} .-45.72 \mathrm{~cm}$.). It was firmly bound around the shaft of the javelin, leaving a free loop of three or four inches long (i.e. $7.62 \mathrm{~cm}$. -10.16 $\mathrm{cm}$.), in which the thrower inserted his index finger, or his index and middle fingers. ${ }^{256}$ While the javelin throwers were practising with the javelins, a slave crossed the field and was killed by a javelin. The persons involved in the legal dispute are the javelin thrower and the master of the slave.

One could wonder whether the field (campum) was a usual place designated for training and/or javelin throwing in the first centuries AD. Already the philologist Henricus Valesius (Henri Valois, 1603-1676) endorsed that once there were tombs outside the city of Edessa; soldiers, possibly trained by a commander, used to practise outside the city borders on a certain field used as a burial field. ${ }^{257}$ Hadrianus Valesius (1607-1692) also mentioned the field (campus) as a place where soldiers used to be trained in various exercises, and as a place to assemble soldiers. These fields were outside the city, in this case in the suburbs of Lutetia (now Paris), i.e. away from the insula (Île de la Cité) and on the other side of the bridges. ${ }^{258}$ Also the 'Marsfield' was a place for spear exercises. ${ }^{259}$ Apparently, the field lay outside the walls of the city. ${ }^{260}$ According to the Spanish legal humanist Ioannes Suárez de Mendoza $(\dagger 1681),{ }^{261}$ the field of the javelin throwers in D. 9.2.9.4 had to be a field designated for training with weapons, such as the Marsfield. Roman leaders used to train their recruits or (new) soldiers (tirones sive novimilites) in times of peace in the use of all kinds

255 See also on this topic Harris 1979, p. 92ff.; Wacke 1977, p. 9; 1979, p. 275; 1991, p. 361; Knütel 2001, p. 357. On the origin of the Roman use of the amentum, see Norman Gardiner 1907, p. 255ff.

256 Norman Gardiner 1907, p. 251; - The first purpose of the amentum was that it enabled the thrower to give a rotary motion to the javelin. This helped to keep its direction and increased its carry and penetrating power. Secondly, it served to mark the point at which the javelin was to be grasped. Finally, the amentum afforded a convenient handle; see Norman Gardiner 1907, p. 25lf.

257 Henricus Valesius in commentary on Ammianus Marcellinus, Res gestae, XVIII.7, ad per Edessena sepulcra. He referred to Artemidorus of Daldis, <Oneirocritica $>$, I.58; Libanius, $\pi \rho \varepsilon \sigma \beta \varepsilon v \tau i \varkappa \omega$ (Presbeutikos) [=Oratio XV.76; EvD]; Zosimus, Historia nova, IV<.54, lines 14-16, EvD >; Ennodius, Panegyricus Theoderico dictus, 19.

258 Valesius referred to Ammianus Marcellinus, Res gestae, XX.4.11f., XX.5.1, XX.9.6, XXI.2.1.

259 Hadrianus Valesius in commentary on Ammianus Marcellinus, Res gestae, XX.4, ad omnes petivere Platium, who referred to Suetonius, Augustus, II.83 and the Historia miscella XVII.74.

260 See also A.Schulting-N.Smallenburg, Notae ad Digesta seu Pandectas, ad D. 9.2.9.4.

261 On Ioannes/Juan Suárez de Mendoza see, e.g., Mesa 1951, p. 280ff.; according to Osler 1996, p. 349, when G. Noodt published his monograph on the Lex Aquilia in 1691, he was completely unaware of the existence of the humanist masterpiece published on the lex Aquilia by Suarez de Mendoza at Salamanca in 1640; Ioannes (Juan) Suárez de Mendoza's Commentarius ad Legem Aquiliam was reprinted by Gerard Meerman in his Novus Thesaurus; - A critical study of Suárez de Mendoza's Commentarius is being prepared by a research project by Dr. P. Święcicka. 
of weapons, among which the throwing of spears. ${ }^{262}$ Furthermore, Church father Cyprianus $(† 258)$ had argued that a soldier had to train in a field before he could go to war; ${ }^{263}$ Theodoretus Cyrensis (393-466) described St. Aphraates walking through a street leading to the suburban fields, then arriving at a field where soldiers used to practise; ${ }^{264}$ and finally, Johannes Chrysostomos (ca. 347-407) described that soldiers were taught tactics by their teachers, in the broad and level plains almost every day (in patentes et latos campos quotidie fere exeuntes) ${ }^{265}$ After their training, the young men could wash off their sweat and dust in the Tiber near the Marsfield and relieve their fatigue from the running they had done by swimming exercises. Furthermore, according to Vergilius the place outside the city might have been used by young men to train in the skills of horsemanship, 'or to break into teams amidst the dust, or to bend eager bows, or to hurl with their arms tough darts, and to challenge others to race or to a boxing bout.'266

\section{The reply of Ulpian}

The master of the slave who was killed asked Ulpian whether there was an actio for this situation and, if so, what the basis of such an actio would be. Firstly, and this considers a more general situation/remark, Ulpian answered that (in general) the lex Aquilia was applicable. ${ }^{267}$ Secondly, he added that in a more specific situation (an exception) there would be no possibility for the master to obtain an actio legis Aquiliae, namely, in the case where persons were javelinthrowing in a field and a slave crossed the field. The reason is that the slave should not have crossed the field of javelin throwers at an inappropriate time. Thirdly, Ulpian added that the person who throws a javelin at the slave with

262 See J. Suarez, Commentarius ad legem Aquiliam, lib. I. cap. II. sectio VII, nr. 3f., who referred to various literary sources, and to C. 1.27.2.9; - Indeed, according to Vegetius' Epitoma rei militari, II.23, the training of soldiers included javelin throwing in exercise fields (reference made by G. Noodt).

263 Cyprianus, Praefatio of Liber de Exhortatio Martyrii, p. 238.

264 Theodoretus Cyrensis, Historia ecclesiastica IV.26.2; also a French translation is available, namely, by Canivet et al. 2009, at p. 301.

265 Johannes Chrysostomus, Homiliae in 1 Thess., III, 4.

266 Vergilius, Aeneis VII.162 (transl. Rushton Fairclough 1986, p. 13, 15); - Apparently neither the humanists nor the scholars of the Dutch Elegant School mentioned the Ars Armandi of Ovidius in their discussion of D. 9.2.9.4. However, one fragment seems to be relevant, namely, Ovidius, Ars Armandi, III.382-385, because it mentioned i.a. ball games, discus games and javelin throwing, and seems to link these to the Campus (field of Mars, EvD).

267 According to Wacke 1979, p. 275, the first sentence of the passage, in which the javelin thrower is held liable, obviously refers to the case in which people play with javelins in public places or streets (also Von Lübtow 1971, p. 106). In such generally accessible localities, this dangerous activity would not be permitted. The practice of sports in these circumstances in itself constitutes a fault, according to Paul D. 9.2.10. The thrower cannot excuse himself by relying on the dead slave's own negligence; also Wacke 1977, p. 8; 1991, p. 361; Castresana 2001, p. 97. 
intention (data opera), will in any case be held (liable) under the lex Aquilia, in which case it is irrelevant what kind of field the slave crossed, an exercise field or just a 'normal' field.

The question addressed to Ulpian obviously referred to the applicability of the first chapter of the lex Aquilia. This chapter was applicable when someone caused loss by unlawfully killing a male or female slave belonging to another or a four-footed animal in the category of pecudes belonging to another. ${ }^{268}$ From the fragment by Ulpian it is clear that a slave was killed. In order to be able to hold someone liable on the basis of the lex Aquilia, it must be proven that the damage caused has been the result of active behaviour. A direct action was possible if the person committed the act directly with his body (corpore). Ulpian was even prepared to make an extension of this rule and also to provide a direct action in case a weapon was thrown. ${ }^{269}$

The act which led to the damage of this chapter of the lex Aquilia was called occidere. Possibly, in this case the interpretation of occidere was crucial. ${ }^{270}$ The problem of the killing caused by means of throwing a javelin (possibly to be categorised under 'alio telo' in Ulp. D. 9.2.7.1) as well as the possible inapplicability of the actio legis Aquiliae if the slave had crossed the campus iaculatorius imprudently, are well connected to the topic of the interpretation of occidere ${ }^{271}$ therefore, all aspects have to be taken into account in the following discussion.

The first sentence of the fragment possibly refers to the situation in which a slave had taken part in a game (per lusum) of javelin throwing, ${ }^{272}$ but it could also be the case that the slave had picked up something (e.g. a spear) or had tried to pick up something. The second sentence of D.9.2.9.4 concerns

268 See Gai. D. 9.2.2pr. and see, for a discussion of the three capita of the lex Aquilia, also, e.g., Crook 1984 and Valditara 1994, p. $830 \mathrm{ff}$.

269 Ulp. D. 9.2.7.1 ('vel alio telo'); Powell 1951, p. 198f.; Falcone 2004/2005, p. 297; Corbino 2008 , p. 114.

270 According to Wollschläger 1976, p. 127, this case is even placed in Ulpian's commentary on occidere in the first section of the lex Aquilia.

271 Albanese 1950, p. 143.

272 Javelin throwing for mere sport (not for proof of valour) was apparently discouraged; see D. 11.5.2.1 and D. 11.5.3; therefore, argues Beinart 1953, p. 292, there was Aquilian liability if a slave was killed, because the throwers had acted contra ius. 
another situation, in which others (alii) were practising in campo. ${ }^{273}$ At a certain moment, a slave crossed the field. In that case, when the slave walked across the exercise area at an inappropriate time, the master would not be granted an actio legis Aquiliae and, as a result, would be denied payment of a poena. However, an actio legis Aquiliae was possible if the javelin was thrown intentionally. In that case the master of the slave could obtain the poena from the wrongdoer consisting of the highest value of the slave in the preceding year.

It is a common view that this is an expression of the so-called 'all-or-nothing approach', predetermined by the formulary procedure. The iudex could only condemn the defendant to the total poena or absolve him (tertium non datur). ${ }^{274}$ So, if the wrongdoer acted with culpa or dolus, and if the other requirements of an actio legis Aquiliae were fulfilled, the iudex would condemn him to a poena; if he did not act with culpa or dolus, the iudex would absolve him.

However, this final outcome did not really change when the formulary procedure disappeared, namely, when the cognition procedure began to be applied. There were indeed differences: the procedure started when the plaintiff handed over a libellus conventionis to the judge, ${ }^{275}$ this magistrate, now a civil servant, was not bound by a formula anymore.

Nevertheless, the decision remained the same, which can no longer be explained as resulting from the procedural rules for litigation. It can be explained, however, against the background of the penal character of the remedy. This would imply that the all-or-nothing approach rather derives from the decision whether or not there was sufficient culpa on the side of the wrongdoer to impose a civil fine (poena) upon him.

\section{Is D. 9.2.9.4 interpolated?}

Before discussing the interpretations of Ulp. D. 9.2.9.4 provided by secondary literature, suspicions of interpolations will be discussed. These suspicions occur in two areas: as to the form and as to the possible relation with Paul D. 9.2.10. ${ }^{276}$ Some authors have made remarks regarding the form: the fragment by Ulpian would have been written in a remarkably loose style (si per lusum iaculantibus servus fuerit occisus; cum alii ... iacularentur; per eum locum; sed si

273 For this antithesis, see also Lawson 1968, p. 88.

274 See, e.g., Hausmaninger 1996a, p. 29.

275 On the beginning of a process by a libellus, see Kaser-Hackl 1996, p. $570 \mathrm{ff}$.

276 See, e.g., Kunkel 1929, p. 176; Albanese 1950, p. 142f.; Longo 1958, p. 64, who considers the end of D. 9.2.9.4 (sed si cum alii - tenebitur) interpolated as well as D. 9.2.10; also already Lenel, Palingenesia iuris civilis, II, col. 524; also Mommsen 1962 (editio maior), p. 280, suspects an interpolation, based on a comparison with Inst. 4.3.4. See also Lawson 1968, p. 88, who notes that the idea of Mommsen that words have dropped out of the Digest is contrary to a Basilica scholion, where the difference between the fragment of the Digest and the fragment of the Institutes is mentioned. 
... sed si), ${ }^{277}$ the start of the fragment with an ablativus-construction is regarded as difficult, and, according to these authors, the two times sed si appears are proof of stylistic poverty. Also, the phrase quia non debuit per campum iaculatorium iter intempestive facere is regarded as not being very elegant, ${ }^{278}$ and it is even suggested that this phrase is a [post-classical] gloss. ${ }^{279}$ Stylistic arguments alone should, however, not be considered sufficient to draw such a conclusion.

The connection with D. 9.2.10 is not defensible for classical Roman law, ${ }^{280}$ already because the two texts are written by different jurists. Besides, the fragment by Paul is stated in a more general way, in contrast with Ulpian's, which was given in a casuistic manner. Ulpian tried to establish whether there was culpa in certain situations. Given this formulation, the comment by Paul (D. 9.2.10) inserted by the compilers ${ }^{281}$ was probably inserted in order to provide an explanation of the last phrase of Ulpian's reply (quitamen ... tenebitur). It is even uncertain whether Paul himself used the phrase lusus noxius in a situation of this kind. ${ }^{282}$ MacCormack understands lusus noxius to describe the situation in which players throw javelins not deliberately to kill the slave or to injure him but to frighten him and provide themselves with a cruel sport. ${ }^{283}$ If he is right in this interpretation, then the compilers were of the opinion that negligence (culpa) also included participation in a mischievous/cruel sport. However, the interpretation of the whole phrase of D. 9.2.10 must be considered as conjectural in classical times, since the original context of the statement is not known to us. ${ }^{284}$

Interpretations in secondary literature: culpae compensatio

Regarding the interpretation of D. 9.2.9.4, some authors advanced that this case (originally) was an example of culpae compensatio, in the sense that the

277 Albanese 1950, p. 143; for suspicions of interpolation regarding the form, see Kunkel 1929, p. 175f., who rejects the conjecture of Mommsen.

278 Not unsuspect, according to Beseler 1922, p. 540; see also Schipani 1969, p. 328 nt. 25.

279 Kunkel 1929, p. 176.

280 Differently, apparently, Travis Laster 1996, p. $208 \mathrm{f}$.

281 Kunkel 1929, p. 176: 'die steife und gedrechselte Ausdrucksweise'; also Von Lübtow 1971, p. 106, treats it as a gloss.

282 Rotondi 1922, p. 487 and nt. 3; MacCormack 1974, p. 214; Kunkel 1929, p. 176 and nt. 2, attributes D. 9.2 .10 to the compilers; also Longo 1958, p. 65; Beseler 1948, p. 332: 'törichte Randbemerkung'; differently Beinart 1953, p. 292; Schipani 1969, p. 361 (on the terms noxius and lusus, see p. 361f.; see also Lawson 1968, p. 88).

283 MacCormack 1974, p. 214.

284 The situation in the reconstruction of Lenel (Palingenesia iuris civilis, I, col. 1010, pal. nr. 360 (Pauli ad edictum lib. XXII)), under the title Ad legem Aquiliam. 1. Ad caput primum, does not provide sufficient information; MacCormack 1974, p. 215, believes that it is not absolutely certain either how D. 9.2.10 was understood by the compilers. 
negligence of the wrongdoer was cancelled out by the one of the injured. ${ }^{285}$ However, this does not seem likely. It is sometimes argued that this case clearly shows that the slave, who crossed the sports field intempestive, i.e. while javelins were being thrown, had full responsibility for what happened. ${ }^{286}$ Only the slave was to be blamed, the javelin thrower did nothing wrong because he acted on a field especially designated for that purpose. ${ }^{287}$ Despite the fact that one could consider the act wrongful (iniuria), ${ }^{288}$ no negligence (culpa) occurred on the side of the javelin thrower. ${ }^{289}$ Accordingly, a prerequisite for a successful actio legis Aquiliae was lacking. As long as the javelin thrower was not negligent (culpa), he was not liable a priori. So there is no need to argue that his negligence could be compensated by the negligence of the slave..$^{290}$

\section{Interpretations in secondary literature: only the slave is negligent}

Secondary literature offers another interpretation which is more or less related to the interpretation elaborated upon above. This second interpretation comprises the thought that Ulpian solved the problem by creating a sole

285 Pernice 1867, p. 62; Grüber 1886, p. 31; see also p. 228f.; Wendt 1892, p. 152; Endemann 1893, p. 57; Heilfron 1920, p. 245; Rossi Masella 1951, p. 190; Von Lübtow 1971, p. 106, 136; Scott 1984, p. 168; see also Hausmaninger 1996a, p. 30; differently Demelius 1861, p. 59f.; Levison 1891, p. 4lf.; Plog 1896, p. 62; Ruhm 1898, p. 26; Coppa-Zuccari 1909, p. 29; Van den Heever 1944, p. 57f.; Wollschläger 1976, p. 127; Castresana 2001, p. 75, 98; Piro 2004, p. 134, qualifies the act of the slave crossing over as 'una responsabilità colposa del servo medesimo', and in that case there was no responsibility. She did not explicitly state whether she applies the theory under discussion here or not. The javelin thrower's act as cause of the occasio was not regarded iniuria, unless the death of the slave can be attributed with apparent certainty to the voluntary behaviour of the agent.

286 Valditara 1994, p. 862; - Obviously an actio legis Aquiliae would be granted when the slave crossed at an appropriate time; however, it remains uncertain what such an appropriate time would be. The following examples are mentioned by Travis Laster 1996, p. 209f. Possibly, when the throwers saw the slave and agreed to let him pass. This may involve waving the slave across. If, in such case, a thrower threw a javelin, because he thought the slave was far enough away to be beyond the range of the javelin cast, and hit him, he would be liable. It could also involve stopping briefly to let him pass, then starting again, because he thought the slave had already crossed the field, only to discover he was not yet out of danger.

287 Wollschläger 1976, p. 127.

288 Travis Laster 1996, p. 209 adds what he called a 'common view' of the javelin case, namely, that it represents action non iure. According to this author, if the javelin throwers are practising in general, they act non iure and are liable. If they practised at a place set aside for such purpose, they act iure and are not liable (see also Watson 1991, p. 348 nt. 9). Indeed, as Travis Laster already argued, this interpretation just focuses on one element of the location of the activity, and ignores other (equally important) aspects of the case; the issue was not solely about a right to throw javelins on a place set aside for such purpose. In Theophilus, Paraphrasis Institutionum, 4.3.4, and Inst. 4.3.4 another decisive element was added, namely that of the person of the thrower (i.e. whether the thrower was a soldier or a private person). This will be further discussed below on p. 75

289 Also Van den Heever 1944, p. 58, believes the javelin thrower had no culpa at all. He grounded this on the fact that citizens had the privilege to practise this warlike skill (javelin throwing) provided they did so at the proper place set aside for it. Public policy required that they be exempt from liability if they accidentally killed a slave who walked over the range.

290 See Van Nierop 1905, p. 7. 
negligence (culpa) on the side of the slave, as he was more negligent than the javelin thrower. ${ }^{291}$ The theory of the Romans may have been that preponderant negligence on the slave's part excluded the liability of the javelin thrower. ${ }^{292}$ Wacke argued that if the arena was clearly marked for javelin throwing, outsiders were expected to avoid the danger, ${ }^{293}$ in contrast with the situation on public roads where no passer-by was obliged to guard himself from such lance exercises. When the area was clearly marked, a person who exposed himself to the danger ran the risk of being killed. The predominant negligence of the injured party would exclude the liability of the thrower; Wacke added the statement of Pomp. D. 50.17.203. This sentence, however, originally had nothing to do with damnum iniuria datum, as is argued in the first section of this chapter. ${ }^{294}$ Possibly, the argumentation could make sense, but only with regard to Justinian law, because Justinian generalised D. 50.17.203 as a maxim, isolated from its original context.

\section{Interpretations in secondary literature: expectations of the javelin throwers}

Except for the case in which the thrower threw intentionally (data opera), the thrower was not liable. According to Ulpian, the slave should have refrained from crossing the javelin field at an improper time. Powell suspects this argument of Ulpian's and adds that it comes entirely out of the blue. ${ }^{295}$ Indeed, this argument is not repeated in Inst. 4.3.4, nor in the Paraphrasis Institutionum of Theophilus, where the example is given in relation to the question whether soldiers practising with javelins on the parade ground are liable for culpa. Possibly the real reason for Ulpian's decision was that people who were throwing javelins on a javelin field would not expect strangers to cross the field and were, therefore, normally not at fault if someone happened to cross and got pierced. But the moment they became aware of a person crossing, their awareness would become a new factor in the situation, creating liability for culpa. ${ }^{296}$ If that view is correct, the javelin throwers who were unaware of the crossing of the slave were exempted from liability, not because of an activity of the slave who intervened between the

291 Kaser \& Knütel 2003, p. 221.

292 See Wacke 1978/79, p. 9; 1979, p. 276; 1991, p. 361; also Luig 1969, p. 194. Ulpian's text does not, however, provide any foundation for such a line of thought.

293 He also mentioned Paul. D. 9.2.28 in which the principle of anticipation was also observed. See on this text Wacke 1979, p. 276.

294 In the same sense Wacke 1978/79, p. 9 nt. 24; 1979, p. 276 nt. 11.

295 Powell 1951, p. 211.

296 See D. 9.2.31, where a similar principle is applied in the case of a tree pruner throwing down branches from a tree. 
act of the javelin thrower and the damage suffered by the master of the slave (novus actus), ${ }^{297}$ but due to the absence of their own negligence (culpa). ${ }^{298}$

\section{Myview: D. 9.2.9.4 as a problem of culpa}

From the above discussion it appears that the particular situation, which could be interpreted from a modern perspective as a problem of contributory negligence, is solved without the use of such a concept. Probably, the Roman jurists did not know contributory negligence as a legal notion. The Roman jurists did not question negligence on both sides, but merely enquired whether the injury, considering the circumstances, was due to the negligence of the wrongdoer or not. ${ }^{299}$ If a slave crossed a sports field and was pierced by a javelin as a result, this was considered due to the slave's own negligence. In any event, the javelin thrower was not to be blamed for such an incident. ${ }^{300}$ Probably, modern scholars have invented and tried to attribute the theory of culpae compensatio to the Roman jurists, and attempted to force that theory upon the Roman sources. ${ }^{301}$

Nevertheless, it is possible that the case concerned the problem of culpa. If so, D. 9.2.9.4 deals with the culpa requirement and provides a specification of culpa for an individual situation. ${ }^{302}$ A certain act could involve culpa at a certain time, but could not involve culpa at another time. ${ }^{303}$ Carefully, Ulpian has drawn a line: no negligence can be ascribed to the javelin thrower if he exercised on an exercise field. ${ }^{304}$ Roman jurists approached the question of culpa in a casuistic manner, as they did with all legal problems. They did not try to subsume the facts of the individual case under a standardised test or

297 In the event of a novus actus interveniens, a (factual) harmful act or cause which occurs subsequent to an initial wrongful act of a tortfeasor. The novus actus breaks the chain of causation between that initial act and the damage or loss sustained by the injured party.

298 Powell 1951, p. 211.

299 See also Travis Laster 1996, p. 201, who rightly stated: 'Rather than singling out the plaintiff and considering his conduct in isolation for conformance with an objective standard, the Roman jurists incorporated the plaintiff's actions into the overall scenario.'

300 Zimmermann 1996, p. 1011; Hausmaninger 1996a, p. 29; Wollschläger 1976, p. 127.

301 In the same sense Buckland, McNair \& Lawson 1974, p. 370.

302 Zimmermann 1996, p. 1007. According to Travis Laster 1996, p. 208f., the jurist first offered a general rule assigning liability in which there was no reference to culpa; because Ulpian seemed to have assumed that javelin throwing was dangerous, he thought the participants were, therefore, at fault in the typical case. Then, Ulpian varied the scenario and added a specific situation, to alter the determination of fault, namely, where the throwers would not be liable.

303 Lawson 1968, p. 38.

304 In this context Paul. D. 9.2.31 (tree pruner) is relevant. The question whether the tree pruner was liable depended on the place where the accident happened and the further relevant circumstances. See also Paul. D. 9.2.30.3 (farmer case). On these texts, see Zimmermann 1996, p. $1007 \mathrm{ff}$. 
formulation. ${ }^{305}$ The jurists, so also Ulpian in this case, asked themselves if the defendant was at fault (culpa): if he had behaved in the way he should have. It is useful to remember that from the perspective of the litigating parties and their jurists/lawyers, the central question (quaestio) of the conflict involves a matter of quality (status qualitatis), because an act is not permitted or appropriate everywhere. ${ }^{306}$ The question whether the javelin thrower acted as he should have depended on the evaluation of all the circumstances of the case and tended to be determined from an objective point of view. ${ }^{307}$ The final phrase of D. 9.2.9.4 comprises the situation in which the thrower aimed intentionally at the slave; this will be discussed in the following.

\section{Interpretations of the final phrase of D. 9.2.9.4: causal connection (I)}

Sometimes the case described by the second part of D. 9.2.9.4 is interpreted by the principle of causal connection. ${ }^{308}$ It is possible that the Romans applied a theory of causation. The negligent or intending person was liable for the harm he caused, but not if some intervening agency prevented his act from producing effect. ${ }^{309}$ The nexus was also broken if between the fault (culpa) of the wrongdoer and the damage, some other cause intervened in the absence of which the damage would not have occurred. ${ }^{310}$ But if the original act was wilful, it is generally held that intervening negligence of the injured person did not constitute a defence, though there was the same breach of causal nexus. ${ }^{311}$ This is problematic since the result ought to be the same regardless of the intentional or merely negligent nature of the original act. If the javelin thrower did not cause the accident in one case, neither would he have in the other. ${ }^{312}$ Obviously, the Roman way of applying the theory of causation did not go so far as to relieve the intentional wrongdoer from his liability.

305 Zimmermann 1996, p. 1008. They did not ask in every case whether the defendant ought to have foreseen the damage. Foreseeability or carelessness could be important issues (e.g. in D. 9.2.31), but would not necessarily and conclusively be decisive for the question of liability; see Zimmermann 1996, p. 1008, and the literature mentioned therein

306 See Quintilianus, Institutio Oratoria, V.10.38-40; - From the perspective of the judge, the question was, of course, whether the accused person should be condemned/punished or not.

307 Zimmermann 1996, p. 1008; - According to the classical notion of liability, the inquiry into culpa was conducted objectively; see Parisi 1992, p. 69ff.

308 Thayer 1929, p. 65; Buckland \& Stein 2007, p. 587; differently Luig 1969, p. 194 (nt. 42). According to Wittmann, p. 22, in case of strict liability for directly caused acts, the culpa in old Roman law is still closely linked with causality; on the denial of liability in case of sole indirect

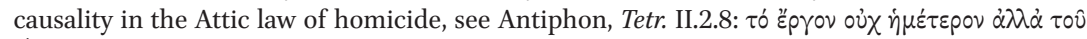

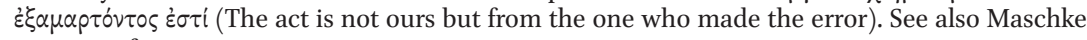
1979, p. 73f.

309 Buckland, McNair \& Lawson 1974, p. 371.

310 Buckland \& Stein 2007, p. 587, who refer to D. 9.2.11pr. and D. 50.17.203.

311 ibid.

312 Buckland, McNair \& Lawson 1974, p. 372. 
Interpretations of the final phrase of D. 9.2.9.4: causal connection (II)

A different interpretation, also regarding causal connection, is to view the intent to kill a person as the last direct effective cause. ${ }^{313}$ Indirect evidence that the decision can be explained with the question of the cause of the culpa (Schuldursache) can be found in another source from Antiquity, namely, a Greek example of the javelin throwers handed down by the sophist and orator Antiphon of Ramnus (about 480-411 BC). ${ }^{314}$ It can be found in his Second Tetralogy. ${ }^{315}$ It concerned a hypothetical case of homicide. ${ }^{316}$ Boys were practising javelin throwing in the gymnasium under the supervision of their trainer. One boy threw his javelin exactly at the moment in which another boy ran out onto the field to pick up javelins already thrown. This boy was pierced by a javelin and died. The question was whether the killing caused by the boy who threw the javelin was due to him, or to the victim, or to the trainer. ${ }^{317}$ The facts were not in dispute, the legal case concerned the interpretation of these facts. The Second Tetralogy of Antiphon consists of four speeches, two on each side. The javelin thrower was sued by the father of the boy who died before the Epheten on the Palladion. ${ }^{318}$ The prosecution accuses the javelin thrower of

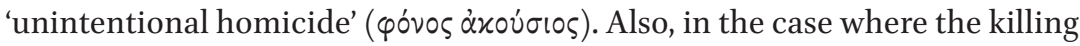
occurred without negligence, the thrower could be punished with exile. ${ }^{319}$ That is why for the defence (i.e. the father of the javelin thrower) it was not sufficient to prove that there was no negligence, and so they tried to prove that it was not the thrower who was the wrongdoer but that the victim was to be blamed for his own death as a consequence of his negligence. The victim himself was the author of his own death by walking onto the field and into the trajectory of the javelins. ${ }^{320}$ Besides the fact that the young men trained in the gymnasium,

313 See also Looschelders 1999, p. 10.

314 Wollschläger 1976, p. 128; - On Antiphon of Ramnus, see, e.g., Thalheim 1984, col. 2527ff.; Maidment 1953, p. 2ff.; Morrison 1972, p. 108ff., 114ff.

315 See Greek text in edn. Blass/Thalheim 1966, p. 28ff.; an English translation can be found in Maidment 1953, p. 89ff.; Morrison 1972, p. 147ff. See on the Second Tetralogy also Blass 1887, p. 162ff.; Pernice 1896, p. 241f.; Condanari-Michler 1948, p. 55ff.; Schmidt \& Stählin 1961, p. 119ff.; MacDowell 1966, p. 74; Daube 1969, p. 168ff.; Maschke 1979, p. 73ff.; Gagarin 1997, p. 144ff.; 2002, p. 103ff. (on the Tetralogies in general), p. 119ff.; Ibbetson 2004, p. 112f.

316 According to Loomis 1972, p. 92, this set of four speeches was never used in a real case, but was a pedagogical device for young orators. The author adds that as a teaching device, however, it was based on current practice; according to Leeman \& Braet 1987, p. 7, the speeches are fictive, but fit the legal reality; also Gagarin 2002, p. 103, according to whom the speeches were not written for delivery in court but for a more intellectual audience. It was written for readers who had the time to think about and assess the arguments (Gagarin 2002, p. 105).

317 Ibbetson 2004, p. 112f.

318 See Knütel 2001, p. 360f., where one can also find a summary of the argumentation of the speech of the defence.

319 Wollschläger 1976, p. 128 and the literature mentioned there.

320 See also Castresana 2001, p. 75. 
which was permitted and the exercise in itself was not forbidden, one could argue that the thrower did exactly what he wanted, i.e. throw the javelin at the target, and would not have missed it if he had not been prevented by the victim who ran out to pick up javelins at the wrong time; however, the victim erred by running out to pick up javelins at the wrong time. ${ }^{321}$ Therefore, the victim was the sole cause and thus had to bear the sole responsibility for his own death. ${ }^{322}$ In the last case the injured would already have been punished by his death. There was no need to (additionally) punish the javelin thrower. Without going into further detail about the finalities of the sophistic discussion as presented in the four speeches, summarising we can say that in fact the question was whether the javelin thrower was guilty of unintentional homicide or whether the injured was guilty of unintentional suicide. ${ }^{323}$

A comparison of D. 9.2.9.4 with the argumentation of the defence of Antiphon of Ramnus has already been made by Desiderius Heraldus (Didier Herault; 1579-1649). ${ }^{324}$ When we read the final phrase of D. 9.2.9.4 against the background of the discussion in the Tetralogy of Antiphon, it is unlikely that D. 9.2.9.4 had anything to do with compensation of culpa. The only reason why the negligence of the victim by which he was injured was considered at all was to eliminate the causal connection between the act of throwing and the homicide. The underlying idea was that one sole culpa had to be established either on the side of the injured or on the side of the javelin thrower. ${ }^{325}$ Probably, the Roman jurists had knowledge of these old Greek fragments due to their training in Rhetoric; ${ }^{326}$ furthermore, in the endphase of the Republic, there were close links between jurisprudence and rhetoric. ${ }^{327}$ One has to consider D. 9.2.9.4 in this way, only the slave was to blame, that he crossed the

321 This is not the theory of novus actus interveniens as there is no original breach of duty on the side of the thrower. The event that the victim erred by running out to pick up javelins at the wrong time did not occur subsequent to any negligent conduct of the defendant.

322 Gagarin 2002, p. 119.

323 See also Loomis 1972, p. 92.

324 The situation would have been different if the javelin thrower intentionally pointed his bow at the second boy; in that case he would have caused the damage unlawfully and the javelin thrower would be liable for negligent homicide; see extensively D. Heraldus, Observationes ad Jus Atticum et Romanum, V.6, nr. 12.

325 Wollschläger 1976, p. 129.

326 See on this, e.g., Cicero, De oratore, I.57.244; Schulz 1961, p. 64; Wollschläger 1976, p. 129.

327 See Knütel 2001, p. 362. Furthermore, the influence of Greek Philosophy and Rhetoric on the Roman jurists was more significant than was thought by scholars far into the last century; see Kaser 1975, p. 7f.; Wieacker 1988, I, p. 662ff., 669ff., with references; Knütel 2001, p. 363. 
field at an inappropriate time; the javelin thrower behaved properly and was not at fault. ${ }^{328}$

The final phrase of D. 9.2.9.4: a different meaning of data opera

Finally, some remarks regarding the last sentence of the fragment have to be made. Ulpian described the person who threw intentionally in the same wording as Alfenus in D. 9.2.52.1, namely, data opera ${ }^{329}$ If the javelin thrower threw with data opera, the victim's interruption at the causation of the result had no effect. ${ }^{330}$ In that case, the liability of the thrower prevailed upon the circumstance that the injured had exposed himself to the danger. ${ }^{331}$ However, according to secondary literature, this data opera has to be interpreted in a more extensive manner than usual. It seems that acting opera data did not necessarily mean the actor had the intention to hit the other person. ${ }^{332}$ Apart from deliberately aiming at the person, even if the aim only was to frighten that person, ${ }^{333}$ or maybe just to show the thrower's capacity not to hit the person, ${ }^{334}$ he would be liable for the damage caused. ${ }^{335}$ The same applies if he threw near enough to make the slave jump, ${ }^{336}$ or perhaps if he recklessly persisted in throwing after he knew the slave was in the area of danger. ${ }^{337}$ In all these interpretations of data opera, the thrower was aware of the presence of the slave and, therefore, was responsible and liable. If one accepted this extension, this category would be somewhat broader than what is normally understood as dolus (namely, with the intention to kill). At any rate, it does not seem necessary to make further complicated distinctions, so in the following I will stick to the generally used word dolus, unless I explicitly state otherwise.

328 In this sense also Wollschläger 1976, p. 127; Knütel 2001, p. 362.

329 On these words see, e.g., Thayer 1929, p. 66f.

330 Aumann 1964, p. 9.

331 Wacke 1991, p. 362.

332 See Wacke 1988, p. 532; 1991, p. 362; Castresana 2001, p. 99.

333 MacCormack 1974, p. 214.

334 Pernice 1867, p. 55 nt. 30; Grüber 1886, p. 31.

335 See also Wacke 1978/79, p. 10; Knütel 2001, p. 358; Castresana 2001, p. 99.

336 Powell 1951, p. 210f.; also Van den Heever 1944, p. 58: 'designedly attempt to register near-miss'.

337 Powell 1951, p. 210f. According to Pollock 1929, p. 615, 'it is not clear whether the words "data opera" are intended to cover the case of reckless persistence in the javelin throwing after the danger to the slave who has put himself in the way is manifest.' In his opinion, there can be no doubt whatsoever that Ulpian would have considered such conduct equivalent to dolus. 
The final phrase of D. 9.2.9.4: dolus opposed to culpa

One possible explanation could be that in such a case the negligence of the slave is opposed to the intentional act of the wrongdoer. The question regards the relation between the two assumptions. Some argue that the more serious degree of negligence, the predominant one, would have been decisive, ${ }^{338}$ and that the victim could only obtain compensation if his negligence was less serious than the negligence of the wrongdoer. ${ }^{339}$ The person who acted with dolus was liable, despite the contributory negligence of the victim. Others argue that the less serious degree of negligence, i.e. culpa, is absorbed by the higher degree, dolus. ${ }^{340}$ Such argumentations are unnecessarily theoretical and difficult, since no such theory can be found within the text. Another seemingly more plausible explanation is that dolus can convert a lawful act into an unlawful one. Thus, the javelin thrower, whether or not on the campus iaculatorius, was liable if he designedly threw a spear at the slave. ${ }^{341}$

\section{The final phrase of D. 9.2.9.4: Plutarchus, Pericles 36.3}

Possibly, another similar case could help to interpret D. 9.2.9.4. The first report of Pericles (ca.490-429 BC), regarding a comparable case that must have occurred in the fifth century BC, is handed down by Plutarchus. ${ }^{342}$ When an (pent) athlete unintentionally struck Epitimus the Pharsalian (a spectator) with a javelin and killed him, Pericles spent the entire day with the sophist Protagoras (ca.485-415 BC) arguing whether one should believe that the javelin or the javelin thrower or those who arranged the contest (the judges) ${ }^{343}$ were more to blame ${ }^{344}$ and if they, according to the most correct account, ${ }^{345}$ ought to be

338 Aumann 1964, p. 9; Luig 1969, p. 194; Hausmaninger 1996a, p. 29.

339 According to Van Nierop, p. 59, this idea floated already among Roman jurists.

340 Visky 1979, p. 494f.; - Pernice 1867, p. 62, argued that the rule of culpa-compensation suffers an exception when the wrongdoer is in dolo, for only similar things can be set off against each other. Dolus and culpa are, however, according to Pernice, completely unlike; according to Van den Heever 1944, p. 58, the javelin thrower exceeded his privilege and is thus liable in case of acting data opera. See also n. 289 above.

341 Beinart 1953, p. 294.

342 For the Greek text and an English translation, see Perrin 1967, p. 104f. For an extensive comparison between Plutarchus, Pericles 36.3 and Ulp. D. 9.2.9.4, see Reinoso-Barbero 1993, p. 489ff.; - Possibly this case had influenced the Table 8.24a and, thereby, the fragments by Cicero and Alfenus (which will be discussed later); see Reinoso-Barbero 1993, p. 505f.

343 MacDowell 1963: 'or were the organisers of the contest to blame for allowing spectators to stand where they might be hit?'

344 An actio legis Aquiliae against the masters of the game was not an option at all in the case of D. 9.2.9.4 because the judges did not fulfil the requisite of corpore-corpori. See Del Castillo Santana 1994, p. 27; Reinoso-Barbero 1993, p. 500ff.

345 Perrin 1967, p. 105: 'in the strictest sense'; also Ibbetson 2004, p. 112; Gagarin 2004,

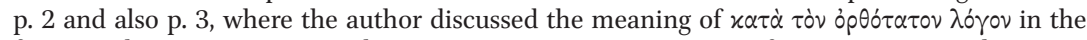
fragment by Protagoras; according to Gagarin 2004, p. 6, sources for Protagoras' work suggest that he was best known for his highly provocative observations aimed at stimulating others to 
responsible for the disaster that occurred. ${ }^{346}$ In comparison with D. 9.2.9.4, the facts appear to be almost identical, but the responses are not. The methodology applied in the answers, however, is the same. ${ }^{347}$ In Plutarchus, Pericles 36.3, three possible solutions are mentioned (that the javelin, ${ }^{348}$ the javelin thrower or those who arranged the contest ought to be held responsible), which is formulated with an exclusive disjunction. The exclusive disjunction excludes the possibility of liability of more than one person. In D. 9.2.9.4 the two possible solutions are also formulated by way of an exclusive disjunction: sed si per ... fuerit occisus: the javelin thrower is liable; sed sicum ... locum transierit: the slave is responsible (and the master of the slave has to suffer the damages). ${ }^{349}$ When comparing the specific possible liabilities, only one is dealt with by Ulpian, i.e. the liability of the javelin thrower.

\section{The final phrase of D. 9.2.9.4: Pseudo-Quintilianus, Declamatio Maior XIII} Another relevant text in which a resemblance with D. 9.2.9.4 can be found is Pseudo-Quintilianus, Declamatio Maior XIII. ${ }^{350}$ This rhetoric fragment from the second or third century AD could, perhaps, provide some insight into the interpretation of the lex Aquilia - moreover, about the reception of the lex Aquilia among intellectuals. ${ }^{351}$ It is a parody on legal practice. A poor man

question traditional views; the assertion that the javelin itself could have been responsible for someone's accidental death may have been in large part heuristic, intended to stimulate further reflection as to the correctness in these and related areas.

346 See also Knütel 2001, p. 359.

347 Reinoso-Barbero 1993, p. 489; - This does not necessarily mean that the Greek influenced the Roman system; according to Reinoso-Barbero 1993, p. 495f., the reason has to be found in criminal law.

348 This seems strange, but one has to keep in mind that it is just a manner of argumentation. On this possibility, see Reinoso-Barbero 1993, p. 496ff.; - The inclusion of the spear in this discussion becomes understandable from the background that in Athens there was a court on murders in the Prytaneion; this court was competent in cases involving the killing of a person by animals or things and perhaps also when the offender was unknown; see Nörr 1986, p. 68; Knütel 2001, p. 359f. The court probably was used over time in cases involving an involuntary or an unintentional killing for the purpose of transferring the result from the person who performed the act onto the tool used; the negligent killing first appears in Greece in the guise of causation of an instrument; see Condanari-Michler 1948, p. 48; Knütel 2001, p. 360. Against the spear, a trial could have been brought, and, in case of conviction, it would have to be removed from Attica; see Nörr 1986, p. 68; Knütel 2001, p. 360.

349 This last possibility is, however, not mentioned in Plutarchus, Pericles 36.3. See Reinoso-Barbero 1993, p. 493; exceptionally, in some legal thought, like the culpae compensatio, an inclusive disjunction is used; see Reinoso-Barbero 1993, p. 496.

350 See Lehnert 1905, p. 246ff.; Håkanson 1982, p. 264ff. Krapinger 2005; Mantovani 2007, p. 379ff.; Nörr 2003, p. 1708*; - On this fragment see also Frier 1994, p. 140f. (also discussing other cases about bees); Mantovani 2007; Corbino 2009a, p. 511ff.

351 Nörr 2003, p. 1708*. 
(pauper) and a rich man (dives) were neighbours in the countryside. The rich man had flowers in his garden, the poor man had bees. The rich man complained that the bees were feeding on his flowers and gave notice that the poor man should change their location. When the poor man did not do so, he sprinkled his flowers with poison. All the bees of the poor man died. ${ }^{352}$ The poor man brought a lawsuit against his wealthy neighbour based on unlawful damage to his property. However, the rich man did not kill his neighbour's bees, but just poisoned his own flowers in his own garden (because the bees were eating his flowers, and the pauper did not want to move his bees to another place). ${ }^{353}$ Although the rich man confessed to doing as he did (poisoning the flowers), he denied that there was a financial loss (damnum), ${ }^{354}$ and he argued that the loss was not caused by his unlawful conduct (iniuria). ${ }^{355}$

One of the arguments with which the rich man objected was that it was not he who killed the bees, but the bees killed themselves. ${ }^{356}$ To lead this argument ad absurdum, the poor man used examples which, regarding the content and sequence, have some resemblance with the commentary of Ulpian. Has the victim killed himself if he brings the poisoned cup to his lips himself? Would the victim have fallen into the ambush on his own accord if someone had stationed an assassin in the woods? If a javelin had been thrown in the dark, would a victim walking into the spear have killed himself? ${ }^{357}$ Of course not, one would think.

Final remarks on the final phrase of D. 9.2.9.4: resemblance with Inst. 4.3.4

Apart from the resemblance with D. 9.2.9.4, Declamatio Maior XIII had a resemblance with Inst. 4.3.4 because in these two texts the same approach was used with regard to the determination of culpa. ${ }^{358}$ Liability seems to be based

352 Summary of the case is based on the English translation by Sussman 1987, p. 165.

353 See also Corbino 2009a, p. 512; there is a resemblance with the case of Ulp. D. 9.2.49pr., in which an actio in factum is given when someone drives away bees belonging to another or even kills them by means of making smoke.

354 Because the poor man lost a creature that was free, able to fly, nomadic and situated beyond human control (transl. Sussman 1987, p. 169); - A discussion of this argument can be found in Corbino 2009a, p. 516ff.

355 Because the rich man destroyed, on his own private property, bees which were harming his interests, and because the bees went to their death voluntarily after some poison had just been sprinkled on his own flowers (transl. Sussman 1987, p. 169); Corbino 2009a, p. 515., also on the second argument, see p. 518; see also Mantovani 2007, esp. 341f.

356 This argument and the following argument are taken from Pseudo-Quintilianus, Declamatio Maior XIII, cap. 14.

357 Nörr 2003, p. 1709*; Sussman 1987, p. 174 (English translation); Krapinger 2005, p. 56f. (Latin text and German translation); - Of course the situation mentioned is slightly different from D. 9.2.9.4, because in that case the spear was thrown on a field (campus), and not in the dark.

358 Reinoso-Barbero 1993, p. 499. 
on the voluntariness of the act; so, in the absence of a voluntary act when an accident occurs, there is an exemption of liability. ${ }^{359}$ Two other fragments on javelin throwers could provide a deeper understanding of these matters, namely, Cicero, Topica $17.64^{360}$ and Alfenus D. 9.2.52.2. The two Roman authors suggest voluntary actions by using similar expressions: si telum manu ... iecit (Topica 17.64) and si quis ex manu telum immisisset (D. 9.2.52.2). They seem to refer to the Twelve Tables (fifth century BC) here, namely, to 8.24a. ${ }^{361}$ This fragment holds a useful application of the topos from causes (locus causarum) for jurists. Causes are places which have to do with things that produce effect (Topica 20.58). Some causes are hidden, namely, those subject to fortune. Actions taken are partly involuntary, partly intentional; intended are those actions preceded by deliberation. Fortuitous events are either involuntary or intentional. Throwing a javelin is subject to a will, hitting someone you did not intend to hit is due to misfortune. ${ }^{362}$ A last case on javelin throwers that seems to be in line with the argumentation of Cicero is Marcianus D. 48.19.11.2. An act is committed either deliberately, or upon a sudden impulse, or by chance. An act is committed by chance, e.g. if a man kills another man while hunting and aiming a dart at a wild beast. Also here the jurist seems to argue on the basis of the idea of voluntary acts.

\subsubsection{Post-classical development}

The compilers inserted the comment by Paul (D. 9.2.10) after D. 9.2.9.4, probably in order to provide an explanation (it starts with nam) of the last phrase of Ulpian's reply in D. 9.2.9.4 (quitamen ... tenebitur). Indeed, as to the interpretation of Justinian law, these fragments (D. 9.2.9.4 and D. 9.2.10) have to be seen in relation to each other. ${ }^{363}$ It has been stated that it is not absolutely certain either how D. 9.2.10 was understood by the compilers. ${ }^{364}$

359 Amaya García 1993, p. 64.

360 Cicero, Topica 17.64: Nam iacere telum voluntatis est, ferire quem nolueris fortunae. Ex quo aries subiciter ille in vestris actionibus 'si telum manu fugit magis quam iecit'; for the Latin text with English translation, see the edition of Reinhardt 2003, p. $148 \mathrm{f}$.

361 Table 8.24a: Si telum manu fugit magis quam iecit; see on this text as well as the abovementioned texts, Del Castillo Santana 1994, p. 25ff. The author concludes (p. 28) by stating that the intervention of the element of intention at the time of the Twelve Tables was limited to the contrast between voluntary or intentional acts and acts caused by accident or force majeure; see also Amaya García 1993, p. 65f.

362 See Cicero, Topica 10.63-20.64.

363 cf. also scholion 11 ad B. 60.3 .9 (BS 3101/12); see page 77.

364 MacCormack 1974, p. 215. 
Although this view seems correct, I will attempt to interpret it, to give it a useful meaning.

According to D. 9.2.9.4, if the javelin thrower threw with data opera, the victim's interruption of the causation of the result had no effect. When putting the text of D. 9.2.9.4 as an explanation (and bringing ludus noxius in relation to the words data opera), this would mean: for a dangerous game should be classed as an act of negligence. This is rather strange, when one would interpret data opera as intention, because intentional throwing would be qualified as a dangerous game and as negligence (culpa).

However, as already mentioned above, the view has been defended in secondary literature, that data opera has to be interpreted in a more extensive manner here. It seems that acting opera data did not necessarily mean the actor had the intention to hit the other person, ${ }^{365}$ but that it could also mean various other things, ${ }^{366}$ which were all interpretations of data opera in this context. In all these possibilities, the thrower was aware of the presence of the slave and, therefore, was responsible and liable. These forms of risky behaviour could be qualified as ludus noxius, and, thus, the view of the compilers could have been that therefore participation in such a mischievous/cruel sport constituted negligence (culpa). ${ }^{367}$

An interesting question is whether the compilers of Justinian's compilation considered D. 9.2.9.4 to be an application of the rule of D. 50.17.203 (generalised as a maxim by Justinian). Could one argue that the slave, who crossed the sports field intempestive, suffered damage as a result of his own fault and, therefore, is not considered to have suffered any damage? This is indeed possible. Is it plausible that the compilers did so? Possibly; but, strangely enough, they did not include this 'own negligence' of the injured party in another fragment about javelin throwers included in the Institutes and showing resemblance with that of D. 9.2.9.4, ${ }^{368}$ namely, Inst. 4.3.4. Apparently,

365 See literature mentioned in section 2.4.4, on page 68.

366 For example: throwing only to frighten that person, throwing just to show the thrower's capacity not to hit the person; the possibilities were discussed above.

367 One can also argue that already throwing javelins in a public place, and thereby killing a slave, would make liable based on (the first chapter) of the lex Aquilia, as a dangerous game (at a wrong place) would justify negligence (culpa); a similar view is held by Knütel 2001, p. 357.

368 According to Grüber 1886, p. 32, the rule of Ulpian in D. 9.2.9.4 must even be taken with the restriction made in Inst. 4.3.4; - The Institutes have an introductory character. Because of the complexity of the Digest for students, Justinian decided an introductory textbook had to be prepared. This task was assigned to Tribonian, Theophilus and Dorotheus. Justianian instructed them to make the Institutes based on earlier introductory works of the early Empire, i.e. the Institutes of Gaius, but also to adjust it to their time; see Tellegen-Couperus 2003a, p. 136. A large part seems to be more or less literally copied from Gaius' Institutes. Inst. 4.3 .4 is, however, not copied from the Institutes of Gaius. Obviously, at the time of the Institutes of Gaius (ca. 161 AD) 
the 'own negligence' was not that important that it had to be included in Inst. 4.3.4. The fragment of Inst 4.3.4, included in book IV, title III. De lege Aquilia, reads as follows:

Itaque si quis, dum iaculis luditvel exercitatur, transeuntem servum tuum traiecerit, distinguitur. Nam si id a milite quidem in campo eoque, ubi solitum est exercitari, admissum est, nulla culpa eius intellegitur: si alius tale quid admisit, culpae reus est. Idem iuris est de milite, si is in alio loco, quam qui exercitandis militibus destinatus est, id admisit. ${ }^{369}$

Therefore, if someone, while playing or exercising with javelins, pierces your slave while he is passing by, a distinction is made. For if this was done by a soldier in a field where one usually practised, no negligence [culpa] is considered of him; if anyone else should commit such an act, he is liable for negligence [culpa]. The same is in accordance with the law to a soldier, if he committed the act in any other place than that designated for military exercises.

With a broader formulation at the beginning, this fragment is not only applicable when a person was playing (in a game), as stated at the beginning of the fragment of D. 9.2.9.4, but also when practising with a javelin. ${ }^{370}$ For the case of the piercing of someone's slave, a distinction is made, and this is a different distinction from the one in D. 9.2.9.4. Firstly, if the damage was caused by a soldier practising in a field where it was usual to do so (i.e. an exercise field), he had no negligence (culpa). If someone else (i.e. a civilian) did so, he would have culpa. ${ }^{371}$ The same goes, i.e. there would be culpa, in the case where a soldier pierced a slave in some place other than one designated for military

Ulpian was probably not even born yet. Possibly, Inst. 4.3.4 is derived from or at least inspired by Ulpian in D. 9.2.9.4.

369 On this fragment, see, e.g., De Robertis 2002, p. 217 f.

370 According to MacCormack 1974, p. 214, Justinian made explicit and brought into force one of the assumptions underlying Ulpian's decision. He made the question of culpa and liability subject to the question of the right to be in the field and throw javelins there; he took the soldier as an example.

371 Beinart argued that in this case damnum iniuria datum meant non iure and not culpa aut dolo. Liability was not negligence, but acting without right, iniuria (also Watson 1962, p. 212). It is on the ground for the exercise of his right that the soldier who performs javelin exercises in a place where practising is permitted, is not liable for killing a passing slave (Inst. 4.3.4; nulla culpa eius invenitur). On the other hand, if it is someone else, not a soldier, then that person would be liable (culpae reus). According to Beinart, whether either was truly at fault is not investigated but presumed. The jurists thought in terms of culpa but still applied earlier solutions. They tried to justify the solutions found in earlier concepts (i.e. iniuria) on the basis of culpa. Hence, they introduced what virtually amounted to presumptions of negligence. Inst. 4.3 .4 would be an attempt to illustrate both the earlier meaning of iniuria as mentioned in Inst. 4.3.1 and the meaning of culpa (Inst. 4.3.3). See Beinart 1953, p. 290ff. 
exercises. Justinian set out specific situations and for each situation he gave a ruling as to whether there was culpa or not. ${ }^{372}$ Only in one situation, namely, the soldier who threw in a field designated for that purpose, could the thrower be exonerated from liability. ${ }^{373}$

Justinian has deleted the motivation of liability of Ulpian (quia non debuit ... $)^{374}$ in this text and by doing so he changed the criterion of culpa, bringing it back from prudence or imprudence (depending on the place where the javelin was thrown, in a field or somewhere else) to the mere question whether the person was a soldier or not, basing the ratio on exercises common to soldiers. ${ }^{375} \mathrm{~A}$ confirmation for such reasoning can be found in the Paraphrasis Institutionum of Theophilus. If the soldier committed the act (at the Campus Martius or) in a place where it is the custom for soldiers to exercise, and thereby a slave was killed by a javelin, the striker will not be liable. ${ }^{376}$ However, if it was a private person and he killed in this place, then he will be liable, as it was not customary for a private person to exercise in arms. ${ }^{377}$ Apart from the new distinction in Inst. 4.3.4 as to the status of the thrower, ${ }^{378}$ the question as to whether the thrower had thrown intentionally has disappeared. ${ }^{379}$

Also the next fragment of the Institutes, Inst. 4.3 .5 (case of a tree pruner), is relevant here as both concern the culpa requirement. Contrary to classical Roman law, where such a link did not exist between the case of the javelin thrower (D. 9.2.9.4) and the case of the tree pruner (D. 9.2.31), in Justinian law there was a link between these cases. In the latter case, the question whether the tree pruner had culpa and was liable depended on the place where the accident happened and the further relevant circumstances. Also D. 9.2.9.4

372 MacCormack 1974, p. 214; one similarity between this text and D. 9.2.9.4 is that both texts concern the question of culpa; also Kunkel 1929, p. 176; according to Beinart 1953, p. 290f., this text, when studied from the perspective of a developed theory of culpa, is unsatisfactory, liability being imputed in cases where there might have been no fault (i.e. the civilian), and vice versa (i.e. the soldier).

373 Also Rossi Masella 1951, p. 146.

374 Also Schipani 1969, p. 455.

375 Schipani 1969, p. 458.

376 The question still was whether a poena could be required based on the first chapter of the lex Aquilia. This is also a civil law sanction, as the criminal law liability is not given in the event of only the negligent killing of a free person; see C. 9.16.1 (a soldier killed another soldier), Mommsen 1955, p. 839; Knütel 2001, p. 359.

377 See Theophilus, Paraphrasis Institutionum, 4.3.4, edn. 2010, p. 762ff. (with English transl.); - On Theophilus, the Paraphrasis Institutionum, and the authorship of the Paraphrasis Institutionum, see Lokin 1976, p. $337 \mathrm{ff}$.

378 See on this point, Schipani 1969, p. 455 nt. 10, for further references; - According to Van den Heever 1944, p. 58, public policy changed as the recollections of a citizen army became dim; Justinian conceded the privilege, so qualified, only to soldiers.

379 See also Rossi Masella 1951, p. $146 f$. 
dealt with the culpa requirement and provided a specification of culpa for an individual situation. An act could involve culpa at one time and not at another. Also in Inst. 4.3.4 the place of the act (practice area or not) was used as a criterion.

In the Institutes, the case of the tree pruner (Inst. 4.3.5) directly follows the case of the javelin throwers (Inst. 4.3.4). ${ }^{380}$ The compilers saw a connection between the fragments and, therefore, placed the fragments immediately next to each other, making this connection more explicit than in classical Roman law. D. 9.2.9.4 and D. 9.2.31 still included decisions made in an individual case on an individual basis. Besides, these decisions were given by two different jurists (Ulpian and Paul) and, therefore, were not, strictly speaking, (directly) connected with each other in classical Roman law. The two fragments in the Institutes, however, are part of a more or less systematic treatise for educational purposes. Moreover, they are promulgated together as law. As to the content, the treatment of Justinian in Inst. 4.3.5 is in large part the same as the content in D. 9.2.31. However, whether the land was public or private was not considered to be decisive, only whether there was a path. A number of possible events are distinguished, and for each case Justinian establishes whether or not there was negligence (culpa) on the side of the tree pruner. ${ }^{381}$

Soon after Justinian completed his Latin codification Greek translations, excerpts and summaries appeared, ${ }^{382}$ because the Byzantine lawyers were Greek-speaking and were hardly able to read Latin anymore. ${ }^{383}$ These writings did not have any formal force of law. This Greek tradition is the true beginning of Byzantine law. ${ }^{384}$ The Basilica ( $\tau \dot{\alpha} \beta \alpha \sigma \iota \lambda \iota x \dot{\alpha} \nu$ ó $\mu \iota \mu \alpha$, the imperial laws) was a collection of Greek texts of rules from Justinian's codification which still applied, and which was completed in final form in 900 under emperor Leo the Wise. ${ }^{385}$ The Basilica reordered Justinian's codification in sixty books, subdivided into titles. Due to the amount of legal texts and the lack of knowledge of the Latin language in the unclear mass of Greek texts, the overview was lost. In the Basilica, texts concerning the same content or issues

380 This is also the case in Theophilus' Paraphrasis Institutionum, edn. 2010, p. 764.

381 MacCormack 1974, p. 214.

382 See also Stolte 2005a, p. 65f.; - General information on Byzantine law written in this section can also, more extensively and profoundly, be found in Van der Wal \& Lokin 1985, esp. p. 38ff., $81 f$.

383 Brandsma 1996, p. 2; see also already Van der Wal 1976, p. 7 f.

384 See Stolte 2005b.

385 See Van der Wal \& Lokin 1985, p. 8f.; on the Basilica, see also, e.g., Lawson 1930, p. 486ff.; 1931, p. 536ff.; Jolowicz \& Nicholas 1972, p. 503f. 
are included under one title. Those texts were Greek summaries, sometimes translations of full texts, of passages of the Digest, the corresponding title(s) of the Codex, the Novel(s) and in some cases of the Institutes. The function of the Basilica was to make the law of Justinian more accessible. They did not have the force of law, but just constituted a new order of the compilation of Justinian. ${ }^{386}$ Around those fragments of the Basilica, so-called scholia, were written. Besides new scholia, which were written after the creation of the Basilica, also old scholia originating from the Justinianic period were written around the main text of the Basilica. ${ }^{387}$ These scholia originated from legal education given by professors (antecessores) at the law schools of Berytus and Constantinople. ${ }^{388}$ The texts of the Basilica, the 'old' scholia and the aforementioned Paraphrasis Institutionum of Theophilus give an explanation of the fragments of the Digest. They can provide better insights into Justinian law and into the way these fragments were understood in the sixth century.

The fragment below (B. 60.3.9) from the Basilica could be considered as a tool to read Justinian's compilation. Although the wording of the text of Basilica text is slightly different, the content is more or less the same as that of D. 9.2.9.4: 'So, if people who were playing ${ }^{389}$ with a javelin killed someone, there is place for the lex Aquilia. But not if they were playing with the javelin in a field [no liability], ${ }^{390}$ because in that case, one should have refrained from crossing the field at an inappropriate time, except for the case when the thrower intentionally aimed at the person, because in that case the person is held liable by the lex Aquilia.' Interesting is the fact that the latter exception is linked by a scholion $^{391}$ to the Basilica text 60.3.10 (=D.9.2.10): because [participating in] a harmful game is regarded/imputed as negligence (culpa). ${ }^{392}$ Furthermore, in another scholion reference is made to Inst 4.3.4. ${ }^{393}$ According to this scholion, the meaning of the passage of the Basilica is that, according to the distinction of Inst. 4.3.4, when a military man killed a passing slave, while playing or exercising with a javelin, and if this happened in the usual place of exercise, the soldier was not held liable by the lex Aquilia. But the soldier was liable if this

386 De Jong 2008, p. 76.

387 Van der Wal \& Lokin 1985, $90 f$.

388 Brandsma 1996, p. 3.

389 See also BS 3101/12-14 (scholion 11 ad B. 60.3.9).

390 This is explained by BS $3101 / 22-23$ (scholion 14 ad B. 60.3.9) in such a way that they were soldiers, - according to the distinction in Inst. 4.3.4 - from which this principle originates.

391 BS 3101/12-14 (scholion 11 ad B. 60.3.9).

392 See BT 2752/7-9.

393 See BS 3101/15-18 (scholion 12 ad B. 60.3.9). 
happened somewhere else, or if he was a private person. The reason is that exercising with arms in private was not allowed. ${ }^{394}$

\subsection{ULPIAN'S REPLY IN THE BARBER CASE}

\subsubsection{The text of D. 9.2.11pr.}

\section{Ulpianus libro octavo decimo ad edictum}

Item Mela scribit, si, cum pila quidam luderent, vehementius quis pila percussa in tonsoris manus eam deiecerit et sic servi, quem tonsor habebat, gula sit praecisa adiecto cultello: in quocumque eorum culpa sit, eum lege Aquilia teneri. Proculus in tonsore esse culpam: et sane si ibi tondebat, ubi ex consuetudine ludebatur vel ubi transitus frequens erat, est quod ei imputetur: quamvis nec illud male dicatur, si in loco periculoso sellam habenti tonsori se quis commiserit, ipsum de se queridebere.

Apart from some minor differences in textual editions, which will not be discussed in detail, ${ }^{395}$ three remarkable peculiarities have to be examined. Firstly, the word habebat. The littera Florentina contains the word habebat, ${ }^{396}$ as also the later (humanist) edition of Torelli does. ${ }^{397}$ The same verb and conjugation can be found in various manuscripts of the vulgate, ${ }^{398}$ of which one, Ms. Biblioteca Vaticana, Barb. lat. 1459, reads tonsor habebat in manu. ${ }^{399}$ However, the Basilica text (B. 60.3.1lpr.)

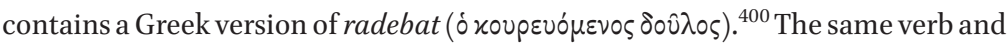
conjugation (radebat) can be found in the editions of Haloander and H. a Porta. ${ }^{401}$

394 Kunkel 1929, p. 175, - who apparently considered this scholion as an old scholion regarded this last phrase as a police consideration, which could well fit in the time of Justinian.

395 The edition of Haloander (edn. of 1550, fo. 256v) reads 'eandem' instead of 'eam', 'quocunque' instead of 'quocumque' and a verb was inserted, namely, ait, after Proculus, so that it reads Proculus ait. The final insertion is, although not made in the vulgate edition $c f$. edn. Kriegel 1844 , p. 191, was made in the vulgate edition with the Accursian gloss in edn. of 1487, fo. 162v.

396 See fo. $148 \mathrm{v}$ of the facsimile edition of the littera Florentina.

397 See edn. of 1553, I, p. 238; according to Gebauer-Spangenberg 1776, p. 171, after this example was written in the littera Florentina, another person wrote an $r$, and after he read tonsor adebat changed it into tonsor habebat.

398 cf. edn. Kriegel 1844, p. 191; see, e.g., Ms. Biblioteca Vaticana, Ottobon. lat. 1605, fo. 124r and Ms. Torino, Bibl. Naz., E. I.4, fo. 139v; more references are made by Gebauer in GebauerSpangenberg 1776, p. 171.

399 Ms. Biblioteca Vaticana, Barb. lat. 1459, fo. 88r.

400 BT 2752/13; Mommsen agrees with this emendation, see Mommsen \& Krüger 1962 (editio maior), I, p. 280.

401 See ed. of Haloander (edn. of 1550, fo. 256v) and edition of H. a Porta (edn. of 1551, p. 700); also in edn. Contius 1576, col. 1061; a later edition of the Digestum Vetus (edn. 1581, p. 700) even reads tradebat; - According to H. Brenkman, Apparatus ad D. 9.2, note habebat (1) ad D. 9.2.11pr. (edn. Van den Bergh/Stolte 1977, p. 263), the word radebat was not only found by 
The second peculiarity concerns the word adiecto. In the littera Florentina a letter ' $\mathrm{a}$ ' is missing, and so written as praecisadiecto. ${ }^{402}$ The edition of Torelli contains the same word (praecisAdiecto) ${ }^{403}$ Furthermore, an emendation is made in the littera Florentina. An 'E' is inserted by hand so one could read praecisadeiecto. In later editions also other different combinations exist, namely, praecisa adacto, ${ }^{404}$ praecisa adiecto, ${ }^{405}$ praecisa deiecto ${ }^{406}$ and praecisa abiecto. ${ }^{407}$

A final peculiarity concerns the word illud. In the littera Florentina it was written as illum. ${ }^{408}$ However, the littera vulgata ${ }^{409}$ contains the word illud, as do also the later humanist editions of Haloander ${ }^{410}$ and Torelli ${ }^{411}$ and, according to Brenkman, other scholars earlier than Torelli. According to Brenkman and later also Gebauer-Spangenberg, the reading illum was a mistake. ${ }^{412}$

Haloander, but also by Robertus Stephanus, Henricus a Porta and others.

402 See fo. $148 \mathrm{v}$ of the facsimile edition of the littera Florentina.

403 See edn. of 1553, I, p. 238.

404 Edn. Contius 1576, col. 1061; see also VIR I col. 1078. The reading adacto was also followed by the littera vulgata; see H. Brenkman, Apparatus ad D. 9.2, note adiecto (2) ad D. 9.2.11pr. (edn. Van den Bergh/Stolte 1977, p. 263f.). Later, J. Hoffmann (1710-1739) provided reasons for the preference for this reading in his Meletematum ad Pandectas, ad D. 9.2, §6. The reading adiecto cultello is completely incompetent and against the Latin way of speaking; furthermore, it was not in accordance with the mind of Ulpian: the ball was not added to the razor, but to the hand of the barber. Hoffmann believed that in general the reading has to be cultello adacto, because of the connection with and the meaning of the verb adigere (which was used in combination with weapons by 'old writers' (veteres) such as in Vergilius, Aeneis, IX.431). This reading may also have come into being because of scribal errors.

405 cf. edn. Kriegel 1844, p. 191; Mss. Paris, Bibl. Nat., Lat. 4450, fo. 93r (emendated reading); Padova, Bibl. Univ. 941, fo. 88v.

406 See, e.g., Ms. Biblioteca Vaticana, vat. lat. 1406, fo. 80v. This manuscript has been qualified as the earliest manuscript of the vulgate tradition (second half of the llth century), and thus closer to the vulgate archetype than any other manuscript; see Radding \& Ciaralli 2007, p. 171, 197f. On Ms. Biblioteca Vaticana, vat. lat. 1406, see extensively Radding \& Ciaralli 2007, p. 195ff., $215 \mathrm{ff}$.

407 See, e.g., Ms. Leipzig, Univ. bibl. 873, fo. 76v and possibly also in Paris, Bibl. Nat., Lat. 4450, fo. 93r (first reading; before emendation into adiecto); more references are made by Gebauer in Gebauer-Spangenberg 1776, p. 171; - Also 'abiecto' in the vulgate edition with the Accursian gloss (in edn. of 1487, fo. 162v) and in the edition of Haloander (edn. 1550, fo. 256v).

408 See fo. $148 \mathrm{v}$ of the facsimile edition of the littera Florentina.

409 cf. edn. Kriegel 1844, p. 191.

410 See edn. of 1550 , fo. $256 \mathrm{v}$.

411 See edn. of 1553, I, p. 238.

412 See H. Brenkman, Apparatus ad D. 9.2, note illud ad D. 9.2.11pr. (edn. Van den Bergh/ Stolte 1977, p. 264); Gebauer-Spangenberg 1776, p. 171. 


\subsubsection{Translation of D. 9.2.11pr.}

\section{Ulpian in his eighteenth book on the edict}

Also Mela writes that ${ }^{413}$ if, when some people were playing with a ball, (some) one hit the ball quite hard ${ }^{414}$ and knocked it against the hands of a barber, ${ }^{415}$ who, as a result cuts the throat of a slave, whom the barber was holding, ${ }^{416}$ with the positioned small knife, ${ }^{417}$ whichever of them is negligent (culpa) is held (liable) under the lex Aquilia. Proculus [says $]^{418}$ the negligence (culpa) is the barber's; and certainly if he was shaving there, where people customarily played games or where there often was crossover, ${ }^{419}$ this is attributed to him. ${ }^{420}$ Although one could also not improperly say that ${ }^{421}$ he who entrusts himself to a barber who held his chair in a dangerous place, ought to blame this on himself. ${ }^{422}$

413 Feenstra/Spruit in: Spruit et al. 1994, p. 715, translate this passage as 'Zo schrijft Mela dat'; - In a more interpretive way Thayer 1929, p. 13, who translates 'Mela gives another case'; d'Ors et al. 1968, p. 381, do not translate Item.

414 In the Basilica text 60.3.11pr. [BT 2752/12-16], a Greek equivalent for the Latin word vehementius is missing. Interesting is the definite way of formulating the final phrase of this

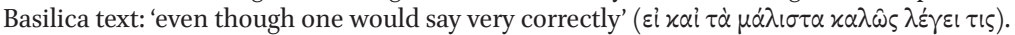

415 According to the VIR II, col. 140, the verb 'deicio' means 'proprie deorsum iacere', in this case therefore to throw the ball downwards into the hands of the barber.

416 Feenstra/Spruit in: Spruit et al. 1994, p. 715: 'die de barbier onder handen had'; differently Thayer 1929, p. 13: 'the throat of the slave being shaved by the barber'; d'Ors et al. 1968, p. 381f.: 'que a un esclavo al que el barbero estaba afeitando'; Otto, Schilling \& Sintenis 1839 (reprint 1984), p. 792: '... einen Sclaven rasierenden Barbiers'; Watson 1985: 'whom the barber was shaving'; Schipani 2005, p. 241: 'un servo che era dal barbiere'.

417 Feenstra/Spruit in: Spruit et al. 1994, p. 715: 'door het reeds daarop geplaatste scheermes'; adiecto is not translated by d'Ors et al. 1968, p. 381f.; Otto, Schilling \& Sintenis 1839 (reprint 1984), p. 792: 'dass durch die Bewegung des Messers ...'; Watson 1985: 'by the jerking of the razor'; Schipani 2005, p. 241: 'dal rasoio ad essa accostato'; Scott 1973, p. 327, translates the previous passage as follows: '... the hand of the barber who is shaving at the time, in such a way that the throat of the latter is cut by the razor'.

418 Differently Otto, Schilling \& Sintenis 1839 (reprint 1984), p. 792: '[hingegen sagt]'.

419 Thayer 1929, p. 13: 'where there was heavy traffic'; Feenstra/Spruit in: Spruit et al. 1994, p. 715: 'waar druk verkeer was'; Scott 1973, p. 327: 'where there was much travel'; Otto, Schilling \& Sintenis 1839 (reprint 1984), p. 792: 'wo häufig Menschen vorübergingen'; Watson 1985: 'where there was much going to and fro'; Schipani 2005, p. 241: 'dove il passaggio era affolato'.

420 Slightly different Feenstra/Spruit in: Spruit et al. 1994, p. 715: 'valt hem terecht een verwijt te maken'; d'Ors et al. 1968: 'hay motivo para imputarle la responsabilidad'; Thayer 1929, p. 13: 'he is partly responsible'; Scott 1973, p. 327: 'he is in a certain degree responsible'; Otto, Schilling \& Sintenis 1839 (reprint 1984), p. 792: 'kann ihm Schuld beigemessen werden'.

421 Differently Thayer 1929, p. 13: 'there is much to be said for the view'; d'Ors et al. 1968, p. 382: 'aunque también se dice acertamente que'.

422 See also Heumann \& Seckel 1907 (reprint 1958), p. 486, s.v. queri: de se queri debere means 'etwas sich selbst zuschreiben müssen'; no reference is, however, made to D. 9.2.11pr.; differently d'Ors et al. 1968, p. 382: 'sólo él tiene la culpa'. 


\subsubsection{Inscriptio}

The context of D. 9.2.11pr.

Just as D. 9.2.9.4, this fragment is derived from the eighteenth book of Ulpian's commentary on the edict (of the praetor); see section 2.4.3. The text of D. 9.2.11pr. was on the actio legis Aquiliae, because in a case where a slave is killed, the first chapter of the lex Aquilia is relevant. ${ }^{423}$ Lenel confirms that this text originally derives from a context of the lex Aquilia. In his Palingenesia, Lenel placed this fragment in book eighteen of Ulpian's commentary on the edict, in the part dealing with the first chapter of the title on title Ad legem Aquiliam. ${ }^{424}$ Also, the compilers of Justinian (527-565) incorporated this fragment in (Justinian's) Digest under the title Ad legem Aquiliam (D. 9.2).

\section{Mela}

The fragment is written by Domitius Ulpianus, ${ }^{425}$ who cites Fabius Mela. ${ }^{426}$ With regard to the latter's life, no exact date of birth and death can be established. However, some indications of time are found in fragments of the Digest. Ulpian cites Mela as an authority of an opinion of Aquilius Gallus (who was a contemporary of Cicero and was praetor in $86 \mathrm{BC}) ;{ }^{427}$ Ulpian also cites Mela as an authority of an opinion of Servius Sulpicius Rufus (ca. 105-43 BC). ${ }^{428}$ Accordingly, Mela must have lived after or in the same period as Aquilius Gallus and Servius Sulpicius Rufus. Because Ulpian first cites Mela and subsequently Proculus in D. 9.2.11pr., we can deduce that Mela lived prior to Proculus or that he was his contemporary. ${ }^{429}$ Finally, Africanus cites Mela in two fragments, D. 46.3.39 and D. 50.16.207. Accordingly, Mela must have lived either in the same period as Africanus or just before. In scholarly literature it is generally accepted that Mela lived in the same time period as Labeo. ${ }^{430}$

The origin of Mela is uncertain. Possibly he came from Spain, or from another area influenced by the Celtics, especially Gallia Cisalpina. In any event, it is plausible that he did not come from Italy, i.e. the region south of the Po. ${ }^{431}$ Mela was literarily active during the reigns of Augustus and Tiberius. No title of his

\footnotetext{
423 See Gai. D. 9.2.2pr.

424 Lenel, Palingenesia iuris civilis, II, col. 523f., pal. nr. 614.

425 For a discussion about Domitius Ulpianus, see section 2.4.3.

426 Long 1870a, p. 1011; Brassloff 1909 (RE 6), col. $1830 f$.; Kunkel 1967 (reprint 2001), p. 116.

427 Ulp. D. 19.1.17.6.

428 Ulp. D. 33.9.3.10.

429 Long 1870a, p. 1011.

430 ibid.; Kunkel 1967 (reprint 2001), p. 116.

431 Kunkel 1967 (reprint 2001), p. 116.
} 
work has remained. From Africanus D. 46.3.39 it becomes clear that the work of Mela mentioned by him consisted at least of ten books. Obviously, his works are directly or indirectly used by later authors, as becomes clear from their excerpts in the Digest (see, e.g., the above-mentioned fragments).

\section{Proculus}

The second jurist mentioned in this fragment is Proculus. ${ }^{432}$ Neither his nomen gentile nor his origin can be established with certainty. ${ }^{433}$ Proculus lived during the Principate; possibly he was born between 12 and $2 \mathrm{BC}$ and he died after the year 66 AD. ${ }^{434} \mathrm{He}$ was one of the first leaders of the school of the Procul(e) iani, and after whom the school is also named. Proculus was a student of Nerva (pater) and succeeded him as head of the secta started by Labeo after Nerva (pater), who died in $33 \mathrm{AD} .{ }^{435}$ He lived in the same period as Nerva (filius). Proculus must have been an important jurist. ${ }^{436}$ Moreover, the fact that the school is named after him confirms that he must have been a jurist of importance in those days. Proculus' most important work is the Epistolarum libri VIII, which was meant in the first place as a manual for educational purposes. ${ }^{437}$ Part of his work is indirectly handed down to us via Justinian's Digest, through which 33 extracts from Proculus' eight or eleven books of Epistulae have survived. ${ }^{438}$ Also, one fragment exposterioribus Labeonis is thus handed down to us (D. 33.6.16). ${ }^{439}$

432 On Proculus, see Long 1870b, p. 541; Mayer-Maly 1957 (RE 45), col. 1234; Honoré 1962b,

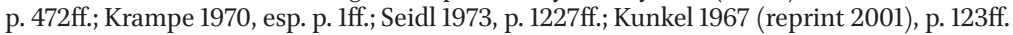

433 See on this topic the literature mentioned in the previous footnote.

434 Honoré 1962b, p. 485ff.; Spruit 1994, p. 169; see also Rodger 1972, p. 404 nt. 9; elaborated and slightly different Kunkel 1967 (reprint 2001), p. 126.

435 See also Pomp. D. 1.2.2.52.

436 This was the view of Pomp. D. 1.2.2.52 ('sed Proculi auctoritas maior fuit, nam etiam plurimum potuit').

437 Spruit 1994, p. 169

438 According to the Index Florentinus, Proculus wrote eight books. However, according to D. 18.1.69 he wrote at least eleven books. See Long 1870b, p. 541; Mayer-Maly 1957 (RE 45), col. 1234; Krampe 1970, p. 8.

439 On this fragment Mayer-Maly 1957 (RE 45), col. $1237 f$. 


\subsubsection{Exegesis according to classical Roman law}

\section{Introduction: the case of D. 9.2.11pr.}

The case concerns some people who were playing with a ball (pila). ${ }^{40}$ The pila was a little ball made of cloth rags, filled with hair or feathers, weighing about one kilogram. According to tradition, the ball was struck by hand only. ${ }^{441}$ Near the place where people were playing, a barber set his chair. People of the lower classes were shaved by these itinerant barbers in the open air, ${ }^{442}$ while for wealthier people elegant barbershops were available. ${ }^{443}$ Romans, freeborn and slaves were frequently shaven after passing their youth. The barbers were street-seller barbers who travelled with chairs at race-tracks and market places,

440 This was also the situation in the case described in Alfenus D. 9.2.52.4. The fact that the Romans played ball can be seen in Seneca, De beneficiis II.17.3-5; II.32; V.8.4; VII.18; on ball games in ancient Rome, see also McDaniel 1906, p. 121ff., and sources mentioned. He also discussed the different sorts of balls used by the Romans, the game trigon (see below) and the fragment of Varro Serapi as recorded by Nonius Marcellus, De compendiosa doctrina. II. De honestis et nove veterum dictis, 104.28-30 (see Lindsay 1964, I, p. 149: expulsim, dictum a frequenti pulsu. Varro Serapi: 'recte purgatum scito, quom videbis Romae in foro ante lanienas pueros pila expulsim ludere'); see also gloss quis pila ad D. 9.2.11pr. in Gothofredus/Van Leeuwen 1663; McDaniel 1906, p. 125, questions the traditional view that these words signify 'hitting repeatedly against a wall'; he argues that one can hardly doubt that the fronts of the butcher-shops, according to ancient fashion, were open; and that any play against whatever wallspace there may have been [on the supposition, for instance, that at some time in the day their fronts were boarded up; nt. 3] would have interrupted traffic; on the game which Brenkman called 'il calcio', see Brenkman, Apparatus ad D. 9.2, note pila (a) ad D. 9.2.11pr. (edn. Van den Bergh/Stolte 1977, p. 263).

441 Wollschläger 1976, p. 132; see also Jansen 2002b, p. 204. On ball games in Rome, see also Mau 1896, col. 2832ff.; Norman Gardiner 1955, p. 230ff.; Reinmuth 1964, p. 817f.; Harris 1972, p. 75ff.; Marquardt 1980, p. 841ff.; Schneider 1929, col. 1680ff. (sphaeristerium): especially the Comitium and Marsfield were favourite places to play ball; see Seneca, Epistulae 104.33 (in comitio pila lusit); Horatius, Sermones I.6.126; II.6.49 (Campus).

442 See also Wollschläger 1976, p. 133; - Already the humanist Marquardt Freher (15651614 ) - on M. Freher, see, e.g., Stintzing 1880, p. 680ff., 736 - made the remark that Rome was a busy city in Antiquity and barbers would put their chairs on streets and public roads; see M. Freher, Verisimilium libri duo, ad D. 9.2.11pr. This is proven by some literary fragments mentioned by Freher; see Martialis, Epigrammata, VII.60(61).7-10 and Horatius, Epistulae, I.7.50ff., from which it clearly emerges that barbers shaved persons outside; this conclusion could also be inferred from Juvenalis, Satires, VI.214f. From Martialis' Epigrams it appears that the grimy shop of the barber monopolised whole streets (together with the tavern keeper, the cook and the butcher) of Rome as one big shop. The Emperor Domitianus tried to change this situation in his municipal policy; in $92 \mathrm{AD}$ he issued an edict in which he forbade stalls protruding into the street, thereby restoring the peace in the streets of Rome; see Ker 1979, p. 465; Shackleton Bailey 1993, p. 127; Galán Vioque 2002, p. 354.

443 Carcopino 2002, p. 209ff.; also Wacke 1977, p. 13; 1979, p. 277; 1991, p. 363; Zimmermann 1996, p. 1012; Knütel 2001, p, 355; on barbers, hairdressers and beard fashions in Antiquity, see Mau 1899, col. 3f., 30ff.; Marquardt 1980, p. 597ff., 604ff.; Blanck 1996, p. 67ff., p. $82 \mathrm{ff.}$ 
clearly to shave where people were present and/or passed by, in this way trying to maximise their profits. ${ }^{44}$

When humanists tried to understand the context of the case of D. 9.2.11pr., G. Noodt remarked that a practice such as what occurred in this case was unknown in his own days and also quite unusual in the area where he lived. He even called D. 9.2.11pr. 'an elegant example that did not occur very often'. However, he made the same remark that it used to be quite usual and common in Rome. ${ }^{45}$ Also U. Huber called the case 'rare' ${ }^{446}$ Later, J.L.E. Püttmann (1730-1796) even wrote that although some will laugh after reading the case of Article 146 CCC (the received version of the barber case), ${ }^{447}$ they will stop laughing after realising that the case really occurred in Rome (based on the text of D. 9.2.11pr. and the normal practice as it appears from the fragment of Martialis). ${ }^{448}$

Obviously, in D. 9.2.11pr. the barber's customer was someone from the first category (i.e. someone of the lower classes), viz. a slave. At a certain moment, one of the ball-players hit the ball quite hard. The ball hit the hands of the barber, who was engaged in shaving the beard of the slave ${ }^{449}$ and therefore holding a small knife in a certain position. ${ }^{450}$ As a consequence, the throat of the slave was cut and the slave died.

In the following legal conflict two persons were involved: the master of the slave and the barber. The barber was sued before the praetor and for this reason he consulted a jurist. The consultation obviously concerned the applicability of the actio legis Aquiliae. He probably asked whether he was liable and/or whether he was at fault (culpa). It is useful to remember that from the perspective of the litigating parties and their jurists/lawyers, the central question (quaestio)

444 See U. Huber, Eunomia Romana, ad D. 9.2.11pr., nr. 2 (edn. 1724, p. 408).

445 G. Noodt, Ad legem Aquiliam liber singularis, c. VII. See also J. van der Linden, Annotatio ad Voet D. 9.2, nr. 17.

446 However, according to Huber, this case could be used (by analogy) to solve other cases; see U. Huber, Eunomia Romana, ad D. 9.2.11pr., nr. 1, p. 408: Casus in hoc loco l. xi. propositus, est historia sine dubio, rara quidem; sed cujus analogia ad alios similes extendi poterat: ideoque decisioni utiliter admovendus.

447 Art. 146 of the criminal code of Charles V will be discussed in chapter four.

448 J.L.E. Püttmann, Adversariorem juris universi, liber I, 16.6, p. 249 f.

449 Many authors regard habebat as interpolated and believe that it has to be radebat; see, e.g., Longo 1958, p. 65; Von Lübtow 1961, p. 106; this conjugation is already used, in Greek, in B. 60.3.11, as mentioned in section 2.5.1, on p. 79 .

450 Also the words adiecto cultello are suspected as being interpolated; see Schulz 1954, p. 41; Longo 1958, p. 65; Von Lübtow 1971, p. 106 (a redundant gloss). According to Beseler 1930, p. 31, adiecto does not fit, and adiecto cultello should be between sic and servi. Furthermore, he qualifies adiecto cultello as superfluous. Differently Albanese 1950, p. 144, who does not consider it as an interpolation and who reminds us of the theme of strict interpretation of occidere; Longo 1958, p. 65, also proposes to add alieni after servi (so it becomes sic alieni servi). 
of the conflict involves a matter of quality (status qualitatis). ${ }^{451}$ Three decisions of jurists were mentioned. The decisions were given in different times, as the jurists lived in different periods (as discussed before). ${ }^{452}$ Because a slave was killed, the first chapter of the lex Aquilia had to be applied. To hold someone liable under the lex Aquilia, the damage had to be the result of a direct act of the wrongdoer. This would be the case, if he had committed the act directly with his body (corpore). Apparently the act, according to Ulpian, could be qualified as killing (occidere), but it is uncertain whether this also holds for the reply of Mela, as probably a part of Mela's original text is missing. ${ }^{453}$ Possibly, as some authors suggest, Mela was discussing the question whether the action should be granted as an actio directa or as an actio in factum? ${ }^{454}$ In the part of Mela's reply that was quoted by Ulpian, it seems as if there was sufficient causal connection between the act of either the ball-player or the barber and the damage to justify an actio legis Aquiliae (directa). ${ }^{455}$

\section{The decision of Mela}

The decision of Mela, as summarised by Ulpian, was that in quocumque eorum culpa sit, eum lege Aquilia teneri. Some authors - mainly, although not exclusively, writing in the first half of the twentieth century - consider in quocumque eorum culpa sit as interpolated. ${ }^{456}$ The argument Mela used, namely, that whichever of them had culpa was liable under the lex Aquilia, can be considered to be obvious. ${ }^{457}$ By such a formulation a concrete decision

451 See Quintilianus, Institutio Oratoria, V.10.38-40; - From the perspective of the judge, the question was, of course, whether the accused person should be condemned/punished or not.

452 According to MacCormack 1974, p. 215, the case of D. 9.2.11pr. was a stock and much discussed case in classical law; differently Zwalve 2008, p. 16, who argued that the example could have been derived from the standard cases used as materials in Roman schools for rhetoric, as it would be a typical case to practise in utramque partem dicere. As there is something to be said for all points of view, one can - unhindered by any knowledge - argue whatever one wants.

453 MacCormack 1974, p. 223, states that the text probably has been preserved only in an abbreviated version: there is, according to MacCormack, no recorded final decision by Ulpian and the report of Mela and Proculus appears truncated; - See Kunkel 1929, p. 177f.; Ziliotto 2000, p. 136.

454 See Pollock 1929, p. 615; Kunkel 1929, p. 177f.; Lawson 1968, p. 88f.; also Albanese 1950, p. 144, believes the problem in this case was 'la corporalità del danno'; already Powell 1951, p. 208, argues that whether the player or the barber had culpa, and thus was liable under the lex Aquilia, or not, it was a direct action. In the case of the barber, if he was liable at all, because the wound was inflicted by the instrument in his hand; in the case of the ball-player, the question could be relevant because it could have been evaluated that there was no direct contact between the ballplayer and the slave; see Powell 1951, p. 208 nt. 47.

455 MacCormack 1975, p. 48; Watson 1984, p. 242 nt. 4; Zimmermann 1996, p. 1011, however, notices that the ball-player could hardly have caused the damage directly (corpori), but then he only provides the question whether Mela was contemplating an actio in factum without answering it; - Differently Beseler 1930, p. 32.

456 Albertario 1923, p. 506f. nt. 4; Beseler 1930, p. 31; Albertario 1936, p. 87 nt. 1; Schulz 1954, p. 42; Schipani 1969, p. 331f.; on this topic, see also Piro 2004, p. 91.

457 Rotondi 1922, p. 487, and Schipani 1969, p. 330, argue that it is possible that eum 
is avoided. ${ }^{458}$ Besides, the fragment seems to have concerned the liability of the barber and of the slave, but not of the ball-player; strangely enough, because under the lex Aquilia the latter would be the first possible responsible person since the damage could not have occurred without his act. Possibly, Mela pointed this out and the compilers changed the text into in quocumqueteneri: any of the people involved can be held responsible, depending on their negligence (culpa). ${ }^{459}$

From the facts it became obvious that a number of people independently from each other contributed to the joint result that a slave was killed by their actions. ${ }^{460}$ Mela stated that whoever acted with culpa was liable under the lex Aquilia. The word eorum does not refer to the several ball-players, ${ }^{461}$ but just to one player, namely, the one who hit the ball, and to the barber. ${ }^{462}$ The phrase in

in this text does not refer to quocumque but to the preceding quis (the ball-player). However, as they correctly state, it is not plausible that Mela first notices/uses the term culpa in order subsequently to exclude the legal importance of it; - 'Wertlos', according to Von Lübtow 1971, p. 107. According to Von Lübtow, Mela would have given an actio in factum against the ball-player because there was no direct physical act. In that perspective, one has to see the fact that he suspected the words lege Aquilia as being a post-classical interpolation and wanted to replace them by in factum actione; see Von Lübtow 1971, p. $106 \mathrm{f}$.

458 Rotondi 1922, p. 487.

459 ibid., p. 487f. According to Rotondi, in the actual redaction of the text the responsibility of the barber at the end is excluded in practice (see A. Faber, Rationalia in Pandectas, ad D. 9.2.11pr.). Differently Albanese 1950, p. 144, who argues that in quocumque eorum in the original text (the text without all interpolations) refers to one of the ball-players, and not to the ballplayer, barber or slave as could be understood from the actual text; also already Coppa-Zuccari 1909, p. 32, argues that it was the ball-player who (according to Mela) was held by the lex Aquilia. The reference of eum to the ball-player emerges from the antithesis of the first part of the decision (eum Aquilia teneri) with the second, namely, the decision of Proculus (Proculus in tonsore esse culpam). Furthermore, Coppa-Zuccari rightly states that Mela, in his responsum, does not suppose that the barber shaved at a dangerous place (namely, one used for playing ball). However, this factor cannot be implicitly decisive for the exclusion of the negligence of the player and for the recognition of the negligence of the slave and the barber.

460 Van den Heever 1944, p. 58.

461 See Schipani 1969, p. 331.

462 Albanese 1950, p. 144, argues that the original (genuine) text did not allow the actio legis Aquiliae against the tonsor. The barber did act corpore because of adiecto cultello, but the ball-player activated the act. After stating that no actio legis Aquiliae was possible against the tonsor, the text mentioned the possibility of an actio utilis against the ball-player. Actio utilis, because the act was performed non corpore; the compilers changed it into the normal action based on the lex Aquilia and thus deleted the related relevant question of the corporality of the act/the question of occidere; differently Schipani 1969, p. 332; Watson 1984, p. 242 nt. 4; According to Powell 1951, p. 208, the liability of the ball-player was considered by the jurists; but it would not have been considered as an alternative to that of the barber, in spite of the ambiguity in in quocumque eorum culpa sit. If both were negligent, the master of the slave has an action against both; see Lawson 1968, p. 89; Powell 1951, p. 208: 'The fact that we do not know the decision reached by the jurists about the liability of the ball player, does not mean that his liability can be ruled out on the ground that the culpa of the barber, if proved, would exclude the liability of the ball player. Proof of the culpa of the barber would make the barber liable, but the ball player could still be liable for his own act.' 
quocumque - teneri seems to mean that either the ball-player or the barber, but not both, might be liable. ${ }^{463}$ It seems to indicate that Mela held the essential question to be one of culpa, but also that he felt unable to determine whether culpa should be imputed to the ball-player or to the barber. ${ }^{464}$ Whether the barber or the ball-player had culpa and was thus liable must have been the main problem for the three jurists. ${ }^{465}$ The remainder of the existing fragment, however, is only about the liability of the barber and the 'contributory negligence' of the injured person, while the ball-player is not mentioned anymore.

Some authors argue that Mela considered the ball-player to be negligent. ${ }^{466}$ The first indication would be the use of the comparativus vehementius, ${ }^{467}$ instead of the more neutral vehementer. ${ }^{468}$ However, the fact that the ball-player threw

463 MacCormack 1975, p. 48; differently Wollschläger 1976, p. 131; Longo 1958, p. 65, has replaced the phrase in quocumque eorum culpa sit, eum lege Aquilia teneri by tonsorem lege Aquilia non teneri; Longo, just like Rotondi 1922, p. 487f., qualified all the references to the motive of culpa as interpolated as well as the foundations of decisions based on the motive of culpa. Therefore, he also considers another part of the fragment, esse culpam - de se queri debere, as interpolated; see Longo 1958, p. 64; already Beseler 1930, p. 31, regarded culpa sit and esse culpam as interpolated; see also Von Lübtow 1971, p. 116, who deleted the references to culpa as postclassical glosses (he deleted in quocumque eorum culpa sit and replaces in tonsorem esse culpam et sane by et tonsorem teneri).

464 MacCormack 1975, p. 48; Wacke 1977, p. 14; on this topic, see also Ziliotto 2000, p. 135f.; - As Ulpian referred to the view of Proculus, who was a younger jurist than Mela, one can deduce that Proculus' view (that the barber was liable) was not defended by Mela; see Krüger 1912, p. 160 (Proculus berichtigt Mela) and Knütel 2001, p. 356; the latter argues that if that is true, it is not unprobable that Mela already pleaded for the third solution as descibed in D. 9.2.11pr.

465 According to Kunkel 1929, p. 177, the fact that this case concerned more contributing acts to the rising damage connects it with the following texts (D. 9.2.11.1ff.); - According to Piro 2004, p. 92, the case as described by Mela, and as discussed by the three jurists, is complicated by a set of variables: the excessive behaviour of the player, the negligent behaviour of the barber in placing his chair at such a dangerous spot, the superficiality of the client in not having considered the risk; therefore the relevance of the culpable component plays a crucial role in the dynamics of the event.

466 Tassin 1912, p. 50; Jansen 2002a, p. 104; 2002b, p. 204. See also De Robertis 2000, p. 74; differently Knütel 2001, p. 355f., who argued that from the word item it can be inferred that the same basic idea as in the previously discussed case of the javelin thrower applies here: sports activities at a sports field (apart from the intentional infliction of harm) do not lead to the reproach of negligence, even in the case when in the heat of the battle or in trying to measure one's own strength, a third party is injured.

467 According to Longo 1958, p. 64, 66, vehementius is interpolated and has to be deleted from the fragment. This is understandable when following his theory. As stated in note 463, Longo wanted to change the text of D. 9.2.11pr. so that Mela explicitly stated that in this case the barber was not held liable by the lex Aquilia ('... tonsorem lege Aquilia non teneri'). Longo is, namely, of the opinion that the original classical fragment could not have permitted an actio utilis against the ball-player (differently in that perspective Albanese 1950, p. 144, who argues that the fragment could have permitted an actio utilis against the ball-player); therefore, the word vehementius has no important role anymore and has to be deleted; - On the word vehementius, see also Cannata 1966, p. 15; according to Del Castillo Santana 1994, p. 31, vehementius corresponds with tam vehementer, which appears in other texts (see Ulp. D. 19.2.13.4; Gai. Inst. 3.219).

468 Jansen 2002a, p. 104; 2002b, p. 204; - The case once described by Mela is entirely attributed to Ulpian in the Greek text of the Basilica. Furthermore, as stated above, the word 
the ball rather hard, possibly somewhat more forcibly than was (normally) customary, does not necessarily constitute culpa. This was something that could be expected in the neighbourhood of fields where people were used to playing ball. In a game, it is normal that the ball flies out of the play area. Spectators of plays have to take into account such circumstances near a (playing) field. ${ }^{469} \mathrm{~A}$ second indication can be found in the nature of the ball game. Possibly it was a game called Trigon, ${ }^{470}$ played with nine people who threw or hit balls to each other (more than one ball at the same time). It was a hard and fast game. ${ }^{471}$ Therefore, players could be blamed if they did not take enough care when choosing an appropriate place to play. Less likely, because it seems contrary to tradition which stated that the ball (pila) was struck by hand only, it could also have been a hockey-like game that was played using sticks. ${ }^{472}$ This may follow from the words pila percussa of which the literal meaning is 'hit ball'. ${ }^{473}$

\section{The decision of Proculus}

The second jurist, Proculus, only stated that the negligence (culpa) was to be imputed to the barber. It is not likely that Proculus would have decided this way easily, i.e. without any consideration on the specific circumstances of the case. ${ }^{474}$ Proculus (and Mela) would have determined whether there was culpa, and hence liability, by an assessment of the particular state of events in the particular case. The question asked was: did these circumstances allow a constitution of culpa ${ }^{475}$ Furthermore, it is uncertain whether the reason ad-

vehementius was deleted. Thereby, a change in perspective was made: not the question whether the player or the barber was liable, as was the case in Mela's decision, but the question whether the barber or the client was liable becomes the core issue. See also Schipani 1969, p. 329f. In addition, nor is the name of Proculus mentioned in the fragment. The whole fragment is attributed to Ulpian, who believes that the barber is liable, even though he mentioned that another opinion circulates, namely, that the person who entrusted himself to the barber was held responsible.

469 Wacke 1977, p. 14; 1979, p. 277; 1991, p. 364; Castresana 2001, p. 103.

470 See Radke 1939, col. 129; a different view is taken by Zwalve 2008, p. 15, who argued that it could have been soccer (follis).

471 Jansen 2002a, p. 104; 2002b, p. 204.

472 See Harris 1972, p. 99ff.

473 Wacke 1979, p. 277; 1991, p. 363; Castresana 2001, p. 103.

474 The ball was made of cloth rags filled with hair or feathers, weighed about a kilo and was struck by hand. Injuries would not be mortal; possibly this was such a circumstance; the killing was made possible due to the circumstance that a barber was shaving nearby; also see Wollschläger 1976, p. 132.

475 MacCormack 1974, p. 216; - According to Hausmaninger 1996b, p. 252, the barber apparently had - being an expert - special duties of care, and he rather than the ball player had to recognize the danger, to warn him and to evade it. Ulpian only agreed with Proculus for the case in which the barber starts to shave his customer at a place where one usually played or where there was heavy traffic. 
vanced by Ulpian for the liability of the barber (et sane-imputetur $)^{476}$ also was already the reason provided by Proculus. ${ }^{477}$ As a consequence, it is uncertain whether this part of the text has to be considered Proculus's or Ulpian's. It is possible that the decision was made by Proculus and that Ulpian argued differently, namely, that the slave should not have entrusted himself to a barber who placed his chair in such a dangerous place. ${ }^{478}$ However, it seems more plausible that the reason Proculus decided as he did was deleted by the compilers and that the reason included in D. 9.2.11pr. was the reason provided by Ulpian. The final part of the text (quamvis - queri debere) will be discussed below.

When taking into consideration another decision of Proculus, D. 9.2.7.3, in this case an action against the barber would be excluded since the barber was the one qui impulsus est. ${ }^{479}$ In that case a person injured another person because of a third person who pushed the first one. Proculus held that the one who was pushed (qui impulsus est) was not liable, because that person did not unlawfully inflict any damage. However, in the barber case, Proculus would have evaluated the specific circumstances of the case differently and considered the barber to be negligent. ${ }^{480}$ In particular he considered the position of the

476 As to this part of the text (et sane - imputetur), Beseler 1913 p. 114, suggested two interpolations. He holds the view that between sane - si two words have disappeared, namely, 'ita est'. He also argues that the words est quod ei imputetur are inserted by Tribonian (or by someone earlier than him); differently Schipani 1969, p. 334, who also discusses the phrase est sane-imputetur.

477 An affirmative view seems to emerge from Ziliotto 2000, p. 138, and Piro 2004, p. 104,123 , who present this argument as Proculus'. Furthermore, Piro argues that Ulpian did not technically provide something new, but limited himself to connecting to the opinion of Proculus by underlining the unforgiveability of the one who let himself be shaved by a barber who put his chair in such a dangerous place. In fact, she argues that Ulpian's contribution went in the direction of a more thorough investigation into the conduct underlying the causal chain.

478 See, e.g., Paschialidis 2008, p. 352f., who adds that the doctrine of contributory negligence would bar recovery. He adds that Proculus' view appears to be in tune with the view of Aristotle that it is impossible to treat oneself injustly. Thus in Proculus' view an action is granted against the barber who, although acting justly, had committed an injustice.

479 Schipani 1969, p. 332. He mentions another possibility, namely, a comparison (analogy) with another decision of Proculus, namely, D. 9.2.27.11; according to Van den Heever 1944, p. 58, Proculus holds the view that the barber is liable, since he cut the slave's throat (occidere), negligently, albeit inadvertently - unlike the mere pulsus (as in D. 9.2.7.3); - On this topic, see also Piro 2004, 91ff., p. 104f., 141ff. She argues that in D. 9.2.11pr. the (denial of liability of the ball-player) and the attribution of responsability to the barber is not made by a mechanical application of the principle of (necessary) direct causality, but an investigation, in order to achieve a certain traceability of the conduct of the event, needs to be supplemented by an assessment of behavioural patterns (of the actors in the case) that have contributed to the determination of the damage.

480 See also Piro 2004, p. 142f., and esp. nt. 277, who argues: 'nella sua valutazione il giurista abbia esteso la riflessione alle circostanze concrete relative alle due fattispecie, ritenendo di speciale natura la posizione del barbiere - alla cui perizia col rasoio il cliente si affida totalmente - che deve mostrare un'attenzione per la situazione in sé che non trova corrispondente ne caso della caduta per spinta altrui; ne conseguirebbe, cosí, che l'agere del barbiere è stato un agere 
barber who shaved in a dangerous place and the fact that erroneous throws can be made (by mistake) during any ball game. Finally, it is not certain what kind of action Proculus would have allowed against the barber, an actio legis Aquiliae or an actio in factum. ${ }^{481}$ A solution to the latter cannot be found in the fragment handed down to us.

\section{The decision of Ulpian}

Finally, Ulpian agrees with Proculus, but limits the possibility of negligence of the barber in a way that if the barber was shaving in a place where people were used to playing or where there was a lot of crossover, he indeed was to blame. ${ }^{482}$ This can probably be explained in such way that Ulpian wanted to let the existence of culpa on the side of the barber depend on the circumstances of the case. ${ }^{483}$ Although, Ulpian continues, it is not improper to say that whoever entrusts himself to a barber working with his chair in a dangerous place, ought to blame himself. ${ }^{484}$ Some authors deduce from this that Ulpian did not want to exclude a third possibility under certain circumstances. The injured has a duty to preserve himself from damage. ${ }^{485}$

Moreover, some Romanists regarded the whole phrase quamvis-finis as spurious or interpolated. ${ }^{486}$ The barber cannot be relieved from his liability due to contributory negligence of the slave, because not the slave but his master was the injured party. ${ }^{487}$ In any event, the fragment ipsum de se queri debere is considered to be interpolated. ${ }^{488}$ The slave can no longer be blamed for what

iniuria, colposo, e dunque sanzionabile in via diretta [references deleted, EvD]; mentre nel comportamento del soggetto caduto rovinosamente su di un altro può non ravvisarsi iniuria.'

481 MacCormack 1975, p. 48f.; on this topic also Ziliotto 2000, p. 138.

482 De Robertis 2002, p. 189, argues that it concerned an objective liability based on the 'temerarietà nell'esposizione a rischio', namely, that the barber placed his sella tonsoria in a place of sports competitions and in the course of carriages; Monro 1898, p. 14, suggests that the phrase ubi transitus frequens erat concerned the players themselves or else that the writer is for the moment not thinking about the game at all. On this phrase also Lawson 1968, p. 89.

483 Also Kunkel 1929, p. 178. According to Powell 1951, p. 211, it is also possible that Ulpian gave alternative reasons for the barber's culpa.

484 To come to such a conclusion one has to make certain assumptions, as already rightly stated by Pollock 1929, p. 616. The danger had to be equally obvious to the barber as to the slave. Consequently, the game, as a condition of imputing culpa to either of them, had to be carried on in an accustomed and convenient place; Schulz 1954, p. 4lf., marks this whole part, et sanedebere, as an interpolation.

485 Jansen 2002b, p. 205; reference is made to Pomp. D. 50.17.203.

486 Beseler 1922, p. 540; also Cannata 1971, p. 8, mentions this part as an alteration (a glossema). According to Schipani 1969, p. 328, 419ff., it is a post-classical or Byzantine reflection, a (scholastical) gloss.

487 Beseler 1922, p. 540; differently Schulz 1954, p. 42.

488 Beseler 1930, p. 31; Von Lübtow 1971, p. 107 (naïve gloss); differently Mayer-Maly 1974, p. 130; Wollschläger 1976, p. 131. 
happened to him, since he was dead. ${ }^{489}$ Mayer-Maly argued differently. Even after someone's death, it was possible to ascribe to him certain acts as well as contributory negligence (Mitverschulden). ${ }^{490}$ Furthermore, it would still be possible to ascribe the acts of a slave as well as his negligence to the master of that slave. That would be in conformity with the general principles that governed the relationship between slaves and their masters in those days. ${ }^{491}$

Unlike what is commonly affirmed, the words de se queri debere plausibly have a more neutral meaning. ${ }^{492}$ Ulpian probably adopted these words from Gaius, especially from his Res cottidianae. ${ }^{493}$ Ulpian more often used a different phrase to indicate the same, viz. sibi imputare debet, but in D. 9.2.11pr. he used de se queri debet. Despite the fact that the meaning of the words de se queri debere was the same in both Gaius' and Ulpian's works, it cannot be concluded with certainty that Ulpian followed Gaius. ${ }^{494}$ In D. 9.2.11pr. the phrase ipsum de se queri debere is only used in the metaphorical sense of the word. Just as sibi ibi imputare, ${ }^{495}$ it means that the slave killed was to be blamed for that himself. Since the negligence of the slave had to be (legally) imputed to the master, it was the master himself who had to complain only to himself about the damage which came about as a result of the imprudence of his slave.

\section{Interpretation of D. 9.2.11pr.: causal connection $(I)$}

Various attempts were made to interpret the last part of D. 9.2.11pr. Firstly, some authors explain this fragment with a theory of causation. ${ }^{496}$ Which act

489 See Beseler 1930, p. 31; Von Lübtow 1971, p. 107, suggests replacing ipsum de se queri debere with dominum servi lege Aquilia agere non posse. However, Von Lübtow also argues that est quod ei imputetur: quamvis nec illud male dicatur is interpolated and suggests replacing it with sed ergo puto. Furthermore, he even wants to add the word servus after tonsori and to delete the following quis. The latter part was earlier suspected of being interpolated as already Beseler 1930, p. 30, wanted to change this part, however, slightly different from Von Lübtow, as according to Beseler se quis has to be servus quis suum.

490 Mayer-Maly 1976, p. 248; according to Luig 1969, p. 193f., from the words est quod male dicatur one can deduce that Ulpian balanced between upon whomever of the two persons (barber or slave) the responsibility fell. The faults of both were considered; it was a problem of 'konkurrierenden Verschuldens'; differently Aumann 1964, p. 6f.; Wollschläger 1976, p. 134.

491 Mayer-Maly 1976, p. 248.

492 Also Wollschläger 1976, p. 133f.

493 Mayer-Maly 1974, p. 130; 1976, p. 236ff. See on this expression in the sources of Gaius: Grupe 1897, p. 219; Kübler 1921, p. 534; Kunkel 1925, p. 288 nt. 1; Wieacker 1934, p. 70.

494 Mayer-Maly 1974, p. 130.

495 cf. Heumann \& Seckel 1907 (reprint 1958), p. 253, s.v. imputare: imputare means 'jemandem etwas anrechnen', 'jemandem zur Schuld an-/zurechnen'; this is a favourite expression of Ulpian's; see Medicus 1962, p. 324 nt. 16; Luig 1969, p. 203 nt. 84; on this topic also Aumann 1962, p. 19 nt. 2.

496 Differently MacCormack 1982, p. 277ff. ('by emphasizing the consideration of fault, the jurist is able to avoid a difficult causal problem'); see also Piro 2004, p. 91f. (discussion of various views in secondary literature). 
precisely has determined the slave's death? At first sight one would say the act of the barber. However, the nexus would be broken if some other cause, in the absence of which the damage would not have occurred, intervened between the fault (culpa) of the defendant and the damage. ${ }^{497}$

Interpretation of D. 9.2.11pr.: causal connection (II)

There is another way of explanation, which is different, but nevertheless somehow connected to the previous. It can be argued that the true explanation of D. 9.2.11pr. is that where the negligent action of two persons jointly caused the death of one of them, the Romans were reluctant to regard the result as imputable to the survivor, since the inference of a causal connection between the survivor's conduct and the death had been shaken (see Paul. D. 9.2.45.3). ${ }^{498}$

Interpretation of D. 9.2.11pr.: causal connection (III)

A final, slightly different, but related interpretation is that it was the customer who had the last opportunity to avoid the accident by taking reasonable care, and should therefore be held liable ${ }^{499}$ His intervention would break the chain of causation that linked the negligence of the barber to the injury. ${ }^{500}$

\section{Interpretation of D. 9.2.11pr.: concurrence of negligence}

Secondly, some argued that the text reflects a theory based on an idea of concurrence of negligence. Two persons acted with culpa. However, there was no such thing as a division of liability in Roman law. This seems to be an unsolvable problem, because one of the parties involved would have to bear full responsibility. ${ }^{501}$ Was there really a comparison of faults of both persons? According to Aumann, there was not. He is of the opinion that any fault of the injured party leads to a denial of liability of the party that caused the injury. ${ }^{502}$

497 Cohen 1956, p. 324; Buckland, McNair \& Lawson 1974, p. 372f.; Buckland \& Stein 2007, p. 587.

498 Van den Heever 1944, p. 58. He adds that while the action was purely penal, the tendency was to excuse acts which unexpectedly had fatal results; when the action became mainly reipersecutory this reluctance disappeared and those who jointly caused the loss were jointly and severally liable.

499 See also Monro 1898, p. 14f.

500 Zimmermann 1996, p. 1012.

501 Schipani 1969, p. 420; see also, differently, Del Castillo Santana 1994, p. 30f., who does not see a concurrence of culpa; this would be contrary to the decision of Mela in this case and to the decision of Ulpian in D. 9.2.9.4, from which it can be concluded that only one of the persons is culpable; see also Wacke 1991, p. 364; on this topic also Corbino 2008, p. $176 \mathrm{ff}$., writing on p. 178 that 'la discussione segue un logica che tende ad individuare - tra i possibili - colui al quale l'evento va imputato. Il concorso di colpa si risolve con un giudizio di prevalenza'.

502 See Aumann 1964, p. 18ff.; according to Aumann 1964, p. 7, the reason that the liability of the wrongdoer is cancelled in D. 9.2.11pr. is because of the fact that the slave carelessly brings himself into a dangerous situation (if foreseeable); he neglects to avoid the damage ( $c f$. Paul. D. 9.2.31). 
Other scholars, however, argue differently and believe a comparison related to the question of whose negligence is preponderant, has to be made. ${ }^{503}$ In this view, a little fault would not cause a denial of liability.

\section{Interpretation of D. 9.2.11pr.: culpae compensatio}

Thirdly, some authors advanced the idea that (the last phrase of) the text is an example of culpae compensatio. ${ }^{504}$ When both the wrongdoer and the injured were at fault (culpa), the injured party could not obtain an actio (and so the wrongdoer was not 'liable', or maybe more precisely, would not have to pay any poena). Because of the negligence of the injured the wrongdoer was not seen as 'schuldvoll causal.' ${ }^{505}$ The inattentiveness of the wrongdoer would be compensated by the inattentiveness of the injured ${ }^{506}$ In secondary literature authors have argued that the true legal basis of culpa-compensation is that the neglegentia of the injured questions the causal connection between the culpa of the wrongdoer and the damnum. ${ }^{507}$ The barber is not liable because of the act of the slave, who entrusted himself to a barber in loco periculoso, eliminating the causal connection between the throwing of the ball and the accident of the slave. ${ }^{508}$ However, someone is in culpa or he is not; this question

503 See Luig 1968, p. 194f.; on this topic also Wacke 1991, p. 364; Zimmermann 1996, p. 1012; Travis Laster 1996, p. 213f.; Castresana 2001, p. 104; Kaser \& Knütel 2003, p. 221; Jansen 2007, p. 658f.

504 Pernice 1867, p. 60; Grüber 1886, p. 33, 229, 284; Levison 1891, p. 44f.; Wendt 1892, p. 152; Endemann 1893, p. 57; Ruhm 1898, p. 13f.; Coppa-Zuccari 1909, p. 31ff.; Tassin 1912, p. 53; Rossi Massela 1951, p. 189ff.; Schulz 1954, p. 41ff.; Von Lübtow 1971, p. 106f., 136; Kaser 1975, p. 355, nt. 57; differently Plog 1896, p. 60f.; Monro 1898, p. 14; Keirse 2003, p. 21; - See also Zitelmann 1925, p. 55, 57; Longo 1958, p. 65f.; Scott 1984, p. 168. According to Albanese 1950, p. 145, it is not possible to establish whether the criterion of culpae compensatio which emerges from D. 9.2.11pr. is classical or not. According to Van den Heever 1944, p. 58, in this case there could be no culpacompensation because the slave is not a party to the suit, nor does a right of action devolve from him upon his master; however, the act of the slave preceded the act of the barber. Following the theory of the causal connection that would be broken, the last act had to be qualified as the cause. It is therefore not explicable why the barber would not be liable. Maybe the Roman jurists also excluded the liability of the wrongdoer if the act of the injured was the indirect cause. See Van Nierop 1905, p. 34.

505 Pernice 1895 , p. 98.

506 Pernice 1867, p. 61. The Roman jurists covered such comparison by only questioning the culpa of the wrongdoer. They denied the culpa both in cases when there was no causal connection despite the negligence of the wrongdoer, as also when there was no negligence at all; see Pernice 1895 , p. $98 f$.

507 Pernice 1867, p. 60; see also Mommsen 1853, p. 157, 164; Rossi Masella 1951, p. 193, who doubted this interpretation because - should the nexus also have been broken by the injured's negligence if the wrongdoer acted intentionally?; differently Coppa-Zuccari 1909, p. 33, Wollschläger 1976, p. 124f. For an overview of the different theories on the foundation of culpa-compensation, see Von Leyden 1902, p. 22ff.; Rossi Masella 1951, p. 192ff.; differently Lawson 1968, p. 89.

508 Pernice 1867, p. 60; Von Bar 1971, p. 123; - According to Coppa-Zuccari 1909, p. 33, de se queri debere does not mean that the slave has to impute the damage exclusively to himself; such an interpretation would be in contradiction to the phrase 'sane, si ibi tondebat'. It only means that due to the negligence of the injured, the possibility of an actio legis Aquiliae is excluded, and the responsibility of the barber is excluded. 
cannot be answered ex post. ${ }^{509}$ Because one person (wrongdoer or injured) is in culpa, that does not mean that the other person is not. ${ }^{510}$ Besides, the text does not at all discuss two culpae, as will be discussed below.

As stated above, it is probable that more recent scholars have invented and tried to attribute the theory of culpae compensatio to the Roman jurists, and have attempted to force that theory into the Roman sources. Probably, Roman law, both classical and Justinian law, did not know cases of compensation of culpa.$^{511}$ Only fragment D. 9.2.11pr. could be examined for the existence of the use of this theory in jurisprudence. However, it is evident that for the three jurists culpa could only be imputed to one of the persons involved. In particular Ulpian, who might have been dependent on a more antique source (quamvis nec illud male dicatur), who is the only one who envisaged negligence on the side of the victim, did not approach the problem in the sense that it was necessary to verify whether both parties were negligent (culpa) but rather to raise the question of who of the two parties (wrongdoer or the injured) acted culpably (culpa). ${ }^{512}$ Mela and Proculus did not consider the negligence of the injured at all.

\section{Interpretation of D. 9.2.11pr.: assumption of risk}

Fourthly, an exclusion of delictual liability could be based on an assumption of risk. ${ }^{513}$ First, Ulpian holds the barber liable; however, he adds that another solution would also be defensible (si in loco ... queri debere). In that case, apparently under special circumstances (e.g. contempt of the warning of the barber), an act of the injured at his own risk (Handeln auf eigene Gefahr) could be accepted. ${ }^{514}$ It is not clear whether this has to be interpreted as consent to potential damages or as assumption of risk. ${ }^{515}$ The reasoning for the last solution

509 Levison 1891, p. 44.

510 ibid., p. 45, where Levison argues that the culpa of the slave could be qualified as 'das überwiegende Moment'. The denial of compensation is only based on the 'schuldhafte Tätigkeit' of the injured, so in correspondence with the maxim of D. 50.17.203.

511 See Valditara 1994, p. 862, and on this topic also the literature mentioned.

512 Valditara 1994, p. 862.

513 Thayer 1929, p. 67; Powell 1951, p. 212; Hausmaninger 1996a, p. 30; Travis Laster 1996, p. 212; Looschelders 1999, p. 12; Castresana 2001, p. 76; - According to Valditara 1994, p. 862, the decision of Ulpian implicated the awareness of risk at the side of the customer and by this his implicit acceptance. The hypothesis in the decision of Ulpian is not unlike that of the boxer or wrestler who accepted the possibility of damaging effects of his actions; see also Mayer-Maly 1974, p. 130, 134; also Lawson 1968, p. 89.

514 Hausmaninger 1996a, p. 30; the behaviour of the slave ('Handeln auf eigene Gefahr') could be imputed to his master; see Mayer Maly 1976, p. $247 \mathrm{ff}$.

515 Wollschläger 1976, p. 133; Travis Laster 1996, p. 212, distinguishes between assumption of risk in its primary and secondary form. In the former, the customer evaluated the situation and accepted the risks inherent in the activity, effectively saying that the level of safety that the 
is that because the injured placed himself in danger, the duty of care-taking on the side of the wrongdoer is removed (Risikoübernahme) ${ }^{516}$ D. 9.2.11pr. in such a case would give an example of a person acting at his own risk, exactly as in Paul. D. 9.2.28pr.-1, in which it is stated that a plaintiff is barred if he could have avoided the danger. ${ }^{517}$ The wrongdoer, who did not give a warning, ${ }^{518}$ is released from his liability if the injured was aware or could have been aware of the risk.

By availing himself of the services of this specific barber, it can even be argued that the customer voluntarily exposed himself to the risk that the shaving might cause an injury. It is this aspect of assumption of risk that made it unreasonable to grant an actio legis Aquiliae to the plaintiff. ${ }^{519}$ Neither the barber nor the injured had therefore been at fault; both acted in a somewhat risky way and therefore had to bear the consequences. ${ }^{520}$ One could object that it was not the master of the slave who placed himself in the chair of the barber, but his slave. Could the slave just pass on his act and the risk he took to his master? Indeed, ${ }^{521}$ as the master constantly had to bear this risk, also when no barber was involved.

barber provided was acceptable. In this case, neither the barber nor the customer would be at fault: the customer made a rational evaluation with regard to the risk, and the barber provided what the customer wanted. In the latter, the customer's acceptance of the risk of being shaved at such a dangerous place was so unreasonable that he was effectively to blame for his injury. The barber was negligent, too. This secondary form functions as contributory negligence: both parties are to blame, blocking the tracing of causation to the barber; therefore, the master of the slave cannot recover his damages.

516 Also Wacke 1979, p. 277;1991, p. 364 and Castresana 2001, p. 103f., interpret this fragment with the criterion of anticipation of danger. The barber should have foreseen the danger, even though he was used to exercising his profession in the vicinity of a game or some other crowded place. However, an argument against the liability of the barber could be that it was the slave's own fault if he had entrusted himself to a barber who put his chair in such a dangerous spot, since, if the barber could have anticipated the danger, the same could be expected from the slave.

517 In the same sense Hausmaninger 1996a, p. 30.

518 One could ask whether or not the barber should have warned the customer of the danger. According to Zwalve 2008, p. 18, this question is even more acute in Roman society because a barber could (sometimes) have known that he was shaving someone else's property and that he therefore had a duty of care (zorgplicht) towards the owner of the slave (which is independent from the acceptance of risk on the part of the slave). Zwalve 2008, p. 18, brought this duty to warn of imminent danger in Roman law in immediate connection with the general duty of care (see D. 9.2.31).

519 Wollschläger 1976, p. 133; Zimmermann 1996, p. 1013; Castresana 2001, p. 77; Jansen 2002b, p. 208f.; support can be found in another text, namely, D. 9.2.7.4.

520 Wollschläger 1976, p. 133; Zimmermann 1996, p. 1013.

521 Also according to Mayer-Maly, this question has to be answered positively. The inattentiveness of the slave harms his owner. Mayer-Maly argues that this is a modification of the 'Argumentationsfigur' de se queri debet; see Mayer-Maly 1974, p. 130; Travis Laster 1996, p. 213 , mentioned also the possible interpretation of reading Ulpian's final statement as a result of contractual liability. The slave who engaged a barber's services for money created a contract of locatio conductio; such an option has, however, no textual basis in the text nor does the context of the fragment (Palingenesia) give rise to such an interpretation. 
Interpretation of D. 9.2.11pr.: determinant role of culpa

Fifthly, one could argue that negligence (culpa), in the context of the lex Aquilia, played the role of a determinant of liability. In the law of delict, the concept of culpa had a causal as well as an evaluative role. The case of the barber is the best example of the causal role, which mirrors the function of blame in Antiphon's Second Tetralogy (as discussed in section 2.4.4). ${ }^{522}$ The first part of the fragment, attributed to Mela, gives no concrete clue as to which party is liable in this case. Mela only stated that the person who was at fault was liable. According to Ibbetson, this is very much the common assumption behind the speeches of Antiphon, namely, that blameworthiness (culpa) was the scalpel that cut through cases of causal ambiguity. The other two Roman jurists, however, said who was at fault, Proculus that it was the barber while Ulpian tried to reason why this might have been so. To which of the possible causes the cutting of the slave's throat should be imputed? Subsequently, Ibbetson stated that a concrete consequence of the approach was the general principle of Pomponius in D. 50.17.203; ${ }^{523}$ in classical Roman law, however, this would not apply, presuming this was no general principle but part of a concrete case (concerning the law of legacies) as explained in the second section of this chapter (2.2).

Probably this fragment also dealt with the culpa requirement and contained a specification of culpa for an individual situation. In that perspective it is useful to take a closer look at the manner in which the argument of Ulpian is presented. Ulpian considers a number of specific situations: whether the barber shaved in or near a place where ball games were customarily played or where passers-by frequently crossed over, or whether it was the slave who entrusted himself to a barber who put his chair in a dangerous place. ${ }^{524}$ If the barber set up his business in close proximity to a dangerous place, namely, a ground where people frequently played games, he had culpa and was accountable for the death of his customer. By doing so a careful attempt was made to draw a line: no fault would be attributable to the barber if he did not shave in a place where people were used to playing games or where people frequently crossed over. ${ }^{525}$ The reply of Ulpian is just an argumentation in which he takes certain circumstances into consideration in order to determine whether or not the ball-player had culpa. Again it appears that the particular situation in this case, which could be interpreted from a modern perspective as a problem of contributory negligence, is solved without the use of such a concept.

522 Ibbetson 2004, p. 115.

523 ibid., p. 116.

524 MacCormack 1974, p. 216.

525 Zimmermann 1996, p. 1008. 
Because of the penal character, and because of the wording of the actio legis Aquiliae, the only question was whether the barber had culpa. The basis for the claim remained the punishing reaction to socially undesired behaviour; the fact that the injured party could be compensated with some money was just a side effect. ${ }^{526}$ Classical lawyers always regarded the actio legis Aquiliae as a purely penal action. ${ }^{527}$ In (late) classical law the sum of the litis aestimatio where it exceeded the sum of the loss of the victim was not divided into a penal and reipersecutory part, but was totally regarded as a poena. ${ }^{528}$ Even if the sum the wrongdoer had to pay was identical to the value of the victim's damage, the action was still considered penal in classical law. ${ }^{529}$

If the iudex was convinced that the requirements of the formula were met, the wrongdoer had to pay the poena. ${ }^{530}$ The final statement of Ulpian (quamvisfine) does not imply any change of the poenal liability of the barber. ${ }^{531}$ One could argue that the fact that the slave should not have entrusted himself to a barber who put his chair in such a dangerous place, does not change the question whether the barber had to be punished or not. The only question remained whether the barber, under the circumstances of the case, could be considered as having acted with culpa. ${ }^{532}$ However, it is not certain whether it is sufficient to base the denial of liability only on the penal character of the lex Aquilia. Besides, possibly Ulpian was also in doubt because the slave also created a certain risk leading to the conclusion that the negligence of the barber no longer plays a role here. It was, as it were, disregarded by the 'bringing oneself into a dangerous situation', so wasting the possibility to sue with the actio legis Aquiliae for his master.

526 See Wallinga 2009, p. 1399, who justly adds that it was just the medieval restitution theory of Thomas Aquinas which created a fundamental different basis for delictual liability. This will be explained in the next chapter.

527 On the actiones mixtae in Justinian law, see Inst. 4.6.16-19 (esp. Inst. 4.6.19; the actio legis Aquiliae as a mixed action). On these texts, see Ankum 1983, p. $4 \mathrm{ff}$.

528 Ankum 1982, p. 38f.

529 ibid., p. 29, 38f.; on the penal nature of the actio legis Aquiliae, see also recently Sirks 2009, p. $303 \mathrm{ff}$.

530 Wollschläger 1976, p. 135; a possibility to give the barber an inferior punishment was not possible; the iudex had no possibility to reduce the poena due to the negligence of the injured.

531 Recently Jansen 2007, p. 659, reminds us that 'Vielmehr war ihr Deliktrecht am Gedanken einer angemessenen Sanktion für ein erlittenes Unrecht ausgerichtet; bei einem solchen sanktionorientierten Ansatz konnte es überhaupt nur auf die Frage ankommen, ob der Schädiger vorwerfbar etwas falsch gemacht hatte, oder ob ihm angesichts des Verhaltens des Geschädigten kein Vorwurf zu machen war'.

532 One of those circumstances indeed was the negligence of the slave. In this case that was not enough to release the barber from his liability. Supposedly, the circumstances were such that they excluded liability of the barber, not because of contributory negligence of the injured, but because the requirements for the lex Aquilia were not fulfilled. See also Wollschläger 1976, p. 137. 


\subsubsection{Post-classical development (Justinian law)}

When considering D. 9.2.11pr. as part of Justinian's compilation, it is superfluous to distinguish the opinions of the jurists included in this fragment (Mela, Proculus, Ulpian) because the text became part of the promulgated law of Justinian. Analysing the argumentation in this fragment the following picture results. The person at fault (culpa) was liable. Firstly, this could be the ball-player, if he acted intentionally (see D. 9.2.9.4) or if he played in a place where people did not customarily play. ${ }^{533}$ Secondly, it could be the barber, if he shaved at a place where people customarily played or where there was a lot of traffic. ${ }^{534}$ However, he who entrusted himself to a barber who put his chair in such a dangerous place ought to be blamed himself. A conclusion might be that the possible liability of the barber is nullified, and only the ball-player could be held liable (which is not mentioned in the fragment) or that no one would be liable. ${ }^{535}$ The last part, in which the decision is made that he who entrusts himself to a barber who has put his chair in such a dangerous place ought to be blamed himself, ${ }^{536}$ can be explained in combination with D. 50.17.203 discussed above. Because he who suffers damage by his own fault, after having entrusted himself to a barber who put his chair in such a dangerous place, is not considered to have suffered any damage.

\subsection{GENERAL TREATMENT OF ALL RELEVANT CASES IN JUSTINIAN LAW}

\section{Introduction}

In later (medieval) times scholars saw a connection between the texts discussed in this chapter. Was such a connection already present in Justinian law ${ }^{537}$ It seems to me that such a coherence is definitely feasible, especially between D. 9.2.9.4, D. 9.2.11pr. and D. 50.17 .203 (D. 9.2.52.1 seems to me a different kind of case and a more complicated one). Apparently, a kind of principle existed by which someone just cannot claim damages if he caused his injury

533 A. Faber, Rationalia in Pandectas, ad D. 9.2.11pr.

534 Perhaps this liability could be set on the basis that the incident could have been avoided if the barber had taken reasonable precautions; Paschialidis 2008, p. 360f., considered this case an example of the approach of Byzantine jurists of culpa as $\alpha i \tau i \alpha$ (responsibility).

535 See, on the ratio of D. 9.2.11pr., A. Faber, Rationalia in Pandectas, ad D. 9.2.11pr.

536 According to Luig 1969, p. 194f., in case of preponderant negligence of the injured the liability of the barber would be excluded.

537 The problem is that no interpretation of Justinian law as such is handed down to us, except possibly the old scholia which originated from legal education provided by professors (antecessores). The Corpus Iuris was only studied again in Western Europe at the beginning of the 12th century, but then in the light of a new socio-legal context. 
due to his own fault. This is more or less the principle as stated in D. 50.17.203. Such an attitude leads to the unreasonableness of punishing a wrongdoer. This possible way of thinking of the compilers is, of course, totally different from that of the classical Roman jurist themselves, who concentrated on the wrongdoer and just asked whether or not he ought to be punished in that case and whether or not the requirements for an action were fulfilled.

\section{Penal character}

Because of the penal character, and because of that the wording of the actio legis Aquiliae, the only and final question in classical Roman law was whether the wrongdoer (e.g. the barber) had been at fault (culpa). If the iudex was convinced that the requirements of the formula were fulfilled, the wrongdoer had to pay the poena. A possibility to give the wrongdoer an inferior punishment was not possible; the iudex had no possibility to reduce the poena due to negligence of the injured. The final statement of Ulpian in D. 9.2.11pr. (quamvis-debere) does not imply any change of the penal liability of the barber. The fact that the slave should not have entrusted himself to a barber who put his chair in such a dangerous place does not change the question whether the barber had to be punished or not. Had the barber, under the circumstances of the case, been at fault (culpa)? One of those circumstances was indeed the negligence of the slave. In this case this was not enough to release the barber from his liability. Supposedly the circumstances were such that they excluded his liability, not because of contributory negligence of the injured, but because the requirements for a successful actio legis Aquiliae were not fulfilled. In that respect another remark is important, namely, that in classical Roman law no balancing of culpable behaviour of the two parties was possible, but only an assessment of the culpable behaviour of the wrongdoer. The view that in case of preponderant negligence of the injured the liability of the barber would be excluded is therefore not correct and for this view insufficient ground is found in the sources.

\section{One compilation}

In Justinian's time all relevant texts discussed in this chapter became part of the same compilation. Therefore, the relevant texts (D. 9.2.52.1, D. 9.2.9.4 and D. 9.2.11pr.) could possibly be explained in combination with D. 50.17.203. Especially, the final phrase of D. 9.2.11pr. (he who entrusts himself to a barber who has put his chair in such a dangerous place ought to be blamed himself) can be considered as an application of the more general rule of D. 50.17.203: because the person who suffers damage as a consequence of his own fault, entrusting himself to a barber who put his chair in a very dangerous place, is not considered to have suffered any damage. 
Some remarks have to be made about changes in Justinian law. The 'new' fragment of Inst. 4.3.4 did not fundamentally change the decisive criterion at stake, i.e. of culpa. Justinian used the case of D. 9.2.9.4 as an example and made a modified version in Inst. 4.3.4. Compared to D. 9.2.9.4, Justinian deleted Ulpian's motivation of liability (quia non debuit ...) in Inst. 4.3.4 and by doing so he took another point of departure as he changed the criterion of culpa, deducing it from prudence or imprudence to the mere question whether the person was a soldier or not. ${ }^{538}$ As discussed in section 2.4.5, based on the Basilica and some scholia, this apparently did not lead to a problem of interpretation in Justinian (or Byzantine) law.

Also the next fragment of the Institutes, Inst. 4.3.5 (tree pruner) is relevant. The compilers of the Institutes placed the case of the tree pruner directly after the case of the javelin throwers in the Institutes, and thereby saw a connection between these fragments, a connection stronger than in classical Roman law. The two fragments in the Institutes are part of a more or less systematic treatise for educational purposes. Moreover, they are promulgated together as law (together with the Digest). In Inst. 4.3.5, a number of possible events are distinguished, and for each case Justinian establishes whether or not culpa is to be placed on the side of the tree pruner.

\section{Allornothing?}

Finally, there could be no consequences of such 'contributory negligence' other than a denial of claims based on insufficiency in the requirements for an actio legis Aquiliae. It is commonly believed that when contributory negligence of the injured occurred, he had no possibility to obtain an actio legis Aquiliae (the all-or-nothing approach). In that respect, only an all-or-nothing approach was possible in classical Roman law as well as in post-classical (and Justinian ${ }^{539}$ ) times. It is inconceivable that a restriction of the obligation to pay full compensation, in the sense that the wrongdoer was only liable for part of the damage, was recognised as a general rule in Justinian law. There are just a few scattered texts in the Digest in which the behaviour of the injured party results in a restriction of the (amount of) damages which the wrongdoer had

538 Besides the new distinction in the Institutes as to the status of the thrower, the question as to whether the thrower intentionally threw also disappeared.

539 Although the procedure per formulam did not exist any longer, the all-or-nothing approach remained to exist in the law at the time of the application of the cognitio procedure in matters of private law. The all-or-nothing approach was inherent to the writings of the (classical) jurists - some of them were even explicitly made authoritative in the Lex Citandi of 426, e.g. Ulpianus (see D. 9.2.9.4 and D. 9.2.11pr., which clearly envisage an all-or-nothing approach as already elaborately discussed in this chapter). These writings became incorporated in Justinian's Digest, and so the all-or-nothing approach was co-inherited along with the substantive rules enclosed in the writings of the (classical) jurists. 
to pay, and they are not in the law of delicts. Certain consequential losses are concerned, not caused by the act of the wrongdoer, but only by wrong behaviour of the injured party. These cases appear only in contract law: Neratius D. 19.1.11.12 and Paul. D. 19.1.45.1. ${ }^{540}$

In the first case (D. 19.1.11.12), a buyer of a slave is sued by an actio noxalis. The buyer can either hand over the slave or pay an amount of money. In both cases, according to Neratius, the buyer can only get the damages back from the seller with the actio empti which would have accrued to him if he had chosen the economically best option. If he chose to pay the monetary fine, but handing over the slave would have been more advantageous for him, the seller only had to pay him the amount of the value of the compensation for handing over the slave. The rest of the disadvantage of the monetary fine had to be borne by the buyer himself. ${ }^{541}$

In the second case (D. 19.1.45.1), someone sold a vacant lot that belonged to a third person and the purchaser built upon it. Subsequently, the owner of the property recovered his lot (through an eviction). If the buyer brought an actio empti against the seller, the latter was - in principle - also liable for the expenses made by the buyer with respect to the purchased item. ${ }^{542}$ According to D. 19.1.45.1, the owner who brought an action against the possessor in order to recover his property could be barred by an exception on the grounds of bad faith (exceptio doli), unless he was willing to pay the building expenses. When the possessor omitted to bring forward this exceptio doli, and thus did not claim the damages regarding the building costs, the actio empti was restricted to the payment of the purchase price, as it is the better view that this was not part of the vendor's risk. ${ }^{543}$ Thus the latter was not liable for those expenses.

In these two cases, the negligence of the injured party only regarded the increase of the damages. These consequential damages were not imputed to the other party. However, these exceptional casuistic decisions do not provide sufficient proof to assume a general rule, implying a restriction of the range of the compensation existed, ${ }^{544}$ and surely not for the classical period.

A general rule containing a restriction of the obligation to pay full compensation, in the sense that the wrongdoer was only liable for part of the damage,

540 Luig 1969, p. 193; see Medicus 1962, p. 322f.; Aumann 1964, p. $14 f f$.

541 See Aumann 1964, p. $14 f$.

542 ibid., p. 15.

543 ibid.; - One could see that Paul. in D. 19.1.45.1 is very careful when writing magis est.

544 See further on this topic Aumann 1964, p. 16f., and Medicus 1962, p. 322ff.; differently Jörs 1927, p. 119 ('im gegebenen Falle nicht oder nicht in vollem Umfang in Anspruch genommen werden'). 
cannot be derived from the wording of D. 50.17.203. ${ }^{545}$ There are no traces of these exceptional casuistic decisions being generalised in post-classical times. One may assume that the compilers, in case of damage resulting from the act of the injured person, in principle adopted the view that in such a case the wrongdoer had no duty to pay any compensation (all-or-nothing approach). No dogmatic foundation for the view that a restriction of liability of the wrongdoer existed can be found in the text of Pomponius, nor did Pomponius ever refer to mutual blame (beiderseitige Schuld). ${ }^{546}$

Medieval scholars (Johannes Bassianus et al.) were the first to consider concausality and concurrences of negligence in case of damnum iniuria datum and Aquilian liability. ${ }^{547}$ These scholars constructed their theory of culpae compensatio among others on the main texts discussed in this chapter. Such a theory could not yet be found in Justinian law. ${ }^{548}$ As discussed above, the conduct of the injured party in delictual cases is still not considered as 'contributory negligence'. The reason why this was not so, and especially not in cases of damnum iniuria datum, should be sought in the penal character of the lex Aquilia.

\subsection{Concluding Remarks}

The central question in this chapter is what were the consequences of the conduct of the injured party to the liability of the wrongdoer in Roman law of Antiquity. In this chapter the view, commonly held in present-day literature, that in classical Roman law the injured party could not recover his damages when his contributory negligence contributed to the occurrence of the damage is rejected. ${ }^{549}$ To understand the approach of the Roman jurists to 'contributory negligence', the question has to be considered from an appropriate perspective. A distinction has to be made between the situation in classical Roman law and in Justinian law.

First of all, at the beginning of this chapter it was made plausible that D. 50.17.203 had no general validity in classical Roman law but only concerned a case about a legacy. The compilers extracted D. 50.17.203 from its original

545 Aumann 1964, p. 31; Medicus 1962, p. $323 f$.

546 Aumann 1964, p. 31, stated that in post-classical Roman law, the conceptual understanding of the culpae compensatio came to the foreground. He also based his conclusion on a study of Paul. D. 18.1.57.

547 In the same sense Castresana 2001, p. 77.

548 Much later, the Pandectists based their theory of Schuldkompensation on the Roman jurisprudence.

549 Unless the wrongdoer had acted intentionally. 
context in Pomponius and designated it as a 'regula'. Because the compilers placed the sentence as a general rule in the Digest (D. 50.17.203), it could become one of the bases for the later medieval theory of contributory negligence. Someone who suffered disadvantage resulting from his own negligence, in a legal sense, was not considered to have suffered any loss for which damages could be claimed. Although in some cases the facts could give rise to damages, the injured would have no remedy because of his 'contributory negligence'.

Secondly, with regard to the approach of legal practice in dealing with what (in the law of delicts) we would now call 'contributory negligence' of the injured party, in classical Roman law as well as in post-classical Roman law contributory negligence was not known as a specific legal notion. The Roman jurists did not question negligence on both sides, but merely enquired whether the injury, considering the circumstances, was due to the negligence of either the wrongdoer or the victim. Therefore, and this conclusion is also affirmed by my investigation of the sources, it is plausible to argue that a theory of culpae compensatio was not present among classical Roman jurists, but was anachronistically forced into their decisions by medieval and modern scholars.

That the classical Roman jurists as well as the jurists in Justinian's time did not question negligence on both sides, but merely enquired whether the injury, considering the circumstances, was due to the negligence of either the wrongdoer or the victim, can for example be seen in the case of the javelin throwers. The classical jurists solved the problem of 'contributory negligence' by interpreting the elements of damnum iniuria datum, especially the element of culpa. Roman jurists approached the culpa requirement in a casuistic manner, as they did with all legal problems. They did not try to subsume the facts of the individual case under a standardised test. The jurists asked themselves whether the defendant had been at fault if he did not behave as he should have. It is useful to acknowledge that in the cases I studied the problem was the status qualitatis. This has to do with quality: an act is not permitted or appropriate everywhere, e.g. the question whether the javelin thrower acted as he should have depended on the evaluation of all circumstances of the case and tended to be determined from an objective point of view. Therefore, it has to be pointed out that there are often no technical theories behind the reply of the classical jurists. Roman jurists were practically oriented, which can be seen, for example, in Alfenus' reply in D. 9.2.52.1. As described before, the situation changed in Justinian law in the sense that the fragments were possibly connected with each other and the idea of D. 50.17 .203 was regarded as a general underlying principle (except possibly for D. 9.2.52.1). The concept 
of culpae compensatio probably did not develop in Justinian law, but was a novelty of medieval scholarship. The all-or-nothing approach was retained and would be in force until the lex Aquilia lost its penal character (only in early modern times). 


\section{CHAPTER THREE}

MEDIEVAL IUS COMMUNE

\subsection{INTRODUCTION}

\subsubsection{Subject and purpose of this chapter}

The renaissance of the twelfth century (1070-1225) brought about an intellectual revival in Western Europe. ${ }^{1}$ From the beginning of the twelfth century Bologna, in the north of Italy, was the centre of legal scholarship. In this city, the authoritative texts of Roman and canon law were studied and taught. ${ }^{2}$ Two periods can be distinguished in the medieval study of Roman law: the period of the Glossators, starting with Irnerius (ca.1055-1130) at the beginning of the twelfth century in Bologna until the end of the thirteenth century, and the period of the Commentators, which roughly covers the fourteenth and fifteenth centuries. Within the study of canon law we can distinguish between the earlier period of classical canon law, in which the Decretum Gratiani (1140/1145) was interpreted, and the period from the beginning of the thirteenth century when the law of the decretals took over the leading role in canon law. In this chapter, the contributions to the concept of contributory negligence of the Glossators, Commentators and canonists from these periods will be discussed. ${ }^{3}$ Strangely enough, no profound study has been made yet on the development of the concept of contributory negligence in medieval scholarship. How did the medieval jurists solve cases of 'contributory negligence'? It appears that the so-called doctrine of culpae compensatio, which might have its origins in medieval (Roman) legal scholarship, could provide the solution. Also in this chapter, clarity will be provided with regard to the question of whether the

1 On this period, see Haskins 1927; Paré, Brunet \& Tremblay 1933; Genzmer 1941, p. $298 \mathrm{ff}$.

2 See on this topic, e.g., Bellomo 1995, p. 58ff., 65ff., 112ff.

3 With contributory negligence, the negligence of the injured party that led to the origination of the initial damage is meant, not the worsening of the damage by lack of self-care, as Descamps 2005, p. 61f., seems to include. His conclusion that contributory negligence led to a diminution of liability (in ius commune) has to be considered in this light. 
medieval scholars formulated such a theory, and if so, whether they used it to solve problems of contributory negligence in cases of damnum iniuria datum.

The main subject of the chapter is the role of the conduct of the injured party. What is new is the fact that medieval scholarship attributed legal significance to the act of the injured party, which was not the case in Roman law. The questions which will be dealt with are: Did the Glossators, Commentators or canonists have a general theory on contributory negligence which applied to all delicts, and if so, what was the range of application of that theory? Were these theories, dealing with contributory negligence, also applied to cases of damnum iniuria datum? Who was the first scholar to do so? Was the doctrine only applied to the negligence of both parties or was the seriousness of the contributions also taken into account? Did the 'all-or-nothing' approach of Roman law of Antiquity still apply?

As mentioned above, the first jurists to study the various parts of the Corpus Iuris Civilis were the Glossators. The intellectual activity of the Bolognese glossators was linked to their teaching. They wrote i.a. glossae, words or short fragments between the lines or in the margins of the text of the Corpus Iuris, to clarify and explain certain words and sentences. Apart from explaining the content of texts, the Glossators tried to harmonise possible contradictions within the Corpus Iuris. When trying to eliminate these contradictions, the Glossators produced references to other texts which were supposed to support or reject a certain solution for the contradiction. ${ }^{4}$ Moreover, they sometimes felt obliged to adapt the Roman texts to the needs of daily practice. It is important to note that the medieval Roman scholars considered the cases described in the Corpus Iuris as very colourful contemporary problems, as if the Corpus Iuris represented the law in force. The method of the Commentators differs from the method of the Glossators, since the Commentators no longer produced glosses. They mainly worked in two ways: by giving on-going comments on the Corpus Iuris Civilis and on the Gloss (Commentaria), and by expressing legal opinions (consilia). ${ }^{5}$ In this period, one can notice an early reception of the learned law (ius commune) into legal practice. ${ }^{6}$ The writings of the Commentators will be discussed in order to see whether they include a

4 On the working method of the Glossators, see Otte 1971.

5 Fried 1960, p. 143.

6 On German law before the reception of the learned law, see Aumann 1964, p. 31ff., who concludes that the influence of the injured party's own conduct on the obligation to compensate was essentially treated similarly to the way it was treated by Roman jurists. The requirements for the rise of the obligation to compensate were considered as not being fulfilled in a case of contributory negligence. The entire liability was then cancelled. Only when the wrongdoer acted on purpose would the injured party's own conduct not be taken into account for liability purposes; see Aumann 1964, p. 37. 
continuation and a further reflection on the doctrine of culpae compensatio, and also whether new approaches were pursued and whether new concepts arose.

The contribution of canon law to the problem of contributory negligence is especially interesting, as its approach to this problem differed from the approach of medieval Roman legal scholarship. I will verify whether or not a general idea on culpae compensatio existed and subsequently if such a theory was actually applied in the law of delicts. Some cases of accidental homicide, in which the injured party obviously played a role in the actual occurrence of the damage, will be discussed. Furthermore, whether canon law applied the doctrine of culpae compensatio, and if so, whether it was further refined or not, and/or whether there were new or other ways in which the problem of contributory negligence was solved will also be discussed.

\subsubsection{Structure and method}

With regard to medieval Roman law, the sedes materiae on this subject can be found in the same texts of the Corpus Iuris Civilis as mentioned in the previous chapter ${ }^{7}$ but, as will appear below, also in some other texts or even in entire titles in the Corpus Iuris Civilis which apparently gave rise to discussion of the subject by the medieval Romanists, such as title C. 3.35, and some texts in the Digest, such as D. 16.2.10pr. and D. 24.3.39. ${ }^{8}$ Firstly, the glosses (glossae) will be dealt with in the next section (3.2). The Glossators (and also the Commentators) treated the question of whether the wrongdoer was liable or not in a scholastic way, meaning that they drew distinctions between various situations to determine in which situation the wrongdoer was liable and in which situation he was not. Therefore, after a short review of the relevant texts from the Corpus Iuris, these distinctions have to be discussed to see for what reason they were made. Offering the easiest accessibility is the so-called Ordinary Gloss

7 The order in which the materials from the periods of the Glossators and the Commentators will be presented in the next section (3.2) differs from the order followed until now, viz. the sequence the fragments have in Justinian's compilation, except for Inst. 4.3.4, which will be dealt with in connection with D. 9.2.9.4.

8 For medieval legal scholarship, the starting point is the littera vulgata of the Corpus Iuris and not the littera Florentina. The Glossators were not familiar with the littera Florentina (see Sass 1963, p. 224). The littera Florentina is probably the oldest manuscript of the Digest still existing, stemming from the 6th century. It is speculated that a copy of the littera Florentina/ Pisana became known in the 12th century. This copy, generally known as the Codex Secundus, laid the foundation of the tradition of the littera Bononiensis (i.e. the Digest vulgate). See Dondorp \& Schrage 2010, p. 14. The differences between the two editions, with regard to the relevant fragments, were discussed in the previous chapter, and mainly concern grammar and spelling. 
(Glossa Ordinaria) of Accursius (ca.1182-1263), ${ }^{9}$ which became the standard commentary on the Corpus Iuris. It was printed in many editions from the early modern period onwards. More problematic are the pre-Accursian glosses, which for the greater part were never published in so far as they were not used by Accursius. Therefore, this study will be supplemented by an investigation of various manuscripts. Unfortunately, it was only possible to examine about twenty-five manuscripts of the Digestum Vetus on microfilm..$^{10}$ Besides glosses, the Glossators produced other writings dealing with Roman law, which are more easily accessible in a printed form, e.g. Summae, ${ }^{11}$ Lecturae, Brocarda and Dissensiones. The same sections will also include the contributions of the Commentators to the discussion on the doctrine of contributory negligence in a selection of relevant fragments derived from their commentaries, mainly found in printed editions. ${ }^{12}$ These include the most important writings from the school of Orléans which flourished at the beginning of the fourteenth century. Therefore, the 'Commentators' include both Italian as well as French jurists of the fourteenth and fifteenth centuries. The contributions of the jurists of the school of Orléans (the ultramontani) will be discussed so far as relevant. ${ }^{13}$

In section 3.3, the contributions of canon law and canon lawyers to the problem of contributory negligence will be discussed. With regard to medieval canon law, the sedes materiae on this subject can mainly be found in three decretals incorporated in the Liber Extra (1234), i.e. X 5.12.8, X 5.12.9 and X 5.16.6 and in one fragment incorporated as regula 86 in the title De regulis iuris of the Liber Sextus (1298), i.e. VI 5.12.86 (the counterpart of D. 50.17.203). For this study, not only these fragments were investigated, but also a selection of glosses and commentaries, mostly available in printed form.

The chapter will conclude by making some comparative remarks on other medieval works which, strictly speaking, lie outside the Romano-canonical tradition (section 3.4), e.g. Byzantine law, the Sachsenspiegel, the Bible (Old-

9 The glossator Accursius, a student of Azo's, was a professor at Bologna. On the story of Accursius' life, see Genzmer 1945, p. $223 \mathrm{ff}$.

10 Microfilms of a selection of manuscripts of the Digestum Vetus could be consulted at the VU University Amsterdam and at the Max Planck Institute for European Legal History in Frankfurt am Main. In this study, reference is only made to manuscripts when they contain pre-Accursian glosses. In the case of Accursian glosses, the siglum is only mentioned if it is not Accursian himself. Furthermore, only the texts transcribed from manuscripts will be given in footnotes; printed sources will in principle not be written down in their entirety in footnotes, unless necessity so demands.

11 On Summae, see, e.g., Fitting 1906, col. 87ff.

12 There is no fundamental contradiction between the Glossators and the mos italicus (the Italian method, i.e. of the Commentators), but rather a gradual transition, which to some degree was prepared by the school of Orléans in the 13th century; see Koschaker 1966, p. 87.

13 On the school of Orléans, see, e.g., Meijers 1918/1919b, p. 108-132, 443-488; 1920/1921, p. 460-518; Bezemer 1997; Duijnstee 2010. 
Testament) and Old-Scandinavian law; by doing so, I will show that of other systems more or less contemporary to that of medieval ius commune some took the same approach, while others chose a different approach. The chapter will end with some concluding observations in which the above questions will be answered (see section 3.5).

\subsection{Medieval Roman LEgal SCHOlarship}

\subsubsection{Introduction}

According to the Glossators, when someone inflicted damage on someone else's property, the injured party (the master who suffered damage, not the slave) could petition for an actio legis Aquiliae. The act causing the damage had to be unlawful (iniuria), the damage had to be inflicted as a result of the negligence (culpa) of the wrongdoer, ${ }^{14}$ and there had to be a causal connection. ${ }^{15}$

According to the medieval scholars, starting with the Glossators, ${ }^{16}$ negligence could be constituted at three moments. Negligence might precede, coincide with or follow the act. ${ }^{17}$ An example of a case in which negligence follows an act is the case of D. 9.2.8: a physician operated well but was negligent in his after-care service. The Glossators understood culpa in the lex Aquilia to imply culpa lata, levis and levissima.$^{18}$ Furthermore, culpa and dolus in the lex Aquilia were punished equally; ${ }^{19}$ culpa levissima was not punished less than dolus. ${ }^{20}$ The examples used by the Glossators were taken from Roman law, as, for example, the case of the javelin throwers (D.9.2.9.4). ${ }^{21}$

Did the notion of culpa have a different meaning for the Commentators? ${ }^{22}$

14 See also Rasi 1968, p. $750 f$.

15 See also Descamps 2005, p. 27.

16 The development of a general theory of culpa was not achieved by the Glossators; see Von Mehren \& Gordley 1977, p. 569.

17 Descamps 2005, p. $63 \mathrm{f}$.

18 See, e.g., Wilhelmus de Cabriano, Casus Codicis, ad C. 3.35.4-5; Summa Vindobonensis, IV.3; - On culpa in medieval Roman scholarship and on the tripartite division of culpa into lata, leuis and leuissima, see Talamanca 1960, p. 523ff. and Descamps 2005, p. 71ff. The medieval Roman legal scholars considered the notion of culpa as the lack of appropriate care (diligentia) required in various situations; see Parisi 1992, p. 91.

19 See Corpus legum sive Brachylogus, III. XXII. 7 (edn. Böcking 1929, p. 116). This legal book of French origin was probably composed in the first quarter of the 12th century; see Vinogradoff 1961, p. 72.

20 Martinus in an addition/gloss at Summa Vindobonensis, IV.3: Sed Martinus dicit non minus ex culpa etiam leuissima, si commisit, quam ex dolo.

21 Medieval scholars used the inductive method to extract rules from the cases found present in the Corpus Iuris.

22 More specifically, according to Ibbetson 2003, p. 506, it seems that at first sight neither 
A starting point for an answer to this question can be found in D. 9.2.31, on which the criterion for culpa (levis), namely, what can be foreseen by a diligent person, could be based. Additionally, according to the commentary of Bartolus de Saxoferrato (1313-1357) ${ }^{23}$ on D. 16.3.32, liability consists in any deviation from the diligence of a careful person (quod cum a diligente provideri poterit). ${ }^{24}$ However, a further investigation into the notion of culpa and especially into the role of the contributory negligence of the injured party seems to be necessary. ${ }^{25}$

It is important to note, and this will be shown below, that in medieval Roman scholarship the contributory negligence of the injured party seems to be regarded as reproachable misconduct that could be sanctioned by a refusal to grant a claim for damages. ${ }^{26}$ Thus, the contributory negligence of the injured party began to be considered a possible legal problem. ${ }^{27}$ Two possible important starting points to solve the problem of contributory negligence in the medieval period can be identified. Firstly, the idea of culpa compensation and, secondly, the rule of D. 50.17.203. ${ }^{28}$ These two possible starting points will be discussed in sections 3.2.2 and 3.2.3. Before a possible application of the doctrine of culpae compensatio can be discussed further, it is necessary to find out whether such a doctrine existed at all.

the Glossators nor the Commentators made any attempt to go further than Paul (in D. 9.2.31) in elaborating the notion of culpa in the lex Aquilia; see also Engelmann 1965, p. 18; both authors refer to Bartolus, Commentaria, ad D. 16.3.32, esp. nr. 7 (who cites and refers to Petrus de Bellapertica): ... culpa est deuiatio ab eo, quod bonum est, quod per diligentiam hominis potuit praeuideri. Nam eo ipso, quod deuiat ab eo, quod bonum est, siue in faciendo malum, siue in omittendo bonum scienter uel ignoranter: ista est culpa, et ideo dixi: quod per diligentiam hominis, etc. ad differentiam casus fortuiti, qui praeuideri non potest ... However, this commentary of Bartolus and other commentaries of medieval civilians show that they did attempt to develop the notion of culpa; see Hallebeek 2001, p. 74ff. On the work of the Commentators on the notion of culpa, see also Parisi 1992, p. 117f. and 1994, p. 331, including the contribution of Revigny who regarded culpa as the general criterion of liability encompassing both cases of intentional dolus and of literal, non-intentional culpa). On Bartolus' system of culpa/dolus, and the six kinds of culpa distinguished by him, see Parisi 1992, p. 118ff. and 1994, p. 331 .

23 Bartolus studied in Bologna and was a student of Cinus de Pistoia's. He became a professor at the universities of Pisa and Perugia and was the most important representative of the school of the Commentators; on Bartolus, see, e.g., Woolf 1913 and Van der Kamp 1936.

24 See Hallebeek 2001, esp. p. 76f.; Descamps 2005, p. 76f.; - However, in his commentary on title D. 9.2 Bartolus did not examine extensively the notion of culpa. Only in his commentary on D. 9.2.11.2 did he deal with the concept and solely in terms of ambiguous causation. See also Ibbetson 2003, p. 506.

25 Even König 1954, who wrote an unpublished dissertation titled 'Das allgemeine Schadenersatzrecht im Mittelalter im Anschluss an die lex Aquilia', does not discuss this topic.

26 Also the medieval jurists understood the obligation to pay compensation for damages as a penal sanction; see Jansen 2007, p. 530f., 660.

27 Jansen 2007, p. 660.

28 In the same sense Luig 1969, p. 198. 


\subsubsection{Starting point 1: the doctrine of culpae compensatio}

The contribution of the Glossators: origins of the doctrine of culpae compensatio The Roman jurists did not treat concurrent negligence in a dogmatic way; the Glossators, however, did. ${ }^{29}$ They took the respective negligence of both parties into account. If two parties acted negligently to some extent, sometimes compensation for their negligence was granted. In that respect D. 39.2.40.1 is relevant: because of a defect in a party-wall, the wall fell down and led to damage. According to D.39.2.40.1, one common owner does not have to pay the other anything since it was through a defect in jointly owned property that the damage occurred. Sabinus argued that if the wall collapsed due to too heavy weight, placed upon it by both parties, both were equally at fault. In the event that one of them lost more property or property of greater value than the other party, neither of them would be entitled to bring an action against the other, since they had both placed the same burden on the party-wall.

Indeed, according to the (Accursian) Gloss, when both parties were the cause (causa) of the damage to the same extent, the negligence of both parties had to be compensated. ${ }^{30}$ However, it was not appropriate to compensate culpa by dolus. Only dolus could be compensated by dolus and culpa by culpa. ${ }^{31}$ The fact that the negligence of party A was nullified by the negligence of party $B$ was called culpae compensatio in later times. ${ }^{32}$

Two allegations were frequently put forward in support of the later called doctrine of culpae compensatio, namely, D. 16.2.10pr. and D. 24.3.39. Although the concept of culpae compensatio was present, the term was not yet used as such (this was an invention of nineteenth-century Pandectism, as will be shown later). The doctrine was built on the words ipso iure compensatione neglegentiae facta of D. 16.2.10pr. and the sentence Paria enim delicta mutua pensatione dissoluuntur of D. 24.3.39..$^{33}$ According to the gloss paria enim ad

29 In the same sense Wollschläger 1976, p. 117.

30 Gloss onera ad D. 39.2.40.1.

31 See D. 4.3.36; see gloss quamuis ad D. 2.10.1.2.

32 Luig 1969, p. 197; Zimmermann 1996, p. 1030; Jansen 2002a, p. 105f.; 2002b, p. 205.

33 See also Thomas 2001, p. 352f.; according to Wollschläger 1976, p. 117, the 'gemeinrechtliche' concept of 'Kulpakompensation' is embossed after the expressions compensatio doli, compensatio neglegentiae and compensatio criminis. He refers to Eisenbach's De compensatione circa maleficia, uel quasi, occasione legis xxxvi. Dig. de dolo malo (also extensively discussed in the next chapter); on this work, see also Aumann 1964, p. 53ff.; Luig 1969, p. 215; according to Kaser \& Knutel 2003, p. 221, based on the rule of D. 50.17.203, since the gloss, the so-called theory of 'Kulpakompensation' developed into the later dominant opinion in the 'gemeine Recht', that each instance of contributory negligence of the injured party excluded any claim for compensation, unless the actor acted deliberately. 
D. 24.3.39, a delictum could be compensated by another delictum. ${ }^{34}$ Similar, but more elaborate, is the Accursian gloss dolo compensando ad D. 2.10.3.3, ${ }^{35}$ according to which dolus is compensated by (another) dolus (see D. 4.3.36 ${ }^{36}$ and D. 18.1.57.3). A delictum is compensated by (another) delictum (see D. 24.3.39), negligentia by negligentia (see D. 16.2.10pr.) ${ }^{37}$ and pena by pena (see D. 50.17.154)..$^{38}$ Apparently, the same sort or degree of negligence had to be attributed to both parties, otherwise there could be no culpae compensatio. ${ }^{39}$

As to the origin of the doctrine of culpae compensatio, it is not clear whether the Glossators themselves already formulated their doctrine as a general theory to the entire law of obligations or even to the law of delicts and what the range of application of that theory was. Possibly they already formulated the beginning of the concept of culpae compensatio and not only applied it to cases of mutual insults or adultery (D.24.3.39) but also to cases in which the negligence of the injured person contributed to the occurrence of the damage. ${ }^{40}$ Some scholars even argue that the concept of culpae compensatio obtained an independent position in Roman law and the ius commune, next to the so-called compensatio delictorum (which had an explicit regulation in the Digest). With compensatio delictorum two similar delicts could be cancelled out by mutual compensation. ${ }^{41}$ In both concepts (that of culpae compensatio and that of compensatio delictorum), the wrongdoer and the injured party were considered to have acted in a reproachable way. However, it seems that the two situations are different. In the case of compensatio delictorum, two delictual acts produced two different injuries. In the case of culpae compensatio, one injury is inflicted by two different acts: the act of the wrongdoer and the act of the injured party. ${ }^{42}$

34 Accursian gloss paria enim ad D. 24.3.39; see also the Accursian gloss deteriore ad D. 2.7.2.

35 Accursian gloss dolo compensando ad D. 2.10.3.3.

36 A cross reference to this text already occurs in the margins next to D. 9.2.9.4 and D. 9.2.11pr. in Ms. Trier SB, 838/1634, fo. 98vb and fo. 99ra.

37 See also Accursian gloss ipso iure ad D. 16.2.10pr.

38 However, according to the aforementioned gloss dolo compensando ad D. 2.10.3.3, no compensation of pudicitia by pudicitia could take place; see D. 48.5.2.5 and D. 48.5.14(13).5.

39 Also Luig 1969, p. 199; - According to Accursian gloss ipso iure ad D. 16.2.10pr., if one person injured another person negligently (culpa), and in another event the latter wounded the former intentionally (dolus), a compensation could take place. Not, as in the (last situation described in the) case of D. 9.2.9.4, when the negligent act of one person and the intentional act of another person concern the same event.

40 Luig 1969, p. 199.

41 Jansen 2002a, p. 106; 2002b, p. 205; D. 24.3.39: Paria delicta mutua pensatione dissolvuntur. Concrete examples could be found in D. 16.2.10pr. and D. 18.1.57.3.

42 Jansen 2002a; p. 106; 2002b, p. 205. In the next subsections, I discuss whether or not the theory of culpae compensatio is applied by the Glossators to cases of contributory negligence in cases of damnum iniuria datum; according to secondary literature, the idea of culpae compensatio was applied to the situation of the contributory negligence of the injured party at a later date; see 


\section{The contributions of the Commentators}

According to the doctrine of compensation of faults as just described, when two people wounded each other in a quarrel, and it was not clear who had provoked the quarrel, the delicta of both persons would be cancelled out (set off) by way of mutual compensation. ${ }^{43}$ Also, if two people committed an act with dolus, they could not sue each other because the dolus of both parties was mutually compensated. ${ }^{44}$ This compensation did not take place upon request of one of the litigating parties, but ipso iure..$^{45}$ Of course this was different if one of the parties committed a second delict or repeatedly acted with dolus. ${ }^{46}$

A new consideration was made by Baldus de Ubaldis (1327-1400), ${ }^{47}$ according to whom the word 'compensation' was sometimes used in the true meaning of the word, and sometimes not. A compensation of debts (debita), as in D. 16.2.10pr. (ipso iure), is a compensation in the true sense of the word, i.e. when claims cancel each other out. In the event of a compensation of delicts, however, it would not mean a compensation in the true sense of the word (compensatio), but some kind of acknowledgment (confessio); this is the case in D. 24.3.39 in which the two delicts cannot really cancel each other out. ${ }^{48}$

Jansen 2002a, p. 106; 2002b, p. 205; see also Pernice 1895, p. $90 \mathrm{ff} . ;$ in the next section it will be argued that possibly Paulus de Castro was the first to do so.

43 See, e.g., Corvinus, Digesta per aphorismos strictim explicata, edn. 1642, p. 171f., with references; Bartolus, Commentaria, ad D. 16.2.10pr.; see also R. Fulgosius, In primam Pandectarum partem commentariorum, II, ad D. 16.2.10pr.

44 Baldus, Commentaria, ad D. 4.3.36. An example of a legal application of this rule to a specific case can be found in Jacobus de Ravannis, Lectura super Codice, ad C. 8.4.1: Dicitis quod ex interuallo non possum te expellere: immo quia compensatur dolus cum dolo, et paria crimina mutua compensatione tolluntur, ut ff. de do. l. Si duo [D. 4.3.36] et ff. so. ma. l. Virum [=Viro; D. 24.3.39]; dicunt quidam uerum est, dolus latens cum dolus latentipotest compensari secus est in dolo qui est in uiolentiane deterius contingat dolus cum dolo in eodem facto commissus compensatur, unde licet unus haberet maius damnum et alius minus. Licet non inspiceremus: immo dolus cum dolo compensabitur, nisi in continenti, sed ubi ex interuallo, ut expense non compensatur dolus cum dolo, sed damnum cum damno, quia ex deiectione primus est obligatus, ex secunda secundus, et non debitum cum debito compensaretur, unde agenti ex una obligatione compensaretur debitum ex alio, sed dolus cum dolo non compensaretur non in continenti dictum est uim ui repellere ubi certum est quod uis patitur uiolentiam. ...

45 See on this topic Pichonnaz 2002, p. 337ff.

46 See the additio of Alexander de Imola on Bartolus, Commentaria, ad D. 16.2.10pr.

47 Baldus studied Roman law as a student of Bartolus', and he studied canon law under Federicus de Petruciis. He taught at Perugia, Pisa, Florence, Pavia and Padua.

48 Baldus, Commentaria, ad D. 24.3.39; - A crimen is opposed by way of an exceptio; see, e.g., Albericus de Rosate, Commentarii in primam Infortiati partem, ad D. 24.3.39: Sed hic erat crimen in modum exceptionis oppositum, et ideo dolus dolo compensatur. ... 
The situation became more complicated when - with regard to the same event - one party acted with dolus and the other with culpa. Already Baldus argued that in such a case no compensation should take place. ${ }^{49}$ He stated that a compensation ipso iure could only occur when culpa or dolus were equal on both sides. ${ }^{50}$ As to this compensation, dolus was considered more serious than culpa, and culpa in acting more serious than culpa in refraining. The situation was different when totally different obligations (diversas obligationes) occurred, because then dolus and culpa were compensated to the same extent. ${ }^{51}$ It seems that in the last case, as far as the amount of the two claims agree, a compensation can place place: for example, when one claim was 100 and the other 80, 80 can be compensated and a claim for 20 will remain.

Apparently, cases in which acts concerned the same matter and cases in which acts concerned different matters have to be distinguished. It seems that a compensation of delicts on both sides was only possible when two persons committed a delict with dolus with regard to the same matter. If two persons committed different delicts with dolus, no compensation could take place and therefore both persons were punished because they both acted with dolus. ${ }^{52}$

To conclude, regarding the situation is most relevant in cases in which the injured party contributed to the occurrence of his own loss, i.e the situation in which one person acted with culpa and the other with dolus, could both 'blameworthy acts' be compensated by setting one off against the other? ${ }^{53}$ Jacobus Butrigarius (ca. 1273-1348) ${ }^{54}$ argued that in the event two persons acted with regard to the same matter and one party acted with dolus and the other with culpa (or negligentia), dolus absorbs culpa, and so the person who acted with

49 Baldus, Commentaria, ad D. 16.2.10pr.

50 Possibly Paulus de Castro had a different view as he seems to be convinced that culpa could be compensated by dolus. It could be that his commentary has to be understood in such a way that the intentional act and the culpable act concern different cases; see Paulus Castrensis, In secundam Digesti Veteris partem, ad D. 16.2.10pr.

51 Baldus, Commentaria, ad D. 16.2.10pr.

52 See J. Butrigarius, In primam e secundam veteris Digesti partem, I, ad D. 4.3.36.

53 The situation in which the actions of two persons do not regard the same case is different (no compensation for actions done with dolus or culpa in that case); see for that situation, e.g., R. Fulgosius, In primam Pandectarum partem commentariorum, II, ad D. 16.2.10pr.; J. Butrigarius, In primam et secundam veteris Digestipartem, II, ad D. 16.2.10pr. See also J. Bertachinus, Repertorium, s.v. compensatio; Albericus de Rosate, Commentarii in secundam Digesti Veteris partem, ad D. 16.2.10pr.; also Albericus de Rosate, Commentarii in primam Infortiati partem, ad D. 24.3.39. This theory of compensatio delictorum can also be placed in a procedural perspective as Angelus Aretinus de Gambilionibus ( $† 1450)$ does; see Angeli de Aretio, In quattuor Institutionum, ad Inst. 4.13pr., nr. 29.

54 Jacobus Butrigarius was an Italian jurist, a professor of Roman law at Bologna, who stood in the tradition of the Commentators as he was a student of Bartolus'. 
culpa was not held liable, but the person who acted with dolus was. ${ }^{55}$ Albericus de Rosate (1290-1354/1360) ${ }^{56}$ agreed when he stated that if one person acted with dolus and the other with negligentia with regard to the same matter, no compensation could take place, since dolus was considered to be more serious. ${ }^{57}$

\subsubsection{The case of the javelin throwers}

\section{The view of the Glossators}

The facts of this case were discussed in the previous chapter. In summary, some people were javelin-throwing ${ }^{58}$ and in doing so killed a slave. The Glossators treated the question whether the wrongdoer was liable or not in a scholastic way, i.e. they made distinctions between various situations to determine in which situation the wrongdoer would be liable and in which situation he would not. To find out for what reason these distinctions were made and whether or not a doctrine such as culpae compensatio was applied, these situations and distinctions have to be discussed.

The first Glossator who seems to explicitly argue on the problem of contributory negligence of the injured party is Johannes Bassianus $(\dagger 1197) .{ }^{59}$ He formulated the view that culpa (of the wrongdoer, i.e. the javelin thrower)

55 J. Butrigarius, In primam et secundam veteris Digesti partem, II, ad D. 16.2.10pr.

56 Albericus de Rosate was an important 14th-century practising lawyer who belonged to the school of the Commentators.

57 Albericus de Rosate, Commentarii in secundam Digesti Veteris partem, ad D. 16.2.10pr.; - An exception was made with regard to the fact that dolus was considered more serious than culpa: in a criminal case, dolus or culpa on the side of one party did not cancel out the dolus or culpa of the other party. The criminal cases brought by the State and these were no longer accusatory procedures. These ideas of Alexander de Imola have to be regarded purely theoretically. See Alexander de Imola, Consilium LXXVII, nr. $12 \mathrm{f}$.

58 'Somewhere', see gloss ad iaculantibus in Mss. Biblioteca Vaticana, vat. lat. 1405, fo. 77v; Biblioteca Vaticana, vat. lat. 1408, fo. 106vb; Biblioteca Vaticana, vat. lat. 2511, fo. 76r; Paris BN, lat. 4459, fo. 90va; Bamberg, Jur 11, fo. 115rb (with siglum az.); London BM, Royal 11.C. III, fo. 93r; München Clm 3887, fo. 92ra; Torino BN, E.I.4, fo. 139va; Paris BN, lat. 4458, fo. 72rb; Stockholm KB, B 680, fo. 101v: (sc.) alicubi; - Affirmation can be found in gloss aiaculantibus with siglum az. in Biblioteca Vaticana, Ottobon. lat. 1605, fo. 124ra: scilicet alicubi (later changed into alibi quam) ut consuetus est., and gloss occisus in Ms. Padova BU, 941, fo. 88rb: in loco non solito ad ludendum, according to which the first situation distinguished in D. 9.2.9.4 was that of javelin throwers not playing at a place where it was not customary to play. The second situation described in D. 9.2.9.4 would be that of a field for javelin-throwing; see gloss ad campo in Mss. Leipzig, Univ. Bibl., 873, fo. 76v; Biblioteca Apostolica Vaticana, vat. lat. 1406, fo. 80v: scilicet iaculatorio.

59 Johannes Bassianus, a professor at Bologna, lived at about the end of the 12th century (Rose 1857, p. 332) and took an important position within the tradition of the Bolognese glossators. He was a student of Bulgarus' and at the same time the master of Azo; - Information on the medieval civilians (Glossators and Commentators) mentioned in this chapter can be found in Von Savigny 1956, esp. volumes IV/V/VI; Cortese 1995; Lange 1997; Lange \& Kriechbaum 2007; therefore, no references to these general works will be made each time, but only if necessary to a specific point; additional literature will be mentioned where necessary. 
could be compensated by culpa (of the injured party, i.e. the slave) and be neutralised: for that reason the javelin thrower was relieved from his own culpa.$^{60}$ Consequently, it may be assumed that he was also relieved from any liability. Furthermore, Johannes Bassianus noted that if the thrower threw at the slave intentionally, the act could be seen as performed with dolus. ${ }^{61}$ He argued that culpa nullifies culpa, but culpa (of the injured party) does not nullify dolus. ${ }^{62}$ Accordingly, if the injured party acted negligently, his negligence (culpa) was set off against that of the wrongdoer, and thus the injured party could not claim compensation from the wrongdoer. ${ }^{63}$

A similar case about javelin throwers, already mentioned above, is Inst. 4.3.4. ${ }^{64}$ In Inst. 4.3.4, a situation is described in which a person acts lawfully (iure): the soldier while exercising in his exercising ground, or where such practice is usually conducted, and who killed a slave who passed by. ${ }^{65}$ Later Glossators do not

60 Gloss quia non debuit with siglum Io. ad D. 9.2.9.4 in Mss. Paris BN, lat. 4459, fo. 90va; Biblioteca Vaticana, vat. lat. 1408, fo. 106vb; Biblioteca Vaticana, Barb. lat. 1459, fo. 88rb; Biblioteca Vaticana, Ottobon. lat. 1605, fo. 124rb; Leipzig 877, fo. 96va; London BM, Royal 11.C. III, fo. 93ra; Bamberg, Jur 11, fo. 115rb; München Clm 3887, fo. 92ra; Torino BN, E.I.4, fo. 139va; Troyes 135, fo. 95vb; Paris BN, lat. 4458, fo. 72rb; Trier SB 838/1634, fo. 98vb [siglum: Accursius]; Stockholm KB, B 680, fo. 10lva: Ergo culpe culpa compensata dissoluitur, ut infra de compe. Si ambo [D. 16.2.10pr.] et infra so. ma. Viro [D. 24.3.39]; adopted by Accursius in his gloss quia non debuit ad D. 9.2.9.4; Johannes Bassianus refers to D. 16.2.10pr. and D. 24.3.39. These two fragments also contain a certain compensation: D. 16.2.10pr. is an example of a set-off of mutual obligations between associates (socii), compensatio neglegentiae, and D. 24.3.39 contains a compensation of delicta.

61 Apparently, dolus and data opera are synonymous. See also gloss ad data opera in Ms. Paris BN, lat. 4461, fo. 101v: id est in dolo; also Scott 1984, p. 168 nt. 18.

62 Gloss tenebitur ad D. 9.2.9.4: Quia dolus praeponderat. Azo. Et sic nota quod hoc casu solus dolus uenit in Aquilia non culpa, ut infra eodem Si putator [D. 9.2.31], et infra de aq. re. do. Homo liber § Item [D. 41.1.54.1-2]. Et est ratio ut dixi, quia culpa culpam abolet, set non dolum, ut infra eodem Qui foueas § Hec tamen actio [D. 9.2.28.1] secundum Io[annem] [Bassianum]; see also a gloss in Biblioteca Vaticana, Ottobon. lat. 1605, fo. 124rb: dolus preponderat culpe, and in the same Ms., a gloss with siglum az. next to gloss tenebitur (the gloss at the beginning of this footnote): Nota quod dolus preponderat culpe.

63 Also Wieling 1970, p. 223; the glosses damnum ad VI. 5.12.86 and commentum ad VI 1.21.1 are also relevant in this perspective, and will be discussed in the section on canon law; Azo, Brocarda, fo. $189 \mathrm{v}$, explains that it is the preceding culpa that neutralises the following culpa; so the culpa of the injured party has to precede the culpa of the wrongdoer; in that case the later culpa (i.e. the culpa of the wrongdoer) is neutralised. There are also references to various texts in the Authenticum.

64 See also a gloss to Summa Vindobonensis, IV.3 (Itaque si quis ...).

65 See already the Summa Trecensis, the oldest anonymous Summa on the Codex, from the middle of the 12th century (Genzmer 1987, p. 30; see also Kantorowicz \& Buckland 1969, p. 146ff.); see Summa Trecensis XIII.2: ... aut cum rationabiliter excusatur, ut miles qui in campo iaculatorio stans [seruum] transeuntem interfecit ...; - A somewhat different starting point is given by the author of Lo Codi (ca. 1170), also an anonymous Summa of the Codex, originally written in the Provençal language. The relevant part concerns the problem of the limits of the lex Aquilia. In describing situations in which there is no culpa of the wrongdoer and therefore no delictual liability, the following example is also given. A soldier was crossing a place where other soldiers were used to crossing over, and during a game he or his horse killed or inflicted damage on a person. According to the author of Lo Codi, if the soldier did not inflict the damage 
seem to have made new explanations with regard to Inst. 4.3.4 that can help us with the problem of contributory negligence ${ }^{66}$ This is not really surprising as Inst. 4.3.4 does not include any reference to the injured party; the Glossators therefore had no firm, clear rule to argue on as to the role of the injured party. Nevertheless, Johannes Bassianus did consider such contributory negligence in his gloss to Inst. 4.3.2/4 (this gloss was not included in the Glossa Ordinaria). If the slave crossed a place that was not used as a campus, both parties acted culpably (the thrower and the slave). Apparently, Johannes was asked whether in such a case the negligence of the thrower and the contributory negligence of the slave could be set off against each other and be compensated (as apparently was the case in normal practice in other areas/cases). Johannes gave a negative answer, because the thrower was considered to have thrown the javelin intentionally (dolus), ${ }^{67}$ and dolus consumes negligence (culpa). ${ }^{68}$

This theory was adopted by Johannes Bassianus' student Azo (ca. 1150-1220), ${ }^{69}$ who applied the theory to the case of D. 9.2.9.4: the thrower was not liable, because the slave should not have crossed the field of the javelin throwers (also on the field of $\mathrm{Mars}^{70}$ ) at an inappropriate time. ${ }^{71}$ Only in the exceptional

intentionally, he was not obliged to provide compensation. See Lo Codi, III.31.7.

66 They only emphasised that a distinction is made in Inst. 4.3.4: If a soldier, throwing in a field where one usually practised, killed a slave, he would not be considered to act with culpa, unless he acted intentionally (data opera); see Accursian gloss nulla culpa ad Inst. 4.3.4: nisi data opera factum est ut ff. lex idem Si obstretix in fi. [D. 9.2.9.4] et l. Nam [D. 9.2.10]. If anyone else (i.e. not a soldier) threw a javelin and killed a slave, the damage could not be imputed to the victim, and the thrower would be liable for culpa; see gloss reus ad Inst. 4.3.4: quia hoc non est ei deputatum arg. in aut. ut hi qui ob. p. res mi. § Sin uero tacuerit [Nov. 72.4 (Coll. 6.2)] collatione uim etff. eodem Idem iuris in finalis [D. 9.2.8]; according to a gloss to Summa Vindobonensis, IV.3, it was considered necessary that the thrower (not being a soldier) had the essential abilities for throwing. If someone nevertheless killed someone, and thus lacked such abilities, that person would be liable for culpa; furthermore, a soldier would also be liable for the killing of a slave when practising in any place other than a field designated for military exercises.

67 Later, Accursius also distinguishes between an act with dolus, one with culpa and one which is neither malicious nor negligent; see Accursian gloss distinguitur ad Inst. 4.3.4: utrum commiserit dolo, uel culpa uel non.

68 Johannes Bassianus, Glossa in Institutiones, Ms. Leiden ABL 3, fo. 16v: De lege Aquilia. Resp. Iniuria autem et cetera et ibi Si alius hoc tale quid amisit, et cetera [Inst. 4.3.2 and 4.3.4], scilicet non seruum qui per talem locum transsiuit. Culpam committit. Queritur ergo non fit compensatio culpe cum culpa. Solet enim culpa cum culpa compensari, utff. de compensation. Si ambo [D. 16.2.10pr.]. Resp. hic ab una parte dolus est, scilicet quod in transeuntem iaculum transmisit, dolus aut culpam exedit....

69 Azo was an influential glossator, a professor at Bologna and the master of Accursius.

70 Gloss ad campum iaculatorium in Ms. Troyes 135, fo. 95v: etiam in campo Mart [io].

71 See also gloss ad intempestiue in Ms. Troyes 135, fo. 95v: id est non idoneo tempore and, slightly different, in Ms. Padova BU, 941, fo. 88r: scilicet non suo tempore; Azo stated in his Brocarda, fo. 20r, that the slave has to be considered culpable (culpa) because he made this journey at an inopportune time, or acted intentionally (culpa est quia non debuit intempestiue facere aut quia data opera hoc fecit, D. 9.2.9.4). 
situation described above, in which the thrower threw intentionally and the injured (the slave) acted negligently, could the injured party claim compensation. While providing a justification for the solution in that situation, Azo formulated a (new) general rule, namely, that when one person acts with culpa and the other with dolus, the act with dolus would be considered to be more serious than that with culpa (and thus the javelin thrower would be liable in the case of D. 9.2.9.4).$^{72}$ This view is also held by his contemporary Roffredus Beneventanus (ca. 1170 - after 1244$),{ }^{73}$ who made similar remarks, but beyond the context of this case. ${ }^{74}$

Another novelty Azo introduced was that it had to be distinguished whether or not the intentional act preceded the negligent act. In this case, the negligence (culpa) of the slave, i.e. crossing the field of the javelin throwers at an inappropriate time, preceded the intentional act (dolus), i.e. throwing at the slave on purpose. In such a case, the rule dolus preponderatculpe ${ }^{75}$ applied and the thrower was held liable, ${ }^{76}$ viz. by means of a direct action based on the lex Aquilia. ${ }^{77}$

72 Gloss ad tenebitur with siglum az. in Mss. Paris BN, lat. 4459, fo. 90va; Paris BN, lat. 4451, fo. 75ra; Bamberg, Jur 11, fo. 115va; Padova BU, 941, fo. 88rb; Biblioteca Vaticana, vat. lat. 1408, fo. 106vb; München Clm 3887, fo. 92ra; Stockholm KB, B 680, fo. 10lva: quia dolus culpa<e> praeponderat; see also Ms. Leipzig 877, fo. 96va; Azo, Summa Codicis, III.35.8; see also gloss data opera in Padova BU, 941, fo. 88rb: arg. quod dolus praeponderat culpe; culpa fuit servi, quod ipse transiuit per campum ludentium, sed cum ille qui dolo eum interfecit tenetur aquilia; - According to Azo, dolus could be compensated by dolus (see D. 18.1.57.3 and D. 24.3.39), but culpa lata is not compared (comparatur) with dolus; see Azo, Brocarda, fo. 18r: dolus dolo compensatur; dolo non comparatur lata culpa; - See also Hugolinus in gloss cessat ad D. 9.2.9.4 in Ms. Paris BN, lat. 4461, fo. 101 va (see $n .79$ below).

73 Roffredus studied law in Bologna and Arezzo, and taught at the University of Naples.

74 Roffredus Beneventanus, Libelli iuris civilis. De actio directa legis aquiliae, uers. Tertium quod culpa, fo. $96 \mathrm{v}$.

75 See gloss (ad D. 9.2.9.4) in Ms. Troyes 135, fo. 95vb: Set quaeritur numquid dolus preponderat culpe. Distingue, quod aut dolus precedit culpam aut sequitur. Si precedit, distingue quod aut ratione culpe peruenit uel adest doloso, aut nichil adest. Si aliquid adest, tenetur dolosus, infra de edilic. edicto Vendicantem [D. 21.2.17]. Si nichil adest, non tenetur, supra de edendo l. Argentarius § Cum autem [D. 2.13.10.3]. Aut culpa precedat dolum, et tunc dolus preponderat, ut hic fecit et in l. Si officium $\$$ f. [probably l. Si obstetrix i.e. D. 9.2.9.4].

76 Gloss ad eum iaculatus with siglum az. in Mss. Biblioteca Vaticana, vat. lat. 1408, fo. 106vb; Biblioteca Vaticana, vat. lat. 2511, fo. 76r; Leipzig 877, fo. 96va; Troyes 135, fo. 95v; München Clm 3887; Trier SB, 838/1634, fo. 98v; Padova BU, 941, fo. 88rb: uel/scilicet ludendo; - See Azo, Summa Codicis, III.35.8.

77 Gloss ad Aquilia (tenebitur) with siglum azo in Mss. Biblioteca Vaticana, vat. lat. 1408, fo. 106vb; Leipzig 877, fo. 96va; München Clm 3887, fo. 92ra; Troyes 135, fo. 95v; Padova BU, 941, fo. 88rb: directa; - See also gloss ad utique Aquilia tenebitur (ad D. 9.2.9.4) in Ms. London BM, Royal 11.C. III, fo. 93r: quamuis in hanc loco et hoc enim non uideatur abesse culpam iacularentur. Id est uerum si per lusionem occisus < fuerit>, Aquilie locus est; also, slightly different, in Ms. Leipzig, Univ. Bibl., 873, fo. 76vb: Quamuis in hoc loco iacularentur. Vere si per lusum occisus fuerit tenetur. 
Hugolinus ( $†$ after 1233$)^{78}$ restated that in the situation in which people are throwing javelins on a javelin field, and someone crossed at that inappropriate time, the thrower was not liable under the lex Aquilia and that the culpa (even levissima) of the thrower was compensated by the culpa of the slave crossing the field. In addition, he also came to the conclusion that if the slave had not acted culpably, his master might bring an action. This could be the case if the slave did not know the place was a campus iaculatorium. ${ }^{79}$

Accursius added one more decisive criterion with regard to the case of the javelin throwers: whether or not the slave took part in the game had to be taken into account. If the slave took part in the game (i.e. a normal game, not an illicit game $)^{80}$ and damage was inflicted on him, the damage would be considered a result of the permissible game and not imputable to anyone ${ }^{81}$ If one of the participants in a game suffered damage, no fault (culpa) could be constituted: whether a game in which the elimination of an opponent was the goal or a game in which no damage should be inflicted, such as a ball game, did not make any difference.$^{82}$ In the case as described in D. 9.2.9.4, the slave, crossing over the field, took no part in the game. ${ }^{83}$ Therefore, another distinction had to be made: if the javelin throwers were playing in a place where it was not customary to play, i.e. not a campus iaculatorium, the thrower was liable pursuant to the lex Aquilia. But if the slave was crossing over a campus iaculatorium, the lex

78 The glossator Hugolinus was another pupil of Johannes Bassianus', and a contemporary of Azo's. He was a professor of Roman law at Bologna.

79 Gloss cessat with siglum h. (Hugolinus) ad D. 9.2.9.4 in Ms. Paris BN, lat. 4461, fo. 10lva: Immo uidetur quod habet locum, quia in Aquilia tenetur quis de leuissima culpa, ut infra e. In lege [D. 9.2.44pr.]. Set dic cum fuerit in culpa compensari culpam cum culpa et infra de compensat. Si ambo et infra solutio. m. fo. Viro [D. 24.3.39]. Atque si autem ponatur seruum non fuisse in culpa hinc poterit agere forte quia ignorabat per locum illum aliquid esse solutum iaculare. Cum autem dolus est, ab altera parte; licet iste sit in culpa, aget similiter, quia praeponderat dolus culpe.

80 See gloss nam with siglum az. ad D. 9.2.10 in Mss. Biblioteca Vaticana, vat. lat. 1408, fo. 106vb (no siglum); Paris BN, lat. 4459, fo. 90va (no siglum); München Clm 3887, fo. 92ra (no siglum); Paris BN, lat. 4451, fo. 75ra; Stockholm KB, B 680, fo. 101va; Bamberg, Jur. 11, fo. 115va: Non enim ludi sunt appellandi ex quibus nascitur occasio criminandi, ut supra in prima oratio $<$ ne $>$ prope finem; - According to Rasi 1968, p. 760f., he who participated in a sport activity and inflicted damage on a third party did not have any responsibility, provided participation was permitted (not all games were allowed; see Rasi 1968, p. $761 \mathrm{nt}$. 96) and it was a manifestation according to the normal rules or the specific rules for that particular game and that there were no intentional excesses.

81 Accursian gloss nam ludus ad D. 9.2.10: Immo non est ludus ex quo crimen oritur ut supra in proemio circa fi[nem] [D. 9.2.9.4 first sentence] alius si esset per ludum etiam nocitum, dummodo ei, qui est de ludo: ludo imputatur ut infra eodem Si ex plagis § fi. [D. 9.2.52.4].

82 See already Placentinus, Summa Codicis, III.35; Rasi 1968, p. 762.

83 Accursian gloss seruus ad D. 9.2.9.4: Qui non erat de ludo alius; secus ut infra eodem titulo Si ex plagis $\S$ fi. [D. 9.2.52.4]. Item in non solito loco ad ludum; see also gloss seruus ad D. 9.2.9.4 in Ms. Troyes 135, fo. 95vb: non ludens, alius sicut infra Si ex plagis Cum pila [D. 9.2.52.4]. [siglum illegible]. 
Aquilia was not applicable, since he should not have crossed a field of javelin throwers at an inopportune time (i.e. when the throwers were throwing). ${ }^{84}$

Odofredus $(\dagger 1265),{ }^{85}$ when discussing the second situation as described in D. 9.2.9.4, connected this case to the text of D. 9.2.10: the thrower who killed the slave certainly acted with culpa or dolus, required for liability under the lex Aquilia, because taking part in a dangerous game was also considered to constitute culpa. ${ }^{86}$ Also Odofredus, based on the last part of D. 9.2.9.4, argued that although the slave acted culpably by crossing the campum iaculatorium, the player who threw a javelin intentionally at the slave acted with dolus, and dolus had to be considered to be more serious than culpa. ${ }^{87}$

\section{The view of the Commentators}

\section{Introduction}

With regard to the cases of the javelin throwers (D. 9.2.9.4 \& Inst. 4.3.4), the following summary of the relevant views of the Commentators can be given.

84 See Accursian gloss sed et si per lusum a iaculantibus ad D. 9.2.9.4: Scilicet alicubi; ubi consuetum non est. Et dicas quod ibat iste seruus per alium locum, non per campum iaculatorium; alius haberet locum inferior $\$$ Sed si cum alii [D. 9.2.9.4 second sentence]; see also gloss sed si per lusum iaculantibus in Ms. Biblioteca Vaticana, Palat. Lat. 737, fo. 70ra: <id> est campo non iaculatorio. [no siglum] and gloss ad iaculantibus in Ms. Troyes 135, fo. 95v: non datum in campo iaculatorio; see already Azo in gloss sed a iaculantibus in Ms. Leipzig 877, fo. 96va: ubi factum culpa sequitur; scilicet alicubi. azo; - Although Accursius did not first argue, with reference to D. 9.2.10, that while the slave is not a participant and while the game was a game causing damage (ludus noxius), there could be reason for Aquilian liability, this could be an implicit idea. See also Henricus de Baila in gloss with siglum Yr. ad D. 9.2.10 in Ms. Biblioteca Vaticana, vat. lat. 2511, fo. 76r: Enim si per lusum occisus fuit, locus est acquilia.

85 Odofredus was a pupil and follower of Hugolinus', and a professor of Roman law at Bologna.

86 Odofredus, Lectura super Digesto veteri ad D. 9.2.9.4, fo. 273r; Engelmann 1965, p. 209, argued that Odofredus believed that playing a dangerous game at a prohibited place was to be considered as acting with culpa; he referred to Odofredus ad D. 9.2.9.4 and to the phrase 'barbitonsor non tenetur, nisi posuit in loco, in quo ponere debebat'. Engelmann argued that since taking part in a dangerous game was considered to constitute culpa, the unfolding situation had to be attributed to the player, so that the 'culpa praecedens' was not the violation of the prohibition as such, but the playing at a place where it was dangerous to do so and therefore was prohibited; - See also a gloss in Ms. Trier SB, 838/1634, fo. 98vb: ludum noxium in culpa esse. An allegation in this manuscript seems also relevant: D. 47.2.50.4, in which it is stated that a dangerous game may not be left unpunished (non debet impunitus esse lusus tam perniciosus).

87 Scott 1984, p. 168f., rightly stated that from the texts there is no clear evidence regarding the position of the plaintiff's acting intentionally to create his own harm in conjunction with a (solely) negligent defendant; furthermore, he stated that in D. 9.2.11pr. the person who allowed himself to be in a place he knew was dangerous, was guilty of more than culpa. His state of mind may be analogous to that described in the words data opera in D. 9.2.9.4. The author suggested that, in spite of the 'dearth of authority', the same ratio applies: in this case the dolus of one party would always eliminate the culpa of the other party; Scott finds support in the gloss tenebitur ad D. 9.2.9.4 ('quia culpa culpam abolet, sed non dolum'). 
They made a distinction between the situation in which the injured party did not take part in the game, and the situation in which the injured party did so. In this last situation, it was presumed the damage was not inflicted intentionally, unless there was proof to the contrary. ${ }^{88}$

In the first situation, in which the injured party took no part in the game, the civilians who played with a lance and wounded or killed somebody were liable. According to Johannes Faber $(\dagger 1340),{ }^{89}$ this would also apply if they played in a field designated for that purpose. They would act culpably because apparently it was not customary that civilians threw javelins. ${ }^{90}$ Johannes Faber argued that it would be different if the civilians played a suitable game, for example a ball game, or a public competition. If civilians played with bows, ${ }^{91}$ and in a public place, Faber was of the opinion that the same applies if they wounded or killed someone and therefore they would not be held liable, because this was often done by young people and workmen. ${ }^{92}$

More elaborate on the reason for culpability are the commentaries of Nicasius de Voerda (ca. 1440-1492) ${ }^{93}$ and Henricus de Pyro (1403-1473). ${ }^{94}$ If someone took part in a game not permissible to him, by reason of the person (ratione personae) or by reason of the wrong place (ratione loci), and killed somebody, he was held liable (for homicide). The reason is that his negligence (culpa) preceded the damage-causing act. ${ }^{95}$ The permissibility of the game seems to be based on the criterion of ratione loci: did he do the right thing in the right way but in the wrong place? Therefore, the permissibility of the game seems to have depended on the question whether the place was designated for such a purpose. If the players were playing with a crossbow or shooting (with arrows) in a place not designated for this purpose and killed someone, the person who shot the arrows was liable. ${ }^{96}$ Someone would not be liable if

88 See Albericus de Rosate, Commentarii in primam Digesti veteris partem, ad D. 9.2.52.4.

89 Johannes Faber (Jean Faure), professor at Montpellier, belonged to the school of Orléans.

90 J. Faber, Commentarii in quatuor Institutionum libros, edn. 1557, fo. 111r.

91 See on arca and balistae in the 13th and 14th centuries (albeit in the southern area of Toscana) De Luca \& Farinelli 2002, p. 455ff.

92 J. Faber, Commentarii in quatuor Institutionum libros, edn. 1557, fo. 111r.

93 Nicasius de Voerda was a professor at Cologne. He qualified in arts and theology at the University of Louvain, and acquired a doctoral degree in canon law at the University of Cologne; on Nicasius Voerda, see, e.g., Von Eisenhart 1896, p. 9lf.; Cobban 1999, p. 19.

94 Henricus Brunonis de Pyro, doctor legum, studied in Paris, Cologne and Bologna, taught at Cologne and Louvain and later became a Carthusian. On Henricus de Pyro/Piro, see, e.g., Feenstra 1996, p. 3ff.

95 According to Nicasius de Voerda, Super Institutionibus, ad Inst. 4.3.2, the same would apply to a cleric if he took part in a game not permitted to him and thereby he killed someone. In my opinion, this is an example of liability ratione personae; Voerda possibly thought of X 5.12.8.

96 Henricus de Pyro, Super Institutis, ad Inst. 4.3. 
he was playing in a place designated for this purpose ${ }^{97}$ In that case, it was dangerous to cross that field where one played with artillery. As to the person who crossed the unsafe field, the blame was to be imputed to him. Of course, an exception had to be made in the event the players threw intentionally or the person using the artillery aimed at a person intentionally, as dolus is more serious than culpa. ${ }^{98}$

\section{The role of the injured party}

Up to now, these solutions are only explicitly discussed from the perspective of the culpability of the wrongdoer. However, a number of Commentators made some remarks on the role of the injured party as well. With regard to D. 9.2.9.4 ${ }^{99}$ Baldus mentioned that nobody is obliged to cross over a dangerous place. If someone nevertheless does so and the crossing ends in an undesired way, this is to be imputed to the victim. ${ }^{100}$ Florianus de Sancto Petro $(\dagger 1441)^{101}$ called it an 'ethical rule' that if someone crosses a dangerous place, negligence is imputed to him; based on this rule, the care to be observed includes not exposing oneself to danger. ${ }^{102}$

\section{Consequences of contributory negligence}

It is not until Paulus de Castro $(c a .1360 / 62-1441)^{103}$ that the consequences of such contributory negligence were made explicit. Paulus de Castro remarked that if culpa of the slave could be established, the thrower was not liable, because the culpa of the thrower was compensated by the culpa of the slave. The situation would be different if the thrower threw intentionally because in that case no compensation took place, since dolus was considered to be more

97 It seems that in such a case no culpa was established beforehand, based on ratione loci. However, to resolve the ambiguity in this text one has to assume that the wrongdoer nevertheless acted culpably, because the act of the injured party is implicitly compared with it, and at the end even explicitly compared with it (dolus vs. culpa). Otherwise, if no culpability of the wrongdoer existed on other grounds, the remark that the injured party acted dangerously and had to blame himself would be superfluous.

98 Nicasius de Voerda, Super Institutionibus, ad Inst. 4.3.2; Henricus de Pyro, Super Institutis, ad Inst. 4.3. Apparently, according to Henricus, even when someone played a game unknown to him, and in playing that game killed another person, he was liable.

99 Unfortunately, Bartolus does not comment on D. 9.2.9.4 (nor on D. 9.2.11pr.).

100 Baldus, Commentaria, ad D. 9.2.9.4; Commentaria, ad D. 9.2.29pr.

101 Florianus de Sancto Petro (Sampieri) was a Bolognese doctor and the master of Antonius de Mincuccius.

102 Florianus de Sancto Petro, Super nono libro Digesti veteris, ad D. 9.2.9.4: .... Nota ex isto tex[to] [i.e. D. 9.2.9.4, EvD] moralem regulam que uult imputari ey qui transit per locum periculosum facit infra e[adem] l[ege] Item Mella in prin. [D. 9.2.11pr.]. Et ex hoc sumitur cautela quod quis non debet se exponere periculo....

103 Paulus de Castro was a student of Baldus de Ubaldis'. He belonged to the tradition of the Commentators, and he was a professor of law at Avignon, Siena, Padua and Florence. 
serious than culpa. ${ }^{104}$ Although this theory was already mentioned in the Gloss, it was not further elaborated; besides Paulus de Castro also Albericus de Rosate applied the same theory to this case. Finally, Florianus and Albericus remind us that anyone who plays a dangerous game also acts with culpa. ${ }^{105}$

\subsubsection{The case of the barber}

\section{The view of the Glossators}

Already in the Summa Vindobonensis, an early work erroneously ascribed to Irnerius, ${ }^{106}$ the importance of the case of D. 9.2.11pr. to the problem of contributory negligence in the medieval period was mentioned. The author of the Summa Vindobonensis brought up a fictitious case in which a person inflicted more damage on himself than on someone else: this person killed an animal owed to him and so inflicted the damage on himself. In this case, the injured party rather than any other party had to be blamed. This, so the anonymous author argued, was comparable to the barber's case in which someone entrusted himself to a barber who put his chair in a dangerous place. The damage suffered by the injured party could not be claimed under the lex Aquilia. ${ }^{107}$ The author of the Summa Vindobonensis referred to the case of the barber (D. 9.2.11pr.) who put his chair near a place where people were playing with a ball. As described before, in this case one of the ball-players threw the ball quite hard ${ }^{108}$ and hit the hand(s) of the barber, ${ }^{109}$ as a result of which the throat of a slave was cut by the barber's knife. ${ }^{110}$

104 Paulus Castrensis, Auenionicae Praelectiones in Digestum Vetus, ad D. 9.2.9.4. See also R. Fulgosius, In primam Pandectarum partem commentariorum, I, ad D. 9.2.11pr. When reading Fulgosius' commentary one comes to the following conclusion. While people were playing with javelins they killed a slave. Apparently, Fulgosius believed that in such a case both the thrower and the (passing) slave acted culpably; the culpability of the thrower was, however, more serious and thus after being set off against the culpability of the slave is the only culpability that still remained. Therefore he was liable. It is not clear what Fulgosius meant with 'more serious' negligence: dolus, or just culpa lata or culpa levis.

105 Albericus de Rosate, Commentarii in primam Digesti veteris partem, ad D. 9.2.9.4; see also Florianus de Sancto Petro, Super nono libro Digesti veteris, ad D. 9.2.9.4.

106 See Cortese 1995, p. 135.

107 Summa Vindobonensis, IV.3.

108 Differently in Azo, Summa Codicis, III.35.8: et pilla uehementer percussa; in Placentinus, Summa Codicis, III.35: fortiter.

109 See also gloss ad tonsor habebat in Ms. Leipzig, Univ. Bibl., 873, fo. 76v: in manibus.

110 Vivianus Tuscus (13th century) wrote a casus to D. 9.2.11pr. Casus were examples used by the Glossators to illustrate the texts/cases of the Corpus Iuris to their students; see Coing 1973, p. 328; Cortese 1995, p. 18. Vivianus' casus deals with two persons, Titius and Mevius, playing a ball game. One of them hit the ball against the hands of a barber who was just shaving a slave. The barber cut the throat of the slave, killing him. Who could be held liable: the ball-thrower or the barber? Vivianus responded that the ball-thrower should be liable, unless the barber had culpa, in which case non agitur; see Vivianus, Casus ad D. 9.2.11pr., in the edition of Corpus Iuris of 1618, 
It is interesting that Placentinus $(\dagger 1192)^{111}$ argued that a fault (culpa) could be attributed to various persons: the lusor, the deiector, the barber if he was shaving in a place were many people were used to crossing over (or where one customarily played; ${ }^{112}$ see D. 9.2.11pr.), ${ }^{113}$ and also the person who was being shaved, because he entrusted himself to a barber who put his chair in such a dangerous place. The Glossator explicitly looked at the role of the injured party. The consequence of such contributory negligence becomes clear from the following. Placentinus stated that if the ball-player threw the ball negligently or intentionally (with culpa or dolus), he would certainly be liable. Apparently, according to Placentinus, the contributory negligence of the injured party had to be regarded as relative: he was negligent in a certain position to another person. The behaviour of the injured party is only to be regarded as contributory negligence against certain actors in the case, and not against other actors. The phrase 'de se queri debet' had to be considered as referring to the barber. ${ }^{114}$ In Placentinus' opinion, first of all an action had to be brought against the barber, while the culpa of the injured party (in

col. 1062. This example provided by Vivianus is interpreted by Engelmann in such a way that the barber was coincidentally hit by the ball. The barber acted with culpa if he had seen people playing there. In the event that he had not seen people playing, all damage had to be considered as inflicted due to casus; Engelmann 1965, p. 209; - However, Engelmann suggests imagining the case in another way: Because people were playing in a square, it is obviously dangerous and reckless to shave there. When, however, no accident happened, and subsequently a horse passed by chance and hit the barber, who harmed his client because of that, the barber was considered to have inflicted the damage by casus. He was not liable, although he acted culpably (in choosing to shave in a square) and (although) the damage could also have resulted as a consequence of his carelessness.

111 Placentinus, one of the most important glossators of the 12th century, was a professor of Roman law at Bologna and Montpellier; on Placentinus, see, e.g., De Tourtoulon 1972.

112 In the paraphrase of D. 9.2.11pr. in the sixth volume of the Corpus Iuris of Daoyz (ludens pila..), it is stated that the ball-player was held liable under the lex Aquilia, unless the barber acted with culpa, which was the case if he shaved in a place where people usually played games or where there was intense traffic; in fact, the consuetudo is used to excuse someone (the thrower) from culpa; see a pre-Accursian gloss ad consuetudine in Ms. Paris BN, lat. 4461, fo. 101va: consuetudo uidetur hic aliquem excusare a culpa.

113 See also gloss ad imputatur in Mss. Leipzig, Univ. Bibl., 873, fo. 76v; Biblioteca Vaticana, vat. lat. 2511, fo. 76r: scilicet tonsori; - A pre-Accursian gloss explicitly stated that it was the barber or the thrower who acted culpably; see gloss ad eorum culpa sit with siglum az. in Ms. Paris BN, lat. 4461, fo. 101va; Troyes 135, fo. 95vb; München Clm 3887, fo. 92r; Leipzig, Univ. Bibl., 873, fo. 76v: uel tonsoris uel pilla deiacentis sensus culpa est. (last three words only in Ms. Leipzig, but there without siglum); - Later, Accursius, in the Glossa Ordinaria, more generally stated that whoever acted culpably was liable under the lex Aquilia, gloss teneri ad D. 9.2.11pr. Apart from this statement, which is more explanatory than pioneering, Accursius does not seem to add anything new.

114 Gloss ad D. 9.2.11pr. with siglum p. (Placentinus) in Ms. Stockholm KB, B 680, fo. 101va: Quid dicem de eo qui deiecit pilam dolo vel culpa certe tenebitur et quod dicitur de se queri debere hoc quantum ad tonsorem intelligatur and (anonymous) gloss ad D. 9.2.11pr. in Ms. München Clm 3887, fo. 92ra: Aliud dicemus de eo qui deiecit pilam dolo uel culpa. Certe tenebitur. Et quod dicetur 'de se queri debet', hic quantum ad tonsorem intelligatur. 
relation to the barber) had to be compensated (by the culpa of the barber). Possibly, and subsidiarily, the master of the slave had the possibility to bring an action against the deiector, ${ }^{115}$ as the contributory negligence did not regard this relation.

The view Placentinus held seems to have been partly followed by Azo, who stated that both the thrower and the barber could have committed the delict (of damnum iniuria datum) in a situation as described in D. 9.2.11pr. However, the injured party could only claim his damages from one of these persons. ${ }^{116}$ Azo seems to have given a different possible consequence to the contributory negligence of the slave. He argued that the barber was not liable, and perhaps neither the deiector or the percussor, unless the latter acted intentionally, ${ }^{117}$ because the person who entrusted himself ${ }^{118}$ to a barber who put his chair in such a dangerous place ${ }^{119}$ (i.e. where one customarily played or where there was a lot of crossing-over $)^{120}$ was responsible himself. ${ }^{121}$ In this way, Azo left open the possibility that the contributory negligence of the injured party was opposed to the negligence of the deiector or the percussor, and in that way cancelled out their liability.

A more restrictive interpretation was made by another (anonymous) Glossator who explicitly explained this final phrase of D. 9.2.11pr. in such a way that both acted negligently, firstly the barber, since he was shaving in a

115 Placentinus, Summa Codicis, III.35. Placentinus also makes a comparison with D. 9.2.52.1 (... culpa enim penes eum tantum residet qui prior flagello percusserat, sicut supra est penes eum qui in loco prohibito se tonsori commiserat). In the case of the shopkeeper, the culpa lay with the person who first struck with the whip, as in this case where a person entrusted himself to a barber at an forbidden place; - According to an anonymous gloss, the act of the barber excuses [the act of] the thrower; see Mss. Biblioteca Vaticana, vat. lat. 1408, fo. 106vb; Biblioteca Vaticana, Palat. Lat. 737, fo. 70ra; Trier SB, 838/1634, fo. 98vb and 99ra; (partly in) London BM, Royal 11.C. III, fo. 93ra; Stockholm KB, B 680, fo. 101va: Hic alterius factum alterum excusat, ut factum tonsoris lusorem. In pari causa potiorem esse causam defendentis. Differently, gloss de se queri debere ad D. 9.2.11pr. in Ms. Paris BN, lat. 4461, fo. 10lva: Si liber sit tonsor ab honere culpe exempto, cuius in prima pari causa poterior est conditio rei quam actoris, secundum I[rnerium]; also in Ms. München Clm 3887, fo. 92ra, where it is ascribed to Azo; from this gloss it can be concluded that the negligence of the barber was nullified by someone else's negligence (the negligence of the injured party).

116 See the allegation of Azo to D. 47.7.6pr., e.g., in Ms. Bamberg, Jur 11, fo. 115va and Stockholm KB, B 680, fo. 101va.

117 Apparently, an anonymous Glossator in Ms. Bibliotheca Apostolica Vaticana, vat. lat. 1406, fo. $80 \mathrm{v}$, used this text to make a more general remark: Nota hic dolo dolo (lege: dolus) compensatur, ut infra de compen. Si ambo [D. 16.2.10pr.] famosibus.

118 Gloss ad se quis ad D. 9.2.11pr. in Ms. Trier SB, 838/1634, fo. 99ra: scilicet sciens.

119 Gloss ad tondebat ad D. 9.2.11pr. in Ms. Trier SB, 838/1634, fo. 99ra: scilicet sciens.

120 See gloss ad in loco periculoso in Padova BU, 941, fo. 88va: distinctione supra dicta.

121 Azo, Summa Codicis, III.35.8; - In this respect, an allegation in Mss. Padova BU, 941, fo. 88 va/Bamberg, Jur. 12 , p. 188 , is especially relevant, namely, to D. 50.17.203. Also another allegation, found in several manuscripts, seems relevant, namely, D. 4.2.21pr. 
dangerous place, ${ }^{122}$ and secondly the slave entrusting himself to that barber. The negligence of both persons had to be compensated, and the (master of the) slave could not bring a claim against the barber. ${ }^{123}$ And it seems then that this became the prevailing view; unfortunately, no decisive decision was explicitly taken on the question of the relative or absolute influence of the contributory negligence of the injured party.

Based on the final phrase of D. 9.2.11pr. several (other) possibilities were provided as a basis for the way to deal with the problem of contributory negligence. The first solution is formulated by Irnerius, who stated that the defendant would not have acted culpably if the plaintiff himself had to be blamed. ${ }^{124}$ The conduct of the injured party is therefore not really considered as contributory negligence, but just taken into consideration when determining the culpability of the wrongdoer's act.

A second solution is that because the slave (or, better, his master) himself had to take the blame, he was considered guilty of his own delict. ${ }^{125}$ This is very interesting, since apparently one of the solutions to the problem of contributory negligence was to qualify the act of the injured party as a delict itself. Seemingly, the Glossators made a parallel here with the compensation theory: if it appears that the other party (the barber) also acted negligently and committed a delict, both delicts, i.e. both culpable acts, were compensated and the barber would not have to pay any compensation to the injured party. ${ }^{126}$

A third interpretation of the final phrase of D. 9.2.11pr. is written by Johannes Bassianus, who explained why the slave himself had to be blamed. ${ }^{127}$

122 Later, Odofredus argued that whether the barber (dominus barbitonsor) would be held liable under the actio legis Aquiliae depended on the question of whether he acted with culpa or dolus. The barber was not held liable unless he put his chair in an inappropriate place; see Odofredus, Lectura super Digesto veteri ad D. 9.2.9.4, fo. 273r. It is interesting that Odofredus explains the last sentence of D. 9.2.11pr. by referring to D. 50.17.203.

123 Gloss in Ms. Paris BN, lat. 4451, fo. 75ra: Immo melius quia uterque fuit in culpa, et qui se tonsori commiserit, et qui in loco pericoloso tonso <rauit $>$, unde culpa culpa compensatur, sic infra solu. ma. l. Viro [D. 24.3.39] et infra de compensa. Si ambo. [D. 16.2.10pr.]. No siglum is written after this gloss; however, considering the frequent glosses of Azo (Azo's Apparatus) and the fact that the glosses surrounding this gloss seem to have been written by the same scribent, it probably stems from Azo (or possibly his master Johannes Bassianus).

124 Irnerian gloss poterit ad D. 9.2.28.1 (edn. Besta 1896, p. 96): quasi reus in culpa non sit, cum petitor de ipso queri debeat; - A different view seems to come from a gloss (to the final sentences of D. 9.2.11pr.) in Ms. Torino BN, E.I.4, fo. 139v: scilicet rei nequaquam dampnum datum est, stating that in such a case there is just no damage to an object at all.

125 See gloss ad ipsum de se queri debere in Ms. Bibliotheca Apostolica Vaticana, vat. lat. 1406, fo. 80v: scilicet teneatur.

126 See gloss ad quis nec illud male dicatur in Ms. Padova BU, 941, fo. 88v: ergo tonsor non tenebitur reparare.

127 See also Summa Vindobonensis, IV.3 in which it is stated that no action could be brought against the other person based on the lex Aquilia if someone entrusted himself to a 
If the slave (consciously) exposed himself to danger, as seems to have been the case in D. 9.2.11pr., this was imputed to him. ${ }^{128}$ However, the act would not be imputed to the slave if the dangerous situation could not have possibly been known to him, i.e. if he was blind or a stranger (peregrinus). In the case of D. 9.2.11pr., the barber was liable in the event that he shaved a blind person. Accordingly, his negligence was not overlooked, and the owner of the slave retained a claim. However, the barber's negligence had no consequences when a slave was aware of the danger of the situation. ${ }^{129}$ It is not clear whether the negligence of the 'conscious' slave was more serious than the barber's because the gloss does not (explicitly) answer this question. ${ }^{130}$ At last the acceptance of risk found its way into the Glossa Ordinaria of Accursius, who stated that an act was imputed to the injured party who put himself in a dangerous situation (as in this case and in D. 13.6.23). ${ }^{131}$

barber who put his chair in such a dangerous spot; - According to Rasi 1968, p. 763, the customer who asked to be shaved near a playing field is an example of an injured party who indicates his willingness to assume risks in a particular situation (and in such a case he could not claim damage from someone else). Of course, this was different if the wrongdoer did not act with culpa, but with dolus, sc. the intention to harm, taking advantage of the particular situation. See, e.g., Azo, Summa Codicis, III.35.8; - According to Rasi 1968, p. 764, even though the Glossators did not discuss this matter in particular in the cases of the tree pruner (D. 9.2.31), of the participants in the ball game and of the tonsor, it seems that the risk taken by the injured party excluded liability of the wrongdoer.

128 Azo did not generalise the exclusion of liability of the barber; see Azo, Summa Codicis, III.35.8; - This is subsequently assumed by Accursius, who also continues with the risk criterion for persons who put themselves in danger; see Schipani 1969, p. 421; - Interesting also is an (anonymous) interlinear gloss ad de se queri debere in Ms. Biblioteca Vaticana, vat. lat. 2511, fo. $76 \mathrm{v}$ : debuit in tonsore debet premonere ne ibi sedere.

129 According to Rasi 1968, p. 764f., when the injured party contributed to the damage or provoked the damage by his own action or omission, the responsibility of the wrongdoer was diminished or even eliminated. The error (of the wrongdoer) or the infirmity had no legal relevancy since the culpa had to be identified precisely in the error and in the infirmity, unless a fortuitous case or a case of force majeure was encountered.

130 See the gloss queri debere ad D. 9.2.11pr.; according to Luig 1969, p. 200, based on the context this can, however, be answered positively.

131 Accursian gloss queri debere ad D. 9.2.11pr.: Cum ipse hoc sciuit, non ita si ignorauit, caecus forte uel peregrinus. Io[annes Bassianus] notat etiam hic quod imputatur ei, qui se posuit in periculum, ut infra commoda lege fi. [D. 13.6.23]. This gloss continues in Ms. Biblioteca Vaticana, Ottobon. lat. 1605, fo. 124va (with a reference sign): item no[ta] quod culpa cum culpa compensatur, ut infra de compensa. Si ambo [D. 16.2.10pr.]; - According to Rasi 1968, p. 764 nt. 107, there could be no doubt that there would have been uncertainties about this in practice, given the inequality of the cases, even in the case submitted to the domini bononienses; see Quaestiones dominorum bononiensium (collectio gratianopolitana) XCIII (p. 226): Quidam bos perterritus, currens in nocte per uiam, interfectus est a Martino putante feram bestiam esse; modo dominus bouis agit aduersus Martinum lege Aquilia de boue interfecto; ille uero uult se tueri, quia putauit feram bestiam esse. Queritur si possit. The domini did not solve the problem. Only the question was put forward; the answer was missing. Apparently, this means it concerned a case for which there was no easy resolution. 


\section{The view of the Commentators}

Baldus made a short remark, namely, that someone should not perform his occupation at a random place, but at a proper place. ${ }^{132}$ Florianus de Sancto Petro explained why the barber was liable. He argued that although the barber was not at fault for the resulting delict (the killing of the slave), the fact that he practised his craft at such a dangerous place did result in an act of negligence (as stated above, culpa can establish itself in a negligent preceding act). He ought not to have employed his activities anywhere, but just at a suitable and proper place. The situation would change if he had informed his customer of the danger of the place. If a slave 'knowingly' entrusted himself to a barber who shaved at such a dangerous place, the act must be imputed to himself. ${ }^{133}$ Accordingly, the victim himself had to be blamed. According to Raphael Fulgosius (1367-1427), ${ }^{134}$ the barber in D. 9.2.11pr. would not, however, be released from liability if the person to be shaved was blind ${ }^{135}$ or if the victim was a stranger (or a forensis), because it was not presumed that a stranger would know the local customs or rules. ${ }^{136}$ Fulgosius generally formulates that the person who culpably (culpa) inflicted damage on someone was to be held liable, unless an act of the equally culpable (culpa) injured party occurred. ${ }^{137}$ Liability would still be established if the wrongdoer acted with dolus and the injured party with culpa, or when both parties coincidentally acted culpably (culpa), and the culpability of the act of one party was more serious than the culpability

132 Baldus, Commentaria, ad D. 9.2.11pr. See also Zwalve 2008, p. 19. One has to remark, as is written in the edition of 1577, that strangers could not know the customs of a place: Peregrini, et aduene possunt ignorare consuetudines locorum (in italics under nr. 1).

133 Florianus de Sancto Petro, Super nono libro Digesti veteris, ad D. 9.2.11pr.

134 Raphael Fulgosius was a commentator who studied under Bartolomaeus de Saliceto, in Bologna, and Castellioneus. He became a professor in Pavia, Piacenza and Padua.

135 R. Fulgosius, In primam Pandectarum partem commentariorum, I, ad D. 9.2.11pr. Fulgosius argued that also the thrower would be liable when acting with culpa, with an actio in factum (with reference to D. 9.2.7.3). Although it is not clear, it seems to me that this is just a remark without any link with the contributory negligence of the injured party.

136 See also Florianus de Sancto Petro, Super nono libro Digesti veteris, ad D. 9.2.11pr.

137 In such an event, the barber was not liable when the slave acted with culpa, because the culpa (of the barber) would have been compensated; see Paulus Castrensis, Auenionicae Praelectiones in Digestum Vetus, ad D. 9.2.11pr.: Pro seruo meo occiso facto plurium ille tenetur, qui reperitur in culpa, nisi esset ipse seruus in culpa fuerit quia tunc culpa compensatur. ... Zwalves' remark (Zwalve 2008, p. 19) that Paulus de Castro's commentary on the Digest lacks a commentary on the title of the lex Aquilia is, in this sense, not correct since this commentary occurs in Paulus de Castro's Auenionicae Praelectiones; Albericus de Rosate's view in his Commentarii in primam Digesti veteris partem, ad D. 9.2.11pr. is not clear to me. According to Albericus de Rosate, the person who acted culpably in the game (the ball-player), or who made a bad choice in choosing a dangerous place to put his chair (the barber), is liable on the ground of the lex Aquilia; and it is imputed to the person who knowingly put himself in danger (the slave). It seems that he could not decide who was liable, and that he did not exactly know what the result of the slave's action was. Zwalve 2008, p. 19, pointed out that there are three possibilities, depending on the answer to the question of who of the three was negligent (the player, the barber or the customer himself). 
of the act of the other party. It seems as though Fulgosius regarded dolus as a more serious form of culpa; in that way one has to regard his remark that liability would still be established if the culpability of the wrongdoer was more serious than the culpability of the injured party: the first is dolus, the latter is culpa. Consequently, no maior culpa doctrine is applied here (this doctrine will be discussed in the next chapter). ${ }^{138}$

\subsubsection{The case of the shopkeeper}

\section{Glossators}

\section{Introduction}

It is generally accepted that according to medieval scholarship there are cases in which inflicted damage seems to be unlawful, but in fact is not and for that reason does not lead to liability. One such case, in which a wrongdoer is not liable, is if the act was committed in self-defence, provided there was no excess of defence ${ }^{139}$ or deliberate intention (dolus). ${ }^{140}$ The case of the shopkeeper, the facts of which are described in the previous chapter, could be an example of such an action in self-defence. To review the case in brief: a shopkeeper's lantern ${ }^{141}$ was taken away by a passer-by ${ }^{142}$ at night; ${ }^{143}$ the shopkeeper ran after him, ${ }^{144}$ and the passer-by started to beat the shopkeeper with a whip, which led to a brawl during which the shopkeeper knocked out an eye of the man who had taken the lantern. It is interesting that the Glossators considered this case as a contemporary problem and resituated it in their time: e.g. Odofredus

138 Fulgosius refers to D. 9.2.9.4.

139 See Rasi 1968, p. 759f., and the literature quoted. A different situation occurs in the event of excess of defence. See also Pope Innocentius III in X 2.13.12, according to whom satisfactio has to be done if the normal measure of defence is exceeded.

140 See Rasi 1968 , p. $757 f f$.

141 Placed on a stone alongside a path; later, Accursius added a short gloss; see gloss tabernarius ad D. 9.2.52.1: in semita id est in uia. It could also be that it was placed in the middle of the path; see the (anonymous) gloss ad in semita in Ms. Biblioteca Vaticana, Barb. lat. 1459, fo. 101ra: id est uel media. According to another gloss, the stone was placed at a public place; see gloss ad D. 9.2.52.1 in Ms. Torino BN, E.I.4, fo. 144v: id est in loco publico.

142 An extraneus, according to gloss ad quidam in Ms. Biblioteca Vaticana, vat. lat. 1405, fo. 80v; legally qualified as a thief (fur) or a robber (raptor) by Placentinus; see gloss with siglum p. ad sustulerat in Ms. Stockholm KB, B 680, fo. 105va: Expone immo: fur uel raptor; later, Odofredus qualified the passer-by as a fool (quidam fatuus); see Lectura super Digesto veteri ad D. 9.2.52.1; - It was indeed the taking away of the lantern that gave the occasion to this case; see gloss with siglum p. ad D. 9.2.52.1 in Ms. Stockholm KB, B 680, fo. 105va: Immo fuisset lucerne qui occasionem dedit huic rei, ut supra e. Itaque. [D. 9.2.4pr.].

143 See also gloss ad noctu in Mss. Biblioteca Vaticana, vat. lat. 2511, fo. 79v; Biblioteca Vaticana, vat. lat. 1405, fo. 80v; Torino BN, E.I.4, fo. 144v: id est de nocte.

144 The thief tried to run away; see also gloss ad fugientem with siglum az. in Ms. Paris BN, lat. 4451, fo. $77 \mathrm{v}$ : id est fugere volet fur. 
referred to the shopkeeper as a tabernarius parisius (a shopkeeper from Paris). ${ }^{145}$ D. 9.2.52.1 states that if the shopkeeper did not attack the passer-by intentionally, he was not considered to have caused the damage unlawfully (iniuria), since whoever struck first with the whip carried the blame (culpa). ${ }^{146}$ However, in the event that the shopkeeper had not been hit $^{147}$ first by the passer-by, ${ }^{148}$ but started the brawl in order to get the lantern back, it seems that the damage was considered to have been inflicted as a result of the culpa of the shopkeeper.

Several Glossators dealt with this case. Some argued that to cause damage with iniuria means doing so without justification (nullo iure). If damage was inflicted culpably, the lex Aquilia was applicable, unless the act was excusable because it was performed lawfully (iure). ${ }^{149}$ Such a lawful act occurred when one acted to protect one's own body. ${ }^{150} \mathrm{In}$ D. 9.2.4pr., it is stated that if someone kills another who is lying in ambush to kill him, he will not be held by the lex Aquilia, as natural reason permits him to defend himself against danger. The same view is held by the Glossators, already by a gloss ascribed to Irnerius, in which it is stated that the person in question was excused and the killing was considered to be lawful. ${ }^{151}$

A different approach, without reference to the term iniuria, is taken by the author of Lo Codi: if damage was inflicted without the negligence (culpa) of the wrongdoer, it did not have to be compensated. So when someone in defending himself inflicted damage on someone else, the wrongdoer did not have to compensate the damage because every person was free to defend his own body. ${ }^{152}$

\section{Several requirements}

With regard to the problem of self-defence in the tradition of the ius commune,

145 See Odofredus, Lectura super Digesto veteri, ad D. 9.2.52.1, fo. 277r and also later (the commentator) Florianus de Sancto Petro, Super nono libro Digestiveteris, ad D. 9.2.52.1.

146 In Ms. Biblioteca Vaticana, Palat. Lat. 737, fo. 73vb a gloss ad D. 9.2.52.1 states: Nota culpam eius esse qui prior uapulasset (Note that the culpa is of the person who hit (the other) first).

147 See also gloss uapulasset with siglum az. ad D. 9.2.52.1 in Mss. Paris BN, lat. 4461, fo. $105 \mathrm{vb}$ (without siglum); London BM, Royal 11.C. III, fo. 96vb; Biblioteca Vaticana, Barb. lat. 1459, fo. 101r; Biblioteca Vaticana, vat. lat. 1405, fo. 80v; Biblioteca Vaticana, vat. lat. 2511, fo. $79 \mathrm{v}$ (with siglum ac.); Biblioteca Vaticana, Borgh. 225, fo. 91rb; Ms. Torino BN, E.I.4, fo. 144va (with siglum ac.); Bamberg, Jur 11, fo. 120ra; München Clm 3887, fo. 96ra; Stockholm KB, B 680, fo. 105va: id est uerberatus esset.

148 Gloss ab eo non prior uapulasset with siglum h. (Hugolinus) in Ms. Paris BN, lat. 4461, fo. 105vb: qui sustulerat lucernam.

149 Rogerius, Summa Codicis, III. XXIV.1; - On Rogerius, see (also) Kantorowicz \& Buckland 1969, p. 122ff.

150 See Summa Vindobonensis, IV.3; Rogerius, Summa Codicis, III. XXIV.1.

151 Gloss igitur iniuria ad D. 9.2.5 in Besta 1896, p. 94: ... iure facis, ut insidiantem occidendo ...

152 See Lo Codi, III.31.7. 
three requirements for a successful defence ${ }^{153}$ are distinguished: ${ }^{154}$ the purpose had to be defence, not vengeance and as a consequence, no other way of defence was allowed (the requirement of necessity); ${ }^{155}$ the defence had to be an immediate reaction upon a direct attack (not after a period of time); and, finally, the person defending himself must not exceed the limits of necessary defence. ${ }^{156}$ If these requirements were fulfilled, the wrongdoer was not liable and no culpa was attributed to the wrongdoer. These requirements will be discussed in the course of this chapter.

If someone's property was stolen, the owner was not allowed to hit the thief. This was already stated in the case of the shopkeeper (D. 9.2.52.1), since the shopkeeper would have acted with culpa if he had hit the thief first (and in doing so provoked a brawl) and this was the case if the thief did not mean to hit the shopkeeper and did not approach the shopkeeper. One could argue that it should have been permitted to kill the thief as it was night. However, an anonymous gloss - by means of a fiction - argued that this is not the case: because the thief was carrying the lantern one must assume that it was daytime. So the rule that one was allowed to kill a thief at night, even when he defended himself with a weapon, did not apply here. This rule did not apply in daylight, but only at night; if there was lighting at night, one has to pretend that it was daytime. ${ }^{157}$

Although it would be permitted for the shopkeeper to kill a thief who approached him with a weapen (the fear of weapons is sufficient), it is not permitted when he could have seized him but rather preferred to kill him. In that case, if the attacker (i.e. thief) was seized and killed, ${ }^{158}$ the killing was

153 See already D. 43.16 .1 .27 (vim vi repellere licere) and D. 4.2.12.4 (nam cum liceat ... vim vi repellere). The familiar form (vim vi repellere licet) - as a summary of different statements - was probably only formulated in the Middle Ages; see Diósdi 1963, p. 187.

154 See Jansen 2004, p. 122 f.

155 See already D. 9.2.45.4: Qui, cum aliter tueri non possent, damni culpa dederint, innoxii sunt: vim enim vi defendere omniaque iura permittunt.

156 A legitimate action in self-defence was also allowed between animals; see Petrus, Exceptiones legum romanorum, III, cap. 50; Odofredus, Lectura super Digesto veteri ad D. 9.1.1.11, fo. 276v; Rasi 1968, p. 759; on the basis of self-defence, and the application in Roman law, ius commune and the early modern period, see, e.g., Jansen 2004, p. 121ff., and the literature mentioned there, and also esp. for the last requirement, see Massetto 1958, p. 1128.

157 Gloss ad D. 9.2.52.1 with siglum az. in Ms. Biblioteca Vaticana, vat. lat. 2511, fo. 79va: Ex hoc uerbo dicunt quidam quod non debeo aliquem percutere, nisi primo ipse me percutiat, quia data opera facit, quod falsum est. Et quod dicitur tabernarium esse in culpa si primo percussit, dico uerum esse, ubi ille qui lucernam sustulerat nolebat eum percutere, nec ad hoc uenerat, scilicet potius cum lucerna fugiebat. Set numquid non licet furem nocturnum occidere, et si non se defendat telo, cum non possum aliter periculum rerum mearum euitare? Resp. Hic habetur pro diurno propter lucernam quam portabat.

158 An elucidation is added by Azo; see gloss ad eripere/rixatus esset with siglum az. ad D. 9.2.52.1 in Mss. Leipzig 877, fo. 100rb; München Clm 3887, fo. 96r; Troyes 135, fo. 99v; Biblioteca 
considered unlawful and the killer (i.e. the shopkeeper) was held liable. ${ }^{159}$ The attack (of the shopkeeper) had to be in defence, not to take vengeance, which would be the case when the shopkeeper ran after his attacker in order to prevent his taking away the lantern; if the shopkeeper plucked out an eye of the thief with his finger before he was hit, the blame was on him. ${ }^{160}$

The situation changes slightly if the owner of the object was first hit with an object by the thief, as in D. 9.2.52.1 (namely, by a blow with the whip), because in that case the owner was allowed to strike the thief. ${ }^{161}$ The Glossators argued that the shopkeeper clearly acted in defence, and that the act of knocking out an eye was not done in vengeance (if the latter was the case, the shopkeeper was liable). It is presumed that the shopkeeper acted in self-defence (and not in vengeance) because he performed the act (of knocking out an eye) immediately after the attack. He did this in order to prevent the attacker from further attacking him. The legal presumption was that when the act was done immediately after the attack, it was done in self-defense (rather than in vengeance). ${ }^{162}$ In addition to this, in C. 8.4.1, the possessor who lawfully possesses is allowed to use a moderate degree of force to repel any attack of violence exerted against him for the purpose of depriving him of his possession. ${ }^{163}$

Vaticana, vat. lat. 1408, fo. 11lr: si quoque ei occulum effodisset.

159 As in D. 9.2.4.1, D. 9.2.5pr. and D. 9.2.52.1; see Azo, Summa Codicis, III.35.5.

160 Gloss data opera (reconstructed) with siglum az. in Mss. München 3887, fo. 96ra; Padova BU, fo. 88r; Troyes 135, fo. 99v; Paris BN, lat. 4461, fo. 105vb; Biblioteca Vaticana, vat. lat. 1408, fo. 11lr; Biblioteca Vaticana, vat. lat. 2511, fo. 79v; Stockholm KB, B 680, fo. 105va: Si defendendi non etiam ulciscendi causa hoc factum sit; the gloss continues (in a different hand) in Ms. Paris BN, lat. 4461, fo. 105rb: sicut istud debet intelli<gi> cum semper audeatur data opera facere, puta cum uere post eum ut ille impediretur et lumine exeret ad equauisse ei et cum digito sibi deberi effodit cum ipse non esset percussus set causam mali dedisse uidetur.

161 See gloss ad D. 9.2.52.1 in Ms. Stockholm KB, B 680, fo. 105va (see n. 164 below).

162 See also D. 9.1.1.11. In the study of manuscripts this text, as well as C. 9.12.6, is often mentioned; sometimes reference is made to D. 9.2.9pr. and D. 9.2.45.4; - See gloss nisi data opera with siglum az. ad D. 9.2.52.1 in Mss. Paris BN, lat 4459, fo. 94rb; London BM, Royal 11.C. III, fo. 96vb; Paris BN, lat. 4451, fo. 77vb; Bamberg, Jur 1, fo. 120ra (no lemma found); Biblioteca Vaticana, vat. lat. 1405, fo. 80vb (no lemma found); Biblioteca Vaticana, Borgh. 225, fo. 91rb (no lemma found); Stockholm KB, B 680, fo. 105va; München Clm 3887, fo. 96ra; Ms. Biblioteca Vaticana, vat. lat. 1408, fo. 111ra: ad casum prepositum restringuitur responsio, secundum Jo[annem] $B[$ assianum $]$. Non enim quia quis faciat incontinenti uidetur facere ad uindictam hoc ipso. Scilicet quia si facit incontinenti uidetur quod ideo faciat ne aggressor iterum insurgat in eum; see also the addition in Ms. München Clm 3887, fo. 96ra: et sic [ex] quo incontinenti praesumitur defensionem item contra probare; gloss penes with siglum az. in Ms. Biblioteca Vaticana, Borgh. 225, fo. 91rb: Liquet ergo quod ad tutelam sui corporis fecerat non ad uindictam, alioquin teneretur. Sumetur tamen et actio, arg. ex hoc loco, quia, si incontinenti facit quis, presumitur facere ad defensionem. Vnde et si faciat incontinenti, ad uindictam dicetur non teneri quis iuris presumptione. Semper uideatur ad defensionem facere, potius quam ad uindictam.

163 Accursian gloss nisi data ad hoc opera ad D. 9.2.52.1: id est uindictam: et sic ex quo incontinenti fecit presumitur quod ad sui defensionem fecerit ut agressor interim eum non inuadat 
It was permissible to take back the object, provided that this was done immediately after the theft. This requirement of immediacy seems to be accepted in various glosses. ${ }^{164}$ Also, when someone attacked another with a weapon (in this case the thief who started to hit the shopkeeper with a whip), ${ }^{165}$ it was permissible to resist, using weapons (it was permitted to repel violence with violence), ${ }^{166}$ provided action was taken immediately and not after some time had elapsed, as stated in D. 43.16.3.9. ${ }^{167}$

The situation, however, can be somewhat more complicated. When someone, not a thief, was approached by a person holding a sword, but not yet striking, ${ }^{168}$ and he killed this person, he would not be considered to have killed unlawfully, because someone who killed his attacker under fear of weapons (i.e. of death) would not be liable. ${ }^{169}$ The fear of approaching weapons was sufficient to justify the use of violence. ${ }^{170}$ However, if one threw a stone in defence and this stone did not hit the attacker but a passer-by, the thrower

nisi contra probetur ut hic supra si quadrupes pauperiem fecisse dicatur lex $i$ \& Cum arietes [D. 9.1.1.11], secundum quosdam. Et sic post contra probari: ut hic secundum Joannem, licet quidem contra. Et adde quod notatur C. unde ui lege prima [C. 8.4.1]. After a slightly different version of this gloss, in Ms. Biblioteca Vaticana, Barb. lat. 1459, fo. 101rb, an addition follows by a different hand with siglum cy. (Cyprianus): dic ut per glossam etc.

164 Gloss ad D. 9.2.52.1 in Ms. Stockholm KB, B 680, fo. 105va: Ex his sumitur intelligendum quod si alius tibi rem tuam auferret. Ideo eum percutere non debes, set in continenti auferre prioris nisi re primo percutiatur ita quod dolorem inferat ut hic de flagelli percutione dicit. Sic quod oculum effodisset.

165 According to Azo, the phrase 'in quo dolor inerat' had to be interpreted in such a way that the whip had to be considered the cause or instrument of the infliction of pain, i.e. that pain can be caused by this whip; see gloss dolor with siglum az. in Ms. Biblioteca Vaticana, Borgh. 225, fo. 91rb: Hoc est causa uel instrumentum inferendi doloris, id est quo flagello poterat dolor inferri; - The passer-by had a whip in his hand, something painful was enclosed in the whip, or more precisely: something painful in its effect (see gloss ad in quo dolor inerat in Bamberg, Jur. 11, fo. 120r: per effectum); Accursius added in a gloss that (it is said that) there is pain in a whip because it causes pain to others; see gloss inerat ad D. 9.2.52.1: nota quod dolor dicitur inesse flagello ex eo quod alii infert dolorem.; an (anonymous) gloss in Ms. Padova BU, 941, fo. 91v, clarifies that it would have been an instrument to cause pain: id est, aliquid quod erat instrumentum in causa doloris; see also gloss dolor with siglum az. in Ms. Paris BN, lat. 4451, fo. 75ra: Id est causa doloris uel: qui dolorem inferebat.; - According to Odofredus, Lectura super Digesto veteri ad D. 9.2.52.1, fo. 277r, however, it was a baculum (staff).

166 See Azo, Summa Codicis, III.35.3-4.

167 Accursian gloss rixatus esset ad D. 9.2.52.1: Et sic eum prius percusserit, collige ergo hec et ex superiori. Resp. arg. quod non debes aliquem percutere ad defendendum, nisi prius te feriat. Sed contra est, ut infra de ui et de ui armata l. iii § Eum igitur [D. 43.16.3.9], et hic sic euenit de facto.

168 Today this would be called a pre-emptive strike; see, e.g., Buruma 2003, p. $116 f$.

169 According to Odofredus, no poena had to be paid if someone acted to defend himself. All leges permit countering violence with violence; see Odofredus, Lectura super Digesto veteri ad D. 9.2.52.1, fo. 276v: ... [uideri] et ita uim ui repellere licet. Item habetis sufficit terror armorum accedit, supra eo. l. Scientiam § Qui cum aliter [D. 9.2.45.4]; see also D. 43.16.1.27 and D. 43.16.3.9.

170 See also the canonist Henricus de Segusio (Hostiensis), Summa. De damno dato. Quando locum habet hec actio, edn. 1537 (reprint 1962), fo. 266r. 
would be held liable. The reason is that the use of violence was only allowed against violence, just for defence purposes and not for revenge. ${ }^{171}$

A different question is whether the situation changed if an owner hit a thief intentionally. This situation seems to have been taken into account in the case of D. 9.2.52.1 and in the glosses on this text. If the shopkeeper inflicted the damage on the thief intentionally, ${ }^{172}$ he would obviously be held liable under the lex Aquilia. ${ }^{173}$ Some clarification is needed to really grasp this exception, and Azo provides the explanation: such an intentional act could be spoken of in the case where the shopkeeper intentionally tried to hit the passer-by (e.g. if he struck in order to knock out an eye). The shopkeeper also acted intentionally if it had been possible to take back the lantern without knocking out the eye of the thief. This argument seems to include a fiction: if the shopkeeper could have taken the lantern back without knocking out the eye, but nevertheless did so, his act is considered to be intentional. However, this was not the case if it had been impossible to spare the thief without danger to himself or to his belongings. ${ }^{174}$ Azo made a distinction in case of intention: such an intentional act is permissible in order to defend oneself, but not in order to take vengeance. ${ }^{175}$

A final remark made by Accursius is that it was not allowed to protect one's belongings by employing violence which exceeds a moderate intensity. ${ }^{176}$

171 Apart from the aforementioned commentary of Odofredus on D. 9.2.52.1, see also Odofredus, Lectura super Digesto veteri ad D. 9.2.3, fo. 272r, in which he states that it is permissible to kill someone who is ambushing you, because ratio naturalis permittit se defendere; - According to Rasi 1968, p. 759, see gloss uellet ad D. 9.2.52.1, the Glossators seem to be very generous in qualifying defence of the body as legitimate; they judged differently, i.e. more reservedly, in cases of protection of property.

172 The gloss (data opera) effodisset ad D. 9.2.52.1 in Mss. Paris BN, lat 4459, fo. 94rb; Biblioteca Vaticana, vat. lat. 1405, fo. 80v (without the final two words/siglum); Biblioteca Vaticana, vat. lat. 1408, fo. 111ra; Biblioteca Vaticana, Borgh. 225, fo. 91rb; London BM, Royal 11.C. III, fo. 96v; München Clm 3887, fo. 96ra; Stockholm KB, B 680, fo. 105va; Bamberg, Jur. 11, fo. 120ra adds: ad uindictam, secundum az[onem].

173 Placentinus explained that the shopkeeper did not have to kill the other or strike out an eye because of the fact that the other took the lantern; see Placentinus, Summa Codicis, III.35. See also gloss ad D. 9.2.52.1 in Ms. Stockholm KB, B 680, fo. 105va: Nonne potuit occidere iure minime licet fur, uel raptor etiam quia eum deprehendat. $p$ [lacentinus].

174 Gloss data opera with siglum az. in Ms. Paris BN, lat. 4451, fo. 77vb: § Hoc intelligas cum tabernarius potuit ab eo lucernam extraquere sine suum oculum effodisse [lege: effodendo]. Alius quando si non potuit ei parcere sine periculo sui et rerum suarum licuit eum interficere, ut supra e. l. Itaque § Lex [D. 9.2.4.1].

175 Gloss nisi data opera with siglum az. in Ms. Biblioteca Vaticana, Borgh. 225, fo. 91rb: Id est, nisi, cum uellet eum percutere, dedit operam, ut ita eum percuteret ut oculum erueret. Licet enim dare operam ut percuteret eum <causa $>$ defendendi, se non ulciscendi.

176 Accursian gloss uellet ad D. 9.2.52.1: ... per quod uides quod incipit tabernarius inquirere rixam. Ergo non licet ob tutelam rerum mearum inferre uim. Resp. hoc: quia non fuit cum moderamine. 
Protection of personal belongings using moderate violence was allowed. No culpa would be attributed to a person who acted as any normal person would in order to protect his own body or his personal belongings. ${ }^{177}$

\section{Commentators}

The Commentators took as starting point the Roman rule that if someone killed the person who provoked him, ${ }^{178}$ in self-defence or in trying to protect his belongings, the killing did not occurr with iniuria and there was no liability based on the lex Aquilia. ${ }^{179}$ Also, the Commentators were of the opinion that it would not be sufficient to argue that the wrongdoer hit his opponent because the latter started the fight (i.e. he was the attacker).$^{180}$ That was not sufficient to exclude liability; it was also required that the wrongdoer could not have possibly behaved in a different way, without the use of violence. ${ }^{181}$ Only in that case did he not act culpably (with culpa). ${ }^{182}$

According to Raphael Fulgosius, in a case of self-defence one did not have to wait until being hit, the fear of violence was sufficient. ${ }^{183}$ However, the person under attack should have no other possibility to avoid inflicting damage on the attacker. In the event a defensive attack was, nevertheless, necessary, it was not permissible to exceed a certain degree of force, because in that case the damage would always be inflicted unlawfully. ${ }^{184}$ In addition, Fulgosius argued that in the case of the shopkeeper, there even was no justified suspicion that the shopkeeper would be hit. The shopkeeper had no reason to suspect that the thief would hit him and the shopkeeper was not entitled to knock out the eye of the thief. ${ }^{185}$

177 See also Summa institutionum 'Iustiniani est in hoc opere' III.19-20.

178 The canonist Panormitanus is of a slightly different opinion and argued that if someone attacked another because of provocation, a mild punishment should follow: Nicolaus de Tudeschis (Panormitanus), Commentaria, ad X 2.25.8, nr. 17f.

179 See Corvinus, Digesta per aphorismos strictim explicata, edn. 1642, p. 169. Corvinus' work is an example of the special type of legal literature which was used until the 19th century and can be considered an additional tool to find the sedes materiae related to a certain topic.

180 Also interesting is Aristoteles, Ethica Nicomachea, V.8, stating that 'acts proceeding from anger are rightly judged not to be done of malice forethought; for it is not the man who acts in anger but he who enraged him that starts the mischief' (translation by Ross 1954, p. 127).

181 Bartolus, Commentaria, ad D. 9.2.45.4.

182 See also Baldus, Commentaria, ad D. 9.2.45.4.

183 See R. Fulgosius, In primam Pandectarum partem commentariorum, I, ad D. 9.2.52.1.

184 A. Corvinus, Digesta per aphorismos strictim explicata, edn. 1642, p. 170.

185 R. Fulgosius, In primam Pandectarum partem commentariorum, I, ad D. 9.2.52.1. 
A new relevant circumstance: the time of the theft

One of the related issues discussed by scholars of the school of Orléans was the question as to what extent a person was liable for the killing of a thief, and if it made a difference whether the thief acted at night or during the daytime. ${ }^{186} \mathrm{In}$ that respect, one has to keep in mind D. 9.2.4.1, which contained a paraphrase of the law of the Twelve Tables, the provision that one was permitted to kill a thief caught in the night, provided one gave evidence of the fact by shouting aloud; someone was only allowedto kill such a thief caught in the daytime if the latter defended himself with a weapon, though only if he provided a warning by shouting.

One of the jurists of the school of Orléans, Johannes Faber mentioned an interesting case in this perspective. While a man lay in bed with his wife he heard a thief on the roof of his house. In a clear and loud voice he shouted to his wife (so that the thief could hear him well), 'Wife, you want to know how to get as many coins as I have in this house. You know I have been a thief and I climbed on the roofs of houses at night. Then when the moon shone brightly, I said "Lord of fortune" and stepped upon the beam of light, and then I settled my hash and climbed up and down. ${ }^{187}$ The thief believed the story, waited until he thought the couple was asleep and then, following the story of the man, stepped through the window, and was killed. ${ }^{188}$ Was such a deception permitted? Comparing D. 9.2.4.1, it was permissible to kill the thief at night. And therefore it was much more strongly permissible to trick him. But the man should have cried out at the moment he heard the thief fall down, as you also have to make an outcry in the event of killing.

On the other hand, and here Johannes Faber referred to D. 9.2.11pr., the thief had no obligation to believe (the story of) the man. Apparently, Faber envisaged a similarity between the last part of D. 9.2.11pr. and this case. In the case of the barber, the fragment ends with the remark that one could say that the slave who entrusted himself to a barber who put his chair in such a dangerous place ought to be blamed himself. In this case, one could say that a thief who entrusted himself to such a silly story also had to be blamed himself. ${ }^{189}$

186 See, e.g., Petrus de Bellapertica (ca. 1250-1308) in his Lectura Institutionum, edn. 1536, p. 303f.; see also J. Faber, Commentarii in quatuor Institutionum libros, edn. 1557, fo. 110v/111r.

187 J. Faber, Commentarii in quatuor Institutionum libros, edn. 1557, fo. 111r.

188 ibid.

189 ibid. 
A central place in the theory of self-defence was taken by C. 8.4.1, which contains the crucial words inculpatae tutelae moderatio. ${ }^{190}$ Various Commentators argued that self-defence had to be a necessary defence that happens with moderamine inculpatae tutelae. ${ }^{191}$ For a successful appeal for self-defence there were three restrictive requirements made by the commentators Bartolus and Baldus: circa causam (the motive has to be defence, not vengeance), circa tempus (immediate repulsion of a violent attack) and circa modum (the way in which someone defends himself has to be moderate).$^{192}$

With regard to the case of D. 9.2.52.1, the Commentators wondered whether it could be considered self-defence when someone hits his attacker immediately upon the attack. They gave an affirmative answer, because in this case it was presumed that the person attacked reacts in order to prevent another attack. ${ }^{193}$ Besides, the person who initiates an attack on another was always considered to have acted culpably. ${ }^{194}$

When someone under attack wounded the attacker before being hit, he was considered to have acted in self-defence. After someone was hit, it was not permissible to strike the attacker, because that would be considered revenge rather than self-defence. A blow already given can no longer be prevented, unless the attacked person coincidentally inflicted a blow and by that blow prevented further blows from his attacker. Later, in a reply to a problem of (daily) practice, a so-called consilium, the sixteenth-century Italian jurist Aymon Cravetta (1504-1569) ${ }^{195}$ argued that if the attacker ran away immediately after he hit the other person, and the injured person wounded his attacker nonetheless, this act would be considered to have been done out of vengeance. It would be different if the attacker did not run away and the injured person expected to be hit again. In conclusion, only in the case where the attacker did not immediately run away would such an act be seen as an act of self-defence. ${ }^{196}$

190 On the requirement of moderamen inculpatae tutelae in Italian criminal law of the 14th century, see Dahm 1931, p. 125ff.

191 See, e.g., A. Gandinus, Tractatus de maleficiis, De defensionibus a reis faciendis, §8 (edn. Kantorowicz 1926, p. 180); Bonifacius de Vitalinis, Tractatus de maleficiis, Qui alium possit offendere, nr. 2 (edn. 1598, fo. 375r); Cinus, Commentaria, ad D. 1.1.3, nr. 1 (edn. 1547, fo. 2v); Alberricus de Rosate, Commentarii in primam Digestiveteris partem, ad D. 9.2.45, 4, nr. 2; Baldus, Consilia, II, cons. 237, nr. 2 (edn. 1575, fo. 67v/68r); Dahm 1931, p. 125; Schmitt-Lermann 1935, p. 23; Wacke 1989, p. 480.

192 Wacke 1989, p. 481; Jansen 2004, p. 122ff.; see also Dahm 1931, p. 126; Schmitt-Lermann 1935 , p. 24.

193 See, e.g., Albericus de Rosate, Commentarii in primam Digestiveteris partem, ad D. 9.2.52.1.

194 Baldus, Commentaria, ad D. 9.2.52.1; see also Baldus, Commentaria, ad D. 9.2.52, and also R. Fulgosius, In primam Pandectarum partem commentariorum, I, ad D. 9.2.52.1: In glos [sa] uellet, ibi $[$ dem $]$ rixam, not $[$ a $]$ quod in dubio presumitur culpa ex parte eius qui rixam inciperet. ...

195 Aymon Cravetta was a celebrated professor of law at several Italian schools.

196 A. Cravetta, Consilia sive responsa, cons. 119, nr. 8 (edn. 1611, p. 214). 
A comparison with the case of D. 9.1.1.11

In case of doubt, when it was not clear who struck first, according to Bartolus, it was presumed that the culpa lay with the person who first provoked the incident. ${ }^{197}$ In that respect, the text of D. 9.1.1.11 as well as the commentaries on this text are relevant. In the case of D. 9.1.1.11, two rams or two bulls fought, and during the fight (rixa) one animal killed the other. Can the owner of the dead animal bring an action? Quintus Mucius argued that an action could not be brought if the aggressor was killed, but if the dead animal was not guilty of provocation, an action could be brought. According to Baldus, the dead animal had not acted in provocation but was attacked, and therefore it was presumed that it had acted in self-defence. This defence is permitted by natural law. ${ }^{198}$

But what if it was not clear which animal or person was attacked? The gloss sibi to D. 9.1.1.11 states that in such a case both had to be exculpated. ${ }^{199}$ This gloss refers to D. 9.2.45.3 concerning the case of two slaves leaping over burning straw. If they collide with one another, and both fall and one is burned to death, no action can be brought when it is not known which of them was overthrown by the other. Therefore, whenever it was not clear which person attacked first, the survivor would not be punished, presuming the one killed attacked first (unless depending on the character of the deceased the contrary was proven by the testimony of character witnesses). When someone committed a delict, an offence (offensa) was always presumed (namely, starting a fight), unless the wrongdoer could prove otherwise (i.e. that he had acted in self-defence). This also applied when two people were fighting in a forest and one of them got killed. In case of doubt, both would be held liable instead of being acquitted. ${ }^{200}$

197 Bartolus, Commentaria, ad D. 9.2.52.1.

198 Baldus, Commentaria, ad D. 9.1.1.11.

199 Gloss sibi ad D. 9.1.1.11, with reference to D. 9.2.45.3; this would be the case, according to Richardus Malumbra, when both were killed (see Albericus de Rosate, Commentarii in primam Digesti veteris partem, ad D. 9.1.1.11). Unfortunately, there is little left of the writings of Richardus Malumbra. Only by means of the works of other medieval civilians have we some information about him. We do know that he wrote additions to the Gloss. Albericus de Rosate, in his Commentarii, would have cited him literally; see Meijers 1920/1921, p. 491; Lange \& Kriechbaum 2007, p. 601f.

200 Baldus, Commentaria, ad D. 9.1.1.11; on this topic also Albericus de Rosate, Commentarii in primam Digesti veteris partem, ad D. 9.1.1.11; - In Bartolus' and Albericus' commentaries on D. 9.1.1.11, they describe a case of two persons who made peace but later would still hit each other. Would one of them then be liable for a breach of the peace? If it was not clear who hit first, neither of them would be. But if one of them started to break the peace, and the other after that, the former was liable. See Bartolus, Commentaria, ad D. 9.1.1.11 and Albericus de Rosate, Commentarii in primam Digesti veteris partem, ad D. 9.1.1.11; see also Paulus Castrensis, Auenionicae Praelectiones in Digestum Vetus, ad D. 9.1.1.11: Item alleg [atur] quod se ipsum uidetur interficere, qui dat causam ut ab altero interficiatur.... (Someone who gives the reason (causa) for which he is killed by someone else, is considered to be responsible for his own death.) 


\subsubsection{Starting point 2: the rule of D. 50.17.203}

According to the rule of D. 50.17.203, someone who suffered damage as a result of his own negligence is not considered to have suffered any damage. It is not until the time of Bulgarus $(\dagger 1166)^{201}$ that the last title of the Digest, 50.17. de diversis regulis iuris, was studied systematically. ${ }^{202}$ Bulgarus discussed D. 50.17.203 in his apparatus to the title de regulis iuris. ${ }^{203}$ He tried to interpret the meaning of this text by providing an example of a case in which this rule is applied. ${ }^{204}$ In my study, I found this text D. 17.2.52.18 in most commentaries on D. 50.17.203 as an example of the content of the rule of D. 50.17.203.

The text on D. 17.2.52.18 concerns a partner in all goods (socius omnium bonorum) against whom a judgment was rendered for having insulted someone (so it was an actio iniuriarum). The question was whether the partner, after having paid the poena, could claim payment back from the community. The answer provided in D. 17.2.52.18 is that if the partner had been unjustly condemned, he would be entitled to recourse. However, if the injury resulted from some illegal act he had committed, he had to bear the entire loss. This coincides with what Aufidius states was the opinion held by Servius: in the case of two general partners, against one of whom a judgment was rendered for not having appeared in court, the latter could not recover the amount of the judgment from the community; but if the partner appeared and suffered an unjust decision, he had to be reimbursed by the community.

Suppose one of the partners stole an object (for example, a horse), and brought it into the community. Then, that partner was sued and had to return the object. Furthermore, he had to pay a fine. Could he claim this from his associate? According to Bulgarus (and Bertram of Metz (1180-1212 $\left.{ }^{205}\right)$ ), one has to make a distinction: did the other partner know about the furtum or not? If the associate was unaware of the theft, the partner could only claim the whole value of the stolen object, but not the poena. ${ }^{206}$ The last part seems

201 The glossator Bulgarus was one of the Quattuor Doctores, the most important pupils of Imerius', the founder of the Bolognese school of law. On Bulgarus, see (also) Kantorowicz \& Buckland 1969 , p. $68 \mathrm{ff}$.

202 Stein 1968, p. 699.

203 Bulgarus, De Diversis regulis iuris antiqui commentarius, ad D. 50.17.203 (edn. Beckhaus, p. 154).

204 More or less the same example was used by Bertrandus Metensis at a later date; see Bertrandus Metensis, De regulis iuris, ad D. 50.17 .203 (edn. Caprioli, 198, p. 211).

205 See on Bertram (Berthold), bishop of Metz, e.g., Ewig 1955, p. 168, with references, and on Betram of Metz and his apparatus on the regulae iuris, see Kuttner 1957, p. 501ff.

206 According to Bulgarus, if it was the partner's own culpa, the blame was his and he had no possibility to claim the poena. The same could be said about a creditor who lost a trial against the debtor through his own negligence, as in D. 46.3.95.11. Such a creditor could obtain nothing from the mandator by the actio mandati, because he himself was to blame for not having been able to assign his rights of action to the mandator; see Beckhaus 1967, p. 154 (explicatio; added in the editio Augustiniana (edn. Antonius Augustinus of 1766)). 
to refer to the situation mentioned in D. 17.2.55: if a party who committed an illegal act is sued, he can either surrender only what he misappropriated, or he can do this with a penalty. He can give up the stolen object alone if the other partner was ignorant of the fact that he had placed it with the property of the partnership. However, if the other partner was aware of the fact, he will also be liable to the penalty, for it is but just that he who participated in the profit should also share in the loss (D. 17.2.55). ${ }^{207}$ However if the other associate was aware of the delict, e.g. a theft, because the thief had informed him, then the partner who committed the theft had recourse against his associate also for part of the poena.

Other cases in which someone endeavours to impute causes to someone else, to fatum or to vis maior, are mentioned by Johannes Bassianus. He described the case in which someone tried to impute the risk of a res given in depositum or the loss suffered in a societas to somebody else's culpa. But this person had to blame himself even more for not having chosen a cautious depositarius or a cautious socius. This is also the case when an object given in commodatum, locatio or pignus was lost as a result of vis (maior) or casus. Apparently, negligence is then to be found in the negligent choice of the person who took an object into custody. ${ }^{208}$

Also, Accursius mentioned D. 17.2.52.18 as an example of D. 50.17.203, but he extended it to contractual liability. Instead of his partner, one of the associates was sentenced by the judge due to a contract because the partner did not come to trial, but had he been present, he would have been absolved. The sentenced partner had no recourse against the community, as would be the case if he were convicted for furtum or some other delict. Accursius also gave another important example. A person crossed over a place where there was no road, neither public nor private; while crossing over, a branch of a tree fell on him, and in that case the lex Aquilia was not applicable (as in D. 9.2.31). ${ }^{209}$ Under those circumstances (where there was no roadway?), this act could be considered to be the person's own fault, and thus the victim would not be considered to have suffered any damage. Therefore, D. 50.17.203 applied to the claim of the one whose corporeal possessions were damaged (action based

207 Later, the commentator Dynus de Mugello also referred to this text while stating that the damnum was imputed to someone else here due to the latter's participation. The maxim of D. 50.17.203 does not apply when culpa can be attributed to someone else; this also appears in Rainerius de Forlivio ( $† 1358$ ), Lectura super Digesto Novo, fo. $153 \mathrm{v}$ (see also the next section on canon law). If it was not possible to impute the damage to someone else, the principal rule applied (D. 50.17.203) and the damnum was imputed to the injured party. See Dynus de Mugello, De regulis iuris, edn. 1518, fo. CXXVr.

208 Johannes Bassianus, Commentum, ad D. 50.17.203, in Caprioli 1963, p. 238.

209 Accursian gloss Quod quis ad D. 50.17.203 (-204). 
on the lex Aquilia) at the end of the gloss Quod quis, and so directly concerned the question of liability. ${ }^{210}$

Other examples are given by Odofredus: an instituted heir who refused an inheritance ${ }^{211}$ and subsequently was regarded as having suffered a loss due to his own negligence (as in C. 6.27.6), and a creditor who concluded a pactum de non petendo with a debtor out of his own free will (as in D. 2.14.7.10). ${ }^{212}$

The rule of D. 50.17.203 is also discussed by various Commentators in commentaries on De regulis iuris. ${ }^{213}$ The Accursian gloss provided six examples of this rule (see previous paragraph). First of all, Dynus de Mugello (ca.1250-1298/1303) 214 $^{21}$ wrote a commentary on D. 50.17.203 which he reproduced in the following manner:Damnum quod si quis sua culpa sentit sibi debet et non alii. Accordingly, if someone suffers damage due to his own negligence, the damage must be attributed to himself and not to another. Dynus provided several examples of this maxim, among which the example of the partner (socius), which was already mentioned by the Glossators (see above). Furthermore, Dynus discussed the case of a procurator who was condemned because of his own fault and who paid the poena, as the fault had to be attributed to him and not to his principal (D. 3.3.46.5). Also in another case, if the payment by a procurator or manager of another's affairs was undue, the loss had to be imputed to him and not to the principal (D. 3.5.24). ${ }^{215}$ Another example of the rule of D. 50.17.203 is given by Jacobus Butrigarius, namely, of a party that, after having accepted arbitration, had to comply with the decision of the arbiter in the matter under dispute, no matter whether this decision was just or unjust (D. 4.8.27.2). Therefore, if a party suffered any damage, the blame was on that party, having agreed to arbitration. ${ }^{216}$ Furthermore, when a person lost a trial, he had to pay the costs (of the lawsuit) to the victorious party except for expenses incurred

210 Jansen 2007, p. 664.

211 More precisely, it concerns an inheritance with a slave, appointed as an heir, to whom liberty was granted under a condition. The slave was guilty of negligence and failed to fulfil the condition. Therefore, the slave forfeited both his freedom and the estate through his own fault; see C. 6.27.6.

212 Odofredus, Lectura super Digesto Novo, ad D. 50.17.203, fo. 202rb; Odofredus also applied the rule of D. 50.17.203 in the case of the malae fidei possessor who made improvements on somebody else's land; see Odofredus, Lectura super Digesto Veteri, ad D. 12.6.33, fo. 39ra.

213 As stated before, this regula can also be found in the canon law compilation of Pope Bonifacius VIII, i.e. the Liber Sextus (1298). Commentaries on the relevant fragment, VI 5.12.86, will be dealt with in the next section.

214 Dynus de Mugello was a professor of law at Bologna in the 13th century; he was the master of Cinus de Pistoia (1270-1336).

215 Dynus de Mugello, De regulis iuris, edn. 1518, fo. CXXIIIIv/CXXVr.

216 J. Butrigarius, In primam et secundam veteris Digesti partem, ad D. 4.8.27.2: Quod quis sua culpa sentit non uidetur sentire, et sibi habet imputare. 
by that party due to his contumacy (contumax $)^{217}$ if he remained absent at the trial or failed in his proof. This case was already mentioned in the earlier commentaries of Wilhelm Durand (1237-1296) ${ }^{218}$ and Panormitanus (Nicolaus de Tudeschis, 1386-1445) $)^{219}$ and later by Philipphus Decius $(1454-1536) .{ }^{220}$ Finally, a surety could not recover interest from the principal if it was paid due to the negligence (culpa) of the surety himself. ${ }^{221}$ In all these cases, the victim suffered damage because of his own negligence (culpa). Remarkably, in the commentary on D. 50.17.203 Albericus de Rosate made no references to the lex Aquilia, nor any reference to the contributory negligence of the injured party in this respect. ${ }^{222}$ Accursius appears to be the only one who made this connection.

\subsubsection{Concluding remarks}

\section{Recapitulation}

As mentioned in the previous chapter, D. 50.17.203 in classical Roman law had nothing to do with a situation in which both wrongdoer and victim were negligent, or with delictual liability. ${ }^{223}$ The compilers placed this fragment in D. 50.17, and subsequently Accursius linked it to the law of delicts in his gloss Quod quis ad D.50.17.203 by the allegation of D. 9.2.31. ${ }^{224}$ In gloss Quod quis ad D. 50.17.203, Accursius explained that an injured party's own negligence

217 See also D. 48.19.5pr.: obviously a person who did not obey notices or the edicts of Governors.

218 See Durantis, Speculum II.III.4; Durantis wrote this ordo iudiciorum, the Speculum iudiciale (1271), which was of great practical importance as these ordines were applied in the canonical courts. In addition, his Speculum was the most widely used procedural treatise of the Middle Ages. Durantis studied canon law in Bologna under Bernardus Parmensis and later taught at Modena. Pope Clement IV (1265-1268) made him auditor generalis of the Rota, and he became bishop of Mende in 1286.

219 Nicolaus de Tudeschis, Commentaria, adX2.14.5; Nicolaus de Tudeschis (Panormitanus) was the last great canonist in the medieval tradition. He studied canon law in Bologna and Padua. He taught canon law at Bologna, Parma and Siena. In 1421, he was named Auditor generalis of the Camera Apostolica. Panormitanus was elected Archbishop of Palermo in 1434. In 1440, he was named cardinal by the antipope Felix V.

220 Ph. Decius, De regulis iuris, edn. 1564, fo. 210v; Philippus Decius (1454-1536) belonged to the school of the Commentators; he was a famous Italian jurist and canon lawyer.

221 Ph. Decius, De regulis iuris, edn. 1564, fo. 211r; - Various examples of the rule of D. 50.17.203 are also given by Hippolytus de Marsiliis (1451-1528) in his Singularia, nr. 350.1.

222 The examples of the rule deal with, e.g., bail, solicitors, interests and mandates; see Albericus de Rosate, Commentarii in secundam Digesti Novi partem, ad D. 50.17.203, fo. 291v and 292r; also Ph. Decius explains D. 50.17 .203 by giving examples of the application of this rule (of which the last two were taken from Albericus). Furthermore, he refers to the case of the procurator (D. 3.3.46.5, the case just discussed above). See Ph. Decius, De regulis iuris, edn. 1564, p. 210.

223 Also in the parallel regula iuris in canon law the commentary refers to one person acting culpably; see gloss damnum ad VI 5.12.86 (this gloss will be discussed in section 3.3.6).

224 The older commentaries of Bulgarus and Bertrandus Metensis only cite the problem of the socii. 
deprived him of the right to claim damages from someone else. D. 50.17.203 could be read in the sense that it only concerned the negligence of the injured party (quod quis sua culpa damnum sentit); however, the Glossator did not understand it to concern only cases in which the negligence of the injured party was the only factor and in which the negligence of the wrongdoer was not in discussion at all. ${ }^{225}$ Furthermore, the application of D. 50.17.203 was extended, as it will be interpreted differently in coherence with other texts from the Digest: when one party acted intentionally (dolus), the negligence of the other party (culpa) would be irrelevant. ${ }^{226}$ Already Johannes Bassianus (in gloss quia non debuit ad D. 9.2.9.4) considered that D. 9.2.9.4 dealt with mutual negligence (as explained above in section 3.2.2.1), and Accursius took over this approach in his gloss. ${ }^{227}$

The Gloss did not provide explicit proof whether or not the Glossators believed that culpae compensatio could only be applied to cases of contributory negligence in which both parties had been negligent to the same degree. It has been argued that an assumption in this sense can, however, be made. The general rule of culpae compensatio would be that if the contributory negligence of the injured party amounted to the same degree as the negligence of the wrongdoer, compensation could take place. A small degree of contributory negligence would not lead to compensatio and thus neither to the deprivation of the possibility to claim compensation for damages/fine. According to this view, an exception to this general rule was made in cases of preponderant contributory negligence, which would certainly lead to the denial of an eventual claim. ${ }^{228}$ The Gloss, however, did not mention this. Plausibly, this refinement was made by the successors to the Glossators (instigated by the canonists).

Unfortunately, as to the contributory negligence of the injured party, no extensive commentaries are given by the Commentators discussed in the preceding

225 See gloss non repetet ad D. 10.2.44.5, gloss Quia non debuit ad D. 9.2.9.4 and Quod si quis ad D. 50.17.203. In the same sense, Lange 1955, p. 72.

226 In the event that two persons acted wrongfully with regard to one case, but one acted with culpa and the other with dolus, no compensation could take place. Furthermore, dolus was considered to be more serious than culpa. See (Accursian) glosses omnimodo ad D. 19.1.45.1, tenebitur ad D. 9.2.9.4, ipso iure ad D. 16.2.10pr. and culpa tua ad D. 17.1.26.7; see Lange 1955, p. 72.

227 See also Jansen 2007, p. 659f.; - The rule of D. 50.17.203 as well as the examples of the rule of D. 50.17.203 discussed above were mainly examples of the injured party's own negligence ('Eigenes Verschulden', only the injured party had been negligent), and not of contributory negligence ('Mitverschulden', both parties have been negligent). However, these glosses show that D. 50.17.203 did not apply only to situations in which negligence was due exclusively to the behaviour of the injured party, but that it made it possible to extend the rule to the second area, that of contributory negligence.

228 Luig 1969, p. 199. 
subsections; only Paulus de Castro mentioned it briefly. In the cases of the javelin thrower and the barber, the culpa of the wrongdoer was compensated by the culpa of the injured party. However, if the wrongdoer acted intentionally, no compensation took place because dolus was considered to be more serious than culpa. Additionally, there are some new concepts, which I will discuss now, that arose in this period.

On the concept of culpa admixta

The origin of the concept of culpa admixta can be found in the contractual sphere. Defining culpa admixta is difficult. The words culpa admixta (literally 'mixed fault') give a legal qualification to the act of the injured party in situations in which a hurtful action by a wrongdoer is mixed with a fault of the injured party. The Consilia of Marianus the Elder (1401-1467) ${ }^{229}$ and Bartholomaeus Socinus (1436-1507) ${ }^{230}$ are relevant. According to consilium 156 , in the case of an agreement to buy the future production of salt (qualified as locatio conductio) in return for annual payments, ${ }^{231}$ because of the negligence (culpa) of the Pope and the Camera Apostolica, a payment had to be made to the conductor for the amount of interest due. Therefore, the absence of (contributory) negligence on the side of the locator (or venditor) was considered a prerequisite for the admissibility of a claim for compensation. However, if there was admixta culpa on the side of the locator (or venditor), e.g. if he prevented the salt production from being received by the conductor, he would be liable for the total interest sum. ${ }^{232}$

After the application of the term culpa admixta in a contractual sphere, this application was expanded to the extra-contractual sphere by Cravetta who used it in the situation in which the wrongdoer killed the initiator of a fight, and where there was culpa admixta on the side of the person killed. Cravetta mentioned in a consilium a case in which someone started a quarrel and was killed during the fight, and who was considered to have acted with culpa because he had started the fight. Negligence (culpa) was attributed to the person who started or provoked a fight. The wrongdoer who killed whomever started the fight was not liable, because there was culpa admixta on the side of the injured party. ${ }^{233}$ In other words, the wrongdoer was not held liable when the

229 Marianus Socinus (the Elder) was a professor of canon law at Padua and Siena.

230 Bartholomaeus Socinus, the son of Marianus, studied law under his father and under Thomas Doctius, in Bologna under Tartagnus and Barbitia, in Pisa under Franciscus Aretinus. He became a professor at Siena, Pisa, Bologna and Padua.

231 See Socinus, Consilia, edn. 1579, cons. 156. nr. 1, fo. 7v.

232 Socinus, Consilia, edn. 1579, cons. 156. nr. 21, fo. 9r; Luig 1969, p. 200.

233 A. Cravetta, Consilia sive responsa, cons. 119, nr. 11 (edn. 1611, p. 215), with reference to Socinus' cons. 156. 
injured party brought danger or risk on himself, because in that case the damage would also result from the contributory negligence of the injured party. ${ }^{234}$

Another case mentioned by Cravetta is the following. Someone said in a arrogant way that someone else should beware of buying some things. That person responded that he had bought them before. This led to a fight, started by the injured party himself, who died during the fight. In this case, the injured party would have been considered to have died because of his own negligence. ${ }^{235}$

The concept of culpa admixta was adopted by Hippolytus Bonacossa (1514-1591), who stressed the fact that no liability for any damage exists in the event of culpa admixta of the injured party. ${ }^{236}$ Thenceforward, this concept is noticeably cited in relation to the rule of D. 50.17.203, the counterpart of the same text in canon law (VI 5.12.86) and the idea of culpae compensatio until the eighteenth century. ${ }^{237}$ The use of this term in the legal sources shows that by applying the fragment from De Regulis Iuris, jurists noticed that it regarded a problem of mutual blame..$^{238}$

Later, another concept developed out of the same perception, i.e. the concept of a culpa communis. Franciscus Niger Cyriacus $(\dagger 1637)^{239}$ argued that when two persons both acted culpably in the same way and their negligence was related to the same event, as each deceived the other, their respective faults (culpa mutua) were compensated (ipso iure) and no claim for compensation for damages could be granted to either of them. ${ }^{240}$ The respective faults were not really cancelled, however, by way of compensation in the true sense of

234 A. Cravetta, Consilia sive responsa, cons. 119, nr. 11 (Et quod dicitur de eo qui suscipit in se periculum, quod non tenetur quando culpa partis illud euenit); also interesting are two of his references here: Bartolus, Commentaria, ad C. 4.33.4 and Baldus, Commentaria, ad C. 4.33.4. Further references can be found in Cravetta's work (edn. 1611, p. 215).

235 A. Cravetta, Consilia sive responsa, nr. 11 (edn. 1611, p. 215).

236 H. Bonacossa, Quaestiones criminales. De damno dato, uers. 'damnificans': Damnificans, non tenetur pro aliquo damno ex statuto. Quando damnum habet admixtam culpam damnificati ...; see also Massetto 1958, p. 1109.

237 Luig 1969, p. 200; see also Jansen 2007, p. 660; the question of culpa admixta is addressed again in the early modern period; see M. Venturini, Decisiones Rotae Florentinae, decis. $45 \mathrm{nr}$. 19f. and Stucke \& Stucke, Consilia sive responsa, esp. cons. IV nr. 827 (both are discussed in the next chapter).

238 Luig 1969, p. 200f. See also chapter four, especially the section on the usus modernus.

239 Franciscus Niger Cyriacus was a lawyer in Mantua.

240 Luig 1969, p. 201; see also Bartolomaeus à Salyceto, Commentaria in Digestum Vetus, ad D. 16.2.10pr., F. Cyriacus, Controversiae forenses, controv. 197, edn. 1644, n. 21ff. and also esp. nr. 23: Si vero sit culpa, vel dolus communis, sed in negotio, vel re ad tertium spectante, et contra terium; tunc quia laborans uno vitio non potest illud, alteri obiicere, hinc inde pariter cessat culpae, vel doli allegatio ... 
the word (compensatio), but by means of melting together (confusio); though figuratively speaking this cancellation was also called compensation. ${ }^{241}$

In conclusion, one can state that the term culpa admixta was used to qualify the behaviour of the injured party in a way that led to the exclusion of liability of the wrongdoer. In this way contributory negligence led to a denial of claim without a discussion of the degree of the negligence of each party. The use of the term culpa admixta (or culpa communis) shows that the damage which occurred was considered the common responsibility of both parties.

\subsection{CANON LAW}

\subsubsection{Introduction}

In addition to secular legal scholarship, the law of the Church, i.e. canon law, was important for the development of the legal concept of contributory negligence. As shown above, in medieval Roman legal scholarship the contributory negligence of the injured party seemed to be regarded as reproachable misconduct that could be sanctioned by a refusal of the claim for damages (more precisely: роела). If both the wrongdoer and the injured party acted negligently, sometimes compensation for their negligence was granted. The idea emerged that the negligence (culpa) of the wrongdoer could be compensated by the negligence (culpa) of the injured party. However, the approach to this problem of 'contributory negligence' by the canonists differed from the approach by medieval Roman legal scholarship as depicted above. In this section, this different approach of medieval canon law will be discussed, focusing on the development of the legal concept of contributory negligence in canon law. Firstly, it will be ascertained whether or not a general idea on culpae compensatio existed and, if so, whether such a theory was actually applied in the law of delicts. For a better understanding, some general remarks will be made about negligence and causation in canon law, then examples of accidental homicide will be discussed. Finally, some conclusions as to the contribution of canon law to the concept of contributory negligence will be presented.

In the twelfth century, Gratianus compiled his Concordia discordantium canonum, a compilation of normative texts of canon law, with the purpose

241 F. Cyriacus, Controversiae forenses, controv. 197, edn. 1644, nr. 30ff. Baldus in his commentary on D. 24.3.39 speaks of confessio (I consulted the edition of 1577), while Cyriacus seems to refer to Baldus' words including confusio. This version seems to make more sense indeed. 
of harmonising contradictions between the canones by using the sic et non method of Abaelardus. After this compilation came into being, new papal constitutions (decretales) were promulgated which were later recorded in new legal collections such as the Liber Extra (1234) and the Liber Sextus (1298). Many popes meddled in all areas of law, with the argument and the excuse of avoidance of sins (ratione peccati). ${ }^{242}$ With regard to medieval canon law, the sedes materiae on the subject of contributory negligence can be found in three decretals incorporated in the Liber Extra (1234), i.e. X 5.12.8 and X 5.12.9, $\mathrm{X}$ 5.16.6, and in one fragment incorporated as regula 86 in the title De regulis iuris of the Liber Sextus (1298), i.e. VI 5.12.86 (the counterpart of D. 50.17.203).

\subsubsection{Negligence and causation in canon law}

As in medieval Roman law, also in medieval canon law the wrongdoer was only liable when he was at fault (culpa). ${ }^{243}$ The construction of a general theory of culpa was undertaken firstly by canonists and then by philosophers and theologians. ${ }^{244}$ The notion of culpa in canon law was slightly different from the notion in medieval Roman law, because in canon law the theological notion of $\sin$ (moral concept of fault $)^{245}$ was also taken into account. ${ }^{246}$

According to the philosophy of Aristotle, which influenced the intellectual climate in the thirteenth century, ${ }^{247}$ blame did not merely follow from an action, but also depended on the mental state of the actor during that action; only if

242 For example, in the Liber Extra of Gregory IX, the Church claimed jurisdiction in the field of criminal law for illicit acts such as adultery and rape (X 4.7; X 5.16), bigamy (X 1.21), calumny (X 5.2), injurious libel (X 5.36), false witness (X 5.20), physical violence (X 5.36), homicide (X 5.12) and theft (X 5.18); see Bellomo 1995, p. 76.

$243 \mathrm{X}$ 5.36.9: If loss is caused by your own fault (culpa), it is right that you make amends for it.

244 Von Mehren \& Gordley 1977, p. 569.

245 The notion of sin was already present in the Judeo-Christian tradition. This can be seen in the writings of St. Augustine of Hippo (354-430), where culpa already had an ethical dimension (Augustine's writings can be found online at http://www.augustinus.it (last visited on 1 May 2013)). In post-classical development of Roman law, influences from Greek philosophy and Christianity changed the notion of culpa. At a certain point in time, the subjective element of moral blameworthiness came to the foreground; see Aumann 1964, p. 25; see also Stein, in: Parisi 1992, p. x, who writes that 'the canon lawyers attempted to link the legal notion of culpa with the moral notion of fault, thus leading to an individualization of the former and the accentuation of the subjective elements of wrongdoing. Theologians got in on the definition of fault. Judicial discretion came to be recognized as the means for reconciling the moral and legal notions of liability'.

246 On the notion of sin in canon law and the relation between crimen and peccatum, see Katz 1881, p. 1ff.; Kuttner 1935, p. 3ff. On the concept of fault in medieval Roman and canon law, see also Parisi 1992, p. $104 \mathrm{ff}$.

247 In the 13th century, Thomas Aquinas interpreted Aristotle to accommodate ideas taken from Roman and canon law; see Gordley 1995, p. 131ff. 
the act was voluntary would the actor be held responsible. ${ }^{248}$ Therefore, an act could not be imputed to a wrongdoer unless he could be blamed for it, at least to a certain extent. ${ }^{249}$ According to Aristotle and his approach of commutative (corrective) justice, if a person caused a loss to another person, he ought to restore equality or - more modern - pay compensation. ${ }^{250}$ In the thirteenth century, Thomas Aquinas (1225-1274) used Aristotle's theory of human responsibility to explain the conclusions of the canonists. By the time Aquinas wrote about this, the canonists decided that a person who injured another person through negligence or lack of due diligence was not only morally guilty, but also stood under a moral obligation to compensate the victim. ${ }^{251}$ According to Thomas Aquinas, an actor is liable if he voluntarily caused harm, meaning harm caused either intentionally or negligently. ${ }^{252}$ A person owed compensation because he 'gained' at another's expense in the sense that he fulfilled his will with another's resources. ${ }^{253}$ Aquinas' theory of restitution is based on a statement by St. Augustine, later part of the Decretum Gratiani (C.14 q.6 c.1) and the Liber Sextus (VI 5.12.4): unless a man restores whatever he took away, his $\sin ^{254}$ will not be forgiven. ${ }^{255}$

At the end of the twelfth and the beginning of the thirteenth century, the canonists developed their own notion of culpa that was not exactly the same as 'acting without due care', in the meaning it was endowed with in Roman law. ${ }^{256}$

According to the canonists, the lex Aquilia was based on the general proposition that an action was available for damages caused through fault (culpa), which in Roman law includes both negligent and wilful misconduct. ${ }^{257}$ According to the canonists, however, culpa has a more extensive meaning.

248 Aristoteles, Ethica Nicomachea, III.1; Ibbetson 2005, p. 9 .

249 Hallebeek 2006, p. 331.

250 This applies when one person's loss is balanced by another's gain, but also, by analogy, in a case of physical assault and homicide, as they can also be considered as a gain to the actor and as a loss to the victim; see Aristoteles, Ethica Nicomachea, V.4

251 Gordley 1995, p. 140; 2006, p. 196.

252 See on this topic also Parisi 1994, p. 331.

253 Gordley 1995, p. 138.

254 The 'taking away' was interpreted very broadly by the theologians: not only theft, but also killing, the mutilation of someone's body, destroying someone's property and damaging someone's reputation. In all of these cases, the wrongdoer took something away from the victim, and he violated the eighth of the Ten Commandments, i.e. Thou shalt not steal (Exodus 20:15). See Broers 2012, p. 61.

255 See Thomas Aquinas. Summa theologiae, II-II, q. 62, art. 2 ad 2 (edn. 1897, p. 42f.); Broers 2012, p. 61; extensively on the development of the theory of restitution, see Weinzierl 1936; 1939; Wolter 1985, esp. p. 26ff., 30ff., 36ff.

256 This will be discussed below.

257 Von Mehren \& Gordley 1977, p. 569. 
Already the early canonists (the decretists) had constructed a doctrine on liability for the unintended consequences of unlawful acts; they based themselves on several texts in the Decretum Gratiani, three of which are the most relevant for our discussion. The first text on which the doctrine rested is St. Augustine's statement that no one can be blamed for having done what is good and lawful (propter bonum et licitum) ${ }^{258}$ According to the second text, D.50 c.50, a provision from the Council of Worms (868), a person who cut down a tree which in falling crushed a passer-by while the tree pruner was carrying out some necessary work only had to do penance if he had acted wilfully or negligently. In a third text, D.50 c.37, a priest threw stones and thereby killed a boy. According to the decision of Pope Urban I, ${ }^{259}$ the priest should do penance for this homicide but would not be suspended from his functions, as was usually applied to those who were guilty of homicide. ${ }^{260}$ The early canonists considered that a priest was not liable if he threw the stone for a reason (causa) or a good reason (iusta causa) and threw with diligence, in a place where people were not walking. ${ }^{261}$ Later, canonists explained that the priest had a reason to throw the stone if he was engaged in a lawful activity rather than in an unlawful one. If the priest threw the stone to chase a wild boar or a pig out of a field of grain, he was not guilty, unless he had been careless. In conclusion, according to the canonists culpa could exist either when acting in contravention of legal provisions or when doing something permissible but without using the required diligence (acting with less care than what might be expected was considered as acting with negligentia). ${ }^{262}$ Thereby, engaging in an unlawful activity could bring about the basis for liability. ${ }^{263}$

Did the canonists use a certain kind of causation theory? With regard to causation, the most relevant text in Roman law in the Digest is D. 9.2.30.3. The text describes a case in which a man sets fire to stubble or thorns in order to

258 See C.23 q.5 c.8; Gordley 2006, p. 190.

259 Urban's pontificate was from 222 to $230 \mathrm{AD}$.

260 Gordley 2006, p. 190; Kuttner 1935, p. 202, mentions D.50 c.39 instead of D.50 c.37 as the third text on which the doctrine of the earlier canonists rested; in D. 50 c.39 someone had struck another person who, due to that, fell from his horse and broke his neck.

261 Gordley 2006, p. 190.

262 Kuttner 1935, p. 201, 225f.; Bussi 1937, p. 205; Gordley 2006, p. 190f., 196; see also Dondorp 2001, p. 102; Hallebeek 2006, p. 332; on the distinction between res licita and res illicita, see Kuttner 1935, p. 200ff.; see also gloss bonum ad C. 23 q.5 c.8 and dederunt ad X 2.20.9; Interesting is Covarruvias who mentioned the general theory of the canonists with reference to Thomas Aquinas, i.e. that culpa can occur either when acting in contravention of legal provisions or when doing something permissible without using the diligence one should use. See Diego Covarruvias a Leyva, Opera Omnia. Pars II. § IV. De homicidio casuali, nr. 1.

263 He who engaged in unlawful activity was liable for all consequences; see Engelmann 1965, p. $211 \mathrm{ff}$. 
burn them up and the fire escapes further afield and spreads and burns another's crops or vineyard. If he did so on a windy day, he is guilty of mischief, for he who even provides the opportunity is deemed to have done the harm. The latter phrase is of major importance as it became the startingpoint for causality in the medieval period of ius commune. The medieval Roman scholars seem to have accepted a causal connection which is very long, with many links.

Although the canonists based the assessment of liability on the two elements of damnum and culpa without mentioning the causal relation between the damage and the act that caused the damage as a separate requirement, this way of assessment indirectly forced the canonists to consider the problem of causation. ${ }^{264}$ In some cases found in the decretals, the causal connection between the damage-causing act and the damage itself is severed as a result of the additional negligence of others, including the injured party. As a general rule, the canonists argued that the person who provided the occasion for the damage to occur had to be considered to have caused it. ${ }^{265}$ This argument was used in the twelfth century to account for the punishment of accidents with a fatal outcome (homicidium casuale) ${ }^{266}$ Ultimately, the reason why someone was punished was because of his own illicit act, even when the act caused the death of another person by chance. ${ }^{267}$

The canonists made a distinction between the terms causa and occasio. The fault (culpa) of the wrongdoer had to be the cause (causa) and not merely the occasio of the damage (damnum). An occasio is not a cause (causa) unless it is direct (directa), proximate (proxima), immediate (propinqua), or immediate and tending/oriented towards this outcome (propinqua et ad hoc tendens) rather than remote (remota). ${ }^{268}$ In this sense, the element of fault with regard to an action was approached in terms of causality. ${ }^{269}$ The above-mentioned adage (qui occasionem damni dat, damnum dedisse videtur) ${ }^{270}$ now needs

264 Von Mehren \& Gordley 1977, p. 570; Parisi 1992, p. 106f.; - According to Luig 1969, p. 201, a range of cases where the causal connection between the damage-causing act and the damage itself is severed as a result of the additional negligence of others, including the injured party, can be found in the decretals; on this Kuttner 1935, p. 193ff.

265 Qui occasionem damni dat, damnum dedisse videtur (adage derived from D. 9.2.30.3); See also gloss bonum ad C.23 q.5 c.8 and gloss dederunt ad X 2.20.9. A more elaborate treatment of this adage can be found in Massetto 1958, p. 1129f., also including a discussion of the later development of this adage in the early modern period.

266 On the exceptions to this adage, see Bussi 1937, p. $206 \mathrm{f}$.

267 See Dondorp 2001, p. 102.

268 Von Mehren \& Gordley 1977, p. 570.

269 See also Parisi 1992, p. 115.

270 The person who created the opportunity that could lead to damage is also deemed to have caused the damage; see W. Durantis, Speculum iudiciale, lib. IV, partic. IV, De Iniuriis et damno dato, § 2 sequitur, nrs. 14 and 15 . The latter number/fragment concerned the case of B who threw rubbish in front of A's door, and subsequently A was fined by the public authorities for contravening some kind of statute dealing with waste removal. A was allowed to recover this 
further explanation. With causa, the canonists only aimed at a proximate or immediate cause (causa proxima or propinqua), not to a remote cause (causa remota). ${ }^{271}$ The contrast between propinqua and remota gradually took the place of the contrast between causa and occasio. Therefore, causa proxima refers to the act that caused the harm, causa remota to the act that occasioned the loss. ${ }^{272}$

Also in practice this causal way of dealing with causation was applied, as becomes clear from the Consilia of Marianus the Elder and Bartholomaeus Socinus who refer to the meaning of the term 'occasio' in the statutes of Pistoia, where it was stated that if someone brought about an occasio that led to damage, he was obliged to provide compensation. ${ }^{273}$ According to Socinus, two situations can be distinguished. The first concerns a causa proxima, in which case the statutes are clear; and the second concerns a causa remota, in which case it was not clear whether the effect could be imputed to the causa or not. He referred to Johannes Andreae (ca. 1270-1348), ${ }^{274}$ who argued that sometimes a certain

fine from B on account of the fact that B's act occasioned A's loss; see also König 1954, p. 22ff.; Zimmermann 1996, p. 1023. The most extensive interpretation of the adage can be found with Albertus Gandinus ( $†$ after 1305). Gandinus discussed a provision of statutory law which stated that murder should be punished by destroying the property of the murderer. Apparently, in a certain case the house of the muderer was demolished, but during that activity the adjacent residence was detroyed by a falling wall. According to Gandinus, if the goods are not confiscated by the authorities, the murderer will be liable. Applying the adage very extensively, Gandinus argued that although the murderer did not himself demolish the house, he is nevertheless considered to have caused the damage: by committing a murder, he created the situation that was eventually to result in the damage to the residence of his neighbour. See A. Gandinus, Tractatus de maleficiis, De bonis malefactorum, $\$ 12$ (edn. Kantorowicz 1926, p. 355f.) and the English paraphrase of Hallebeek 2001, p. 95. On the adage, see also the juristic encyclopaedist Bertachinus ( $\dagger 1497)$, Repertorium juris, ad occasio damni and his commentary ad damnum.

271 Kuttner 1935, p. 190, 195ff.; Bussi 1937, p. 204; Massetto 1958, p. 1129f., Luig 1969, p. 201; see also Descamps 2005, p. 98f.; Jansen 2007, p. 668f.; on the (philosophical) origin of this theory, see Lange 1955, p. 163, and Feenstra 1956, p. 472f.; - The causa finalis is first subdivided into causa propinqua and causa remota by Petrus de Bellapertica; see Lange 1955, p. 163; Feenstra 1956, p. 472; Kurtz-Eckhardt 1977, p. 31, Bruck \& Möller 1980, p. 151; - The distinction between causa propinqua/proxima and remota is already made by Thomas Aquinas; see Schütz 1895, p. 107; Kurtz-Eckhardt 1977, p. 31.

272 See Kuttner 1935, p. 196f.; Bussi 1937, p. 204; Parisi 1992, p. 107; also Von Mehren \& Gordley 1977, p. 569ff.

273 See already Roffredus Beneventanus' Quaestiones sabbatinae, quaestio 22 (Si aliquis occasione alterius exigatur inuitus an habeat actionem contra eum cuius occasione fuit exactus). He mentions a case of someone from Pistoia (informatus) who owed a debt to a Florentine, but was unwilling to pay the debt. Another man from Pistoia, Sempronius, went to Florence with his merchandise; the just-mentioned creditor from Florence grabbed Sempronius, robbed and hit him. Sempronius wanted to sue the informatus, because his act (indirectly) caused his damage. He wanted to bring an action because the civitas of Pistoia determined that he who suffers damage because of the occasio of someone else has to be compensated by the person who gave the occasio for the damage.

274 Johannes Andreae was the most renowned and successful canonist of the later Middle Ages. Johannes studied law in Bologna: Roman law under Martinus Sillimanus and Riccardus Malumbra; canon law under Egidius Fuscarariis and Guido de Baysio. He taught canon law at Bologna and Padua. 
effect could result from a certain causa remota ${ }^{275}$ However, according to Socinus, one had to interpret the statutes restrictively in this respect. When such a cause (causa) in its entirety had no relation with the consequence, it was not possible to conclude that the cause produced the consequence nevertheless. ${ }^{276}$

This 'theory' of causation could be used to solve cases in which there was contributory negligence. The contributory negligence of the injured party was seen as contributory causation (co-causation), and therefore in such cases one had to decide whether the wrongdoer or the injured party had produced the causa proxima. ${ }^{277}$ If the causa proxima could be attributed to the wrongdoer, the injured party received full compensation; if the causa proxima could be attributed to the injured party, he received no compensation at all. ${ }^{278}$ Apparently, in the latter case the damage is not imputable to the wrongdoer even if his action was one of the causes. ${ }^{279}$

According to the secondary literature, a small error made by the injured party would only result in an irrelevant causa remota. ${ }^{280}$ This thought is troubling, as it seems to consider causation here in the meaning of negligence (causa remota as 'remote negligence'). Some authors, however, made an exception in the case where the wrongdoer acted with malicious intent (animus malignandi), because in such a case every occasio replaced the causa proxima

275 See additio of the canonist Johannes Andreae ad Speculum Iudiciale van Durantis 'Cum quis dicitur'.

276 Socinus, Consilia, edn. 1579, cons. 156. nr. 21, fo. 9r.

277 Luig 1969, p. 201; also interesting is 5 Comp. 5.6.2 (not part of the later Liber Extra): While eating, clerics threw peach pits at each other as a joke, and later also water and dirt. One of them threw a little stone and injured an archdeacon below the eye, but not very severely. However, the injury got worse because of the carelessness of the injured party (horse-riding) and as a result of that he died. Pope Honorius forbade the cleric to receive major orders, but forgivingly allowed him to continue to 'serve the Lord with psalms and sacred canticles'; see also Kuttner 1935, p. 194f.

278 Wacke 1978/79, p. 11; 1979, p. 276; 1991, p. 362f.; it was just a little later that the maior or gravior culpa was considered. It is, however, not clear to me in what period of time the author situated this development.

279 Jansen 2007, p. 669, argued that in this thought it is only consistent to reformulate the rule of VI 5.12.86 (Damnum, quod quis sua culpa sentit, sibi debet, non aliis, imputare), as a rule of imputation. Modified as a rule of negligence, this thought found entry in the later period of ius commune and specified the theory of culpae compensatio. See Mevius, Decisiones super causis praecipuis, I, decisio 221, nt. 7 (discussed in the next chapter).

280 It seems that causation and negligence were not unlinked in this period, nor in the period of early modern times, and that the terms are sometimes used alternately to identify behaviour which makes for responsibility. See also Luig 1969, p. 201 nt. 71, who holds that the dogmatic development of the doctrine of contributory negligence could have been delayed by this interchangeability insofar as when applying the causation in fact only affirmation or denial (all-or-nothing) was possible, and that the recognition of different levels of negligence could also lead to a partition of damage, as Wolff ultimately does. Also Kaufmann 1958, p. 79, remarks that the treatment of contributory negligence in the early modern period gives a rather mixted picture, and that this should not lastly be attributed to the deficient separation of causation and fault. 
and thus led to responsibility. ${ }^{281}$ In this way, an objectively inadequate causal connection is supplemented by a culpable disposition/attitude, which did not have to include the intention to kill, a general culpa was sufficient. ${ }^{282}$

\subsubsection{Accidental homicide: early canonists}

The question of when exactly negligence (culpa) had to be imputed is discussed by various decretists. ${ }^{283}$ Often the above-mentioned example of D.50 c.37, in which a person died from injuries suffered from being struck by a stone, is given. In such a case the reason why the stone was thrown had to be established. Throwing stones at people was illicit, unless there was a particular reason to do so, e.g. self-defence. A victim might be struck by a rock thrown in order to chase away birds or pigs. ${ }^{284}$ In such a case culpa could not be established out of the act itself (which was lawful), and if the actor had been sufficiently careful in the act (in this case he had warned the passers-by), he committed no wrong even if he caused damage (in this case if someone had been struck). ${ }^{285}$

If an accident with deadly outcome was accidentally caused by someone, according to Bernardus Papiensis $(\dagger 1213)^{286}$ it was necessary to distinguish whether the act was permitted by law and whether the wrongdoer acted with due care. If he did, the wrongdoer was not to be blamed (no culpa). ${ }^{287}$ If his

281 Kuttner 1935, p. 198; Luig 1969, p. 201.

282 Kuttner 1935, p. 198.

283 Kuttner - in his famous book Kanonistische Schuldlehre - concluded that Huguccio, in his Summa Decreti (1188), considered negligentia a wrong, to be punished more harshly as the severity of the concequences increased. Huguccio tried to explain why a number of texts in Gratian's Decretum determine that clerics had to be punished for their actions, when these actions, by accident, led to the death of another person; see Kuttner 1935, p. 227; Dondorp 2001, p. 101.

284 See, e.g., Goffredus Tranensis, Summa super titulis decretalium, De homicidio, nr. 1, fo. $211 \mathrm{v}$.

285 Dondorp 2001, p. 101; therefore, according to Huguccio, in a case of negligent wrongdoing, one could be at fault either for having undertaken the activity at all because it was criminal or excessively dangerous (culpa praecedens), or for having performed a permissible activity in an unsafe manner (culpa interveniens); see Von Mehren \& Gordley 1977, p. 458f.; see also Kuttner 1935, p. 225.

286 Bernardus Papiensis (Balbus) studied in Bologna under Bazianus, Gandulphus and (perhaps) Huguccio. He taught at Bologna and spent time in Rome working in the curia. In 1191, he became bishop of Faenza. In 1198, he was postulated to the bishopric of Pavia. Bernardus was the most important 12th-century canonist after Huguccio; - The short bibliographical information provided on canon lawyers in this section is based on the bio-bibliographical listing of Pennington; see http://faculty.cua.edu/pennington/biobibl.htm (last visited on 1 May 2013).

287 See, e.g., D.50 c.50; - According to canon law (D. 50 c.37 and 1 Comp. 5.10 .9 [X 5.12.8]), accidental homicide would deprive a cleric of his office, unless dispensation was granted; see Bernardus Papiensis, Summa decretalium, V.10.7. However, dispensation was not required when the accidental homicide took place without any preceeding negligence. When negligence was indeed present, dispensation could take three shapes. Large dispensation (dispensatio magna) 
action was not permissible or if it was permitted but he did not act with due care, he acted culpably (with culpa) and the damage could be imputed to him. ${ }^{288}$ Bernardus Papiensis explicitly stated that the case of 1 Comp. 5.10.10 (X 5.12.9) was different from the case of 1 Comp. 5.10.9 (X 5.12.8), because in the first case the killing was due to culpa of the injured party, in the latter to culpa of the wrongdoer. ${ }^{289}$

One of the texts used by the decretists to construct their doctrine on liability for unintended consequences of unlawful acts, as mentioned before, is D.50 c.50. This fragment of the Decretum Gratiani contains a provision from the Council of Worms (868), including a case about a tree pruner, who, while he was carrying out some necessary work, cut down a tree, and as a result a passer-by was crushed. This person only had to do penance if he acted by voluntas or by negligentia. This would not be the case, however, if the passer-by acted without proper care (incuria) and walked under a tree at an unexpected moment; in that case, the tree pruner would not be liable for manslaughter. ${ }^{290}$ The Summa 'Animal est substantia' (written between 1206 and 1216), formerly known as Summa Bambergensis, a - rather romanistic - commentary on the Decretum, ${ }^{291}$ is of particular interest. From this anonymous work it appears that culpability (culpa) could reveal itself in many different ways. According to the author of Animal, culpability could exist because of the act (ratione operis), the manner of performing the act (ratione modiagendi), the place (ratione loci) or the time (ratione temporis) of occurrence of the act. When someone acted

would allow those who had received major orders to serve in minor orders (X 5.12.8). Major dispensation (dispensatio maior) would allow them to continue to serve in their own major order (D.50 c.37), while the most extensive dispensation (dispensatio maxima) would take away the impediment to being promoted to a hierarchically higher order (X 5.12.9). Voluntary homicide, on the other hand, which was unjust, unnecessary and was performed without any urgent coercion could not be dispensated at all. See Goffredus Tranensis, Summa super titulis decretalium, De homicidio, nr. 11, fo. 213v.

288 See also 1 Comp. 5.10 .9 (X 5.12.8); - Bernardus Papiensis, Summa decretalium, V.10.5; see also Goffredus Tranensis, Summa super titulis decretalium, De homicidio, nr. 1, fo. 21lv.

289 Bernardus Papiensis, Summa decretalium, V.10.5: ... nec obloquitur sequens hic capitulum, scil[ icet] Lator [1 Comp. 5.10 .10 (X 5.12.9)], quia hic culpa occidentis, ibi culpa occisi mors interuenit. De his hos uersus habe:

Si licitus, cautus, non est culpabilis actus;

In reliquis culpam reor et pro crimine mulctam. (dactylic hexameter, EvD) ...

290 D.50 c.50: Item ex Concilio Guarmatiensi. Sepe contingit, dum quis operi necessario insistens arborem inciderit, ut aliquis subtus ipsam ueniens deprimatur. Et iccirco, si uoluntate uel negligentia incidentis arborem factum est, ut homicida penitenciae debet omnino submitti. Quod si non uoto, sed incuria illius, non hoc eum sentencia contingit. Si enim dum ille operi necessario fortassis incumberet, iste insperatus occurrit sub arbore et sub ipsa oppressus est, incisor arboris non tenetur pro homicida.

291 See http://www.medcanonlaw.nl/Animal_est_substantia/Introduction.html (last visited on 1 May 2013). 
in contravention to any provision and thereby inflicted damage on someone else, the wrongdoer was always considered to have acted culpably. The author of Animal referred to Roman law, more specifically to D. 9.2.11pr.: the case of the barber who put his chair near a public field where people where playing a ball game. If the customer was killed after a ball hit the barber's razor, the barber would be liable, because he shaved where he should not have done so (ratione loci). ${ }^{292}$ It is curious that the negligence of the injured party was not mentioned. According to Luig, the reason for this was that the negligence of the injured party was less than the negligence of the wrongdoer, and therefore unremarkable. ${ }^{293}$

Furthermore, the Apparatus mentioned that with regard to the question of (Aquilian) liability for damage, culpa could be compensated by culpa, with reference to D. 9.2.11pr. With regard to the question whether a cleric could be granted a higher ordination, this was different, because in that case culpa could never be compensated by culpa. The author of Animal referred to 1 Comp. 5.10.9 (X 5.12.8) and also stated that when the wrongdoer and the person killed, both acted culpably; even if the culpability of the wrongdoer was less serious, he could never ascend to a higher rank. ${ }^{294}$

The author of Animal est substantia denied the wrongdoer the ordination to the priesthood, without taking into account the amount of negligence on either side. From the text in Animal it becomes clear that not every kind of contributory negligence on the side of the person injured absolved the wrongdoer from his responsibility, not even when his contributory negligence was considerable. It may be concluded that the importance of canon law, at least in the commentary of the author of the Animal on D.50 c.50, regarding contributory negligence lay in the fact that the problem of the scope of contributory negligence (the question of minor culpa) was explicitly discussed for the first time in the legal development of the Romano-canonical tradition. ${ }^{295}$

292 He had not acted culpably - neither because of the act nor because of the manner of performing the act in this case; see also Kuttner 1935, p. 226.

293 Luig 1969, p. 202.

294 Animal est substantia ad D.50 c.50 (edn. E.C. Coppens): ... Et nota quod in lege quantum ad dampnum culpa bene compensatur culpe, ff. Ad legem Aquiliam. Item Mela [D. 9.2.11pr.]. At quantum ad promotionem numquam dicerem quod culpa compensanda sit culpe. Nam etsi ille qui occisus est fuerit in culpa et alius qui fecit homicidium similiter etiam forte in minori, numquam tamen deinceps poterit promoueri, extra. De homicidio. Continebatur [1 Comp. 5.10.9 (X 5.12.8)]....

295 Luig 1969, p. 203. 


\subsubsection{Accidental homicide: two cases from the Liber Extra}

\subsubsection{The case of $X 5.12 .8$}

\section{Introduction}

Two decretals, X 5.12.8 and X 5.12.9, seem relevant regarding contributory negligence. ${ }^{296}$ The first text I want to discuss is a decretal from Pope Alexander III ${ }^{297}$ issued somewhere between 1159 and $1181^{298}$ contained in the Compilatio prima (1 Comp. 5.10.9) and the Liber Extra (1234), namely, X 5.12.8:

Idem Cusentinensi Archiepiscopo. Continebatur in literis tuis, quod, quum diaconus, praesentium lator, et quidam alii clerici a uineis ecclesiae opere consummato redirent, leuiandi laboris gratia quendam ludum imitati sunt uiatorum, proiicientes baculos suos in longum; studebant enim iacere in directum, et alter alterius fustem ferire. Cuius ludi, sicut asserunt, solet esse conditio, ut, qui alterius baculum percuteret, quasi uictor, pro equo alio, cuius baculus percussus est, uteretur; sed praefati clerici, equitandi licentia non utentes, sola erant iactione contenti, ut, dum alacrius ad baculos suos concurrerent, laborem itineris non sentirent. Quidam autem laicus, sicut praedictus diaconus asserit, dum baculum eiusdem diaconi percussisset, incautus in eum equitaturus insiliit, et sic a falce illius diaconi, qua erat accinctus, mortale uulnus accepit, de quo post dies octo exspirauit. Ideoque mandamus, quatenus eundem diaconum sine licentia Romani Pontificis ad superiorem gradum non adscendere, uel in diaconatus officio nullo unquam tempore ministrare permittas, sed eum dispensatiue ministrare in subdiaconatus officio patiaris. ${ }^{299}$

The same [Pope Alexander III] to the Archbishop of Cosenza (Italy). In your petition it is stated that a deacon, the applicant of this petition, and other clerics, after completing their work at the church-owned vineyard, would have returned, [and,] as a relief after work, for pleasure simulated a certain game pilgrims used to play. While throwing their sticks at a spot far away, they practised throwing in a certain direction, and moreover that one stick would touch the other's. The rule of the game, as we consider it, used to be that, whose stick hit someone else's stick, ${ }^{300}$ as if he were a victor, for reward was allowed to use the other as a horse, i.e. the one whose stick was hit; but the above-mentioned clerics did not make

296 Kuttner 1935, p. 24lf.; Luig 1969, p. 202.

297 The pontificate of Pope Alexander III, born Orlando Bandinelli, was from 1159 to 1181.

298 Jaffé 1851, p. 798, nr. 8921.

299 Friedberg 1881, col. 796.

300 Petrus Pantoja de Ayala $(\dagger 1584)$ explained it in such a way that the stick of one person should hit the other one's in the air; see his Comment. ad D. 11.5.2, nr. 45. 
use of this possibility to horse ride, but were satisfied with the throwing, ${ }^{301}$ in a way that, while they swung their sticks quite excitedly, would not feel the effort of the journey. A certain layman, however, as the above-mentioned deacon stated, while he had hit the stick of the same deacon, jumped on him with imprudence (incautus) in order to 'horse ride', and in this way he received a fatal injury by the sickle of that deacon, which he (the deacon) had fastened [to his belt], as a result of which the layman died after eight days. ${ }^{302}$ Therefore, we order that you (i.e. bishop of Cosenza), insofar as the same deacon will not ascend to a higher rank without the permission of the Roman pontifex (the Pope) and you will never permit him to exercise the office of deacon, permit him, by way of dispensation, to serve in the office of subdeacon. ${ }^{303}$

\section{Facts of the case: an exciting game}

Reading the text of X 5.12.8, one immediately wonders what kind of game the clerics were playing. Apparently, the game, which travellers used to play, was very widespread. It was known under the Greek name commonovolon. The word commonovolon is probably a corruption of the word condomonobolon, ${ }^{304}$ the game of jumping with a leaping pole, ${ }^{305}$ as mentioned in (and permitted by) C. 3.43.1.4..$^{306}$

301 A later addition gives a different wording which also makes sense, namely, iactatione (with the gesture).

302 Another translation of the contents of X 5.12.8 can be found in Schilling \& Sintenis 1838, p. 735f., and Kuttner 1935, p. 241 (German), Bellini 2003, p. 375 (Italian); a somewhat different summary can be found in Katz 1881, p. 19: 'Mehrere Geistliche und Laien kehren mit Sicheln vom Weinberge zurück. Auf dem Rückwege spielen sie ein Spiel, bei dem ein Jeder sich bemüht, mit seiner Sichel die Sichel des Andern niederzuschlagen, und dann nach Art eines Reiters sich auf den Rücken des Besiegten zu schwingen. Ein Laie springt auf den Rücken eines Geistlichen, der seine Sichel über die Schulter trug. Er springt in das Messer hinein und stirbt in Folge der Verletzung.'

303 The case of X 5.12.8 was also expounded by Bernardus Parmensis ( $† 1266)$ in the casus (to X 5.12.8) as reproduced in the Glossa ordinaria.

304 Or contomonobolon, as the reading in the old edition of Kriegel 1887, p. $217 \mathrm{f}$.

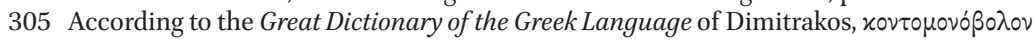
resembles the contemporary game of pole-jumping; it was performed by acrobats and balancers of the Byzantine amphitheatres to leap across moats and to jump over bodies of enraged beasts with the use of a long pole (stick), in the hippodrome (racetracks); reference is made to the fragment in Justinian's Code. See also Zamora Manzano 2011, p. 93: El monobolon ( $\mu$ ovóßo $0 v$ ) que consistía en el salto sin pértiga o libre, el otro tipo de salto en el que ésta si se usaba

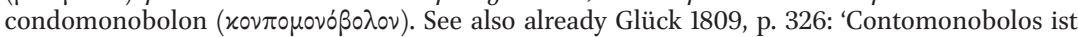
das Springen mit Hülfe einer Stange oder Springstocks.' He referred to I. Cuiacius (saltus conto suffultus) <Paratitla, ad C. 3.43; see edn. 1751, p. 345, EvD>, P. de Ayala [<Comment. ad C. 3.43, nr. 5 (edn. 1733, col. 1086): Contomonobolos saltus etiam, non singularis et simplex, sed cum conti seu sudis adminiculo ...] and Th. Balsamon (<scholion ad Photius' Nomocanon, tit. XIII, cap. 29, edn. 1615, p. 243: saltus>, EvD). However, Glück also referred to G. Pancirolus < Thesaurus variarum lectionum, lib. I, cap. 47; see edn. 1610, p. 59, EvD), who stated that 'Contomonobulum ludus est conti et ipsius semel iaculandi'.

306 Also D.35 c.l is especially relevant as it concerns the prohibition for clergy to play dice 
While the players threw their sticks at a spot far away, they practised throwing far away, i.e. in a certain direction (straight ahead), and tried to touch another's stick, but apparently with some kind of armour to protect the armpits, ${ }^{307}$ to make it more difficult to hit the stick. ${ }^{308}$ Hundreds of years later, Petrus Pantoja de Ayala $(\dagger 1584)^{309}$ seems to refer to this game of throwing sticks. ${ }^{310}$ As appears from X 5.12.8, the clerics did not completely practise the game as it used to be practised, since they did not use the possibility to horse ride (the more dangerous part of the game). ${ }^{311}$

\section{Interpretations of the canonists}

Various canonists gave interpretations of the papal decision by providing possible explanations for the declared culpability of the deacon in question. In general, as I have mentioned before, canonists argued that in a case of accidental homicide, the homicide had to be imputed to the wrongdoer if his culpa existed either (1) by acting in contravention of legal provisions or (2) by doing something permissible, but without using due diligence.

and get drunk; see on this text as well as the later commentaries on this text Hallebeek 2012, p. 145ff. Furthermore, according to C 3.43.1<.4> (which became known around ca. 1205), no one is allowed to gamble except in five types of games and for no more than one solidum. According to authentica Interdicimus just after C. 1.3.17, clerics were even forbidden to play or watch a board game or to visit any spectacle. See also J. de Breitenbach, Repetitio ad X 5.12.9, fo. 8r: ... ubi quinque ludi admittuntur, scilicet Comelon. Et est ludus ubi iactus uel lapis in longum protrahitur. Sicut forte est ludere ad paletum, uel sagittare. Hydolomonon. Et est ludus ubi iactus uel lapis in breue spatium retrahitur. Sicut forte est ludus pilarum. ... The game comelon was a game of throwing a spear for distance, as was maybe also the case with paletum or with the shooting of arrows. The same formulation can be found (under a slightly different term, i.e. comonbelon) with DuCange et al., Glossarium mediae et infimae latinitatis, II, col. 459b. s.v. comonbelon: deinde vero ordinent quinque ludos; Comonbelon, id est, ludus, ubi lapis in longum projicitur; Comondiaulion, id est, ludus, ubi lapis vel palus in breve spacium projicitur; - The constitution Alearum lusus (C. 3.43.1, dating from 529) of Justinian was originally a Greek constitution but summarised and translated into Latin in the Middle Ages. See Hallebeek 2012, p. 154, 158, who argues that the translation into Latin was probably done by Petrus de Cardona.

307 DuCange et al., Glossarium mediae et infimae latinitatis, VI, col. 108b. s.v. palectus: vel Palettus, Armorum genus, quod palmulam lusoriam, Gall. Palette, referret, sic appellari videtur. ...

308 Johannes Andreae, Commentaria, ad X 5.12.8, nr. 1; Henricus de Segusio, Commentaria, ad X 5.12.8, nr. 1 .

309 Little information is available on Pedro/Petrus Pantoja de Ayala (or: Ajala); a short description can be found in Jöcher 1750 (repr. 1960), col. 166; Vidal y Diaz 1869, p. 543f.

310 Pedro Pantoja de Ayala mentioned the game of throwing sticks in his commentary on D. 11.5.2, nr. 40 and compared it with the game of his own time called tirar bohordos (throwing lances at a wooden board while riding on a horse and trying to keep the lance sticking upright in the wood or going through it; see on the game of bohordos Del Mar Agudo Romeo 1993, esp. p. 20f.).

311 Henricus de Segusio, Commentaria, ad X 5.12.8, start and nr. 1. 
(1) The culpa could be sought in the following way. The game could be considered dangerous and therefore participation was prohibited for clerics ${ }^{312}$ or the game described was unbecoming of a cleric ${ }^{313}$ (since taking part in a dangerous game was regarded as acting culpably ${ }^{314}$ ) or the horse-riding condition was not suited for a cleric. ${ }^{315}$ Furthermore, some argued that the custom attached to the game was forbidden or that participation in the game was prohibited because of the intermingling with a layman. ${ }^{316}$

(2) Even if the game with its horse-riding condition was allowed (licitus), the deacon's act was not performed with due care.${ }^{317}$ Firstly, his sickle was disguised and therefore totally invisible, and he should have been aware that this could be dangerous because of the horse-riding custom of the game. Secondly, he should have removed the sickle from his belt, knowing the customs of the game..$^{318}$

There seems to have been a difference of opinion between Panormitanus who argued that it was permitted for clerics to play a game for relief and pleasure, ${ }^{319}$ but argued that the game was nevertheless not allowed because of the intermingling

312 See Bernardus Parmensis in gloss eiusdem Diaconi; Antonio a Butrio, Commentaria, ad X 5.12.8, nr. 5; - In general, in cases where injuries were inflicted during a game, and led to a fatal outcome, the canonists raised the question whether the game was permitted or prohibited. Dangerous games were considered res illicitae; see Kuttner 1935, p. 240, in accordance with the Roman fragment in D. 9.2.10 (ludus noxius in culpa est).

313 See Bernardus Parmensis in gloss ludum ad X 5.12.8.

314 According to Bellini 2003, p. 375, this game was dangerous because of its similarity with dice, and it was forbidden by the Church as such, especially when practised by religious people (religiosi).

315 Henricus de Segusio, Commentaria, ad X 5.12.8 (begin) and see also Johannes Andreae, Commentaria, ad X 5.12.8, nr. 4.

316 Sinibaldus Fliscus, Commentaria, ad X 5.12.8; Bernardus Parmensis in gloss eiusdem Diaconi and gloss Romanis Pontificis ad X 5.12.8; Henricus de Segusio, Summa. De homicidio uoluntario uel casuali. Qua pena feriatur, fo. 242v; Antonio a Butrio, Commentaria, ad X 5.12.8, nr. 5; Nicolaus de Tudeschis, Commentaria, ad X 5.12.8, nr. 1ff., and see also additiones a and b of Alexander de Nevo (ca. 1419-1485) to this fragment of Nicolaus de Tudeschis. See also, e.g., Felinus Sandeus, Commentaria, ad X 5.12.8. See also Breitenbach, Repetitio ad X 5.12.9, fo. 7v.

317 See Bernardus Parmensis at the end of the casus (to X 5.12.8); Henricus de Segusio, Commentaria, ad X 5.12.8, nr. If.; see also the Italian theologian and Dominican Sylvester Mazzolini da Prierio (1456/57-1523) in his Summa Summarium (1514), a manual for confessors, who argued that despite the fact that the game was allowed (licitae), it was not performed with due care. Because the deacon knew the customs of the game, he should have removed the sickle. See Sylvester de Prierio, Summa Summarium. Rursus de homicidio secundo, inquantum est casuale, nr. 5 .

318 Gloss Romanis Pontificis ad X 5.12.8; Antonio a Butrio, Commentaria, ad X 5.12.8, nr. 6. See also Katz 1881, p. 19: 'Die gl. Romani imputirt dem Geistlichen culpa, weil er wissen musste, dass es bei diesem Spiel Sitte ist, auf den Rücken des Andern zu springen, und er daher die Sichel nicht über die Schulter nehmen durfte.'

319 On this topic, see also Felinus Sandeus, Commentaria, ad X 5.12.9. 
with a layman, and others who argued that the game was permitted even with such a condition, but the deacon nevertheless acted culpably because, knowing the custom of the game, he did not remove his sickle.

But what would have been the case if the (sub)deacon clearly had refused permission to be used for a horse ride? Could any negligence be imputed to him then? Hostiensis (Henricus de Segusio, ca. 1200-1271) ) $^{320}$ argued that because of the game the deacon should have considered the possibility that someone could jump on him. However, according to Parnormitanus, he could have doubt on this matter; nevertheless, a decision was better taken in favour of the cleric. ${ }^{321}$ Hostiensis argued that even though the deacon had not given permission to the layman to jump on him to horse ride, he nevertheless should be judged to be at fault because he should have been aware of the custom of the game: the layman did no wrong, because the custom of the game allowed him to horse ride. The fact that clerics did not make use of the horse-riding rule does not excuse the deacon. He acted culpably all the same, because he should have been aware of the fact that someone could jump on him and he should have taken precautions. ${ }^{322}$

An interesting argument is put forward by Sinibaldus Fliscus $(\dagger 1254),{ }^{323}$ who states that the deacon can also be considered to have acted culpably because the sickle was disguised. The sickle was girded in such a way that it was invisible to others, and therefore the layman who jumped on the cleric was excused by law since he could not possibly have seen the sickle (so no contributory negligence on his side occurred). Furthermore, if horse-riding was a custom in this game, the loser had to remove the sickle so the winner could ride on his back. Despite the fact that clerics made no use of the possibility of horse-riding, the act of the deacon could still be imputed to him. He had been careless since he could have given up his right to horse ride, but did not have the right to take away that right from other players. ${ }^{324}$

320 The decretalist Henricus de Segusio (Hostiensis) studied law in Bologna. He received the bishopric of Sisteron, became archbishop of Embrun and, in 1262, received the cardinalate from Pope Urban IV in the form of the bishopric of Ostia whence he was later called Hostiensis.

321 Nicolaus de Tudeschis, Commentaria, ad X 5.12.8, nr. 3.

322 Henricus de Segusio, Commentaria, ad X 5.12.8, nr. 1; see also Antonio a Butrio, Commentaria, ad X 5.12.8, nr. 6 .

323 Pope Innocent IV was born in Genoa before 1200. Born Sinibaldo dei Fieschi (Fliscus), he studied law in Parma and perhaps in Bologna. He worked as a jurist at the papal curia beginning in 1226 and was for some time the auditor of the court of audientia litterarum contradictarum. He was made a cardinal by Pope Gregory IX in 1227. He was elected Pope in 1243 and held the pontificate until his death in 1254 .

324 Sinibaldus Fliscus, Commentaria, ad X 5.12.8 and see also Johannes Andreae, Commentaria, ad X 5.12.8, nr. 1 . 


\section{On irregularity}

In canon law, an irregularity (namely, irregularitas ex delicto) prevented the priest from canonically performing the sacraments and the other duties of his office. ${ }^{325}$ Irregularity can have three effects: the prohibition of promotion in the law of ordination, the prohibition to exercise an office (without removal of the degree of consecration) and deposition from the present ordination and office. ${ }^{326}$ The institute of irregularity was intended to safeguard the dignity of the Church, by the selection of a clergy of an irreproachable state. In order not to give offence to the faithful, not in order to punish the guilty person, ${ }^{327}$ the Church prevented ordination and promotion in cases where ordinees did not have sufficient external dignity. ${ }^{328}$

Persons who wanted to be promoted to holy orders (subdiaconate, diaconate or priesthood) even though they had been involved in a casual homicide had to be given dispensation. ${ }^{329}$ Dispensation could be given by the Pope (later delegated to the Penitentiary) to persons who pursued an ecclesiastical career but were considered irregular and thus incapable of acting in an ecclesiastical office. After a papal dispensation they could continue with or enter into their ecclesiastical career despite their defect. ${ }^{330}$ Candidates for an ecclesiastical office could not be illegitimate, they had to be old enough, bodily defects were not allowed, they had to be qualified enough to be able to act in the office and had to have a good reputation. ${ }^{331}$ Persons who did not meet these requirements were considered irregular. Such irregularity was suspendable by a papal dispensation, which cancelled the irregularity. ${ }^{332}$

The case of X 5.12.8 deals with an irregularitas ex delicto because homicide (homicidium) was concerned. Committing a crime led to the non-fulfilment of the requirement 'to have a good reputation'. The dispensation had to be granted by papal authority because it concerned the holy orders; with regard to minor orders the local bishop could grant dispensation suo iure. ${ }^{333}$ Indeed,

325 Kjeldsen 2009, p. 2.

326 See, e.g., Breitenbach, Repetitio ad X 5.12.9, fo. 3r, and on fo. 4r. See also Metz 1954, p. 96, who writes: '... irrégularité, qui entraîne l'interdiction d'accéder aux ordres ecclésiastiques, d'avancer aux ordres supérieurs s'il en a déjà reçu ou d'exercer les fonctions dont il a été investi.'

327 According to Metz 1954, p. 96, '... elle ne constitue pas une peine ...' and on p. 97: 'Mais la mesure prise à son egard n'a pas un caractère pénal.'

328 See Kuttner 1935, p. 187f., 232ff.; Metz 1954, p. $96 f$.

329 See Göller 1911, II, p. 3 (bulls of Pius II and Paul II); Salonen 2001, p. 62. Certain grants of absolution, dispensation or special licenses in matters reserved to the Pope were dealt with by the Penitentiary, i.e. those especially delegated by the Pope to the poenitentiarius maior or to the office in general; see also Göller 1907, I, p. 100ff.

330 Salonen 2001, p. 67.

331 On these requirements, see also Salonen 2001, p. $178 \mathrm{ff}$.

332 Salonen 2001, p. 68.

333 See also Johannes Andreae, Commentaria, ad X 5.12.8, nr. 2; see also Diego Covarruvias 
only in the case of an accidental homicide could dispensation be granted but, with regard to the major or holy orders, only by the Pope. Furthermore, the (arch)bishop could not give dispensation iure suo, but only as commissarius of the Pope, since as to the holy orders only the Pope could grant dispensation and a bishop could grant dispensation iure suo only for the minor orders. ${ }^{334}$

\section{Contributory negligence of the deacon?}

In this case, despite the imprudence (incautus) of the layman, the deacon was considered responsible and was degraded (to the position of subdeacon). Therefore, one could argue that, despite the contributory negligence of the injured party, the wrongdoer was held responsible because the contributory negligence was less serious than the negligence of the wrongdoer. However, the commentaries of the decretalists do not explain X 5.12.8 in this way. ${ }^{335}$ They directly focused on the question of the negligence of the deacon, ${ }^{336}$ the most relevant question in the appeal to the Pope. It has been unjustly suggested in the secondary literature that the fact that one aimed directly at the question of the negligence of the deacon was because of the lack of a partial solution in case of contributory negligence (still an all-or-nothing approach ${ }^{337}$ ) and that therefore the jurists tended to attribute the 'sole guilt' to the party that acted with the highest degree of negligence. ${ }^{338}$ The source (X 5.12.8) does not necessarily lead to this conclusion. The question of the negligence of the deacon was the only relevant issue in this trial and more specifically the question whether the deacon could still be promoted and/or exercise his function as a deacon, for which all relevant circumstances had to be taken into account. The question submitted to the Pope was not the question of which

a Leyva, Opera Omnia. Pars II. § III. De abortu, bello et homicidio, nr. 5, who - among others refers to Siete Partidas I.6.15.

334 Nicolaus de Tudeschis, Commentaria, ad X 5.12.8, nr. 3f.

335 Luig 1969, p. 202.

336 Kuttner 1935, p. 241; according to Kuttner, some decretalists argued that the game was not permitted, however most decretalists were of the opinion that it certainly existed as a permissible game but that the deacon acted without the necessary care: he had to put his sickle aside or warn the other players; see Kuttner 1935, p. 241, esp. nts. 1 and 2 in which transcriptions of parts of these (early) decret(al)ists are given. Comprehensive research of the relevant manuscripts of the decretists and decretalists on this topic would clarify the matter, but lies beyond the scope of this study.

337 X 5.36.3 could indicate differently (division of damage); however, it is not clear whether this text is used in cases where both parties acted negligently nor whether this text has been generalised by the decretalists; see Lange 1955, p. 73; therefore, it can be assumed that the approach was still all-or-nothing. A different view has been taken by Kiefer 1989, p. 33, who argued that the idea of the division of damage according to the degrees of negligence first appeared in canon law, but without evidence of generalisation. In that respect, he refers to X 5.36.3 and states that Exodus 21:35-36 was the model for this (this text will be discussed later).

338 Argued by Luig 1969, p. 202. 
of the two parties had to be held liable for the accident, but only whether the culpability of the deacon was at stake. ${ }^{339}$

\subsubsection{The case of X5.12.9}

The second text I want to discuss is a decretal from Pope Alexander III issued between 1161 and $1168^{340}$ contained in the Compilatio prima (1 Comp. 5.10.10) and the Liber Extra (1234), namely, X 5.12.9:

Idem Exoniensi Episcopo. Lator praesentium P. clericus nobis uiua uoce proposuit, quod, quum quadam die casu cum quodam clerico luderet, contigit, quodille proiecit istum ad terram, cuius cultellus, quem ad latus suum habebat, in alterum incidit, et fortuito casu occubuit uulneratus. Ideoque mandamus, quatenus, rei ueritate comperta, si ita res se habuit, et alia iusta causa non impedit, praedictum P. libere permittas ad sacros ordines promoueri. ${ }^{341}$

The same [=Pope Alexander III] to the bishop of Exeter. The applicant of this petition, a cleric P., orally expounded his view to us that, when a certain day it occurred that he played with another cleric and he had pushed him, [and] that the other cleric threw him to the ground; the knife he had [attached] to his side cut the other (the cleric who threw him) accidentally wounding him [so that] he died on the event. And therefore, if it is proven to be true, and if the case happened in this way, and [if] no other valid reason obstruct this, we order, that you, bishop, are free to promote the aforementioned P. to a higher ordination. ${ }^{342}$

From a modern perspective, X 5.12.9 can also be considered to be a problem of contributory negligence. One could argue that the responsibility of the wrongdoer (the cleric P.) is cancelled out because of the preponderant contributory negligence of the injured party (the other cleric). ${ }^{343}$ This, however, cannot be concluded from the commentaries of the decretalists. ${ }^{344}$

339 Regarding the question whether the deacon could be promoted to a higher rank, the negligence of the injured party was brought up and was taken into account, in this case leading to the conclusion that the deacon could not ascend to a higher rank. This conclusion is confirmed by some commentaries on the text discussed above (esp. those of Innocent IV and of Hostiensis).

340 Jaffé 1851, p. 820, nr. 9273.

341 Friedberg 1881, col. 797.

342 Another translation of the contents of X 5.12.9 in German can be found in Schilling \& Sintenis 1837, p. 736, and Kuttner 1935, p. 242.

343 Luig 1969, p. $202 \mathrm{f}$.

344 According to Kuttner, the injured party acted culpably, but the wrongdoer did not act culpably at all; see Kuttner 1935, p. 242, where also parts of transcriptions of early decretists/ decretalists on this point can be found. With regard to the promotion of a cleric who killed someone, and thereby acted culpably, according to Animal ad D.50 c.50, no culpae compensatio 
Various interpretations of $X 5.12 .9$

As already stated above, an accidental homicide without a preceding culpable act could not be imputed to the wrongdoer. In this case, the Pope concluded that the accidental homicide was certainly not caused by any negligence of the cleric (Bernardus Parmensis ${ }^{345}$ named him Petrus). ${ }^{346}$ Various canonists provided divergent reasons to explain this solution. An accidental death could not be imputed to someone who did not act culpably (aliqua culpa), ${ }^{347}$ and to support the conclusion that the cleric was not culpable in this case, the decretalists considered the cleric to have acted with due care and to have taken the necessary precautions. ${ }^{348}$

First of all, they preconceived that the cleric was allowed to play with another cleric. ${ }^{349}$ Most decretalists argue that the game was allowed because it was a chess game or some other smooth, harmless recreational game (not a noxius) harmful game) ${ }^{350}$ A diverting game was indeed not forbidden for clerics. ${ }^{351}$ If a game had been forbidden, taking part in such a game would be imputed to the wrongdoer himself (as in X 5.12.8). But chess or other insignificant games were not forbidden to clerics. A brief look at the relevant legal rules provides us with the following information. Clerics were forbidden to play or watch a board game or to visit any spectacle (see authentica Interdicimus, just after C. $\left.1.3 .17^{352}\right)$. Already Pope Innocentius III (1160/61-1216), ${ }^{353}$ in the decretal Inter dilectos of $1209,{ }^{354}$ complained about the established practice of French clerics

could take place (see chapter three, p. 155).

345 Bernardus Parmensis (Bottono, de Botone) was born in the late 12th or early 13th century, and studied canon law in Bologna under Tancred. Later he taught canon law in Bologna. By 1247 , he was also a papal chaplain.

346 See casus ad X 5.12.9.

347 Nicolaus de Tudeschis, Commentaria, ad X 5.12.9, nrs. 1 and 3.

348 Finally, Covarruvias (1512-1577), who belonged to the school of early modern Scholasticism, questions why the two cases in which someone killed accidentally (X 5.12.8 and X 5.12.9) resulted in a different verdict. According to Covarruvias, the difference lay in the culpability: the wrongdoer in X 5.12.8 acted culpably, since he did not act with due care, because he did not take precautions as he should have. The wrongdoer in X 5.12.9, however, did take precautions and therefore no irregularity occurred (the carefulness seems to justify the act). See Diego Covarruvias a Leyva, Opera Omnia. Pars II. § IV. De homicidio casuali, nr. 8.

349 Gloss luderet ad X 5.12.9; Johannes Andreae, Commentaria, ad X 5.12.9, nr. 3; Henricus de Segusio, Commentaria, ad X 5.12.9; Isaac would have played with Ismaël (C.32 q.4 c.2); see also Genesis 21; Joseph would have played with his brothers (C.22 q.2 c.18); see also Genesis 44.

350 Sinibaldus Fliscus, Commentaria, ad X 5.12.9; J. de Breitenbach, Repetitio ad X 5.12.9, fo. $5 \mathrm{v}$; on chess in medieval Europe, see Van Egmond \& Mostert 2001.

351 See Nicolaus de Tudeschis, Commentaria, ad X 5.12.9 (see below). On a ludus solatiosus see also additio a of Zacharias Ferrerius (1479-1524) ad Nicolaus de Tudeschis, Commentaria, ad X 5.12.9; J. de Breitenbach, Repetitio ad X 5.12.9, fo. 5r.

352 Nicolaus de Tudeschis, Commentaria, ad X 5.12.9, nr. 2.

353 Pope Innocentius III, born Lotario dei Conti di Segni, held the pontificate from 1198-1216.

354 Potthast 1874 (reprint 1957), p. 316, nr. 3662. 
to game. He strongly disapproved of this habit, calling it a perverse custom, which should rather be qualified as depravation. ${ }^{355}$ Furthermore, in canon 16 of the Fourth Lateran Council of 1215 (later adopted as a decretal in the Compilatio quarta of Johannes Teutonicus as the decretal Clerici (4 Comp. 3.1.4) and adopted in the Liber Extra in X 3.1.15), gambling was prohibited. Clerics should not gamble or play dice, nor be present when such games were played. ${ }^{356}$

In the case of X 5.12.9, because of the 'push', some decretalists argue that it concerned a game of wrestling or similar game, ${ }^{357}$ but they came to the same conclusion, namely, that this game was permitted also to clerics (for the purpose of displaying courage and tenacity; see D. 11.5.2.1). ${ }^{358}$

Secondly, one argued based on the facts, since it was the other cleric who threw him on the ground, and so it was not the act of the cleric Petrus that produced the damage ${ }^{359}$ Therefore, the cleric could not possibly have taken precautions in order to avoid injuring his companion, ${ }^{360}$ as he could not have foreseen that someone would throw him on the ground. ${ }^{361}$

Thirdly, one argued that it was rather normal to wear a small knife because of its usefulness in cutting bread and that it was more commonly used than a sickle (as in the case in X 5.12.8); ${ }^{362}$ it was even argued that the small knife was in its sheath. ${ }^{363}$ Cutting bread is an act performed on a daily basis. It would have been different if a sword was involved. ${ }^{364}$ To wear a knife on a belt with

355 Around 1210 this decretal was adopted in the Compilatio tertia of Petrus Beneventanus $(† 1219 / 20)$, namely, 3 Comp. 5.14.4, and later it was adopted in X 5.31.11. See also Hallebeek 2012, p. 152.

356 Canon 16 in Alberigo \& Jedin 1973, p. 243; Hallebeek 2012, p. 153.

357 Later, also Pedro Pantoja de Ayala seems to have taken this interpretation of the facts of the case and just stated that two clerics were wrestling; see his Comment. ad D. 11.5.2, nr. 46 .

358 Antonio a Butrio, Commentaria, ad X 5.12.9, nr. 4; Diego Covarruvias a Leyva, Opera Omnia. Pars II. § IV. De homicidio casuali, nr. 8.

359 Gloss proiecit istum ad terram ad X 5.12.9; Henricus de Segusio, Commentaria, ad X 5.12.9, nr. 2; Johannes Andreae, Commentaria, ad X 5.12.9; Antonio a Butrio, Commentaria, ad X 5.12.9, nr. 4; Sylvester de Prierio, Summa Summarium. Rursus de homicidio secundo, inquantum est casuale, nr. 6.

360 See Sinibaldus Fliscus, Commentaria, ad X 5.12.9.

361 In cases of casus, where the cleric could not have foreseen certain events (such as the fact that someone would throw him on the ground?), he did not act culpably. This would be different if certain consequences could be foreseen but nevertheless the wrongdoer did not act accordingly; see Henricus de Segusio, Commentaria, ad X 5.12.9, nr. If.

362 Henricus de Segusio, Commentaria, ad X 5.12.9, nr. 2; Johannes Andreae, Commentaria, ad X 5.12.9, nr. 3; Breitenbach, Repetitio ad X 5.12.9, fo. 5v.

363 Johannes Andreae, Commentaria, ad X 5.12.9, nr. 1ff.; Antonio a Butrio, Commentaria, ad X 5.12.9, nr. 4; unfortunately, I could not find the reference made by the two just-mentioned canonists to Panormitanus. See also Breitenbach, Repetitio ad X 5.12.9, fo. 5v, who also mentioned the fact that the small knife was in its sheath (Potest etiam dici quod iste clericus habebat cultellum in uagina).

364 Nicolaus de Tudeschis, Commentaria, ad X 5.12.9, nr. 3, who referred to X 3.1.2. This 
the sharp side downwards was also the custom, and therefore not putting it away was not malicious. ${ }^{365}$

Fourthly, some argued that the throwing of the cleric to the ground was not part of the (original) game of chess, ${ }^{366}$ but happened unexpectedly and therefore this struggle did not occur upon mutual agreement. ${ }^{367}$ Of course the situation would have been different if the cleric had deliberately played the game of wrestling (ex deliberatione), because in that case he should have put aside his knife, and since he did not do that, his act could be imputed to him, ${ }^{368}$ at least he could not be regarded as having acted without culpa. If there had been mutual agreement on the game of wrestling, the person who was thrown to the ground should have put his knife aside, and the omission of that would have been imputed to him. ${ }^{369}$

Two remarks are interesting with regard to the problem of 'contributory negligence'. Firstly, the remark of Bernardus that it was not the cleric thrown to the ground who acted culpably, but the person who threw him (D. 9.1.1.11 is used as an argument). ${ }^{370}$ Secondly, the remark of Hostiensis is interesting for the fact that wearing a knife on one's belt was customary and therefore the other cleric should have been aware of that and have acted with care, so this should not be imputed to the cleric Petrus. ${ }^{371}$

\section{The issue of dispensation}

The end of X 5.12.9 is not quite clear and can be explained in two different ways. The central question, discussed by the canonists, is what the Pope exactly de-

text of X 3.1.2 (Clerici arma portantes et usurarii excommunicentur) is interesting as a sword seems to be part of the more general 'arma', and therefore would lead to the excommunication of the cleric; - Differently Sylvester de Prierio (1456-1523), in his Summa Summarium. Rursus de homicidio secundo, inquantum est casuale, nr. 5, uses the word sword (gladium) which, in my opinion, indeed changed the situation.

365 See also Antonio a Butrio, Commentaria, ad X 5.12.9, nr. 4.

366 See also J. de Breitenbach, Repetitio ad X 5.12.9, fo. $5 \mathrm{v}$.

367 Henricus de Segusio, Commentaria, ad X 5.12.9, nr. lf.; Johannes Andreae, Commentaria, ad X 5.12.9, nr. 3; Antonio a Butrio, Commentaria, ad X 5.12.9, nr. 4. See also Nicolaus de Tudeschis, Commentaria, ad X 5.12.9, nr. 2.

368 Antonio a Butrio, Commentaria, ad X 5.12.9, nr. 4

369 Nicolaus de Tudeschis, Commentaria, ad X 5.12.9, nr. 2; - In that case the thrower would not have acted culpably because throwing the other to the ground is the main aim of wrestling; see also the later P.P. de Ayala, Comment. ad D. 11.5.2, nr. 46.

370 Gloss Romanis Pontificis ad X 5.12.8: ... et ille potius ingessit se, proiiciendo alium ad terram: et sic non fuit in culpa, sic 12 q.4 Inter caetera, in fin. [C.22 q.4 c.22 §2]. Sed ille, qui ipsum proiecit, fuit in culpa, arg.ff. Si quadr. pau.fe. dica. l.i § Cum arietes [D. 9.1.1.11]. ...

371 Henricus de Segusio, Commentaria, ad X 5.12.9, nr. 2. 
cided in this decretal: did he just determine what the content of ius commune is or did he grant dispensation?

Some jurists ${ }^{372}$ apparently argued that the phrase 'that the bishop is free (libere) to promote the aforementioned P. to a higher ordination' meant that a (personal/subjective) right (of the bishop to decide on this matter) based on the ius commune is concerned. ${ }^{373}$ Accordingly, Nicolaus de Tudeschis argued, based on the Gloss, that the cleric could be promoted based on the ius commune, since he was not hit by any irregularity because he did not act with a certain negligence (aliqua culpa). The bishop would not be free to grant a promotion if a dispensation was necessary. But here the cleric was promoted based on the law and a dispensation was unnecessary. ${ }^{374}$ According to Hostiensis, from the last sentence of X 5.12.9 it may be concluded that the cleric Petrus, who in this case of accidental homicide acted in a way that was permitted, could be promoted without need for dispensation. He could even continue to practise in the same function he already had. ${ }^{375}$

Others argued that libere meant free, namely, after dispensation by the Pope (i.e. an exception for an individual case). ${ }^{376}$ However, as already stated by Johannes Andreae, the possible promotion of the aforementioned P. to a higher ordination by the bishop was not free (libere) if dispensation was needed to be provided first (by the Pope, EvD). ${ }^{377}$

\section{Concluding remarks}

Two canonists explicitly commented on the position of the injured party. After it was already stated by Bernardus Papiensis in his Summa decretalium

372 Alanus and Vincentius, according to Johannes Andreae, Commentaria, ad X 5.12.9, nr. 3.

373 See gloss libere ad X 5.12.9.

374 Nicolaus de Tudeschis, Commentaria, ad X 5.12.9, nr. 4; see also Antonio a Butrio, Commentaria, ad X 5.12.9, nr. 5.

375 Henricus de Segusio, Commentaria, ad X 5.12.9,nr. 3; and implicitly gloss Romanis Pontificis with siglum Ber. (Bernardus) ad X 5.12.8.

376 Bernardus Parmensis in gloss libere ad X 5.12.9 (who just referred to 'alii' without mentioning which canonists hold this view); - According to Kuttner 1935, p. 242f., the decretalists examined whether the solution of X 5.12.9 was not in contradiction with that of X 5.12.8. According to them, this is not the case because in X 5.12.9 the negligence was put on the injured party, who threw the other party to the ground. Furthermore, in X 5.12.9 the game was permitted and the person whose knife cut another person did not act negligently because it was not possible to have foreseen such a turn (of events). Otherwise, the guilt of the wrongdoer has to be assumed, and the decision of Pope Alexander has to be considered as a dispensation.

377 Johannes Andreae, Commentaria, ad X 5.12.9, nr. 3f.; - Of course, the removal of one impediment (e.g. the accidental homicide without preceding culpa) does not lead to the removal of another (e.g. another crime which he committed). The removal of one impediment does not directly mean that the cleric in question could be ordained, because there could be another impediment on the side of the cleric (if it has a legitimate reason) which prevents such an ordination. See Antonio a Butrio, Commentaria, ad X 5.12.9, nr. 2. 
that in the case of 1 Comp. 5.10.10 (X 5.12.9), the fatal accident was due to the negligence of the deceased, the same comment was now made by Bernardus Parmensis, in a gloss to X 5.12.8, who argued that the killing was due to the negligence (culpa) of the injured party (who threw the other onto the ground). ${ }^{378}$ One has to keep in mind that the question in this case before the Pope was only whether the cleric did or did not act with negligence and whether the cleric could or could not be promoted (and if dispensation was necessary). The conclusion that due to the lack of a possibility to distribute the damages over both parties in case of contributory negligence (which was not at all at stake here) the jurists tended to attribute the 'sole guilt' to the party that acted with the highest degree of negligence can only be taken with care (analogous interpretation).

Hostiensis argued that the other cleric should have been aware that wearing a knife attached to a belt was customary, and therefore he should have been careful. ${ }^{379}$ It seems that therefore the 'contributory negligence' led to the sole guilt on the side of the injured party. One could argue, as some modern scholars do, that the liability of the tortfeasor in question is cancelled out because of the preponderant contributory negligence of the injured party. Although the question of liability was not at all at stake in the legal case brought before the Pope if one looked at it from that modern perspective; the majority of the commentaries of the decretalists I consulted do not follow such a theory. However, the just-mentioned comments of Bernardus Parmensis and Hostiensis, who were two influential persons, could indeed indicate that this theory was applied. ${ }^{380}$

\subsubsection{Contributory negligence according to the law of decretals}

\subsubsection{The case of $X$ 5.16.6}

\section{Introduction}

Another case, already mentioned earlier in this chapter because it was frequently cited by the Commentators, is a decretal of Pope Innocentius III of $1208^{381}$ contained in the Compilatio tertia (3 Comp. 5.8.1) and the Liber Extra (1234), namely, X 5.16.6. According to this fragment, a husband could not blame his wife for adultery if it was proven that he also committed adultery.

378 Gloss Romanis Pontificis ad X 5.12.8.

379 Henricus de Segusio, Commentaria, ad X 5.12.9, nr. 2.

380 Gloss Romanis Pontificis ad X 5.12.8; Henricus de Segusio, Commentaria, ad X 5.12.9, nr. 2.

381 Potthast 1874 (reprint 1957), p. 289, nr. 3387. 
Innocentius III. Turonensi Archiepiscopo. Intelleximus tam per literas uenerabilis fratris nostri Pictauiensis episcopi, quam per ea, quae coram dilecto filio Andrea subdiacono et capellano nostro, super hoc auditore concesso, proposita pro partibus exstiterunt, quod, quum S. laicus H. uxorem suam a maritali consortio sine causa rationabili depulisset, idem episcopus dioecesanus eorum, audiens, mulierem eandem cum quodam adultero fornicari, eam et illum uinculo excommunicationis adstrinxit, quae, tandem adulterum abiurans, absolutione recepta coram episcopo memorato praedictum uirum sibi restitui postulauit. At ille, huiusmodi obiiciens ei adulterium, de quo prolem genuisse dicebat eandem, et quod ab ipso non expulsa, sed spontanea recessisset, restitutionem sui proposuit ei esse minime faciendam; quod mulier memorata prorsus inficians, replicauit in ipsum, quod fuerat fornicatus, et de fornicatione sobolem procrearat, propter quod tali exceptione uti non poterat contra ipsam. Quum autem, utrique parti probandi haec facultate concessa, praefata mulier per quosdam testes eiusdem uiri adulterium probauisset, quos uir ipse dicebat tanquam minus idoneos reprobandos, tandem ab eo fuit ad nostram praesentiam appellatum. Quocirca fraternitatituae per apostolica scripta mandamus, quatenus, nisi tibi constiterit, uel per euidentiam rei, uel per confessionem legitimam mulieris, quod adulterata sponte fuisset adulterii etiam, quod uir dicitur commisisse, probatione cessante, ipsum recipere compellas eandem. Quodsi praedicto modo de mulieris fornicatione constiterit, nisi testes, per quos uiri adulterium est probatum, fuerint reprobati, quum matrimonii ius in utroque laesum consistat, et paria delicta mutua compensatione tollantur: nihilominus eum cogas, ut eam recipiat, et maritali affectione pertractet; alioquin mulieripraedictae silentium imponere non postponas. [Dat. Lat. VI. Kal. Maii Ao. XI. 1208.] ${ }^{382}$

Innocentius III to the archbishop of Tours. Not only from the letter of our respectable brother the bishop of Poitiers have we understood, but we also understand from the things that were said in the presence of the beloved son Andreas, our subdeacon and our chaplain, who is admitted as an auditor into this case, that the following intention has come into being: when layman S. repudiated his wife $\mathrm{H}$. without a reasonable reason from the marital union, their diocesan bishop, hearing that the wife committed adultery with a certain adulterer, restrained her and the adulterer with excommunication; if the wife at last renounced the adulterer after she received absolution, in the presence of the aforementioned bishop, the latter requested that her aforementioned husband return to her. But he argued that if the husband, nevertheless, blamed her for the adultery, from which a child was born, and she was not repudiated by him, but voluntarily departed from him, the husband did not have to take her back; the wife totally denied and replied to

382 Friedberg 1881, col. 807. 
him that the husband committed adultery and by means of this illicit sexual act had a child, and therefore the husband could not have any right to any exception. Then, nevertheless, while the competence to prove this is granted to both parties, the aforementioned wife by certain witnesses of the same man had proven his adultery, of whom the man pretended that these witnesses had to be refused as less suitable; after all it was the husband who brought an appeal to 'our presence' (i.e. to the Pope). Therefore by way of this apostolic writing we order your fraternity, unless it is certain for you by the clearness of the case or by the lawful confession of the wife that the adultery the woman committed was committed of her own accord, while the evidence for the husband's adultery had no effect, you order the husband to take her back. But when it is proven, in the aforementioned way, that the wife committed adultery, unless witnesses by whom the adultery of the man is proven were refused, that to both spouses damage is inflicted based on marital law, and both equal delicts are cancelled out by way of mutual compensation, nevertheless you force him to take her back, and to treat her with marital affection; otherwise ${ }^{383}$ you will not postpone to silence the aforementioned woman. ${ }^{384}$

\section{Facts of the case}

The wife was considered to be deprived (of her possession of her marital rights) because after having left the house she wanted to return, but was not allowed to do so. ${ }^{385}$ In this conflict the husband objected that the wife had committed adultery and she replied that he had also committed adultery ${ }^{386}$ and that because of that circumstance he could not defend himself as he did. The voluntariness of the adultery of the wife could be evident, because her adultery was committed in public or a child was born, ${ }^{387}$ or it became clear from a confession of the woman (in iure and by her own free will). ${ }^{388}$

383 This means the adultery of the woman was proven but her witnesses to prove her husband's adultery had been refused, so the adultery of the man could not be proven; see, e.g., also Bernardus Parmensis in gloss alioquin ad X 5.16.6 (and also Johannes Teutonicus in his apparatus ad alioquin): Id est, si constiterit de adulterio mulieris, et non uiri.

384 In that case, the man was not obliged to take her back; - A translation of the Latin text in German can be found in Schilling \& Sintenis 1837, p. 747f.

385 See gloss spontanea ad X 5.16.6.

386 Already Goffredus Tranensis $(\dagger 1245)$, in the first full apparatus on the Decretales Gregorii $I X$, affirmed that when a wife was accused of adultery by her husband, she could object that the husband also committed (a similar kind of) adultery; see Goffredus Tranensis, Summa super titulis decretalium, De adulteriis et stupro, nr. 3, fo. $215 \mathrm{v}$.

387 Gloss euidentiam ad X 5.16.6.

388 Gloss confessionem ad X 5.16.6; see also Laurentius Hispanus, Apparatus glossarum, ad 3 Comp. 5.8.1 (X 5.16.6), ad per confessionem legitimam: Spontaneam, arg. xxxi. q. ii. Lotharius [C.31 q.2 c.4] et in iure et presente aduersario. 
What was the legal problem in this case? The case of X 5.16 .6 obviously concerned a case in which the woman brought a remedy to enforce a marriage contract. It concerned a remedy known as restitution of conjugal rights. ${ }^{389}$ The woman had to prove that she had been in possession and that she was deprived of her possession by her husband without process of law. If she succeeded in this, she would be entitled to restitution, unless it was shown she deprived herself of her right. ${ }^{390}$ If the woman won the lawsuit, the man had to accept the woman as his legitimate spouse and treat her with marital affection. ${ }^{391}$ In this case, by leaving the house she did not lose the quasi-possession of her husband, because she could have retained it by her mere intention; however, because the man did not permit her to come back, she was considered deprived (of her possession).

The requested restitution of the woman cannot be refused with the argument of adultery, unless it was committed by the woman in public (the criterion of 'public and manifest fornication' ${ }^{392}$ ). Despite the fact that the woman went away of her own free will, she had to be considered deprived of her possession because she wanted to return and was not permitted to do so, and therefore she could claim restitution. ${ }^{393}$.

\section{Various views on $X$ 5.16.6}

Canonists argued that when the evidence produced by the woman to prove that the man committed adultery succeeded, the fact that the woman also committed adultery (an act with dolus) would be compensated by the fact that the man committed adultery (also an act with dolus). ${ }^{394}$ When both parties committed adultery, the intentional act of both parties (dolus) was compensated. ${ }^{395}$ A compensation of crimes was regarded as permitted because equal delicts were cancelled out by way of mutual compensation. ${ }^{396}$ This leads to the

$389 c f$. Danahue 2007, p. 36.

390 See Donahue 2007, p. 36.

391 On the restitution of conjugal rights, see Helmholz 1974, p. 67ff.

392 See Tancredus, Summa de matrimonio, 33 (edn. Wunderlich 1841, p. 73f.) - also mentioning other exceptions - and also Donahue 2007, p. 36.

393 However, according to Johannes Teutonicus ( $c a$. 1170-1245), there are many exceptions as a result of which the claim of the deprived woman nevertheless had to be denied; see Johannes Teutonicus, Apparatus glossarum, ad 3 Comp. 5.8.1 (X 5.16.6) (edn. K. Pennington, available at http://faculty.cua.edu/Pennington (last visited on 1 May 2013)).

394 Laurentius Hispanus in his gloss ad probatione cessante ad 3 Comp. 5.8.1 (X 5.16.6): Nam si probetur dolus dolo compensabitur, infra c. sequenti, supra eodem titulo, Significasti [1 Comp. 5.13.6 (X 5.16.5)].

395 Gloss cessante ad X 5.16.6.

396 See also gloss of Laurentius Hispanus ad paria delicta mutua compensatione tollantur ad 3 Comp. 5.8.1 (X 5.16.6): supra xxxii. q. vi. Nichil iniquius [C.32 q.6 c.1], ff. soluto matrim. Viro atque uxore [D. 24.3.39], iuxta illud facinus quos inquiunt et longe equius omnem maliciam actori licere quam reo, ff. de doli excepti. Apud Celsum $\$$ Marcellus [D. 44.4.4.13]; see also Durantis, 
conclusion that a husband could not blame his wife for committing adultery if he also committed a similar delict of adultery. ${ }^{397}$

If two parties committed similar crimes (crimina), their crimes were cancelled out by way of mutual compensation, ${ }^{398}$ and if both parties acted fraudulently (with dolus), dolus was compensated with dolus. ${ }^{399}$ The same rule applied when both parties acted culpably (with culpa). The respective negligence (culpa) of both parties in that case had to be equal. When they were unequal, no compensation could take place. ${ }^{400}$ The same considerations as made by the medieval Roman scholars can be recognised here: when one party acted with dolus and the other with culpa, no compensation could take place because dolus is more serious than culpa. ${ }^{401}$ One argued that the adultery of one party can be compensated by the adultery of the other party, in the same way culpa is compensated by culpa, and dolus by dolus. ${ }^{402}$ The question whether delicts could be compensated was also broadly discussed by Johannes Andreae. ${ }^{403}$ Many cases were provided, but it is not necessary to discuss all of them. Several cases were already mentioned by earlier canonists and by medieval Roman legal scholars, such as the case of two partners in a partnership contract (D. 4.3.36). Where two persons were guilty of dolus, they could not bring an action against one another on this ground; the dolus of both parties was compensated; similar delicts were compensated by way of mutual compensation. Also, when both parties acted with an equal degree of negligence, the negligence of both

Speculum iudiciale, lib. III, partic. I, De criminibus in modum exceptionis propositis, $\S 1$, nr. 2 and also the casus ad X 5.16.6. Note that compensation of delicts (delictorum compensatio), in which two different acts produce two different harmful consequences, differs from the main problem dealt with in this study. In cases of contributory negligence of the injured party, there are two different acts producing one consequence (the damage). In this case, the injured party acted wrongfully against himself; see also Van Nierop 1905, p. $16 f$.

397 See the following works in which one can also find other situations in which the husband cannot blame his wife for the adultery. See gloss mutua compensatione ad X 5.16.6; Sinibaldus Fliscus, Commentaria, ad X 5.16.6, nr. 1.

398 The man brought forward the adultery of the wife, and then the wife was permitted to bring forward the adultery of the man; in this way, both crimina were abolished by mutual compensation. See Nicolaus de Tudeschis, Commentaria, ad X 2.25.8, nr. 7. Furthermore, one has to be aware that this process was a civil suit, not a criminal one. It is important to distinguish facts upon which exception and replication were brought up into more different facts or just one same fact. An exception could not be abolished by a replication in the first case, but only in the second, i.e. if these facts concerned the same effect, e.g. different adulteries of both partners with respect to the same marriage; see Nicolaus de Tudeschis, Commentaria, ad X 2.25.8, nr. 19.

399 Sinibaldus Fliscus, Commentaria, ad X 5.16.6, nr. 2; see also Antonius a Butrio, Commentaria, ad X 5.16.6, nr. 18.

400 See also J. Bertachinus, Repertorium, s.v. ad culpa (with references).

401 Sinibaldus Fliscus, Commentaria, ad X 5.16.6, nr. 4; see also additio d ad Nicolaus de Tudeschis, Commentaria, ad X 5.16.6.

402 Henricus de Segusio, Commentaria, ad X 5.16.6, nr. 3. On this topic, see also Kéry 2006, p. 641.

403 See (quite extensively) Johannes Andreae, Commentaria, ad X 5.16.6, nr. 5 and nr. 7. 
parties was compensated. ${ }^{404}$ These rules applied when the claim of both parties was directed at private interests. X 5.16.6 concerns a civil case directed at separation of bed and board, and in proceedings directed at private interests equal delicts were cancelled out by way of mutual compensation. ${ }^{405}$ The compensation applies as to the separation of bed and board, not with regard to the imposement of a fine. ${ }^{406}$

A dissenting opinion can be found with Durantis in his Speculum, where he treated the same subject. If two persons called each other names, could they accuse each other of that in court? One commonly argued that this question should be answered in the negative, because an unlawful act turns aside another unlawful act, and equal delicts were compensated by means of mutual compensation. However, Durantis was of a different opinion and stated that even if the unlawful acts were equal, both parties could go to court, since the unlawful acts would not be compensated but both rather remain existent (see D. 48.5.2.5). Besides, some - according to Durantis - argued that no compensation should take place when the first offender provoked the other to anger by words or act and the second offender did wrong to the first by words or act. In that case the second offender should not be condemned. ${ }^{407}$

\subsubsection{Culpae compensatio}

It is interesting to see whether or not the theory of culpae compensatio was applied by the canonists. As seen in the previous section, that was the case in marital cases. But what about other areas of the law?

In the decision of Pope Gregory IX ${ }^{408}$ in VI 1.21.1 and in the gloss of Johannes Andreae on this text, the plaintiff (the Church) had been at fault (culpa) $)^{409}$

404 Johannes Andreae, Commentaria, ad X 5.16.6, nrs. 5 and 7; also Antonius a Butrio, Commentaria, ad X 5.16.6, nr. 9 .

405 Nicolaus de Tudeschis, Commentaria, ad X 5.16.6, nr. 5. No compensation - of dolus with dolus, or of a delict with a delict - could take place in a criminal suit. In a civil suit when both delicts concerned the same matter (as in X 5.16.6) a compensation could take place, but not if the delicts concerned different matters; see Nicolaus de Tudeschis, Commentaria, ad X 5.16.6, $\mathrm{nr}$. 8f. In the event someone is sued because of a legal fine, the delict of one party is not compensated by the delict of the other party. In that respect, D. 48.5.2.5 is relevant; it concerns a husband who attempted to prosecute his wife in a criminal case because of adultery. The wife argued that he acted as her pander. This did not bar him from bringing the accusation. In such a case the act of the husband rendered him liable but did not excuse the wife.

406 Sinibaldus Fliscus, Commentaria, ad X 5.16.6, nr. 5. See also Kéry 2006, p. 642, according to whom it is clear that the compensation did not concern the punishment of the crime as such, but only the damages or the obligations were compensated.

407 W. Durantis, Speculum, Pars I, De accusatore §1, nr. 11.

408 Pope Gregory IX (Ugolino dei Conti di Segni) held the pontificate from 1227 to 1241.

409 If the Church omitted revoking a judgment or contractus by means of a restitutio in 
[legal fiction] and could not claim restitution (restitutio in integrum ${ }^{410}$ for that reason anymore, unless the defendant acted intentionally (with dolus; namely, by false accusation or fraud); in that case dolus is considered to be more serious than culpa (with reference to the gloss tenebitur ad D.9.2.9.4). ${ }^{411}$ Consequently, the Church, after four years, could claim restitution, in spite of her contributory negligence.

Furthermore, as already mentioned by the Commentators, Dynus de Mugello ad VI 5.12.65, with regard to the question whether a compensation of delicts could take place, argued as follows. In a civil lawsuit, when both parties acted culpably (culpa) or intentionally (dolus), a compensation on both sides was possible $^{412}$ regardless of whether they concerned a single event or different events. If one acted intentionally and the other person acted culpably in the same matter, compensation could not take place because dolus was considered to be more serious than culpa. If one party acted culpably in one case and the other with dolus in different matters, compensation could take place on the claims for an equal amount. ${ }^{413}$

But would this also apply in cases where one party committed a delict, but there was contributory negligence from the side of the defendant? An affirmative answer can possibly be found in the Summa on the title De damno dato by Hostiensis - which part is very similar to the relevant parts of Azo's Summa

integrum (a judicial decree restored the condition of things which existed before the contract by which the Church suffered), and did not do so for a period of four years out of negligence, after that limitation period (from the time of injury) she was regarded as having acted culpably in not revoking the judgment of contractus.

410 In principle, ecclesiastical possessions could not be expropriated. If a priest, with the purpose of personal enrichment, sold some objects belonging to the Church, a restitutio in integrum could be given. In that case one assumed a legal fiction, namely, that the Church was in an identical position as a minor (X 1.41.1); see Wauters 2005, p. 229. On the Church as a minor, see also Helmholz 1996, p. 96f. Canon law has accepted the provisions of Roman law regarding restitutio in integrum in cases of minors and applied them to churches (see on the use of a restitutio in integrum on behalf of the Church X 1.41.1). Minors were protected with regard to the administration of property and the obligations which they can assume in reference to third parties. Minors cannot make any contracts burdensome to themselves, except under certain determined formalities, and with the required authorisation. If they suffered by such contracts by the terms of Roman law, during the four years after they reached majority of twenty-five years, they could obtain the restitutio in integrum. Churches were assimilated to minors, meaning that, in respect to burdensome contracts, they were subject to the same protective measures and enjoyed the same privileges as minors. See Boudinhon 1913, p. 331f.

411 Gloss commentum ad VI 1.21.1; see also Wieling 1970, p. 223, also with reference to gloss damnum ad VI 5.12.86 (see section 3.3.6).

412 On the question of when culpa can be compensated or when equal delicts can be nullified by way of compensation, see also Felinus Sandeus, Commentaria, ad X 2.25.8, e.g., fo. 16r 2nd col.

413 Dynus de Mugello, Commentarius, ad VI 5.12.65. 
Codicis $^{414}$ - who argued that in the case where damage was inflicted culpably and the injured party also acted culpably, no action could be brought against the wrongdoer because the culpa of the wrongdoer was compensated by the culpa of the injured party. The injured party could only bring an action if the wrongdoer acted with dolus, because in that situation no compensation takes place, as dolus was more serious than culpa. Therefore, in these cases (where the injured party acted culpably) only actions of the defendant with dolus could lead to liability. ${ }^{415}$

In various other cases, in general cases not dealing with the law of delict or in cases of delict in which both persons were laymen and in that case their conclusions were generally based on texts of Roman law, the doctrine of culpae compensatio of (Roman) law seems to be accepted and to be further refined by the canonists in their commentaries on several decretals. ${ }^{416}$ If both the tortfeasor and the injured party acted negligently, no action could be brought against the wrongdoer because the culpa of the wrongdoer was compensated by the culpa of the injured party. However, with regard to the question whether a cleric could be granted a higher ordination, this was different, because in that case culpa could never be compensated by culpa. The author of Animal referred to 1 Comp. 5.10.9 (X 5.12.8) and also stated that when the wrongdoer and the person who was killed both acted culpably, even if the culpability of the first was less serious, the cleric could never be promoted to a higher rank. ${ }^{417}$

\subsubsection{The maxim of VI5.12.86}

Despite the fact that in canon law the problem of the scope of contributory negligence was discussed explicitly for the first time, the canonists did not seem to have pursued this approach. In later developments, questions of contribu-

414 Azo, Summa Codicis, III.35.8.

415 Hostiensis referred to the case of D. 9.2.9.4: the thrower was not held liable because the guilt was imputed to the slave who should not have crossed the field at such an inappropriate time, unless the thrower intentionally threw a spear at the slave, because playing a dangerous game implied culpa. Also the death of the slave in the case of D. 9.2.11pr. had to be imputed to the injured person because this person entrusted himself to the barber who put his chair in such a dangerous place. Neither the barber - unless the barber cut the throat of the slave intentionally nor the thrower were held responsible; see Henricus de Segusio (Hostiensis), Summa. De damno dato. Quando locum habet hec actio, edn. 1537 (reprint 1962), fo. 266r.

416 X 5.16.6, the decision of Pope Gregory IX in VI 1.21.1, Dynus de Mugello ad VI 5.12.65 and by Hostiensis in his Summa on the title De damno dato.

417 Although this part of Animal does not refer to the problem of dispensation, it does refer to 1 Comp. 5.10 .9 (X 5.12.8). As discussed above, the case of X 5.12.8 came to be regarded as a case concerning an irregularitas ex delicto. Following this line of thought, a dispensation could be granted by papal authority. 
tory negligence were usually solved with the help of D. 50.17.203, which, however slightly different but probably more precise, found its counterpart in the compilation of Pope Boniface VIII, ${ }^{418}$ i.e. the Liber Sextus (1298) in VI. 5.12.86. ${ }^{419}$

Idem. Reg. LXXXVI. Damnum, quod quis sua culpa sentit, sibi debet, non aliis, imputare. ${ }^{420}$ The same [=Pope Bonifacius VIII]. Regula 86. One has to impute damage, which someone suffers due to one's own negligence, to himself, not to others.

Several examples of this maxim are provided by scholars such as Johannes Monachus Picardus (†1313), Dynus de Mugello and Johannes Andreae (12701348) in their commentaries as well as by the Glossa Ordinaria on VI 5.12.86, which shows $^{421}$ that the rule of VI 5.12.86 (just as the rule of D. 50.17.203) was used in a wide range of cases. The following picture appears.

Although the rule of VI 5.12.86 has its origin in fact in D. 50.17.203, Dynus de Mugello referred as general confirmation of this rule to some other Digest texts, namely, that of D. 46.8.22.4, D. 14.3.7.2 and D. 10.2.44.5. ${ }^{422}$ The (other) examples of the maxim of VI 5.12.86 are partly the same as those already mentioned by the Glossators and by the Commentators in their comments on D. 50.17.203; ${ }^{423}$ apart from those, the following examples (of the maxim of VI 5.12.86) can be quoted. A first example of the maxim is the case in which a person who lost his trial was not obliged to pay certain costs which took place after the litis contestatio to the victor, namely, those which the victor paid or had to pay due to his contumacy (disobedience to judicial order). ${ }^{424}$ Secondly, the already frequently mentioned case of the tree pruner. ${ }^{425}$ Thirdly, the bailiff who paid undue interest and thus suffered damage because of his own negligence (culpa), and therefore he could not recover this interest from the debtor. ${ }^{426}$ Fourthly, the case in which a cleric was suspected of an enormous crime. He was in the presence of his bishop when the bishop gave sentence in accordance with the

418 Pope Bonifacius VIII, born Benedetto Gaetani, held the pontificate from 1294-1304.

419 Lange 1955, p. 72f.; Luig 1969, p. 203.

420 Friedberg 1881, col. 1122.

421 See gloss damnum ad VI 5.12.86 and what has been written before the gloss: glo[ssa] seq[uens] dicit unde sumpta: et tota instat in exemplis.

422 Sometimes the damnum could be imputed to someone other than the wrongdoer (see D. 17.2.55) due to participation in the cause of the damage; in other cases this was not possible. In the first case D. 17.2.55 applies, in the second case VI 5.12.86; see Dynus de Mugello, Commentarius, ad VI 5.12.86.

423 See, e.g., Dynus de Mugello, Commentarius, ad VI 5.12.86.

424 W. Durantis, Speculum. De expen. \$ Nunc de expensis, uers. 'ceterum'.

425 Johannes Andreae, Novella Commentaria, ad VI 5.12.86.

426 The question whether the bailiff could recover from the debtor the interest, paid to the creditor, is extensively dealt with by Johannes Andreae in his Novella Commentaria, fo. $14 \mathrm{r}$ and v. 
crime: life imprisonment. To evade this judgment and prison, he threw himself from his horse on the ground in front of his bishop and thereby was injured and died. His death had to be imputed to the cleric himself (C.23 q.4 c.38). Fifthly, the case in which a cleric to whom the prospect of receiving a prebend was given. ${ }^{427}$ One has to keep in mind that before there was a vacancy, a cleric was already appointed. Only when the person holding the prebend died leading to a vacancy, did it become necessary to decide whether or not he could be given the prebend. In this specific case, the cleric negligently did not claim it when he could have done so, and as a result of this the prebend went to someone else. This cleric could not claim from the recipient ${ }^{428}$ nor could he claim the next prebend which became vacant because he had to blame himself for his own negligence in that he had not claimed the first vacant prebend (VI 3.4.11) ${ }^{429}$

That the rule continued to be applied to a wider range of cases than those currently understood by contemporary scholars to fall under the scope of the problem of contributory negligence can also be seen in some examples from the early modern period. This will be shown in the following chapter.

In later canon law, it seems likely that a theoretical debate on contributory negligence, based on the principles mentioned above, did not occur. ${ }^{430}$

\subsection{SHort Comparative REMARKS}

\subsubsection{Structure and purpose}

The cases of contributory negligence in Roman and medieval law have been extensively discussed in this chapter and in the previous one. Little attention has been paid in the sources of law beyond the learned law as taught at universities and law schools. As some are remarkably interesting from a compara-

427 The right of someone presented a beneficium by a patron for a beneficium, but who is not yet confirmed (ius ad rem petendam, non in re). See Feenstra 1979, p. 15f. Apparently, it is a kind of right of expectation that can be placed somewhere between a right in rem and a personal right. See on this topic and on the concept of ius ad rem, among others, Landau 1971, p. 81ff.; Dondorp 1991, p. 285ff.; 1997, p. 553ff.

428 J. Monachus Picardus, Glossa aurea, ad VI 5.12.86.

429 On the question in VI 3.4.11 whether the cleric who forgot to make an effort to receive the first vacancy also limits the power of the executor (of the papal mandate), i.e. whether the cleric could apply for the next prebend or whether the (papal) gratia is thereby void, see Hitzbleck 2009, p. 68ff.; - Finally, the case of a purchaser of a piece of land who did not show up at the trial and lost the land due to eviction, this purchaser could not bring an action against the vendor (C. 8.44.8); in the Glossa Ordinaria Johannes Andreae even provided more examples of the rule of VI 5.12.86; see casus ad VI 5.12.86 and gloss damnum ad VI 5.12.86.

430 Luig 1969, p. $203 f$. 
tive point of view, they will be discussed briefly in this section (3.4). First, a 'new' scholion will be dealt with - a part of Byzantine law, an interpretation of the Corpus Iuris, unknown to western European medieval legal scholars. Thereafter, I deal with indigenous law. To begin, some examples are given in a chronological manner - which also apply an all-or-nothing approach. Then, to conclude, some examples are given which give a different approach (a partition of damages).

\subsubsection{Byzantine law}

Around 1200, Hagiotheodoritès wrote a large 'new' scholion on the barber case. ${ }^{431}$ In contrast to the 'old' scholia mentioned in the previous chapter, this 'new' scholion can provide some insight into the way the Byzantine lawyers interpreted this case positioned in their time. Hagiotheodoritès started to explain the decision of Ulpian. Two persons did something wrong, the barber and the person who was being shaved. According to Hagiotheodoritès' record of Ulpian's view, from a procedural perspective the person being shaved was in the weakest position (or better, his master): he had to be blamed himself and as a consequence (his master) could not obtain an actio against the barber.

However, Hagiotheodoritès himself argues differently. According to him, the barber found himself in the weakest position in litigation and therefore is subject to an actio (not specified by Hagiotheodoritès) because of two reasons (the ball-player is not considered in the scholion). Firstly, it would be unjust to harm the master (of the slave) and let him bear the loss, since he did nothing wrong and he was absolutely unaware of what happened. Secondly, and this is hypothetical reasoning, if the injured slave had been a free man, it would be more reasonable to prefer, between two evils, to prevent an even greater injustice, rather than to punish the lesser evil. If the barber was left unpunished, he could have damaged other persons in the same way. It was important to deter the barber from this kind of conduct. Thus, a large number of people are protected against possible damage. This is the greater evil that has to be prevented. ${ }^{432}$ Apparently, Hagiotheodoritès is aware that hereby not the ideal

431 See on this person Graves 1870, p. 324; Van der Wal \& Lokin 1985, p. 100; Kazhdan 1991, p. 899; see, namely, BS 3104/28-3105/13 (scholion 41 ad B. 60.3.11); a translation of this scholion can be found in Lawson 1968, p. 180-183, Lawson \& Markesinis 1982, II, p. 45; see also Lawson 1968, p. 89; Ibbetson 2003, p. 506.

432 Hagiotheodoritès based his argumentation on a rule B. 2.3.200 (=D. 50.17.200): if one cannot make a choice without causing damage, the less unjust option should be chosen; according to Kunkel 1929, p. 179, the last part of Hagiotheodoritès is - at the core not unjustified, but severely exaggerated and yet extraordinarily characteristic for the intellectual world of the Byzantines. Kunkel qualified the argument of public safety as 'der Gedanke des Polizeistaats in der Zivilrechtspflege'. Remarkably, this scholion is the first text in which the failures of two 
but the less unjust solution is achieved. Furthermore, it can be argued that Hagiotheodoritès was also aware of the doubtfulness of the level of justice of the all-or-nothing approach when one starts from fault on both sides. ${ }^{43}$ However, his solution is still all-or-nothing, and Hagiotheodoritès, despite the contributory negligence of the slave, did not deny the liability of the barber. ${ }^{434}$

\subsubsection{Indigenous law}

\subsubsection{Examples following the all-or-nothing approach}

In the laws of the western Goths there are also some provisions dealing with the role of the negligence of the injured party. Certain situations are mentioned in which the damage does not have to be ascribed to the wrongdoer but to the plaintiff's own negligence (culpa). These situations are the following. (1) If it were uncovered that a freeborn woman voluntarily committed adultery with a man, and if, afterwards, he should wish to marry her, he is permitted to do so. But if the man should be unwilling, the adultery should be imputed

persons are explicitly discussed; see also Wollschläger 1976, p. 134. However, in the scholion there is more concern with prevention of future harm than with punishment of a wrongdoer. According to Lawson 1968, p. 182, Lawson \& Markesinis 1982, II, p. 45, the two injustices do not seem to be assessed on their moral blameworthiness, but on their capacity to harm.

433 Looschelders 1999, p. 13.

434 The Klagspiegel (ca.1400-1425) applied compensation of culpa in the case where both instances of negligence were equal in degree, and only the intentional wrongdoer was liable. In the same sense Knütel 2001, p. 365. The Klagspiegel, de actione legis aquilie, Blatt XCIXv, stated: 'Item unterweylen wurt nit clag uß unfleyß wann ein unfleyß mit dem andern compensiert und vergleycht wurt/und auch wo uff ein teyl argerlist und dem andern teyl unfleyß ist/so überwiget argerlist den unfleyß/und darumb kompt underweylen allein argerlist in diser clage/und das ist darumb/wann der unfleyß ist deshalb enn der den schaden gelitten hat.' Immediately after, the example of D. 9.2.9.4 follows, and in the next paragraph also the case of D. 9.2.11pr. With regard to D. 9.2.11pr. the Klagspiegel seems to have applied the same theory (in the event of contributory negligence, the wrongdoer is only liable if he acted intentionally) (Blatt XCIXv): '... es ist wed $<$ er $>$ der scherer/wed<er> der werffer/ noch der schlager schuldig/es sey dann solchs geschehe mit fleiß/ wann sollichs mag dem zů gezelt werden/ der sich so gar an ein sorglich oder schädlich statt dem scherer empfolhen hat' (supplemention based on Brunnenmeister 1879, p. 172). See also Kiefer 1989, p. 4. 
to her own culpa, namely, that she willingly mingled in adultery. ${ }^{435}$ (2) If a person, after handing over an object to a slave without the knowledge of the slave's master, and if this leads to the disappearance of this object, this has to be imputed to the negligence of that person. ${ }^{436}$ (3) If someone provokes an animal and the animal strikes or bites the provoker, the provoker has to impute the damage to his own negligence. ${ }^{437}$ However, although one can see a legal qualification of the act of the injured party in these examples, an explicit discussion of both acts of the parties in question is additionally made; an allor-nothing approach is still followed here.

In the edict of the Lombard King Liutprand ( $† 744)$, a case is described in which a man is drawing water from a well by means of a crane-like mechanism, and in manipulating this without due care (incaute) he knocks over and kills a man standing in the well. The wrongdoer is not held liable for homicide nor did he have to pay the full compositio, but only one-third, the other two-thirds being borne by the dead man (i.e. his heirs) because he should have been aware of

On the reception of these cases in the Klagspiegel, see Knütel 2001, p. 363ff. The dependency of these parts of the Klagspiegel on Digest fragments was probably brought to the attention of the author of the Klagspiegel by Roffredus' De libellis iuris civilis (as to the arrangement, this work is directed after Johannes Bassianus' Arbor actionum). Roffredus' De libellis iuris civilis is in general the basis for the first treatise (the work consists of two treatises, the first one is on civil law and the second one on criminal law and criminal procedure); see Stintzing 1959, p. 360ff. In addition, in the domain of the lex Aquilia, there are also ties with Durantis' Speculum iudiciale recognisable; see Stintzing 1959, p. 399; Knütel 2001, p. 364.

435 See Lex Visigothorum III.4.8: Si ingenua mulier cuicumque se viro adulterio volens miscuisse detegitur, si eam ipse uxorem habere voluerit, habeat potestatem. Sin autem noluerit, sue inp.utet culpe, que se adulterio volens miscuisse cognoscitur (edn. Zeumer 1902, p. 150).

436 See Lex Visigothorum V.5.6: Quod nesciente domino servo fuerit conmendatum, si id perierit, nec dominus nec servus ullum damnum incurrant. Sue enim inputet culpe, qui servo alieno res suas conmendaverit domino nesciente. Si vero alicuius rei animal sit, et per fraudem pastorum diminutum repperiatur, hec reddere conpellatur. Similis et de commodatis forma servetur, si fraude aut malitia consumta aut dissipata noscuntur (edn. Zeumer 1902, p. 229).

437 See Lex Visigothorum VIII.4.18: Si quis vitiosum bobem aut canem vel alium animal contra se in ira concitaverit, quidquid passus fuerit, culpe eius, qui hoc pertulerit, oportet adscribi (edn. Zeumer 1902, p. 339). See on the just-mentioned legal provisions of the Leges Visigothorum also Jansen 2007, p. 658.; - On the development of the laws of the Goths, see Conrad 1962, p. 56ff.; - Also Mayer-Maly 1976, p. 260, thinks that in Leges Visigothorum III.4.8 and VIII.4.18 the thought arises that the damage must be imputed to the injured party's own culpa. Besides these two fragments, Mayer-Maly referred to the Codex Euricianus 283 (a slightly different text than that of Lex Visigothorum V.5.6), where he (also) finds the thought of a Verschulden gegen sich selbst. The text is about someone who entrusts his belongings to someone else's slave, without knowledge of this by the slave's master; if they are destroyed, he did not have a claim against the master (see also d'Ors 1960, p. 208). He is not regarded as having suffered damaged (nullum damnum incurrat); the damage is imputed to his own negligence. See Codex Euricianus 283: Quod nesciente domino servis fuerit commendatum, si id perierit, dominus servi nullum damnum incurrat. Suae enim inpotet culpae, qui servo alieno res suas commendaverit nesciente. Similis et de commodatis forma servetur (cited after Mayer-Maly 1976, p. 260). Already d'Ors 1960, p. 139, made the remark that 'sue inputet culpe' in Lex Visigothorum III.4.8, which calls to mind the similar Codex Euricianus 283 ('recuerda la similar de'). 
the danger in that position. ${ }^{438}$ In this case, the contributory negligence of the injured party is taken into account (by way of an acceptance of risk) and is discounted in the compensation amount, while in medieval Roman law the all-or-nothing approach was still used.

The Sachsenspiegel, a description of mainly Eastphalian law, was composed by Knight Eike von Repgau between 1225 and $1235 .{ }^{439}$ In the perspective of contributory negligence, Sachsenspiegel II. 48.2 is relevant: 'If a man leaves his grain standing, once all others have taken theirs in, and it is eaten or trodden on, no one compensates him. ${ }^{440}$ After bringing in the harvest, farmers let their cattle, which until that time grazed on closed plots, graze free. Whoever left his corn standing on the land in spite of the local custom could not complain when the animals ate or trampled it. ${ }^{441}$ In this case, the injured party caused the danger (Gefahrenquelle) and therefore there could be no liability for a third person, since the injured party could have prevented the damage by harvesting the corn on time. ${ }^{442}$ The thought behind the rule could have been an economic one: when someone harvests his grain too late, it diminishes the grain's economic value. If one person leaves his grain in the field after all others have harvested, that person in fact renounces his rights on this object. ${ }^{443}$ Possibly, originally this could have been the reason behind the rule, rather than a legal reason. Nevertheless, one has to remark that in this case the contributory negligence of the injured party led to a denial of his claim for compensation ${ }^{444}$ and that also in this case an all-or-nothing approach is followed. According to the secondary literature, commentators on Sachsenspiegel II. 48

438 LiutprandiLeges AnniXXI, cap. 136 (edn. Beyerle 1949, p. 302ff., with German translation); see Fried 1960, p. 152; also Conrad 1962, I, p. 163f.; Luig 1969, p. 196; cap. 136 gives the reason why the man is responsible himself for two-thirds of the damage: the man who died was not an animal, but rather had the reasonable sense which a man should have. He therefore had to see for himself at what place he found himself and what weight he had against himself.

439 Richter 2005, p. 119; on the Sachsenspiegel, see also Bellomo 1995, p. 109; Kannowski 2005, p. 139ff.; Richter 2005, p. 119ff.

440 Translation by Dobozy 1999, p. 107; Aumann 1964, p. 32; Van Wassenaer 1971, p. 12.

441 See Aumann 1964, p. 33; also Van Wassenaer 1971, p. 12; - However, according to Aumann, the case did not concern the contributory negligence of the injured party because the principle of negligence (Verschuldensgrundsatz als Haftungsprinzip) did not occur until the beginning of the influence of Roman law.

442 Aumann 1964, p. 33; also Hammer 1885, p. 72f.; - In general, this can also be found in Nicolaus Wurms' Blume von Magdeburg II.3.98: Schade, der einem von siner vorwarlosunge geschyt, darf er keinem scholt gebin (edn. Böhlau 1868). Carelessness (with care the damage could have been prevented) of the injured party apparently excluded negligence of a third party. On this sentence, see Hammer 1885, p. 72, and Aumann 1964, p. 33.

443 It could also have been the case that someone, after harvest, left some grain outside in the field. In that case the grain could be freely taken by persons who were strangers, fatherless or widowed (see also Deuteronomium 24: 19-22).

444 See also Kiefer 1989, p. 25. 
seem to have regarded this text as an expression of the thought of D. 50.17.203. ${ }^{445}$ This view is indeed supported by Hieronymus Christoph Meckbach in his Anmerkungen on Sachsenspiegel II.48 in 1764: '... der nachläßige, der das Geträide allein im Felde stehen lassen, empfindet durch seine eigne Schuld den Schaden, welcher nicht dem Hirten, sondern dem nachläßigen zuzurechnen ist'. ${ }^{446}$

Another relevant source from German law before the reception of Roman law is a decision from 'Ober-Ingelheimer Haderbuch' from 23 February 1426. In this case, the contributory negligence of the injured party, which was the essential contribution to the occurrence of the damage, led to a total denial of compensation. ${ }^{447}$ In the events of this case, the plaintiff placed an oil jug in a risky place. The defendant accidentally knocked over the jug when he left the room. It is stated that the only person at fault was the plaintiff, although according to Ingelheim's law an objectively harmful act (in this case knocking over a jug) made the wrongdoer liable. ${ }^{448}$

\subsubsection{Examples including a partition of damages}

As discussed before, in Roman and medieval ius commune, no division of damage between parties was made (the all-or-nothing approach). However, this idea of division of damage can be found in cases in other old traditions, one of them being medieval Irish law, namely, the Bretha Étgid (ca. eighth century: 'Judgments Concerning Irresponsible Acts'). This text deals with the various circumstances that might surround a homicide or injury, especially those circumstances that make the actions of the wrongdoer more or less blameworthy. ${ }^{449}$ Relevant to this is a case regarding woodcutters (Bretha Étgid §30), especially the later medieval commentary on it. Appararently, a tree-feller cut a tree and the tree fell on a passer-by. The tree-feller was negligent, not having shouted a warning when the tree was about to fall. But the idlers also acted negligently in hanging around while the tree-feller was at work chopping down trees. Therefore, the compensation paid to them was halved. ${ }^{450}$ So, people who have no good reason to be present when accidents occurred only received half restitution, i.e. because of their 'contributory negligence'.

445 Luig 1969, p. 196.

446 H.C. Meckbach, Anmerkungen über den Sachsen-Spiegel, Anm. zu II. 48 (p. 528); according to Luig 1969, p. 196, the reference to D. 50.17 .203 and VI 5.12.86 is unmistakable, although the Germanist Meckbach did not quote these texts, of course.

447 See also Luig 1969, p. 196; Kiefer 1989, p. 25 nt. 160, refers to this example mentioned by Luig as an example of preponderant contributory negligence.

448 Gudian 1968, p. 270; Luig 1969, p. 196.

449 McLeod 1999, p. 6 ff.

450 ibid., p. 14. 
Some other cases are also relevant in this respect, although they may not exactly concern cases of contributory negligence. Firstly, Exodus 21:35 (later included in X 5.36.3) concerned the rule that if someone's ox injured someone else's ox causing its death, the owner had to sell the surviving ox and share the proceeds with the owner of the dead ox; also the dead animal was shared. Apparently, the owner of the dead ox received partial compensation. ${ }^{451}$ The ancient authors called this solution a judicium rusticorum, as such was the decision of Solomon in the case of the two mothers (1 Kings 3:16-28). ${ }^{452}$

It seems that such compensation was also allowed in an exceptional case in Old-Scandinavian law; ${ }^{453}$ namely, the Wendisch-Rügianische Landgebrauch, as summarised by Normann in $1531 .{ }^{454}$ In summary, if damage was caused by the injured party himself, because he let his animals come close to other animals, or to someone else's stable, or if he put his belongings on the road where one would not expect them, and then damage was caused to animals or goods, the owners had to bear half the damages. ${ }^{455}$

\subsection{CONCLUDING REMARKS}

In medieval Roman scholarship, the contributory negligence of the injured party seems to be regarded as reproachable misconduct that could be sanctioned by a refusal of a claim for compensation. Thus the contributory negligence of the injured party came to be considered a possible legal problem. Two starting points to solve the problem of contributory negligence in the

451 Also Van Wassenaer 1971, p. 12, 171; according to Exodus 21:36, if it is known that the ox has been accustomed to gore in the past, and its owner has not kept it in, he shall repay ox for ox, and the dead beast shall be his. In the event the owner knew of the habit of goring, the owner had to pay full compensation.

452 Lebreton 1941, p. 5f.

453 Aumann 1964, p. 36; - In old French law, such a rule of division of damages was unknown; see Mazeaud-Tunc 1970, para. 1448ff., esp. 1450; Van Wassenaer 1971, p. 12 . However, according to Mazeaud-Tunc 1970, para. 1455, the all-or-nothing approach of Roman law was not expressly incorporated by any author of old French law.

454 Matthäus von Normann, Wendisch-Rügianisches Landgebrauch (edn. Th. H. Gadebusch 1777, p. 220), tit. 177 al. 4 and 5.

455 Aumann 1964, p. 36; Van Wassenaer 1971, p. 12; - Because Rügen, according to Aumann 1964, p. 36, 'für langere Zeit der dänischen Krone zinspflichtig war, ist ein Einfluß des alten westnordischen Rechts nicht ganz ausgeschlossen'. Therefore, see also the Westnordische Obligationenrecht of Von Amira 1895, p. 411: 'Beim Ausmass von Wergelden und andern Ersatzleistungen findet sich im norwegischen Recht wie im schwedischen die Frage berücksichtigt, ob der Geschädigte selbst seinen Schaden etwa mit verursacht hat. Trifft ihn die Mitschuld - ist er z. B. "selbst sein halber Todtschläger" (sjálfr halfr bane sinn) geworden, - so mindert sich die Ersatzschuld um seinen Kopftheil.' Further reseach on this point unfortunately falls outside the scope of this study. 
medieval period were identified. The first starting point is the idea of culpae compensatio; the second is the rule laid down in D. 50.17.203.

The doctrine of culpae compensatio has its origin in medieval (Roman) scholarship. The Glossators took the respective negligence of both parties into account. They applied this doctrine to situations in which both parties acted with negligence of the same sort or were negligent to the same degree. It seems that the concept of culpae compensatio obtained an independent position next to the so-called compensatio delictorum. The doctrine of culpae compensatio was only formulated as a general theory by the Commentators, who explained it in a more encompassing way than the Glossators, taking into account also more procedural law aspects.

The Gloss does not provide explicit proof whether or not the Glossators believed that culpae compensatio could only be applied to cases of contributory negligence in which both parties had been negligent to the same degree or whether it also applied to cases in which the degree of negligence was not identical. Therefore, all kinds of contributory negligence of the injured party, as long as they could be qualified as culpa, seem to have cancelled out liability. A comparison of the amounts of negligence, and the refinement in the sense that a small degree of contributory negligence would not lead to compensatio and thus to the deprivation of the possibility to claim compensation for damages/fine, was probably made by the successors to the Glossators at the instigation of the canonists.

Did the medieval Roman scholars use this doctrine of culpae compensatio to solve problems of contributory negligence in cases of damnum iniuria datum? D. 9.2.9.4 gave the glossator Johannes Bassianus reason to discuss the contributory negligence of the injured party. He formulated the view that the culpa of the wrongdoer could be compensated by culpa of the injured party. ${ }^{456}$ However, he argued that culpa nullifies culpa, but that culpa (of the injured party) does not nullify dolus. Azo gave the reason for this exception: an act done with dolus was considered to be more serious than an act done with culpa ${ }^{457}$ These formulations by the Glossators were quite abstract. It is not until the commentator Paulus de Castro that the consequences of such contributory negligence were made explicit. He was the first who explicitly applied these abstract rules to the case of D. 9.2.9.4. Although this application of the culpae compensatio theory was already mentioned in the Gloss, it was not further elaborated.

456 Gloss quia non debuit ad D. 9.2.9.4 (see n. 60 above). Johannes Bassianus refers to D. 16.2.10pr. and D. 24.3.39.

457 Gloss ad tenebitur with siglum az. (see n. 72 above): quia dolus culpa<e $>$ praeponderat. 
Also the case of the barber is interesting as to the consequence of contributory negligence, since Placentinus seems to have considered the contributory negligence of the injured party as relative: he was negligent in a certain relation to another person. The phrase 'de se queri debet' should be seen as referring to the barber. Only if an action was brought against the barber could his negligence be compensated by that of the slave. According to Azo, the contributory negligence of the slave could possibly exclude liability of all the other actors in D. 9.2.11pr. In this way, Azo left the possibility open that the contributory negligence of the injured party could be opposed to the negligence of the deiector or the percussor, and in that way cancel out their liability.

In medieval Roman scholarship, there were various opinions on the effects of contributory negligence. Firstly, one just took the behaviour of the injured party into consideration when determining the culpability of the wrongdoer's act; in this approach, the behaviour of the injured party was therefore not really considered as contributory negligence. Secondly, the injured party was regarded as guilty of his own delict; the Glossators then made a parallel here with the compensation theory, both delicts and both culpable acts were compensated. Thirdly, it seems the fact that an injured party exposed himself to the danger that caused the injury led to a denial of compensation.

Some Commentators applied the theory of culpae compensatio in a general way to solve problems of contributory negligence in the cases of damnum iniuria datum, especially Paulus de Castro. Furthermore, Fulgosius did not add much to this prevailing view when he stated that when both parties coincidentally acted culpably (culpa), and the culpability of the act of one party was more serious than the culpability of the act of the other party, this led to the total denial of damages. Fulgosius regarded dolus as a more serious form of culpa; in that way one has to regard his remark that liability would still be established if the culpability of the wrongdoer was more serious than the culpability of the injured party as: the first is dolus, the latter is culpa. Consequently, no maior culpa doctrine is applied here. ${ }^{458}$

Accursius linked D. 50.17.203 to the law of delicts in his gloss Quod quis ad D. 50.17.203 by the allegation of D. 9.2.31. In this gloss, Accursius explained that an injured party's own negligence prevented him from claiming damages from someone else. D. 50.17.203 could be read in the sense that it only concerned the negligence of the injured party; however, the Glossator understood that it not only concerned cases in which the wrongdoer's act was not at all in discussion

458 Fulgosius refers to D. 9.2.9.4. 
(because only the victim's fault was discussed) but that it also concerned cases in which the wrongdoer's fault was relevant as well. The rule of D. 50.17.203 is also discussed by the Commentators, and on its counterpart - VI 5.12.86 - by the canonists. It is rather strange that the examples of this maxim are all cases where there is only negligence on the side of the injured party, and not of contributory negligence, as Accursius opened the door for such an approach.

The canonists also embraced the theory of culpae compensatio, in various areas of law, generally in those areas not dealing with the law of delicts or in cases of the law of delict in which both persons were laymen. However, with regard to the question whether a cleric could be granted a higher ordination, this was different, according to the commentary of Animal on D.50 c.50, because in that case culpa could never be compensated by culpa. The author of the Animal also stated that when the wrongdoer and the person killed both acted culpably, even if the culpability of the first was less serious, the cleric could never be promoted to a higher rank.

Two canonists explicitly commented on the position of the injured party. With regard to X 5.12.9, Bernardus Parmensis argued that the killing was due to the negligence (culpa) of the injured party (who threw the other on the ground). One has to keep in mind that the question in this case before the Pope was only whether the cleric did or did not act with negligence and whether the cleric could or could not be promoted (and if dispensation was necessary). The conclusion that due to the lack of a possibility to distribute the damages over both parties in case of contributory negligence (which was not at all at stake here) the jurists tended to attribute the 'sole guilt' to the party that acted with the highest degree of negligence can only be taken with care (analogous interpretation).

Hostiensis argued that the other cleric should have been aware that wearing a knife attached to a belt was customary, and therefore he should have been careful. It seems that therefore the 'contributory negligence' led to the sole guilt on the side of the injured party. One could argue, as some modern scholars do, that the liability of the tortfeasor in question is cancelled out because of the preponderant contributory negligence of the injured party. Although the question of liability was not at all at stake in the legal case brought before the Pope if one looked at it from that modern perspective; the majority of the commentaries of the decretalists I consulted do not follow such a theory. However, the just-mentioned comments of Bernardus Parmensis and Hostiensis, who were two influential persons, could indeed indicate that this theory was applied. 
In canon law for the first time in Western legal scholarship some texts can be found that support the idea that not a small but a considerable contributory negligence on the part of the injured party is relevant from a legal perspective. ${ }^{459}$ However, because of the applied all-or-nothing approach, a preponderant negligence of the injured party led to a total denial of guilt on the side of the wrongdoer. From the text in the Animal est substantia it becomes clear that with regard to the question whether a cleric could be granted a higher ordination contributory negligence on the side of the injured person did not release the wrongdoer from his responsibility, not even when his contributory negligence was considerable. Therefore, one has to conclude that the importance of canon law, as to contributory negligence, lies in the fact that the problem of the scope of contributory negligence was explicitly discussed for the first time (in the Continental Romano-canonical tradition).

Finally, there are some new concepts, or two new ways of dealing with contributory negligence, that arose in this period. According to canon law, the contributory negligence of the injured party could be seen as contributory causation (co-causation), and therefore in such cases one had to decide whether the wrongdoer or the injured party had produced the causa proxima. It seems that the causational contributions of both parties were compared. The Socini seem to have applied this theory in their Consilia and they refined it in the sense that when a cause (causa) in its entirety had no relation with the consequence, it was not possible to conclude that the cause produced the consequence anyway. The second concept is that of culpa admixta used to give a legal qualification to the act of the injured party in situations in which a hurtful action by a wrongdoer is mixed with a fault of the injured party. The Socini and Cravetta used the term culpa admixta on the side of the injured party in such a way that it led to the exclusion of liability of the wrongdoer. Later, e.g. in the work of Cyriacus, another concept was developed out of the same perception, i.e. the concept of a culpa communis.

In the tradition of ius commune, one, for the first time, finds a qualification of the act of the injured party, and an explicit discussion of both acts of the parties in question can be observed. A similar approach is also already present in some other medieval sources outside the Romano-canonical tradition, where an all-or-nothing approach was also still followed. Neither in Roman nor in medieval ius commune was a division of damages made. However, in some cases in other old traditions, this idea of the division of damages can be 
found. The contributory negligence of the injured party could lead to partial compensation, the so-called solution of a judicium rusticorum, or to a reduction of damages to the amount of two-thirds. These options were only applied in the Continental tradition (and also in English law) in the early modern period (see next chapter). 


\section{CHAPTER FOUR}

\section{EARLY MODERN PERIOD}

\subsection{INTRODUCTION}

\subsubsection{Subject and purpose of this chapter}

Between 1400 and 1600 the Renaissance brought about a renewed study of Antiquity. In the sixteenth century, a new stream studying Roman law arose, the school of legal humanism. ${ }^{1}$ Besides this new stream, called mos gallicus, the old stream (mos italicus) continued with a new, mainly practice-oriented legal science routine developed in Germany in the seventeenth century. This movement was named after the book Usus modernus Pandectarum by the German jurist Samuel Stryk (1640-1710). The Corpus Iuris was considered a starting point and, unlike the humanists, the jurists who followed this approach did not try to reconstruct classical Roman law. To be able to assess the contributions of the humanists and the jurists of the usus modernus, it is necessary to outline the main differences between the mos gallicus and the mos italicus. This will be done in section 4.2.1. That these different approaches led to different answers as to the question of the role of contributory negligence of the injured party will be made clear throughout this chapter. In trying to reconstruct the original context, theoretically the humanists should have come toconclusions similar to those that we reached in chapter two. ${ }^{2}$ Now did they, or did they nevertheless preserve more medieval interpretations than one might expect? This part of my study contains new research into many humanistic authors and literary sources. Apart from the more frequently read

1 See Troje 1977, p. 615; - However, as Van den Bergh 1994, p. 49, noted, humanism as a criticalphilological movement in Italy had already started in the 13th century. Humanism penetrated legal science relatively late, in the first quarter of the sixteenth century (according to Osler, 'Legal Humanism', available online at: www.rg.mpg.de (last consulted on 1 May 2013), the first manifestations of legal humanism can already be detected in Italy in the 15 th century). However, this view is slightly distorted because in Italy humanists were already working on text-critical problems of the Corpus Iuris in the 14th century.

2 Although the Institutes of Gaius were not available to them. 
authors such as Gerard Noodt, there are many others, unfortunately forgotten - but not here. However, some of these lesser-known jurists contributed greatly to the argument on contributory negligence in the context of damnum iniuria datum, as will be shown below.

The main issue in this chapter is (again) the role of the conduct of the injured party. In medieval Roman scholarship, opinions on the effects of contributory negligence varied. It was only in the tradition of ius commune that the question of how to qualify the act of the injured party in legal terms became for the first time explicitly discussed; also for the first time a discussion of the acts of both parties concerned can be observed. The medieval approach of ius commune to the problem of contributory negligence was an approach of all-or-nothing. The question remains whether and if so to what extent this allor-nothing idea was received into the early modern period. If it was received, a similar question arises with regard to the important doctrine of culpae compensatio. Some slight traces of the maior culpa theory have been found, but the majority of medieval jurists did not yet apply this theory. Did this change in the early modern period? The central question in this chapter will be why the injured party had no right to claim compensation. New questions arise in this period, such as: does the (extent of the) role/effect of contributory negligence of the injured party depend on the kind of damage compensation asked for by the injured party? Is a reduction of the compensation amount at all possible?

As stated in the previous chapter, in other legal traditions outside the Romano-canonical tradition, especially (medieval) indigenous law, the idea of division of damages can be found in some cases. Contributory negligence of the injured party could lead to partial compensation, namely of half the damage, the so-called solution of judicium rusticorum, ${ }^{3}$ or to a reduction by two-thirds of damages to be paid. Can traces of this approach be found in the early modern period? To this issue the views of the jurists of the Dutch Elegant School, in which an elegante Richtung and a usus modernus Richtung can be distinguished, ${ }^{4}$ are important. The latter dealt with so-called Roman-Dutch law, and being a mixture of Roman law and indigenous law, this subject has to be discussed separately in this study. ${ }^{5}$ This topic is especially interesting as

3 Bouman 1855, p. 41, argued that such decision was normally given by arbitrators (scheidsmannen) when the case was not clear or when however clear, both parties had been negligent. See also art. 4, $\$ 4$ of title 10, book 6 of the Jus provinciale Ducatus Prussiae, stating that if two animals fight and one kills the other and it is not clear which of the animals provoked the other animal, the master of the one that survived should pay half of the damages of the animal that was killed to its master. See also S. Stryk, Specimen usus moderni pandectarum, lib. IX tit. I §IX (edn. 1730, p. 137f.).

4 Osler 1996, p. 350.

5 More on this topic later; a provincial variant, Roman-Frisian law, will also be discussed, as far as relevant to this study. 
some collision cases relevant to the question of contributory negligence have been found. In particular, the great influence of local law will be shown, which led to a different solution to the cases of contributory negligence from the one provided in (medieval) Roman law.

The seventeenth and eighteenth centuries can be considered as 'The Age of the Law of Reason'. In these two hundred years of legal 'science', legislation and legal practice in most parts of Europe experienced the direct impact of natural law. ${ }^{6}$ The scholars of natural law schools did not feel bound to the Roman legal tradition as their predecessors had. Rather, they respected the Roman sources for their texts because in their opinion they incorporated notions of natural law and provided material for the construction of a new system of natural jurisprudence. ${ }^{7}$ Did their approach lead to a different solution in the event of contributory negligence from the solution offered by Roman law?

\subsubsection{Method and structure}

In this chapter, the most important jurists of the early modern period will be discussed. In this context, their commentaries on the sedes materiae were taken as a starting point. The search for and the selection of jurists was not only made based on secondary literature, but also on editions of the Corpus Iuris, references in the Notae by Schulting-Smallenburg (Dutch Elegant School) ${ }^{8}$ and manuals such as Simon van Leeuwen's Censura forensis (Roman-Dutch law), Stryk's Specimen usus moderni pandectarum, Glück's Ausführliche Erläuterungen and Coing's Europäische Privatrecht. While some works were available online, the majority still had to be consulted in various libraries in the Netherlands and abroad. This chapter contains a discussion of their interpretation of sources of the ius commune (Roman and canon law) and their references to and discussion on literary sources, case law and legal doctrine as well as early modern legislation. ${ }^{9}$

First, a short overview of the mos gallicus and the mos italicus and their main differences will be provided in section 4.2.1. Thereafter, the interpretation by the most influential humanists of the sedes materiae will be discussed as far

6 Wieacker \& Weir 1995, p. 199; - On natural law, in particular in Germany, see Koschaker 1966, p. $245 \mathrm{ff}$.

7 Parisi 1992, p. 136; on the school of natural law see, e.g., Fassò, II, 1968, p. $113 \mathrm{ff}$.

8 This chapter will contain a discussion of the authors and works mentioned in Schulting's notae and the observations (animadversiones) of the editor of the work of Smallenburg, among which no sharp distinction will be made. This edition is primarily used as a bridge to relevant literature found in Dutch (Elegant) scholarship.

9 With regard to the literary sources, the English translations, as they appear in the Loeb Classical Library, are used as auxiliary resource, also where no explicit reference is made. 
as relevant to the development of contributory negligence. ${ }^{10}$ The relevant work of the jurists of the elegante Richtung of the Dutch Elegant School is discussed together with the work of the humanists in the second section (4.2.2-4.2.5). After a general introduction to the period of the Reception of Roman law (4.3), the usus modernus Richtung of the Dutch Elegant School will be discussed in the fourth section of this chapter (4.4) on Dutch-Roman law. In that section the work of the Roman-Dutch jurists will be covered, especially with regard to the so-called collision cases. Other contributions of jurists of the Usus modernus Pandectarum, not being Dutch jurists, will be discussed in the fifth section (4.5). The Spanish legal doctrine of the sixteenth century was partially covered in the previous chapter, as far as the continuation of the canon law theory as to homicide is concerned. Although a comprehensive study on these scholars has not been possible, the relevant scholars will be discussed in this final part on natural law as far as necessary for a good understanding of the seventeenth-century natural law jurists. A treatment of their contributions will also be included in that section (4.6). My conclusions will follow in the last section (4.7).

\subsection{LEgAL HUMANISM}

\subsubsection{Introduction to the mos gallicus and mos italicus}

The Italian scholar Andreas Alciatus (1492-1550) founded the school of legal humanism in Bourges (France). The University of Bourges became the centre of study of Roman law, called the mos gallicus. ${ }^{11}$ The mos gallicus reached its full development in France in the sixteenth century and then spread throughout Europe. ${ }^{12}$ The humanists did not agree with the way Justinian's compilation (and also Canon law) was studied in their time. Three tendencies can be distinguished in the works of these French humanists. Some jurists discredited Justinian's compilation, for example François Hotman, whose critical judg-

10 The (text critical) discussion of the legal humanists on the original text of the Digest fragments has already been discussed in the second chapter; - However, the invention of printing did not lead to the mass production of identical texts (the invention of book printing occurred in the middle of the 15th century). For economic reasons, many editions of the same work were printed; see Osler, 'Legal Humanism'. As Osler rightly stated with regard to research on legal humanists, an accurate analytical bibliography of all the editions of their works has to be made first. Changes made by the author in successive editions will thus become clear. Unfortunately, this was not possible within the scope of this research; where possible, however, I checked more than one edition of the same work.

11 Feenstra \& Waal 1975, p. 16.

12 Riccobono 1935, p. 382. 
ments were openly aimed at promoting French national law. Other jurists argued that fragments of the Corpus Iuris could be rearranged in a new and rational order. They tried to accomplish this by reformulating fragments and arguments in fragments of the Corpus Iuris. ${ }^{13}$ Others studied and used Justinian's compilation only as an important witness of Roman and Greek Antiquity. Some of them continued to study the Corpus Iuris in depth, but with a shift in method and within the context of other sources. ${ }^{14}$

The humanists' enthusiasm for classical Antiquity encouraged a search of original classical sources (now also Greek ones) to acquire a more precise understanding of the texts of the Corpus Iuris. The medieval Glossators and Commentators considered the Corpus Iuris a consistent code. They abstracted from the historical and social context of the sources and used texts from the Corpus Iuris as if they were contemporary sources of law to be interpreted or commented upon; ${ }^{15}$ in that sense they used it in the way Justinian intended, namely, as one consistent legislation with universal validity. ${ }^{16}$ In that perspective, both activities addressed diverse purposes, and had different merits. They were also divided territorially (the centres were located in Bologna - in the medieval period - resp. Bourges - in the sixteenth century). The Glossators can be considered the true interpreters of the compilation of Justinian, though they paid little attention to historical elements; on the other hand, the humanists inaugurated a new era of the study of old sources, animated as they were by a vivifying idea as regards all Antiquity. ${ }^{17}$

While the medieval Glossators and Commentators tried to find a workable rule for a contemporary problem, and this pragmatic application by the Bartolists (mos italicus) continued in the sixteenth century, the humanists put their emphasis instead on the revelation of the original meaning of Justinian's texts in their classical context. ${ }^{18}$ They analysed them in a more historical perspective, with the aid of philosophical and literary sources from classical Antiquity. This new legal humanist approach, the so-called mos gallicus, continued to be applied and even flourished again in the Netherlands with later scholars of the Dutch Elegant School. ${ }^{19}$ The humanists were the first who

13 Bellomo 1995, p. 206 f.

14 ibid., p. 208.

15 Parisi 1992, p. 123.

16 Nevertheless, they did break Justinian's prohibition against writing any commentaries on the text as well as the prohibition against using sigla; therefore, one must say that they were not totally obedient to Justinian.

17 See Riccobono 1935, p. 396f.

18 Stein 2002, p. $76 f$.

19 With regard to the principles and methods, the humanistic direction was diametrically 
attempted to reconstruct classical Roman law, and so they saw a need for a critical reconstruction of Roman texts. The humanist approach considered classical texts as valuable tools for a better understanding of the ancient world. This led to a more attentive reading of the classics and to an appraisal of the legal sources of Roman law, by philological and historical analysis. ${ }^{20}$

As the work of the humanists of the mos gallicus (and of the Dutch Elegant School) can be qualified as academically created legal rules with the purpose of gathering knowledge, their work differed from the work of the jurists of the mos italicus. The work of the latter was oriented to legal practice, law-creating; what they produced was law made by practising lawyers. This method of interpretation and education was followed in Italy since the Gloss. The jurists of the mos italicus took Justinianic law as a starting point, to which they applied their harmonising interpretation. The German legal practitioners put an even stronger emphasis on local law with their usus modernus pandectarum, and therefore the results were more regional. ${ }^{21}$

In general, it can be said that the humanists studied the Corpus Iuris because it could teach them about ancient society, but they renounced applying its legal rules to contemporary problems. ${ }^{22}$ This led to three main activities. (1) To reconstruct classical Roman law, the medieval glosses and commentaries had to be removed from the text of the Digest. (2)This restoration did not take place based on the littera Bononiensis from the eleventh century, ${ }^{23}$ but on the littera Florentina from the sixth century, which possibly contained the text Justinian had sent to Pope Vigilius. The humanists criticised the littera Bononiensis. ${ }^{24}$ Starting with Poliziano, humanistic philologists produced various text editions,

opposed to that of the Commentators, as mos gallicus is opposite to mos italicus, see also Koschaker 1966, p. 109; for a discussion of the different methods of interpretation of the Corpus Iuris, see Riccobono 1935; Astuti 1937, esp. p. $27 \mathrm{f}$.

20 Parisi 1994, p. 332f.; see also Coing 1977, p. 30; Osler, 'Legal Humanism'; - These philological studies of Roman law contained the study of a civilisation and culture that belonged to Roman society and was therefore a study of a civilisation and culture that no longer took part in the society of the 16th century.

21 Koschaker 1966, p. 246. 17th-century lawyers-practitioners in distinct areas in today's Germany aimed at a synthesis of the received Roman law and the local legal institutions, and therefore worked in the same way as the Italian Commentators; see Koschaker 1966, p. 101.

22 Furthermore, on legal humanism and legal education, and the interaction between the humanists and the jurists, see, e.g., Hewett 2010, p. 73f.

23 According to Van den Bergh/Stolte 1977, p. 228, the text of the littera Bononiensis seems to have received a more or less established form towards the middle of the 13th century, but a final and authoritative recensio has never been established. Therefore, strictly speaking, it is not correct to talk about the Vulgate Digest.

24 See Van den Bergh 1994, p. 51ff., who discussed five main criticisms of the humanists on the medieval jurists. Summarising, it included a return to the sources (adfontes), the fact that the humanists did read Greek (Graeca leguntur), an attack on the traditional authorities, a reform of legal eduction and the deficiency of the traditional systematics. 
e.g. Torelli (see also chapter two). 3. As stated above, the humanists attempted to reconstruct classical Roman law (by way of interpolation criticism and palingenesis $\left.{ }^{25}\right)$. They tried to 'deconstruct' the Corpus Iuris to get to the original sources. Through textual criticism the humanists attempted to cleanse the text of scribal errors and also to retrieve elements that, considered of no interest at the time, had been omitted in the Middle Ages. ${ }^{26}$

To conclude this short introduction on mos gallicus and mos italicus, it can be argued that the approach of the humanists was focussed on classical Roman law, as was part of chapter two of this study. As I have shown in chapter two, in classical Roman law an all-or-nothing approach was followed in delictual liability cases and no division of damages was possible between wrongdoer and injured party. Furthermore, D. 50.17.203 originated in the law of legacies and should be interpreted palingetically in this context. One would expect the same results in the various treatments of the humanists. This is not totally the case as will be shown below, as they were also influenced by medieval doctrine. Another question is whether the humanists contributed to the development of the thinking on contributory negligence. As to the mos italicus, on the other hand, one would expect such development. But the humanists were also familiar with the Gloss and with Bartolus (et al.), and they were well acquainted with legal practice in areas where Roman law was received. This makes the picture more interesting but also more complex. The central question I will answer in the following sections is whether the humanists were nevertheless tempted to express themselves on the consequences of contributory negligence of the injured party as to the extent of the claim for damages.

\subsubsection{Humanistic thoughts based on the rule of D. 50.17.203}

In this section, I will study whether my main conclusions on classical Roman law in chapter two differ from the classical (i.e. pre-Justinianic) context provided by the humanists. It will be shown that the humanists did not go so far as my main conclusions. The humanists kept in mind legal practice. Furthermore, one has to keep in mind that Gaius' Institutiones were not available to the humanists, that they did not have an extensive Palingenesia such as Lenel made

25 The humanists sought to detect the interpolations of Tribonian and to reconstruct Roman law based on the littera Florentina, and attempted to make the reconstruction by palingenesis. As noted before, the humanists recognised that the littera Florentina was older and closer to the original (Digest) than the littera Bononiensis.

26 See Osler, 'Legal Humanism'. 
and they did not fully carry through the close connection between rhetoric, on the one hand, and law (and politics), on the other.

The humanists lectured on the two final titles of the Digests (D. 50.16 and D. 50.17), which texts they regarded as a sort of summary of legal thinking. ${ }^{27}$ As to the comments on D. 50.17.203, three different aspects were discussed by the humanists and the scholars of the Dutch Elegant School as to the importance of contributory negligence: (1) the origin of D. 50.17.203, (2) the meaning of this text and (3) examples of the effect of the rule contained in D. 50.17.203.

I will show that the humanists used the same examples as the medieval lawyers when explaining the rule of D. 50.17.203. This ius commune application shows that the humanists were of two minds about the way they worked with the Roman law texts. In addition, the humanists tried to reconstruct the original classical context of D. 50.17.203. This aspect is the only new (and really humanistic) aspect: ${ }^{28}$ such a reconstruction had not been made before in (legal) history.

\subsubsection{The origin of D. 50.17 .203}

In their attempt to reconstruct the contextual origin of D. 50.17.203, some humanists used palingenesis to put D. 50.17.203 back into its original context. However, they came to a conclusion different from the views of Aumann and Wollschläger, which were both plausible (see chapter two). The examples of the rule of D. 50.17.203 given by the humanists show that the prevailing view was that D. 50.17.203 concerned a situation in which the damage is due to the negligence of the injured party. This is in accord with the conclusion resulting from the presumable original context of D. 50.17.203 (law of legacies). What is new is the view of Petrus Faber (1540-1600) and Johannes de Sande (1568-1638), who for the first time considered the possibility of a partial compensation. ${ }^{29}$ This is remarkable, as this approach is not purely humanistic. There was no reason whatsoever to consider such a partial compensation in

27 Van den Bergh 1994, p. 53.

28 According to Wieling 1970, p. 223f., the French humanists do not seem to have gone any further than the replies of the classical jurists in the Corpus Iuris with regard to the question of contributory negligence. Wieling referred to Charles Dumoulin's (Molinaeus) Tractatus de eo quod interest, edn. 1612, nr. 64 col. 809 [=859]. I found another part of Molinaeus which is also relevant: in Tractatus contractum et usurarum, q. 56, nr. 399 (edn. 1612, col. 1434), Molinaeus mentioned a seller who stipulated a right of repurchase of a piece of land, thus enabling the seller to repurchase his property at any time so that he would not lose the fruit harvest, unless he was negligent (i.e. he repurchased the field too late, that is to say, after the fruit had been harvested and sold). In that case he had to blame himself for this damage ( $c f$. D. 50.17.203).

29 Faber and De Sande did not theorise any further on this topic. Extending this view would have meant the abandonment of the all-or-nothing approach; such abandonment was, however, not yet accepted. 
classical Roman law, due to the all-or-nothing approach. This will be more extensively discussed below.

As to the origin of D. 50.17.203, the Dutch humanist Jacobus Raevardus (1535-1568) tried to put D. 50.17 .203 back into its original context, i.e. the law of legacies (palingenesis, namely, with D. 29.2.77). This is a different palingenetical connection than the one taken by modern scholars (such as Lenel) which I followed (see chapter two). Apparently the case concerned a testamentary heir, who also would have been an heir ab intestato. If this heir accepted the inheritance based on a will which also included disadvantages, the heir was not considered to have suffered any damage (based on D. 50.17.203), because he had the possibility to reject one or both of these ways of receiving an inheritance ${ }^{30}$ Furthermore, he could have asked for a period of time in order to consider accepting or rejecting the inheritance (see also D. 28.8.5). ${ }^{31}$ The view of Raevardus has found no supporters among twentieth-century scholars; only D. 29.2.77 stems from the same origin as D. 50.17.203, while the other texts referred to Raevardus - Inst. 2.22.2 \& D. 28.8.5 - do not; the former text, however, does not contain the word damnum. Nevertheless, as stated in chapter two, there must have been a case concerning a legacy for which Pomponius found it necessary to define or interpret the legal term damnum more closely, as D. 50.17.203 indicates that there was an explicit reason to interpret this word in the original (classical) context.

Also Hugo Donellus (1527-1591) ${ }^{32}$ considered the origin of the text to be a case of damage or loss of legacies. Donellus, too, applied palingenesis to this text. ${ }^{33}$ Three possible situations can be distinguished for the application of D. 50.17.203. In the first situation a usufruct was granted as a legacy. Subsequently the heir deprived the legatee of enjoying the usufruct (D. 43.16.9.1). Accordingly, the usufruct came to an end by the lapse of time and the heir's ownership was again unencumbered. According to Paul at the end of D. 43.16.9.1, the heir/owner was compelled to restore the situation, viz. by granting the usufruct for a second time. The loss resulting from this act had

30 Raevardus referred to Inst. 2.22.2; this text, however, is part of Justinian law but not of classical Roman law. Although Raevardus had no access to Gaius' Institutes, he must have thought that some classical Roman law survived in this text of Justinian. However, after comparing the relevant part in the Institutiones of Gaius and Justinian, the conclusion must be taken that the relevant part - as described below in the main text - was not already present in the correspondent text in Gaius' Institutiones.

31 Raevardus, Commentarius, ad D. 50.17.203.

32 On Donellus, see in particular Eyssell 1860; Holhöfer 1982, p. 157ff.; Ahsmann 1990, p. 49ff.; Feenstra 1991, p. 231ff.; Pfister 2007, p. $256 \mathrm{ff}$.

33 See H. Donellus, Commentarii, ad D. 50.17.203. 
to be imputed to himself. Based on a palingenetical link with D. 50.17.155pr., Donellus came to the conclusion that negligence of one party implied that the resulting loss had to be imputed to himself and not to the other party. ${ }^{34}$

In the second situation, described in D. 23.3.66, the usufruct of a plot of land, which was not owned by the husband's bride, was granted by the owner of the land, a third party, as a dowry. In the event of a divorce, this dowry had to be returned to the wife. However, this would be a problem, as a usufruct cannot be transferred by the usufructuary to anyone but the owner of the bare property rights. If it is assigned to an extraneous person (someone who has no ownership), i.e. the wife in this case, that person acquires nothing, and the usufruct reverts to the owner of the property. If the usufructuary nevertheless made such an assignment (i.e. to an extraneous person), the loss of the usufruct (it ceased to exist) had to be imputed to his own fault. The damage or loss was imputed to the negligence of the person who rescinded the usufruct by assigning it. Donellus drew this conclusion by palingenetically linking D. 23.6.66 to D. 50.17.203. ${ }^{35}$

In the third situation the legatee repudiated a legacy containing a usufruct. The rule of D. 50.17.203 applies, unless the following situation occurs. Suppose the legacy containing a usufruct was bequeathed under a (suspensive) condition, or a condition as to time, and the legatee coincidentally rejected the usufruct before that condition was fulfilled. According to D. 31.45.1, a legacy bequeathed under a condition cannot be rejected before the condition is fulfilled or the set period of time has elapsed, since before that moment the legacy does not belong to the legatee. Therefore, the legatee did not suffer any damage. According to Donellus, D. 31.45.1 has to be connected to D. 50.17.203 because both texts (palingenetically) originate from Pomponius' commentary in his eighth book on Quintus Mucius. ${ }^{36}$

34 According to Donellus, this conclusion had to be drawn from the text of D. 50.17.155pr., which was connected to D. 43.16.9.1 as both originated from Paul's commentary in book $65 \mathrm{Ad}$ edictum.

35 Both texts originated from Pomponius' commentary in his eighth book on Quintus Mucius; H. Donellus, Commentarii, ad D. 50.17.203.

36 In addition, according to Donellus the same applies in the case of an inheritance. An heir who rejected an inheritance before a certain period of time, set as a condition, had elapsed, or before a set (suspensive) condition was fulfilled, could not claim damages, because he did not suffer any damage due to his own negligence (see also D. 50.17.174.1). Additionally, an example can be mentioned of a slave who was set free by testament under a (suspensive) condition, and subsequently the slave did not comply with the condition. As a result, the slave would not be set free, either never or for a rather long period. See H. Donellus, Commentarii, ad D. 50.17.203. 
4.2.2.2 According to the humanists, did D. 50.17.203 really concern contributory negligence in classical Roman law?

The prevailing interpretation of the rule of D. 50.17.203 among the humanists was that if someone suffered damage due to his own negligence, no compensation for the damage could be claimed from the wrongdoer. The injured party himself had to suffer the damage if it was caused by his own negligence. ${ }^{37}$

A minority interpreted the rule of D. 50.17.203 differently: specifically, Petrus Faber ${ }^{38}$ and Johannes de Sande. They argued that the person who gave the causa (or occasio) that produced the damage through his own culpa (or negligentia) could not partially or totally claim compensation for the damage from someone else. This view is important because it would at least demonstrate they contemplated a diminution of damages, meaning an abandonment of the all-or-nothing approach. ${ }^{39}$ Unfortunately, no continuation seems to have been given to this observation by themselves or by other humanists. The same can be said about Donellus (and Gothofredus), who treated the text of D. 50.17.203 under the heading of 'de damni communione' (common participation in damage). ${ }^{40}$ Apparently, Donellus really considered this text to include the situation we now call contributory negligence. The central question to him was whether an injured party that contributed to the realisation of the damage and suffered damage because of his own negligence could partially or totally claim damages from the wrongdoer, to the extent the damage had resulted from the actions of the injured party, actions taken at the injured party's own risk. This is all the more important since Donellus was possibly the first scholar who dogmatically formulated the main problem in general terms. Donellus argued that in the event an act was considered to be undertaken at a person's own risk, any damage could not be claimed from the other party involved, because in such case the person was not considered to have suffered damage (see D. 50.17.203). ${ }^{41}$ Furthermore, from D. 50.17.155pr. and D. 50.17.173.2. in connection

37 See, e.g., E. Bronchorst, Commentarius, ad D. 50.17.203.

38 P. Faber, Commentarius ad D. 50.17.203: Qui in causa ipse est ut damnum sentiat, eum non intelligi damnum sentire Pomponius hoc loco refert: quod eo arbitror pertinere, ut scilicet intendere non possit quo magis ei damnum hoc ab alio vel in totum, vel ex parte sarciatur. ...; J. de Sande, Commentarius, ad D. 50.17.203: Docet $h[$ oc] l[ege] Pomponius quod is non intelligitur damnum sentire, qui damno sua culpa aut negligentia causam vel occasionem dedit, itaque is agere non potest, ut ei damnum ab alio in totum, vel ex parte sarciatur ....

39 Also Luig 1969, p. 206, nt. 94.

40 Wieling 1970, p. 223f., referred to the commentary of Gothofredus on D. 50.17.203. He meant the commentary of Jacobus Gothofredus, a jurist born just a couple of years before Donellus died; Gothofredus' commentary on D. 50.17.203, however, is exactly the same as Donellus'; therefore in this specific case I only referred to Donellus' commentary.

41 See H. Donellus, Commentarii, ad D. 50.17.203. 
with D. 50.17.203, the general rule can be established that in such case any act had to be to the detriment of the actor himself, not to the other party. ${ }^{42}$ Donellus mentioned two consequences of the rule of D. 50.17.203. Firstly, the risk had to rest with the person by whose negligence the damage was caused, e.g. the purchaser for whom the vendor had made a stipulatio duplae as a guarantee against eviction. However, if the purchaser/promisee lost possession through his own fault, he had no right to bring an action either under a stipulation for double selling prices or on the contract for purchase against the vendor (D. 21.2.29.1). Secondly, the person who suffered damage because of his own negligence could not claim anything from the other person of a community; e.g. when one of the co-heirs makes a payment under a heritable stipulation in consequence of his own act, he cannot reclaim anything from his co-heir (D. 10.2.44.5). Donellus mentioned various examples of the application of the rule of D. 50.17.203 in different areas of law, among which an example with a reference to the lex Aquilia. ${ }^{43}$ These examples show the application of the rule that when someone suffered damage because of his own negligence, and only this injured party suffered damage because of his act, no liability could be imposed upon the wrongdoer, because the damage to the injured party was not considered claimable. ${ }^{44}$

\subsubsection{Examples of the application of D. 50.17.203}

In this section I will give a short overview of the cases mentioned as examples of D. 50.17.203. However, from the fact that they originated from different contexts, and from the fact that they were written by various different Roman jurists, one can conclude that the research of the humanists was not that palingenetical. They supported the idea expressed by D. 50.17 .203 in various examples from the Digest. Most of these had already been mentioned by medieval scholars (see the previous chapter on the ius commune). The cases frequently mentioned by various humanists and scholars of the Dutch Elegant School are: the case of the procurator (D. 3.3.46.5), the buyer who was evicted (D. 21.2.29.1 and D. 21.2.55pr.), ${ }^{45}$ the guarantor (D. 17.1.29), ${ }^{46}$ the victor ${ }^{47}$, the

42 This connection is not at all self-evident, as this connection was not present in classical Roman law. Donellus can maybe present it as logical but it is not, as the texts were written by different Roman jurists: Paul (D. 50.17.155pr. and D. 50.17.173.2) vs. Pomponius (D. 50.17.203); H. Donellus, Commentarii, ad D. 50.17.203. Similarly, G. Majansius, Commentarius ad D. 50.17.203, nr. I.

43 See some examples mentioned by Donellus in his commentary on D. 50.17.203.

44 Donellus, Commentarii, ad D. 50.17.203.

45 See E. Bronchorst, Commentarius, ad D. 50.17.203.

46 ibid.

47 See W. Durantis, Speculum, De expensis $\S$ Nunc de expensis. 
promise of financial security against losses, ${ }^{48}$ a partner (socius) who performed a delict of furtum or iniuria (D. 17.2.52.18), ${ }^{49}$ the creditor who lost a case against his debtor through his own negligence ${ }^{50}$ the jointly owned slave (D. 9.4.9 and D. 9.4.17pr.) and the co-heirs (D. 10.2.44.5).$^{51}$ An additional example is given by J.J. Wissenbach (1607-1665) ${ }^{52}$ who stated that someone who lost an object as a consequence of usucaption could not file a complaint, since the loss had to be imputed to this person's negligentia and careless inactivity for not having searched better to find his object for a certain period of time nor for having tried to claim it back by vindication (D. 41.3.1)..$^{53}$

Also cases of delictual liability based on the lex Aquilia were mentioned. If someone suffered damage due to his own negligence, based on the lex Aquilia no compensation of the damage could be claimed, and this was apparently considered an example of the application of D. 50.17 .203 (e.g. in D. 9.2.7.4 and D. 9.2.52). ${ }^{54}$ Also the case of the shopkeeper (D. 9.2.52.1) is frequently mentioned as an example of the rule of D. $50.17 .203^{55}$ (the case of the shopkeeper will be shortly recapitulated in the next subsection). Additionally, Faber mentioned the Aquilian cases of the slave lying in ambush. If he was killed by the person he was trying to attack, his master could not bring an action under the lex Aquilia, because of the slave's negligence, attacking the other first (see D. 9.2.4pr.). Furthermore, no action could be brought in the case of D. 9.2.9.4, because the slave himself was to be blamed for having crossed the field of the javelin throwers at an inappropriate time. The same applied in the case of the barber (D. 9.2.11pr.), because the slave entrusted himself to a barber shaving in such a dangerous place. ${ }^{56}$

48 This example was mentioned by the Renaissance lawyer H. Cagnolus (1491-1551) in his Commentarii, ad D. 50.17.204 (=203), nr. 5 .

49 See I. Cuiacius, Commentarius, ad D. 50.17.203, also on the partner who paid a poena because of a delict of furtum or iniuria. Besides, Cuiacius also provided the commentary of Bulgarus on D. 50.17 .203 (see the previous chapter) that was, however, wrongly attributed to Martinus; - According to Faber, the poena follows the wrongdoer and the poena should be where the offence is. Therefore, the crime (maleficium) had to be imputed to the actor and not to his partners. This is an application of the rule that someone who suffered damage because of his own negligence was not considered to have suffered damage; see A. Faber, Rationalia, ad D. 17.2.52.18.

50 See A. Augustinus, Explanationes, ad D. 50.17.203.

51 Mentioned among various other examples by G. Majansius, Commentarius ad D. 50.17.203, nr. II.

52 On Wissenbach, see Van den Bergh 2002, p. $215 \mathrm{ff}$.

$53 \mathrm{~J}$. Wissenbach, In extremum pandectarum titulum, de diversis regulis iuris antiqui, exercitationes cathedrariae, ad D. 50.17.203.

54 See J. de Sande, Commentarius, ad D. 50.17.203.

55 See, e.g., E. Bronchorst, Commentarius, ad D. 50.17.203.

56 P. Faber, Commentarius, ad D. 50.17.203; - These examples mentioned in the main text are repeated by Wissenbach; see J. Wissenbach, In extremum pandectarum titulum, de diversis 
Some sales cases will be discussed now, as they - at least in the treatises of the humanists - seem relevant for contributory negligence. In these cases the rule of D. 50.17.203 appears to have been applied, though the rule was not explicitly mentioned. As will be shown below, these cases, however, do not really concern contributory negligence, but rather damages caused by the sole negligence of the injured party.

The first relevant sales case is C. 8.44(45).8, in which apparently the vendor gave a promise to pay double the amount of the purchase price in the event of eviction (a stipulatio duplae). According to C. 8.44(45).8, the purchaser of land (fundus), if evicted, in principle had no right to bring an action whether under a stipulation or for double the selling price, or on the contract for purchase whether against the vendor or his sureties. This would be different had he previously ${ }^{57}$ notified the vendor (or his heir) of the suit for eviction. In his commentary to this text, Donellus stated that in the event of eviction the vendor was not liable if the eviction took place as a result of the negligence of the purchaser or by an unjust judgment rendered against him. ${ }^{58}$ Donellus discussed various sorts of contributory negligence of the purchaser, e.g. in the case of the purchaser who unintentionally lost the object due to his own fault. Instead of bringing an action against the new possessor, which required relatively easier evidence, i.e. the burden of proof was less difficult (e.g. the actio Publiciana), and despite the fact the vendor advised him to bring that action, ${ }^{59}$ he preferred to bring an action for which the burden of proof was more difficult (e.g. the reivindicatio). Such an act (in bad faith) would only be to his detriment, and so the purchaser would not be granted any right to bring an action under a stipulation against the vendor. ${ }^{60}$

The second case in which the question of contributory negligence was mentioned, namely by Cuiacius (1522-1590), ${ }^{61}$ was the case of C. 8.44.9. Apparently in that case a controversy was raised by someone who claimed to be entitled to the land, sold and conveyed. If the purchaser was evicted by the dominus,

regulis iuris antiqui, exercitationes cathedrariae, ad D 50.17.203; see P. Faber, Commentarius ad D. 50.17.203, p. 773ff. in edn. of 1618; Faber mentioned various examples of the rule of D. 50.17.203 which are not discussed any further here - among which the cases of the lex Aquilia (D. 9.2.52.1, D. 9.2.9.4-D. 9.2.11pr.).

57 Apparently, when it became clear to the purchaser that he might be evicted from his property, he had to inform the vendor (before the actual eviction). In this way the vendor was enabled to defend himself against the claims of third parties.

58 H. Donellus, Commentarium ad C. 8.45.8, esp. nr. $2 \mathrm{ff}$.

59 See also D. 21.2.66pr.

60 See H. Donellus, Commentarium ad C. 8.45.8, nr. 4.

61 On Cuiacius see, e.g., Declareuil 1925, p. 848f.; Astuti 1937, p. 29 (and the literature mentioned there). 
the purchaser could recover damages from the vendor (or his heir) (quanti tua interest). The expenses he incurred to improve the property purchased could be included in the claim. So C. 8.44 .9 provides the purchaser with a claim against the vendor for the compensation of expenses. This seems to be in contrast with D. 19.1.45.1. In this text, someone sold a vacant lot that belonged to a third person and the purchaser built upon it. Subsequently, the owner of the property recovered his lot. According to D. 19.1.45.1, the owner who brought an action in order to recover his property could be barred by an exception on the grounds of bad faith, unless he was willing to pay the building costs. The vendor was not liable for those expenses. However, anyone who knowingly sold property belonging to a third person was liable. According to Cuiacius, the rule of C. 8.44.9 has to be understood as follows: the purchaser could claim the price and the costs of the lawsuit from the person he bought the land from by actio empti. He could not claim the improvement costs if it was possible to acquire these from the evictor (apparently by means of a lien, i.e. a right of retention). If the purchaser did not do so, he had to bear the loss ${ }^{62}$ and could not claim these expenses from the vendor since the loss was due to his own negligence. However, if the vendor acted with bad faith (mala fide), a claim by the evicted purchaser for damages as well as for expenses incurred for improvement to the property was possible. ${ }^{63}$

\subsubsection{Preliminary conclusion}

Some humanists held the view that D. 50.17.203 dealt with common participation in the total damage, i.e. with situations in which both parties acted negligently. This view was influenced by the medieval approach. Most applications and the examples of the rule of D. 50.17.203 are mainly the same as in medieval Roman scholarship. In addition to this, the humanists applied the rule of D. 50.17.203 also explicitly to the relevant sedes materiae I discussed in the previous chapters: D. 9.2.52.1, D. 9.2.9.4 and D. 9.2.11pr. This approach is not purely humanistic, on the contrary. In fact, it will be made explicit in the next subsections that the latter cases concern cases of 'contributory negligence' of the injured party, i.e. cases in which the injured party acted negligently. I will now turn to this topic of contributory negligence in cases of Aquilian liability.

62 Although this seems like an application of D. 50.17.203, no direct reference is made to this rule; also in the Glossa Ordinaria, no reference is made to D. 50.17.203.

63 I. Cuiacius, Comment. ad C. 8.44.9; see also Wieling 1970, p. 223f., esp. p. 224 where he concluded that 'Auch Cuiacius verschmäht also die von ihm so oft bekämpften mittelalterlichen Methoden nicht, hier den Schluß von der Entscheidung auf den Sachverhalt. Sachlich ergibt sich nichts Neues.' 


\subsubsection{The case of D. 9.2.52.1 as an example of self-defence}

Two interpretations of D. 9.2.52.1 which appear from humanistic writings will be discussed now: in the first interpretation D. 9.2.52.1 is considered an example of self-defence; and in the second interpretation the text is explained by making a comparison with (the writings of) Quintilian (an example of compensation of unlawful acts [invicem iniuriae compensatio]). Remarkably, this comparison differs from the one defended in the second chapter of this study. I will make clear that both interpretations, as mentioned above, in fact are not really humanistic, but are influenced by the Bartolistic approach of the medieval scholars.

The case of D. 9.2.52.1 was used by various humanists to develop their views on self-defence. Alexander ab Alexandro (1461-1523) ${ }^{64}$ already argued that if the shopkeeper had been hit by a weapon hidden in a wooden stick (dolon), he would be permitted to hit the passer-by with his sword. ${ }^{65}$ In addition, François Hotman (1524-1590) argued that someone who had not been able to defend himself in a way other than by inflicting damage did not act negligently: all provisions (in the Corpus Iuris) permit using violence against violence. However, it is only permissible to hit somebody in a case of personal attack and solely for the purpose of self-defence, and not for revenge. ${ }^{66}$

According to D. 9.2.52.1, the party who was first hit by a whip and then hit the instigator of the fight in the following quarrel, knocking out an eye of the instigator, did not act with negligence. Antonius Faber (1557-1624) concluded that after all in a quarrel all negligence was often ascribed to the instigator of the fight, as in D. 11.3.10. ${ }^{67}$ According to Faber, to the prejudice of the instigator (unless the contrary was proven), it was presumed that all actions of the person subject to the attack had taken place in self-defence, provided these were performed immediately after the attack (and not after a period of time).

64 Alexander ab Alexandro (Neapolitanus) was a 'civilian and polite scholar' born in Naples. He studied and practised law, first in Naples and afterwards in Rome. On Alexander ab Alexandro, see Enfield 1799, p. 172.

65 Alexander ab Alexandro, Genialium dierum libri sex, Caput XV.

66 F. Hotman, Opera, ad Inst. 4.3, edn. 1599, col. 744.

67 Although these texts can be connected, due to overlap in content, this should not be allowed according to purely humanistic thought: D. 11.3.10 is from Paul, who lived at a later time than Alfenus. 
Furthermore, it was not necessary to wait until the aggressor actually inflicted his first blow. ${ }^{68}$

Later, the Dutch jurist Johannes Voet asked to what extent self-defence justifies wounding or killing a person. According to Voet, the provisions of the Corpus Iuris approve of a moderate defence of property. It was unlawful, however, to kill or wound a thief when the he stole without using violence. ${ }^{69}$ In conclusion, these scholars' elaborations on self-defence led to the same conclusion as drawn by the medieval Roman scholars, but are not truly humanistic in the sense that they return to the interpretation of D. 9.2.52.1 according to classical Roman law. The same applies to the aforementioned connection of D. 9.2.52.1 with D. 50.17.203 (see, e.g., Bronckhorst, Noodt and Majansius), which is not justified by the palingenetical context.

\subsubsection{The connection with D. 50.17.203}

Already Everard van Bronckhorst (1554-1627) observed that the case of the shopkeeper is frequently mentioned as an example of the rule of D. 50.17.203. In D. 9.2.52.1, Alfenus considered the shopkeeper not liable for having knocked out an eye of the passer-by, as the damage was not considered to be inflicted with iniuria, because the thief inflicted the first blow. The thief could not obtain an actio legis Aquiliae, since he suffered damage (he lost his eye) due to his own negligence by stealing the lantern and by hitting the shopkeeper with a whip and/or a dagger. In other words, two reasons are given which constitute contributory negligence: firstly, he stole a lantern from the shopkeeper, and, secondly, after this theft, when the shopkeeper claimed his lantern back, he struck the shopkeeper with a whip or a dagger hidden in a wooden stick. ${ }^{70}$

68 A. Faber, Rationalia in Pandectas, ad D. 9.2.52.1, who, besides D. 11.3.10, also referred to D. 9.1.1.11 and D. 43.16.3.9. The same remark as in the previous footnote has to be made here, as the latter two Digest texts were not written by Alfenus, but by Ulpian.

69 See J. Voet, Commentarius ad Pandectas, ad D. 9.2 nr. 22 (edn. 1778, p. 434).

70 E. Bronchorst, Commentarius, ad D. 50.17.203. 


\subsubsection{Compensation of unlawfulacts}

Also Gerard Noodt (1647-1725) ${ }^{71}$ interpreted D. 9.2.52.1 as a case in which the shopkeeper acted lawfully (iure), as he acted in self-defence, and even though the eye of the passer-by was knocked out, according to Noodt the injury would be forgiven by human nature. This is most particularly the case here, where the damage was due to the negligence of the injured party, who was therefore not considered to have suffered any claimable damage, according to the rule of D. 50.17.203. ${ }^{72}$ This application is not humanistic - since these two texts originate from a different palingenetical origin and since these texts are writen by different Roman jurists in different periods (the first century BC vs. the second century $\mathrm{AD}$ ) - but rather a continuation of the Bartolistic tradition. Also the next part of Noodt's treatment can be characterised as such. According to Noodt, if the shopkeeper acted intentionally because he wanted to get the lantern back from the passer-by by force and started a fight using violence, the damage would be considered as inflicted with iniuria. The shopkeeper was not allowed to cause damage out of revenge or to kill the unarmed thief of the small lantern; he should not even hit or wound the thief. But he had the right to retain the lantern or claim it back, to grab the thief and hold him. If he was hit by the thief, the shopkeeper could also defend himself in any possible way, and if he was (physically) in danger, he would have no duty to prevent the thief from being harmed. If he intentionally or accidentally knocked out an eye of the thief while defending himself after having quarrelled in order to get the lantern back, both parties acted negligently. Based on Quintilianus' Declamatio (Maior) XIII.11, ${ }^{73}$ Noodt claimed that when a delict was on both

71 G. Noodt is regarded as one of the leading figures of the Dutch Elegant School; on Noodt, see, e.g., Van den Bergh 1987, p. 135ff.; 1988; 2002, p. 193ff.; Hewett 2010, p. 120ff.; Noodt generally followed the method of legal humanism; unlike more orthodox jurists such as Huber and Van Bijnkershoek, he did not hesitate to emend the littera Florentina; see Hallebeek 2009, p. 235; also Van den Bergh 1988, p. 119f.; - Usually humanists only emended passages in the textus receptus that were corrupt or incomprehensible, the so-called loci difficiliores; see Van den Bergh 1988, p. 115; - In Noodt's writing and teaching both the philology of legal humanism and the rationalism of natural law played an important role; see also Luig 1990, p. 204f.; 1999, p. 103; Van den Bergh 1988, p. 124ff., esp. p. 132; on the method of Noodt (methodus Noodtiana), see Van den Bergh 1988, p. 133ff.; - There were rationalistic tendencies in his interpretation of the texts of the Corpus Iuris Civilis; reason also induced him to consider Roman law primarily as the product of a certain social and historical context; see Hallebeek 2009, p. 236 (a short list of the literature on G. Noodt is also included).

72 G. Noodt, Ad legem Aquiliam liber singularis, c. XIX, edn. 1767, p. 143.

73 Quintilianus' Declamatio (Maior) XIII.11 (edn. Burmann 1720, p. 284f.): At enim adversus inferentem damnum justa ultio fuit. Dicam nunc, quam iniqua fit invicem injuriae compensatio, quamque non solum legi adversa, sed etiam paci. Barbarorum mos est populorum, quos procul omnis juris humani societate summotos proxima bellvis natura efferavit. Nos ideo magistratus legesque a majoribus nostris accepimus, ne sui quisque doloris vindex sit, et assiduae scelerum causae se refellant, si ultio crimen imitabitur. Damnum accepisti. Erat lex, forum, iudex: nisi si vox 
sides, a compensation of unlawfulness took place. ${ }^{74}$ This comparison would seem humanistic, as Noodt quoted a rhetorical passage from Antiquity, but in fact is not. The idea of compensation of unlawfulness is of medieval origin and is influenced by the Bartolistic (medieval) approach rather than based on a thorough comparison with and knowledge of rhetorical figures. Nevertheless the same approach can be found with the Spaniard Gregorio Mayáns y Siscar (Gregorius Majansius; 1699-1781), ${ }^{75}$ who argued that if the shopkeeper acted in revenge, i.e. if he started a fight just to get back his lantern, both persons acted unlawfully (in the case of D. 9.2.52.1). Majansius concluded with a comparison with the same fragment from Quintilian, and stated that when both acted unlawfully, a compensation of unlawful acts (iniuria) could take place. ${ }^{76}$

\subsubsection{New insights as regards the case of the javelin throwers}

\subsubsection{The link between D. 9.2.9.4 and D. 9.2.10}

In the second chapter of this study, I defended the view that there was no direct relation between D. 9.2.9.4 and D. 9.2.10 in classical Roman law (although one has to admit that Ulpian and Paul were contemporaries). The compilors created such a direct relation by the word 'nam'. Ideally, the humanists should have come to the same conclusion. Now, did they? As will be shown below, they did not; humanists used D. 9.2.10 ${ }^{77}$ to interpret the text of D. 9.2.9.4. In principle, one could state that this is defensable as both texts originated from the third century AD. Still, the texts were written by different jurists. Only a few humanists were critical in this respect (see below) ${ }^{78}$ D. 9.2.10 reads as

jure vindicari pudet. At mehercle jam ad arma mittimur, et instituitur perniciosa nocendi contentio, et in vicem legis ira succedit....

74 G. Noodt, Ad legem Aquiliam liber singularis, c. XIX, edn. 1767, p. 143.

75 Majansius did not belong to the Dutch Elegant School; however, his work was obviously seen as important, since it had been included in the edition of Schulting-Smallenburg. On Majansius, see, e.g., Alvadaro 2004, p. 589ff.

76 G. Majansius, Commentarius ad D. 50.17.203. Interesting is also a remark of Majansius that if the shopkeeper asked for the lantern back, but the thief was not willing to do so, the shopkeeper should reclaim his lantern by means of the magistrate (in court?). I have not found this remark in other sources.

77 With regard to D. 9.2.10, an alternative reading is provided by Brenkman (1681-1736), who stated that the littera vulgata contained 'ludus'. In Ms. Torino BN, E.I.4, fo. 139v, lusus was indeed changed by a later corrector into ludus, as also ludum into lusum in D. 9.2.9.4. However, Brenkman also questioned the reading lusus because of the fact that this reading was not followed in D. 9.2.9.4. See H. Brenkman, Apparatus ad D. 9.2, note lusus $\left(^{*}\right.$ ) ad D. 9.2.10 (edn. Van den Bergh/Stolte 1977, p. 263). On H. Brenkman, see Stolte 1987, p. 150ff.; Van den Bergh 2002, p. 169ff.; Van den Bergh/Stolte 1977, p. 227ff., esp. 230ff., and on the vulgate readings in Brenkman's Apparatus, see Van den Bergh/Stolte 1977, p. $243 \mathrm{ff}$.

78 For example, A. Schulting-N. Smallenburg added that the phrase 'but nevertheless, if anyone intentionally casts a javelin at him, he will be liable under the Lex Aquilia' ought to be connected to D. 9.2.11pr. 
follows: Nam lusus quoque noxius in culpa est. Based on D. 9.2.10, a distinction had to be made between games that were harmful and games that were lawful, a distinction already present with Cicero. ${ }^{79}$

Already in the work of the German humanist Ulrich Zasius (1461-1535) it becomes clear that the case of D. 9.2.9.4 was seen as an example of a situation in which both wrongdoer and injured party acted negligently. Zasius apparently saw a connection with D. 9.2.10, as he stated that the javelin thrower acted negligently, because participation in a harmful game was to be regarded as culpable behaviour. The behaviour of the injured party could also be considered negligent for having undertaken such a dangerous crossing (over the field of the javelin throwers). In this situation, in which both acted negligently, the actio legis Aquiliae would not be applicable. ${ }^{80}$

The French philologist and jurist Desiderius Heraldus (Didier Herault; 1579-1649) stated that Roman law provisions concern public games and competitions, but not games played in private. The exercise field in D. 9.2.9.4 was a public place, designated for exercise such as javelin throwing. If someone crossed this field as the slave did in D. 9.2.9.4, he had to blame himself for this act. The outcome would be different if the field was not designated for such exercises. If someone crossed that field and was hit, the thrower would not remain unpunished. The reason for this was that participating in a harmful game was also seen as an act of negligence (culpa) (see D. 9.2.10). Heraldus tried to reconstruct the original order: D. 9.2.10 had to be connected to the first sentence of D. 9.2.9.4. ${ }^{81}$ However, this is in contrast to the palingenetic origins of these two texts; the connection of D. 9.2.9.4 to D. 9.2.10 is not of classical origin, but Justinianic. Also from the fact that D. 9.2.10 starts with 'nam' it appears that the compilers brought these two fragments (D. 9.2.9.4 and D. 9.2.10) together. With regard to the content, the texts of D. 9.2.9.4 and

79 See Cicero, De officiis, I.103f.; - Later, in the Basilica, 'ludus noxius' changed into ह̇ $\pi \beta \lambda \alpha \beta \dot{\varepsilon} \varsigma$

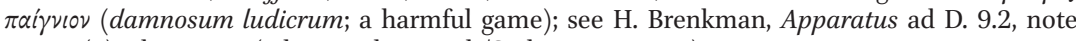
noxius (a) ad D. 9.2.10 (edn. Van den Bergh/Stolte 1977, p. 263).

80 However, if the javelin thrower aimed at the passer-by intentionally (with dolus), his behaviour could not be excused by the negligent behaviour of the injured party.

81 Also the 18th-century Utrecht professor Jacobus Voorda (1698-1768) argued in his Electorum liber singularis (1749), cap. 5, p. 59, that the ratio in D. 9.2.10 ought to belong to the first sentence of D. 9.2.9.4, and not to the second sentence (the slave crossed the field at an inappropriate place, etc.). This view is incorporated by P.I. de Fremery's Dissertatio de rationibus veterum jurisconsultorum (1801), in cap. 1 \$10 p. 37f. De Fremery (1776-1862) also referred to G. Noodt, Ad legem Aquiliam liber singularis, c. VII and Pothier, Ad legem Aquiliam, XX. The latter brought the text of D. 9.2.10 into connection with the first part of D. 9.2.9.4 (Sed si per lusum jaculantibus servus fuerit occisus, Aquiliae locus est) - a place where it was not permitted to play - not with the second part (Sed si quum alii...). 
D. 9.2.10 could connect to each other, but no such connection can be made with the inscriptiones of these texts. The argument of Heraldus, that the Digest consists of various kinds of definitions and decisions of classical jurists, that therefore the fragments in the Digest cannot always be put very accurately in the right order, and that therefore some fragments might not have been connected to the closest fragments, but to earlier ones - is not sound..$^{82}$ The other example Heraldus gave, namely, of D. 5.2.5 and D. 5.2.3, is more plausible as the inscriptiones of these texts, indeed, point at the same palingenetical context/ origin. However, no such thing can be said about D. 9.2.9.4 and D. 9.2.10, as the latter texts are written by different Roman jurists.

The Spanish legal humanist Ioannes Suárez de Mendoza $(† 1681)$ tried to explain the distinction drawn in D. 9.2.9.4. The thrower would be held liable if the javelin was thrown somewhere else other than on the Marsfield or at a place designated for javelin throwing. The reason is that such a game was considered noxius and therefore participating in it was considered as acting with culpa (reference to D. 9.2.10). ${ }^{83}$ That throwing javelins was considered dangerous also becomes clear from some examples of hunting cases mentioned in classical literature. ${ }^{84}$

Also Noodt discussed the case of the javelin thrower in his Ad legem Aquiliam liber singularis. ${ }^{85}$ The criterion of the place apparently was more relevant than the criterion of the person, since a soldier who threw javelins at an unusual place was not entitled to do so (sine iure). According to Noodt, the throwing of javelins was dangerous for others and a harmful game always led to guilt (in case of accidents) and was seen as unlawful (iniuria). Noodt referred to Paul in D. 9.2.10, whose statement fits well into the preceding text in the Digest, D. 9.2.9.4, and is logically connected to it. ${ }^{86}$ However, this connection is contrary to classical Roman law (as D. 9.2.9.4 and D.9.2.10 palingenetically come from different origins). The logical connection is indeed true from the perspective of the compilors; to reconstruct classical Roman law, one has to undo this

82 D. Heraldus, Observationes ad Jus Atticum et Romanum, V.6, nr. 11.

83 J. Suarez, Commentarius ad legem Aquiliam, lib. I. cap. II sectio VII, nr. 6 f.

84 See J. Suarez, Commentarius ad legem Aquiliam, lib. I. cap. II sectio VII, nr. 8f., who referred to Ovidius, Metamorphoses, VII.841, Herodotos, < I $\sigma \tau$ opíal > , I [esp. I.43, EvD], Valerius Maximus, <Facta et dicta memorabilia,> I.7 ext. 4.

85 Although Van den Bergh 1988, p. 174, argued that Noodt's Ad legem Aquiliam liber singularis was - as far as he knew - the first humanistic monograph published on the lex Aquilia, Osler proved that this was not the case. Suarez de Mendoza's humanistic work on the same theme was published in 1640, while Noodt published his monograph in 1691; see Osler 1996, p. 349; on Noodt's Ad legem Aquiliam liber singularis in general, see, e.g., Van den Bergh 1988, p. $173 \mathrm{ff}$.

86 G. Noodt, Ad legem Aquiliam liber singularis, c. VII, edn. 1767, p. 125. 
connection. The same can be said about the connection of D. 9.2.9.4 with Justinian's Inst. 4.3.4, to which Noodt also referred and that according to him compared to D. 9.2.9.4 was 'more complete' (plenius).$^{87}$ As already dealt with earlier, the text of Justinian's Inst. 4.3.4 introduced another criterion, namely, whether the javelin thrower was a soldier or a civilian. ${ }^{88}$

\subsubsection{Solving D. 9.2.9.4 with a new criterion: (in)iustum?}

According to Zasius, no liability based on the lex Aquilia occurred when the injured party acted culpably. However, when the crossing of the passer-by was the right/just thing to do (iustum) and this was not considered dangerous, no such negligence could be attributed to the injured party and the javelin thrower would be held liable for the killing of the passer-by. ${ }^{89}$ The same criterion has been applied by François Hotman, discussing whether the killing of the passing slave by a soldier in Inst. 4.3.4 was commanded or forbidden by (Roman) law. He argued that nobody would consider such a killing the right/just thing to do (iustum). However, neither could the killing be considered to have been done unjustly (iniustum, meaning with dolus or with culpa). According to Hotman, in this case the killing was neither just (iustum) nor unjust (iniustum), but it had to be regarded as more remote from unjust (iniustum), which opinion is agreed to by (Roman) law in a certain way: because the law (ius) is not so much what the laws (leges) command, but also what they do not forbid. ${ }^{90}$

87 See G. Noodt, Ad legem Aquiliam liber singularis, c. VII, edn. 1767, p. 125. Noodt found support in Manilius, Astronomicon, 4.227-229, in which the custom was described of people enjoying mock-fights and jousts in arms, such was their love for fights, and the use of leisure time to war studies and to everything that had to do with the art of war (my paraphrase is based on the English translation by Goold 1977, p. 241).

88 Therefore, the possibilities described by Noodt are as follows: (a.) the person throwing the javelin was a soldier, or not (i.e. a civilian); (b.) if he was a soldier, he threw at an unusual place, or in an exercise field; (c.) if he threw in an exercise field, he either hit the passer-by intentionally (dedita opera), or not; (d.) if he threw intentionally, the accident was considered to be caused by the negligence of the thrower; if he did not throw intentionally, it was considered to be caused by the negligence (culpa) of the slave, because the slave had no right to walk there, and the thrower could not and should not have foreseen that the slave would pass by; of course this was the case when the thrower practised a game in the usual place legally designated to that purpose and usual for military training. See G. Noodt, Ad legem Aquiliam liber singularis, c. VII, edn. 1767, p. 125.

89 See U. Zasius, Commentaria, ad D. 9.2, nr. 11, who also mentioned D. 9.2.11pr. as an example of this compensation rule.

90 F. Hotman, Opera, ad Inst. 4.3, edn. 1599, col. 745. Further, Hotman seems to reformulate the text of Inst. 4.3.4: If the wrongdoer was a soldier who exercised customarily in a field and then killed a slave, he would not be liable. The slave should not have crossed the exercise field at an inappropriate time. Nevertheless, the soldier would have been liable if he threw a javelin at the slave intentionally. However, if the thrower was a civilian throwing javelins in a field designated for practice by soldiers, he would be liable if he killed a slave. See F. Hotman, Opera, ad Inst. 4.3, edn. 1599, col. 746 . 


\subsubsection{A case from practice: application of a iudicatio scheme}

Hotman described the following case. A student went to a place, where soldiers were used to practising with iron pipes, to practise with a hollow tube. A young slave was coincidentally present and was killed by the student: either the slave had not seen the student, or he had but, being unfamiliar with the rules of the game, had not taken precautions. The student was sued by means of an action based on the lex Aquilia. It is remarkable that in his argumentation Hotman used rhetoric, more specifically the so-called iudicatio scheme. ${ }^{91}$ The accusation (intentio) of the master of the young slave was that his slave had been killed because of the negligence of the student. The objection (depulsio) of the student was that the accident did not occur because of his negligence, but rather because of the slave's own negligence. The definition of the problem (quaestio) arising from these two contradictory claims is: who (of the two persons) had been negligent? The student tried to justify the killing of the slave (ratio): according to the student, his act was justified because the slave, not taking care of himself at that place where such dangers frequently occurred, had been negligent. In the end, the strongest argument (firmamentum) was: on the contrary, the student had not been negligent at all because he had not been in a position to take precautions at that place, since he had not seen anyone who could have been exposed to risk..$^{92}$

\subsubsection{Contributory negligence as avoidability}

Situations in which someone acts on purpose may occur, coincidentally inflicting damage on another person. According to Donellus, there were two possible justifications for such an act in which case the wrongdoer was not considered to have acted culpably. ${ }^{93}$ Firstly, if the damage was unforeseeable: e.g. in the case of a tree pruner cutting a tree far from the road who would not expect someone to pass by, but someone nevertheless passed underneath and was killed by a branch falling from the tree (see also D.9.2.31). Secondly, when the injured party acted negligently: i.e. when he could have avoided being injured, but did not, as in the cases of D. 9.2.28.1 and D. 9.2.31. In this respect,

91 See on the iudicatio scheme Braet 2007, esp. p. $230 \mathrm{ff}$.

92 See F. Hotman, Opera, ad Inst. 4.3, edn. 1599, col. 746.

93 Donellus also argued that someone is not liable when an act by casus is not preceded by a culpable act. Accidental damage can be excused when no negligence of the wrongdoer can be established. This was the case in two situations: the accident was unforeseeable under normal human care or it was foreseeable, but there was no obligation to take precautions; see $\mathrm{H}$. Donellus, Commentarius (in Opera Omnia IV), lib. 15, cap. 27, nr. 5. 
Donellus referred to the rule of D. 50.17.203. ${ }^{94}$ This connection is contrary to the humanistic ideal of the reconstruction of classical Roman law and to the palingenetical context. It must therefore be qualified as a continuation of medieval Bartolistic thought. Examples can be found - such as in the cases of D. 9.2.9.4, D. 9.2.28 and D. 9.2.11pr. - for the situation in which the injured party was aware of the fact that a certain action which took place frequently was not forbidden but, nevertheless, was dangerous. ${ }^{95}$ However, participation in a harmful game (lusus damni) would not be an excuse, because it was in every person's own power to refuse to participate in the game. ${ }^{96}$

\subsubsection{Faber's criterion of gravior culpa}

Antonius Faber (1557-1624) observed two problems in D. 9.2.9.4. Firstly, the javelin thrower did not have the intention to cause injury or to act unlawfully. ${ }^{97}$ Secondly, he did not inflict damage directly with his own body but by means of a spear. Because of these two aspects, one could argue that the javelin thrower was not to be held liable. However, with regard to the second aspect (in fact a problem of causality), Faber concluded that throwing a spear (at someone) can be considered similar to locking someone up (resulting in death by starvation; C. 3.35.5), and therefore the wrongdoer is not free from negligence. With regard to the first aspect, if the javelin throwers threw their spears outside a campus iaculatorium, they would not be free from negligence. Furthermore, participation in a harmful game should also be considered as an act of negligence, and should not remain unpunished ( $c f$. D. 9.2.10 and D. 47.2.50.4).${ }^{98} \mathrm{~A}$ game is played for the purpose of recreation, and is not meant to harm others. Therefore, games should be innocuous in order for people to play with impunity (in case an accident occurred). ${ }^{99}$

If someone who exercised with javelins in an exercise field noticed a passerby, he should foresee the eventuality of an accident. However, if someone crossed an exercise field at an inappropriate time, the blame was imputable

94 H. Donellus, Commentaria ad D. 9.2, Caput 1, nr. 9. See also H. Donellus, Commentarius (in Opera Omnia IV), lib. 15, cap. 27, nr. 5.

95 H. Donellus, Commentaria ad D. 9.2, Caput 1, nr. 9.

96 ibid., nr. 13.

97 Also François Hotman treated the case of D. 9.2.9.4 (and D. 9.2.10) as an example of a situation in which someone did not kill with iniuria; see F. Hotman, Opera, ad D. 9.2, nr. 4; more specifically, Hotman argued that the javelin thrower (in the situation of Inst. 4.3.4) acted negligently (with culpa) if he threw at a place where no persons, or only soldiers, customarily practised; see F. Hotman, Opera, ad Inst. 4.3, edn. 1599, col. $743 f$.

98 A. Faber, Rationalia in Pandectas, ad D. 9.2.9.4.

99 A. Faber, Rationalia in Pandectas, ad D. 9.2.10. 
to that person. ${ }^{100} \mathrm{He}$ should have foreseen the danger, and not deterred the throwers from the game out of fear for danger. Neither was the lex Aquilia applicable when someone who played a game was hurt if this happened by accident rather than because of negligence. In such a case the blame was attributed to the game, just as other unfortunate events that could occur when playing a game..$^{101}$

An important remark made by Faber is, however, that no action could be brought by the injured party who had been negligent himself (propria culpa); was it possible to impute a certain amount of negligence to the person hit by the javelin? If this question were answered positively, ${ }^{102}$ the equal amounts of negligence on both sides would be cancelled out by way of mutual compensation ( $c f$. D. 24.3.39). Notice that the case discussed by Faber is the case in which both parties acted negligently. It is remarkable that Faber compared the negligence of both parties and argued that the more serious form of negligence, the gravior culpa in this case, was attributed to the person who intentionally aimed (his javelin) at a passer-by crossing a field, even though this field was an exercise field. Therefore, no fine was imposed on the injured person who crossed the field at an inappropriate time, and the person who killed on purpose did not remain unpunished (because of the doctrine of culpae compensatio, dolus could not be compensated by culpa, but only by dolus). ${ }^{103}$ Thus, in his commentary, not only does Faber build his theory on medieval doctrine, and does his view have to be situated in the tradition of the mos italicus, but he also reveals the first traces of the so-called maior culpa theory. ${ }^{104}$

100 Of course when the javelin thrower threw intentionally at the slave, he would nevertheless be liable (see D. 9.2.9.4).

101 A. Faber, Rationalia in Pandectas, in note (a) sed si cum alii. ad D. 9.2.9.4, who ends with a nice distichon:

Ludus, opes, rixas, fas, furtum, numina, sortem,

Perdit, amat, nescit, parturit, odit, habet.

The distichon - in which Faber eruditely described the unfortunate events - shows that Faber had good knowledge of the Latin language.

102 Also in the Disputatio juridica inauguralis ad tit. instit. de lege Aquilia (1718) submitted by Gerardus Aemilius van Hoogeveen (eruditorum examini submittit) under authority of Ant. Schulting (ex auctoritate magnifici rectoris), the case of the javelin throwers is mentioned. Faber's view does not seem to have been accepted immediately, as in this Disputatio it is still stated that liability is only established if the wrongdoer acted negligently (culpa), not when the injured party (laesus) acted culpably (what seems only to be the medieval ius commune view); see G.A. van Hoogeveen/A. Schulting, Dissertatio juridica inauguralis, p. 14: ... Denique Aquiliae locus non est, si non sit culpa in eo, qui damnum dedit, verum in eo, qui laesus est. ... As to the authorship of this dissertation, however, one can doubt whether Van Hoogeveen wrote the dissertation himself. According to Söllner 1977, p. 575, it is impossible to tell in such disputations what the contribution/share was by the respondent to the information contained in the disputation.

103 A. Faber, Rationalia in Pandectas, in (b) Qui tamen data opera, ad D. 9.2.9.4.

104 Also Luig 1969, p. $207 f$. 


\subsubsection{Conclusion on the humanistic contribution to the development of the theory based on D. 9.2.9.4}

Various humanists directly connected D. 9.2.9.4 in an, for classical law, ahistorical manner to D. 9.2.10. Furthermore, humanists such as, for example, Zasius and Faber considered D. 9.2.9.4 to cover the case in which both parties acted negligently. This, however, does no justice to the procedural approach of the classical jurists ${ }^{105}$ (the same applies to D. 9.2.11pr., which will be discussed below). Only by considering the cases as cases of concurring negligence could the negligent acts be compared and could theories develop. A new approach was the question of (in)iustum, with which the justness of the act of crossing the field was examined (see Zasius and Hotman). Also new and interesting is Hotman's application of rhetoric and the iudicatio scheme to the case of D. 9.2.9.4. Some jurists connected the cases of contributory negligence in the lex Aquilia to D. 50.17 .203 (e.g. D. 9.2.9.4 and D. 9.2.11pr.), which is not justified from a palingenetical perspective. Again medieval influence occurred in the application of the theory of culpae compensatio by Faber, in whose work the first traces of the maior culpa theory appeared. ${ }^{106}$

\subsubsection{New insights as regards the case of the barber}

\subsubsection{A new approach to the actors in D. 9.2.11pr.}

What was new in the approach of various humanists to D. 9.2.11pr. ${ }^{107}$ was the fact that they considered the role of the ball-player important in this respect, ${ }^{108}$ and that they discussed whether the player could be held liable, while this is not covered by D. 9.2.11pr. (except possibly - implicitly - in Mela's opinion). According to Faber, the barber could also have acted culpably, i.e. when he shaved near a place where people usually played, or where there was intense

105 The jurists gave replies as to the requirements of the relevant formula of a certain actio in question, as the fulfilment of these requirements was relevant for the success or the failure of the action. No extensive consideration had to be given to all other circumstances insofar as they were not directly relevant for the fulfilment of these requirements.

106 Heraldus' comparison of D. 9.2.9.4 with Antiphon of Ramnus is also interesting (see chapter two, p. $66 \mathrm{ff}$.).

107 According to A. Schulting- N. Smallenburg, Notae ad Digesta seu Pandectas, ad D. 9.2.11pr., the case of D. 9.2.11pr. has to be connected to the case in D. 9.2.9.4 as both are taken from Ulpian in his 18th book on the Edict. In this sense, they make a palingenetical link, which indeed seems correct.

108 In the same sense the early modern (usus modernus) period professor J. Brunnemann, Commentarius ad D. 9.2.11, who wrote that the player who hit the ball forcefully causing damage was liable, unless the place was designated for such purpose (ball-playing); in that case the barber would be liable. 
traffic. ${ }^{109}$ However, as already stated in D. 9.2.11pr., someone who entrusted himself to a barber who put his chair in such a dangerous place ought to blame himself, and therefore the barber should never be held liable. The player should be held liable if he played where it was not customary, ${ }^{110}$ or if he aimed intentionally at the hands of the barber, or no one would be liable (because the accident was due to casus rather than to culpa).${ }^{111}$ After all, the blame had to be imputed to someone whose culpa preceded the accident. ${ }^{112}$

Also Gerard Noodt ${ }^{113}$ explicitly discussed the position of the ball-players: when the ball-players played somewhere where they had a right to play, no liability was imputed to them. In support of this, Noodt referred to Ovidius' Metamorphoses, to the part on the young man Hyacinthus who was killed during a game of discus throwing. ${ }^{114}$ In this story, Apollo tried to excuse himself from liability, because in his view Hyacinthus had been killed because of his own imprudence. Even though the death was accidental, Apollo was held liable. Apollo admitted that it was his discus that had caused the death of Hyacinthus, but tried to justify his act by arguing that there was no reason to assume that he was negligent, unless the fact that his entry into playing the game with Hyacinthus could be qualified as a fault. ${ }^{115}$

109 Also interesting is J. Heineccius, Recitationes, IV.3 De lege Aquilia, §MLXXX-MLXXXIV. Apparently, Heineccius considered the barber liable because he acted at least with culpa levis (levis sane admodum culpa erat tonsoris), shaving somewhere where children were used to playing ball.

110 In the same sense M. Freher, Verisimilium libri duo, ad D. 9.2.11pr.

111 In that case both persons (the barber and the player) would have acted in a permissible manner. The ball-player did not act culpably even when he hit the ball quite hard and it landed on the hands of the barber as a result of which the slave's throat was cut; the barber did not act culpably either.

112 A. Faber, Rationalia in Pandectas, ad D. 9.2.11pr., with reference to D. 9.2.52.4 and D. 13.6.23.

113 According to Noodt, if one acted lawfully, within certain limits (with proportionality), and another person was killed by accident or by necessity, the actor was not held liable under the lex Aquilia because the wrongdoer did not act unlawfully (iniuria). When someone acted lawfully, but exceeded the due limits when defending himself, this would be different, as was the case when someone killed another coincidentally but a negligent act of the wrongdoer had preceded the coincidental event. Those acts were considered more unlawful than lawful or coincidental, and would lead to liability, based on the lex Aquilia. An example is the case of the barber (D. 9.2.11pr.): G. Noodt, Ad legem Aquiliam liber singularis, c. VII, edn. 1767, p. 124; see also Luig 1999, p. 108.

114 Ovidius, Metamorphoses, X.174ff., esp. $196 \mathrm{ff}$.

115 G. Noodt, Ad legem Aquiliam liber singularis, c. VII, edn. 1767, p. 125, who referred to the fragment of Ovidius just discussed in the main text. This literary source supports Noodt's argument that the ball-player did not act with negligence. See also Luig 1999, p. 108f. 


\subsubsection{Application of the medieval doctrine of culpae compensatio?}

A humanist scholar active at the University of Salamanca was the seventeenthcentury Spanish scholar Pedro Pantoja de Ayala, who, in his Commentaria (1625), argued that in D. 9.2.11pr. there was a doubt whether the barber or the player was exposed to liability under the lex Aquilia. According to De Ayala, Ulpian excused both the barber and the player, and denied the master of the slave an actio legis Aquiliae because he had to complain about his own slave. The final phrase of Ulpian (quamvis nec ... queri debere) led to the exculpation of the player in this case. The player did something permissible (playing ball; unless the way of playing was dangerous; see also D. 9.2.10), ${ }^{116}$ did not throw the ball with the intention to hit the hand of the barber and the instrument he used, and ultimately the ball in itself was not sufficient to cause the damage in question. ${ }^{117}$ Indeed, already older sources state that no actio iniuriarum was granted against someone who, while playing with a ball, hit the ball and caused a personal injury to someone else - unless he did so intentionally. Apparently what was considered decisive was whether or not the instrument was suitable to cause injuries; a ball was normally not suitable to cause injuries. ${ }^{118}$

According to Ayala, nor would the barber be liable because he could not have prevented the damage in any way. ${ }^{119}$ At first sight, it seems that the negligence of the slave cancelled out the negligence of the barber as well as the negligence of the player. However, a more precise reading leads to the conclusion that the theory of culpae compensatio was not applied here. The 'contributory negligence' was just considered as a circumstance, relevant to the determination of (possible) negligence on the side of the barber and/or the player.

\subsubsection{Influence of the mos italicus in the thinking of Suarez de Mendoza}

The Spanish legal humanist Ioannes Suarez de Mendoza $(\dagger 1681)^{120}$ stated that the question in D. 9.2.11pr. was who should the master of the slave hold liable:

116 See also Angelus de Ubaldis, Consilia, 397, nr. 1.

117 De Ayala refers to Angelus de Ubaldis' Consilia, 397 and Cardinal Dominicus Tuschus' Practicarum conclusionum iuris, concl. 456, nr. 16; the relevant parts are used in the previous and in the next footnote, with a slight change and/or narrowing down based on the content of these works.

118 A. de Ubaldis, Consilia, 397, nr. 3f.; D. Tuschus, Practicarum conclusionum iuris, concl. 456, nr's $15 f$.

119 P.P. de Ayala, Commentaria ad D. 11.5.2, nr. 42, col. 984.

120 Luig 1969, p. 204f., discussed Ioannes Suarez de Mendoza in a subsection on the älterer Usus modernus'; to me this distinction seems unnecessary and confusing, although with regard to this specific fragment the author could possibly fall into this category. Because of the inclusion of his work in Meermann's Thesaurus, because of his influence on humanistic authors of the Dutch Elegant School, and when reading Suarez's section seven of his commentary on the lex Aquilia and considering his method in this section, he can best be considered a humanist. 
the ball-player or the barber. Because of the negligence of the barber (shaving at a place where people were used to playing), there is no negligence left for the ball-player; furthermore, the ball game was permitted by law, because it belonged to the exercises for the purpose of displaying courage (see D. 11.5.2.1). ${ }^{121}$ Besides, this ball game was practised outside Rome, namely, in the field of Mars, which was designated for the practice of such games. ${ }^{122}$ Therefore, any imprudence would go unpunished. ${ }^{123}$

Furthermore, according to Suarez, Ulpian meant to argue that the barber was to blame. With the final phrase 'de se queri debere', Ulpian only seemed to reverse his decision, but what he really meant was that the barber acted negligently in any case, but that his liability could be denied if the slave also acted negligently. This only occurred when the slave acted in a careless way (namely, by entrusting himself to a barber who shaved at such a dangerous place). When the slave acted with care, no negligence could be imputed to him, and thus the slave did not act negligently and the barber would be liable. This, for example, was the case if the slave was a stranger, not familiar with the customs of the place, or blind. ${ }^{124}$ By doing so Suarez returned to the opinion of the glossator Johannes Bassianus, which was adopted by and incorporated in the Glossa Ordinaria by Accursius (gloss queri debere ad D. 9.2.11pr.). ${ }^{125}$ This is remarkable since it demonstrates a Bartolistic approach rather than a humanistic approach.

\subsubsection{Application of the maior culpa doctrine to D. 9.2.11pr.?}

Ulpian ends the text of D.9.2.11pr. with the remark that it may not be improper to state that when anyone seats himself in a barber's chair in a dangerous place, he can only blame himself. ${ }^{126}$ It is interesting to consider the commentaries

121 J.Suarez, Commentarius ad legem Aquiliam, lib. I. cap. II sectio VII, nr. 10ff. The reference to D. 11.5.2.1, including the various types of activities, is based on P. Faber, Agonisticon, liber I, cap. 6 (edn. 1595, p. 29f.), who referred to various literary sources, among which Plautus, Bacchides, III.3, where these games can also be found (which were exercised on athletic grounds).

122 See, e.g., Strabo, Geographica, V.3.8.

123 See J. Suarez, Commentarius ad legem Aquiliam, lib. I. cap. II sectio VII, nr. 16f., who referred to a few legislative texts concerning situations in which someone remained unpunished, namely, Fuero Real IV.7.7, Nueva Recopilacion VIII.7.8 \& VIII.23.3 (later also recorded in Novísima Recopilación XII.23.7 \& XII.21.4).

124 J. Suarez, Commentarius ad legem Aquiliam, lib. I. cap. II sectio VII, nr. $18 \mathrm{ff}$.

125 See also Luig 1969, p. 205.

126 According to the edition of A. Schulting-N. Smallenburg, Notae adDigesta seu Pandectas, ad D. 9.2.11pr., the fragment 'Although it is not improper to say that someone who has entrusted himself to a barber who put his chair in such a dangerous place, ought to blame himself,' is not sufficient to conclude that the master of the slave should blame himself and therefore could not claim damages. In Schulting-Smallenburg, reference is made to D. 47.10.1.15, D. 47.10.26 and Inst. 4.3.16. However, the reason remains uncertain in this phrasing. See also G.A. van Hoogeveen/A. 
of the humanists on this phrase more closely: do they see an application of the medieval culpae compensatio doctrine here, or maybe even the renewed doctrine of maior culpa? According to the latter doctrine, not every degree of contributory negligence cancelled out the injured party's right to claim damages. Only when the injured party's contributory negligence was more serious was no recovery of damages possible. This will be made clearer below.

An affirmative answer can already be found with the humanist Marquard(t) Freher, who argued that the slave who entrusted himself to be shaved at such a dangerous place was culpable to some extent. However, the negligence of the barber is held to be more serious and therefore the barber was held liable (cf. decision of Proculus). ${ }^{127}$

Noodt gave two possible explanations for Ulpian's opinion in the final part of his reply in D. 9.2.11pr. First, Ulpian could have meant that although it is not incorrect to say that the slave had to blame himself, nevertheless the barber was also negligent. A second interpretation of the final part of Ulpian's reply could be that the barber acted negligently, but the negligence of the slave, who could have taken precautions but did not, was more serious (maior). There is no doubt as to whether Ulpian left open the question as to which party had to be considered responsible. Noodt, however, supposed that Ulpian chose one of the parties to be responsible, and asked himself which party that would be. ${ }^{128}$ According to Noodt, this becomes clear when studying the use of the word quamvis, the initial word of the final part of Ulpian's reply stating that the negligence of the slave was more serious, correcting or tempering (corrigat, aut temperet) the preceding sentence in which the negligence of the barber was assumed. ${ }^{129}$ In that case, Ulpian would opt for the negligence of the slave to be more serious. However, also another interpretation of the use of the word quamvis is possible: the most natural use of the word quamvis does not

Schulting, Dissertatio juridica inauguralis (1718), p. 15f., stating that Ulpian's view seems to be that the barber was liable because of his imprudence, namely, that he put his chair in a place where people were used to playing or where there was a lot of traffic. However, Ulpian's doubt about this conclusion can be read in the phrase starting with quamvis. Unfortunately, in the disputatio the problem is solved simply by referring to the solution provided by G. Noodt's $\mathrm{Ad}$ legem Aquiliam liber singularis, c. VII.

127 M. Freher, Verisimilium libri duo, ad D. 9.2.11pr.

128 Also Luig 1999, p. 109.

129 Noodt cited four texts from the Corpus Iuris (D. 10.4.7.5, D. 6.1.15.3, Inst. 1.25.8 and D. 27.1.6.19); for a treatment and discussion of these texts, see Luig 1999, p. 109f.; - See also Jansen 2002 b, p. 206, nt. 14, who argued that Noodt supported his explanation of D. 9.2.11pr. by his reference to the word quamvis, namely, by making a restriction. The first sentence expressed the real opinion of Ulpian, namely, that it is correct to blame the barber, while the second sentence is an objection to this starting with quamvis. 
preclude the assumption that Ulpian believed the negligence of the barber to be crucial. ${ }^{130}$

Which interpretation has to be preferred? Noodt solves the ambiguity ( $\alpha \mu \varphi ı \beta \circ \lambda i \alpha)$ by referring to Quintilianus, Institutio Oratoria VII.9.15. According to Quintilian, the whole question in any ambiguity concerns the following: sometimes which of the two interpretations is the more natural; and always which of the two interpretations is the more equitable, and what was the intention of the writer or speaker. ${ }^{131}$ Noodt argued to his reader that when reading Quintilian, the reader would clearly come to the same conclusion as Noodt himself, i.e. that the first sentence expressed Ulpian's true opinion. ${ }^{132}$ According to Noodt, this interpretation is more useful (utilior) and more consistent with (principles of) morality. ${ }^{133}$

Noodt's view on the last part of D. 9.2.11pr. ${ }^{134}$ seems to have become the prevailing view in legal scholarship (considering the references to Noodt in this

130 For this interpretation, Noodt cited two texts from the Corpus Iuris (D. 2.10.1.2 and D. 11.5.1.1), also treated and discussed by Luig 1999, p. 110.

131 Quintilianus, Institutio Oratoria VII.9.15.

132 See also Johannes van der Linden (1756-1835) in his Annotatio ad Voet D. 9.2, nr. 17.

133 G. Noodt, Ad legem Aquiliam liber singularis, c. VII, edn. 1767, p. 125; - Also provided by H. Brenkman, Apparatus ad D. 9.2, note quamvis (e) ad D. 9.2.11pr. (edn. Van den Bergh/ Stolte 1977, p. 264): Amphiboliam in hisce observat Clariss [imus] Noodt c. 7 Ad leg [em] Aquil[iam] putatque priorem sententiam Ulpiani esse, quia utilior est et bonis moribus convenientior. Apart from the value for the reconstruction of Justinian's Digest (as used in the second chapter), Brenkman's papers are important, being part of the legacy of the Dutch Elegant School and providing information on Roman legal science in the 16th, 17th and 18th centuries; see Van den Bergh/Stolte 1977, p. 235. Brenkman's Apparatus hardly ever departs from the opinions of Noodt, as was not the case in the quamvis matter. According to Van den Bergh/Stolte 1977, p. 235f., Brenkman's Apparatus is just as philological and antiquarian as Noodt's work, and, therefore, only a few traces of the usus modernus are found in his Apparatus on the lex Aquilia. One interesting example, mentioned by Van den Bergh/Stolte 1977, p. 236, is Brenkman's note (s) ad D. 9.2.30.3, which, based on a so-called Gothofredus note, referred to a regula framed by Baldus based on this fragment of the Digest, on being killed by one's own negligence. Brenkman hereby reproduced a late medieval marginal note referring to Baldus' opinion; see note culpa (s) ad D. 9.2.30.3 (edn. Van den Bergh/Stolte 1977, p. 289). According to this note, if one did not permit a doctor to take care of oneself and because of that one died, one would have been killed because of one's own negligence.

134 More in general, Noodt's argumentation with regard to the case of D. 9.2.11pr., can be considered as situated between humanism and the practical usus modernus. In the same sense Luig 1999, p. 107; differently Van den Bergh 1988, p. 180, according to whom Noodt's book had been written with a purely humanistic or elegant purpose, without any practical orientation (no traces of the usus modernus) and that it therefore did not have any influence on legal reality. However, Luig 1999, p. 107, states that a closer inspection reveals that Noodt by his interpretation of the source aimed to improve the practice of positive law; furthermore, Luig states that Noodt's interpretation of D. 9.2.11pr. is related to the interpretation of the practice-oriented Johannes Voet; - Although Noodt's interpretation could be proof of his interest in Antiquity (a scene from daily street life in Rome); see Van den Bergh 1988, p. 174; it can also be connected to his attention to relevant practical issues; see Luig 1999, p. 107f., 112. 
respect in which his view was adopted). It has been argued in the literature that Noodt interpreted D. 9.2.11pr. in such a way that, according to Ulpian, the negligence of the barber was more serious than that of the slave and therefore crucial. ${ }^{135}$ If that is true, Noodt considered D. 9.2.11pr. as concerning mutual negligence, and so the question would be who had the maior culpa and thus had to bear the damage. ${ }^{136}$ In that case, a parallel can be drawn with the very practical Johannes Voet (see section 4.4.2), who argued that although it is not improper to say that the slave should blame himself (in these circumstances), the more serious negligence and carelessness of the barber cannot be excused. Therefore, if there was concurrence of negligence on both sides, the relative culpability of both had to be weighed in order to determine the liability for the ultimate accident: the person whose negligence was considered to be more serious was liable. ${ }^{137}$ In conclusion, one can state that Noodt's interpretation of D. 9.2.11pr. (theory of maior culpa) is an example of his way of finding a rational and reasonable solution, which later became legal practice (see below). ${ }^{138}$

A different interpretation of the just-mentioned phrase is provided by U. Huber's (1636-1694) posthumously published Eunomia Romana (1700). ${ }^{139}$ Huber argued that Ulpian, after having argued that the barber would be liable if he placed his chair at such a dangerous spot, added an adversative word (namely, quamvis) that it is just (recte) to say that the slave should blame himself if he entrusted himself to a barber who put his chair at such a dangerous spot. How to solve Ulpian's double judgment? Huber solved it by referring to the Basilica, in which quamvis was interpreted in an ampliative manner ( $\varepsilon \dot{i}$ x $\boldsymbol{i}$

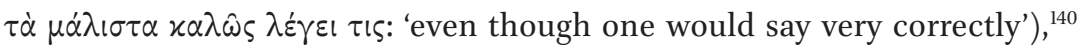
namely, by translating it as 'not standing in the way the fact that'. ${ }^{141}$ The negligence of the barber would then prevail (praevalere) over the responsibility

135 Luig 1999, p. 111.

136 This seems to be clearer than the medieval criterion of 'culpa admixta'; see also Luig 1990, 207: 'Van den Bergh meint, Noodt habe es nicht als seine Aufgabe angesehen, ein modernes Schadensersatzrecht in naturrechtlichem Geiste zu entwerfen. Er findet hier nur ein einziges Beispiel einer Regel, die der Usus modernus ergeben hatte. Ebenso modern schient mir jedoch Noodts Entscheidung für die Maßgeblichkeit der maior culpa anstelle der mittelalterlich unklaren culpa admixta in Melas viel erörtertem Barbier-Fall zu sein (D. 9,2,11pr.) ....

137 Luig 1999, p. 111; see J. Voet, Commentarius ad Pandectas, ad D. 9.2 n. 17 (edn. 1778, p. 432); Aquarius 1945, p. 142; Powell 1951, p. 212.

138 See Luig 1999, p. 112.

139 On U. Huber, see, e.g., Veen 1976; 1987, p. 120ff.; Zimmermann 1992, p. 36ff.; Van den Bergh 2002, p. 184ff.; Hewett 2010, esp. p. 79ff.

140 See also already chapter two, footnote 414, in which I noted the interesting, definite way of formulating the final phrase of B. 60.3.11pr.

141 Also G. Noodt, in his Ad legem Aquiliam, cap. 7, seems to have come to the same conclusion. He considered these words in a way that, although it is not wrong to say that the slave ought to blame himself, the negligence of the barber would prevail. 
of the slave who entrusted himself to the barber, and thus the barber would be obliged to pay damages. ${ }^{142}$ This function of the word quamvis corresponds to the use of that word in Inst. 1.25.8. Huber argued that the real opinion of Proculus/Ulpianus was that in order to determine whether the barber was liable, distinctions had to be made: was the place noticeably dangerous? If it was, a second distinction was necessary: was the slave aware of the (place and) danger, and was the unexpected cut due to the slave's own behaviour/ choice because he wanted to enjoy the spectacle or was he ignorant of the danger of the game? In the latter case the negligence was on the barber's side. ${ }^{143}$

\subsubsection{Some concluding words on the theories developed by humanists based on D. 9.2.11pr.}

In Ioannes Suarez de Mendoza's view on D. 9.2.11pr., one can notice the influence of the view of the medieval glossator Johannes Bassianus (i.e. by way of the Gloss), namely, in writing that Ulpian meant that the barber had acted negligently in any case, but that his liability could be denied if the slave had also acted negligently. This only occurred if the slave had acted in a careless way. If the slave had acted with care and no negligence could be attributed to him, the barber would be liable. This was the case, for example, when the slave was a stranger and did not know the customs of the place; or when the slave was blind. By doing so Suarez returned to the opinion of the glossator Johannes Bassianus. This is not the only proof of the remaining influence of the mos italicus in the writings of the humanists, as more traces can be found. Marquardt Freher considered the negligence of the barber to be more serious: his work includes a comparison of negligences, in which a trace of the later maior culpa theory is already present, which is not only a continuation, but even an elaboration of the medieval doctrine of culpae compensatio. Another trace of the elaboration of the newly revised doctrine of culpae compensatio (i.e. with the addition of the culpa maior doctrine) can be found in Noodt's commentary, in which Noodt tried to solve the ambiguity of the quamvis-phrase by referring to Quintilianus, Institutio Oratoria VII.9.15: upon which Gerard Noodt tried to prove that the ball thrower did not act with negligence, comparing the text with Ovidius' Metamorphoses. Although this seems purely humanistic (using

142 This humanistic approach fits well into my interpretation of D. 9.2.11pr.; see section 2.5.

143 U. Huber, Eunomia Romana, ad D. 9.2.11pr., nr. 2, edn. 1724, p. 408f. this 'alternative view' is also provided by J. van der Linden, Annotatio ad Voet D. 9.2, nr. 17; - Scott 1984, p. 170, rightly stated that no light is, however, shed by the Roman-Dutch sources on the question regarding contributory intent, in which both plaintiff and defendant displayed a blameworthy state of mind in regard to the former's harm. 
literary sources), it is not. The result is more in line with the just-mentioned doctrines. In contrast, Huber tried to solve the ambiguity by referring to the Basilica. He stated that the negligence of the barber would prevail (praevalere) over the slave's, and thus the barber would be obliged to pay damages. Huber's view is more humanistic, in the sense that he did not make use of medieval theories developed by the tradition of mos italicus.

\subsection{A general introduction to the period of THE RECEPTION OF ROMAN LAW}

\subsubsection{Reception of the lex Aquilia}

The term 'Reception' refers to the influence (or even inclusion) of Roman law on legal practice and indigenous law. For example, within the Roman-Dutch tradition, Roman law was applied as the generally applicable subsidiary law. Since the reception of Roman law, the Aquilian concepts are sometimes said to have framed legal thinking about extracontractual liability. ${ }^{144}$ However, the very question is what exactly has been received of the lex Aquilia. ${ }^{145}$ This topic will be touched upon below.

The Glossators and Commentators still felt bound to adhere to the Roman law of the Corpus Iuris, with, among others, the penal character of the lex Aquilia. Even in the fifteenth century, the scholars of Roman law assumed the penal character of delictual actions. ${ }^{146}$ However, in canon law, presumably from approximately 1300 onwards, the payment made by the wrongdoer to the injured party was considered compensation for damage. ${ }^{147}$ Before the thirteenth century, courts applied indigenous law with its system of the (penal) compositio. Between the thirteenth and fifteenth centuries, a change occurred in this ancient system of compositio in indigenous law, due to several events: the rising authorities/government with its officials, of whom the sovereign had to be able to command obedience, and the rise of the cities, which led to acting more firmly against offenders. These developments led to the fact that

144 See, e.g., Jansen 2004, p. 450.

145 I will refer to this question in my conclusions when discussing the question of which ideas of Roman law on contributory negligence were received.

146 Hallebeek 2006, p. 323. The penal character can still be seen in the assessment of damages (with practice-oriented jurists of the 15th century such as Baptista de Sancto Blasio and Johannes Cripsus de Montibus; see Hallebeek 2001, p. 82), the passive intransmissibility and the unrestricted accumulation against co-offenders.

147 See also Dondorp 1998, p. 40, 58. 
punishing the offender came to be conducted by means of a procedure extraordinaris, and led to the emergence of a public criminal law..$^{148}$

About the time Roman law began to be received, the repression of crime was considered a duty/function of the public authorities. ${ }^{149}$ Nevertheless, a part of the ancient compositio still had to be paid to the family of the deceased. In the event of a delict, the public authorities could allow a remission, but only if the family of the deceased (the murdered person) received satisfaction through compositio. ${ }^{150}$ The Roman Catholic Church combatted the system of private vengeance and succeeded in several ways in changing the character of the compositio into a reparation (a restitutio). Such restitution had to go first to the nearest relations of the deceased, i.e. his widow and his children. ${ }^{151}$

The view of canon law that all crimes belong to public law - omnia crimina publica esse -was generally adopted in practice as appears from the work of the legal humanist P. Gudelinus. ${ }^{152}$ The prevailing view of jurists at the time of the Reception ${ }^{153}$ has been that the injured party had to be compensated in the event of a delict, while punishing the wrongdoer was the sole task of the authorities. Therefore, the view was that in the event of private delicts no fine could be claimed, but only compensation for damages. ${ }^{154}$ Furthermore, the thought of restitutio came up in canon law (see previous chapter), ${ }_{1}^{155}$ but only through the Spanish moral theologians did this idea reach the secular world in the fifteenth and sixteenth centuries. Moreover, the idea worked through that every delict, apart from criminal consequences, had to lead to a possible claim for damages to the injured party. ${ }^{156}$

148 Hallebeek 2006, p. 325.

149 Lawson \& Markesinis 1982, I, p. 39f.

150 Feenstra 1972, p. 232.

151 ibid., p. 233.

152 See P. Gudelinus, Commentariorum de jure novissimo, lib. III, cap. 13 (edn. 1643, p. 136).

153 In general, in my references to scholars of the early modern period, I excluded the notes and references of these scholars to other scholars in my footnotes; I also studied those references, and, where relevant for the discussion as included in this study, I included these works.

154 Hallebeek 2006, p. 325; Broers 2012, p. 82f. See P. Gudelinus, Commentariorum de jure novissimo, lib. III, cap. 13 (edn. 1643, p. 136) and J. Voet, Commentarius ad Pandectas, ad D. 47.1, para. 3 (edn. 1778, p. 803).

155 In medieval canon law, the wrongdoer was only liable when he was at fault (culpa); see the decretal Si culpa tua, i.e. X 5.36.9: If loss is caused by your own fault (culpa), it is right that you make amends for it (satisfacere te oportet).

156 See, e.g., A. Gomez, Variae Resolutiones, III, III.37 (edn. 1616, p. 470);- Already in the Corpus Iuris there are some texts which deal with recovery of purely patrimonial loss, namely D. 48.10.25 and D. 48.10.32.1. The Accursian Gloss described an actio poenalis in factum as a remedy for the plaintiff's interest and does likewise for the remedy granted for the duplum in the second case. See gloss penali ad D. 48.10.25 and gloss condemnatur ad D. 48.10.32.1; see more elaborately Dondorp 1998, p. 43; Hallebeek 2001, p. 83ff.; 2006, p. 339f. According to the medieval jurists, there must be a civil remedy in damages available provided that there was a public crime or penal action for reprehensible behaviour from which the damage results. 
To conclude this brief introduction on the Reception, around 1700 the general action for damages (sometimes with the name actio legis Aquiliae or with the name actio de damno dato) lost its penal character throughout Europe; the reasons whereof were discussed above. ${ }^{157}$ This is an important development, as it implies that no accumulation against co-actors or any passive intransmissibility applied any longer. ${ }^{158}$ The change into a reipersecutory action could possibly have contributed to the gradual abandonment of the all-or-nothing approach. The reason is that because of this change the question 'Must the wrongdoer be punished, yes or no?' changed into 'Has the injured party a right to claim compensation?' The latter question, or at least its answer, probably (might have) developed (gradually) into the taking into account of the injured party's contributory negligence. This question of contributory negligence was now placed into another, different, context.

\subsubsection{Requirements for a succesful claim for damages}

What exactly has been received of the lex Aquilia? According to Thomasius' Larva, the action is now purely reipersecutory, ${ }^{159}$ the heirs of a person who caused the damage are liable (passive transmissibility) ${ }^{160}$ and - finally - in cases where several persons caused the damage and one of them paid the whole claim, the other wrongdoers were released. ${ }^{161}$ The peculiar retrospective (or prospective?) assessment of the value of the object killed or damaged, as written in chapters one and three of the lex Aquilia, appears to have never been received in Europe. Courts simply assessed the value of the object of the plaintiff as present at the moment the damage was caused. ${ }^{162}$

By the end of the seventeenth century it had become manifest that modern law in action no longer reflected the Aquilian delict of the Corpus Iuris. ${ }^{163}$ The Aquilian action for damages was disposed of a large part of its Roman law characteristics. One could argue that it rather contains indigenous law and canon law with Roman law terminology. A general action for damage done unlawfully was provided, which was only Roman in its name. The actio legis Aquiliae in

157 See Dondorp 1998, p. 64f., 70. The penal character of the actio legis Aquiliae had already disappeared in the 17th century: a purely compensatory action remained. European jurists had to convert the penal actio legis Aquiliae into a compensatory actio de damno dato; see Jansen 2003, p. 294; 2004, p. 451.

158 See Zimmermann 1996, p. 1020ff.; 2000, p. 62; Jansen 2003, p. 294f.; Broers 2012, p. 84.

159 Thomasius, Larva, § 12 .

160 ibid., § 13.

161 ibid., § 14.

162 Zimmermann 2000, p. 61.

163 Coing 1985, p. 509f.; Zimmermann 1990, p. 68; 1996, p. 1018. 
Roman-Dutch law and in usus modernus showed large differences with the actio legis Aquiliae of the Corpus Iuris. ${ }^{164}$ Nevertheless, in other respects the lex Aquilia was still considered the basis for a general delictual liability. The concept of culpa (in the sense of fault) as a requirement for Aquilian liability remained essentially unchanged. It could take the form of intention (dolus) or negligence (culpa in the narrow sense). Wrongfulness (iniuria) remained an essential prerequisite for Aquilian liability, but terminologically it was not distinguished from fault. ${ }^{165}$ Furthermore, a general theory of causation was never developed or applied. The adagium 'Nam qui occasionem damnipraestat, damnum fecisse videtur' (derived from D. 9.2.30.3) was maintained as a criterion for causality in legal doctrine: the wrongdoer had to provide the occasio damni, the inquiry of which was often linked up with the broader problem of fault. ${ }^{166}$ This means that all consequences of someone's imprudence were imputed to him, no matter how far the causal connection between his act and the damage occurred. ${ }^{167}$

According to Hugo de Groot (Grotius, 1583-1645), and many others with him, it was not sufficient that damage resulted from the act, there had to be imputable blame. He followed the approach of the canonists who started from the fault (culpa) of the individual. Fault was more than careless behaviour, namely, also knowing or having to know that an act was unlawful, or if the act was not unlawful, but careless. ${ }^{168}$ The restitution theory of Thomas Aquinas in the way explained by the Spanish moral theologians was the basis of Hugo de Groot's general claim for compensation. His famous phrase in De iure belli ac pacis describes maleficium in terms of culpa, which he defined as 'acting differently from how one ought to.' ${ }^{169}$ In his definition he does not only mention carelessness, but he emphasises the wrong act in itself, not the imputability of the act to the wrongdoer.

164 Also Hallebeek 2006, p. 344.

165 Zimmermann 1990, p. 77f.; 1996, p. 1027f.; 2000, p. 63f.; - Until the 18th century, unlawfulness, negligence and causality as requirements for a successful claim for damages were still strongly connected with each other. Instead of considering unlawfulness as a separate requirement (which the jurists did not), it was examined whether negligence was present. If negligence was missing on the side of the wrongdoer, his act was considered lawful. See also Dondorp 1998, p. 71.

166 Kaufmann 1958, p. 65; Zimmermann 1990, p. 78.

167 Dondorp 1998, p. 71f.

168 Hallebeek 2006, p. 333f.

169 H. Grotius, De iure belli ac pacis, II 17.1 (edn. De Kanter-Van Hettinga Tromp 1993, p. 427): Maleficium hic appellamus culpam omnem, sive in faciendo, sive in non faciendo, pugnantem cum eo quod aut homines communiter, aut pro ratione certae qualitatis facere debent. Ex tali culpa obligatio naturaliter oritur si damnum datum est, nempe ut id resarciatur. 


\subsubsection{Different types of damage}

All sorts of damage had to be compensated, even when no physical object was damaged and nobody was wounded or killed; this conclusion was already made by the medieval scholars. ${ }^{170}$ According to the medieval interpretation of Roman law, in the event of the death of a freeman, only medical expenses and damages for loss of earnings/wages could be claimed, not for scars and disfigurement. ${ }^{171}$ From two texts of Hugo de Groot, it turns out that the law of Holland deviated from Roman law. The first text, Inleidinge III.33.2, regards manslaughter, and states that the wrongdoer does not have to pay compensation, except for funeral costs (a deviation from the medieval interpretation of the Roman law as contained in the Corpus Iuris), and other costs caused by the crime. ${ }^{172}$ Another deviation from the texts of the Corpus Iuris and its medieval interpretation is the fact that the widow of the victim, and his children, as well as other persons who were maintained by his labour, were granted an action for compensation for the loss of support as a result of the death of the family breadwinner (the influence of (Spanish) natural law scholars and indigenous law). ${ }^{173}$

Medieval Roman scholarship generally maintained that there was no valuation of scars and disfigurement ( $c f$. the Roman principle), although Jacques de Revigny and Albericus de Rosate and other later authors made an exception in the event of disfigurement of women. ${ }^{174}$ The rationale behind this is probably that the (unmarried) woman is not able to get an equally good marriage and to compensate the resulting financial loss - her dos must be increased by a payment of the wrongdoer so that she will be in the same position with regard to her marriage prospects as she was in the situation before her disfigurement. ${ }^{175}$

According to the the second text, Inleidinge III.34.2, in a case of injuries inflicted on a man, a duty to compensate for medical costs and loss of (future) income was accepted, both in accord with Roman law texts of the Corpus Iuris,

170 Dondorp 1998, p. 70.

171 Feenstra 1972, p. 231. See Accursian gloss glori(a)e causa ad D. 9.2.7.4 (a transcription can also be found in Feenstra 1972, p. 237), where Azo stated - with reference to D. 9.2.13pr. that an actio legis Aquiliae utilis was possible in the event of the killing or wounding of a freeman. Although Bulgarus denied the action, and according to Rogerius D. 9.2.15.1 and D. 21.1.42 plead for this point of view, as these texts show that the value of a freeman's body cannot be assessed. According to Azo, however, although the value of a freeman's body cannot be assessed, the other kinds of damage can be claimed (cetera damna). An extensive study on the compensation for pain and suffering can be found with Olivier 1978.

172 Feenstra 1992a, p. 440f.; Broers 2012, p. 87.

173 See Feenstra 1958, 29ff.; 1992, p. 440f.; Broers 2012, p. 87f.; according to Dondorp 1998, p. 73 , this claim originated in indigenous legal practice. However, also the moral theologians did defend such maintainance duty.

174 Feenstra 1972, p. 235; Pauw 1977, p. 244 f.

175 Olivier 1978, p. 68, 74. 
and additionally a compensation for pain and suffering (or for scars and disfiguration of the (human) body) was provided (a deviation from Roman law; the influence of local law and Spanish natural law scholars). ${ }^{176}$ According to Grotius, pain and disfigurement of the body of a freeman, although properly speaking incapable of compensation, are assessed in a sum of money, when such damages are demanded. ${ }^{177}$

\subsection{Roman-Dutch LAW}

\subsubsection{Introduction}

In the fifteenth and sixteenth centuries Roman law was 'received' in the province of Holland. Under the rule of the Counts of Holland, the law of Holland consisted principally in general and local customs. ${ }^{178}$ These Germanic customs were supplemented by privileges (handvesten) and local regulations (keuren) and were themselves affected by an earlier infiltration of Roman law (early reception). The resulting mixed system was called 'Roman-Dutch law'. ${ }^{179}$ Apart from these customary laws of Germanic origin (custom), Roman-Dutch law was composed of other sources of law, such as local laws, legislation (e.g. decrees, edicts, ordinances and resolutions), judicial decisions and rules set out in legal literature, treatises and opinions of jurists. ${ }^{180}$ As already stated above, the Corpus Iuris Civilis was accepted as an additional source of law in many parts of continental Europe in early modern times. Also in the province of Holland, as well as in other provinces of the Dutch Republic, the Corpus Iuris Civilis was accepted as such. The extent of the reception of Roman law or the legal rules in force was not always identical. Each province was autonomous as regards its private law. Also, the legal authorities displayed divergent views when describing the law in force in the various provinces. ${ }^{181}$ The majority of the jurists from the province of Holland used the concepts of Roman law to describe the private law of their time, and added whether or not the Roman

176 Feenstra 1972, p. 235f.; 1992, p. 452f.; Dondorp 1998, p. 74; Broers 2012, p. 88f.

177 H. Grotius, Inleidinge, III.34.2; see also Feenstra 1958, p. 40f.; 1972, p. 235; 1992, p. 451f.; Pauw 1977, p. 246; Olivier 1978, p. 137 f.

178 Lee 1953, p. 3.

179 This term was invented by Simon van Leeuwen in 1652. See on this matter, e.g., Lee 1953, p. 2. Roman-Dutch law remained in force in Holland until it was superseded in 1809 by the 'Wetboek Napoleon ingerigt voor het Koningrijk Holland', which in its turn gave place to the Code civil in 1811 and the Dutch Civil Code (Burgerlijk Wetboek) in 1838.

180 See on these sources of Roman-Dutch law, e.g., Lee 1953, p. 14ff.; Smits 2002, p. 153ff. with references.

181 See Hallebeek \& Merkel 2010, p. 84. 
rules were received in legal practice of the seventeenth and eighteenth centuries. This private law, as conceived by Dutch jurists, was called RomanDutch law. The question of Aquilian liability seems to have risen when a person caused patrimonial loss to another, pure economic loss, loss resulting from the death of a breadwinner and even immaterial damages. ${ }^{182}$ The (divergent?) treatment of the different types of damages will be discussed below.

\subsubsection{Liability based on the lex Aquilia}

There was sufficient legal ground for liability if the wrongdoer acted in contravention of a rule of positive law, or acted with dolus or with culpa. ${ }^{183}$ Liability could thus only be based on the lex Aquilia if the damage was inflicted unlawfully (iniuria). Iniuria only occurred if the damage had been inflicted due to negligence, not in case of coincidence (casus). If culpa (even levissima) preceded the accident, the wrongdoer was liable, even if he did not mean to inflict damage. ${ }^{184}$

The foundation upon which the law of contributory negligence has been built in Roman-Dutch law is to be found in certain passages in the Digest, among which the most important is D. 50.17.203. According to the secondary literature, particular attention may be given to D. 9.2.28, which includes the general rule that an injured plaintiff is refused relief if it had been in his power to avoid the danger created by the defendant. ${ }^{185}$ The words 'culpa sua' in the rule of D. 50.17 .203 could be understood as applying to any carelessness in safeguarding a person's own life or property. That would be negligence in the sense of failing to look after a person's own interests. ${ }^{186}$ If the rule was applied to deprive a plaintiff of a remedy whenever his damage was partly caused by

182 According to Roman-Dutch law, in cases of defamation one could ask for an amende honorabele (recantation and apology) as well as an amende profitabele (monetary penalty) - the latter had to be paid to himself or to the poor. See on this topic Zimmermann 1996, p. 1070ff.; Broers 1996, p. 158ff.; 2003, p. 55.

183 See also A. Matthaeus, De criminibus, XLVII.3, caput I, nr. 4.

184 See, e.g., Paulus Voet (1619-1667), In quatuor libros Institutionum imperialium Commentarius, §. 3.4, who also mentioned the case of a soldier who was doing exercises on the Marsfield, and coincidentally killed a passer-by with a javelin; he would not be liable, because the soldier did not act negligently (culpa); but the passer-by acted negligently (culpa) by inappropriately (importune) and imprudently (imprudenter) crossing the field designated for javelin throwing (see also Inst. 4.3.4 \& D. 9.2.9.4).

185 Aquarius 1941, p. 248.

186 ibid. 
his own negligence, this rule would be a hard one. ${ }^{187}$ I will show that some decisions and opinions nevertheless point at such a rule and such an application.

Some jurists seem to have applied the theory of contributory negligence to cases of their time; theoretically, the usual ius commune approach is followed and they do not provide anything new. This appears from the commentary of Arnold Vinnius (1588-1657) ${ }^{188}$ on the Institutes (first published in 1642), in which he stated that a wrongdoer could not be held liable if an injured party also acted negligently and this contributory negligence of the injured party was the cause of his damage. ${ }^{189} \mathrm{With}$ regard to the case of the javelin throwers, Vinnius argued that what is said in Inst. 4.3.4 about soldiers practising in an exercise field ${ }^{190}$ is also applicable to civilians who were used to exercising in a certain place. ${ }^{191}$ Vinnius asked what was to be said about a meeting of civilian archers who regularly competed by shooting at targets in a certain field. Also in case of a person of a group of non-soldiers who, while training in a field where they regularly trained, killed someone who crossed the area at an inappropriate moment, no negligence would be assumed unless the spear was aimed intentionally at the passer-by. ${ }^{192}$

187 Mazeaud-Tunc 1970, para. 1449, described the adoption of D. 50.17.203 in Roman law as 'une règle brutale'; and added that 'la victime qui a participé au dommage ne peut rien réclamer; il n'y a pas à distinguer selon que sa faute est ou non la cause unique du préjudice.'

188 On Vinnius see, e.g., Arnaud 1969, p. 319; Zimmermann 1992, p. 42f.; 2005, p. XIff.

189 A. Vinnius, Commentarius ad Inst. 4.3.2, nr. 1: Qui hac actione non teneantur? ... Aut si in eo, qui laesus est, culpa sit, cur sit laesus, vid. infr. $\$ 4 \& 5$. [Inst. 4.3.4 \& 5] ...

190 In the case described in the second line of Inst. 4.3.4, a soldier was exercising in an exercise field when one of his javelins pierced a slave. According to A. Vinnius, Commentarius ad Inst. 4.3.4, nr. 1, in this case two circumstances led to the fact that the conduct of the thrower was considered to be without negligence and that therefore the Lex Aquilia was not applicable. Firstly, the place, predetermined or not for exercise and, secondly, the person practising, i.e. a soldier, were important circumstances. If either one of these circumstances did not occur, the Lex Aquilia would again become applicable. Thus, if either a civilian threw a spear in an exercise field for soldiers and killed a slave, or a soldier did this outside the exercise field, both would be liable under the lex Aquilia. The same distinction was made by (the German) C. Rittershusius (1560-1613) in his Commentarius novus, ad Inst. 4.3.4 He argues that if someone acted without negligence, he should not be punished by a poena based on the lex Aquilia. In the case of the javelin thrower one has to make a twofold distinction: based on the person and based on the place. If the thrower was a civilian, he would have acted negligently in any case (the place where he threw javelins in that case did not matter), because he should not have thrown javelins (only allowed to soldiers). If the thrower was a soldier, javelin throwing would have been permitted at a usual place or a place designated for such a purpose; if that was not the case (so if he threw in an unusual place), he was negligent.

191 See A. Vinnius, Commentarius ad Inst. 4.3.4, nr. 1 (edn. J.G. Heineccius, Leiden 1726, p. 755).

192 See also H. Grotius, Inleidinge, III.33.8: Voor onschuldig werden ghehouden die oeffening van wapenen doen daer sulcks gewoonlick is te gheschieden, oock die boomen snoeien niet aen de weg, ofte die sulcks doende aen de weg de voorby-gaenden luiden door gheroep waerschouwen; also interesting is D.G. van der Keessel's Praelectiones iuris hodierni ad Grotius' Inleidinge III.33.8, wherein he referred to the view of the jurists who write in the Rechtgeleerde Observatien, III, obs. 95 (edn. 1778, p. 250ff., EvD) that Grotius' view that no poena nor compensation of the damage 
The aforementioned view of Vinnius that what is said in Inst. 4.3.4 about soldiers practising in an exercise field is also applicable to civilians who were used to exercising in a certain place, ${ }^{193}$ is affirmed by a similar case that occurred in the area of the Duchy of Brabant (Brabantia) and which is mentioned in the Consilia of Wamesius (1524-1590). ${ }^{194}$ In Consilium II.51 Wamesius described the case of Wilhelm van Arschot and Wilhelm vanden Putte. Young people were playing at a place where men as well as young men were used to practising shooting arrows at targets during their holidays. The just-mentioned Wilhelmus van Arschot passed this field and unfortunately was hit in his right eye by one of the arrows, as a result of which he lost his sight. According to Wamesius, the archer could only be held liable if it could be proven that he had acted negligently. ${ }^{195}$ In his argumentation, Wamesius referred to D. 9.2.9.4, when he stated that the thrower played at a place where one generally was used to playing with spears, and a passer-by crossed the field without reason and was hurt in any way, the thrower did not act negligently. Therefore, in the case in question, Wilhelm vanden Putte could not be held liable unless some other (special) kind of negligence was proven. ${ }^{196}$ In this case, nothing that could have impeded excusing the defendant from liability (not because of place, time or genus lusus) was proven by the plaintiff. By way of witnesses, it was even proven that the defendant shouted loudly before he threw the javelin, so bystanders could have secured their safety. ${ }^{197}$ In conclusion, Wamesius explicitly dealt with the question whether this kind of behaviour was permitted only to soldiers or also to civilians. Training with javelins was only permitted to soldiers, and only on exercise fields; however, based on the general custom of that time, civilians also played with arrows

had to be paid by the thrower must be understood in the way that such a thrower needed a pardon. Although Van der Keesel has doubts on this, he admitted that indeed such a pardon is sometimes given (so-called remissie) and he referred to the existence of a special privilege, namely the Voorrecht aan de Schutters van Sint Joris Gilde te Leiden, verleend door Hertog van Bourgondië d.d. 15 juni 1438, given to the shooters of the Sint Joris Gilde in Leiden. The privilege granted a pardon for the case in which they performed military exercises at a usual place and coincidentally killed someone, but nevertheless imposed upon the shooter the making of a payment of compensation (beteringe) to the relatives (maghen) of the victim.

193 See also Cyprianus Regneri ab Oosterga, Censura Belgica, edn. 1648, p. 567f.: ... Sed quia militibus ita se exercentibus, et amputatoribus, qui plerumque pauperes sunt, aliquid remittendum sit, posset hic sententiae nostrae exceptio esse ..., with reference to Grotius, Inleidinge, III.33 and J. Wamesius, Consilium 51 (centuria 2). Apparently, with regard to soldiers and tree pruners, who are often poor, an exception was made and their liability was slightly diminished.

194 Johann Wamesius studied at Louvain, not only law but also ancient languages, and in particular Greek. He became ordinary professor of law in 1555 and professor primarius of canon law in 1570. On Wamesius, see Von Schulte 1896, p. $131 f$.

195 J. Wamesius, Consilium 51 (centuria 2), nr. 1.

196 ibid., nr. 2.

197 ibid., nr. 5. 
and catapults (arcum aut balistam). Therefore it was allowed for civilians to play such games if it was permitted to play games of shooting with arrows in the area of the Duchy of Brabant. ${ }^{198}$

A similar application of contributory negligence in conformity with the ius commune approach can be found in Ulrich Huber's Heedendaegse Rechtsgeleertheydt. ${ }^{199}$ In this influential work he mainly treated Frisian law, not the law of Holland. In his chapter on loss (Van Schade), which he described as 'the worsening of another's property by the fault of the offender, whether occasioned intentionally or unintentionally, ${ }^{200}$ he argued that if a wrongdoer inflicted damage negligently, he had to bear the loss. ${ }^{201}$ An exception was made in the case of an accident (ongeluck), e.g. if a person in accordance with normal practice started any physical exercise at a place meant for it and then killed someone, provided that he had to give a warning where warnings were usually given, as in the (ball)game of Palmasie (rincket). In case of a game of kaetsen, ${ }^{202}$ no such warning had to be given and everyone had to look after himself. So an injured person should blame himself if he suffered any damage during that game. ${ }^{203}$ This reasoning looks like an exact application of the rule of D. 50.17.203.

\subsubsection{New starting points for the theory of culpa maior}

In the commentary on the Digest by the Utrecht professor Johannes Voet (1647-1713) $)^{204}$ on the liability of the barber (D. 9.2.11pr.), the relevance of contributory negligence in Roman-Dutch law becomes immediately clear. ${ }^{205}$ In interpreting Ulpians' reply, Johannes Voet argued as follows. It is true that it may be said that someone who entrusted himself into the hands of a barber

198 ibid., nr. 3.

199 Huber was a professor at the Franeker University, teaching Rhetoric and History from 1657 to 1665 , and Law from 1665 until his death, which period was interrupted by three years of service at the Provincial Court (Hof van Friesland) at Leeuwarden (1679-1682); see Hewett 2010, p. xix.

200 Translation cited from Gane 1939, p. 388; the original words in Dutch are as follows: 'verslimmeringe van een ander sijn goedt, door des Daders schuldt, het zy met, of sonder opzet veroorzaekt' (U. Huber, Heedendaegse Rechtsgeleertheydt, VI.4.2, edn. 1768, p. 886).

201 U. Huber, Heedendaegse Rechtsgeleertheydt, VI.4.4; - Also VI.4.11 is relevant as to the statement that, apart from an accident, any kind of fault and imprudence (schuldt en onvoorzichtigheyt) must be made good, so a person who did not act with the most scrupulous possible diligence was obliged to pay for the damage caused to another's property.

202 On palmasie and kaetsen, see Schotel 1869, esp. p. 127.

203 U. Huber, Heedendaegse Rechtsgeleertheydt, VI.4.7 (4th edn. of the Dutch version (1742); I also used the English translation by Gane 1939, p. 388f.).

204 On Johannes Voet see, e.g., Roberts 1933; Kop 1987, p. 130ff.; Zimmermann 1992, p. 39ff.; Moosheimer 1996, p. 440ff.; Ashmann 2001, p. 656; López-Jacoiste Díaz 2004, p. 465ff.

205 Scott 1984, p. 170. 
who put his chair in a dangerous place (i.c. where it was customary to play games) ought to blame himself. Nevertheless, such greater negligence and carelessness on the barber's part in plying his craft at an unsafe place could not just be excused for that reason. Voet qualified it as 'common knowledge' that when two persons were negligent at the same time, the person whose negligence is considered more serious was held liable. ${ }^{206}$ The same would apply if someone put himself under the treatment of an unskilled medical man. Such person was not entirely free from negligence, yet the unskilled medical man was liable if he was responsible for bad treatment, due to his unskillfulness. ${ }^{207}$

Voet's approach appears to be based on culpae compensatio ${ }^{208}$ but with a more logical application of the rules of set-off (than the medieval (Roman) rules) since Voet believed that the greater fault of the barber could not be excused. ${ }^{209}$ This text of Voet's is indeed important since it clearly outlines the idea of greater fault/negligence (culpa maior).${ }^{210}$ Voet believed that in the case of D. 9.2.11pr. the negligence and carelessness on the barber's part could not be excused just because of the fact that the slave ought to blame himself as he put himself into the hands of a barber with his chair in a dangerous spot. When two persons were negligent at the same time, but their faults were unequal, the person whose negligence was considered to be the more serious was held liable/responsible. ${ }^{211}$ Voet's approach implies a quantitative estimation of the negligence on each side; if the negligence on each side was unequal,

206 My paraphrase is based on the translation by Gane 1955, p. 576 here.

207 J. Voet, Commentarius ad Pandectas, ad D. 9.2 nr. 17 (edn 1778, p. 432): ... non tamen inde excusata videri potest major illa tonsoris culpa ac imprudentia, in loco non tuto artem profitentis; dum novum non est, ut in concurrente duorum culpa is teneatur, cujus culpa major conspicitur .... Voet refers to D. 18.6.13(12), D. 18.6.14(13), D. 2.7.1.2 and 2. Van den Bergh 2002, p. 55, rightly stated that these texts only imply that negligent behaviour of one party excluded negligence of the other party, but that the concept of 'maior culpa' cannot be found in these fragments.

208 With regard to the theory of culpae compensatio as applied by the Dutch Elegant School, the disputation of E. Emtinck (1701) under the presidency of Schultingh is relevant; see Schultingh, Thesium controversarium, thesis 57.7. There seems to be no large difference in the application of this theory compared to medieval practice: in contractual relations, as well as in the case of delicts, a mutual compensation of the respective negligent acts (culpa), or dolus (as far as one is legally demanding a financial compensation) was possible. Therefore, no one could legally bring an action against the other.

209 Thomas 2001, p. 353, 359.

210 Also Aquarius 1941, p. 260; see also Voet (9.2.22) in which he solves a responsibility problem by fault comparison.

211 Scott 1984, p. 170. As Scott rightly stated, Voet apparently agreed with the view that the greater blame is of the person to whom blameworthy conduct is imputed, as a consequence of the rule 'imperitia culpae adnumeratur'; this can be concluded from Voet's aforementioned commentary (9.2 sect. 17) and more in general from his commentary on D. 9.2. sect. 3 in fin. and sect. 23; - According to Kotzé 1953, p. 68, 'is teneatur' apparently has to be interpreted in such a way that it also concerns the case in which the negligence (culpa) of the plaintiff is more serious. Then is teneatur does not necessary imply liability of the plaintiff-injured, but the plaintiff was not granted an action. 
the person who committed the smaller fault was discharged and the bigger fault remained. As a result of this rule, the claim against the more negligent person succeeded in totality. ${ }^{212}$ Although the all-or-nothing approach was still the same as in medieval times, it was now renewed in the sense that the less serious negligence of the injured party did not cancel out his right to claim for damages. $^{213}$

This approach is not applied by Voet to the case of the javelin throwers. Voet discussed whether injuries inflicted during games would lead to liability under the lex Aquilia. According to Voet, people were regarded as liable when hurting another while engaging in a lawful exercise or a game, in case the harm occurred because no proper attention was paid to the particular place or to persons at a certain time. Liability would also occur when harm was done knowingly and deliberately, although no negligence in respect of time, place or persons could be held against the wrongdoer(s). In the case of the javelin throwers, one of the throwers, while playing or exercising with javelins, pierced another's slave (passer-by). If this throwing was committed by a soldier on a field where exercising was common, the thrower did not act negligently. But if someone else, not being a soldier, performed such an action, he would have. The same would apply when a soldier committed such an action in a place outside the allotted exercising field, or threw his javelin at the man on purpose, even in an allotted javelin exercising field. ${ }^{214}$

\subsubsection{Criminal law}

The relevant sources of the ius commune had also found their way into criminal law. As mentioned before, in the early modern period, Roman delicts lost their penal character. However, some rules of these (Roman) delicts were still used in (public) criminal law, as revealed in the elaborate treatise on homicide written by Simon van Leeuwen (1625-1682) in his Censura forensis where he compared the regional and local law with Roman law. ${ }^{215}$ Furthermore,

212 Thomas 2001, p. 353f.; according to Thomas 2001, p. 354, if both negligences were equal, the situation could be regarded as comparable to an accidental situation in which no fault was made. In Roman-Dutch marine collisions the principle applied that the loss on both sides was borne in halves (see section 4.4.3), this moiety rule should apply in marine collisions where an equal mutual fault occurred. Voet (Commentarius ad Pandectas, ad D. 9.2, nr. 15), however, did not draw these conclusions from his own rule on culpa compensation.

213 According to medieval Roman law, the mere existence of culpa led to the denial of claim for damages.

214 J. Voet, Commentarius ad Pandectas, ad D. 9.2 nr. 24 (edn. 1778, p. 435); my paraphrase is based on the English translation by Gane 1955, p. 585.

215 On Simon van Leeuwen see, e.g., Zimmermann 1992, p. 44f.;- Besides, Antonius Matthaeus II (1601-1654) wrote a treatise called De Criminibus (1644) in which he treated books 47 and 48 of the Digest (the so-called Libri terribiles) and discussed the Roman criminal law as 
it is also interesting to see the way in which the rules of canon law are used in criminal law in the early modern period. The concept of culpa as used in canon law is incorporated in the early modern treatments on homicide. Contributory negligence of the injured party has no explicit place in this theory; however, this is not implausible, because of the criminal character of homicide.

With regard to homicide, as in canon law a distinction was made between accidental and culpable homicide. A homicide was regarded culpable if negligence was involved. ${ }^{216}$ Negligence was considered to be present if the death of the victim by sheer chance occurred while doing something illegally ${ }^{217}$ or if someone, although performing a lawful and permitted act, had not taken adequate care. ${ }^{218}$ Also, this definition of negligence by Van Leeuwen reminds us of the definition of canon law (see the previous chapter) ${ }^{219}$ When a homicide regarded as culpable (aliqua culpa) had been committed, the judge had to decide the penalty according to his judgement and discretion and depending on the extent of the negligence involved in the delict. ${ }^{220}$

Conversely, a different situation occurred in the event of accidental homicide, i.e. homicide committed by chance with absolutely no malicious intent or negligence of the killer during or before the homicide. ${ }^{221}$ No penalty was given, nor was the wrongdoer imputed any irregularity by an ecclesiastical judge in case of fortuitous chance. ${ }^{22}$ An example, already thoroughly discussed in the previous chapter, ${ }^{223}$ and mentioned in this context, is the case of a cleric who, playing boisterously, threw another cleric to the ground and in doing that,

received in (the United Provinces of) the Netherlands.

216 See also already, e.g., P. Farinacius, Praxis Criminalis, De homicidio, q. 125, nr. 36.

217 See also the example given by F. Wielant, Corte instructie I, cap. 53/14, in which he states that when someone intentionally threw another from a bridge into the water, or from a window onto the street, and the victim drowned or died as a result of the fall, the wrongdoer would be punished on the charge of homicide, even though it was meant as a game, because such a game was not permitted; see also Vrolijk 2004, p. 170.

218 See S. van Leeuwen, Censura Forensis I.V.XI De homicidio, nr. 11.

219 See also L. Carerius, Practica causarum criminalium. De homicidio, nr. 2.

220 S. van Leeuwen, Censura Forensis I.V.XI De homicidio, nr. 11: Quibus duobus casibus, si infortunio ac casu quodam ex facto alicujus quis interficiatur, homicidium pro culposo habendum est: eoque commisso judex pro arbitrio et discretione sua poenam decernet, secundum culpae aut levitatem, aut gravitatem, quae communiter esse solet, exilium, relegatio, damnatio ad carceres sive perpetuos, sive temporales, etiam pecuniaria. ... See also already P. Farinacius, Praxis Criminalis, De homicidio, q. 125, nr. 27.

221 S. van Leeuwen, Censura Forensis I.V.XI De homicidio, nr. 7.

222 On this topic, see also J. Ayrerus, De Homicidio, pars 3, num.1 et 10ff.; - This corresponds with what Carerius argued with regard to the accidental homicide in ius civile in his Practica causarum criminalium. De homicidio, nr. 1.

223 Other examples of homicidium casuale and homicidium culposum are mentioned by L. Carerius, Practica causarum criminalium. De homicidio, nr.'s $12 \mathrm{ff.}$., $19 \mathrm{ff}$. 
a knife he had attached to his side got loose and fell on the other by chance, causing fatal wounds (X 5.12.9). ${ }^{224}$

Another example, which was mentioned (in the German and Latin versions) by Van Leeuwen is Article 146 of the Constitutio Criminalis Carolina of Charles V of 1532 (CCC). ${ }^{225}$ The Constitutio criminalis Carolina of 1532 was a revision - known by its Latin title but retaining the German of the original ${ }^{226}$ - of the Bamberg Code, the Peinliche Halsgerichtsordnung of Charles V of 1507, authored in large part by J. von Schwarzenberg (see below). ${ }^{227}$ From Article 146 CCC it appears that a homicide was not punished in the presence of a justification to the act which was valued according to objective circumstances. ${ }^{228}$ Article 146 CCC, concerning accidental homicide against the actor's will (except for self-defence), is especially interesting as two cases are listed which are comparable to the case mentioned in Justinian's Digest: the case of the barber and the case of the javelin throwers. As to the reception of these fragments, in chapter three I discussed the

224 According to the report of the facts of the case as presented by Joost de Damhouder (1507-1581) in his Practycke in Criminele saken, cap. 84, nr. 16ff., two clerics played a wrestling game, and one of them threw the other to the ground. The cleric thrown to the ground coincidentally held a knife in his hand, and the cleric who threw him fell on the knife, was wounded and subsequently died. Because of the coincidental nature of the accident, the clericwrongdoer did not act negligently. According to Joost de Damhouder, this coincidental accident was only excused if the wrongdoer acted without intention to harm, did something which was allowed to him, and used great care to prevent the accident. Otherwise, the wrongdoer acted negligently, and he would become irregular. Dispensation for such irregularity could only be given by the Pope, or in minor cases by a bishop (however not based on his own authority but on a mandate from the Pope). See also already F. Wielant, Corte instructie in materie criminele, cap. 85, nr. 4: Zo zyn ooc die ghesleghen [hebben] onwetens ende onwillens end zonder malencien, of diet deden by messchieve of ongheval, zonder culpe of groote roukelooshede, of diet deden in spele als tspel gheoorlooft was, ende niet te ruude, ende ooc tgrief niet te groot, noch scadieuselic ghedaen.

225 Van Leeuwen's version seems to be derived from the Latin text of art. 146, which reads: Cum Titius in tonstrina sua (qui locus ei nogocio commodus est) Sempronio barbam raderet, inopinato casu in manus tonsoris iactatum quid est, aut tonsor percussu, unde gula eius, quem radebat, cultello, praeciditur. Exemplum dari et hoc potest: Si balearis quis funditor, aut miles in campo Martio iaculationibus atque militaribus exercitationibus atque militaribus exercitationibus destinato, iaculis ludens, palum iaciens, dum telum emittit, bombardam ad metam exonerat, transeuntem transcurrentemve laeserit, traiecerit: vel si, cum nondum collimasset, telum inuito manu fugerit, atque hominem occiderit, quia improviso casu factum est, nulla horum culpa intelligitur; \$1. Sivero tonsor in via publica aut ubi homines ex consuetudine tonderinon solent, quem radat: aut miles, sagittarius, bombardarius in alio loco, quam qui ad exercitandum iaculandum datus est, ut qua vulgo iter fit, eiaculatus fuerit: aut si imprudentius arcum, tormentumve in loco ipso destinato tractarit et versarit: si quis ab eo tonsore vel milite occidatur, quod in lata culpa sint, puniri possunt....

226 The Carolina was composed in what is today is called Frühneuhochdeutsch; see Langbein 1974, p. 259.

227 Reinhart 2007, p. 766.

228 Krikke 1980, p. 205. He reminds us of the glossator Vivianus who discussed the case of the barber. He argued that if the barber was sitting at a public place near to people who were throwing, and if, for example, he had been hit by a horse, that could be considered casus fortuitus. However, the barber would have acted with culpa if the accident occurred as the result of a game which did not prevent him from doing his job as if there was nothing going on; see Van Zuylen 1912, p. 32f. 
Klagspiegel which included diverse explanations of culpa; these became a model (Vorbild) for the Halsgerichtsordnung of Bamberg (1507) of Johann von Schwarzenberg und Hohenlandsberg (1465-1528), ${ }^{229}$ and later in Article 172 of the Bambergensis. ${ }^{230}$ The fact that the Klagspiegel was taken as a model can be explained by the fact that Von Schwarzenberg could not base himself directly on the sources, not being familiar with the Latin language. ${ }^{231}$

As (generally speaking) Roman jurists derived fundamental ideas and relationships from casuistry, Schwarzenberg adopted the results of this derivation and adduced the Roman cases as examples to convey the right understanding of these derivations to the 'common man, as sitting at the courts', with the aim of explaining the relevant distinctions made by the law even to uneducated ('nicht gelehrten') judges. ${ }^{232}$ Soon after this, Article 172 of the Bambergensis was adopted unchanged in Article 146 of the Carolina of 1532, which text is also recorded by Van Leeuwen. ${ }^{233}$

Von Schwarzenberg distinguished three kinds of damage-inflicting acts. The first is the coincidental act, which remained unpunished and which was excused. The second is the intentional (malicious and wilful) act and the third is the negligent act ${ }^{234}$ which was careless, for which he - with mercy provides a reduction of the punishment. ${ }^{235}$ With regard to negligent killing,

229 Knütel 2001, p. 365. On J.F. von Schwarzenberg, see, e.g., Wolf 1963, p. 102ff.; Conrad 1966, p. 408; Kleinheyer/Schröder 1996, p. 364ff.

230 See Brunnenmeister 1879, p. $172 \mathrm{f}$.

231 Hälschner 1855, p. 90; Stintzing 1959, p. 400; Knütel 2001, p. 365.

232 Knütel 2001, p. 366.

233 See S. van Leeuwen, Censura Forensis I.V.XI De homicidio, nr. 8; - Art. 146 of the Constitutio criminalis Carolina of Charles V (1532) is based on art. 172 of the Halsgerichtsordnung of Bamberg drawn up by J.F. von Schwarzenberg in 1507, fo. 48v/49r; - The German text version of the Constitutio criminalis Carolina as reproduced by Van Leeuwen slightly differs from the text of the Peinliche Gerichtsordnung Kaiser Karels V. of 1532 as reproduced in the edition of RadbruchKaufmann of 1978, p. 92f: Eyn balbirer schiert eynem den bart inn seiner stuben, als gewonlich zu schern ist, und würd durch eynen also gestossen oder geworffen, daß er dem so er schiert, die gurgel wider seinen willen abschneidet, Eyn ander gleichnuß, so eyn schütz inn eyner gewonlichen zilstatt steht, oder sitzt, und zu dem gewonlich blatt scheust, und es laufft im eyner under den schuß, oder jm lest ungeuerlicher weiß unnd wider sein willen sein büchs oder armbrust, ehe und er recht anschlecht und abkompt, unnd scheust also jemandt zu todt, dise beyde seind entschuldigt. Understünd sich aber der balbirer an der gassen oder sunst an eyner ungewonlichen statt jemandts zu schern, oder der schütz an eyner dergleichen ungewonlichen statt, da man sich versehen mocht, daß leut wanderten, zu schiessen, oder hielt sich der schütz inn der zilstatt unfürsichtiger weiß, unnd würde also von dem balbirer, oder dem schützen, als obsteht, jemandt entleibt, der thätter keyner würd gnug entschuldigt. ...

234 An act has to be regarded as done with negligence if it is done 'ungeferlich, auss geylheit oder unfursichtigkeitt, doch widder des thätters willen'; see Schmidt 1965, p. 118.

235 Schwarzenberg took over the principle of liability in case of negligence (Schuldhaftung) for public penalties (and eliminated the remainder of the Erfolgshaftung, in particular the 'Ungefährwerke'); see Hälschner 1855, p. 88f., 94f.; Schmidt 1965, p. 117; Conrad 1966, p. 409; Knütel 2001, p. 367. Also J. Brunnemann, Commentarius ad D. 9.2.9, nr. 3, in his commentary on the contents of D. 9.2.9.4 (and D. 9.2.10), referred to art. 146 of the Constitutio Criminalis of Charles V. 
Schwarzenberg endeavours to make the facts clear by examples borrowed from the Digest (see Article 146 CCC). ${ }^{236}$ As stated above, coincidental killings led to the full excusing of the killer from liability; in the examples Schwarzenberg shows the distinction between negligent behaviour and not-punishable coincidental acts. Finally, the fact that he declared negligent manslaughter a culpable act shows that he followed the view developed by the medieval jurists (Glossators and Commentators) and that in canon law. ${ }^{237}$

As to the example of the barber (D. 9.2.11pr.), it is remarkable that Von Schwarzenberg distantiated himself from the version as provided in the Klagspiegel in which the final solution of D. 9.2.11pr. (quamvis nec illudmale ...) was adopted. Von Schwarzenberg seems to put aside Ulpian's view and return to that of Proculus, affirming the liability of the barber because of negligence on his side. ${ }^{238}$ It has been argued that Von Schwarzenberg, probably advised by his associate, the learned jurist Leonard von Egloffstein, ${ }^{239}$ supplied himself with the knowledge of the text of D. 9.2.11pr. (and further relevant fragments) ${ }^{240}$ and decided consciously thereupon against (the solution of) the Klagspiegel. ${ }^{241}$

Another instance of reception can be found in an example referred to by Van Leeuwen, which can be found in Article 6, §2 of title 5, book 6 of the Landrecht des Hertogtums Preußen of $1620 .{ }^{242}$ In this article some examples are discussed

236 Knütel 2001, p. 367f.; see also Roßhirt 1839, p. 193f., 214ff.; Engelmann 1922, p. 37f., esp. nt. 2., p. $257 ; 1965$, p. $186,209,224 \mathrm{ff}$.

237 In the same sense Knütel 2001, p. 367; - An English translation of the relevant part of the (later) Carolina (i.e. of the case of the barber and the case of the javelin throwers) can be found with Hewett 1991, p. 65.

238 On the suspected influence of this jurist on the Bambergensis, see Trusen 1984, p. $101 \mathrm{ff}$.

239 Von Schwarzenberg had no learned and legal education; see, e.g., Conrad 1966, p. 408.

240 See Brunnenmeister 1879, p. 173; Knütel 2001, p. 367; - The examples of the barber and the javelin thrower are also mentioned in later times; see, e.g., B. Carpzovius, Practicae novae, I, quaest. XXVII, n. 9, where they were mentioned as examples of homicidium culposum.

241 Although it was originally written in German, it was translated into Latin in 1623/1624, and it is this version to which Van Leeuwen referred. See S. van Leeuwen, Censura Forensis I.V.XI De homicidio, nr. 9; Van Leeuwen's version slightly differed from the original Latin version I consulted in the University Library of Leiden (Jus provinciale Ducatus Prussiae, edn. Rostock $1623 / 1624)$.

242 See Art. 6, § 2 of title 5, book 6 of the Jus Provinciale Ducatus Prussiae (edn. Rostock 1623/1624, p. 139): Aliud exemplum animadvertere licet in tonsore, qui cum in tonstrina sua, loco ei negotio destinato, barbam alicui raderet, inopinato casu inpulsus, aut percussus gulam ei quem radebat, praecidit: itemque aliud in funditore baleari vel jaculatore, qui in loco jaculationibus atque militaribus exercitiis destinato, jaculis ludens vel bombardam ad metam exonerans subeuntem transcurrentemve laeserit, trajecerit, vel cui invito et nondum collimanti, arcus vel bombarda exploditur, exoneraturque, atque ita hominem occidit: horum culpa nulla intelligitur. At si tonsor in via publica aut ubi homines tonderi non solent, quem radat; aut miles, sagittarius vel sclopetarius sive bombardarius in alio loco quam qui ad exercitandum datus est, et qua vulgo iter fit, ejaculatus fuerit: aut si imprudentius arcum tormentumve in ipso loco destinato tractavit et versavit: si quis ab eo tonsore vel jaculatore occidatur, delinquens non satis excusatur. Humaniores tamen in homicidiis per lasciviam imprudentiamve et invito auctore admissis; severiores in plectendis, studio et deliberato factis, judices esse par erit. Similiter si venator, dum venationi operam dat, et in feram telum mittit, hominem forte fortuna percusserit, tanquam homicida puniri non debet. Si igitur caedes ejusmodi, 
to show in which cases a person acted negligently and in which situations he did not. No negligence can be found with the barber who when shaving a customer's beard in his barber's shop, got accidentally struck and cut the throat of the man he was shaving; nor a slinger or soldier, in a place set aside for target practice and military exercises, who, when throwing a pike or firing a gun at a target, injured or killed someone passing or running by, or when a soldier had not yet aimed, his crossbow or gun automatically went off and thus killed a man. ${ }^{243}$ The actor will not be excused in the following situations: if the barber killed someone while shaving him in the public road or at a place where people were not accustomed to be shaved; or a soldier, archer or crossbowman if he killed someone while shooting in a place other than one which has been set aside for target practice, and where there is a public way, or if he handled his bow or cocked his crossbow rather carelessly albeit in the place assigned. ${ }^{244}$

Another example mentioned in Article 6, §2 of title 5, book 6 of the Landrecht (and later referred to by Van Leeuwen), is that of a hunter who, while concentrating on the hunt, shoots at an animal and by chance and ill luck strikes a man. In this case he ought not to be punished for a homicide. Interestingly, the view of the Landrecht here is that if a killing of this kind - which was unintentional but with an element of negligence - is brought to court, and the judges consult the jurists about it, they will decide from the law and its workings and from their own knowledge what punishment corresponds to each act committed. ${ }^{245}$ This example of the hunter is similar to a remark made by Gratian's, ${ }^{246}$ namely, that a blind man is considered guilty if he hurt someone while hunting with a javelin. ${ }^{247}$ As already recapitulated above, according to the doctrine of canon law, if A unintentionally hurt B, A was responsible (for the unintended consequences) if he was engaged in an unlawful activity. ${ }^{248}$ Already in the Decretum Gratiani one can find texts that support this doctrine. ${ }^{249}$ Especially interesting is D.50 c.37, a case about a priest who killed a boy by throwing a stone. The priest was guilty if he engaged in an unlawful activity or if his activity was lawful but he failed to use due diligence. ${ }^{250}$ Such a situation occurred, for

quae non quidem ex proposito, sed tamen culpa aliqua interveniente fuerit facta sit, in judicium deferatur, judices super ea prudentes consulant, qui, quae cuique facto opposito paena respondeat, ex jure ejusque arte, pro sua peritia statuent. Ex exemplis autem, quae a Nobis relata sunt, non obscure quivis animadvertere potest. Quae homicidia casu fiant, et quomodo rei excusentur.

243 My paraphrase is based on the English translation by Hewett 1991, p. 65.

244 See also translation by Hewett 1991, p. 65.

245 See also translation by Hewett 1991, p. 65f.

246 C.15 q.1 p.c.2; see already Genesis 4:23-24.

247 See Gordley 2006, p. 191 nt. 68 with references.

248 See, e.g., gloss penitus ad C. 15 q.1 p.c.2.

249 See, e.g., D.50 c.6, 37, 39, 43-44.

250 Gordley 2006, p. 190. 
example, when the priest threw the stone to chase a wild boar out of a field of grain, unless he had been careless. The canon law theory was endorsed in the thirteenth century by Thomas Aquinas (ca. 1225-1274) ${ }^{251}$ Interesting is Summa Theologiae II.II, q. 64, art. 8 co, ${ }^{252}$ concerning the question whether a person is guilty of murder after having killed someone by chance. In order for an action to be sinful, it must be undertaken by voluntary choice. In principle, this rule did not apply to cases of accidental homicide. However, it may happen that something which is not actually and directly voluntary and intended, is nevertheless voluntary and intended accidentally, according to which what removes an obstacle was considered an accidental cause. When someone did not remove something, and because of that a homicide occurred, while the wrongdoer had an obligation to remove it, in a sense was guilty of voluntary homicide. This could happen in two ways: when someone caused another's death by doing something unlawful which he ought to avoid or when he did not take sufficient care. ${ }^{253}$

The first example discussed by Aquinas is especially relevant: the case of Lamech, ${ }^{254}$ an old and blind man, who went hunting. His son was used to giving directions to Lamech; at a certain moment he told Lamech that farther away something was moving in the bush, and therefore, that it could be an animal. Lamech tightened his bow and arrow and shot. However, it was not an animal, but his grandfather Cain, who was killed by the arrow. Aquinas concluded that Lamech had not used sufficient care to avoid the killing of the man, and

251 ibid., p. 192; even though Aquinas accepted the doctrine, many later scholastics rejected it. The doctrine died out in continental Europe in the 16th and 17th centuries; see Gordley 2006, p. $189 f$.

252 This part of the Summa Theologiae of Thomas Aquinas is called De iustitia et jure, the part dealing with the virtue of justice. De justitia et jure is an integral part of the Secunda secundae of the Summa Theologiae of Thomas Aquinas and covers the questions from 57 to 80 (see Hallebeek 2010, p. 58).

253 Thomas Aquinas, Summa Theologiae, II.II. q. 64, art. 8 (edn. Leonina 1897, IX, p. 76): Respondeo dicendum quod, secundum philosophum, in II Physic [cap. 6], casus est causa agens praeter intentionem. Et ideo ea quae casualia sunt, simpliciter loquendo, non sunt intenta neque voluntaria. Et quia omne peccatum est voluntarium, secundum Augustinum [lib[er] de ver[a] relig[ione] cap. XIV], consequens est quod casualia, inquantum huiusmodi, non sunt peccata. Contingit tamen id quod non est actu et per se volitum vel intentum, esse per accidens volitum et intentum, secundum quod causa per accidens dicitur removens prohibens. Unde ille qui non removet ea ex quibus sequitur homicidium, si debeat removere, erit quodammodo homicidium voluntarium. Hoc autem contingit dupliciter: uno modo, quando dans operam rebus illicitis, quas vitare debebat, homicidium incurrit; alio modo, quando non adhibet debitam sollicitudinem. Et ideo secundum iura, si aliquis det operam rei licitae, debitam diligentiam adhibens, et ex hoc homicidium sequatur, non incurrit homicidii reatum: si vero det operam rei illicitae, vel etiam det operam rei licitae non adhibens diligentiam debitam, non evadit homicidii reatum si ex eius opere mors hominis consequatur.

254 See also Genesis 4: 23-24, from which one can deduce that Lamech killed a man, although it is not clear who that was. Ancient interpreters came to the conclusion that the man was the same man as reffered to in Genesis 4:1, namely Cain. See Kugel 1998, p. 167 and also Kugel 1990, p. 159ff. 
therefore he did not escape the negligence for homicide. ${ }^{255}$

Also in early modern literature the case of the hunter is discussed, e.g. by Jacobus Menochius (1532-1607). While hunting, the hunter aimed at an animal but coincidentally hit and killed a person. In this case the hunter had not to be punished for murder. ${ }^{256}$ The same view was held by Prosper Farinacius (1554-1618), who mentioned the case of someone shooting arrows (at an animal) who coincidentally killed a person. In this case, to prove he did not act negligently, the hunter had to prove that he had not seen the passer-by and also that he did not have a feud with that person but, on the contrary, a (close) and affectionate relationship. ${ }^{257}$

\subsubsection{Preliminary conclusion}

Before going into maritime decisions, a short conclusion can be made. The idea that an equal or preponderant contributory negligence excluded any right for compensation of the injured party began to gain acceptance from the beginning of the seventeenth century. ${ }^{258}$ I have found a first trace in the thought of dolus as gravior culpa in Faber: if one party acted with dolus, and the other with culpa, no compensation could take place. This idea also appeared in the views of important jurists in the Dutch Republic in the pre-codification era; after having been formulated by Gerard Noodt, the idea of maior culpa came

255 Thomas Aquinas, Summa Theologiae, II.II. q. 64, art. 8, esp.: 1. Legitur enim Gen. 4 [23-24] quod Lamech, credens interficere bestiam, interfecit hominem, et reputatum est ei ad homicidium. Ergo reatum homicidii incurrit qui casualiter hominem occidit. ... AD PRIMUM ergo dicendum quod Lamech non adhibuit sufficientem diligentiam ad homicidium vitandum, et ideo reatum homicidii no evasit. ...

256 I. Menochius, De Arbitrariis iudicum quaestionibus et causis, casus CCCXXIV, nr. 2. One reference is to Herodotos, 'I $\sigma \tau \circ p^{\prime} \alpha l, 1 .<43, \mathrm{EvD}>$, which included a story which is quite similar to that under discussion above, namely that of Adrastus, son of Gordias, who threw a spear at a boar but missed and mortally hit Atys, the son of Croesus.

257 P. Farinacius, Praxis Criminalis, De homicidio, q. 125, nr. 27. The case is also mentioned by J. Ayrerus, De homicidio, Pars II, nr. 103, who referred to the case of D. 48.19.11.2 stating that a crime is committed by chance in the case in which a man while hunting aims a dart at a wild beast, but thereby kills another man.This Digest text has also been cited by others, such as Farinacius, in their discussions on (accidental) homicide.

258 Also Jansen 2002a, p. 106f.; 2002b, p. 206; Keirse 2003, p. 23f.; also Zimmermann 1996, p. 1030 (in the later usus modernus); - However, according to Aumann 1964, p. 50, the theory of the 'Vernunftrecht' remained a theory in the beginning. In practice, Roman law was applied ('das römisch-gemeine Recht'; see in general Molitor 1949, p. 37). Also with regard to the contributory negligence of the injured party, jurisprudence continued to apply the principles of 'das ältere gemeine Recht'/ältere Usus modernus', according to which any negligence of the injured party, even a small amount, would lead to the removal of the liability of the wrongdoer, because the conditions for a duty to compensate were not present. Under the influence of rational law, the theory of ius commune and its practice, in the course of time, was used to interpret and apply the Roman sources, in a more free and critical way. The usus modernus pandectarum developed, with which jurists endeavoured to meet the needs of the individual case (Einzelfall; see Aumann 1964, p. 50). This will be discussed in more detail in the section on the usus modernus pandectarum (4.5). 
also to be adopted by Johannes Voet. ${ }^{259}$ Noodt and Voet came to the conclusion that if the wrongdoer's negligence exceeded the negligence of the injured party, the wrongdoer would be fully liable. ${ }^{260}$ However, this was not yet generally accepted, as some still applied the rule of D. 50.17.203 and just let contributory negligence lead to a denial of a claim for compensation.

\subsubsection{Maritime collisions}

\subsubsection{Introduction to the topic}

As has already become clear, and will become even clearer in the following, various opinions can be found on the manner of handling contributory negligence of the injured party in Roman-Dutch law. ${ }^{261}$ Firstly, it is important to remark that the Roman-Dutch scholars did not regard 'wrong behaviour' of the injured party as contributory negligence, but as 'negligence' only. This will become clear from the following description. ${ }^{262}$ With regard to the development of the concept of contributory negligence, cases of ship collisions are particularly interesting. Roughly three situations can be distinguished: neither party acted culpably (i.e. the incident was due to casus or if it was uncertain who was to blame), the wrongdoer acted with negligence or intention, or both parties acted negligently. Below, I will discuss the most

259 In general, on 17th-century Leyden law professors, and especially Bronchorst, Vinnius and Voet, see Feenstra \& Waal 1975. One can also find bibliographical information on other 17thand 18-century Dutch professors in this work.

260 In this respect D. 9.2.11pr. seems to be a much debated case. Noodt as well as Voet came to the conclusion that the barber who performed his work in an unsafe place was liable, because his negligence was more serious than that of the slave. Voet incorporated Noodt's view; according to Voet, however, this view was not new. See J. Voet, Commentarius ad Pandectas, ad D. 9.2, nr. 17 .

261 On the collisions of ships in 17th-century London, see Steckley 2003, esp. p. 45f.: 'English Admiralty judges experimented early in the 17th century with a remedy long available in European maritime codes: they occasionally abandoned efforts to identify only one party as responsible for the collision, decided instead that the damage was in some measure due either to accident or the carelessness of both crews, and consequently reduced to the plaintiff's award. Thus they were finding contributory negligence long before the notion took hold at common law. And the cases studied here reveal when this approach became Admiralty routine in the 17th century, the simple rule (rusticum judicium) by which liability was divided and the defendant typically required to pay for only half the plaintiff's losses being applied. But the cases show more, namely that the civilians went further in their search for equity by the 1670 s and develop a purely no-fault doctrine, a rule enforced at Doctor's Common throughout the 18th century and requiring defendant and plaintiff to bear equal shares of the total damage on both sides.' Unfortunately, however, this topic falls outside the scope of this study. On the application of the rule of judicium rusticorum by admiralty courts in cases of collision, see, e.g., Marsden 1886, p. 357ff.; Street 1906 (reprint 1999), p. 144ff.; Staring 1957, p. 304ff.

262 See, e.g., S. van Leeuwen, Het Rooms-Hollands regt, IV.39.8, C. van Bijnkershoek, Quaestiones Juris Privati, IV.22 and D.G. van der Keessel, in his Thesis 816 (all discussed below); Kotzé 1953, p. 57. 
relevant rules applicable in determining liability for collision damage in RomanDutch law. Under what circumstances could the owner of the ship recover from the owner of the other ship in the event of a collision at sea? Before going into this topic, one important remark has to be made. A medieval principle of maritime law was that a shipowner could not lose more on an adventure than he had entrusted to or ventured on it. ${ }^{263}$ Therefore, if the master of his ship, acting within the scope of his duties, caused damage, the shipowner was only liable limited to the value of his ship. ${ }^{264}$ According to Van Niekerk, judgment against the shipowner could be levied only against the ship, which was arrested for that purpose. By relinquishment or abandonment (or: fictional abandonment) ${ }^{265}$ of the ship for that purpose and not appearing to defend the action personally, the shipowner(s) in effect limited his liability to (their share in) the value of his ship. ${ }^{266}$ The limitation was also recognised in Roman-Dutch law. ${ }^{267}$

\subsubsection{Collision cases described by Grotius}

Hugo Grotius - the father of the jurisprudence of Holland $-{ }^{268}$ deals in his Inleidinge with the actual legal practice in the province of Holland. Two relevant texts on contributory negligence can be found in his discussion of quasi-delictual maritime collisions in part 38, on several situations in which Aquilian liability would apply. ${ }^{269}$ The first text is Inleidinge III.38.16, describing

263 s'Jacob 1890, p. 14, 32; Van Niekerk 1998, II, p. 1282. This principle is already visible in the Consolato del mare, see, e.g., cap. 33, 34, 183.

264 Van Niekerk 1998, II, p. 1282.

265 See Van Niekerk 1998, II, p. 1283. On the right to abandonment, see s'Jacob 1890.

266 According to Van Niekerk 1998, II, p. 1282, the limitation of the shipowner's liability was achieved by a personalisation of his ship: the ship was, as it were, considered liable for the actions by her master in the prosecution of her voyage. But, of course, it was impossible to institute an action against a ship, and, therefore, the action was directed at the shipowner(s);- This idea of limitation of the shipowners' liability reminds us of the Roman law principle of noxae deditio, where the owner could discharge his liability for damage caused by his property (e.g. an animal) to someone else's property by surrendering the offending object (e.g. the animal). On the origins and development of the limitation of shipowners' liability, see Donovan 1979, p. 999ff.

267 See Munniks 1776, p. 47; Van Niekerk 1998, II, p. 1282; on the right to abandonment in Roman-Dutch law, see s'Jacob 1890, p. 26ff. Apparently, two systems can be found in RomanDutch law: restricted liability by the law (Art. 167 of the Ordonnance of Rotterdam, S. van Leeuwen, Het Rooms-Hollands regt, XXXI.2, S. van Groenewegen van der Made, Tractatus de legibus abrogatis, IV.7.32) and entire liability with the alternative of a restricted one dependent on whether or not renunciation was made (see Ordonnance de la Marine, II.8.2; H. Grotius, Inleidinge, III.1.32; Voet, Commentarius ad Pandectas, ad D. 14.1, nr. 5).

268 On the life, work and influence of Hugo Grotius, see, e.g., Edwards 1981; Roelofsen 1987, p. 113ff.; Vreeland 1917 (reprint 1986); Bull, Kingsbury \& Roberts 1990; Zimmermann 1992, p. 26ff.; Nellen 2007. The literature on Grotius is overwhelming, but see, e.g., Wieacker \& Weir 1995, p. $227 \mathrm{ff}$., who give some references for further reading.

269 Thomas 2001, p. 347. 
a collision of two ships under sail, which could not have been avoided. If one ship went down or was damaged, the loss had to be borne in equal parts by both parties, irrespective of the time of the collision, day or night, or of the weather conditions, clear or bad. However, if the collision occurred as a result of intent or negligence of one party, that party alone had to bear the damage. ${ }^{270}$ The second text is Inleidinge III.38.18, describing a vessel under sail that runs into an anchored or moored ship. If that ship suffered any damage, the sailing ship would be liable for all damages if the collision was its fault. If it was not, the sailing ship was liable for half the damage caused to the other ship and for all of its own damage. ${ }^{271}$ The absence of fault on the side of the sailing ship had to be purged by an oath. However, the second ship could provide proof of the fault of the sailing ship, in which case the second ship (i.e. the ship which was run into) also had to prove that there was no fault on its own side. ${ }^{272}$ However, there can be situations in which both parties cannot prove they were faultless. ${ }^{273}$ Grotius' Inleidinge III.38.18 did not cover the situation in which the injured party also acted negligently. Grotius only incorporated certain rules, derived from the statutes, ${ }^{274}$ into the system of delictual and quasi-delictual

270 H. Grotius, Inleidinge III.38.16.

271 See also Fockema Andreae ad Hugo Grotius' Inleidinge III. 38.18; - See also C. van Bijnkershoek, Quaestiones Juris Privati, IV.21, edn. 1744, p. 467, who argued that the party that suffered had to blame himself in this case. He referred to D. 9.1.1.11, in which a bull killed another bull that was attacking him; there would be no liability, neither would there be liability if a bull ran into a rock. It is impossible to say that the rock did not act according to its nature, and the same goes for the anchored ship in this case.

272 H. Grotius, Inleidinge III.38.18; Thomas 2001, p. $347 f$.

273 In part 37, another text is relevant from which one can deduce an application of the rule that if due to the circumstances the exact proportion could not be established or if the faults on either side appeared to be equal, the responsibility was shared 50/50, namely, Inleidinge III.37.7. This rule was already applied in the decisions of the Hoge Raad as recorded in Neostadius, Decisiones, 48 and 49, and also later by Louis XIV in Ordonnance de la Marine (1681), III.7.10 (edn. 1756, p. 302).

274 According to Simon van Groenewegen van der Made (1613-1652); see notes of Simon van Groenewegen van der Made at Grotius' Inleidinge; the edition of 1692, i.c. p. 306, is used and see also Thomas 2001, p. 348; Grotius must have used the Ordinance of Emperor Charles V on maritime matters of 1551 (arts. 46 and 48 of the Placaet ende Ordonnantie, Op 't stuck vande ZeeRechten of 19 July 1551 are relevant here), the Ordinance of King Philip of Spain on the same of 1563 (see the title 'Van Schepen die malkanderen beschadigen' of the Ordonnantie, Statuyt ende eeuwige Edict etc. of 31 October 1563, arts. 1 and 3), as well as the laws of Whisby (arts. 27, 48 and 68 of the Wisbuische Zee-Rechten). As a result of editorial oversight, the publication called 'Laws of Whisby' in fact also contained two other collections, namely, the decisions on maritime law from Damme in Flanders (a Flemish transplant of a collection of judgments by the court of admiralty of the French isle of Oléron) and the collected customs on maritime matters in Amsterdam (but which, according to Thomas 2001, p. 350, probably originated in Staveren). See Verwer 1764, esp. p. VIIIff.; - A new rule developed by the Court of Oléron was generally adopted and slightly adapted. As a result of this, Dutch maritime law held that the loss on both sides had to be borne in moieties. This rule was only applicable in no-fault collisions. This fact is stressed by art 1. of the Ordonnantie of King Philip of Spain, adding that in the event of fault of one of the parties, that ship had to bear the entire loss; see Thomas 2001, p. 351. On the laws of Whisby, see 
claims. He did not pronounce himself on the possibility of fault on the part of both ships. Nevertheless, these texts provided the basis for the development of contributory negligence in Roman-Dutch law. ${ }^{275}$ Subsequently, two eighteenthcentury jurists, namely Cornelis van Bijnkershoek (1673-1743) ${ }^{276}$ and Dionysius Godefridus van der Keessel (1738-1816), ${ }^{277}$ posed the question of contributory negligence and due to them the concept of contributory negligence could further develop. These two jurists will be discussed below. ${ }^{278}$

It has been argued that in a situation in which both parties in a collision acted negligently, in maritime law in the period of Roman Dutch law a division into halves had to be made. ${ }^{279}$ However, this conclusion has not necessarily to be taken. Theoretically, there can be a number of options: (1.) each party had to bear its own damage; (2.) the party that had been preponderantly negligent had to bear all the damage (culpa maior theory); ${ }^{280}$ (3.) the older variant of culpae compensatio, i.e. that even a little contributory negligence cancels out the claim of the injured party; and (4.) an apportionment of damages proportionate to the degree of negligence and/or causation. As will be shown below, while the first option is found in Roman-Dutch law, the fourth option - the solution of apportionment of damages - has not yet been adopted, and the second and third options were adopted in a slightly different manner.

\subsubsection{Cases in which one ship was to blame}

In cases in which ship damage was caused by the fault of one of two ships or by both, Roman law has been the starting point. However, there was no special Roman legal rule on collisions, and therefore the ordinary rules applied. The

Thomas 2001, p. 350f.

275 Thomas 2001, p. 351.

276 On Van Bynkershoek, see, e.g., Star Numan 1869; Krikke \& Faber 1987a, p. 141ff.; Zimmermann 1992, p. 32ff.; Van den Bergh 1995, p. 423ff.; Brom 2008, p. $27 \mathrm{ff}$.

277 On Van der Keessel, see, e.g., Krikke \& Faber 1987b, p. 185ff.; Feenstra 2001b, p. 353; Ashmann \& Feenstra 1984, p. 132ff.

278 Of course also Grotius' De iure belli ac pacis is relevant; a further investigation on this work will follow in a later section on natural law (namely 4.6.2.1).

279 Aumann 1964, p. 158.

280 These first two possibilities were already mentioned by Luig; see Luig 1969, p. 225f.; he refers to H. Grotius, De iure belli ac pacis II.17.21, and states that Grotius' division into halves was taken due to the difficulty in determining who was to blame. But, Luig states: 'Aus die Erwähung der Beweisschwierigkeiten der Schuld läßt sich jedoch nicht auf die Anwendung der Halbteilung bei Mitverschulden schließen, da in der Regel die Schuldlosigkeit beschworen werden mußte.' However, the second opinion would require traces of the maior culpa theory in the sources on maritime matters, which, as will become clear in this subsection, could not (explicitly) be found. Accordingly, Luig 1969, p. 228. 
lex Aquilia was applied in cases of collisions between ships. ${ }^{281}$ Liability of those navigating the ship was based on the lex Aquilia and more specifically depended on the question whether culpa (or dolus) could be imputed to them. ${ }^{282}$ Furthermore, according to the Roman legal rules described in D. 9.2.29.2-5, in the event of accidental loss no action based on the lex Aquilia could be brought by the owner of the damaged ship. Van Bijnkershoek based his opinion on Roman law when he stated that the damage had to be borne by the party who acted negligently. He mentioned the example of a ship under sail that caused damage to another ship under sail, or to another ship at anchor or in moorings, or damage caused by a ship adrift, had to bear the entire damage if the damage was caused due to its negligence. ${ }^{283}$

\subsubsection{Accidental collision damage}

According to (the medieval interpretation of) Roman law, if damage was inflicted by accident, no action could be brought against the wrongdoer (unless the act was forbidden by law). No explicit rule can be found in D. 9.2.29 dealing with the situation in which no negligence of the parties involved can be proven. ${ }^{284}$ In his De iure belli ac pacis, Grotius stated that the law of nature dictates that someone whose ship caused damage to the ship of another without fault on his part is not liable (this view would be in accordance with Roman law, EvD). However, Grotius continued, by the laws of many peoples, as also by the law of the province of Holland, such a loss was commonly divided between both parties, due to the difficulty of determining who was at fault in such a case. ${ }^{285}$ The (medieval) maritime law rule that in the event of a collision of two ships,

281 See D. 9.2.29.2-5 - in particular D. 9.2.29.2 and 4; see also Pöhls 1832, III, p. 778; Lobingier 1935, p. $29 \mathrm{f}$.

282 See Ashburner 1909 (reprint 1976), p. cclxxxv; Gormley 1961, p. 327; - The shipowner (exercitor) might be liable for goods and other property of which he had undertaken the safe carriage, for injuries done on board ship by the crew to goods or persons, and on contracts made by the magister. See Ashburner 1909 (reprint 1976), p. clix-clxiii/.

283 C. van Bijnkershoek, Quaestiones Juris privati, IV.22, edn. 1744, p. 467f.; Thomas 2001, p. 355f.; - See also Fockema Andreae ad Hugo Grotius' Inleidinge III.38.16.

284 See also Lichtenauer 1956, p. 192.

285 H. Grotius, De iure belli ac pacis, II.17.21. See also Aumann 1964, p. 158; Parisi 1992, p. 146; 1994, p. 341, nt. 74. According to the latter, in the last part of Grotius' text mentioned here, the focus on the nature of the injurer's activity shifts towards the need to provide the victim with equitable compensation for the harm suffered. Parisi rightly states that Grotius' equitable approach to compensation was not shared later by Domat and Pothier, and that the reception in the further development was confined to hypotheses of comparative negligence, which generally entail a proportional assessment of fault and liability (when acts of both parties causally contributed to the loss, not when the loss originated by concurrence of fault and casus). This topic will be touched upon below;- This is confirmed by H. Grotius' Inleidinge III.38.16 \& 18 . These texts primarily concerned quasi-delicts, which in the institutional system of Grotius were limited to no-fault liability in cases in which someone suffered damage 'from or by what is ours'. 
if no negligence of one of them could be established, the damage was divided between them, was (partly) founded on the old German idea of a cooperative damage community (Schadensgemeinschaft). ${ }^{286}$ The maritime laws (leges nostrae nauticae) argued that in case of an accident where none of the parties acted negligently, the damage still had to be partially compensated, based on an obligatio quasi ex delicto. ${ }^{287}$ When damage occurred in a collision of ships, and there was no (proven) negligence of either one of the parties, the damage would be commonly shared by halves. ${ }^{288}$ This rule (of rusticum judicium or judicium rusticorum - as already mentioned above), the rule of arbitrators to a partial compensation of half of the damages, can already be found in the Rôles d'Oléron, ${ }^{289}$ the Laws of Whisby, ${ }^{290}$ and also in the Ordonnance of Emperor Charles V of 1551 on maritime matters, ${ }^{291}$ and in the Ordonnance of King Philip of Spain of 1563 also on maritime matters, ${ }^{292}$ for a certain situation, namely, that in which a buoy on a cast anchor went adrift without the ship being at fault for that. ${ }^{293}$

Apparently, the just-mentioned rule that in the event of accidental collision damage, i.e. where both ships suffered damage due to a collision, was borne $50 / 50$ by each ship involved, was applied in practice in Roman-Dutch law in the seventeenth and eighteenth centuries. ${ }^{294}$ This meant that the owner of each ship had to pay for half of the damage to the other.

In a decision of the Court of Holland (Hof van Holland) of 4 July 1662 recorded by P. Ockers (1628-1678), ${ }^{295}$ two ships collided; both of them were freighters, one larger than the other. Due to a storm the steersman of the larger freighter was thrown overboard resulting in a collision of the larger ship against the smaller ship. The anchor of the larger freighter stuck behind the mast of

286 Aumann 1964, p. 157f.; Luig 1969, p. 225; see also Endemann 1884, p. 287. In general, on the collision of ships, and on the (various) ways cases were solved when both ships were at fault in the early modern period in several countries until the 19th century, see Endemann 1884, p. 288ff.; Scott 1897, p. 17ff., 241ff.; Luig 1969, p. 228.

287 See D.G. van der Keessel, Praelectiones iuris hodierni ad Grotius' Inleidinge, III.37.7.

288 See also C. van Bijnkershoek, Quaestiones juris privati, IV.18, edn. 1744, p. 671ff.; - It seems that the partition rule in the event of accidental losses was still being applied in the period after the Reception; see also Aumann 1964, p. 157; Luig 1969, p. 225.

289 Art. 14 Rôles d'Oléron. On this rule, see also Staring 1957, p. 306.

290 Arts. 48, 49, 50 \& 71 of the Wisbuische Seerechten.

291 Art. 49 of the Placaet ende Ordonnantie, Op 't stuck vande Zee-Rechten of 19 July 1551.

292 Art. 4 of title 'Van Schepen die malkanderen beschadigen' of the Ordonnantie, Statuyt ende eeuwige Edict etc., of 31 October 1563.

293 Lichtenauer 1956, p. 192.

294 See C. van Bijnkershoek, Observationes Tumultuariae 1320 and also the decision of the Hoge Raad as recorded by Neostadius 1667, decisio nr. 48; - On the (published and unpublished) sources of case law of the Hoge Raad, see Meijers 1918/1919a.

295 On the decisiën of P. Ockers, see esp. Sirks 2003, p. 197ff. 
the smaller ship, the mast was torn from the vessel and fell into the sea together with the gold hidden inside it. ${ }^{296}$ According to the decision recorded by Ockers, neither of the ships acted negligently. ${ }^{297}$ The rule of customary law was applied as described above, i.e. the damage to the ships was divided between both parties (the owner of the ship from Rotterdam and the skipper of the larger ship). There was disagreement on the question of whether each ship with its cargo should bear half of the loss, ${ }^{298}$ or whether the loss (the merchandise of both ships had to be valued in cash) should be divided proportionally to the value of the ships and cargoes. The aldermen from Rotterdam and the Court of Holland adopted the latter solution, deciding to interpret the Edict of King Philip of Spain in accordance with Article 68 of the laws of Whisby. ${ }^{299}$

The rule was also applied in the case decided upon by the judges of Amsterdam on 17 August 1710, in first appeal by the Court of Holland on 19 September 1713 and in second appeal by the Hoge Raad van Holland, Zeeland en WestFriesland $)^{300}$ on 12 February 1717; a description of this example has been found in Van Bijnkershoek in his Observationes Tumultuariae 1320. A ship, coming from Hamburg, arrived at the isle of Texel and then sailed out with other ships under a convoy of the Admiral of Holland. At a certain moment, the Admiral commanded the convoy to change tack. The ship from Hamburg obeyed, but another ship, belonging to the Dutch East-India Company could not perform this manoeuvre due to its heavy load and the rather rough sea and ran against the Hamburg ship and because of that impact the Hamburg ship sank. The proprietors of the Hamburg vessel claimed half of the damages from the Dutch East India Company. ${ }^{301}$ In this case the accident was considered to have taken place coincidentally, and not because of negligence of one of the parties, and

296 P. Ockers, Decisien, part 1, title 3, dec. 1 (edn. Gall 2002, p. 85f.).

297 P. Ockers, Decisien, part 1, title 3, dec. 1: Visum fuit et damnum satis probari, et neutrius culpam probari intervenisse. ... However the Dutch summary above - wrongly in my opinion stated, '... dat beide schepen geacht meten worden evenveel schuld te hebben ....'

$298 c f$. art 1 of the Ordonnance of Philip II of 1563, title 'Van Schepen die malkanderen beschadigen'.

299 P. Ockers, Decisien, part 1, title 3, dec. 1 (edn. Gall 2002, p. 85f.). In the decision of the Court of Holland of 15 July 1665 recorded by P. Ockers, Decisien, part 1, title 3, dec. 2 (edn. Gall 2002, p. 86f.), another collision is described which also occurred without negligence of one of the parties involved. Apparently, the skippers had mutually arranged the damage. The merchants brought a legal claim against the skipper of the colliding ship. The alderman of Delft and the Court of Holland confirmed this, decided that in the event of a collision inland (on rivers, etc.) the normal rule of $50 \%$, which applied on the sea, did not apply and the owners of the merchandise had to bear their damage themselves.

300 Recently, on the case law of the Hoge Raad van Holland, Zeeland en West-Friesland, see Punt 2010, p. 3ff., who also discuss matters such as the competences of the Hoge Raad, the organisation of the Hoge Raad, etc.

301 C. van Bijnkershoek, Observationes Tumultuariae 1320 (edn. Meijers et al. 1934, II, p. 191f.). 
so the Hoge Raad concluded that the damage ought to be borne in common. ${ }^{302}$

The method of assesment was a point of discussion. Van Bijnkershoek - who first and foremost focussed on legal practice ${ }^{303}$ - argued in his Quaestiones Iuris privati that the parties should bear a loss in proportion to the value of ship and cargo, so by way of geometrical (not arithmetical) calculation. ${ }^{304}$ In fact, this would mean a proportional partition in accordince with the value of the ships instead of a partition in equal shares (50/50). This was not, however, the prevailing opinion of the justices of the Hoge Raad on 23 November $1720 .^{305}$ Van Bijnkershoek argued that in the situation in which damage was caused without negligence of one of the parties, a geometrical calculation was more just than an arithmetical one. The damage had to be regarded as being caused by bad fortune (fatum). Both parties suffered losses because of the collision, and both should bear the damage equally in proportion to the means (opes) of each party. Who had more property is exposed to greater danger and risk. This meant that each party had to bear the losses in accordance with its means or worth of its property. Half of the value of the sunken ship will absolutely not exceed the full value of the retained vessel, since the amount by which the sunken ship is worth more is deducted from the total estimated damage. ${ }^{306}$ This is in agreement with a decision of the Dutch Hoge Raad of 1629, stating that it would be absurd that the owners would be liable for more than the value of the retained vessel, because in that case they would have to pay more than the amount they were at risk for. ${ }^{307}$ In this way, i.e. the view of Van Bijnkershoek, the liability of the owner of the ship was capped by the value of his own ship.

302 C. van Bijnkershoek, Observationes Tumultuariae 1320 (edn. Meijers et al. 1934, II, p. 192), with reference to arts. 50, 70, and 73 of the Wisbuische Seerechten; this case has also been discussed by Weskett 1781, p. 479f.

303 Punt 2010, p. 23. Van Bijnkershoek's Quaestionum iuris privati libri quatuor (1744) was translated into Dutch in 1747 (Verhandelingen over Burgerlijke Rechts-Zaaken) and was a manual frequently used in legal practice. See Van den Bergh 1995, p. 432. Although the Dutch version has also been used, reference will only be made in this study to the Latin original.

304 C. van Bijnkershoek, Quaestiones juris privati, IV.20, p. 689ff.

305 ibid.; Fockema Andrea ad Hugo Grotius' Inleidinge III.38.16; Bouman 1855, p. 63; Van Bijnkershoek referred to the decisions of the Hoge Raad recorded Neostadius, decisiones 48 \& 49 [without dates mentioned therein] and that of 21 December 1629 (J. Cooren, Observationes, nr. 40, esp. nr. 26, p. 265f.) and of 17 May 1630 (J. Cooren, Observationes, nr. 41).

306 C. van Bijnkershoek, Quaestiones juris privati, IV.20, edn. 1744, p. 689f.; - With regard to the case in which both ships were at fault, Pöhls seem to have defended the view of oldDutch Law, and wanted to divide the damage into halves (see Pöhls 1832, III, p. 778), which view was followed by Dutch legal practice at the time of Van Bijnkershoek. Van Kaltenborn 1851, p. 7, defended the view that found its way into art. $535 \mathrm{WvK}$, i.e. that each ship should carry its own loss, and called this an application of the rule of D. 50.17.203; II.8 $\S 1930$ jo. I.6 $§ 22$ of the Allgemeine Landrecht of Prussia contains the rule that each ship has to bear the damage that it caused to the other ship in accordance with its negligence; Bouman 1855, p. 42.

307 See J. Cooren, Observatio 40, nr. 26. 
The owners are freed from further demands by giving up what was theirs. The custom of equally dividing was heretofore not generally applicable; the liability for half of the other ship's damage extended no further than the (undamaged) value of the owner's own ship. ${ }^{308}$

The same opinion can be found in Van Bijnkershoek's Observatio Tumultuaria 1711 [686]. In this case a convoy ship of the Admiralty of Amsterdam, which led merchant vessels through the Baltic Sea to the areas belonging to Holland, on the night of 16 September 1702, sailed against a merchant vessel and damaged it so badly that it sank. The shipmasters of the merchant vessel sued the captain of the convoy ship before the Hoge Raadvan Holland, Zeeland en West-Friesland ${ }^{309}$ and claimed half of the value of the sunken ship and the cargo. The commanders of both ships blamed each other for the negligence that led to the damage. In this collision case, because of conflicting testimony, it was not possible to determine the negligence of either party. The Hoge Raad, differently from Roman law, according to maritime law decided on 20 January 1711 that each party had to bear half of the damage since negligence was not proven. According to maritime law, when it was not clear whether the damage was caused culpably, the damage was regarded as mutual. ${ }^{310}$ Also in this case (although this was a minority opinion) van Bijnkershoek argued that the damage should be divided geometrically. ${ }^{311}$

308 See also Magens 1755, p. 78; Weskett 1781, s.v. running foul, p. 481; Van Niekerk 1998, II, p. 1295 , nt. 53 .

309 cf. $\$ 20$ of the Instructie van den Hoogen Raedt of 31 May 1582 (in: Cau, GPB II, col. 792): Ende ten derden, in saecken roerende de Zeevaert, te weten, als Schepen malkanderen buyten's Lants, of in Zee beschadight sullen hebben, ende diergelijcke saecken, begrepen onder d'Ordonnantie vande Zee-rechten, blyvende het Placaet vande Visscherye ofte Buys-Neeringe in sijn gheheel ende wesen, sonder't selve by desen te veranderen.

310 See C. van Bijnkershoek, Observationes Tumultuariae 1711 [686] (edn. 1926, I, p. 377f.); Van Bijnkershoek referred to the Farragines, which, however, as being part of the Corpus iuris Hollandici et Zelandici, are not published. The latter consisted in three parts, i.e. Commentariijuris Hollandici, Commentarii de jure feudali Hollandico et Zelandico et Farragines. The whereabouts of the manuscript of the Corpus iuris Hollandici et Zelandici is unknown since 1867. See Meijers 1818/1819a, p. 413, 416; Star Numan 1869, p. 234; Brom 2008, p. 28f., esp. nt. 25.

311 C. van Bijnkershoek, Observationes Tumultuariae 1711 [686] (edn. 1926, I, p. 378); also C. van Bijnkershoek, Observationes Tumultuariae 1689 seems relevant in that the defendant was absolved because the collision could not be proven; this was the majority opinion, however Van Bijnkershoek belonged to the dissenting minority. He believed the collision to have been proven. In that case half of the damage should have been paid, according to maritime law (when no negligence of one of the parties had been proven). Bijnkershoek pleaded for the damage to be borne by the parties in geometrical proportion; however, this question was finally not dealt with. Interesting is Van Bijnkershoek's remark that 'quamvis plurimi ex Senatoribus sententiam meam, si condemnandifuissent rei, probarent'. 
Later writers/scholars were undecided on this topic. ${ }^{312}$ Van der Keessel ${ }^{313}$ and Van der Linden ${ }^{314}$ mentioned both views: while the arithmetical proportion is expressly enacted in the Edict of Kings Charles V, ${ }^{315}$ it is supported by articles in the Edict of King Philip II, ${ }^{316}$ admitted by the Laws of Rotterdam ${ }^{317}$ and Dordrecht ${ }^{318}$ and was decided accordingly by the Hoge Raad; $;^{319}$ the geometrical proportion - for which one can bring many reasons of importance - is defended by Van Bijnkershoek. ${ }^{320}$ Practice seems to have given more approval to the arithmetical proportion. ${ }^{321}$

\subsubsection{Collision damage caused by the fault of both parties}

According to Roman-Dutch law, if someone inflicted damage unlawfully and culpably, he had to compensate the loss. What if also the injured party acted negligently? ${ }^{322}$ What if both parties in a collision had acted negligently? Although one could argue that in this case both parties should pay for each other's damage, this solution was not found in collision cases. ${ }^{323}$ But one can find two different views in Roman-Dutch law.

In one instance, the contributory negligence of the injured party was mentioned by the Hoge Raad van Holland, Zeeland en West-Friesland, and the Hofvan Holland (Court of Holland), namely, in a case brought before the Hoge Raad which was recorded by Cornelis van Nieustadt (Neostadius, 1549-1606) ) $^{324}$

312 On this topic, see also Taunay 1802, p. $42 \mathrm{ff}$.

313 D.G. van der Keessel, Theses selectae juris Hollandici et Zelandici, thesis 815.

314 J. van der Linden, Koopmanshandboek IV.5.7.

315 Art. 46 of Placaet ende Ordonnantie, Op 't stuck vande Zee-Rechten of 19 July 1551.

316 Arts. 1-3, Title 5 of Ordonnantie, Statuyt ende eeuwige Edict etc., of 31 October 1563.

317 Art. 255 of title 'Van schepen malkanderen beschadigende' of Ordonnantie of Rotterdam (1721).

318 Art. 172 Instructie of Dordrecht (1775).

319 Neostadius, Decisiones, 48 and 49; Cooren, Observationes, 40 and 41.

320 C. van Bijnkershoek, Quaestiones juris privati, IV.20.

321 On this topic, also already Munniks 1776, p. 47; - In fact, one remained loyal in this way to the custom of peasants (vulgaris rusticorum opinio), mentioned in the Accursian Gloss uideantur ad D. 3.5.33; Lichtenauer 1956, p. 193. Apparently, this division in halves was still applied in this way in decisions in legal practice, as a later addition is made to the Glossa Ordinaria (I consulted the edn. of 1625): rustici lites per medium dividunt.

322 A short summary is provided by Kotzé 1953, p. 67f.

323 Simon van Leeuwen was of the opinion that in a case of a collision of drivers of wagons, where there was negligence on both sides, the parties had to pay for each other's damages; see S. van Leeuwen, Het Rooms-Hollands regt, IV.39.8: 'So zyn ook de Wagenaars verbonden elkandren te vergoeden de schade die sy in het voor bij ryden en aanstoten van de Wagens, elkander komen aan te doen ...'

324 On Neostadius, see.e.g., Ahsmann 1990, p. 46ff. The collection with the name 'Utriusque Hollandiae, Zelandiae, Frisiaeque Curiae Decisiones' (first edn. 1617) was wrongly stated on the name of Neostadius. See on this topic Van Apeldoorn 1938, p. 3ff.; Zeylemaker 1952, p. 123f.; Ahsmann 1990, p. 48. 
as decisio 49. The case concerned a collision of two ships, as a result of which one of them sank. The skipper of the sunken ship sued the owner of the other ship. The defendant, however, replied that the collision was not due to his fault. On the contrary, the accident was due to the skipper of the sunken ship, who, in the middle of the day, while guests were eating, put an inexperienced midshipman (vix Mesonautam) ${ }^{325}$ behind the rudder, and it was by the lack of experience of this man that the ships collided. ${ }^{326}$ The Court(s) had already ruled that if it was not clear which ship was to blame, or the negligence was equal on both sides, the damage had to be borne in common. ${ }^{327}$ In this case both parties blamed each other and the Hof van Holland and the Hoge Raad came to the conclusion that since the fault appeared to be equal on each side, the loss had to be borne equally. ${ }^{328}$

However, legal doctrine scholars such as Van Bijnkershoek adopted the Roman approach. Van Bijnkershoek argued that in the case decided by the Hoge Raad, it would have been more correct to conclude that neither side could bring an action and that each ship had to carry its own damage. Whoever acted negligently could not bring an action. ${ }^{329}$ The plaintiff suffered damage, but this

325 According to Forcellini et al., Totius latinitatis Lexicon, III, s.v. mesonauta, this word is composed of medius and nauta, and can be found in Ulpian's record of Pomponius' view in D. 4.9.1<.2>; one has to position him in the middle between the highest seamen (e.g. the helmsman and the look-out man) and the lowest (e.g. the rowers and the men who obey orders of all the others). The positioning of the mesonauta between the highest and the lowest seamen can already be found in A. Turnebus, Adversaria, XXVIII.31 (edn. 1599, col. 1016).

326 Neostadius, decisio nr. 49 (edn. 1667, p. 167); Van Nieuwstad, Kooren \& Van Nispen 1655 , p. 131.

327 Van Bijnkershoek's different interpretation that in such case no action was available and each party should bear its own losses, seems to have been preferred by D.G. van der Keessel in Thesis 821 ad Gr. III.38.18.

328 Neostadius, decisio nr. 49; C. van Bijnkershoek, Quaestiones juris privati, IV.22, edn. 1744, p. 468; Pöhls 1832, III, p. 778; Bouman 1855, p. 42; Thomas 2001, p. 355.

329 Also Kotzé 1953, p. 68; - Later, i.e. at the beginning of the twentieth century, Van Nierop questioned whether the principle of culpae compensatio was applicable in Dutch law. This rule of ius commune implied that in the event of contributory negligence of the injured, the victim had to bear the damage himself. According to Van Nierop 1905, p. 4f., four articles seem to take into account contributory negligence of the injured party, among which art. 535 WvK. This article was part of Book Two, Title Six, called Van schade door het overzeilen, aanzeilen, aanvaren en aandrijven veroorzaakt. Art. 535 WvK: Bijaldien dit een en ander door de schuld van wederzijde veroorzaakt is, draagt elk zijne eigene schade. De schippers zijn, zoo in dit, als in het bij het vooraangaande artikel bepaalde geval, aan de eigenaars van de schepen en koopmanschappen tot vergoeding gehouden, onverminderd hun verhaal op de officieren en het scheepsvolk, indien daartoe gronden zijn; the edition of 1873 is used. However, in the older (official) edition of 1830 the (slightly different text was contained in art. 413 of Title Six Van schade door aanzeiling of aandrijving veroorzaakt. According to Van Nierop, this presumption in favour of the applicability of this rule is strengthened by the history of art. $535 \mathrm{WvK}$, and ultimately by C. van Bijnkershoek, Quaestiones juris privati, IV 22. As already stated, Van Bijnkershoek believed it more correct that when two ships acted negligently in the event of a collision, both should bear their own damage based on D. 50.17 .203 (see also Van Nierop 1905, p. 18f.). Art. 535 WvK is rooted in this statement. Therefore, there is a strong presumption that the theory of culpae compensatio was 
was due to his own negligence and he was therefore considered as not having suffered any damage, based on D. 50.17.203. Furthermore, it would not help a defendant to argue that the other party also acted negligently, because in order to bring an action he had to have the law more on his side. When someone acted negligently, it was not possible to bring an action. If both parties acted negligently, each party had to bear its own damage. ${ }^{330}$

Let us take a closer look at Van Bynkershoek's argument. Van Bynkershoek proposed a contra-argument against his own opinion, namely, that Article 3, title 5 of the Edict of King Philip could have introduced an exception to the Roman rule that if both parties to a collision were to blame, no actions were available and that each party had to bear its own loss. ${ }^{331}$ According to this article, a ship under sail that collided with a ship at anchor bears its own loss. The damage to the stationary ship was to be borne in equal parts, provided the crew of the sailing ship declared under oath that they had no blame whatsoever. However, if the stationary ship could prove that the sailing ship was at fault, the latter was liable for the total loss, provided the stationary ship could also prove that there was no fault on its side. ${ }^{332}$ Van Bijnkershoek questions whether the rule

still applicable in Van Nierop's time. However, a decisive answer cannot be given, unless it turns out that the principle of culpae compensatio is founded on general principles of law (Van Nierop 1905, p. 19).

330 C. van Bijnkershoek, Quaestiones juris privati, IV.22, edn. 1744, p. 468; Kotzé 1953, p. 68. Accordingly J. van der Linden, Adnotatio ad Voet D. 9.2, nr. 15 (edn. 1793, p. 157); see also the English translation by Gane 1955, p. 574; - It seems that with regard to collision cases, the laws of the sea, after the reception of Roman law, are interpreted from the background of the actio legis Aquiliae. Accordingly S. van Groenewegen van der Made, Tractatus de legibus abrogatis, ad D. 9.2.29(.2-4): Si navis tua impacta in meam navem damnum mihi dederit, si quidem in potestate fuerit ne id accideret, adeoque et culpa eorum factum sit, actio legis Aquiliae locum habet. Hic. Caeterum si oborta tempestate et vi ventorum, aut alioqui sine culpa id factum sit, tunc hodie damnum utrinque commune est ...; - See also Luig 1969, p. 227, who mentions the strict manner of interpretation of statutes of the Middle Ages, according to which a statute (i.c. of the laws of the sea) was not allowed to be interpreted a contrario if that led to a result contrary to Roman law. Therefore, Luig 1969, p. 227f., concluded, while no other evidence is available, that it may be assumed that Grotius and Van Bijnkershoek did not take the conclusion as argued by Aumann (i.e. the conclusion that if both parties in a collision acted negligently, a division of the damage into halves had to be made according to the laws of the sea in the period of the usus modernus).

331 The words of this article are as follows: In gevalle dat een Schip van binnen ofte buyten 's Landts komende, seylende ofte fockende, een ander Schip vaste liggende, inne seylde, ende schade dede, soo sal de geene die alsoo is komen seylende, den ghequetsten ofte beschadighden Schepe, de helft vande schade betalen, ende hem met sijnen Schiplieden purgeren by eede, dattet by sune schult niet gheschiedt en is, ten zy dat die beschadighde contrarie weet te toonen, ende dat hy selve oock buyten alle schult is, in welcken ghevalle sal 't voorschreven Schip van buyten komende, de gheheele schade betalen (edn. Cau 1658, col. 817);- See C. van Bijnkershoek, Quaestiones juris privati, IV.22, p. 468. Van Bijnkershoek's interpretation here, as Thomas 2001, p. 356, rightly states, seems to be in accordance with Van Bijnkershoeks' belief that no action was available in case of contributory negligence.

332 See also Thomas 2001, p. 356. 
of the equal division of loss would apply in case the stationary ship succeeded in proving the fault of the ship under sail, but failed to prove the absence of all blame on its side. Van Bijnkershoek rejected this solution and stated that the correct interpretation must be that the guilty party has to carry all losses, unless the injured party also was to blame. In the latter case both sides had to bear their own losses. ${ }^{333}$

At the end of the eighteenth century, Van der Keessel, in his Select Theses on the Laws of Holland and Zeeland (1800),, ${ }^{334}$ adopted Van Bijnkerhoek's solution. ${ }^{335}$ According to Thesis 816 (ad Grotius' Inleidinge III.38.16), if two ships collided and both captains acted negligently, the loss had not to be borne equally ${ }^{336}$ but both parties had to bear their own damage. ${ }^{337}$ This solution was also supported by two local statutes, namely the Law of Rotterdam and the Law of Dordrecht. ${ }^{338}$

However, Van der Keessel was completely new insofar as he interpreted Article 3, title 5 of the Edict of King Philip regarding a case of contributory negligence in a way that in the event of a collision, the negligence of a ship under sail was considered more serious than that of a stationary ship. Therefore, culpae compensatio was not allowed and the ship under sail had to pay half the loss of the ship at anchor. ${ }^{339}$ It can be concluded that he estimated the negligence of both parties quantitatively. Contrary to Voet's way to apply this estimate, the party whose negligence was greater was not liable for the total damage but (surprisingly) had to pay only half the damage of the counterparty, besides all of its own damage. ${ }^{340}$

333 ibid.; Van Bijnkershoek found support for his argument in art. 46 of the Placaet of Charles and art. 1 of title 5 of the Placaet of Philip, which provide that only in the event of no fault on either side is the loss borne equally by both parties.

334 These Theses were a condensed written version of his lectures (Praelectiones), which were based on the Inleidinge of Hugo Grotius; see Zimmermann 1992, p. 31.

$335 c f$. C. van Bijnkershoek, Quaestiones juris privati, IV.22, edn. 1744, p. $705 \mathrm{ff}$.

336 As decided by the Hoge Raad; see Neostadius, Decisio, 49.

337 D.G. van der Keessel, Theses selectae juris Hollandici et Zelandici, thesis 816.

338 See art. 262 Ordonnantie of Rotterdam (1721): Als den Beschadigde het hadde konnen ontgaan, zal hy zijn eygene schade, als door zijn eygen of zijn eygen Schippers schuld opgekomen, moeten dragen, zonder deswegens eenige Actie te hebben op het zeylende Schip, and art. 179 Instructie of Dordrecht: Als den Beschadigde het had konnen ontgaan, zal hy zijn eigene Schade, als door eigen, of zijn eigen Schippers schuld bygekomen, moeten dragen, zonder deswegens eenige actie te hebben op het zeilende Schip.

339 See D.G. van der Keessel, Praelectiones ad III.38.16 (edn. P. van Warmelo et al., p. 406f.), s.v. Schuld van de eene; Thomas 2001, p. 357.

340 Also Thomas 2001, p. 358f., who even stated that Van der Keessel, by teaching his students that in the event of contributory negligence the loss had to be shared, sowed the seed for the proportionate fault rule with its system of comparative negligence; - Ultimately, Van der Linden (re)formulated some general rules regarding maritime collisions (overzeiling van schepen) in his Koopmanshandboek. These rules are discussed in this section. In his treatment, 
Van der Keessel also discussed another case. Because ships were usually controlled by a rudder, in a collision between a ship under sail and a ship at anchor, the negligence of the skipper and the crew of the vessel under sail was presumed. Van der Keessel stated that the correct interpretation of Article 3 of the aforementioned Edict of King Philip was that if any negligence was attributed to a ship at anchor, the liability of the ship under sail was reduced by half of the total damage caused to the stationary ship. ${ }^{341}$ The Edict of King Philip was amended by Article 262 of the Ordonnantie van Rotterdam, including the rule that if a vessel which was struck could have avoided the collision, that vessel had to bear the loss, since the damage was caused by her skipper's negligence. In this way, the statutory law of Rotterdam reintroduced the Roman principle of D. 50.17.203. ${ }^{342}$

\subsubsection{Preliminary conclusion on collision cases}

If two ships collided, and one of them acted negligently, its captain was liable for the total damage ( $c f$. the rule of Roman law). The Hoge Raad decided that when it was not clear which skipper had acted negligently, or the negligence was equal on both sides, the damage had to be regarded as common and both had to bear the total damage in equal parts. This decision is obviously contrary to the rules in Roman law and the rules in ius commune. However, the approach of the Hoge Raad was based on maritime law (the idea of the cooperative damage community). Some legal doctrine scholars, however, did not follow this prevailing view in the eighteenth century. They adopted the Roman approach (and applied the rule of D. 50.17.203) arguing that if both ships acted negligently, each ship had to bear its own loss. Interestingly, this view was supported by two municipal laws of the cities of Rotterdam and Dordrecht.

Another situation that occasionally occurred was when a stationary ship was struck by a ship under sail. For this case, Article 3, title 5 of the Edict of King Philip was relevant. Based on this statutory provision, Van der Keessel

\footnotetext{
Van der Linden, among others, also explicitly referred to the Placaet of 1563, van Bijnkershoek and Van der Keessel. See Van der Linden's Koopmanshandboek IV.5.7. Van der Linden stated that if a ship, under sail or anchored, was damaged due to a collision with another ship, the negligent vessel had to bear the loss alone. If both vessels were to blame to the same extent, they both bore their own loss. If it was unclear by whose fault the collision had occurred, each vessel had to bear half of the damage. Unfortunately, Van der Linden did not comment on the question as to the outcome if the negligence of one of the parties was more serious than the other's. According to Thomas 2001, p. 358, Van der Linden skirted the issue of contributory negligence with unequal blame. Thomas correctly remarked that Van der Linden's way of formulating general rules cannot avoid the exceptional case of a ship sailing into a moored or anchored ship.

341 D.G. van der Keessel, Praelectiones ad III.38.18 (edn. Van Warmelo et al. 1967, p. 412f.), s.v. In gevalle een schip; Theses selectae juris Hollandici et Zelandici, thesis 821; Thomas 2001, p. 357f.

342 Accordingly Thomas 2001, p. 358
} 
argued that in the event of a collision between a ship under sail and a stationary ship, the negligence of the former was always more serious. Therefore, according to Van der Keessel the fault of the (captain of the) sailing ship could not be compensated by the fault of the stationary ship. This was a renewed interpretation and application of the culpae compensatio doctrine. According to Van der Keessel, the outcome had to be that the liability of the colliding ship was reduced to half of the total damage of the stationary ship. This result is different from the outcome according to Voet, although Voet also applied a quantitative estimation of the negligence on both sides. According to Voet, the wrongdoer whose negligence was more serious compared to the negligence of the injured party was fully liable for the damage to the latter. This difference can be explained by considering the fact that in the event of a collision caused by casus, the laws of the sea stated that half of the damage had to be compensated (while Roman law would state: no liability). According to Van der Keessel, apparently, if the negligence of the injured party was less serious than that of the wrongdoer, one fell back into the casus-regime, and could only claim half of the damages.

\subsection{USUS MODERNUS PANDECTARUM}

\subsubsection{Introduction}

A general introduction on the use of the actio legis Aquiliae in early modern times has already been made above (in section 4.3). The jurists of the usus modernus applied the actio legis Aquiliae in all cases of damnum culpa datum, irrespective of the existence of contractual relationships between the parties concerned. ${ }^{343}$ Furthermore, although the lex Aquilia was used to cover cases of physical injury inflicted upon freemen, the question of applicability in a case of the killing of a freeman was a more difficult matter. The view of Azo prevailed in the long run: the wrongdoer was held liable in a case of the killing of a freeman, ${ }^{344}$ however the injured party died and, according to some authors, relatives or heirs could only claim expenses for hospitalisation, medical care, etc. ${ }^{345}$ Based on the reception of Roman law the rule was established that, with regard to the infliction of bodily harm upon freemen, medical expenses and loss of income could be claimed. By the end of the seventeenth century, com-

343 Kaufman 1958, p. 117f.; Zimmermann 1990, p. 74.

344 Feenstra 1987a, esp. 207ff., 210f.; Zimmermann 1990, p. 74.

345 Zimmermann 1990, p. 75, also on the question of whether funeral expenses could be reimbursed. 
pensation to wife and children for the loss of support resulting from the death of a man (breadwinner) was a widely accepted addition to the lex Aquilia. ${ }^{346}$

In this section, the compensation to wife and children for the loss of support will be considered in particular. Was this claim (actio) based on the wife's own right or an inherited action based on the Roman lex Aquilia? A claim for the widow and/or relatives could be an independent claim based on customary law (see Grotius, Inleidinge III.33.2), but also a claim of the deceased passed to the heirs in case - and which is not always the case - they were also the heirs of the deceased. It is important to make this distinction, as it is not self-evident that contributory negligence is relevant for both sorts of claims. Although one would suspect this relevancy as to the second claim, it is questionable whether the same applies for the first claim. This will be studied more in detail later in this section.

A second issue that arose in this period was the claim for compensation of pain, suffering and disfigurement. Such a claim could not be compensated in the period of the Middle Ages, i.e. could not be based on the Corpus Iuris. Apparently, this sort of claim came into existence when the penal character of the actio legis Aquiliae disappeared. However, as will be shown below, the question whether an injured person could claim compensation for pain, suffering and disfigurement was not always answered in the same way. Roman law denied such compensation with regard to disfigurement, and also academic writers of usus modernus tended to follow this view. However, Germanic customary law already provided fixed amounts of money, which provisions were eventually followed by the courts in the seventeenth and eighteenth centuries. Eventually, the academic writers resigned themselves to the practical realities. ${ }^{347}$ Interesting is the opinion of Grotius, who argued that pain and disfigurement of the body of a freeman, although properly speaking incapable of compensation (i.e. according to Roman law), are assessed in a sum of money, when such damages are demanded (apparently a concession to the actual practice of that time).$^{348}$ This aspect of immaterial damages will particularly be examined as it is connected with the consequences of contributory negligence. This will be made clear below.

By the end of the seventeenth century it had become manifest that modern

346 ibid.; Gordley 2006, p. 161.

347 Zimmermann 1990, p. 76f.; according to Gordley 2006, p. 161, by the 17th century it had become accepted that the plaintiff could recover compensation for pain and suffering.

348 H. Grotius, Inleidinge, III.34.1-2; see section 4.3.3. 
law in action no longer reflected the actio legis Aquiliae as recorded in the Corpus Iuris, thus the view of Christian Thomasius. ${ }^{349}$ Other jurists preferred to award damages according to Germanic principles because they regarded the actio legis Aquiliae as not received into the ius commune. ${ }^{350}$ However, none of these opinions prevailed. The jurists of the usus modernus were normally not interested in theoretical debates. They applied the revised principles of the actio de damno dato and discussed these using terminology derived from the lex Aquilia. ${ }^{351}$ The most relevant jurists of the usus modernus in Germany and Italy will be presented in sections 4.5 .2 and 4.5.3. ${ }^{352}$

A final aspect that has to be mentioned in this introduction is the rule of D. 50.17.203. This text has been used as a specific principle applied to concrete cases. ${ }^{353}$ The text of D. 50.17.203 was used by the jurists of the usus modernus as an argument to deny the right to claim damages in cases in which both wrongdoer and injured party acted negligently, and so together caused the damage to the injured party. This is remarkable, as D. 50.17.203 can also be understood as a rule to solve a problem of causality, which approach apparently was followed in some cases (see below).

There are also situations in which the victim himself was the only cause of the damage, but these situations cannot be qualified as concerning contributory negligence. In fact, in such cases the wrongdoer is not liable because the causal connection between his act and the damage is absent. In some cases (like the

349 See Chr. Thomasius, Larva legis Aquiliae, §1.

350 Jansen 2004, p. 452f.

351 Jansen 2003, p. 291f.; on the usus modernus and the completion of the Reception see, e.g., Wieacker 1967, 204ff.; - On the usus modernus legis Aquiliae in general, see Zimmermann 1990, p. 67ff.; 1996, p. 1017ff.

352 Other countries unfortunately fall outside the scope of this study. In France, the problem of contributory negligence seems to have been solved by applying the rules of D. 50.17.203 and VI 5.12.86. As discussed before, Faber, in his commentary on D. 9.2.9.4, compared the negligence of both parties and discussed which party bore the more serious form of negligence, the gravior culpa. Luig 1969, p. 217, did not find more sources which could establish an express statement in the sense of the maior culpa theory. Nor in the works of Domat and Pothier (see section 4.6.2.1) can such a statement be found. Finally, in M. Guy du Rousseaud de la Combe's Recueil du Jurisprudence (1st edn. of 1736), under the word dommage there is no case of contributory negligence. In the new edition of his Recueil du Jurisprudence Civile (corrigée et considerablement augmentée; edn. of 1746), the section on dommage is indeed considerably extended; the rule of D. 50.17.203 is printed under section II. 'Des dommages et intérêts pour quasi délit' (nr. 4), however, without explanation or example. Also interesting, but apparently considered as something different by De la Combe, is the rule of D. 9.2.44pr. mentioned in part under nr. 3. An addition is made, namely, that when someone acted in a permissible way (quifait une chose licite) in which both time and place were accustomed, and the actor had performed all diligence he was supposed to, he was not held liable for the damage done to another person (he refers to Inst. 4.3.4); - Scotland lies beyond the scope of this study, as is also the case with the common law. For an overview, see Luig 1969, p. 220ff., p. $222 \mathrm{ff}$.

353 See, e.g., J. Brunnemann who applied the rule in a consilium, i.e. cons. II.143: Sed damnum, quod quis sua culpa sentit, sibi non aliis debet imputare ... 
one of the child run over by a cart; see below) the problem of negligence can be transformed into a problem of causality. Below I will discuss in which sort of cases this seems appropriate, i.e. in cases in which the underlying problem concerned a causation issue.

\subsubsection{Usus modernus in Germany}

\subsubsection{Introduction}

The debate as to how far contributory responsibility of the injured party should be taken into account to determine the liability of the wrongdoer continued both in practice and in science in the period of the usus modernus pandectarum. As discussed above in the chapter on Roman law (chapter two), the cases described in the texts of the Corpus Iuris only concern the question whether the wrongdoer, considering the circumstances of the case, had to pay the poena or not. ${ }^{354}$ In the medieval period of ius commune, Glossators and Commentators came to the conclusion that if both wrongdoer and injured party acted culpably, any liability ceased to exist, unless the wrongdoer acted intentionally. The early ius commune that developed after the reception of Roman law in the Holy Roman Empire of the German nation initially resulted in the reproduction, without criticism, of the sources of the Corpus Iuris passed down to them. This also happened to fragments concerning (Aquilian) liability. If an injured party suffered loss as a result of his own negligence, there was no right to claim for compensation. The victim's own behaviour put into question the conditions required for the claim for damages, with the result that the wrongdoer completely escaped liability. ${ }^{355}$

Accordingly, in the secondary literature it is argued that the jurists of the usus modernus did not come to a different solution as to the problem of contributory negligence: if the injured party acted negligently, no damage could be claimed, unless the wrongdoer acted intentionally. ${ }^{356}$ However, the Roman

354 According to Kaufmann 1958, p. 77, the sources of German law handed down to us seem to suggest that the liability of the perpetrator in many cases was related to unlawful causation, and that the obligation to pay compensation would only cease if contributory negligence was attributed to the victim. See also Hammer 1885, p. 72.

355 See Aumann 1964, p. 38.

356 Wieling 1970, p. 224; this principle also becomes clear already in the definition of interesse, when in cases of ersetzbare Interesse compensation is denied in case of contributory negligence; see Wieling 1970, p. 58f.; see also a case at the Reichskammergericht of 24 January 1763 discussed by J.U. von Cramer (1706-1772). Cramer was assessor at the Reichskammergericht; the Nebenstunden emerged from his function as a judge (see Döhring 1957b, p. 391). Also, this decision seems to stem from the idea that no compensation was granted when the injured party acted negligently. See Cramer 1763, p. 112ff. (esp. 117). 
texts of the Corpus Iuris were not clear as to the question when (in which cases) exactly this liability of the wrongdoer expired (only when his negligence was equal or preponderant to the victim's negligence or also if his negligence was small). ${ }^{357}$ Therefore, it is not surprising that it has been argued that the concept of culpamaior arose in the usus modernus as the decisive criterion to determine whether liability existed or not since the beginning of the seventeenth century. The meaning of this concept becomes clear from the writings of legal scholars (legal doctrine), decisions of the courts (case law) and from (legal) opinions. In this section, a more elaborate discussion on this topic will follow. The various contributions of jurists of the usus modernus will be discussed, as well as various consilia of the Faculties of Tübingen, Wittenberg, Halle and Helmstadt. ${ }^{358}$ These court legal opinions (consilia) were drafted by university professors and introduced into the legal proceedings by advocates. Important is the so-called system of Aktenversendung. It was common for a German court, from at least the beginning of the sixteenth century, in the event of a difficult, complex case to consult learned experts: the court sent the records of the case to a bench of professors at the Law Faculties (Spruchkollegium), together with a request for an (collective) opinion on the legal issue(s) at stake. ${ }^{359}$

I will deal with the question of how to explain that an injured party had no right to claim compensation in case of contributory negligence. It will become clear that the approach was still the all-or-nothing one. The approach now took place in terms of a concurrence of faults (i.e. a fault of the wrongdoer and contributory negligence of the injured party). In such cases as a rule of human equity $^{360}$ the injured party was not allowed to bring a claim based on the negligence of the wrongdoer when a similar accusation could be made towards himself; ${ }^{361}$ and thus contributory negligence leads to the annulment of the negligence of the wrongdoer. ${ }^{362}$ As will be shown below, in order to provide a

357 According to Aumann 1964, p. 50, one view in the period of the ius commune was that the injured party lost his right for compensation in case of a small mistake, irrespectively of the fault of the wrongdoer. A second view was that the injured party did not have any right for compensation if his negligence was equal to that of the wrongdoer, or if the injured party was responsible for the decisive fault. Luig 1969, p. 196ff., argues that, over the course of history, the first view has rarely been defended (and so he argued that the second view prevailed). The solution of contributory negligence in the period of ius commune was mainly based on D. 9.2.11pr., D. 50.17.203 and the theory of culpae compensatio.

358 On the 'praktische Thätigkeit der Juristenfakultäten' in the 17th and 18th centuries, especially on their influence on the development of German criminal law from Carpzovius onwards, see Hegler 1899.

359 Feenstra 1992b, p. 415; Letto-Vanamo 2012, p. 162. On the Aktenversendung, see Klugkist 1967, p. 155ff., with references to older secondary literature.

360 Chr. Thomasius, Larva, $\S 6$ (edn. Hewett 2000, p. 9): regula aequalitatis et humanitatis.

361 See, e.g., J.F. Eisenbach, De compensatione circa maleficia, §10 and §19; Chr. Thomasius, Larva, $\S 6$.

362 Jansen 2007, p. 664; - This view is shown to be applicable law until the 19th century, 
basis for this annulment, jurists did not always base themselves on the idea of culpae compensatio, but sometimes just referred to the rule of D. 50.17.203. ${ }^{363}$ When taking a closer look at theory and practice, several doctrinal starting points dealing with the problem of contributory negligence are provided. Three main views can be distinguished, which will be further explained below and, if necessary, subdivided as follows: considering contributory negligence as a causality problem or as a negligence problem (with several subdivisions, among which the use of the culpae compensatio doctrine), or solving the case without any reference to contributory negligence.

\subsubsection{Contributory negligence in theory and in practice: a problem of causality}

In a consilium given by the Faculty of Tübingen on 6 June 1695, collected by Michael Grass (1657-1731), it was reported that a thief (Sauter) was killed during the act of stealing at night. The relatives (wife and children) claimed compensation for the loss of support resulting from the death of their husband and father. This claim was denied. The consilium states that Sauter, by committing the theft, gave occasion for and caused the accident. ${ }^{364}$ Therefore, one could even argue that it seems to have been purely a problem of causality, exactly as in the rule already described in D. 9.2.30.3. However, apparently, this was not the case, as according to the wording of the consilium (confirmed by references to the Digest), the decisive criterion was not causality at all. The surviving relatives were denied any action because the negligence of the injured party (i.e. the theft by the thief) concurred with the fault in the act of killing. ${ }^{365}$ However, to maintain - as Luig did - that the decisive reason to come to this conclusion was that the negligence of the thief was considered preponderant, ${ }^{366}$ cannot be based on the consilium in question.

see, e.g., Glück 1812, p. 68ff.; see also Krug 1833, p. $142 \mathrm{ff}$.

363 In the same sense Jansen 2007, p. 664; - See, e.g., H. Donellus, Commentaria ad D. 9.2, Caput 1, nr. 9.

364 M. Grass, Consilia, V, cons. 78, nr. 34.

365 M. Grass, Consilia, V, cons. 78, nr. 35: Ubi vero culpa patientis concurrit, actio L[egis] Aquiliae aut subsidiaria, accommodata ad L[egem] Aquiliam, locum haud invenit l. 11. pr.ff. ad L. Aquil. [D. 9.2.11pr.], l. 203.ff. de R.I. [D. 50.17.203].

366 Luig 1969, p. 210. 


\subsubsection{Contributory negligence in theory and in practice: a problem of negligence}

View 1: Application of the theory of culpae compensatio but only when the respective negligence was equal on both sides

Some jurists in the period of the usus modernus still applied the (medieval) theory of culpae compensatio in a way that compensation could only take place when the delicts and/or negligence of two opposing parties were equal in degree. ${ }^{367}$ This theory has been studied on a doctrinal level for practical purposes. However, although some cases mentioned by Johannes Zanger (1557-1607) ${ }^{368}$ show that the theory was applicable to cases in which both parties acted negligently, no situation of contributory negligence in the event of Aquilian liability cases is mentioned in his work. This approach is very conservative in the sense that it shows a continuation of the Bartolistic view and the Bartolistic way of argumentation.

View 2: The mere existence of contributory negligence (i.e. even a very small degree of contributory negligence) leads to the deprivation of the possibility to obtain compensation

A forerunner of this view can already be found with the German humanist Ulrich Zasius, who considered the problem of the scope of the compensation solely a problem of fault and therefore, because of the analogy to the sources of Roman law, the role of the contributory responsibility of the injured party was not regarded as a problem of contributory causation, but only appears in terms of contributory negligence. ${ }^{369} \mathrm{He}$ argued that if both wrongdoer and injured party acted negligently, the actio legis Aquiliae was not applicable. ${ }^{370}$ This approach is similar to that in Justinianic Roman law. Zasius's conclusion,

367 See J. Zanger, Tractatus de exceptionibus, cap. 6, nr. 27;- A similar position seems to have been taken by Sebastiano Medici, Tractatus de compensationibus, pars I, quaestio 35ff., and Celsus Bargalius, Tractatus de dolo, liber VI, regula 15 (dolus cum dolo compensatur), esp. nr. 6lf. Summarising, the two latter authors agree with the prevailing view: culpa can be compensated with culpa, dolus with dolus, negligentia with negligentia. However, culpa lata cannot be compensated with culpa levis, because culpa lata is preponderant; so only when the negligence was equal could compensation take place. Furthermore, the negligence on both sides had to constitute an act or an omission and no compensation could take place if one party's negligence constituted an act and the other's an omission.

368 On J. Zanger see, e.g., Landsberg 1898, p. 685.

369 U. Zasius, Commentaria, ad D. 9.2, nr. 11; Kaufmann 1958, p. 78.

370 As examples, Zasius mentioned the cases of D. 9.2.9.4 (and D. 9.2.10) and D. 9.2.11pr.; Ulrich Zasius treated the problem of the negligence of the injured party as an abstract legal question of law; see also Kaufmann 1958, p. 78, who wrote that Zasius treated the problem as an 'abstrakte Rechtsfrage' without 'erkennbare Anknüpfung an die mittelalterlichen Juristen'. Because Zasius can be considered a humanist, this is not extraordinary; Luig 1969, p. 206. 
namely, that if both wrongdoer and injured party acted negligently, the actio legis Aquiliae was not applicable, can be considered as an expression of the all-or-nothing approach. This approach, in which the degree of mutual participation or the more subtle differentiations within the concept of culpa were not taken into account, at first was mainly followed in practice and representatives of this line applied it until the second half of the eighteenth century. ${ }^{371}$ This becomes clear from several consilia from the Law Faculty of Tübingen. ${ }^{372}$

Also in two decisions of the Reichskammergericht, as recorded in the compilation of decisions by Adrian Gilman, an all-or-nothing approach was followed, namely, by applying the rule of D. 50.17.203. ${ }^{373}$ Other jurists - e.g. Johannes Stucke (1587-1653) $)^{374}$ in various consilia - seem to have applied the same thought but by means of the rule of D. 50.17.203. Stucke argued that the injured party could bring no action if he was held to have been contributorily negligent (if there was culpa admixta on his side), because damage suffered due to one's own negligence was not considered claimable damage. ${ }^{375}$ Apparently, the use of the words culpa admixta is typical in consilia literature, e.g. in the consilia of the Socini, Cravetta, Stucke and Venturini (all discussed in this chapter), but is not followed in other kinds of literature of the usus modernus pandectarum.

371 Kaufmann 1958, p. 78

372 See several decisions of the Faculty of Tübingen where, in case of contributory negligence of the plaintiff, the claim was (totally) denied. See G. Schweder, Cons. Tub., I.12.88ff. (decision of 1685); I.70.12 (decision of 1698); I.98.15 (decision of 1701); Lauterbach, Cons. Tub., II.66.15 (decision of 1652); II.89.11 (decision 1673); III.204.26 (decision of 1656); III.205.36 (decision of 1657); M. Grass, Cons. Tub., V.1.39 (decision of 1699); V.78.35 (decision of 1695); see also a consilium of the Faculty of Altdorf, C. Rittershusius, Consilia sive responsa iuris Altdorfina, pars I, resp. 42: Nam damnum quod quis sua culpa sentit, non intelligitur sentire, Welche ursach dann im Rechten der Importantz, das wann gleich der Beklagter angezogene sachen mitverursachet hette, er dannoch darumb nicht köndte belanget werden. Nam quando ex utraque parte culpa intervenit, cessat Aquilia. Zas [ius] in paratit. D. ad l. Aquil. n. 11. ...

373 A. Gilmannus, Decisionum sive rerum in camera imperiali iudicatarum, book 1 decisio 5, nr. 75: ... Ex quo etiam Reus nullum damnum sentit, etiamsi quid pensionum loco dederit. Nam iuris regula est, quod is qui ex sua culpa sentit damnum, nullum intelligatur damnum sentire, l. Quod quis de reg. Iuris [D. 50.17.203]. ...; book 2 decisio 41, nr. 50: ... Propterea quando quis ex culpa sua damnum sentit, non videtur damnum sentire, l. Quod quis ex culpa sua, ff. de regulis iuris [D. 50.17.203], c. Damnum eod. tit. in 6 [VI 5.12.86].

374 On J. Stucke see, e.g., Köcher 1893, p. 716f.; Südkamp 2007.

375 See Stucke \& Stucke, Consilia sive responsa, cons. II.114: Quod vero damnum, siquidem ex proprio facto obvenisset, sibi imputarent et non emptori. Neque enim quod quis ex culpa sua damnum sentit intelligitur sentire l. Quod quis 203. ff. de reg. jur. [D. 50.17.203] ... and IV.827f.: Quinto juris esse ajunt, quod quis ob damnum datum vel dolum seu culpam commissam, contra damnificantem vel dolum seu culpa committentem in litem jurare non possit, si dolus admixtam habeat culpam damnificati Cravett [a] cons [ilio] 119 num [ero] 11, Paris [ius] in vol. 4 cons [ilio] 158 n. 10 et 12. Et facit regula, quod damnum, quod quis sua culpa sentit, sibimet ipsi et non alii imputare debeat, unde et Plotus de in lit [em] jur [ando] $\$ 50$ n. 14. ... and V.534: Nec potest Ecclesia ea ratione de damno et injuria conqueri. Cum quod sentit, propria a culpa sentiat, quae damni nomen plane excludit, l. Quod quis 203. digest. [D. 50.17.203] et cap. damnum 86. de R.I. in 6. [VI 5.12.86]. 
Another example of an approach in which the rule of D. 50.17.203 was applied in the event of Aquilian liability, can be found with Wolfgang Adam Lauterbach (1618-1678). ${ }^{376}$ Lauterbach used the text of D. 50.17.203 to argue that seen ethically, nobody was considered to have suffered damage ${ }^{377}$ if that damage was caused by the negligence of the victim and therefore, when contributory negligence of the victim occurred, the wrongdoer was not considered to have committed a delict. ${ }^{378}$ The approach was therefore still all-or-nothing, but for the first time the problem was really seen in terms of concurrence of fault. ${ }^{379}$ Lauterbach drew no further conclusions from his new point of view: in case of mutual negligence, the requirements of an actio ex lege Aquilia were apparently not fulfilled. Because of the contributory negligence of the injured party, either the recoverable damage itself was considered to have been moraliter absent or the negligence of wrongdoer, required to establish liability, was absent. ${ }^{380}$ According to Lauterbach, if someone, being provoked to a duel, attacked his provoker with arms, even if he exceeded the appropriate measure for self-protection, the wounded person was denied an actio legis Aquiliae. ${ }^{381} \mathrm{It}$ is interesting that Lauterbach even denied the action when the provoked party had acted excessively. ${ }^{382}$ Lauterbach did not take into account the degree of contributory negligence, ${ }^{383}$ implying that even a small degree of contributory negligence annulled the negligence of the wrongdoer. ${ }^{384}$

From Lauterbach's treatment it becomes clear that one can distinguish two situations: the first one, in which the wrongdoer committed a delict and the injured party was contributorily negligent; the second one, in which two par-

376 On bibliographical information on W.A. Lauterbach, see, e.g., Eisenhart 1883, p. 75ff.; Stintzing-Landsberg 1978, II, p. 139ff.; Luig 1982, p. 736ff.; Kleinheyer/Schröder 1996, p. 493.

377 Lauterbach defined damage as a financial loss, namely, as a decrease in one's assets.

378 Also Kaufmann 1958, p. 78.

379 Also Zimmermann 1990, p. 80; 1996, p. 1030;-According to Aumann 1964, p. 51, Lauterbach deviated from the prevailing opinion of his time, according to which the origination of the total damage was traced back to the wrongdoer or to the injured party. In this respect, the description of Lauterbach corresponds to that of his contemporarily natural law teacher Pufendorf (see also Aumann 1964, p. 41).

380 W.A. Lauterbach, Collegium theoretico-practicum, exerc. 19, Th. 10, ad D. $9.2 \S 7$. See also Aumann 1964, p. 51.

381 W.A. Lauterbach, Collegium theoretico-practicum, exerc. 19, Th. 10, ad D. $9.2 \S 7$, and see also §11: Ubi itaque talis abest culpa, ibi non locum habet Lex Aquilia; ut si damnum casu, sine hominis culpa, acciderit; Vel si culpa agentis interveniat, et concurrat culpa patientis, e.g. si provocatus provocantem vulneravit; ex proprio enim delicto, licet alter in re illicita sit constitutus, actio non competit [D. 50.17.203].

382 See also W.A. Lauterbach, Exercitatio 19 § 10: Si provocatus ad duellum provocantem, vel armis insultatus aggressorem, vulneravit, licet moderamen inculpatae tutelae excesserit, vulnerato tamen actio legis Aquiliae ad expensas et interesse non competit ...

383 According to Luig 1969, p. 211, this was not the usual position taken in legal practice at that time.

384 In the same sense Jansen 2007, p. 664, nt. 60. 
ties (i.e. including the 'injured party') committed a delict. Lauterbach discusses the second situation, the event of proprium delictum, in the same treatment, although this cannot strictly be included under 'contributory negligence'.

According to Lauterbach, the existence of contributory negligence of the injured party led to the denial to grant an action; Lauterbach substantiated this denial by referring to D. 50.17.203 and stating that someone who suffered damage because of his own delict could not claim damages. However, the text of D. 50.17.203 only considered contributory negligence that contributed to the victim's own damage and not, as Lauterbach stated, because of a 'proprium delictum, ${ }^{385}$ In that sense, Lauterbach interprets ex sua culpa in D. 50.17.203 as ex suo proprio delicto and thereby interprets D. 50.17.203 in a different direction. A proprium delictum is an action contrary to the law, which immediately brings damage to someone else. ${ }^{386}$ These actions cannot be referred to as cases of contributory negligence, because that would mean that someone's act coproduced his own damage. Lauterbach did not distinguish between these two situations (of an act of the injured party who caused damage to himself by sua culpa, or to someone else by his proprium delictum), ${ }^{387}$ probably due to the practical application of the rule, and because it fitted well into his line of arguing.

View 3: The theory of maior culpa

Already the glossator Azo was of the opinion that in the event of damage caused by the intentional behaviour of the wrongdoer and contributory negligence of the injured party, the negligence of the latter was considered irrelevant. ${ }^{388} \mathrm{~A}$ further elaboration of the degrees of negligence cannot be found in the sources. According to Jansen, jurists (I suppose early modern) did not qualify the less serious behaviour of the injured party as negligent, when the wrongdoer's negligence was preponderant. ${ }^{389}$ Since the seventeenth century this rigid approach seems to have been overcome and a more flexible approach

385 Aumann 1964, p. 51.

386 An example of such a delict of the injured party can be found in the already frequently mentioned text of D. 24.3.39; according to D. 24.3.39, if both husband and wife acted with bad conduct, and both of them gave cause for repudiation, neither can bring a claim, as the offence of each of them is compensated by that of the other; - According to M. Wesenbecius, Commentarii in Pandectas, I, ad D. 9.2 (edn. 1589, p. 135), when two people wounded each other in a fight, and it could not be established who provoked the other, both delicts would be compensated mutually. This view is in conformity with D. 9.2.45.3, and the gloss sibi ad D. 9.1.1.11; see also the commentaries on the latter text (mentioned in the previous chapter), and also A. Tiraquellus, $D e$ poenis, causa 62.

387 See also Aumann 1964, p. 5lf.

388 See gloss tenebitur ad D. 9.2.9.4.

389 Jansen 2007, p. 664f.; this was indeed true as regards J. Brunnemann, Commentarius, ad D. 9.2.31, esp. nr. 2f. (see below). 
taken. ${ }^{390}$ From the rule on liability in the event of intentional misbehaviour, it can be deduced that the degrees of negligence had to be weighed: ${ }^{391}$ only equal or preponderant contributory negligence should exclude liability. ${ }^{392}$ According to Luig, this conclusion can be made for the majority of jurists of the usus modernus in the eighteenth century: a claim filed by an injured party only had to be rejected when this party acted with negligence to an extent equal to or preponderant with respect to the negligence of the wrongdoer. ${ }^{393}$ This mainly appears in their decisions and advice/opinions. However, as will be explained below, this did not apply in all cases.

A first trace of the maior culpa theory can be found in the work of the humanist Marquard Freher, who argued that in D. 9.2.11pr. the negligence of the barber had to be considered as being more serious, and therefore the barber should be held liable. ${ }^{394}$ In the usus modernus in Germany, this renewal of the medieval culpae compensatio doctrine can also be found in a consilium of the Law Faculty of Tübingen, recorded by Christoph Besold (1577-1638). ${ }^{395}$ In the case described by Besold, the plaintiff provoked the other (the defendant) to a fight, resulting in the disembodiment of the first one. Here, the plaintiff's contributory negligence was more serious (major culpa) than the negligence of the defendant. Apparently, the negligence of the plaintiff had to be qualified as malicious intent (dolus) or gross negligence (culpa lata). ${ }^{396}$ Therefore, the negligence of one party was compensated by the other party's negligence, in

390 See the theory of A. Faber on the gravior culpa in which first traces of the so-called maior culpa theory can be found (see section 4.2.4.5).

391 See J. Brunnemann, Commentarius in pandectas, ad D. 16.2.10, nr. 2, and also already Tyndarus Alphanus, Tractatus de compensationibus, art. 5, nrs. 30 and 36.

392 Jansen 2007, p. 665.

393 Luig 1969, p. 198; on this topic also Zimmermann 1996, p. 1030; - The view of Luig 1969 , p. 212, that the judge, although often by different or ambiguous legal arguments always aimed at establishing to which party the greater blame had to be imputed, in my opinion is not sufficiently supported in the sources.

394 M. Freher, Verisimilium libri duo, ad D. 9.2.11pr. (discussed above).

395 Chr. Besold, Consilia Tubingensia, vol. VI, cons. 290, nr. 43f.: 'Unnd abermal gesetzt, es sollte einige Culpa dem Reo imputirt werden: so ist jedoch der Entleibte, als provocans, in majori culpa. Itaque culpa cum culpa et delictum cum delicto compensandum ...' He referred to D. 24.3.39, D. 24.3.47, X 5.16.6 and X 5.16.7, L. Schrader, Tractatus feudalis, pars 9, cap. 4. num. 74; on Besold, see, e.g., Muther 1875b, p. 556ff.;- See also J.H. Böhmer, Doctrina de actionibus, sect. II, cap. XI, $\S X X V$, barring an action based on the lex Aquilia brought by an injured party against a wrongdoer if the injured party's negligence was more serious than that of the wrongdoer. Böhmer referred to D. 9.2.11pr.

396 See also L. Schrader, Tractatus feudalis, pars 9, cap. 4, nr. 74: ... Quia is, qui alterum provocat in dolo vel saltem lata culpa esse dicitur, d. $\$$ Tabernarius [D. 9.2.52.1]. ...; see also nr. 75: Et culpa cum culpa, quatenus agitur de privato interesse, compensatur, l. Item obstetrix 9. § fin. et l. Si putator, 31.ff. ad l. Aquil. [D. 9.2.9.4 \& D. 9.2.31], l. Si ambo. 10.ff. de compensatio[nibus] [D. 16.2.10pr.]. Et damnum, quod quis sua culpa sentit, sibi, et non alteri imputare debet, l. Item Mela 11. in prin.ff. ad l. Aquil., c. Damnum et ibi Dyn. de reg iur. Lib. 6. [VI 5.12.86]. 
the same way as two delicts were compensated. This argument is a dogmatic one; the theory of culpae compensatio was elaborated for various degrees of culpa, and, since in this case the injured party's negligence was preponderant to the less serious negligence of the wrongdoer, the plaintiff (who provoked the other to a fight) could not recover any damages.

The view of the 'königliche Hannoversche Justizkanzlei' in 1762, object of legal considerations by David Georg Strube (1694-1776), ${ }^{397}$ is important in this respect. A maidservant rode the horse of her Lord Titius (Dienstherr) to a place where it could drink water. On the ride back, at full speed, the horse toppled over and died. Titius claimed compensation from the servant. Strube argued in the following manner. It was not proved that the servant deliberately beat the horse or could have restrained it; the plaintiff was not free from negligence since he let his servant ride an irrepressible horse, and one could not believe that a female could control the horse equal to a young man. If the plaintiff also acted with some negligence, no actio legis Aquiliae was granted. Apparently, a different conclusion was taken if the servant deliberately beat the horse, and in order to determine whether this was the case, the Justizkanzlei ordered the performance of a submission of evidence for this statement. ${ }^{398}$

Strube's view is not very clear. The secondary literature provides various interpretations that can be given to the view of Strube. Firstly, Strube's view can be understood as viewing the preponderant negligence as the decisive criterion for the Justizkanzlei. This implies the assumption that a small degree of negligence of the injured party did not lead to a denial of the claim. In such case, the submission of evidence would have been useless since the Justizkanzlei had already decided that Titius was 'nicht ausser aller Schuld'. The Justizkanzlei apparently considered the negligence of Titius less serious than that of the servant, which did not lead to a denial of the claim. ${ }^{399}$ However, the negligence of the servant was possibly closer to intention (dolus) than to negligence (culpa).

Secondly, Strube's view could be interpreted as an example of a legal interpretation in which neither the degree of mutual participation nor the more

397 On Strube, see, e.g., Frensdorff 1893, p. 635ff.

398 D.G. Strube, Rechtliche Bedenken, III, Bed. 61, esp. p. 229. Strube, among others, referred to Lauterbach, Collegii theoretici-practici Pandectarum, ad D. 9.2, §7 \& 11. See also F.-C. Harpprecht, Responsorum criminalium et civilium, vol. IV, resp. 83 n. 379: Quod vero in omnibus ejusmodi casibus, quando scilicet culpa a duobus commissa est, unius culpa cum alterius compensetur nullam dubitationem relinquit argumentum Legis 36. ff. de dolo [D. 4.3.36] et Leg. 39 sol. matr. [D. 24.3.39] ...; also interesting in this respect is the case of D. 13.6.23, which was mentioned by Peter Faber in his commentary on D. 50.17.203 as a case of contributory negligence (in edn. of 1618, p. 776).

399 Luig 1969, p. 212. 
subtle distinctions within the concept of culpa were taken into account. ${ }^{400}$ In that case, the Justinianic solution to the problem of contributory negligence was followed, and in the event of contributory negligence, no action was granted. This conclusion can be found in a contemporary scholar of Strube's, namely Johann Müller (1750-1795), who in his Promtuarium juris, based on Strube and other authors already mentioned by Strube, stated that an action based on the lex Aquilia could not be granted if the injured party acted with negligence to a certain measure. ${ }^{401}$ It can be questioned whether Müller took the degree of negligence of the injured party into account, possibly if understood in the sense that even a slight degree of negligence excluded an action.

A jurist who clearly thought that the degrees of negligence were of importance was Karl Hommel (1722-1781). ${ }^{402}$ In his Observatio 792, he applied the medieval doctrine of culpae compensatio and further elaborated on this doctrine in the sense that if two parties acted negligently, compensation could only take place if the respective negligence was equal in degree. ${ }^{403} \mathrm{He}$ gave two examples. The first example is actually not about contributory negligence, but about two offences. However, this situation is brought up, as it could be relevant - by way of an analogy - for the situation of contributory negligence. This fictitious example can be summarised as follows: concerning a married couple, the wife cheated repeatedly on her husband - since she liked men, and her husband could barely bear a tenth of the marital burden $-{ }^{404}$ and from her adultery six children were born. Almost dying at her last childbirth, she confessed her adultery to her husband to obtain forgiveness for her sin. The husband, in tears, confessed his own sin. He knew about the adulteries, and because he was tired of these 'comedies', he had mixed poison and had given it to her. This poison was the reason she was dying now. ${ }^{405}$ According to Hommel, these two delicts, the wife's carnal sin and the man's poisoning are not comparable (as they are entirely different in nature); ${ }^{406}$ therefore, the exceptio of compensation which

400 Kaufmann 1958, p. 78.

401 J. Müller, Promtuarium juris, s.v. Aquilia lex. Actio ex lege Aquilia, nr. 14: Actio ex Lege Aquilia nullam plane invenit locum, si actor quodammodo in culpa est.

402 On K.F. Hommel, see, e.g., Lieberwirth 1972, p. 592.

403 K. Hommel, Rhapsodia quaestionum, obs. 792, esp. nr. 1.

404 ibid., nr. 2: Mulier valde pia, in rebus domesticis assidua, benefica, nullo vitio deformis, nisi quod virorum amantior esset, nupta erat homini debiliori, qui vix decimam partem onerum maritalium ferret. ...

405 ibid.

406 Although this is not explicitly stated by Hommel, one can suppose that the heirs of the woman tried to obtain recovery from the husband; this is rather strange, of course, as this is their father (although not biologically). All in all, it is just a fictitious case, made by Hommel to show the application of the culpae compensatio doctrine. 
was brought forward by the defendant in order to plea for a diminution of the damages, was brought forward in vain. ${ }^{407}$

According to Hommel, malicious intent (dolus) could not be compensated with another form of malicious intent (dolus) if both intents were not equal in degree, just as in the case of two acts performed with an equal amount of negligence (culpa). ${ }^{408}$ Hommel argued that the prevailing opinion of the jurists was based on D. 9.2.11pr., namely, that the wrongdoer was exculpated if the injured person also acted negligently, ${ }^{409}$ and that no replicatio doli was granted against an exceptio doli if both parties acted in bad faith (see D. 44.4.4.13), and that no exceptio and replicatio are granted in the event in which both parties were at fault (culpa). ${ }^{410}$ Hommel did not agree with this prevailing view, because he believed that the exact measure of various degrees of negligence (culpa) in a case had to be taken into account: a more serious fault should lead to a more serious inconvenience and/or punishment than a minor fault (see X 5.31.18). ${ }^{411}$

This appears from Hommel's application of the theory of compensatio culpae to a second, this time real case that occurred in Martisburg in October 1779: a woman (let us call her A) put poison into her homemade soup she prepared for her husband but then she put it aside, before he had a chance to eat it. But unfortunately a poor hungry woman, Catharina (C), who was accidentally present, ate this soup. ${ }^{412} \mathrm{C}$ was not killed, but the poison weakened her and she claimed the costs of cure plus one hundred thalers from A because of missed income from work. Hommel argued that A had not prevented $\mathrm{C}$ from eating the soup, even though she knew it was poisoned, nor did she act when she

407 K. Hommel, Rhapsodia quaestionum, obs. 792, nr. 2: Stoicus haec paria dixerit, non ego. Quis enim delictum carnis cum veneficio comparare audeat? Itaque vereor, ne frustra ad minuendam poenam compensationis exceptio ei profutura sit. The stoicus mentioned by Hommel seems to be Seneca Maior (namely, Controversiae, VI.6), and not his son Seneca the Philosopher. The case described by Seneca Maior could indeed be regarded 'haec paria': a man told his wife to whom he proposed to marry their daughter. The daughter died before the marriage, due to poison. Apparently, the wife was unfaithful with the bridegroom. The man accused his wife of adultery and murder. Apparently, and this also stems from Seneca Maior, Controversiae, VII.3.6, one says that a woman has been an adulteress to make people believe that she is therefore a poisoner. In that sense also Quintilianus, Institutio Oratoria, V.11.39 is relevant, questioning whether an adulteress who is accused of poisoning is not already condemned by the sentence of Cato the Elder. The latter stated (according to Quintilian) that every adulteress was as good as a poisoner. Here Cato equated a woman making poison with an adulteress; see also Kaufman 1932, p. 157f.; apparently, the adultera-venefica was a stock character of practical cases argued in the school of rhetoric. See Santoro l'Hoir 2006, p. 161.

408 K. Hommel, Rhapsodia quaestionum, obs. 792, nr. 3.

409 J.H. von Berger, Oeconomia juris, III.9.12, nota 1 (see below).

410 K. Hommel, Rhapsodia quaestionum, obs. 792, nr. 4f.

411 See K. Hommel, Rhapsodia quaestionum, obs. 792, nr. 5.

412 From Hommel's Rhapsodia the reason for this removal is not clear. Possibly, she was driven by remorse but also other scenarios are imaginable: it could also be that the soup burned, or that she used too many spices, etc. 
actually saw that $\mathrm{C}$ was eating it. $\mathrm{C}$ ate the soup, despite a mild warning from A who said: 'It is not good for you'. In that respect $\mathrm{C}$ acted negligently herself, but her negligence (according to Hommel) had to be qualified as minor negligence, while the defendant A's failing to interfere and prevent $\mathrm{C}$ from eating, knowing that the soup was poisoned, had to be qualified as an irresponsible and more serious act. Therefore, these acts were not reciprocally compensated and the possibility for $\mathrm{C}$ to claim damages from A was not totally excluded. ${ }^{413}$ So, despite the contributory negligence of the plaintiff, an action could be brought, because the negligence of the defendant was more serious. In such cases, in which divergent degrees of negligence occurred, a total compensation was inadmissible. ${ }^{414}$ At the most the negligence on the side of the plaintiff was taken into account/compared with regard to the costs of the trial. ${ }^{415}$

With regard to the concept of contributory negligence, progress was made by a study of Eisenbach (1778). Eisenbach noticed that the question of contributory negligence had not yet been dealt with in a separate monograph treatise. ${ }^{416} \mathrm{He}$ found his theory of compensation essentially already in existing material, and used it as a basis upon which he intended to clarify this material in a systematic manner, eliminating errors and consolidating its practical application. ${ }^{417}$ Eisenbach drew a distinction between the compensation of claims originating from negligent behaviour, and the compensation of negligences as such. ${ }^{418}$

In Eisenbach's dissertation, D. 4.3.36 is considered to contain a basic rule regarding negligence of the injured party. ${ }^{419}$ According to D. 4.3.36, if two persons acted with a fraudulent intent (dolo malo), they could not bring an actio de dolo against each other. Although D. 4.3.3.6 does not mention any compensation, Eisenbach maintained that a general principle of compensatio doli cum dolo could be deduced from this rule. ${ }^{420}$ Because of his focus on D. 4.3.36, the starting point of his research was the intentional acts of two parties against each other. These acts are different from situations of contributory

413 See K. Hommel, Rhapsodia quaestionum, obs. 792, nr. 5 f.

414 Luig 1969, p. 213.

415 K. Hommel, Rhapsodia quaestionum, obs. 792, nr. 6: ... also beyderseits sehrverschiedene Ungebührnisse sich gegen einander nicht völlig aufheben, sondern was Klägerin hieran an ihrer Seite zu Schulden kommen lassen, allenfalls nur die Vergleichung der auf diesen Proceß verwanten Unkosten bewirket, so ist etc.

416 J.F. Eisenbach, De compensatione circa maleficia, §1: Quotquot enim evolverim librorum indices, a nemini tamen thema nostrum speciale opere tractatum fuisse, inveni ...;- See also Wieling 1970 , p. 224 , who wrongly referred to $§ 3$.

417 Rother 1965 , p. 31

418 ibid., p. $31 f$.

419 In the same sense Aumann 1964, p. 54.

420 J.F. Eisenbach, De compensatione circa maleficia, §2; also Rother 1965, p. 32. 
negligence, because in the case of D. 4.3.36 both parties are wrongdoer and injured at the same time. The sources discussed in the course of his study were, however, put on a par by Eisenbach with cases of contributory negligence (e.g. D. 9.2.11pr.). ${ }^{41}$ However, by doing so Eisenbach came up with new points of view, which could equally be applied to contractual and delictual claims. This can be regarded as the first record of a tendency to generalise the problem of contributory negligence by a jurist of the usus modernus. ${ }^{422}$ Eisenbach questioned the rigid prevailing use of the brocard dolus cum dolo compensatur, culpa cum culpa. ${ }^{423}$ Eisenbach felt that a total disclaim did not have to follow in all cases of contributory negligence (culpa) of the injured party, but rather a weighing of degrees of negligence of both parties. If an injured party acted with more serious negligence than, or equal negligence to, the other party, the victim could not bring an action (as in D. 9.2.11pr. and Inst. 4.3.5, in which case the injured party's negligence was more serious than that of the wrongdoer). ${ }^{424}$

421 Aumann 1964, p. 54.

422 ibid., p. 54f.;- Finally, with regard to the theory of culpae compensatio, C.F. von Glück (1755-1831) - the last exponent of the usus modernus pandectarum - stated that in a situation in which there was insulting behaviour on both sides, a compensation of these injuries could only be granted when the manner and extent of the insults were equal. See Glück 1813, p. 71f.; he referred to D. 9.2.52.1 and A. Schulting, Thesium controversarum, thesis 57.7 and C.A. Tittmann, Handbuch des gemeinen deutschen Peinlichen Rechts, I, § 177; see esp. p. 452; in the preceding pages Von Glück also discussed the sedes materiae with regard to the theory of culpae compensatio, like the cases mentioned in D.16.2.10pr., D. 4.3.36, D. 24.3.39 and X 5.16.7. Von Glück mainly referred to Eisenbach's dissertatio; see also G.C. Bastineller, de pari turpitudine, § 9. On C.F. von Glück, see, e.g., Hirata 2006, p. 330ff. The situation in which there was a compensation of insulting behaviour on both sides is an analogous situation to that in which two delicts are compensated by way of mutual compensation. Based on Von Glück and the references made by Von Glück, the following summary can be given. In principle, injuries can be caused by acts (i.e. physical assaults) or words (i.e. non-physical assaults) - note that already in D. 47.10.1.1 it is stated that an injury (iniuria) can be caused by a thing (re) or by words (verbis). When two injuries (Beleidigungen) are equal as to extent, but not as to manner, both parties had to pay each other compensation. See C.A. Tittmann, Handbuch des gemeinen deutschen Peinlichen Rechts, I, § 177, p. 452 and also G.A. Kleinschrod, Systematische Entwicklung der Grundbegriffe und Grundwahrheiten des peinlichen Rechts, II, §92, p. 248f. (where he talks about 'zum nämlichen Geschlecht gehören'). If one insult excessively exceeded the other, the person who was more injured could definitely claim damages. Such a situation occurred, for example, when a nonphysical assault (insulting words) was opposed to physical acts of violence. See G.C. Bastineller, de pari turpitudine, para. 17; see also J. Wernher, Selectae Observationes forenses Pars I, obs. 83; Pars III, obs. 14 \& 143. With regard to the causation of the damage, pure negligence of the injured party, provided no insults took place, did not exclude the possibility to claim damages. Neither was the injured party who failed to apply the appropriate resources in order to repair the damage excluded from the right to claim compensation, but an exception was made in the case in which the injured party's negligence was more serious than that of the wrongdoer, or when the injured party intentionally failed to use an antidote. See C.A. Tittmann, Handbuch des gemeinen deutschen Peinlichen Rechts, I, § 177, p. 454.

423 See J.F. Eisenbach, De compensatione circa maleficia, §2.

424 ibid., §10. Eisenbach referred to G. Noodt, Ad legem Aquiliam liber singularis, c. VII, U. Huber, Praelectiones iuris civilis ad D. $9.2 \S 11$ and Chr. Wildvogel, de imputatione culpae propriae, cap. $3 \S 48$. The argumentation of Wildvogel does not seem to provide a new point of view in 
So the contributory negligence of the injured party cancelled out an equal or smaller negligence of the wrongdoer; the negligence of the wrongdoer was compensated by that of the injured party. ${ }^{425}$ Therefore, the judge - based on the circumstances of the case - could deny applying a compensation, namely, in the situation in which the negligence of the injured party was considerably less serious (multo levior) compared to the wrongdoer's (apparently the prevailing opinion in Eisenbach's time) ${ }^{426}$ With this consideration, it seems that Eisenbach borrowed an idea already expressed by the natural law jurist Pufendorf. ${ }^{427}$ Furthermore, Eisenbach pointed at the importance of the individual decision of a judge - who should take into account the factual circumstances of the individual case - in his assessment of the degrees of negligence. ${ }^{428}$ However, a partition of damage between parties was not yet considered since Eisenbach still applied the all-or-nothing approach. ${ }^{429}$

Also Gallus Aloys Kleinschrod (1762-1824) ${ }^{430}$ discussed the question of whether an injured party could claim recovery if his damage was due to his own negligence. Apparently, the decisive criterion was whether either the negligence of the injured party gave cause to the delict (the damage-inflicting act; damnum iniuria datum), or whether the negligence of the injured party had any relation or connection with the origin of the damage-inflicting act. Only in the first case was no claim for damages granted, because negligence of the injured party also contributed to the cause of the damage, the injured party in fact being totally or largely causer of the damage. His negligence was the cause of the delict and its consequences, and therefore the rule of D. 50.17.203

the sense that it only seems to reproduce and rearrange the information already provided in the sources (D. 9.2.9.4, D. 9.2.10, Inst. 4.3.4 and D. 9.2.11pr.); the latter he calls a 'jocosum exemplum' (humorous example)). Also U. Huber, Praelectiones iuris civilis ad D. $9.2 \S 11$, does not add novelty as to the legal interpretation of D. 9.2.11pr. Interesting is Huber's statement that although barbers once shaved in public places, in his time they no longer did, but instead they shaved their customers inside houses.

425 Looschelders 1999, p. 20f.; - According to the secondary literature, Eisenbach did not invent the theory of the decisiveness of the maior culpa, but just confirmed the rule that gradually developed as the prevailing opinion in the usus modernus from the beginning of the seventeenth century onwards; see Luig 1969, p. 215; Lorenz 1972, p. 312.

426 J.F. Eisenbach, De compensatione circa maleficia, §10. See also J. Heeser, Loci communes de rationibus reddendis, loc. 10, nr. 179, F.-C. Harpprecht, Consiliorum Tubingensium, VI, cons. 95, nr. 584 \& nr. 585, and see also W.A. Schoepff, Selectae Decisiones et Resolutiones Tubingenses, dec. 192, n. $16 \mathrm{ff}$.

427 Aumann 1964, p. 41, 55; - Additionally, according to Aumann 1964, p. 58, his tendency to generalise and his assessment (Abwägung) of the respective negligence and also the stronger emphasis on the specific case reflects the influence of the natural law thinking of fairness.

428 Aumann 1964, p. 55f.

429 Aumann 1964, p. 56; Rother 1965, p. 32f.; Wieling 1970, p. 225.

430 On Kleinschrod, see, e.g., Merzbacher 1979, p. $8 f$. 
applied. ${ }^{431}$ However, when the injured party acted culpably, but his negligence stood in no connection to the delict (e.g. when he was careless with regard to the protection of his own property and by this gave occasion for theft), he could still bring a claim for compensation. In such case the injured party contributed in no way to the origination of the damage-inflicting act; he was neither originator, nor assistant to the event, and no exception (of negligence) could be adduced against him. Therefore, the wrongdoer had to pay compensation, even in this case, in which the injured party, due to his negligence, gave some remote cause (causa remota) for the wrongdoing, and in some way advanced it. Although the injured party was negligent, the negligence of the wrongdoer had to be regarded - according to Kleinschrod - as being more serious and the wrongdoer was therefore held liable. ${ }^{432}$

View 4: Proximity of damage

A different opinion can be found in the works of David Mevius (1609-1670). ${ }^{433}$ In a case that actually occurred, ${ }^{434}$ a child tried to grab corn from a cart and then fell underneath the cart, after which the child was killed when the driver drove off. According to Mevius, to establish if it was possible to claim damages from the driver, it was decisive whether the accident was due to his negligence. To determine this the question of whether the driver could be accused of any neglect, i.e. in respect of what he ought to have done, had to be answered. Firstly, Mevius argued that the driver had not acted in a neglectful manner: he did something which was permitted, i.e. transporting corn on the street. Furthermore, a witness stated that the driver called out loudly before he drove off. Secondly, he sustained that (even) if it could not be proven that the driver had called out loudly, the accident still could not be imputed to him, as he could have been seen and been warned by everyone. So Mevius concluded that the driver did not act with negligence, ${ }^{435}$ and that the injured party, considering the circumstances of the case, was contributorily negligent (the child did not leave his position after the warning), and therefore ( $c f$. D. 50.17.203) was not considered to have suffered claimable damage. When both parties acted with some negligence, the person whose negligence was the latest in time and less remote to the accident would be liable. The person whose negligence was considered the ultima et casui proximior, had to bear the damage alone. ${ }^{436}$

431 G.A. Kleinschrod, Doctrina de reparatione damni delicto dati, Spec. I, §5; Abhandlungen aus dem peinlichen Rechte und dem peinlichen Processe, 3. Th. 2. Abt., §5.

432 ibid.

433 On Mevius, see, e.g., Wieacker \& Weir 1995, p. 170.

434 The title of the work 'Decisiones super causis praecipuis ad tribunal regium Wismarensium delatis' suggests that it concerns decisions to important cases brough to the regal chair of Wismar.

435 D. Mevius, Decisiones, I, decisio 221.

436 D. Mevius, Decisiones, I, decisio 221, nt. 7: Culpa sua quod quis sentit, damnum sentire 


\subsubsection{Solving cases of contributory negligence without replying upon the contributory negligence of the injured party}

Interestingly, the case described by Mevius is also described by his contemporary Johann Brunnemann (1608-1672). ${ }^{437}$ Brunnemann was of a different opinion than Mevius and argued that the driver, had an obligation to stop his cart after he noticed the danger. If the driver asserted that he could not possibly have stopped his cart, he had to confirm this by oath. If he, while noticing the danger, could have stopped but did not, and so did not spare a person's life, his act had to be considered a negligent one especially since a small boy was concerned. Brunnemann's argument shows that this case, which can be seen as a case of contributory negligence, is actually solved without any reference to contributory negligence. ${ }^{438}$ It is remarkable that the question of negligence

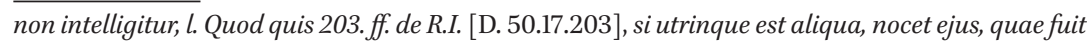
ultima et casui proximior, l. Si et per emptorem 51.ff. de action. emt. [D. 19.1.51]; see also Kaufmann 1958, p. 78; Luig 1969, p. 213f. Luig adds that Mevius' explanation reminds us of the canon law distinction between causa proxima and causa remota. Mevius, however, seems to argue based on culpa instead of causa (see decisio 221, nr. 7). More clearly, Rittershusius adopted the causa proxima theory of canon law. As already mentioned in a previous footnote, as a legal basis Rittershusius referred to the older theory as described by Zasius (any contributory negligence of the injured party excluded his right to any compensation). Apparently, the defendant was not liable, because his act, compared to the act of the injured party, was not the causa proxima. See

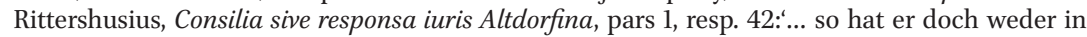
erster, noch ander Instantz Acten nirgends, wie recht, außgeführet, daß beklagter solcher tortur, etc. ursach, zugeschweigen, daß er caussa proxima sey. Nun ist aber im Rechten klärlich versehen, Neminem damnum praestare, nisi qui caussam, et quidem proximam, damno dedit. ...'; - While Mevius emphasised the decisive role of the most recent negligence, others put more weight on the degree of negligence on both sides. They considered this more important, because in case of preponderant negligence of the injured, the wrongdoer escaped from liability; $c f$. Chr. Besold, Consilia Tubingensia, VI, cons. 290, nr. 43f.; see also I.H. Böhmer, Doctrina de actionibus, sect. II, cap. XI, §XXV. Therefore, the wrongdoer was liable when his negligence was preponderant, even though the injured also acted negligently. This was the case when someone was attacked and the victim in the defensive act exceeded the limits of self-defence (noodweerexces); in that case he was liable. See Kaufmann 1958, p. 78f.; - According to Kaufmann 1958, p. 79, the overall approach of contributory negligence gave a rather heterogeneous picture. Not lastly this should be attributed to the ambiguous lack of separation between cause and negligence.

437 See J. Brunnemann, Commentarius, ad D. 9.2.31, esp. nr. 2f. On Brunnemann, see, e.g., Wieacker \& Weir 1995, p. 170.

438 Luig 1969, p. 214, writes that 'Da das gemeine Recht für die Fälle von Mitverschulden nur ein Entweder-Oder vorsah, wurden solche Fälle oft auch ohne jede Erwähnung des Problems des mitwirkende Verschulden gelöst, indem man nämlich die überwiegend schuldige Partei für alleinschuldig erklärte. Ein gutes Beispiel dafür bietet Brunnemanns Kritik an der von Mevius überlieferten Entscheidung ....' However, that the driver is considered to be the party that acted with preponderant negligence in my opinion could not be based on this fragment (Brunnemann's commentary on D. 9.2.31); the total focus seems to be on the negligence of the wrongdoer.; - In English law, there was the (civil) liability in trespass, which was strict rather than fault-based. Throughout the medieval and early modern periods there was a strong focus on the loss suffered by the injured party rather than on the wrongful conduct of the wrongdoer; see Ibbetson 1999, p. 58. The absence of negligence of the wrongdoer was in a concealed way discussed as an issue of causation: the arguement was that the injury was caused by the injured party rather than by 
is linked to the age of the injured party. This connection has no foundation in the received Roman law on damnum iniuria datum.

\subsubsection{The criterion of the auctor rixae as an alternative way to solve the problem of contributory negligence}

The problem of contributory negligence also manifested itself in the event of quarrels, when one of the parties was wounded (or even killed) and he (or his relatives) sued the other party for damages. Early modern jurists agreed on the fact that the person who started a fight or provoked a fight (the so-called auctor rixae), and was wounded - in principle - could not claim any damages. ${ }^{439}$ However, the qualification of 'instigator of the fight' is not undisputable. This apparently simple criterion in reality is more complex in the sense that the perpetrator of the fight was not the person who acted out of anger (the person who first hit the other; D. 9.2.52.1), but the person who by means of words provoked the anger of the other party, ${ }^{440}$ who should understand that his verbal provocations could ignite a fight. Whenever a fight occurred (more or less immediately, not after a period of time), the person who provoked with words was regarded as the auctor rixae. ${ }^{441}$ That person was the cause of the unlawfulness, and negligence (culpa) was attributed to that person. ${ }^{442}$

the defendant/wrongdoer. Ibbetson 1999, p. 59, rightly stated that there is a world of difference between the man running under the cart and the cart running over the man. While both formulations may refer to the same facts of the case, the difference between them is nonetheless significant. The first formulation ascribed the responsibility to the man; the second formulation to the cart and presumably to its driver. In this way, a problem of contributory negligence can be reformulated into a problem regarding the causal connection. The argumentation is in that case as follows: the injured party himself jumped before the cart, and therefore there is no causal connection between the act of the wrongdoer and the damage that occurred; the injured party himself caused his damage.

439 See J.H. von Berger, Oeconomia juris, III.9.12, nota 1; i.e. according to Berger, medical costs and other damages. According to S. Cocceji, Jus civile controversum, ad D. 9.2 and J. Wernher, Selectae observationes forenses, III, obs. 143, 'expensas et interesse'.

440 See also N.C. von Lyncker, decisio 1056.

441 C.F. Hommel, Rhapsodia quaestionum, II, obs. 383, esp. nr. 2f. The situation is different if the fight occurred after a lapse of time. Neither party could be regarded as auctor rixae, unless one of them had the maior culpa.

442 See B. Carpzovius, Jurisprudentia Forensis, IV, const. 9, def. 4, nr. 5; J. Brunnemann, Commentarius ad D. 9.2.52, nr. 5ff.; see also B. Carpzovius, Jurisprudentia Forensis, IV, const. 10, def. 4, esp. nr. 3, from which it appears that the provoking party gave the causa for the damage inflicted to himself, and thus he had to blame himself (he referred to D. 50.17.151 and D. 9.2.11pr.); - An exception is made by Modestinus Pistoris, who described a case concerning a lawful assault (e.g. by a magistrate). Any resistance to such a lawful act was considered to bring about culpa, and therefore if damage resulted - the homicide of the defender - that 'damage' was considered to be the defender's own fault. See Modestinus Pistoris, Consilia sive responsa, II, cons. IIII, nr. 28, with reference to D. 9.2.11pr. and VI 5.12.86. 
To make this theoretical exposé clearer, I will shortly descibe a case found in a responsum of Johann Nikolaus Hertius (1651-1710). ${ }^{43}$ As a result of a fight, one of the fighters, a fisherman, died. The fisherman's widow ${ }^{444}$ wanted to use the confiscated goods of the person who killed her husband as monetary support for the necessary maintenance for herself and her children. The question arose whether this was at all possible. In answering this question, Hertius applied the culpae compensatio doctrine: the actio legis Aquiliae was not applicable, because negligence of the injured party occurred (with that of the wrongdoer). Therefore, in this case, the claim of the widow was denied. The reason for this denial was a particular form of this doctrine, namely, the criterion of auctor rixae: no claim was granted because the fisherman appeared to have been the initiator (auctor rixae) of the fight. Whoever was the auctor rixae was at fault (culpa). ${ }^{445}$ The fisherman's wife's claim was rejected because the fisherman had acted with negligence, being the initiator of the fight. Luig argued that the criterion of culpa maior was often moulded in the question of the auctor rixae. ${ }^{446}$ However, no such conclusion can be drawn from this responsum. In the approach in this responsum no explicit mention was made of the mutual degrees of negligence of both parties. The question of auctor rixae is relevant in order to determine whether an injured person acted negligently. In this case the victim did, and therefore the negligences were mutually compensated (apparently no subtleties in degrees of negligence were considered by Hertius in this case). ${ }^{447}$

In early modern literature, many cases in which an initial provocation led to an excessive reaction can be found. The general rule that the originator of a fight could not claim compensation from the other party (no compensation for medical expenses or immaterial damage $)^{448}$ did not apply - according to Johann Berger $(1657-1732)^{449}$ - if the other party acted excessively in defence. ${ }^{450}$ If the

443 On Hertius, see, e.g., Sellert 1969, p. 700f.; according to Sellert, Hertius belonged to the Epoche of natural law, which was especially also characterised by the revival of German law.

444 Apparently, the widow has a claim in her capacity as heir (an inherited action); contributory negligence cannot be imputed otherwise than to the heirs.

445 J. Hertius, Responsa et consilia, resp. 399, nr. 4f.: ... des entleibten Wittib aber und Kinder können nichts praetendieren, weilen ex actis erhellet, daß der entleibte Fischer autor rixae gewesen, actio autem ex lege Aquilia locum non habet, si patientis concurrit...

446 Luig 1969, p. 209f.

447 Also Kaufmann 1958, p. 78.

448 No right to recovery due to the fact that he himself was negligent (contributory negligence), which negligence excluded the right to recovery based on D. 9.2.11pr.jo. D. 50.17.203; see, e.g., J. Wernher, Selectae observationes forenses, I, obs. 83.

449 On J.H. Berger, see, e.g., Muther 1875a, p. 364f.

450 J. Berger, Electa Iurisprudentiae Criminalis. Supplementa Pars 1, obs. 25, with reference - among others - to X 2.13.12 and Exodus 21:19. 
initial aggressor tried to sue the other, his claim was not denied if the other party exceeded the limits of normal self-defence (see X 2.13.12). ${ }^{451}$ The latter exception can also be found in an answer (to a consultation) given by jurists of the (Law) Faculty of Wittenberg, as reproduced by Johannes Wernher (1677-1743), ${ }^{452}$ where one can find that this excess had to be ruled on by the judge in a given case, based on the specific circumstances. Apparently, a large and extraordinary excess (magnus et insignis excessus) was required. ${ }^{453}$ In such case (i.e. not in the event of a slight overreaction ${ }^{454}$ ), the instigator of the fight could claim damages and expenses (damna et expensa). ${ }^{455}$ It seems that this was the usual way of dealing with this matter at the Faculty of Wittenberg (Ordo Vitembergensis), and thus represents the leading view in the opinions at the beginning of the eighteenth century in Wittenberg. ${ }^{456}$ According to one observation, this view even included compensation for inflicted grief and pain (immaterial damages). ${ }^{457}$ This was not the prevailing view, as appears from others, who argued that in the latter case no damages for pain and suffering had to be paid. ${ }^{458}$

451 J. Berger, Oeconomia juris, III.9.12. One reference of Berger is particularly interesting, namelt toa part of Berger's Resolutiones legum obstantium quae in compendio iuris Lauterbachiano, p. 151f. in edition of 1716, where he discussed the question 'An provocanti vulnerato actio $L$. Aquiliae detur ad expensas et interesse?' Firstly, he referred to D. 47.2.12.1, according to which the answer should be 'no', because no one can obtain an action due to his own improbitas. Thereafter three obstantia follow, with a response (D. 9.2.5pr., D. 9.2.45.4 and D. 9.2.7.4). The fourth and fifth obstantia are particularly of interest: D. 9.2.52.1, where it is stated that the damage would be done due to the negligence of the shopkeeper (tabernarii culpa factum videri). That would be the case if the shopkeeper started the fight himself because he wanted to take back the lantern, and in that case he would have been the instigator of the fight (alternative scenario); and X 2.13 .12 (satisfactionem debitam exhibere), that is, if someone reacted very excessively (Berger: casum magni excessus; X 2.13.12: modum excessistis); see also S. Cocceji, Jus civile controversum, ad D. 9.2; A. Leyser, Meditationes ad Pandectas, Med. 112 ad D. 9.2, §2.

452 J. Wernher, Selectae observationes forenses, III, obs. 143, with reference to a decision of the Faculty of Wittenberg of 1714.

453 J. Wernher, Selectae observationes forenses, I, obs. 83, with reference to a decision of the Faculty of Wittenberg of 1707. On J.B. Wernher see, e.g., Kathe 2002, p. 324f.; - The originator (auctor rixae) of a fight could only claim compensation for medical expenses when the other party had (re)acted in a very excessive way (compared to the act of the originator); see C.F. Hommel, Rhapsodia quaestionum, vol. II, obs. 383, nr. 1; Glück 1808, p. 389; - See also D. Strube, Rechtliche Bedenken, IV, 43, p. 101, and J. Quistorp, Grundsätze des Peinlichen Rechts, I, §336, p. 503.

454 It is not exactly clear how these two situations (a large and extraordinary excess vs. slight overreaction) should be distinguished.

455 See also Supplementum novum ad J. Wernher, Selectae observationes forenses, I, obs. 83; and also W.A. Schoepff, Selectae Decisiones et Resolutiones Tubingenses, dec. 192, nr. 18, who referred to this decision of the jurists of the Faculty of Wittenberg as reproduced by Wernher.

456 J. Wernher, Selectae observationes forenses, III, obs. 14.

457 ibid.

458 See, e.g., G. Meister, Principia iuris criminalis, §173, p. 182. See also C.F. Hommel, Rhapsodia quaestionum, vol. II, obs. 383, nr. 1 and also C.A. Tittmann, Handbuch des gemeinen deutschen Peinlichen Rechts, 1. Th., § 177, p. 453. 
Augustinus Leyser (1683-1752 $)^{459}$ mentioned a case in which the jurists of the Faculty of Helmstadt in September 1719 possibly applied the maior culpa theory. The provoking party, Jacob, brought a case against Duderstedt and Elzen, who apparently had taken revenge on him. The defendants tried to excuse their excessive actions by stating that Jacob provoked their actions by throwing water out the window onto passers-by and by calling them 'Taschenspieler' (conjurer). However, the jurists argued that even in such a situation, in which the defendants exceeded the measure of defence, the provoked persons Duderstedt and Elzen could be held liable. ${ }^{460}$ This example can indeed be considered as a clear application of the rule that a small amount of negligence of the injured party (i.e. Jacob, namely, by throwing water out the window onto passers-by and calling them 'Taschenspieler') did not free the wrongdoers of liability; however, the reason behind this was not revealed. It could be an example of a doctrine of major culpa. ${ }^{461}$

The action of Jacob was a delict against the other(s), which as a provocation was (indirectly) causal to his damage. Nevertheless, if the other party (re) acted very excessively (compared to the act of the originator), the originator (auctor rixae) of the fight could claim recovery for medical expenses and loss of future earnings, but recovery for immaterial damages was denied because of the conduct of the injured party. ${ }^{462}$

This was the case in an example described by the jurists of the Faculty of Helmstadt in September 1715. Keltze and Mertensen played a game with dice all night long in the pub. This led to a quarrel and a fight. Ultimately, Mertensen's head seemed to be injured very seriously by Keltze. Based on the circumstances of the case, it appeared that both parties acted negligently. Especially relevant was the fact that Mertensen, by taking away money belonging to Keltze, gave occasion and cause to the quarrel and the fight, as well as the fact that Keltze started the fight and ultimately caused the serious injury to Mertensen's head. Mertensen, being the originator of the fight, could only claim satisfaction because Keltze had acted excessively, but only for medical expenses, not for lost income, costs of the failure to comply with procedural requirements or damages for pain and suffering (immaterial damages). ${ }^{463}$

459 On Leyser, see, e.g., Wieacker 1967, p. 22lf.; Luig 1980, p. 41ff.; 1985, p. 437ff.; Wieacker \& Weir 1995, p. 172 f.

460 A. Leyser, Meditationes ad Pandectas, Med. 112 ad D. 9.2, §2.

461 Differently Luig 1969, p. 215.

462 See A. Leyser, Meditationes ad Pandectas, Med. 112 ad D. 9.2, §3; Aumann 1964, p. 53; Van Wassenaer van Catwijck 1971, p. 241.

463 See A. Leyser, Meditationes ad Pandectas, Med. 112 ad D. 9.2, §3. 
So the criterion of the auctor rixae could be used as an alternative way to solve the problem of contributory negligence. Wernher gave two alternative reasons for the general denial of a claim for damages in the event that an injured party originated the fight: firstly, because the damage was inflicted on him during the fight and he was the instigator ${ }^{464}$ or, secondly, because his negligent act (negligence of the 'injured party') coincided with the negligent act of the other party (the 'wrongdoer' in this respect). ${ }^{465}$ A similar consideration can be found with Eisenbach, who stated that the injured party could not bring an action if he acted negligently (culpa) to an equal or more serious extent, ${ }^{466}$ or if he was the instigator of the fight. ${ }^{467}$

According to Samuel Cocceji (1679-1755), ${ }^{468}$ the reason for a denial of a claim for damages (expensas et interesse) in the event of a provocation was that someone who suffered damage due to his own negligence was not considered to have suffered claimable damages (based on D. 50.17.203). Furthermore, whomever acted wickedly was not granted an action. Cocceji introduced another new criterion, namely, that a person who attacked his attacker and killed him was liable for his death, depending on the outcome of the question of whether he could have avoided the death of his attacker by running away. ${ }^{469}$

\section{Consequences of contributory negligence: reducing the damages?}

As shown above, the idea of a reduction of the total amount of damages was not completely foreign to some jurists of the usus modernus. ${ }^{470}$ In the fragment

464 See J. Wernher, Selectae observationes forenses, I, obs. 83 and III, obs. 14.

465 See J. Wernher, Selectae observationes forenses, III, obs. 143 \& Supplementum novum ad Wernher, Selectae observationes forenses, I, obs. 83.

466 Eisenbach also wrote an interesting part on the lex Aquilia. A wrongdoer who had to pay a poena based on the lex Aquilia became, because of that obligation debtor to the other party. It is possible that the other party was also indebted to this party, due to contract (conventio) or delict (maleficium). In such case a compensation of debita/delicta was possible, and neither party could claim damages from the other.

467 Due to his own delict he behaved in an unworthy manner, and the damage was imputed rather to him than to the wrongdoer, in such a way that neither the widow nor the heirs of the dead (killed) instigator of a fight could bring an action. If, on the contrary, the person who knocked out an eye was the originator of the fight, or if the provoked party exceeded the measure of self-defence, this party could - in principle - be condemned by a decision of the judge based on the lex Aquilia. No such condemnation to grant private satisfaction took place if the provoked party exceeded his defence even rather slightly; see J.F. Eisenbach, De compensatione circa maleficia, §19. See also the already mentioned Schoepff, in his Selectae Decisiones et Resolutiones Tubingenses, dec. 192, nr. 14: quo casu, si culpa agentis interveniat et concurrat culpa patientis, tunc cessat, v.g. in provocatione, actio L. Aquiliae cum ex proprio delicto, licet alter in re illicita constitutus, actio haud competat, et damnum quod quis sua culpa sentit, non sentire videatur ....

468 On Cocceji, see, e.g., Döhring 1957a, p. $301 f$.

469 S. Cocceji, Jus civile controversum, ad D. 9.2.

470 See the aforementioned commentaries of Peter Faber and Johannes de Sande ad D. 50.17.203; see also Liutpriand c. 136, as discussed by Conrad 1962, p. 164f.; - This example seems very similar to the example mentioned in D. 11.5.1pr.-2. According to D. 11.5.1pr., no action 
of Leyser's Meditationes discussed above, including a responsum of the Faculty of Heldstedt from 1715, ${ }^{471}$ damages for medical expenses and a monetary fine had to be paid, but not for immaterial damages and loss of earnings, which were denied because of the negligent conduct of the injured party. ${ }^{472}$ The approach of the jurists of the Faculty of Helmstadt was considered 'new' in the sense that for the first time a reduced amount of damages was discussed. ${ }^{473}$ Apparently, the question whether immaterial damages could be recovered became an issue in this period, while this topic was not prominently present in legal discussion in earlier times. After the Reception, immaterial damages were considered a separate category of loss.

In this respect, for a proper assessment of the issue of immaterial damages, one has to distinguish two different matters. Firstly, which kind of losses could be compensated (material or immaterial losses) and, secondly, whether the judge was competent to mitigate/reduce the amount of compensation. It is the first matter which is relevant in the responsum of the jurists of the Faculty of Helmstedt, as only certain kinds of losses (immaterial damages and loss of earnings) were excluded from compensation, therefore a division of damage as proposed later by Wolff was not yet applied. The second matter is not in question: the total damages are not reduced, but some kinds of damages are excluded. ${ }^{474}$ This is not different in the following cases and doctrinal works.

In the view of two scholars, Hommel and Schoepff, a small amount of negligence of the injured party did not exclude this party's compensation claim, but was taken into account in order to determine the exact amount of damage. Hommel, in an opinion discussed above, proposed to divide the costs of the litigation because of the contributory negligence of the injured party, ${ }^{475}$ probably meaning that each should bear its own costs of the litigation. The second jurist is Schoepff who, in a decision - which will be dealt with now - discussed

was granted if someone beat a person (or in any way damages him) in whose house a game with dice is said to have taken place. Where someone employs violence because of a game with dice, he will be punished as the circumstances may demand. According to D. 11.5.1.2, when the proprietor of such a house was beaten or suffered a loss, he could not bring an action, no matter when or where this occurred. Theft can be committed with impunity in the house at the time of gambling, even though the party who committed one of these offences may not have taken part in the game.

471 A. Leyser, Meditationes ad Pandectas, Med. 112 ad D. 9.2, §3.

472 See A. Leyser, Meditationes ad Pandectas, Med. 112 ad D. 9.2, §3; accordingly Aumann 1964, p. 53.

473 Aumann 1964, p. 53.

474 Possibly, the exclusion of damages for inflicted grief was dictated by the practical circumstances of this specific case; see Aumann 1964, p. 53. Luig 1969, p. 216, added that if this was the case, it could - according to his opinion - be explained by Leyser's 'eigenwilligen Billigkeitsjurisprudenz'; see Wieacker 1967, p. 221.

475 See C.F. Hommel, Rhapsodia, obs. 792. 
the amount for maintenance expenses. ${ }^{476}$

In a decisio of the Faculty of Tübingen, passed down to us by Wolffgang Adam Schoepff (1679-1770), ${ }^{477}$ the case concerned a man who provoked another man by throwing flour on him. This man reacted by giving a crude verbal reply. The conflict worsened as follows: the provoker then hit the other man with a stick, and this man then defended himself with a butcher's knife and killed his adversary. The widow wished to recover medical expenses, costs for surgery, funeral costs and mourning clothes and also claimed private satisfaction (satisfactio privata; by means of an actio utilis) and an assessment of her interest (apparently the future loss of revenue) for her and her fiveyear-old child. In Schoepff's discussion on the determination of the amount for maintenance expenses, the contributory negligence of the injured party was taken into account. ${ }^{478}$

One can argue that the husband was the auctor rixae realis, and, if so, the throwing of flour was the cause of the quarrel. ${ }^{479}$ However, this was not the case, as the second person (provoked due to the flour which was thrown on him) should not have reacted verbally in such an excessive manner as he did, which made him the auctor rixae verbalis. Although the one whose ear was boxed with the stick and subsequently wounded his attacker, was - in principle - not given an action based on the lex Aquilia (based on D. 47.10.1.5 and D. 50.17.203), ${ }^{480}$ at the same time the circumstances of the case, including the question of who could be regarded the originator of the fight and whose negligence was the more serious, had to be taken into account.

This appears from the following case. A person of servile status accused a nobleman of a lie, and the nobleman subsequently gave him a box on the ear (which was apparently justified: ex justa causa alapae infligantur), and then the person of servile status wounded the nobleman. ${ }^{481}$ In this case an action based on the lex Aquilia could be brought against the person of servile status, since culpa maior (the person of servile rank who wounded a nobleman) could never be compensated with culpa minor (the box on the ear by the nobleman),

476 See W.A. Schoepff, Selectae Decisiones et Resolutiones Tubingenses, I, dec. 192, nr. 5.

477 On Schoepff, see, e.g., Eisenhart 1891, p. 358.

478 W.A. Schoepff, Selectae Decisiones et Resolutiones Tubingenses, I, dec. 192, nr 5: '... weilen jedoch die Beklagte auch nicht von denen Reichsten, und die andere Kosten auch was erlauffen, zudem der Erstochene auch gefehlet, so ist diese Summ denen Umständen nach vor billich geachtet worden ....'

479 In that case, contributory negligence would concur with the fault of the wrongdoer and no action based on the lex Aquilia would be granted.

480 See also, e.g., P. Farinacius, Praxis Criminalis, De homicidio, q. 119, nr. 122 (necessary defence); M. Lederer, De iure belli privati, lib. 1, c. $6 \S 5$ (the provoked person who wounded the provoker does not have to pay a poena).

481 See also S. Stryk, Disputatione juridica de alapa, cap. 4, nr. 23. 
but only mutual negligence could be compensated when equal in degree. ${ }^{482}$

From this decision one can deduce that the difference in status/rank between the two persons was one of the factors which was decisive for the seriousness of an act or of a provocation. This element has no basis in Roman law rules on damnum iniuria datum nor in canon law. This must have been a typical indigenous feature, as it had no place in the ius commune tradition. A strict line was followed: the first provocation had to be qualified as serious, when apparently (when applicable also) based on the difference in status. The first serious provocation makes someone auctor rixae. But, as appears from the last case, it was not the box on the ear by the nobleman but the accusation of the person of servile rank which was regarded as the first serious provocation (this could also have been decided the other way around, but apparently, the status was decisive for the outcome), and made the other the auctor rixae.

\subsection{3 'Giurisprudenza pratica' in Italy}

With regard to contributory negligence of the injured party, did the Italian jurists continue to apply the medieval doctrine of culpae compensatio? If so, did they apply the theory of culpae compensatio in cases in which the contributory negligence of the injured party was less serious than the negligence of the wrongdoer? In this section a short overview of the views of some Italian scholars in early modern times will be given. Thereby, I shall distinguish three ways in which one dealt with contributory negligence.

1. As already discussed in the previous chapter, the Italian jurist Aymon Cravetta (1504-1569) mentions in a consilium a case in which someone started a quarrel and was killed during the fight. Negligence (culpa) was attributed to the person who started or provoked a fight. In this case, the wrongdoer who killed the initiator of the fight was, however, not liable, due to the culpa admixta on the side of the injured party (who started the fight). ${ }^{483}$ It has been

482 W.A. Schoepff, Selectae Decisiones et Resolutiones Tubingenses, I, dec. 192, nr. 13ff.: ..., who - among others - referred to S. Stryk, Disputatione juridica de alapa, cap. 4, nr. 22 and 23, J. Heeser, Loci communes de rationibus reddendis, loc. 10, nr. 179, F. Pacianus, De probationibus, I, cap. 59, nr.15 and Sebastiano Medici, Tractatus de compensationibus, q. $34-36$ ['quaest. 34. num. 36', does not exist, EvD]. According to S. Stryk, Disputatione juridica de alapa, cap. 4, nr. 23, the action is permitted because of D. 9.2.45.4 based on the criterion of revenge (apparently, the action of the person of servile status is considered as revenge here by Stryk); - See also Luig 1969, p. 210f., according to whom in this decisio the question of the application of D. 50.17.203 and culpae compensatio is solved by referring to the decisiveness of the maior culpa.

483 A. Cravetta, Consilia sive responsa, cons. 119, nr. 11 (edn. 1611, p. 215): Praesupposito igitur quod defunctus fuerit in culpa incipiendo rixam, dico, quod uulnerans non tenetur pro aliquo 
argued in the secondary literature that with the words culpa admixta Cravetta meant the preponderant negligence of the injured party; ${ }^{484}$ however, this is not plausible, since Cravetta makes no explicit mention of such a culpa maior theory. Besides, I believe that this interpretation reads more into the source than Cravetta intended.

The Rota Florentina also mentioned this concept of culpa admixta. This appears from a decision recorded by Marzio Venturini in his decisiones Rotae Florentinae. ${ }^{485}$ In the case in which a decision was given on 31 March 1640, a certain Caesar Franciscus de Marsilia gave an order (mandatum) to Boier and Gantelmo to buy certain coins (piastre del leone) and to transport them by ship to Smirna. (Consul) Caesar received the coins and thought that they were good, as they normally were; however, afterwards he discovered that they were false. In the meantime, he spent some coins in trade with the Turks. However, the Turks made a fuss about it and even complained to the Ministers of Smirna. As a result of this Caesar was placed in danger and suffered damage. Caesar ordered the captain to give the false coins back to Boier and Gantelmo; furthermore, Caesar wanted his money back (the money with which he had bought the coins) with damages and interest.

Although Caesar denied knowing that the coins were false, the Rota Florentina supposed that this was so and even that this was part of the mandate. According to the Rota Florentina, if any loss to Caesar resulted from this mandate, the same Caesar would be held responsible, and he was not allowed to claim any damages from his mandatarii. ${ }^{486}$ In the elaborate decision of the Rota, several arguments are used to come to the conclusion that Caesar had no claim against his mandatarii, among which the argument that nobody who gave cause to a delict could impute negligence or malicious intent to another person, and the persons who apparently directly caused damage (Boier and Gantelmo) were not held liable when sued by Caesar because there was culpa admixta on the part of the injured party (Caesar) ${ }^{487}$ In conclusion, it can be stated that the role of the injured party

damno, quia damnificans non tenetur, quando damnum habet admixtam culpam damnificati ...; see also Farinacius, de homicidio, q. CXIX, nr. 125: Quamvis contrarium voluisse videatur Aym [on] in cons [ilio] $119 \mathrm{nu}$ [mero] 11, ubi facit conclusionum, quod quando occisus fuit in culpa incipiendo rixam, et verbis provocando occidentem, tunc vulnerans seu occidens non tenetur pro aliquo damno, quia damnificans non tenetur, quando damnum habet admixtam culpam damnificati, ex Soccin [o] quem allegat in cons [ilio] 156 col. fin. lib. 2 ....

484 Luig 1969, p. 209.

485 Venturini became a judge at the Rota Florentina in 1635; on Venturini, see Gerini 1829, p. $257 \mathrm{ff}$.

486 M. Venturini, Decisiones Rotae Florentinae, dec. 45, nr. 16.

487 M. Venturini, Decisiones Rotae Florentinae, dec. 45, nr. 19f.: ... et non tenetur de damno quando damnum habet admixtam culpam damnificari .... ... et nemo potest cuiquam dolum, vel culpa imputare, cui ipse causam dedit ... et damnificans non tenetur de damno quando damnum 
is qualified in terms of culpa admixta. This cancels out the injured party's right to claim for compensation, without looking any further to the seriousness of the respective faults.

2. Regarding the problem of contributory negligence of the injured party in the giurisprudenza pratica, ${ }^{488}$ a decision of the Rota Romana of 1763, collected by Bartholomaeus Olivatius (1704-1791), ${ }^{489}$ is relevant. ${ }^{490}$ Someone took possession of a bolt and a key from the inner door of a millhouse. The millhouse was the entrance to his island (called Isca). Due to this the owner was obstructed from entering. Because of the force of a flood from a nearby river, the door-bars were destroyed, the dikes were moved, trees destroyed, etc. ${ }^{491}$ In this case, a possessory remedy of manutentio was given, and the obstructing party (defendant) was (also) condemned to pay for the damage due to the obstruction of possession (i.e. the damage to the estate). In this lawsuit the defendant had two counter-pleadings: the plaintiff could have built a bridge or he could have reached the place by walking under the arch of the leper's bridge. The Rota Romana rejected these defences, with the motivation that the negligence of someone obstructing the possessor (from using his possession) was considered to be more serious (maior) compared with the negligence of the possessor who had not tried other ways to reach his possession, and that the possessor was not obliged to build a temporary bridge or to make a difficult and dangerous, at least inconvenient, journey to reach his possession. ${ }^{492}$ In conclusion, it can be said that

$\overline{\text { habet admixtam }}$ culpam damnificari, prout ex Soccin[o] consil[io] $161 \mathrm{col}$. fin. lib. 2, tradit idem Cravett $[a]$ consil[ $[$ io] 119. numer[o] 11 ...; - Furthermore, the doctrine of culpae compensatio is discussed and applied to the case. A full account of this application, however, goes beyond the scope of the present study. Interesting and new is the remark that delicts could be compensated by mutual compensation, but only when delicts were equal; not when one delict was more serious than the other. Therefore, dolus was not compensated with culpa lata, and culpa lata not with culpa levissima; see Venturini, Decisiones Rotae Florentinae, dec. 45, nr. 79.

488 According to Luig 1969, p. 217f., the problem of contributory negligence in Italy was commonly solved by a denial of claim, based on D. 50.17.203 and VI 5.12.86. Unfortunately, it is not clear to me which sources he referred to, whether these are the sources described in this subsection or if other sources exist that are not contained in Luig's article.

489 Bartholomeo Olivazzi (Olivatius) was first a Prelate Auditor of the Sacra Rota Romana, then Dean of the Sacra Rota Romana, and later a Bishop of Pavia from 1769 until 1791.

490 In a decision of 1737, collected by Carlo della Torre di Rezzonico (the later Pope Clemens XIII), the Rota Romana applied the rule of D. 50.17.203. However - although argued by Luig 1969, p. 218 - no explicit application of the maior culpa theory can be found in this decision. It concerns a difficult case regarding a testament (a dowry). The decision of the Rota Romana showed that the injured party (a certain Marchio de Maximis) suffered damage (the rights to the dowry were assigned to him and due to that fact this cessio was extincted) was either more due to an act of himself (based on D. 50.17.203), or the latter had to admit that he did in fact not suffer any damage at all. However it may be, there was no comparison of the negligent act of both parties nor a trace of the maior culpa theory. See C. Rezzonico, Decisiones Sacrae Rotae Romanae, III, dec. 325, n. 11.

491 C. Olivatius, Decisiones Sacrae Rotae Romanae, dec. 352.

492 C. Olivatius, Decisiones Sacrae Rotae Romanae, dec. 352, nr. 16: ... Praeter quod enim 
contributory negligence of the injured party was dealt with by applying the rule of D. 50.17.203, sometimes with and sometimes without the renewed application of the maior culpa theory. ${ }^{493}$

3. A totally different approach follows from a decision of the Rota Fiorentina in 1780 on the liability for damages caused by a ball game. ${ }^{494}$ The Rota Fiorentina was one of the highest courts in the Grand Duchy under the rule of the Medicis (until 1737) and the Lorenas. ${ }^{495}$ The facts of the case are as follows: in the Tuscan town of Marradi it was customary for a team of amateurs to play once a year, in summertime, a ball game (namely, gioco del pallone) in the public square. The custom was that this team notified the owners of the houses surrounding the square where the game took place in advance, before the day the game would commence, so that the house-owners could take measures to prevent damage to their houses. Despite this warning, damage was caused to the house of the Fabronis during the game of the summer of $1778 .^{496}$

The judicial decision was given in appeal on a commission of the Magistrato Supremo to a judge of the Rota Fiorentina, in this case Judge Giuseppe Vernaccini. Vernaccini referred to the common opinion of the Doctores interpreting the lex Aquilia, in order to constitute an iniuria or wrong and thereby give rise to liability for damages, the act causing the damage had to be committed with dolus or at least with culpa. When the act causing the damage was 'licit and permitted by law', there was no culpa. According to the decision, no culpa was

maior est culpa impedientis diuturnum possessorem, ne sua possessione utatur, quam possessoris non experientis alias vias, aliasque transeundi rationes ...

493 Another example of the application of the maior culpa theory can be found in a fragment of an auditor of the Rota Romana, the later Cardinal de Luca (1614-1683); see G.B. de Luca, Theatrum veritatis et justitiae, lib. VIII, disc. 58, n. 22. Cardinal de Luca described a lawsuit of the Roman Mons Pietatis against the Collegium orphanorum. The administrators of the Collegium orphanorum were - in accordance with the almost general use of other charitable institutions - accustomed to deposit money at the Mons Pietatis with a continuous administration of expenditure and revenue. This was done so that - in accordance with the mutual good faith and shown helpfulness - as the bank at any time has a considerable amount of money from the depositor, the bank likewise complies with his obligations, although the money is missing, and this due to future supplement. In this case, one of the servants (a bookkeeper or a scribe) of the Collegium falsified the signature of the administrators (approving the accounts written in the lists/(year)books of the Collegium, i.e. the donations (made and received) and payments still to be made). Apparently both parties were considered negligent - at least their officials or administrators, because the parties had legal personality - but the negligence of the administrators of the Collegium was more serious (maior) in this case than that of the bank.

494 The decision was called 'Marradien[sis] Praetensae Refectionis Damnorum'; see G. Vernaccini, Collezione completa delle decisioni, II, p. 279ff.

495 See Gorla 1974/1975, p. 346, and literature on the Rota Fiorentina mentioned in footnote 1.

496 Gorla 1974/1975, p. 349f.; the facts of the case can be found in G. Vernaccini, Collezione completa delle decisioni, II, p. $280 \mathrm{ff}$. 
assumed in this case. ${ }^{497}$ Furthermore, the Fabronis ignored the warning of the players and left exposed items that could have been protected and they also embellished (abbelita) the façade of their house, located exactly where the game was customarily played, and they were well aware of that. Thus, they willingly exposed themselves to possible damage. ${ }^{498}$ In his decision Vernaccini argued that the barber case (D. 9.2.11pr.) had to be applied. According to Gorla, in Vernaccini's decision an argumentum a similibus in D. 9.2.11pr. was applied: the barber had willingly put his trade chair in a place where it was customary to play ball, and in a similar manner the Fabronis did not protect the windows and the embellished façade of their house, while the house stood in a place where people were used to playing ball games. ${ }^{499}$

In conclusion, according to the Argomento of Vernaccini's decision, there was no liability for damages when a ball game, licit in itself, was played in a place where playing such a game was also lawful, and previous notice had been given to the owners of the surrounding houses. ${ }^{500}$ Furthermore, the ball games were played mainly as public amusement for the people of Marradi. According to Gorla, the decision of Vernaccini imposes a burden ${ }^{501}$ upon the owners of the houses surrounding the place of the ball games to avoid damage and also to accept a small amount of damage to these houses caused by the game, when this was played in an ordinary manner. ${ }^{502}$ In brief, in this case the behaviour of the wrongdoer and that of the injured party were considered and compared, and the conclusion was that the wrongdoer had done nothing wrong and that he had acted without negligence and that the injured party had willingly accepted the risk.

\subsection{THE NORTHERN NATURAL LAW SCHOOL}

\subsubsection{Introduction}

In the sixteenth century scholars at the University of Salamanca integrated

497 English reproduction/paraphrase by Gorla 1974/1975, p. 351f.

498 G. Vernaccini, Collezione completa delle decisioni, II, p. 285f.; Gorla 1974/1975, p. 353.

499 Gorla 1974/1975, p. 354.

500 Harm that might be suffered by the surrounding houses was considered to derive from 'a natural and intrinsic defect' of the ball game. See G. Vernaccini, Collezione completa delle decisioni, II, p. 279; Gorla 1974/1975, p. 256. The ball game had 'a natural and intrinsic defect' inasmuch as a ball cannot always be directed by the players precisely to where they want it to go, and therefore harm to the surrounding houses may be expected; see Gorla 1974/1975, p. 355, 357.

501 Gorla 1974/1975, p. 356, called it 'a burden similar to a legal servitude (i.e. deriving from the law)'.

502 According to Gorla 1974/1975, p. 356, the reason or policy underlying such legal servitude seems to be the fact that the ball games were mainly played as public amusement. 
civilian and canonist ideas into a framework provided by scholastic theology, more in particular the doctrine of restitution as described by Thomas Aquinas. These early modern scholastics were important for the development of the law of delicts. They were willing to look behind the rules of Roman law; and, furthermore, the works of the early modern scholastics united the civilian tradition based upon Roman law and Aristotelian philosophy. ${ }^{503}$ In particular, the early lawyers of the (northern) natural law school such as Grotius, and through them jurists such as Domat and Pothier, relied heavily on the doctrinal framework elaborated by the Spanish natural law school. ${ }^{504}$ In the seventeenth century, Hugo Grotius, the founder of the northern natural law school, was strongly influenced by the doctrines of the early modern scholastics. The doctrines remained much the same in the work of his successors, Pufendorf and Barbeyrac, and in that of the French jurists Domat and Pothier. ${ }^{505}$

As elaborately discussed in the previous section, according to the authors of the usus modernus, no partition of damage between the wrongdoer and the injured party was possible. As long as one principally stuck to the validity of Roman law, the all-or-nothing approach could not have been abandoned, as the principle of culpae compensatio led to a total annulment of the claim for damages in the event of contributory negligence of the injured party ${ }^{506}$ With regard to the view of natural law scholars to the problem of contributory negligence, the secondary literature refers to Grotius, Pufendorf and Wolff. From these scholars, Grotius and Pufendorf still followed the same line of thought as in the 'gemeinrechtliche Lehre' ${ }^{507}$ Wolff followed a different approach, as will be discussed below.

\subsubsection{Scholars who followed the old approach}

\subsubsection{Variant 1: the existence of contributory negligence leads to a denial of claim}

According to some scholars, the problem of contributory negligence can be solved by just denying the claim for damages if the victim acted with negligence, possibly with application of the rule of D. 50.17.203. This view,

503 Parisi 1992, p. 121.

504 Parisi 1994, p. 339, nt. 66.

505 Gordley 1991, p. 71; - Unfortunately, the works of the early modern scholastics could not be elaborately discussed in this study. Where necessary and relevant these scholars were mentioned and their works were discussed in this and in the previous chapter.

506 Luig 1969, p. 216.

507 Aumann 1964, p. 38ff., 48; Luig 1969, p. 229. 
which does not permit a partition of damage, can be found with the early modern scholastics ${ }^{508}$ and with Grotius, Domat and Pothier. Contributory negligence was a condition which excluded the attribution of the act to the wrongdoer. It seems what was decisive was less the Roman imput but more the normative beliefs of justice: if the injured party had a considerable coresponsibility, apparently for the natural law scholars a denial of claim was the only fair, appropriate outcome..$^{509}$

One of the most important works of natural law was Grotius' De iure belli ac pacis (1625). ${ }^{510}$ According to De iure belli ac pacis II.17.17, ${ }^{511}$ someone who obtained (literally: gave cause to (the origination of)) a contract or a promise by deceit, violence or duress was obliged to pay compensation. ${ }^{512}$ According to De iure belli ac pacis II.17.18, ${ }^{513}$ someone who himself gave the cause to why he suffered violence or was compelled by duress should blame himself. For an involuntary act that had its origin in a voluntary act was - from a moral perspective - considered to be a voluntary act. As this is rather puzzling, these thoughts will be explained below and will be enriched by examples.

Aumann argued with regard to Grotius, De iure belli ac pacis II.17.18, that Grotius thought that a claim for compensation had to be denied in the case in which the injured himself gave cause (causa) to being forced to conclude a contract or to commit a crime. ${ }^{514}$ To 'give cause' (causam dare) also had to include the 'Willenselement', which also becomes clear from the words 'ex voluntario ortum' in the second sentence of Grotius' De iure belli ac pacis, II.17.18. Therefore, only objectively causing damage did not suffice to exclude the possibility to claim damages. Grotius discussed contributory negligence

508 See L. de Molina, De iustitia et iure, edn. 1614, tract. II, disp. 697, nrs. 11, 12, 14 (discussing the Roman law cases of the javelin thrower, barber and tree pruner). See also Jansen 2007, p. 672.

509 Jansen 2007, p. 673.

510 Grotius' work formed the basis of the theorising of the natural lawyers of the 17th and 18th centuries - such as Pufendorf, Thomasius, Barbeyrac and Wolff - whose ideas penetrated into the general intellectual circulation of Europe of the Enlightenment; see Ibbetson 2003, p. 477; - On Hugo Grotius and the transition from natural law to 'Vernunftrecht', see Schlosser/Molitor 1979, p. 42ff.; - Furthermore, the lawyers of the natural law school from the 17th century formulated the general rule that all damage caused to another by one's fault is recoverable, starting with the famous passage of H. Grotius' De Iure belli ac pacis, II.17.1. See also Jansen 2009, p. 24lf.

511 H. Grotius, De iure belli ac pacis, II.17.17 (edn. De Kanter-Van Hettinga Tromp 1993, p. 432): Sed et qui contractui aut promissioni causam dedit dolo, vi aut metu iniusto tenetur eum quicum actum est in integrum restituere, quia ille ius habuit, tum ne deciperetur, tum ne cogeretur; illud ex natura contractus, hoc ex naturali etiam libertate. His annumerandi sunt qui id quod ex officio facere tenebantur facere noluerunt nisi pecunia accepta.

512 See also Aumann 1964, p. 38f.

513 H. Grotius, De iure belli ac pacis, II.17.18 (edn. De Kanter-Van Hettinga Tromp 1993, p. 432): At qui causam dedit cur vim pati, aut metu cogi debeat habet quod sibi imputet. Nam involuntarium ex voluntario ortum habens moraliter pro voluntario habetur.

514 Aumann 1964, p. 39. 
only for a specific individual case, in which the injured party suffered damages after having concluded a contract or committed wrongdoing (Verbrechen), due to deceit, violence or menace by the other person, and had to stand in for the fulfilment of that contract or to answer for that crime. ${ }^{515}$ Except for this final restriction, Grotius only followed the Justinianic interpretation of D. 50.17.203: because of contributory negligence the victim's claim was totally denied, without any possibility to consider mutual negligences.

Luig argued that, ${ }^{516}$ as in the last sentence of De iure belli ac pacis II.17.17, Grotius assumed that the person described in De iure belli ac pacis II.17.18 did not want to comply with his duty. If such a person had to be brought to comply, he could not bring the usual claim in case of violence (vis), deceit (dolus) or duress (metus).$^{517}$ Luig argued that these fragments of Grotius do not concern cases of contributory negligence. The coerced person is treated as having acted voluntarily within the legal order. Negligence of the coercer in this case was not only remarkable, but was even considered non-existent. ${ }^{518}$

A comparison with the work of the Flemish Jesuit and theologian Leonardus Lessius (Lenaert Leys, 1554-1623), whose thoughts were adopted by Grotius, supports the interpretation of Luig as described above. ${ }^{519}$ Lessius wrote about the influence of coercion on contractual freedom. ${ }^{520}$ Is there a difference between legitimate and illegitimate duress? ${ }^{521}$ Lessius stated that from an objective point of view one could think that both in the case of legitimate threat to sue someone as well as in the case of illegitimate threat both threats would lead to a nullification of the transaction, because the will of the other

515 ibid.

516 See also the different translation/interpretation of the text (different than that of Aumann) that can be found with Luig 1969, p. 229f.: 'Wer Anlaß dazu gibt, daß er mit Gewalt etwas zulassen oder durch Drohung zu etwas gezwungen werden muß, soll sich das selbst zuschreiben; denn ein unfreiwilliger Akt, der seinen Ursprung in einem freiwilligen Verhalten hat, wird im Bereich des Sittlichen als freiwillig behandelt.'

517 Luig 1969, p. 230.

518 ibid., p. $229 f$.

519 Luig 1969, p. 230; - The reference can be found in an annotated version of Grotius' De iure belli ac pacis; see, e.g., the edn. of De Kanter-Van Hettinga Tromp et al., 1993, p. 432, nt. 2 , but also in the annotated version of Gronovius 1773 , p. 518 , next to $\$ 18 / 19$ (b); according to Krause 1949, p. 64 (nt. a), this reference is found for the first time in the editions annotated by Gronovius.

520 On Lessius' contract doctrine, see Decock 2011. For Lessius freedom of contract is the absence of external coercion in entering into a contract. According to Lessius, the 'doctores' spoke about free consent if it had not been forced through an external cause, namely by unjust duress, or induced through deceit.

521 Two topics are revelevant: namely, whether there is a difference between legitimate and illegitimate duress, and whether, in the event of legitime duress, one has to make a distinction between legitimate and illegitimate execution of the duress based on the intention with which the legitimate duress is exercised. The second topic will shortly be dealth with in the next footnote. 
party is in both scenarios affected by coercion. However, Lessius argues that from a subjective point of view (moraliter, i.e. considered from the perspective of the will/consent of the threatened party) one has to say that just coercion (that someone has the right to sue the other in court (ius accusandi)) does not result in involuntary consent. Lessius argued that the fear coming from just coercion was considered not to originate from a force external ${ }^{522}$ to the intimidated party, but from a force coming from within the person involved. Therefore, the subsequent assent is not deemed to be involuntary, since the assent is entirely voluntary as to its cause. ${ }^{523}$

The interpretation of Luig seems to be comfirmed by two later commentaries on the text of Grotius. According to J.F. Gronovius (1611-1671), if someone did not want to comply with his duty as in Grotius, De iure belli ac pacis, II.17.18, and if this person had to be forced, the coercion (i.e. something involuntary) was not considered against one's will, since the injured party was seen as wanting to be forced. ${ }^{524}$ Also Vitriarius (1647-1720) commented on the text of Grotius, De iure belli ac pacis, II.17.18, stating that someone who gave cause that by means of force he needed to permit something, or by means of threat he was forced to do something, had to blame himself. Vitriarius distinguished two examples in which someone acted iure suo and therefore was not considered to have been injured by someone else. In the first example, someone who enters onto another's property without having a good reason to do so (iusta causa), could be repelled with violence (a right given to men by nature). In the second example, someone declares war on another, in which case it is allowed to the other party (based on the law of war) to cause harm to his enemy (i.e. the person declaring war on him), in person and in his possessions. Vitriarius concluded that in these situations one had to impute it to himself if he was injured by the other party, and if in this way something involuntary arose from his voluntary act, the resulting damage - from the subjective point of view of

522 Recently, Decock made clear that Lessius indicated that fear is about psychology and appearance rather than about objective truth and reality, whether an evil event is really out there did not really matter. The perception of the evil event in the mind of the intimidated party is the crucial element; see Decock 2011, p. 222. Applied to the case mentioned above, it means that it does not make a difference whether the litigation threats are based on an actual will to take the intimidated party to court or not. As long as the intimidating party is perceived to have the intention of actually executing his right, the same degree of (legitimate) duress affects the intimidated party, according to Decock 2011, p. 222.

523 Lessius, De iustitia et iure, lib. II, cap. 17, dub. 6, rdn. 43. My paraphrase is based on the English translation/paraphrase of Decock 2011, p. 222.

524 Gronovius explained the words qui causam dedit with the phrase: Negando scilicet quod jure ab eo petebatur. Furthermore, he explained involuntarium ex voluntario in the following way: Coactio, quam quis meruit recusando, quod omnino illi faciendum erat, non putatur invito in hibita, sed ipsum cogi voluisse existimatur. See the annotations of Gronovius in edition of 1773, p. 517f. 
the will of the injured party - was considered to have occurred voluntarily. ${ }^{525}$

Unfortunately, Jean Domat (1625-1696), ${ }^{526}$ in his Les loix civiles, did not include a discussion of the law of delicts. ${ }^{527}$ Nevertheless, two fragments are relevant as to the topic of contributory negligence. According to the first one, if something happens by an unforeseen consequence of an innocent act, without any blame on the side of the actor, the actor is not held for the damage. The event is considered caused by another cause joined with the cause of the act, namely, by the imprudence of the injured party or some accident (cas fortuit). According to Domat, it is either to the injured party or to accident that the damage ought to be imputed. Domat gave an example of someone who crossed a public mall while people were playing there. If a ball was struck and hit the person who crossed over, the person who struck the ball was not held liable for the event, which ought to be imputed to the imprudence of the injured party if he could not have been ignorant that the place he crossed was a public mall, or ought to be imputed to a mere accident if it was altogether unknown to the injured party that the place he crossed was a public mall, and if no imprudence could be imputed to the actor. ${ }^{528}$

The other fragment can be found in the section on damage caused by animals. If someone provoked or irritated a dog or another (similar) animal and caused him to bite, the provoker was to be held liable. If the provoker and the injured party were one and the same person, he had to blame himself. ${ }^{529}$ The latter part seems to have been based on VI 5.12.86. ${ }^{530}$ An affirmation of the use of this rule as a total obstacle for compensation (the 'old view') can be found in the applications given in the Pandectae of Pothier (1699-1772), ${ }^{531}$ where D. 50.17.203 appears as rule $13 .{ }^{532}$ Within this rule, Pothier arranged applications from the Digest,

525 See Ph. Vitriarius, Institutiones juris naturae et gentium, II.XVII.XIV. Vitriarius' interpretation could somehow be understood to be the modern expression of volenti non fit iniuria, a thought which, according to Luig 1969, p. 230, is often linked to D. 50.17.203; Barbeyrac referred to the aforementioned commentary of Vitriarius and argued that although forced to do something, the consent could still be considered voluntary, because the person coerced gave the occasion leading to the duress, namely, by his voluntary refusal; see Barbeyrac 1746, p. 7f., note 2 ad II.XVII.XVIII: L'auteur veut dire, qu'une contrainte, dont on avoit droit d'user envers quelcun, n'empêche pas que son consentement, quoique forcé, ne passe pour libre, parce qu'il a donné lieu à la contrainte par un refus volontaire. Mais la pensée est exprimée d'une manière à faire prendre le change au Lecteur: et je vois qu'effectivement Mr. VITRIARIUS, dans son Abrégé de notre Auteur ...

526 On Domat, see, e.g., Sherman 1922, p. 237; Voeltzel 1936; Baudelot 1938; Arnaud 1969, p. 309.

527 See J. Domat, Les loix civiles, Liv. II. Titre VIII pr.: De ces trois fortes de fautes il n'y a que celles de la derniere espece qui soient la matiere de ce Titre. Car les crimes et les délits ne doivent pas être mêlés avec matieres civiles, et tout ce qui regarde les conventions, a été expliqué dans le premier Livre....

528 J. Domat, Les loix civiles, Liv. II. Titre VIII sect. 4 § 3 (with reference to D. 9.2.9.4 and D. 9.2.11pr.).

529 ibid., sect. 2 § 10 .

530 In the same sense Luig 1969, p. 217.

531 On Pothier, see, e.g., Dupin 1825; De Curzon 1919, p. 266ff.; Sherman 1922, p. $237 f$.

532 See Pandectae Justinianae in novum ordine digestae 1782, p. 700. He also mentioned 
among which the example of a partner (socius) who suffered damage due to his own negligence - in that case the loss cannot be partly claimed from the other partner of the partnership (see D. 17.2.52.4). ${ }^{533}$

\subsubsection{Variant 2: applying the doctrine of maior culpa}

Some natural law scholars, like Pufendorf and Thomasius, seem to have followed the maior culpa theory. ${ }^{534}$ With regard to an inflicted injury, Samuel von Pufendorf (1632-1694) ${ }^{535}$ argued that liability ${ }^{536}$ could only be imposed upon the wrongdoer if the negligence of the injured party was not more serious ${ }^{537}$ than that of the wrongdoer, ${ }^{538}$ therefore a weighing of mutual faults was necessary. The negligence of the injured party had to be more serious than the culpa (levissima) of the wrongdoer, in which case the total claim for compensation would be denied (a partial compensation based on the degree of negligences was not yet considered possible ${ }^{539}$ ). A small amount of negligence apparently would not lead to the denial of a compensation claim. ${ }^{540}$ A dogmatic explanation

the already discussed examples of the procurator, the eviction of the buyer; furthermore, he discussed the case of D. 39.2.44 as an example of the rule of D. 50.17.203. D. 39.2.44pr. concerns the case of a threatened injury/anticipated injury due to a building which is in a dangerous state. If the neighbour started legal proceedings regarding a cautio damni infecti (in order to force the owner of the dangerous building to give surety for possible damage due to the (future) collapse of the building) too late, namely after the dangerous building fell down and caused damage to his building, the damage suffered was due to his own fault; - In Larva, Thomasius completely changed the basis of the Pufendorfian (and Grotian) general principles of responsibility for wrongs. A fault was apparently no longer required: liability was merely based on the fact that a person caused damage to another person. The new doctrine of Thomasius, however, had no great influence on the 18th century-natural law treatises as far as this deviation from the fault principle is concerned, thus Feenstra 2001, p. 163; - On Pothier and on his Pandectae, see, e.g., Arnaud 1969, p. 111ff., 163ff., 315f.

533 R. Pothier, Pandectae Justinianeae, in novum ordinem Digestae, note b. ad D. 50.17.203; the question of preponderant negligence was not put here; see also Luig 1969, p. 217.

534 Luig 1969, p. 214; 230f.; Kiefer 1989, p. 91.

535 Samuel von Pufendorf taught from 1661 until 1686 at the University of Heidelberg; on Pufendorf, see, e.g., Arnaud 1969, p. 317; Wieacker \& Weir 1995, p. $243 f f$.

536 According to Pufendorf, causation was not sufficient for imputation; it was necessary to show that the injury stemmed from an act of the wrongdoer with dolus or culpa (not only physical cause but moral cause was needed); see Ibbetson 2005, p. 25.

537 Differently Jansen 2007, p. 673, who argued that 'Es komme darauf an, ob das Verschulden eher (magis) beim Verletzten als beim Schädiger liege; ein Verschulden des Geschädigten schließe - ebenso wie höhere Gewalt - die Zurechenbarkeit aus.'

538 S. von Pufendorf, De iure naturae, III, I $§ 6$.

539 As will be discussed below, the first scholar who decided that in the event of contributory negligence damages should be split was the natural law jurist Christian Wolff; see Aumann 1964, p. $42 \mathrm{ff}$. However, according to Kiefer 1989, p. 86f., 110, the first to propose a general gradation according to the degree of negligence was J. Barbeyrac, who translated Pufendorf's work into French and commented upon it as to the amount of compensation according to the degree of negligence. However, Thomasius, Wolff and Darjes did not take on this division, but stuck to the total compensation of damage in case of preponderant negligence of the wrongdoer.

540 See also Kiefer 1989, p. 86. 
of this rule cannot be found in Pufendorf's description. ${ }^{541}$

With regard to murder cases, Pufendorf did not take into consideration such balancing. This appears from the following. In principle, a person who killed wantonly (lascivia) was bound to render compensation, as anyone who killed with evil intent; such compensation also existed in cases in which death was the result of negligence (cases of culpable homicide). An example is the case of a soldier who practised with his arms in a place not meant for this purpose, and killed someone; another example is the case of a countryman practising with arms in a place where soldiers regularly practised. ${ }^{542}$

Apparently, if the injured party contributed to the occurrence of the damage, due to his contributory negligence the wrongdoer was without fault and no liability was imposed on the wrongdoer. For example, if a person was accidentally struck by a soldier in a place where soldiers regularly practised, the soldier would get off scot-free, because it was that person's own fault to be in that place, and the soldier was there to do his duty. Likewise, in the case of the pruner in D. 9.2.31, if the pruner killed a slave who crossed an area far from the road in the middle of farmland, even without warning first, since a stranger had no right to be on the landowner's property. ${ }^{543}$

According to Luig, it seems that Christian Thomasius (1655-1728) $)^{544}$ followed the same approach as Pufendorf, in his Institutiones jurisprudentiae divinae. ${ }^{545}$ In this respect, one phrase in Thomasius' section on not causing harm to others and on compensation for inflicted damage (de non laedendis aliis, et de damno dato resarciendo) is particularly relevant. However, in my view this phrase did not concern the balancing of mutual negligences. It just states that one has to consider whether the damage possibly had been caused by negligence of the injured party rather than by that of the wrongdoer. If so, the injured party himself had to be regarded as the cause of his damage, and there was no contributory negligence whatsoever. Thomasius described the case of the death of slaves who had no more food after the theft of grain. It becomes clear that the negligence in question did not concern the delict of inflicted loss as such, but the question of whether consequential damage (in this case the death of slaves was a result of the theft of grain, i.e. they starved due to lack of food) had

541 Aumann 1964, p. 40f. Aumann regards Pufendorf as the initiator of the typical natural law idea of the weighing of faults. See Aumann 1964, p. 41; according to Luig 1969, p. 231, because Aumann paid no further attention to writers of usus modernus.

542 S. von Pufendorf, De iure naturae, III, I $\$ 7$ (an English translation can be found in Oldfather \& Oldfather 1934).

543 ibid.

544 On Thomasius, see, e.g., Wieacker \& Weir 1995, p. 251ff.; Zimmermann 2000, p. 49ff.

545 Luig 1969, p. 214; Kiefer 1989, p. 91. 
to be imputed to the injured party rather than to the wrongdoer. ${ }^{546}$ Thomasius argued that this loss did not have to be compensated.

Thomasius examined topic after topic, rule after rule, in order to determine the application of Roman law in German practice. In some cases, he affirmed the use of Roman law, but rejected it in many other cases. ${ }^{547}$ In his treatise, Thomasius tried to reconsider the fundamental issues of delictual liability on a rational basis. The usus modernus of the Aquilian delict had absorbed Germanic customary law, some elements of canon law and of medieval moral theology and was formed by the efforts of generations of judges and counsels (as also discussed in the previous section). Thomasius believed that a new theoretical framework was needed for this vigorous, but flexible, jurisprudentia forensis. ${ }^{548}$ According to Thomasius, nature dictates that damage (damnum) done should be made good, including damage done by mere negligence, but also damage caused by accident. ${ }^{549}$ Thomasius argued it was equitable and just that one should make good damage caused by accident.

An example of a person looking at some valuable glass at a friend's house is given. Suddenly something entirely unforeseen happened (unfortunately, it is not clear what exactly happened) that greatly startled not only the visitor but also the owner of the glass. The visitor, while turning the glass around to have a closer look, let it fall from his hands. The damage in this case was purely accidental: no negligence could be imputed either to the owner of the glass or to the visitor. It is interesting that Thomasius questioned whether the damage should be divided between the two, but concluded negatively, because the owner could act and hold the visitor responsible for his act. ${ }^{550}$ If the visitor had not taken the glass into his hands, it would not have been broken. The visitor should suffer for the loss, however innocent his curiosity, as it was nevertheless his curiosity, not that of the owner. In other words, since the visitor derived pleasure from this innocent act of curiosity he should also suffer the loss. ${ }^{551}$

546 Chr. Thomasius, Institutionum jurisprudentiae divinae, II.V.30. Thomasius referred to D. 9.2.21.3 ['l. 21 § 3 ad L. Aquil.'; edn. 1730, p. 124]; this text, however, does not exist; I think he meant D. 19.1.21.3 (nam pretium tritici, non servorum fame necatorum consequitur) which dealt with the interest of the owner.

547 Zimmermann 2000, p. 58f.

548 ibid., p. 64.

549 See Chr. Thomasius, Larva legis Aquiliae, §2ff.; - According to Ibbetson 2005, p. 24, Thomasius' fundamental principle was that no one should be injured by another: nemo laedendus (let no one be harmed). The starting point was not a shortcoming on the part of the wrongdoer, but the fact that the injured party suffered some loss.

550 Chr. Thomasius, Larva legis Aquiliae, §4 (edn. Hewett 2000, p. 7f.); on this case, see also Jansen 2009, p. 231f.

551 Chr. Thomasius, Larva legis Aquiliae, §4 (edn. Hewett 2000, p. 7f.); see also Zimmermann 1996, p. 1033; Chao-Duivis 2005, p. 14. 
For Thomasius, to impute a loss to someone there was no need to prove any fault of the wrongdoer. If there was a physical causation, the wrongdoer was liable, unless it could be shown that the victim was at fault in a way that was considered sufficiently serious to blot out the responsibility of the wrongdoer. ${ }^{552}$ Grotius, Pufendorf and most of the other natural law lawyers took a different view as they focussed their attention on the injuring party, rather than on the injured party, and emphasised the duty aspect of the matter; someone can only be held liable if he did something that he ought not to have done or if he did not do what he ought to have done. ${ }^{553}$

Thomasius also discussed a situation in which two persons intentionally injured each other or damaged each other's property. The rules of human equity in such a situation require that intent may be offset by intent (dolus cum dolo compensetur) and thus each person should bear the loss suffered in excess of his own fault. The reasoning is not very different - according to Thomasius - if negligence (culpa) of an owner concurred with negligence (culpa) of a wrongdoer, it would not be fair for the owner to acquire something from the other because of a human failure. Thomasius provided some examples of this rule. If someone deposits his property with a friend who is negligent with regard to his own property, or gives it into the care of a person not very careful in looking after his own property, or if someone joined a partnership with a very negligent man, and then damage is done to the deposited object or to the (common) property of the partners, provided the friend or partner did not look after his own property better than the injured party's property, the former was to be blamed. In that case it is clear, or according to Thomasius at least assumable, that intent (dolus) is present. ${ }^{554}$ So, according to the ius gentium, the person who physically caused damage by accident was liable and had to pay compensation. The liability was, however, limited if the owner contributed to the cause (causa) of the act or at least provided the occasion (occasio) for the damage to occur. That would be the case, e.g., if the owner had put the valuable glass into the hands of his visiting friend in order for him to look at it, or if he had asked his friend to take it from a high place where it was standing and his friend fell from a stool. ${ }^{555}$

552 Ibbetson 2005, p. 24.

553 Zimmermann 1990, p. 83; 1996, p. 1033f.

554 Chr. Thomasius, Larva legis Aquiliae, §6. My paraphrase is based on the translation by Hewett 2009, p. 9.

555 ibid., §7. My paraphrase is based on the translation by Hewett 2009, p. 9. 


\subsubsection{A new approach: Christian Wolff}

The possible attribution of damage both to the wrongdoer and to the injured party (according to the resp. faults or causal contributions) had its origin in the 'Aufklärungstheorie' of Christian Wolff (1679-1754) ${ }^{556}$ and is therefore a relatively recent phenomenon. But the assessment and balancing of the respective gradations of negligence of both parties was already a step in that direction. ${ }^{557}$ So, although Wolff was the first legal scholar ${ }^{558}$ who turned away from the 'all-or-nothing principle', his theory - as described below - can also be considered a continuation of the preceding development. Wolff did not treat the matter of contributory negligence in an abstract way, but only for some concrete cases, as will be shown below. In particular, no remarks are found as to the relation with the delictual obligation to pay damages. ${ }^{559}$ In that respect, the aforementioned example included in the Selectae decisiones of Schoepff (see p. 280), of an earlier date than the work of Wolff, is a much clearer example of a partial compensation of damages in the area of liability for damages, in the sense that certain specific sorts of damages (amount for maintenance expenses) were not recoverable due to the contributory negligence of the injured party.

Wolff's theory implied an apportionment of damage. He argued that when both the wrongdoer and the party injured were negligent, the damage should be borne by both parties according to the extent of their individual negligence (in ratione culpae) ${ }^{560}$ He rejected the idea of placing the burden of all damage on the party whose negligence was regarded to be more serious than the other's negligence. Wolff's theory of division of damage based on quota is founded on the mutual responsibilities of the parties involved. However, the sources mentioned by Wolff do not really concern contributory negligence of the injured party; but the considerations made by Wolff - considering the fact that according to the traditional solutions the uniform damage had to be imposed on the owner or on the possessor (no partition) - can be transferred to the contributory negligence situation. ${ }^{561}$

556 On Wolff, see, e.g., Arnaud 1969, p. 319; Wieacker \& Weir 1995, p. $253 f f$.

557 Equally important for dogmatic legal history was the new idea of a partition of the total amount of damages; see also Jansen 2007, p. 675, nt. 129.

558 Aumann 1964, esp. p. 44f.; Luig 1969, p. 231; Jansen 2009, p. 242.

559 Jansen 2007, p. 674; see Chr. Wolff, Jus naturae, II, §580.

560 See Chr. Wolff, Institutiones juris naturae et gentium, §283, p. 153; Chr. Wolff, Grundsätze des Natur-und Völkerrechts, §283, p. 176; Luig 1969, p. 231; Kiefer 1989, p. 99, 110; Jansen 2009, p. 242.

561 Looschelders 1999, p. 17. 
The situation discussed by Wolff is that of an owner who brought a reivindicatio against the possessor. The possessor made expenses for improvements, among which luxurious expenses. However, these could not be taken away without damaging the property of the owner, or could not easily be taken away at all. The question was whether a possessor bonae fidei was entitled to compensation as to the expenses incurred for improvements, more specifically for these luxurious expenses (impensae voluptuariae) ${ }^{562}$ As the possessor lost the expenses of the materials, he suffered loss; if the owner had to recover these costs, it would be he who suffered loss.

One of the questions Wolff dealt with was who had to bear the damage if the damage of two persons (that of the owner and that of the possessor) collide (Si damna duorum collidantur, quinam id ferre debeat).$^{563}$ At first sight one could think that the words collisio damnorum duorum concerned a case in which one act caused damage to two persons' estates. This is not the case; it only regards one kind of 'damage', namely the luxurious expenses. These expenses, which did not lead to an increase in value of the object, could theoretically damage two people: the possessor, who did not have an action but only a lien, and the owner, who had to pay compensation. How should the damage be divided between two persons when both suffered damage from the same act? According to Wolff, the decisive criterion is who acted negligently: the owner, the possessor or both?

In accordance with this criterion, Wolff argued - in more general terms - that if one of the parties was negligent, that party had to bear the damage. If the injured party caused his damage alone, he had to bear it, and no compensation whatsoever was possible. ${ }^{564}$ However, if both parties could be considered the free cause (causa libera) of the damage, the wrongdoer's duty to pay compensation was not put aside. The question now shifted focus: the situation in which both parties were at fault was solely considered as to the question of the extent of damages to be paid. ${ }^{565}$ An apportionment of the total damage was made, proportional to the negligence (culpa) of both parties. ${ }^{566}$

Wolff recognised that the equal treatment of the injured party and the wrongdoer obliges giving a certain (negative) consequence to both the contributory negligence of the injured party and the negligence of the wrongdoer,

562 Aumann 1964, p. 42; see Chr. Wolff, Jus naturae, II, §628.

563 Several arguments were used by Wolff; see Chr. Wolff, Jus naturae, II, §§629-632; Institutiones juris naturae et gentium, § 283; see also Aumann 1964, p. $42 \mathrm{f}$.

564 Aumann 1964, p. 44; Looschelder 1999, p. 18; see Chr. Wolff, Jus naturae, II, §629.

565 Aumann 1964, p. 44, 48.

566 ibid., p. 47, 49; Looschelders 1999, p. 18; see Chr. Wolff, Jus naturae, II, §632. 
namely on the basis of the 'ratio culpae'. The negligence (culpa) of the wrongdoer and the negligence (culpa) of the injured party are compared and balanced against each other. In secondary German literature, 'ratio culpae' has been translated as 'Art' or 'Beschaffenheit' of the negligence, ${ }^{567}$ but it has also been explained as 'Verhältnis' or 'Maß' of negligence (in the German translation of §283: Proportion der Schuld). ${ }^{568}$ If both parties acted negligently, they had to bear an amount of damage corresponding to the degree of negligence of each party (in ratione culpae utriusque). It is generally assumed that in Wolff's work, culpa also included causation (causa) ${ }^{569}$ Hereby, Wolff discovered a general principle of equity (Gerechtigkeitsprinzip) that when more persons are responsible for the whole damage, each had to bear the damage in the proportion to which he was responsible for it. ${ }^{570}$ Therefore, the party whose negligence was preponderant did not have to bear all of the damage, but the larger share. ${ }^{571}$

The transmissibility of Wolff's theory developed within the framework of the law of property to the contributory negligence situation is confirmed by Wolff's Pflichtenlehre. Duties can exist towards oneself, towards another person or towards God. ${ }^{572}$ Regarding the first duty, Wolff put extensive duties to someone to avoid damage to oneself. Furthermore, the duty to others is equal to that owed to oneself. ${ }^{573}$ Therefore, in the event of contributory negligence, the accusation of blame towards the wrongdoer and (towards) the injured party regards an infringement of similar duties. ${ }^{574}$ Wolff's theory made an imputation of damage to both the wrongdoer and to the injured party possible. The partition according to quota seems a logical consequence; this partition had nothing to do with the older ideas of equity (see above) except from the central idea of equal treatment of the parties. ${ }^{575}$

567 Aumann 1964, p. 45.

568 Luig 1969, p. 231, nt. 208.

569 See Lorenz 1972, p. 312; 1979, p. 36. This also appears from the information provided in my main text. According to Lorenz, probably, when writing 'ratio culpae', Wolff had in mind the degree of negligence and causation. See also Aumann 1964, p. 45f.: 'Da aber Wolff mit der Zurechnung der culpa zugleich die Eigenschaft des Verhaltens als causa libera damni bejaht, enthält der Begriff culpa bei ihm neben dem subjektiven Element des Willens (libera) auch das objective der Verursachung (causa).' See also Looschelders 1999, p. 18.

570 Looschelders 1999, p. 18. See also Jansen 2007, p. 674 f.

571 Luig 1969, p. 231; also Aumann 1964, p. 46; Keirse 2003, p. 24; see also Chr. Wolff, Jus naturae, II, §590 and Chr. Wolff, Jus naturae, IV, §591.

572 Looschelders 1999, p. 18.

573 Chr. Wolff, Institutiones juris naturae et gentium, § 133.

574 Lorenz 1979, p. 35; Looschelders 1999, p. 19.

575 Jansen 2007, p. 675. 
Wolff's theory of Rechtspflichten gegen sich selbst was not accepted in later (German) codifications or legal scholarship. ${ }^{576}$ On the other hand, the idea of a partition of damage, the solution based on quota and the idea of proportionality between the duty to pay damages and negligence or causal contribution did find their way into various codifications. ${ }^{577}$ Yet, Wolff's doctrine was still contested in the nineteenth century in legal doctrine as well as in case law. ${ }^{578}$ The modern - twentieth century - solution in which a partition of damage is made between the wrongdoer and the injured party, based on the respective contributions of causation and negligence, originated in Wolff's 'Enlightenment philosophy' ${ }^{579}$ However, it might be argued that it is more precise to say that the considerations of Wolff did not concern the actual situation of contributory negligence and therefore a direct immediate influence of his theory cannot be established. ${ }^{580}$

Wolff's theory of a partition of damage was introduced into the majority of European codifications (e.g. § 1304 of the Austrian Allgemeine Bürgerliche Gesetzbuch of 1811, Article 51 II of the Schweizerische Obligationenrecht of 1881, Article 44 of the Schweizerische Obligationenrecht of 1911 and $\S 254$ of the German Bürgerliche Gesetzbuch), notable exceptions being the Code Civil and the Burgerlijk Wetboek of $1838 .{ }^{581}$ The reasons for and the consequences of this choice will be discussed in the next chapter.

\subsection{Concluding Remarks}

\subsubsection{The humanistic contribution}

In this chapter, the contributions of the humanists (and the scholars of the Dutch Elegant School) to the problem of contributory negligence were discussed. With regard to D. 50.17.203, Donellus formulated the central question:

576 See Looschelders 1999, p. 19f., who stated that the Rechtsflicht gegen sich selbst was - in principle - accepted in the Allgemeine Landrecht (I.3 $\S 27 f$.) but only when it was legally prescribed. See also on this legal provision Mayer-Maly 1976, p. 263.

577 In the same sense Jansen 2007, p. 675.

578 Aumann 1964, p. 50; Luig 1969, p. 231; Lorenz 1972, p. 312; Wacke 1977, p. 11; 1979, p. 276; 1991, p. 362; - This will be extensively discussed in the next chapter.

579 Wollschläger 1976, p. 115; see also Aumann 1964, p. 42ff. \& Luig 1969, p. 231.

580 Looschelders 1999, p. 20; differently Jansen 2007, p. 676, with references, who argued that at least an influence already by Martini und Zeiller on the Austrian Allgemeines Bürgerliches Gesetzbuch is plausible.

581 Also Jansen 2002a, p. 107; 2002b, p. 206; 2009, p. 242; however, in France from 1875 onwards the all-or-nothing principle was released in case law. This will be discussed in the next chapter. 
whether an injured party that contributed to the realisation of the damage and suffered damage because of his own negligence could totally or partially claim damages from the counterparty to the extent the damage resulted from his own actions and furthermore: to what extent the damage would be due to his own risk? This is all the more important since Donellus was (possibly) the first scholar who dogmatically formulated the main problem in general terms. The text of D. 50.17.203 was a starting point for the doctrine of contributory negligence in the medieval period. The humanists, however, tried to re-situate this fragment in its original context (law of legacies). The examples of this rule given by the humanists are, however, mainly the same as those given in the medieval period. Without looking to the different palingenetical contexts, this rule is connected to the cases of D. 9.2.52.1, D. 9.2.9.4 and D. 9.2.11pr. It is explicitly stated that these cases concern events in which the injured party acted negligently.

More features were found in the approach of the humanists which do not point at reconstructing classical law: based on a comparison of D. 9.2.52.1 with Quintilian (Noodt and Majansius), it was stated that when a delict was on both sides, a compensation of unlawful acts (iniuria) took place. Considering D. 9.2.52.1 as an example of a compensation of unlawfulness is rather a sign of a Bartolistic approach than that it was based on a thorough comparison with and knowledge of rhetorical features. Also the interpretation of D. 9.2.52.1, from a perspective of self-defence, is contrary to the classical interpretation of Alfenus in D. 9.2.52.1 (see chapter two). Nor is the connection of D. 9.2.9.4 with D. 9.2.10, as defended by the humanists, defendable - because such connection is not in conformity with the inscriptions of the fragments- nor is the fact that D. 9.2.9.4 and D.9.2.11pr. are considered examples of the situation in which both parties acted negligently. However, only by doing so could the negligent acts be compared and theories be developed. One of those theories is the criterion of (in)iustum, the application of the iudicatio scheme, the continuation of the application of the culpae compensatio, and also the first traces of the theory of gravior culpa (A. Faber) or maior culpa (M. Freher and G. Noodt) appeared. The last new development of major importance is that P. Faber and J. de Sande envisaged the possibility of a partial compensation for the first time.

\subsubsection{Reception and usus modernus}

In this chapter the central question was: why did the injured party have no right to claim compensation? This question is based on the hypothesis that the approach to compensation based on the actio de damno dato was still all-or-nothing. In the period of the Reception, the actio legis Aquiliae lost its 
original characteristics, because the penal character disappeared. This could have made it easier to abandon the all-or-nothing approach, but that did not happen at once, as will become clear from the summary below.

From a purely normative perspective it is possible to draw the conclusion that the idea that an equal or preponderant contributory negligence excluded the right to claim compensation began to gain acceptance in the early modern period. However, from a functional perspective the answer as to how the problem of 'contributory negligence' was solved by jurists in the period of the usus modernus is more heterogenous. Some Roman-Dutch scholars still explained texts of the Corpus Iuris in which contributory negligence of the injured party was at stake in the same way as the scholars in the Middle Ages. Some (RomanDutch) scholars still applied the rule of D. 50.17.203 and just let contributory negligence lead to a denial of a claim for damages. Others indeed applied the so-called maior culpa theory, as, e.g., Voet did. Voet even suggested that this doctrine was nothing new, which conclusion, however, cannot be drawn from the Digest texts to which he referred. Furthermore, Voet did not always apply this doctrine, since he applied it in the case of the barber, but not in the case of the javelin throwers.

Also, from the usus modernus in Germany it appears that several starting points were or could be used to solve the problem of 'contributory negligence'. Firstly, the role of the injured party was considered a problem of causality. Secondly, the role of the injured party was considered a question of negligence, and in that respect it was considered a question of concurrence of faults. Several variants of the application of the culpae compensatio doctrine were found, among which the maior culpa theory. Another solution was to solve the problem of contributory negligence without any reference to the contributory negligence of the injured party. In this variant, the negligence of the wrongdoer was the only relevant factor and the contributory negligence of the injured party was not considered as such. A last solution was provided by the use of the criterion of the auctor rixae as an alternative way to solve the problem of contributory negligence. The initiator of a fight could not claim damages for injuries suffered during the fight, unless the other party acted excessively in self-defence.

In the giurisprudenza pratica in Italy, the criterion of auctor rixae was connected with the concept of culpa admixta. If someone started a fight or provoked a fight (the so-called auctor rixae) and during that fight was injured, the act of the injured party is called culpa admixta because the hurtful action by a wrongdoer is now mixed with a fault of the injured party. As a result of the injured party's culpa admixta, his claim was denied in totality (see Cravetta, Venturini). The Rota Romana sometimes held the view that contributory 
negligence, however small, led to a denial of claim, while in another case it seemed to require culpa maior on the side of the injured party. The third option of the usus modernus in Germany was also applied in Italy, namely by the Rota Fiorentina in 1780: sometimes the wrongdoer(s) had not acted negligently, but the injured party willingly exposed himself to possible damage and therefore did not obtain any compensation.

The criterion of auctor rixae brings us to the question of whether the allor-nothing approach was still applied in its totality. Apparently, there was some discussion at that time on the question of what sort of damages could be recovered, and especially whether immaterial damages could be recovered or not. In case of an excessive reaction by the provoked party, the provoker could only claim medical costs and no immaterial damages (and loss of earnings) were granted. This can be based on Leyser, and on a decision of the Faculty of Helmstadt (of 1715) included in his work. In two cases a small amount of negligence of the injured party did not exclude the victim's claim for damages, but was taken into account in order to determine the amount of damage, according to the advice of Hommel, who proposed sharing the costs of the litigation because of the contributory negligence of the injured party, and a decision of the Faculty of Tübingen provided by Schoepff on the amount for maintenance expenses. Since these last examples are all examples of non-compensation of certain types of damages, and not of a reduction of the total damage in question, depending on certain standards, the all-or-nothing approach has to be considered still intact.

\subsubsection{Collision cases}

In Roman-Dutch law, collision cases are particularly interesting. In these cases a different starting point is taken from the one in Roman law. If a ship hit another ship, without negligence, this ship still had to pay 50 per cent of the damage. But if two ships collided and both had acted negligently, there were various views on what the law dictated. In cases where damage was caused to ships by fault of one of two ships or by both, Roman law has been the starting point. If one party acted negligently, it had to pay for all of the damage. If it was not clear which party had been negligent, or when the negligence was equal on both sides, the Hoge Raad decided that the damage had to be regarded as common, and both should bear the damage in equal proportions; Van Bijnkershoek and Van der Keessel argued that each party should carry its own loss, because the party that had been negligent could not bring an action and the damage that occurred was not regarded as damage ( $c f$. D. 50.17.203). Another problem was to determine what the law dictated in case a stationary ship was hit by a 
moving ship. Van der Keessel considered the negligence of the latter as more serious, and therefore no culpae compensatio (mark the application of the ius commune theory) could take place. Thus one ship had to bear 50 per cent of the damage of the other ship, and so something quite similar to the idea of division of damage occurred. Compare this with the old tradition of judicium rusticorum, with one renewal, namely, that in case of culpa maior 50 per cent of the damage of the other party had to be paid.

\subsubsection{Natural law/rationalism}

The scholars of the natural law schools did not feel as strongly bound to the Roman tradition. Did this new approach in case of contributory negligence lead to a different solution from the solution in the tradition of ius commune? No, not really, since in the natural law tradition there were still some scholars who followed the 'old' ius commune approach: in case of contributory negligence of the injured party, they just applied the rule of D. 50.17.203. In such case the application of that rule led to a total denial of a claim for compensation. This view might have been held by Grotius, while it can also be argued that the relevant fragments in his work do not really concern the problem of contributory negligence. In any event, this approach was followed by Domat and Pothier. Others applied the doctrine of culpa maior, such as Pufendorf and Thomasius. Both approaches, if answered in the affirmative, led to a denial of claim and in that sense the all-or-nothing approach was still followed. A break with this approach only came about with the new theory of Wolff. He argued that when both the wrongdoer and the injured party acted negligently, the damage should be borne according to the extent of their individual negligence. What was the influence of this doctrinal point of view? It will be shown in the next chapter that Wolff's doctrine of apportionment was still contested in the nineteenth century in legal doctrine as well as in case law. In the end, most twentieth-century national states followed his approach in their codifications, but the respective negligence of both parties was not always taken as the (only) decisive factor. Furthermore, it will be made clear that there were new tendencies in the twentieth century and in the early twenty-first century which contrast with the principle sustained by Wolff. 


\section{CHAPTER FIVE}

\section{MODERN AND CONTEMPORARY LAW}

\subsection{INTRODUCTION: CONTENT, METHOD AND STRUCTURE}

It has already become apparent that in the development of contributory negligence two different concepts influenced the rules on this subject: the approach(es) from Roman law and the approach from natural law. The Roman concept of claim for damages (i.e. the rule as laid down in the Corpus Iuris) has been the prevailing view for centuries, in situations which modern lawyers would consider as contributory negligence, ${ }^{1}$ that the negligence of the injured party led to a denial of his claim (unless the wrongdoer acted intentionally ${ }^{2}$ ). This starting point was challenged in the early modern period. The first steps as to the 'diminution' of the amount of damages were made by the jurists of the Faculty of Heldstedt (see Leyser's Meditationes) and by Schoepff in the Selectae decisiones - showing that certain types of damages were not recoverable due to contributory negligence. This development was continued by the natural law scholar Chr. Wolff, who considered contributory negligence a question of the extent of damage - although one has to note that no remarks are found as to the relation with the delictual obligation to pay damages; his solution did notchoose to exclude certain sorts of damages from recovery but reduced the total amount of damages in cases of contributory negligence. The total damage was divided between the two parties, proportionate to the level of their negligence.The two different approaches - that of Roman law and that of natural law - decisively influenced the discussion from the eighteenth century onwards. The natural law jurist Wolff, although holding a minority view at

1 Although I used the term 'contributory negligence' in this study as a 'useful shorthand', in modern and contemporary times it became a technical term. In this chapter contributory negligence will be used in this 'modern' sense.

2 This latter exception did, in principle, not apply any longer under the German BGB: also in the event of intentional wrongdoing (at least in the area of $\S 254$ Abs. II BGB), contributory negligence of the injured party can be taken into account; see Rother 1965, p. 40, with reference to the 'Motive' (to $§ 222$ Entwurf I) in Mugdan 1899, II, p. 13. In practice, intentional wrongdoing mostly resulted in the mere negligence of the injured party not being taken into consideration. 
that time, turned away from the all-or-nothing approach. He believed that if the negligence of the wrongdoer as well as the contributory negligence of the injured party contributed to the damage in question, both parties should bear the damage, proportionate to the gravity of faults on either side. ${ }^{3}$ The question remains whether a partition of damages or the all-or-nothing approach was laid down in codes and which approach was applied in nineteenth- and twentieth-century legal scholarship and legal practice. ${ }^{4}$

Around 1800, in a fairly short period of time the Prussian Allgemeine Landrecht (1794), the French Code civil (1804) and the Austrian Allgemeine Bürgerliche Gesetzbuch (1811) were enacted. How were rules concerning contributory negligence laid down in these codes (and in the (much later) German Bürgerliche Gesetzbuch of 1900), ${ }^{5}$ and which traces of old approaches and which new approaches can be found in these codes? If a partition of damages was applied as a consequence of contributory negligence, what was the legal basis for this 'contributory negligence' and what were the requirements in order to come to such a partition? Furthermore, it is interesting to examine whether at the beginning of the nineteenth century the all-or-nothing approach was abandoned or still applied and whether the maior culpa theory was still followed. Does the answer to this question differ in case law from legal doctrine?

This chapter will mainly concern the situation in which the fault of the victim is one but not the sole cause of his damage. First, of course, the liability of the

3 That is, the natural law principle of proportionality between fault and extent of liability.

4 In England, contributory defence at first was a complete defence against an action in negligence, but later this was mitigated by the last opportunity rule (the party who had the last opportunity to avert the damage would be regarded as having brought about the proximate cause and was thus held solely responsible); see Scott 1984, p. 171; Von Bar \& Clive 2009, p. 3640 . The principle of partition of damages was introduced for the first time in the UK by the legislator in the Maritime Conventions Act 1911. Further, in common law, an injured party who was partly responsible for his own harm could not recover damages in tort until the Law Reform (Contributory Negligence) Act of 1945. This Act provided the rule that in such cases the claim did not fail, but the defence of contributory negligence may apply and if it applies may lead to a reduction of the account of damages to be paid. See, e.g., Elliot \& Quinn 1999, p. 90, 93. In Ireland, contributory negligence led to complete exemption from liability even until 1961 (Civil Liability Act; except in cases where the defendant, in spite of his contributory negligence, had the last opportunity to avoid the accident, in which case he had to compensate the total damage of the injured party); see McMahon \& Binchy 2000, p. 113. The subject of this study is contributory negligence. As can be noticed, the common law (and English law) is virtually absent from mention. This is not at all intended to belittle its role - it is certainly important in the development of thought on contributory negligence, nor is it an oversight. Rather, it is intended to allow the concentration, in the hope that 'less is [truly] more', in this subject on the role of the continental civil law tradition. A recent overview of the historical evolution in AngloAmerican law, with regard to the all-or-nothing approach of the rule of contributory negligence, can be found in Weyts 2003, p. 327ff.

5 I will discuss the conditions to be fulfilled in order that the fault of the injured party is considered legally relevant, as well as, if legally relevant, the effect(s) of the fault of the injured party. 
wrongdoer had to be established and subsequently the fault of the injured party (more on this requirement later).

The defence of contributory negligence is pre-eminently suitable to make differentiations in the area of liability law, an area that is expanding. The defence of contributory negligence is frequently brought up, not only in personal injury cases and damage to objects, but also in the area of the new professional liabilities, liability for products and state liability. ${ }^{6}$ The assessment of contributory negligence influences the range of liability. As will be discussed in this chapter, development did not progress in a lineal fashion but rather in a rising and falling fashion, and the development of the doctrine of contributory negligence today shows a reversion to older times.

Theoretically and historically, three possibilities are provided as to the consequences of the contributory fault of the injured party. ${ }^{7}$ According to the first possibility, coming from postclassical Roman law (and common law), the injured party cannot recover damages if his injury is partly due to his own negligence, unless the wrongdoer acted intentionally. The second possibility allows a certain limited amount of compensation, depending on different criteria, such as fault, causal contribution, equity or a mixture of these. ${ }^{8}$ The Austrian Allgemeine Bürgerliche Gesetzbuch , the Swiss Obligationenrecht and the German Bürgerliche Gesetzbuch are examples (these codes will be discussed later in this chapter). A third possibility is that the fault of the injured party under certain circumstances is totally ignored (e.g. the French Accident Compensation Law of $1898^{9}$ ). It has been suggested that the comparative examination of various systems reveals a trend towards fuller compensation as the economy of a particular state expands. Thus the fault of the victim, first a complete bar to recovery, later led only to a reduction of the victim's compensation and finally was completely disregarded, unless the fault was especially serious or flagrant..$^{10}$ This is obviously the all-or-nothing approach,

\footnotetext{
6 Keirse 2010, p. 126.

7 On the rationale of these solutions, see, e.g., Honoré 1983, p. $97 \mathrm{f}$

8 Lawson \& Markesinis 1982, I, p. 131; Honoré 1983, p. 97.

9 But also in the Civil Code of the USSR of 1964; see Bloembergen 1997, p. 8; Honoré 1983, p. 95f., 111, only gross negligence of the injured party that helped to cause or aggravate the harm can lead to a reduction or extinction of the victim's claim for compensation; see Art. 458 Civil Code of the RSFSR; sometimes this possibility is applied in cases of a qualified fault, as will be shown below.

10 Lawson \& Markesinis 1982, I, p. 132; Honoré 1983, p. 97; Keirse 2003, p. 30f.; the same development is detected in Dutch personal injury law; see also Bloembergen 1997, esp. p. 13, and a discussion of the latter view, e.g. in Hartlief 1997a, p. 131ff., 140. According to Bloembergen, this development is related to the development of liability law from offender-based law to a victim-based law: before, the focus was on the punishment of the offender, today, especially in personal injury law, the focus lies on the protection of victims. According to Bloembergen, this will probably lead to further erosion of the defence of contributory negligence; South Africa lies
} 
which regains acceptance in the area of contributory negligence of the injured party. ${ }^{11}$ However, recently the track/course has been set in the opposite direction: contributory negligence is becoming more and more of importance and leads more and more to a restriction of liability; ${ }^{12}$ the proportional approach advanced again and as a rule a partition of the damage between the wrongdoer and the injured party is supported..$^{13}$ Possibly, if this movement continues, the importance of contributory negligence will increase in the near future. ${ }^{14}$

The tendency to reduce the contributory negligence defence, stimulated by legal doctrine, stands in sharp contrast to the views defended by the economic approach of contributory negligence. Legal rules should give incentives for efficient care to both injurer and victim in the event of bilateral accident cases (i.e. where victims can have an influence on the accident risk). ${ }^{15}$ From a theoretical perspective, pure strict liability is not considered as optimal in these cases. It would become efficient in the joint-care case - cases in which the victim's care also has an influence on the accident risk - if a contributory negligence defence (or comparative negligence) ${ }^{16}$ is added to this strict liability rule to control the incentives of the victim. ${ }^{17}$ Under the normal fault-rule, the judge will only examine whether the wrongdoer did take efficient care, and according to the majority of the economic literature - a defence does not add

beyond the scope of my study. Section 1(1)(a) of the Apportionment of Damages Act of 1956 allows a reduction of damages in the event in which both parties were at fault. This regards a reduction by the court to such an extent as the court may deem just and equitable, having regard to the degree in which the injured party was at fault in relation to the damage. A discussion of this section can be found with Scott 1984, p. 166ff. His treatment is interesting as he states that in South African law, no apportionment based on the aforementioned rule takes place in the situation in which, if the wrongdoer acted intentionally and the injured party negligently regarding the same damage, full compensation is given (with reference to D. 9.2.9.4); in the opposite situation, i.e. if the injured party acted intentionally and the wrongdoer negligently regarding the same damage, no compensation will be granted as the contributory intent of the injured party forms an absolute defence (with reference to the Accursian gloss tenebitur to D. 9.2.9.4: culpa culpam abolet sed non dolum and also the English common-law principle generally denying a person with 'unclean hands' a remedy); see Scott 1984, esp. p. 176 .

11 The increasing influence of insurance law is one of the most important causes for this; see Weyts 2003, p. 324.

12 There are also other instruments which lead to a restriction of liability, e.g. by the principle of relativity; see, e.g., HR 13 April 2007, NJ 2008, 576.

13 Keirse 2010, p. 127.

14 In this sense Keirse 2009, p. 561f.; 2010, p. 127, who argued that there are certainly indications for that to descry (i.e. that the injured party's responsibility is increasing). She referred to case law of the Dutch Hoge Raad in the area of liability of employers, where the Hoge Raad seems to attach importance to the employee's own responsibility. She also refers to the (Dutch) developments in the area of the duty of the injured party to limit his damage. See also Keirse 2009, p. 557ff., esp. p. 562.

15 Faure 2004, p. 237.

16 An elaborate overview of the law and economics literature on contributory and comparative negligence can be found in Artigot i Golobardes \& Gómez Pomar 2009, p. 46ff.

17 Faure 2004, p. 238, 255; also Magnus \& Martín-Casals 2004, p. 278. 
anything new since under fault the victim would expect to be fully exposed to the risk anyway. ${ }^{18}$ This result seems to run counter to the tendencies in the law as described above (and further described later in this chapter).

In this chapter some connecting lines with and thoughts on modern codifications will be presented by providing the main developments of the nineteenth and twentieth centuries leading to the most important codes of Western Europe (French Code civil and German Bürgerliches Gesetzbuch) and the recent Dutch Burgerlijk Wetboek of 1992. The chapter concludes with a brief study of the contemporary concept of contributory negligence, especially the way 'contributory negligence' is dealt with in France, Germany and the Netherlands. The chapter aims at establishing which traditions influenced the codes just mentioned. It draws connecting lines from the period of ius commune to modern times $;^{19}$ this will enable obtaining a more complete picture of the historical development and of the influence of certain ideas on the concept of contributory negligence. Particular attention will be paid to the question of which elements of the two major traditions - natural law (which provided a partition of damages in the event of contributory negligence) and (the various manifestations, which all applied an all-or-nothing approach, of) Roman lawwere followed by the codifications. ${ }^{20}$ In general, three important questions will be answered: Did contributory negligence have any role in the determination

18 Faure 2004, p. 239ff., 255; - Other views can also be found in legal literature, namely that of a legal-economics point of view which seems to point to a preference for a partition of damages rather than an all-or-nothing approach. The former approach stimulates both parties to keep the costs of damage as low as possible by applying efficient care; see Keirse 2003, p. 319 . In the same sense Van Boom 2004, who argued that - from a law and economics perspective the principle of contributory negligence provides an incentive for achieving an efficient level of care for the potentially injured party. A short discussion of some criticism on whether or not to abolish the defence of contributory negligence from a legal and economic perspective can also be found in Hartlief 1997a, p. 132f., note 21, 138. Differently, Honoré 1983, p. 98 (with references), who stated that, according to economic criticism, the machinery of apportionment is relatively expensive in comparison with a solution that transfers the whole or none of the loss from one party to another. A more profound study on this lies beyond the scope of the study.

19 Special attention will be dedicated to traffic accidents, as in these cases the defence of contributory negligence occurs most frequently in practice.

20 And whether approaches possibly included new aspects as decisive for the outcome and/or manner in which contributory negligence was taken into account (see, e.g., Art. 6:101 BW below). 
of liability? ${ }^{21}$ If so, what consequences were given to contributory negligence? What was the dogmatic foundation of contributory negligence?

In this chapter, I will study the problem of contributory negligence in a chronological manner and I will discuss the major codifications and scholarly movements which existed in chronological order: the French Code civil (and the Dutch Burgerlijk Wetboek of 1838), the Austrian Allgemeine Bürgerliche Gesetzbuch, the German Historical School, German Bürgerliche Gesetzbuch and the (new) Dutch Burgerlijk Wetboek of 1992. Thereafter, I will give a brief overview of the contemporary manner in which Germany, the Netherlands and France deal with the problem of contributory negligence, with a particular focus on the topic of traffic accidents (section 5.6). Some final words on contributory negligence after the damaging event follow (section 5.7). The chapter ends by discussing the possibility of a (European) harmonisation (section 5.8), and finally, with some concluding remarks (section 5.9).

\subsection{Codifications ARound 1800}

As to the problem of contributory negligence, the first codifications of the Enlightenment did not entitle an apportionment of damages. ${ }^{22}$ The Codex Maximilaneus Bavaricus Civilis of 1756 seems to follow the view of the gemeine Recht, namely (the older view) of the usus modernus pandectarum - that in cases of contributory negligence in contractual relationships - if the party that suffered damage or loss also acted negligently (culpa), then that party was not entitled to claim reimbursement from the culpable party. ${ }^{23}$ But no remark is made as to the application of this rule to delictual liability.

Although the Allgemeine Landrecht (1794) of Prussia gave a differentiated solution for the problem of contributory negligence, ${ }^{24}$ in principle (predominantly) it

21 The question of whether a young victim can be contributorily negligent is a delicate one and will not be broadly discussed in this study, but only when obviously crucial.

22 Various 18th- and 19th-century codes, namely the Codex Maximilianeus Bavaricus Civilis (1756), the Prussian Allgemeine Landrecht (1794), the Code Civil (1804) and the Badische Landrecht (1809) and the Austrian Allgemeine Bürgerliche Gesetzbuch (1811), are thoroughly discussed by Aumann 1964, p. 58-79 (which he dealt with under the part called 'Die Aufklärungsgesetze').

23 Aumann 1964, p. 58ff.; Jansen 2007, p. 665f.; see, e.g., CMBC IV 1 §20, IV 2 §5, IV 3 §16 and also Kreittmayr's Anmerkung zu CMBC IV 1 §20.

24 ALR I.6 §§ 18-21' are summarised by Wieling 1970, p. 225, in the following manner. If both parties are equally at fault, only the direct damage (unmittelbaren Schaden) can be claimed; if the wrongdoer's negligence has been preponderant, he has to pay the total damage (direct and indirect loss). When the injured party's fault is predominant, the wrongdoer is not liable. The Allgemeine Landrecht only distinguishes degrees of negligence, namely between intentional misconduct, gross neglect, moderate neglect and minor neglect as possible degrees of fault (within these levels of negligence no further differentiation is applied), each of which corresponds to a different level of liability; see also Stoll 1972, p. 139. On these legal provisions, 
attached to the gemeine Recht. ${ }^{25}$ However, as in particular I $6 \S 20$ of the Allgemeine Landrecht shows, ${ }^{26}$ the principle of culpa maior was applied. ${ }^{27}$ Thus, if the injured party's negligence was large and the wrongdoer's mistake was moderate or slight, the former could not claim any damages. However, the Allgemeine Landrecht of Prussia did not consider all sorts of damages as one unity, but distinguished two categories of damages. According to the first category ( $\S 19,21$ of the Allgemeine Landrecht), the duty to pay recovery was excluded as regards indirect damage and loss of earnings; this primarily concerned cases in which the injured party did not perform his duty to limit the damage. It is not certain whether the partition of damage as proposed in the Allgemeine Landrecht also applied to the second category, i.e. contributory negligence: when the injured party contributed to the occurrence of the damage. ${ }^{28}$

see also Looschelders 1999, p. 24f.; Van Wassenaer van Catwijck 1971, p. 3, argues that §§ 19-21 of the Allgemeine Landrecht was the first Western code which offered the possibility of partition of damages. See also Van Wassenaer van Catwijck \& Jongeneel 1995, p. 5; Weyts 2003 p. 326. According to Haller 1926, p. 123, in $\S 22$ there are traces of the principle of a division of damages proportionate to the respective faults. Indeed, in $\$ 22$ each party is liable for damage done to the other in accordance with his fault; however, this concerns the situation in which two or more parties injured each other reciprocally, and is thus a different situation from contributory negligence.

25 See Aumann 1964, p. 60-68, 192, who makes clear that based on reasonableness a diminution of the amount of damages was possible in the event of contributory negligence. The casuistic approach seems an echo of the exceptional decisions in Roman law as discussed in chapter two.

26 ALR I.6 § 20: Ein dergleichen eigenes grobes Versehen des Beschädigten macht denselben aller Schadloshaltung verlustig, wenn der Schade nur aus einem mäßigen oder geringen Versehen des Beschädigers entstanden ist (cited after Aumann 1964, p. 60/Kiefer 1989, p. 303); this is still the case in Reitemeier's proposal for an Algemeinen Deutschen Gesetzbuches, namely in Titel $23 \S 81$ : 'Hat sich bey einem mäßigen oder geringen Versehen des Beleidigers der Beschädigte ein grobes Versehen zu Schulden kommen lassen, so macht sich dieser aller Schadeloshaftung verlustig' (based on $\S 20$ of the Allgemeine Landrecht). Also $§ 78$ is important: 'Ist der Beschädigte mit Schuld an dem angerichteten Schaden, so fällt, nach Maaßgabe seiner Verschuldung, der Ersatz entweder ganz oder zum Theil weg. As appears from a footnote, the text is based on D. 9.2.28.1, D. 9.2.9.4 and D. 9.2.11pr.

27 Luig 1969, p. 232; on this topic more elaborately, see Kiefer 1989, p. 152f.; - However, Aumann 1964, p. 192, stated 'Dabei hat er [der preußische Gesetzgeber, EvD] sich aber zugleich von dem vernunftrechtlichen Gedanken der Proportionalität zwischen Höhe der Schuld und dem Umfang der Ersatzleistung leiten lassen.'

28 See also Looschelders 1999, p. 25; - In the event of a collision of ships, when both ships suffered damage, and provided none of the parties acted with gross negligence, ALR II. 8 \$ 1911 . apply and both ships have to pay for half of the total mutual loss. 
The French Code civil of 30 ventôse XII (21 March 1804) ${ }^{29}$ contained neither a conceptualisation nor an explicit legal rule on 'contributory negligence', nor did it contain a rule on contributory negligence set for damage claims in the law of delict. ${ }^{30}$ In any event, the relevant principles in France were developed in legal doctrine and practice. ${ }^{31}$ However, in the Code civil in the part on contractual relationships, in the title on damages resulting from the non-performance of an obligation, two articles, namely Articles 1150 and 1151, could be relevant for the problem of contributory negligence. These articles regard claims for damages and interest as a result of the non-compliance with a contract by the debtor. It has been argued that the contributory negligence of the creditor who suffered loss was taken into account by recourse to Articles 1150 and 1151 of the Code civil. ${ }^{32}$ According to these articles, after a breach of contract the debtor only has to compensate the creditor for foreseeable damage (dommage prévu), ${ }^{33}$ i.e. damage foreseen or to be foreseen at the conclusion of the contract, and anyhow if the debtor intentionally caused the breach. ${ }^{34}$ In the latter case the debtor is liable for damage which is the immediate and direct consequence of the violation of the agreement. ${ }^{35}$

Therefore, the fault of the creditor could be relevant in two situations: in cases where the actual damage was in fact caused by a negligent act of the creditor that occurred after the breach of the contract, and in situations in

29 On the Code civil in general, see Halpérin 2001; - General articles such as Art. 1382 CC, according to which any human act that causes damage to another person obligates the person by whose fault the damage occurred to offer reparation for the damage, lead to the result that judges had to decide upon each singular case, based on the circumstances, with a much freer interpretation of the rules of law; see Aumann 1964, p. 68; $c f$. also Heinsheimer 1928, p. X.

30 Possibly, this can be explained by the fact that Pothier did not give any explicit rule on contributory negligence for these claims (see previous chapter).

31 The Code civil became applicable also in the territory that is now Belgium and therefore no explicit rule on contributory negligence applied there either; no explicit rule existed in the Netherlands under the Burgerlijk Wetboek of 1838; - No explicit rule on contributory negligence existed in Italy under the Codice Civile (del Regno d'Italia) of 1865. In Italy, under the aforementioned code, the principle of culpae compensatio was applied in doctrine and practice. Based on this principle, the division of damage according to the faults of both parties was recognised more and more and ultimately sanctioned by Art. 1227 of the Codice Civile of 1942. See Luig 1969, p. 236 nt. 225 with further references; Keirse 2003, p. $26 f$.

32 Aumann 1964, p. 132.

$33 c f$. Art. 1149 CC: with damages owed to the creditor, his losses as well as the profit denied to him are meant. In this chapter both losses will be referred to as 'damage', unless otherwise demanded by the context.

34 See also Priester 1896, p. 29; - In case of intent (dol), the debtor had to pay compensation for the damage suffered by the creditor and also for loss of profit, if the loss was the immediate and direct consequence of the non-performance; see on this topic Kaden, Anm. II to Art. 11491152 CC, in: Heinsheimer 1932.

35 Priester 1896, p. 29. 
which the debtor could not foresee the serious consequences of his fault due to the the culpable act of the creditor. ${ }^{36}$

In general, contributory negligence of the creditor cannot be predicted at the time of the conclusion of the contract. Therefore, one can state that - as to contributory negligence regarding the law concerning compensation in contractual relations - French doctrine upheld recognition of the Roman law principles of the ius commune: ${ }^{37}$ if the act of the creditor contributed to the causation of the damage, even if it consisted in an omission, the requirements for liability were not met, because the debtor could not foresee such an act. ${ }^{38}$ Therefore the duty to compensate the damage is not present at all.

As in the early accounts of the Historical School, still founded on the Roman sources, ${ }^{39}$ in older French doctrine the case in which both parties were at fault was not dealt with. Instead, the negligence is placed on one or the other as the (only) cause of the damage..$^{40}$ In conclusion, one can state that in French contract law the idea of a partition of damage according to the ratio of the respective negligence of both parties was not applied, neither in doctrine nor in practice. ${ }^{41}$

The first code in which Wolff's natural law principle of partition of damage was accepted was the Austrian Allgemeine Bürgerliche Gesetzbuch of 1811, more specifically $\S 1304 .{ }^{42}$ The decisive criterion was the respective negligence

36 ibid., p. $29 f$.

37 Aumann 1964, p. 132. cf. Zachariae-Dreyer 1886, p. 331: Haben beide Theile den Schaden verschuldet, so kann der Gläubiger in der Regel nicht auf Ersatz Anspruch machen. The application of the principle of ius commune is justified by the reference to Art. 1599 CC. According to that article, the sale of property belonging to another person is void and can give rise to damages if the buyer is unaware of this fact. Accordingly, no compensation was granted to the buyer if he was familiar with the quality of the object at the time of the agreement.

38 Aumann 1964, p. 132f.; - However, if contributory negligence of the creditor just related to certain consequential damages, the act of the injured party would give rise to a deduction of damages since these consequential damages were not foreseeable for the debtor, and the amount of compensation due was reduced accordingly; see Aumann 1964, p. 133; - So, according to Luig 1969, p. 234, in French contract law the problem of contributory negligence, in jurisprudence and in practice, was solved by taking the predictability of damages into account.

$39 c f$. Unterholzner 1840, p. 254, 272. The duty to compensate expired if the injured party had acted negligently; but not if, although the injured party acted negligently, the wrongdoer had acted in an unscrupulous manner (dolus). Unterholzer (among others) refers to D. 50.17.203 and D. 9.2.11pr.

40 See Larombière 1862, no. 23 ad Art. 1148 CC, p. 224; - Exceptionally, this principle was also applied outside contract law in cases of statutory obligations for surety, in which negligence of the originator of the damage was not required. See Aumann 1964, p. 133. This is for example the case for the liability of an innkeeper for objects delivered to him; see Larombière 1862, no. 23 ad Art. 1148 CC, p. 224. Another example is the liability of the owner of an animal that caused damage (Art. 1384 CC). In that case, according to Priester 1896, p. 30, the owner could bring an exception against a noxal action, namely the exception that the damage was caused by the negligence of the injured party himself.

41 Aumann 1964, p. $133 f$.

42 Luig 1969, p. 232; Koziol 1998, p. 593; also Kontogianni 2003, p. 146f., who called it the outcome of the influence of the doctrine of rationalism; - This was done under the influence of 
of both parties. ${ }^{43}$ The Allgemeine Bürgerliche Gesetzbuch furthermore gave the judge discretionary power to decide upon the legal consequences of contributory negligence, which was a novelty. ${ }^{44}$ Then the injured party was considered proportionately 'liable', and if the correct proportion could not be established, he would be equally liable as the defendant. ${ }^{45}$

\subsection{Conservatism in Nineteenth-Century LEgAL Doctrine AND THE STRUGGLE OF NINETEENTH-CENTURY JUDGES}

\subsubsection{French exegetical school: faute de la victime}

\subsubsection{Introduction}

French law of delict does not contain any specific provision for the apportionment of liability due to contributory negligence. Apparently, predictability/ foreseeability of damage (as in Articles 1150 \& 1151 Code civil) is not the core criterion. However, in French judicial practice, the concept of 'la faute de la victime' was developed as a criterion to reduce the wrongdoer's liability, if necessary. Some argue that the rule of apportionment of liability, based on the gravity of the respective faults in French law, seems to have prevailed soon after the introduction of the Code civil. ${ }^{46}$ Others argue that in the first half of

Karl A. F. von Martini and Franz A.F.E. von Zeiller; see on these scholars, their influence and a treatment of the topic of contributory negligence in the Austrian codifications Aumann 1964, p. 70-79; - §1304 ABGB: Wenn bei einer Beschädigung zugleich ein Verschulden von Seiten des Beschädigten eintritt, so trägt er mit dem Beschädiger den Schaden verhältnißmäßig; und, wenn sich das Verhältniß nicht bestimmen läßt, zu gleichen Theilen (cited after Aumann 1964, p. 73). Notice the subsidiary rule of partition in halves; - See also the drafts of codes in the German Länder Hessen, Sachsen and Bayern in the 19th century, where the natural law solution of partition of the uniformly calculated damages (the total damage as one unity) is connected with differentiations of individual consequential losses (Schadensfolgen) which were based on exceptional Roman law decisions; see Aumann 1964, p. 140-152; Luig 1969, p. 235. No natural law thoughts, especially not on a partition of damage - but instead, of the idea of fault compensation - can be found in the Sachsian BGB (1865) in which the solution prepared by Pandectism was codified in its entirety (culpae compensatio doctrine), and the Dresdener Entwurf (1866) which was more closely oriented towards the older doctrine of ius commune. See Aumann 1964, p. 152ff., 155ff.; Luig 1969, p. 234; also Jansen 2007, p. 666, 676.

43 The prevailing view on the term Verschulden in $\$ 1304$ ABGB is that it concerns a nontechnical term, namely 'Sorglosigkeit in eigenen Angelegenheit', which does not presuppose unlawfulness; see Looschelders 1999, p. 67 with references.

44 Aumann 1964, p. 77ff., 192.

45 Lawson 1968, p. 56.

46 Lawson \& Markesinis 1982, I, p. 132f.; according to these authors, the French judge-made rule had to find its true justification elsewhere (than in a statutory provision) and many have hence chosen to fall back on wider considerations of equity (see, e.g., Honoré 1983, p. 98) rather than on any particular operation of the doctrine of causation, while others have chosen to explain 
the nineteenth century the all-or-nothing approach still applied. ${ }^{47}$ It should be noted that there were two basic types of contributory negligence. First, when the injured party contributed to the damage and, second, contributory negligence was presumed in the event the injured party did not endeavour to limit the extent of the damage arising from his injury. ${ }^{48}$ This subsection will only deal with the first type of contributory negligence; the second type will be discussed shortly in section 5.7 .

\subsubsection{Faute commune}

Based on the Code civil one can state that a necessary condition of civil liability was the requirement of fault (faute). ${ }^{49}$ According to Article 1382 Code civil, following any human act causing damage to another, the person through whose fault the damage occurred is obligated to pay compensation. Article 1383 Code civiladded that everyone is liable for damage caused, not only by a wrongful act but also by negligence or imprudence. ${ }^{50}$ Already at the end of the nineteenth century the problem of negligence of the injured party came up and Demolombe (1804-1887 $)^{51}$ argued that the central question was which of the parties acted negligently (faute). Two different situations can be distinguished. First, the situation in which only one of the parties acted negligently: the wrongdoer was negligent but the injured party was not, or the injured party acted negligently and the wrongdoer did not. In the latter case, in which the injured party

the reduction as a sanction, corollary to the notion of fault. Lawson \& Markesinis 1982, I, p. 133f., gave a causal explanation based on an assessment of comparative causations. They argued that the apportionment of damages seems to be attempted more on the basis of the conduct's potential to cause injury than on the basis of the relative gravity of the respective faults.

47 Jansen 2007, p. 676 (with the literature and references).

48 Van Dam 2000b, p. 555.

49 This principle had already been accepted by Domat, and the travaux préparatoires of the Code civil show that the draftsmen desired to follow that same tradition; see Amos/Walton 1967, p. 203, who added that this conclusion is confirmed by the arrangement of Arts. 1382-1386. In the years following the publication of the Code civil it was taken for granted that a person incurred liability only if he was at fault; the special cases described in Arts. 1384-1386 can be explained on the ground that there were legal presumptions of fault.

50 Domat's influence on these articles is remarkable; see esp. J. Domat, Les lois civiles dans leur ordre naturel, I, book ii, title VIII, section iv, 1 (quoted in English by Auzary-Schmaltz 2001, p. 330f., nt. 135), according to which all damage that may arise from the act of another, whether by imprudence, thoughtlessness, ignorance, or other comparable faults, however slight, must be made good by the person whose imprudence or other fault has given rise to the damage. According to Domat, the reason was the wrong of the wrongdoer, even if there was no intention to cause harm. Thus a person unwisely playing ball in a place where there was a risk of damage to passersby (apparently Domat thought about D. 9.2.11pr.) was to be held liable if someone got injured.

51 On Demolombe, see, e.g., Bouckaert 1981, p. 60; Halpérin 2001, p. 67 f. 
was the sole cause of the total damage, ${ }^{52}$ no liability occurred, because no one was responsible for damage caused by the injured party himself. ${ }^{53}$

Second, the situation in which both parties acted at fault is explicitly distinguished from the situation in which only the injured party did. ${ }^{54}$ The former situation is more complex and in that case judges could exercise their discretion. The term faute commun ${ }^{55}$ - foreign to Roman law - was used in legal practice for situations in which damage resulted from the faute of the wrongdoer as well as from the faute of the victim. ${ }^{56}$ This situation occurs also when an injured party was at fault, imprudent or negligent (faute, imprudence or négligence). It did not, however, mean that the imprudent or negligent wrongdoer was freed from all liability. ${ }^{57}$ In these cases - as will be more elaborately discussed below - French legal doctrine and practice seem to have applied a partition of damages, ${ }^{58}$ proportionate to the gravity of the faults on either side. ${ }^{59}$ It is worth remarking that a 'faute commune' only affects the extent of the amount of damages. The nature of the damage and the way it was caused, e.g. directly or indirectly, had no influence on the admissibility of the claim (for damages) ${ }^{60}$

Demolombe defended the opinion that if the negligence of the wrongdoer was equal to the negligence of the injured, the negligences of both parties

52 Extensively on damage caused by the seule faute de la victime, see Haller 1926, p. $33 \mathrm{ff}$.

53 Zachariae-Dreyser 1886, p. 740; - The participation of the wrongdoer was too remote to be considered when the victim's fault was the more direct cause of the damage. Not the gravity of the respective faults, but the causal connection (lien de causalité) is at stake; see Ripert 1933, p. 112; Aumann 1964, p. 134, argued that already in the distinction between different cases a parallel with the treatments of the natural law scholars Pufendorf and Wolff becomes clear.

54 Demolombe 1882 , no. 502 , p. 434.

55 However, in itself this term is inaccurate, since in this situation the two parties have nothing in common: neither the damage, nor the fault. In fact, it is more correct to refer to this as a concurrence of two faults. See also Le Tourneau 2004, nr. 1876, p. 444.

56 On the faute commune or the compensation of fautes, see Demogue 1924, p. 508ff.; Haller 1926, p. 17ff.; Mazeaud \& Mazeaud 1970, p. 621ff.; Marty \& Raynaud 1988, p.707, wrote that 'C'est d'abord dans le cas de la responsabilité de droit commun que le problème de l'incidence de la faute de la victime s'est posée. Ce problème a été résolu en considérant la victime comme co-responsable du dommage qu'elle subit en organisant un partage de la responsabilité entre victime et responsable: c'est la théorie de la faute commune.' It is interesting to see that the victim is regarded as co-author of his own damage and that, therefore, the responsibility is divided between wrongdoer and injured party.

57 Laurent 1878, p. 522; Demolombe 1882, no. 503, p. 434; - In the French system the wrongdoer cannot be freed from all responsibility, as the wrongdoer's fault has to a certain extent contributed to bringing about the accident or to aggravating its effects; see Honoré 1983, p. 124 with references.

58 See also Demogue 1924, p. 510f. and case law and the literature mentioned.

59 Zachariae-Dreyser 1886, p. 740 nt. 11; also Laurent 1878, p. 522; Guex 1904, p. 163 (adopting the Swiss theory of Art. 51 (II) OR); Tassin 1912, p. 103f.; Demogue 1924, p. 512ff.; Aquarius 1941, p. 249; Ripert-Boulanger 1949, p. 357f.; Aubry \& Rau 1951, p. 454f.; on this topic also Haller 1926, p. 120ff.; - Various arguments against this theory of proportionality are given by Terlez 1938, p. $19 \mathrm{ff}$.

60 Zachariae-Dreyser 1886, p. $740 f$. 
were annulled and compensated, so no damage had to be paid. In my opinion, this is in accordance with the rules of ius commune. Furthermore, he held that if the gravity of their responsibilities was not equal because the fault of the wrongdoer and that of the injured party were not equal, both parties had to pay for the damages according to the respective proportion of damages suffered and the respective gravity of fault imputed to them. The judge had to determine the gravity and the proportion of the damage according to the specific circumstances of the case. ${ }^{61}$

The traditional all-or-nothing approach - meaning that in cases where there was contributory negligence on the side of the injured party a denial of claim for damages followed, which even applied until the early modern period - was now set aside as one started to apply a partition of damages in the event of contributory negligence. However, the new concept of common fault ('faute commune') could not be subsumed under any statutory provision, and therefore the French judge was allowed significant leeway in the assessment of the effects of mutual negligence. ${ }^{62}$

While the majority of the legal scholars in France accepted the theory of partition according to the gravity of faults, the judges initially stuck to the application of the all-or-nothing approach ${ }^{63}$ and denied compensation when the fault had contributed to the occurrence of the damage of the victim. ${ }^{64}$ The doctrine of common fault (faute commune) seems to have prevailed definitely in the late forties of the nineteenth century. ${ }^{65}$ So, after initially sticking to the

61 Demolombe 1882 , no. 503 , p. 435.

62 Aumann 1964, p. 135; on the faute commune, see also, e.g., Planiol-Ripert-Esmein 1952, p. $790 f$.

63 As to the question of whether the Pomponian rule of D. 50.17.203 (Quod quis culpa sua damnum sentit, non intellegitur damnum sentire) was directly applied, Haller 1926, p. 21 and Neumann-Schniedewind 1969, p. 73f., stated that the Pomponian rule of D. 50.17.203 could not be found as such, i.e. as a general rule, although the scholars of the ancien droit no doubt knew this rule. Only applications of the rule could be found, namely in the event of damage caused by an animal or in the event of theft of objects from a traveller at an inn. See for the traveller case F. Bourjon, Le droit commun de la France et la Coutume de Paris, II, livre VI, titre III, chap. III, sect. I, §V and more in general §IX (Outre les cas marques ci-dessus, cette action cesse lorsqu'ily a une imprudence marquee de la part du voyageur ...). See for the damage caused by animal J. Domat, Les loix civiles, Liv. II. Titre VIII sect. 2 § 10. See also Mazeaud \& Mazeaud 1970, p. 543; Hinrichs 1991, p. $55 f$.

64 See C Lyon 17 January 1844, S. 1844.2.401 and C Douai 14 December 1846, JdP 1848, 492; Mazeaud \& Mazeaud 1970, p. 625; Honoré 1983, p. 95; Hinrichs 1991, p. 56.

65 Lawson 1968, p. 56. According to Lawson, it is well attested that French courts occasionally applied the doctrine of common fault (faute commune) even before the enactment of the Code civil. Furthermore, Lawson stated that in the first decades of the 19th century the French courts sometimes applied the proximate cause rule instead; Lawson 1968, p. 56; - In legal doctrine various dogmatic justifications for this partition of damages are given. See, e.g., Neumann-Schniedewind 1969, p. 76 (with references to the secondary literature): due to a responsabilité envers soi-même (see also, e.g., Lalou 1962, nr. 348, p. 256), the injured party had to bear the damage caused by himself; some considered the victim to be a co-causer, and he had to bear the damage in total, but 
principle of ius commune, ${ }^{66}$ the natural law solution was adopted, namely the doctrine of 'faute commune, ${ }^{67}$

Clearly, the all-or-nothing approach of Roman law was abandoned with the new course of the French Cour de cassation from 1875 onwards. ${ }^{68}$ Already in a case of 1867, the Cour de Paris decided that if there was some imprudence on the side of the victim, this did not exclude a faute on the side of the driver (of the horse carriage), nor did this lead to the non-liability of the latter. ${ }^{69}$ The principle that a partition of damages had to take place proportionate to the gravity of the respective faults was accepted by the Cour de cassation ${ }^{70}$ in the case of Marquant (1879). The Cour de cassation argued that Articles 1382 and 1384 Code civil did not only concern the situation in which the wrongdoer's action was the only and immediate cause of the damage. When the injured party also acted imprudently, as in the case of Marquant, the judge had to reduce the compensation amount but could not free the wrongdoer from all liability, because the negligence of the latter to a certain extent contributed to the cause of the accident, or made it worse. ${ }^{71}$

Although no (direct) reference to the work of the natural law scholar Wolff can be found, it is possible that, taking into consideration the probable familiarity of the jurists with the works of Wolff - his Instutiones were even translated into

could take recourse against the other wrongdoer (see, e.g., Rodière 1952, p. 245).

66 According to Luig 1969, p. 234f., this was the principle of preponderant negligence; however, as argued in the previous chapter, this should not be taken as the general view.

67 Luig 1969, p. 234f.; see Aumann 1964, p. 135.

68 See Cass. req., 8 Feb. 1875, D.P. 1875.1.320; see already C Poitiers, 29 June 1864, D. 1864.2.181 (50/50); C Lyon, 5 May 1865, D. 1866.3.63; CA Paris, 16 November 1871, D. 1871.2.208; see also Von Bar 2000, p. 547 nt. 268; Weyts 2003, p. 326.

69 C Paris 6 July $1867, D .1871 .5 .334$ nr. 5 .; the same view was held in legal doctrine: the Belgian Laurent (1810-1887) concluded that in case of contributory negligence, and thus of faute commune, it would affect the extent of the amount of compensation; see Laurent 1878, p. 521f. Also Demolombe compared the fault of the injured with the wrongdoer's fault. According to Demolombe, both parties share responsibility proportionate to the respective faults; only if these are equal are the faults compensated and no payment of compensation whatsoever will take place. See Demolombe 1882, no. 503, p. 434f.; - Thus the criterion to define the compensation amount is the extent of the faute, in which 'faute', as a complex concept in French doctrine, includes subjective negligence as well as objective causation elements. See Aumann 1964, p. 136; cf. Kaden, Anm. B I 1 at Art. 1382-1386 CC in Heinsheimer 1932.

70 Later, Ripert 1933, p. 114f., argued that case law diminished the extent of compensation in cases where the victim was also at fault. However, he did not explicitly mention whether this was because of the seriousness of the fault or because of the causal impact of the fault. According to Ripert, it seems that the extent of the compensation is more influenced by the causal impact of the fault than by the gravity of the fault. If the influence of the victim is preponderant, his action could be the cause principale of the damage, and could completely absorb the liability of the wrongdoer. However, in most cases the degree of causality as well as the degree of the seriousness of the fault were taken into account and equally influenced the proportional amount of the compensation.

71 Cass., 20 August 1879, JdP 1880, 123f.; Demolombe 1882, no. 503, p. 434f.; also Tassin 1912, p. 104, 107; Haller 1926, p. 141 . 
French in the eighteenth century - his ideas could have played a role in the intellectual luggage of the jurists. ${ }^{72}$ It seems that the legal consequences of contributory negligence in the law of delicts in nineteenth-century French doctrine $^{73}$ resemble the consequences of Wolff's natural law solution (first codified in $§ 1304$ of the Austrian Allgemeine Bürgerliche Gesetzbuch (1811)). ${ }^{74}$ These solutions, however, are not exactly similar. Wolff placed the respective negligences of the parties independently next to each other, and related the negligences of both parties directly to the damage which occurred. Because the negligent person always had to bear the damages, mutual negligence led to an equal partition of the damages. According to French doctrine, the contributory negligence of the injured party firstly influenced the level of negligence of the wrongdoer. As a consequence of the contributory negligence of the injured party, the negligence of the wrongdoer appeared to be less. Because the gravity of the negligence decreased, the damages that the wrongdoer had to pay were lower. ${ }^{75}$ Therefore, French doctrine better expressed the rationalistic idea of proportionality between the level of negligence and the extent of compensation to pay. ${ }^{76}$ The treatment of the faute de la victime is based on the idea of natural fairness - as was also the case in Wolff's theory. ${ }^{77}$

72 In general, on the influence of Wolff on the political and legal ideas in 18th-century France, see Thomann 1968, p. $233 f f$.

73 As described above, the development in France was initiated by the acceptance of judicial discretion when assessing the question of whether negligence (in cases in which both parties were at fault) had to give rise to liability and determining each party's share of compensation; see Aubry \& Rau 1871, IV, §446 p. 755; Aumann 1964, p. 135; Honoré 1983, p. 124; Therefore, it was not only the effect of Wolff's theory that was crucial for the development of the doctrine of the partition of damages; see also Luig 1969, p. 235.

74 Aumann 1964, p. 136.

75 ibid., p. 136; - A different view was adhered to by (Art. 20 of) the Loi du 9 avril 1898 sur les accidents du travail; under certain circumstances the victim's fault could be completely ignored and, consequently, the wrongdoer had to pay full compensation. This law allowed employers to diminish their awards to their employees for injuries suffered during work only if the employee was at fault and the faute was inexcusable; see Art. 20 of the Loi du 9 avril 1898 sur les accidents du travail and, e.g., Mazeaud \& Mazeaud 1970, p. 546; Lawson \& Markesinis 1982, I, p. 132.

76 Aumann 1964, p. 136.

77 See especially Laurent's treatment of this matter; see Laurent 1878, nr. 491, p. 522 ('La conséquence la plus naturelle de la faute est, non d'affranchir de toute responsabilité l'auteur du fait dommageable, mais de la diminuer, en ce sens que les dommages-intérêts auxquels il est condamné doivent être proportionnés à l'étendue de la faute, et la faute est diminuée quand le dommage est imputable, en partie, à la faute de celui qui l'éprouve.'). 
Later, the term faute commune was also adopted in maritime law in collision matters. According to Article 4 of the 1910 Collision Convention of Brussels, ${ }^{78}$ whenever there was a common fault during a collision, the responsibility of each ship was proportionate ${ }^{79}$ to the gravity of the respective faults. However, if due to the circumstances the exact proportion could not be established or if the fault on either side appeared to be equal, the responsibility was shared $50 / 50$. The subsidiary rule of partition in halves, ${ }^{80}$ a rule in accordance with the concept of the causal connection concept, seems to have already been present in the law before the French codification (ancien droit français) ${ }^{81} \mathrm{It}$ was called the judicium rusticorum, ${ }^{82}$ as such was the decision of King Solomon in the case of the two mothers (1 Kings 3:16-28) - see already the discussion in chapter three, section $3.4 .3 .^{83}$ This rule has the advantage of simplicity: if the judge held that the damage was caused by both parties, he could simply hold the wrongdoer liable for half of the damage. But this rule can also lead to unfair solutions, since it is rather arbitrary and devoid of flexibility. ${ }^{84}$

78 Tetley 2001, p. 76; see Art. 4 of the Convention for the Unification of Certain Rules of Law with respect to Collisions between Vessels (Brussels, 23 September 1910).

79 Apparently, traces of proportional sharing can be found in chap. 157 of Consulat de la Mer: see Demey 1906, p. 28f. and Haller 1926, p. 122f. (based on the fact that the damages had to be partitioned 'bien et diligemment'; this included all relevant circumstances and preponderantly the gravity of the respective faults; see Haller 1926, p. 123).

80 The partition in halves has also been defended as the rule for partition by various authors; see Weyts 2003, p. 396f. and footnote 1816, including a discussion of the advantages of this approach.

81 See comment 5 ad Art. 14 of the Rôles d'Oléron, in Cleirac 1647, p. 67ff.; see already Ordonnance de la Marine (1681), III.VII.X (edn. 1756, p. 302).

82 See also Haller 1926, p. 109, and see also p. 112f., 115ff. on the application of this rule in collision matters in England in the 18th and 19th centuries. The judicium rusticorum was not totally abandoned with the new rules from the Collision Convention, as it became the subsidiary rule as also explained above in the part on France.

83 See also Bouman 1855, p. 41; Terlez 1938, p. 19; and comment 5 under Art. 14 of the Rôles d'Oléron as referred to by Haller 1926, p. 109 nt. 1 (this reference to Solomon is found in the edn. of 1671, but not in the edn. of 1647); Terlez 1938, p. 22, argues that from a legal perspective the division in halves is the only logical solution, but from a perspective of equity and practice the rule of partition based on the respective degrees of fault gives better results.

84 Haller 1926, p. 109f.; - The primary rule of proportionate damage recovery (but also the subsidiary rule) was adopted and inserted in Art. 407 (\$4) Code de commerce, subsequently modified by the law on maritime collisions of 15 July 1915 (see Demogue 1924, p. 517f.; Haller 1926, p. 23f.; Ripert-Boulanger 1949, p. 357; on this article see also Lebreton 1941, p. 142ff.) and later found its way into another statutory provision, namely Art. 4 of the Loi relative aux événements de mer (1967; see Loi 67-545 du 7 juillet 1967 modifiee. Loi relative aux événements de mer). 


\subsubsection{The revival of Roman law in nineteenth-century Germany}

The Historical School ${ }^{85}$ has paid relatively little attention to the problem of contributory negligence. Actually, it only reproduced the relevant texts from the Corpus Iuris, which showed their interpretation of these texts including the view that contributory negligence led to a total denial of claim for damages. ${ }^{86}$

The dogmatic foundation of the denial of claim in the event of contributory negligence appeared to be controversial in legal scholarship during the nineteenth century. The Pandectists tried to find new reasons - though only dogmatic - in order to justify the loss of the claim for compensation. ${ }^{87}$ They developed mainly causation theories based on the idea of a legal-fictive or factual interruption of the causal connection in case of (preponderant) ${ }^{88}$ contributory negligence. ${ }^{89}$ They did not consider the wrongdoer's act causal to the damages due to the injured party's negligent behaviour. ${ }^{90}$ This view can be linked to another (older) doctrine, constructed in the nineteenth century, the theory of compensation of fault (Kulpakompensation).${ }^{91}$ According to the pandectist theory, if the damage was caused both by the culpa of the wrongdoer and by the culpa of the injured party, the culpa of the wrongdoer was cancelled out by the culpa of the injured party. The pandectist theory of compensation of fault rested in essence on D. 50.17.203, ${ }^{92}$ which was understood as a statutory

85 The topic of contributory negligence in legal (German) doctrine in the 19th century is elaborately discussed by Aumann 1964, p. 80-140. The contributions of Prussian legal doctrine will not be discussed in this study, but can extensively be found in Aumann 1964, p. 91ff.; also Luig 1969, p. 233. On 19th century Austrian legal theory, see Aumann 1964, p. 137ff. Interestingly, Austrian case law set the exceptional subsidiary rule of partition in halves (50-50) as the rule, because of the lack of appropriate balancing standards. See Aumann 1964, p. 138; Luig 1969, p. $233 f$.

86 Von Löhr 1806, p. 89, wrote that to establish liability for damages, it is also required that he unlawfully caused the damage by his actions. This is not the case if an act of the injured party contains the same cause (den Grund desselben enthält). In that case it must be attributed to the injured party himself. The author referred to D. 9.2.28pr.-1, D. 50.17.203, D. 9.2.9.4, D. 9.2.10, D. 9.2.11pr., D. 9.2.29.7, D. 9.2.31, D. 9.2.7.4 and D. 9.2.52.1.

87 Aumann 1964, p. 125; - A good overview of the theories on 'Mitverschulden' by the Pandectists can be found in Honsell 1977, p. 4-51.

88 Hedemann 1910 (reprint 1968), p. 103 note 17.

89 Luig 1969, p. 233; see Aumann 1964, p. 101-129.

90 In the same sense Wieling 1970, p. 226.

91 The relevant authors have already been mentioned in the second chapter of this study (Mommsen, Pernice, V. Bar, Wendt et al.). Except for these authors, on the theory of 'Kompensation der Kulpa'/'Kulpakompensation', see also (as to 19th-century scholars) Demelius 1861, p. 52-87; Arndts v. Arnesberg 1889 (14th edn.), p. 498; Levison 1891; Endemann 1893, p. 51ff., 55ff.; Plog 1896; Priester 1896; Ruhm 1898; Labowsky 1898, esp. p. 34ff.; Von Leyden 1902; Gottschalk 1903, p. 53ff, esp. p. 57f.; also Coppa-Zucari 1909; Tassin 1912; - The dogmatic basis for this theory has been exhaustively discussed in pandectist literature; an overview can be found in Von Leyden 1902, p. 22-26.

92 See, e.g., ObLG Bayern, 20 May 1880, SeuffA 35, 285; - Critical on the meaning of D. 50.17.203 for the treatment of contributory negligence is already Cohnfeldt 1865 (repr. 1971), p. 148f.; Brinz 1879, II, 1, p. 353, nt. 13. 
norm $;{ }^{93}$ the statement of Pomponius in D. 50.17 .203 also dominated practice in the areas of the gemeine Recht ${ }^{94}$ until the coming into effect of the Bürgerliche Gesetzbuch. ${ }^{95}$ The pandectist theory contained the rule that if the injured party could have avoided (or lessened) the damage by proper care ${ }^{96}$ he could not claim damages. ${ }^{97}$ An exception was made (by the Pandectists) in the event the wrongdoer acted in dolo (in that case there could be no set-off).$^{98}$ In that event the damage would be recovered in total. ${ }^{99}$ This exception did not apply if the injured party acted with dolus or culpa lata himself. ${ }^{100}$ Nevertheless, one can see that the idea that the negligence of the injured party compensated the negligence of the wrongdoer receded into the background. Two other points of view gained influence, namely that of interruption of causal chain and that of limitation of recoverable interests. ${ }^{101}$ The latter view meant that the damage, which was caused by the injured party himself, did not have to be compensated by the wrongdoer. ${ }^{102}$

A special expression of the idea of compensation can be found with Demelius (1831-1891), who considered as the basis for the denial of a claim for damages the fact that the injured party was regarded to have wanted his damage, and this volition stepped between the volition of wrongdoer and the damage. And thus the injured party's damage was wanted by the injured party and due to the principle of implied consent (volenti non fit iniuria) the damage he suffered was not considered to have been inflicted wrongfully. ${ }^{103}$ Others considered equity as the correct basis for the theory of denial of claim of the injured party. ${ }^{104}$ As equity became the basis, the weighing could also

93 See also Wollschläger 1976, p. 118; see, e.g., Windscheid/Kipp 1906, §258, p. 64 nt. 17 with reference to the literature.

94 From MünchKommentar BGB/Säcker Einleitung (2006), nr. 11, p. 10, it becomes clear in which various areas the 'gemeine Recht' applied until it was replaced by the BGB in 1900 .

95 Henke 1988, p. 757.

96 Mommsen 1855, p. 157; Windscheid/Kipp 1906, §258, p. 64.

97 See, e.g., Heilfron 1920, p. 245, and later Looschelders 1999, p. 21.

98 See, e.g., Burckhardt 1885, p. 109; Priester 1896, p. 10f.; Labowsky 1898, p. $37 f$.

99 Mommsen 1855, p. 157, 257ff.; Windscheid/Kipp 1906, §258, p. 64f.; differently (minority view) see Cohnfeldt 1865 (repr. 1971), p. 142ff., 149, arguing that there is also no liability in the event of intentional wrongdoing, as the contributory negligence of the injured party excludes the required causal connection; see also Jansen 2007, p. 666.

100 Mommsen 1855, p. 258; Looschelders 1999, p. 21.

101 Looschelders 1999, p. $26 f$.

102 See on this view and its adherents Looschelders 1999, p. $27 \mathrm{f}$.

103 Demelius 1861, p. 67; Von Leyden 1902, p. 26; Tassin 1912, p. 19; Honsell 1977, p. 16f.; Looschelders 1999, p. 28.

104 Wieling 1970, p. 226; see, e.g., Von Leyden 1902, p. 24, 35f.; according to Von Leyden, from the nature of a subjective right follows that everyone has to bear his own damage (casum sentit dominus), unless (exception based on equity) someone else was the cause for this damage. An exception to the latter rule based on equity, is a re-entrance of the first rule, the damage was caused by contributory negligence of the injured party (rule D. 50.17.203). The latter rule is 
come to include a weighing of the degrees of negligence. As the Pandectists generally had a large impact on nineteenth-century legal science, the ideas about contributory negligence in this period have been strongly influenced by these scholars as well. ${ }^{105} \mathrm{~A}$ weighing of faults is predominantly denied in nineteenth-century German legal scholarship (Pandectism). The prevailing view seems to have been that the theory of fault compensation implied that even a small contributory negligence of the injured party led to a denial of his claim for compensation, unless the wrongdoer acted intentionally. ${ }^{106}$ Near the end of the nineteenth century, the idea that such compensation was possible nevertheless and that a claim for damages should not be denied, provided the negligence of the injured party was less serious than the wrongdoer's, was defended. ${ }^{107}$

Apart from the more commonly argued view of culpae compensatio (stating only that culpa is compensated by culpa), Heinrich Dernburg (1829-1907) $)^{108}$ argued that only preponderant contributory negligence of the injured party cancelled out his right for damages (thus only in that case compensation should take place), ${ }^{109}$ and he seemed to accept the maior culpa theory. His main criterion seems to be: '... die Frage auf das Gebiet thatsächlicher Erwägung

based on equity, see also Wendt 1892, p. 157; Tassin 1912, p. 12, 26f., 30f.; Haller 1926, p. 69. Later, some scholars argued that rudimentary $\S 254$ BGB could be explained with the concept/idea of personal legal sphere (casum sentit dominus). On the latter theory see Soergel/Mertens 1986, p. 348f., and various scholars mentioned by Jansen 2007, p. 693.

105 The German Allgemeine Deutsche Handelsgesetzbuch of 1861 did not even apply the rule of equal division to collisions of ships, but left the loss where it fell. See Art. 737 (I used the reprint of Friedberg 1890): 'Fällt keiner Person der Besatzung des einen oder anderen Schiffs ein Verschulden zur Last, oder ist der Zusammenstoß durch beiderseitiges Verschulden herbeigeführt, so findet ein Anspruch auf Ersatz des dem einen oder anderen oder beider Schiffen zugefügten Schadens nicht statt.' See also Stobbe 1885, p. 379f.; Lawson 1968, p. 56. This rule seems to have applied even when a 'faute commune' was at stake. This changed in $\S 736$ of the Handelsgesetzbuch of 1897 (still applicable today): (1) 'Ist der Zusammenstoß durch gemeinsames Verschulden der Besatzung der beteiligten Schiffe herbeigeführt, so sind die Reeder dieser Schiffe zum Ersatz des Schadens, der durch den Zusammenstoß den Schiffen oder den an Bord befindlichen Sachen zugefügt wird, nach Verhältnis der Schwere des auf jeder Seite obwaltenden Verschuldens verpflichtet. Kann nach den Umständen ein solches Verhältnis nicht festgesetzt werden oder erscheint das auf jeder Seite obwaltende Verschulden als gleich schwer, so sind die Reeder zu gleichen Teilen ersatzpflichtig.'

106 Rother 1965, p. 30, 35; Lorenz 1972, p. 312; Looschelders 1999, p. 21; see also Henke 1988, p. 757; Jansen 2007, p. 666 .

107 Wendt 1892, p. 171f.; Ruhm 1898, p. 51; Van Leyden 1902, p. 36; see also Gottschalk 1903, p. 54f.

108 On Dernburg see, e.g., Luig 2001, p. $175 f$.

109 Dernburg 1886, p. 121. Also Wendt adhered to this maior culpa theory. Wendt (1892, p. 165ff.) thought the respective negligence of both parties was the only decisive factor for the balancing out of culpa. Only an equal or preponderant negligence of the injured party should be detrimental to the latter; this view was shared by Priester 1896, p. 103f.; see also Ruhm 1898, p. 5lff., with explicit reference to the maior culpa theory (of Noodt). However, this view was not generally held, as Labowsky 1898, p. 38f., argued that in the entire literature it was agreed that also a small contributory negligence led to a denial of any claim for compensation, also when the wrongdoer's negligence was more serious (unless he acted intentionally). 
gestellt, wer die Hauptursache des Schadens ist'. Next to the doctrinal scientific works, also more practical manuals came into being; ${ }^{110}$ in particular Von WeningIngenheim also followed this maior culpa doctrine of Usus modernus. ${ }^{111}$ As to the all-or-nothing approach, however, an adjustment was made in this literary genre. It was generally stated that according to the principles in D. 19.1.11.12 and D. 19.1.45.1 the individual consequential losses, for which the injured was responsible, could not be imputed to the wrongdoer. ${ }^{112}$ Contributory negligence would not always result in a complete denial of the claim anymore, but only as far as the claim concerned self-inflicted damage. ${ }^{113}$ In fact, this was a first escape from the all-or-nothing approach. This very important change away from the solution in the time of usus modernus possibly came about because of the break of the Historical School with the tradition of ius commune. This doctrinal change, however, was not absolute, as is proven by the survival of the maior culpa rule of usus modernus in the nineteenth century. ${ }^{114}$

German nineteenth-century case law did not provide a uniform picture. Although different legal codes applied in various areas of the German Empire (e.g. Allgemeine Landrecht, Code civil, ${ }^{115}$ Codex Maximilianeus Bavaricus Civilis etc.), the solutions as regarding the problem of contributory negligence do not seem to be influenced by that and in the following cases the court apparently applied the gemeine Recht. In the second half of the nineteenth century, German case law of the highest courts was strongly influenced by the pandectistic interpretation of Roman law. ${ }^{116}$ A small contributory negligence was considered sufficient to

110 On their view on the topic of contributory negligence, see Aumann 1964, p. 84ff. These will not be discussed in this study.

111 See Von Wening-Ingenheim 1841, p. 48, 79; Luig 1969, p. 232; see also Aumann 1964, p. 87.

112 No compensation for damages is provided if they could have been averted or avoided by due diligence; see Jansen 2007, p. 671, with reference to various 19th-century scholarly literature.

113 Aumann 1964, p. 90; Luig 1969, p. 232.

114 Luig 1969, p. $232 \mathrm{f}$.

115 A similar view was held in the event of claims for damages that were assessed based on the Code civil. In cases of contributory negligence, what was meant as decisive was which fault was the effective cause; no reduction of the (total) amount of damages was allowed by the Reichsgericht in these cases; see Aumann 1964, p. 171f.

116 See Aumann 1964, p. 168-174; Looschelders 1999, p. 22; - In ROHG, 22 June 1876, ROHGE 20, 99, the Reichsoberhandelsgericht decided - with use of, among others, D. 9.2.9.4 - that in the event of contributory negligence, no fault compensation was applied if the wrongdoer acted intentionally; if the wrongdoer acted gross negligently (culpa lata), however, this exception did not apply. See also Knütel 2001, p. 369. An example of the application of D. 9.2.11pr. in a 19thcentury decision can be found in a decision of the Obertribunal Stuttgart of 1875 , in which a horse was positioned at a public street where there was a lot of traffic of animals and carriages, and where, especially on a market day, also extraordinary incidents of every kind were possible. Here, the plaintiff put his horse in danger as he put it in a place where frequens transitus and in loco periculoso. The Obertribunal considered this contributory negligence of the plaintiff to compensate a possible fault of the defendant (whose running horse collided with the horse of 
deny any claim for compensation (unless the wrongdoer acted unscrupulously, because in that case the injured party would still receive full compensation). ${ }^{117}$ In these cases, a weighing of the negligence of both parties was considered incompatible with the principles of the gemeine Recht.$^{118}$ The acceptability of such a weighing was left open by the Reichsgericht in $1885,{ }^{119}$ but in 1891 the Reichsgericht decided that in the event of contributory negligence of the injured party a claim for damages was denied, without examination as to the degree of negligence of the injured party. ${ }^{120}$ An exception was acknowledged only for the case in which the contributory negligence was not of (great) importance to the outcome, because also with proper care the damage could not have been avoided. However, this is not a genuine exception as in such a case the causal connection between the act of the wrongdoer and the outcome is missing. ${ }^{121}$

However, to avoid unfair solutions, judges increasingly objected to this approach. ${ }^{122}$ Already the Reichsoberhandelsgericht in some cases ruled that a small contributory negligence of the injured party was irrelevant (i.e. not leading to the denial of a claim). ${ }^{123}$ In a case where contributory negligence was obvious due to the injured party's unlawful act, the Reichsgericht seems to have refused to accept contributory negligence as it argued that the occurring damage was not foreseeable for the injured party. ${ }^{124}$ Although in two instances the Bayerische

the plaintiff); see OTR Stuttgart, 26 February 1875, SeuffA 32, 44, p. 49f. and Knütel 2001, p. 368f.

117 See also the case law mentioned by Rother 1965, p. 35, nt. 2; - Case law which proves an approach against a weighing of the degrees of fault can be found with Jansen 2007, p. 666f., footnote 76; other case law is expressly fond of such weighing and can also be found in the justmentioned footnote.

118 ObLG Bayern, 20 May 1880, SeuffA 35, 285; OLG Braunschweig, 21 November 1887, SeuffA 44, 86; see Looschelders 1999, p. 22.

119 RG, 25 September 1885, SeuffA 41, 89; Jansen 2007 p. 667.

120 RG, 5 May 1891, SeuffA 48, 30. See also Looschelders 1999, p. 22.

121 Looschelders 1999, p. 22. According to Jansen 2007, p. 670, case law seems to have considered the main cause; furthermore, it considered the problem of contributory negligence to be a problem of causality; see, e.g., RG, 25 February 1882, SeuffA 37, 219 ('Vielmehr kommt es im Falle eines concurrirenden Verschuldens der Bahnverwaltung und des Getödteten oder Verletzten darauf an, ob die Schuld auf Seiten des Letzteren in einer solchen Weise vorwiegend gewesen ist, daß man sagen kann, der Unfall sei hierdurch verursacht.').

122 According to Luig 1969, p. 234, practice turned to the preponderant responsibility of one of the parties, following also the doctrine of maior culpa as Von Wening-Ingenheim and Dernburg (the latter has been discussed above). Indeed, Von Wening-Ingenheim 1841, p. 48, made an exception to the rule that one cannot claim compensation if the damage was due to one's own fault: the negligence of one party may not be greater (größer) than the negligence of the other party, as far as they are not equal in degree (like dolus and culpa lata). In this context the following may be true (according to Von Wening-Ingenheim): dolus culpa est peior, when, e.g., the wrongdoer was in dolo and the injured party in culpa.

123 Labowsky 1898, p. 39, who referred to ROHG, 7 June 1871, ROHGE 20, 40; ROHG, 9 February 1875, ROHGE 16, 32; ROHG 18 March 1876, ROHGE 20, 66; - A discussion on the case law on contributory negligence in the second half of the 19th century can be found in Aumann 1964, p. 168ff.; Honsell 1977, p. 52ff.

124 RG, 25 September 1885, SeuffA 41, 89. 
Oberste Landesgericht and Oberlandesgericht Braunschweig decided that the weighing of mutual negligences was contrary to the principles of the gemeine Recht regarding contributory negligence. Apparently, in these instances the tendency of a weighing of the negligence of both parties, and to decide only to a reduction of the damages in the event of contributory negligence, existed by the judges of fact. ${ }^{125}$ In 1883, the Reichsgericht for the first time accepted a reduction of the compensation amount in case of contributory negligence. ${ }^{126}$ The principle of judicial estimation of damage according to $\$ 260$ Reichscivilprozessordnung of 1877 (RCPO; now § 287 Zivilprozeßordnung (ZPO)) allowed the Reichsgericht to apply the natural law rule in practice in its totality. ${ }^{127}$ The Reichsgericht held that in case of contributory negligence the judge could determine the compensation amount using the discretionary leeway provided by $\S 260$ (Abs. 1) RCPO. ${ }^{128}$ Nevertheless, the theory of compensation of fault (Kulpakompensation) was still applied in a decision of the Reichsgericht in $1891 .{ }^{129}$ In that case the fault of the injured party led to a denial of his claim for compensation; according to the decision of the Reichsgericht, this would have been different if the victim's fault was insignificant (unerheblich) to the outcome of the case. ${ }^{130}$

\subsubsection{The situation in the Netherlands until 1916}

In the Netherlands, the problem of contributory negligence had to be solved in legal doctrine and practice, as there was no explicit statutory provision on contributory negligence in the Burgerlijk Wetboek of $1838 .{ }^{131}$ Nevertheless,

125 ObLG Bayern, 20 May 1880, SeuffA 35, 285; OLG Braunschweig, 21 November 1887, SeuffA 44, 86; see also Looschelders 1999, p. 22.

126 Aumann 1964, p. 172.

127 ibid.,p.172ff; Luig 1969, p. 234; Honsell 1977, p. 71f., considered the discretionary leeway as a 'eine gewisse begriffliche Erstarrung innerhalb der Pandektenwissenschaft vernunftrechtlichen Ursprungs'; in any case, Honsell argued, the judges without express encouragement had also observed the circumstances of the case and made free use of it to create a legal consequence.

128 RG, 15 October 1883, RGZ 10, 74, 80f.; Aumann notes that one could see the victory of Wolff's doctrine here. Luig, however, argued that the 'gemeinrechtliche Lehre' of maior culpa in essence also dominated the 19th century, and in that sense the decision of the Reichsgericht could be regarded as a completion of a development, i.e. that which started with the decisions of Schoepff and Leyser as mentioned in the previous chapter of this study.

129 RG, 5 May 1891, SeuffA 48, 30.

130 Hübner 1976, p. 496f.; according to Von Leyden 1902, p. 38, § 254 BGB contains the principle of culpae compensatio. However, sometimes a small contributory negligence does not lead to a reduction in the amount of damages, see, e.g., recently Geigel/Rixecker 2001, p. 56; - Occasionally this view in which a small degree of contributory negligence is simply not accounted for can be found; see Jansen 2007, p. 667, footnote 76, who referred to a decision of the OLG Braunschweig of 1891; see OLG Braunschweig, 23 April 1891, SeuffA 47, 28.

131 Also in Voorduin's History and Principles on the part on unlawful acts no explicit reference to contributory negligence is made. This was different in the event of collision of ships, as Article 272 of the draft of the WvK of 1822 stated that in the event of a collision if a considerable fault ('merkelijke schuld') on each side was present, each party had to bear its 
in the Wetboek van Koophandel (Commercial Code, WvK) one provision is relevant as to contributory negligence in collision cases, namely Article 535 WvK (see also below). ${ }^{132}$

The thesis of Van Nierop (in 1905) provides an overview of the legal situation in case law and doctrine on contributory negligence at the end of the nineteenth century and the beginning of the twentieth century. It seems that until then Dutch scholars had not extensively dealt with this matter except for $\operatorname{Ger}(\mathrm{h})$ ardus Diephuis (1817-1899). ${ }^{133}$ Van Nierop tried to explain the legal basis of the deprival of recovery in the event of contributory negligence; what is the legal basis for the principle of culpae compensatio? The views discussed by Van Nierop follow the discussion and the arguments of the Pandectists. Van Nierop rejected various views, namely: the idea that negligence of the injured party cancels out the negligence of the wrongdoer (as defended in pandectist doctrine), ${ }^{134}$ or that the negligence of the injured party lifts the causal connection (as defended in doctrine as well as in case law ${ }^{135}$ ), or that negligence of the injured party is based on the presumption that the victim wants the damage to occur and therefore the maxim volenti non fit injuria applies (theory of Demelius). According to Van Nierop another basis applied, namely equity: ${ }^{136}$

own damage. It is remarkable that the word 'considerable' ('merkelijk') has disappeared in the draft of 1825. See Voorduin 1841, X-III, p. 107; - Arts. 276 and 294 (old) WvK (1838) mention the contributory negligence of the injured insured party. $c f .276$ WvK no loss or damage can be claimed which were due to the negligence of the injured insured party. $c f$. $294 \mathrm{WvK}$ the insurer does not have to compensate the insured party, if the former can prove that the fire was caused due to considerable fault or neglect ('merkelijke schuld of nalatigheid') of the insured person.

132 This article was part of Book Two, Title Six, called Van schade door het overzeilen, aanzeilen, aanvaren en aandrijven veroorzaakt. The wording of Art. $535 \mathrm{WvK}$ is as follows (edn. 1838, p. 121): Bijaldien dit een en ander door de schuld van wederzijde veroorzaakt is, draagt elkzijne eigene schade. De schippers zijn, zoo in dit, als in het bij het vooraangaande artikel bepaalde geval, aan de eigenaars van de schepen en koopmanschappen tot vergoeding gehouden, onverminderd hun verhaal op de officieren en het scheepsvolk, indien daartoe gronden zijn.

133 Diephuis 1888 , p. 87, stated that there was no general rule that gave the solution in the event in which injured party and wrongdoer both acted negligently. It was left to the judge to decide what seemed most appropriate to him, in view of the circumstances. Diephuis refers to the French doctrine of Demolombe (XXXI, no. 502f.) and thereby implicitly alluded to a partition of damage; - Ten years after the thesis of Van Nierop, Scholten also dealt with the matter of contributory negligence; see Scholten 1915, p. 17ff. Legal provisions are only available in collision cases; see Art. 535 WvK: if both are negligent, each party has to bear its own damage. Of course these are rather special cases, in which often both parties have incurred losses. See also Ribbius 1906, p. 210. There are no further legal provisions available in the beginning of the 19th century. Scholten refers to D. 50.17.203, but states that this rule is not correct in its general sense. See Scholten 1902, p. 434f. On p. 436 he states that he did not succeed in finding examples of the application of the weighing of the causality of faults in case law, although the silence on this point in the law could have given way to such interpretation; Scholten presumed that the reason was that one strictly held to the rule of Roman law (D. 50.17.203).

134 In the same sense Ribbius 1906, p. 191, 215.

135 Van Nierop 1905, p. 30ff.

136 Also Ribbius 1906, p. 191. 
considerations of fairness may lead to denial of compensation to the injured party, when he has to impute the damage to himself (as he acted as a foolish person). ${ }^{137}$ If the injured party could have prevented the damage from occurring, his claim for damages will be denied. When the basis is fairness/equity, the fact that the act of the injured party contributed to his own damage, however, does not always have to lead to a denial of the claim for compensation, this only occurs when such a denial seems fair in a concrete case. ${ }^{138}$

Assuming the injured party acted negligently, did this always lead to a denial of claim, even though his negligence was small? Van Nierop rejected Dernburg's criterion of the 'main cause' of the damage; he argued that instead of weighing causality, negligence should be weighed. ${ }^{139}$ One should consider the 'main fault': whose negligence was the most serious? Only when the negligence of the injured party was less than that of the wrongdoer could the victim obtain compensation; ${ }^{140}$ otherwise, his compensation would be totally denied. Van Nierop seems to support the maior culpa theory (in the sense that the negligence of one party could mean little in comparison to the negligence of the other party). The weighing of negligence is in fact a restriction to the doctrine of culpae compensatio, based on fairness. ${ }^{141}$ Apparently, Van Nierop did not yet consider a middle course a possibility. Although Van Nierop seems to leave this possibility - in passing - open when he wrote that the possibility to partition the damages depends on the question of whether the judge has the competence to moderate the amount of damages, to which question Van Nierop did not go into. ${ }^{142}$

137 Van Nierop referred to Roman law, namely to the de se queri debet phrase of Ulp. D. 9.2.11pr., and to Molière: 'Vous l'avez voulu, George Dandin!. See J.B.P. de Molière, George Dandin, I.VII (edn. 1693, p. 22): ‘Ah que je ... vous l'avez voulu, vous l'avez voulu, George Dandin, vous l'avez voulu, cela vous sied fort bien, et vous voilà ajusté comme il faut, vous avez injustement ce que vous meritez. Allons il s'agit seulement de desabuser le pere et la mere, et je pourrai trouver peut-étre quelque moyen d'y réüssir.'

138 Van Nierop 1905, p. 42 f.

139 ibid., p. 54, 58.

140 ibid., p. $58 \mathrm{f}$.

141 ibid., p. 65. Van Nierop also discusses contributory negligence in the situation in which a wrongdoer is liable based on risk, as in the situation of a subordinate; see Van Nierop 1905, p. 68ff.

142 Van Nierop 1905, p. 69f.: 'Ik hoop aangetoond te hebben onder welke omstandigheden wel, onder welke omstandigheden niet, de aansprakelijkheid van den benadeeler door de eigen schuld van den benadeelde opgeheven wordt. Of dan, wanneer dit laatste niet het geval is, bij de bepaling van de schadevergoeding toch eenigszins met de schuld van den benadeelde rekening gehouden mag worden, is een vraag, die hier niet uitgemaakt kan worden. Daarvoor zou eerst onderzocht dienen te worden, in hoever de rechter de bevoegdheid heeft het bedrag der schadevergoeding te matigen, of die bevoegdheid al of niet beperkt is tot de gevallen, waarop art. 1392 B.W. slaat. Het is een vraag, die onze materie niet raakt, daar het mij slechts te doen was te onderzoeken, wanneer de schuld van den benadeelde vrijdom van aansprakelijkheid medebrengt, en wanneer dit niet het geval is.' See also Ekering 1941, p. 132. However, one has to keep in mind that the competence to moderate the (total) damages is something different than 
In case law, a partition of damages in cases of traffic accidents was rarely applied in the period before $1916 .{ }^{143}$ In its decision in a collision case in 1896 , the district court (Rechtbank Rotterdam) decided that both plaintiff and defendant acted negligently. The court decided to dismiss the claim for damages; it argued that one had to consider the rule of Article $700 \mathrm{WvK}^{144}$ as a confirmation of the rule that he who suffers damage as a result of his own fault is not able to lay any claim for damages ${ }^{145}$ - although the court did not mention it explicitly, ${ }^{146}$ this, in my opinion, is a clear application of the rule of D. 50.17.203. In another case decided by the Gerechtshof Amsterdam in 1913, it was decided that the injured party could not claim recovery due to his contributory negligence; the Gerechtshof came to this conclusion by applying the culpae compensatio doctrine. The lower court, the Rechtbank, already had decided that in this case of a collision between a person and a steam tram that the fault of the wrongdoer was cancelled out by the carelessness of the injured party. ${ }^{147}$ The Gerechtshof agreed and argued that in this case the injured party acted with a large amount of carelessness, which in the first place caused the accident, and the fault of the wrongdoer - on the other hand - was very small. ${ }^{148}$

In some other cases, despite the carelessness of the injured party, the liability of the wrongdoer remains existent in full (also outside the intention of the wrongdoer): no culpae compensatio took place (apparently it would be different if the injured party acted intentionally). ${ }^{149}$

an apportionment of damages.

143 See also Ekering 1941, p. 137. The all-or-nothing approach was still applied by the Rechtbank Amsterdam in a decision of 1 February 1918. In this case, a steam tram hit a car, which stood still on the railroad track due to problems with the engine. The court of first instance stated that the injured party could only claim damages if the fact that the car stood still on the railroad track was not due to the negligence of the injured party. This point of view repudiated by a decision of the Gh. Amsterdam 16 May 1919, NJ 1919, 989, who argued that contributory negligence of the injured party does not have to lead to a denial of claim but can also lead to a reduction of the amount of damages; - It has also been stated that in Dutch case law of lower courts, the development from the all-or-nothing approach to the partition of damages as can be found in the judgment of the Hoge Raad of 1916 was gradual; see Smits 1997, p. $214 f$.

144 Article $700 \mathrm{WvK}$ (edn. 1838, p. 165): Wanneer inwendige gebreken van het schip, dezelfs ondeugdzaamheid tot het doen der reize, of schuld en nalatigheid van den schipper of het scheepsvolk, de schade of onkosten hebben veroorzaakt, zijn laatstgemelden, hoezeer ten nutte van schip en lading vrijwillig gemaakt, geene gemeene avarij.

145 A-Rb. Rotterdam, 9 December 1896, W. 6910 (1897).

146 This is understandable since Roman law was abolished as a source of law in the Wet Algemene Bepalingen (General Provisions Act) of 1829.

147 One of the results of the Industrial Revolution was a revolution in the means of transport, among which also rail transport and (steam) trains; unfortunately, this also led to (new) accidents. People crossed railway tracks sometimes without first looking both ways carefully. Also in Belgium comparable accidents with trains occurred. See on this topic elaborately Picard \& d'Hoffschmidt (eds.), Pandectes belges, II, vers. Accident de chemin de fer.

148 Gh. Amsterdam 31 March 1913, W. 9586.

149 See, e.g., A-Rb. Arnhem, 5 October 1899, W. 7343; A-Rb. Haarlem, 20 June 1903, W. 8083. 
In a case submitted to the Rechtbank Arnhem in 1899, the plaintiff (a widow) received three debentures by means of payments to the mayor of the municipality Valburg. The mayor and an alderman of Valburg signed the debentures; however, the debentures appeared to be false and were not based on legal decisions of the council of the municipality. In the lawsuit, in which the plaintiff demanded compensation of her payments made with interests, the Rechtbank Arnhem decided that the defendant in this case, i.e. the alderman, acted very carelessly (by countersigning the false debentures) and committed a wrongful act; the unlawfulness of the act of the defendant was not removed according to the court - by the carelessness of the plaintiff (who, according to the defendant, could have convinced herself of the falsity of the debentures). The latter's carelessness/imprudence was so small compared to that of the defendant that the defendant could not be excused because of that. ${ }^{150}$ Another interesting case is one decided by the Rechtbank Haarlem in 1903. In this case, the plaintiff's daughter (aged 14) worked in a factory where she seized and stacked envelopes, which, by the roller of a sorting machine, were flattened and thrown out. By accident she got her hand stuck between the cogwheels of the machine (a part of which was not shielded) and was seriously injured. The defendant, the public limited company Vereenigde Koninklijke Papierfabrieken of the firm Van Gelder Zonen, was held liable based on Articles 1401 jo. 1402 of the Burgerlijk Wetboek of 1838 for the damage caused by its negligence; that the carelessness of the injured party did not cancel out the negligence of the wrongdoer, and that it was not proven that the injured party (or in this case the man's daughter) acted intentionally. ${ }^{151}$

In other cases, a partition of damage was permitted..$^{152}$ An interesting application of the culpae compensatio doctrine can still be found in a decision of the Rechtbank Rotterdam of 1911. The court decided that the acts of each party were not without carelessness (onvoorzichtigheid), the negligence of the injured party did not completely nullify the wrongdoer's negligence (schuld), and the liability partially remained; finally, the court awarded half of the damages to the injured party. ${ }^{153}$ This decision indeed proves an application of a partition of damages, and proves that the lower court took distance from the all-or-

150 A-Rb. Arnhem, 5 October 1899, W. 7343

151 A-Rb. Haarlem, 20 June 1903, W. 8083.

152 However, without being clear on what basis the decisions rest; see Smits 1997, p. 215, who refers to A-Rb. Zierikzee, 7 June 1898, W. 7191 (1898): ' ... dat de ingestelde vordering tot schadevergoeding ook niet ondeelbaar is, omdat zij strekt tot betaling van een geldsom, welke zeer goed vatbaar is voor verdeeling', and to A-Rb. Rotterdam, 24 November 1902, W. 7969 (1903), where a similar formulation can be found. However, these decisions seem as having to do with the situation in which there are more wrongdoers, not with contributory negligence.

153 A-Rb. Rotterdam, 6 March 1911, NJ 1914, 1223. 
nothing approach. Also in the case that later led to the important decision of the Hoge Raad in 1916, the Gerechtshof Amsterdam in 1915 applied the culpae compensatio doctrine and decided to partition the damage 50/50, i.e. the injured party got only half of his loss compensated. According to the Gerechtshof, the carelessness of the injured party could lead to a total or partial expiration of his claim for damages. ${ }^{154}$ It is interesting that the cassation plea to the latter case referred to the French term 'faute commune' ${ }^{155}$ (and to several Articles of the Burgerlijk Wetboek and Wetboekvan Koophandel which should have been violated) and argued that in such a case the damage should be partitioned proportionate to the degree of the faults of both parties instead of leading to a denial of claim for damages. In his conclusion, Procurator-General Tarquinius Johannes Noyon (1848-1929), ${ }^{156}$ argued that no partition of damages should be made: the damage was not due to the negligence of the injured party, but due to the negligence of the wrongdoer. ${ }^{157}$ Noyon argued that Article 1401 and following of the Burgerlijk Wetboek did not deal with this question as in this case only Article $535 \mathrm{WvK}$ - as mentioned above - was relevant as to the matter of contributory negligence. In that article it is stated that in the event of a collision of two ships where both were to blame, each ship should carry its own loss. ${ }^{158}$ Article $535 \mathrm{WvK}$ only cuts the knot of the matter, and even in an unfair way, as the degree of the faults on both sides is not taken into account, and small fault and big loss and small fault or large loss can coincide in one ship. ${ }^{159}$ According to Noyon, one cannot deduce a general system of law regarding partition of fault and damage from this article. Noyon argued that the answer

154 Gh. Amsterdam, 8 February 1915, NJ 1915, 955; in Gh. Amsterdam, 28 January 1910, W. 9066, a steam tram-train collided with a cart and its horse (horse and carriage) that had got stuck on the rail/track when it tried to cross it. In its decision, the Court made the observation that a fault of the injured party could eliminate or reduce the liability of the wrongdoer.

155 In the facts of HR, 30 October 1925, NJ 1926, 157, a collision of a steamship called Mijriam against a suction dredger occurred (owned by Compagnie Auxiliaire resp. by Volker). When the injured party, Volker, brought a suit against the owner of the steamship Mijriam, i.e. Compagnie Auxiliaire, the latter served a third-party notice on the owner of the ship Aldebaran, i.e. Van Nievelt Goudriaan. According to the Compagnie Auxiliaire, the Mijriam had hit the suction dredger due to a dangerous manouvre of the Aldebaran. The court of first instance (Rechtbank) decided that due to the concurrence of faults each party was only liable for part of the damage, namely proportionate to its fault; in that case a faute commune would be present as meant in Article 4 of the Collision Convention of Brussels of 1910 (see section 5.3.1.2); however, the Gerechtshof argued that the case under dispute did not fall under the words faute commune as this term implied contributory negligence of the injured party. The Dutch Hoge Raad, however, stated that, $c f$. Art. $1401 \mathrm{BW}$, in cases where there are more persons at fault each is liable in full. Furthermore, the wrongdoers have recourse against each other.

156 On T.J. Noyon, see, e.g., Van Koppen \& Ten Kate 2003, p. $189 \mathrm{f}$.

157 T.J. Noyon in his opinion ('conclusie') ad HR, 4 December 1916, NJ 1916, 450.

158 However, Noyon stated this article is unique in the Dutch legislation, which came about via Van der Keessel, Thesis 816, and was derived from Van Bijnkershoek, Quaestiones juris privati, IV, cap. 22.

159 See also Kist 1889, p. $402 f$. 
as to the problem of contributory negligence could (only) be found in Article 1401 and following of the Burgerlijk Wetboek. According to Noyon, in the case under dispute there is no faute commune, as the fault on one side totally differs in nature from that on the other side. As to Article 1401, there is only one alternative: if the wrongdoer was at fault, he is liable in total; if he was not at fault, he is not liable at all. Therefore, the Gerechtshof should have balanced/weighed the 'negligent degree of the' facts on both sides and only come to the conclusion that the wrongdoer was at fault or not based on the preponderant 'negligence' on one of the sides (which seems similar to the earlier culpa maior theory). ${ }^{160}$

As stated before, the Dutch Hoge Raad decided on the partition of damages in its decision of 1916 (partition of the damage based on unlawful acts ${ }^{161}$ of multiple persons). ${ }^{162}$ The facts of the case were, in brief, the following. A pedestrian was hit on a public road in Amsterdam when he tried to cross the rails which were used to shunt (railway) trains. He was grabbed by a shunting train of the Hollandsche IJzeren Spoorwegmaatschappij which just at that moment passed by. The arm of the pedestrian was so mutilated that it had to be amputated. In legal doctrine, this turn could have been initiated by two proponents, Paul Scholten (1875-1946) ${ }^{163}$ and Hendrik Rudolph Ribbius (1881-1934). ${ }^{164,165}$ Scholten and Ribbius were indeed proponents of the idea of reducing the amount of damages in the event of contributory negligence. ${ }^{166}$ Scholten argued that there was no relevant legal

160 T.J. Noyon in his opinion ('conclusie') ad HR, 4 December 1916, NJ 1916, 450.

161 Furthermore, in 1919 the Hoge Raad fundamentally distanced itself from the restricted interpretation of the word 'wrongful' in Article 1401 of the Burgerlijk Wetboek and stated that a wrongful act can also exist in behaviour which is contrary either to good morals or to the care which is due in society with regard to another's person or property. See HR, 31 January 1919, NJ 1919, 161; Van Maanen 1995, p. 47. The trend to broaden liability can possibly already be seen in the decision of the Hoge Raad of 1916 mentioned in the main text above, where the central question was whether contributory negligence of the injured party cancels out or limits the fault of the personnel of the railways. The Hoge Raad did not test whether the behaviour was a violation of a right or contrary to a legal obligation, but just spoke about fault ('schuld'). According to Van Maanen 1995, p. 50, it is not impossible that by using this term, the Dutch Hoge Raad would have wanted to distance itself from the restricted scope of the extra-contractual liability, which was the consequence of the interpretation of the term 'wrongful' ('onrechtmatig') in the decision of the Hoge Raad of 1910 (HR, 10 June 1910, W. 9038).

162 After the decision of the Hoge Raad, a note was written to the decision by Meijers in 1916 (WPNR 2425), where he wrote: 'Een alleszins billijke beslissing, maar waartoe men moeilijk kan komen zonder gebruik te maken van een - overigens zeer toe te juichen - vrije rechtshanteering.'

163 P. Scholten was a professor of law at Amsterdam University. On Scholten, see elaborately Peletier 1979, p. $536 \mathrm{ff}$.

164 H.R. Ribbius became a professor of law at the Netherlands School of Economics, Rotterdam.

165 Keirse 2005, p. 5; see also note by Meijers to HR, 4 December 1916, NJ 1916, 450.

166 As discussed above, a partition was already alluded to by Diephuis, who argued that in the event of contributory negligence, although no legal provision existed (except for Arts. 534ff. WvK), the judge had to decide based on the circumstances of the case what the legal consequences of such contributory negligence were in a way that seemed to him most appropriate ('zoo als hem het meest gepast voorkomt'); see Diephuis 1888, p. 87. 
provision as to contributory negligence - except for Article 535 of the Wetboek van Koophandel - and thus legal doctrine had to give a solution on this. Legal doctrine often applied the pandectist rule of D.50.17.203; however, according to Scholten, this rule was in general incorrect. In the event of contributory negligence, one does not have to deny a claim for damages. He referred to $§ 254$ of the German Bürgerliche Gesetzbuch and argued that such a partition of damages would be desirable. ${ }^{167}$ Scholten stated that he could not find examples of such a partition based on a weighing of causality or fault, although the silence of the law would definitely leave room for such weighing. He explained this by saying that the reason presumably was that judges strictly applied the Roman law rule of D. 50.17.203. ${ }^{168}$ Besides $§ 254$ of the German Bürgerliche Gesetzbuch, Ribbius also referred to Article 51 II of the Schweizerische Obligationenrecht; Ribbius noticed that these two legal provisions (which were 'newer' compared to the 'older' Burgerlijk Wetboek) did not ignore/pass over the problem of contributory negligence, but regulated this topic in a general way and showed that the carelessness of the injured party could have an influence on the extent of liability of the wrongdoer. ${ }^{169}$

\subsection{CODIFICATIONS AROUND 1900}

\subsubsection{The German drafts for codification}

The detailed rules on contributory negligence in the Prussian Allgemeine Landrecht (discussed above) led to criticism in legal doctrine; the objections that the rule(s) of the Allgemeine Landrecht were not adequate and practical could have been reasons which persuaded the drafters of the Bürgerliche Gesetzbuch not to make a similar rule and to leave the treatment of the problem in essence to the judicial discretion (of the judge).${ }^{170}$ As to the dogmatic principles on contributory negligence, which already became clear in section 5.3.2, the drafters of the Bürgerliche Gesetzbuch could not base themselves on one established doctrine. This insecurity can also be found in the two drafts (Entwürfe) of the Bürgerliche Gesetzbuch: what is it exactly that is balanced, negligence or causation? As will be discussed below, the first draft started from the idea of culpae compensatio, while the second draft focussed on the causal relation. ${ }^{171}$

167 Scholten 1902, p. 434f.

168 ibid., p. 436; Scholten also refers to French case law where the damage was partitioned, the total amount of damages was reduced, in cases of contributory negligence.

169 Ribbius 1906, p. 190ff., esp. p. 212ff.

170 Looschelders 1999, p. 26.

171 See also Looschelders 1999, p. 29. Furthermore, the author of the Bürgerliche Gesetzbuch was also influenced by the idea of the limitation of the recoverable interests. 
It is unclear whether a division of damages according to quotas known in Germany as the partition of shares ('Quotenteilung') was not yet provided by $\S 222$ Entwurf $\mathrm{I} ;{ }^{172}$ the latter provision reasons from a weighing of faults: which fault was preponderant as to its consequences on the result (damage) in question. In this way it provided a limitation of the attribution of damage. ${ }^{173}$ It is self-evident that $§ 222$ Entwurf I implies that the injured party's contributory negligence does not eliminate the causal connection between the wrongdoer's act and the damage. Because if this causal connection were absent, no liability would occur at all (among others the Motiven refer to D. 50.17.203). ${ }^{174}$ Although Entwurf I contained the words 'mitwirkende Fahrlässigkeit', the Motiven show that the quality, i.e. the culpability, of the act of the injured party is especially relevant here. Due to the rule of weighing it is pretended that negligence of the wrongdoer and contributory negligence are of similar nature. ${ }^{175}$ Possibly the draft was not so much a renewal (no distribution of damage in the form of quotas) but just a codification of the situation in the gemeine Recht was this view held by various scholars (see already above; the idea of compensation of faults). ${ }^{176}$ Some argued that such renewal was indeed the case: according to Levison, $§ 222$ Entwurf I made it possible to provide partial compensation in the event of a small contributory negligence (he probably did think about a creation of quotas). ${ }^{177}$ Recently, Looschelders argued that the author of $§ 222$ Entwurf I wanted to grant the judge the possibility to make a partition based on quota. ${ }^{178}$

The decisive criterion changed in $\S 217$ Entwurf II to the extent to which the injury was caused predominantly by one or the other party ('vorwiegende Verursachung'), in order to - according to the Protocol - cover cases of strict liability (i.e. liability without fault) ${ }^{179}$ However, it is improbable that one departed from the dogmatic concept of weighing (Abwägung) of faults as a result

172 In this sense Honsell 1977, p. 74; On (the relevant provision on contributory negligence in) the first draft and the second draft of the Bürgerliche Gesetzbuch (1887 resp. 1895), see also Looschelders 1999, p. 30ff., 32ff.

173 Honsell 1977, p. 74f.

174 'Motive' in Mugdan 1899 (reprint 1979), II, p. 13; see also Looschelders p. 34; - § 254 BGB is only relevant when the injured party's own responsibility a priori did not cancel out all responsibility of the wrongdoer; these cases should be distinguished from the cases which fall under § 254 BGB. See Looschelders 1999, p. 429ff.; Jansen 2007, p. 661.

175 Honsell 1977, p. 75.

176 See Honsell 1977, p. $76 f$.

177 ibid., p. 78.

178 Looschelders 1999, p. 30.

179 'Protokolle' to $\$ 222$ Entwurf (I) in Mugdan 1899 (reprint 1979), I, p. 519: ‘... auch solche Fälle zu decken, bei welchen Jemand für seine eigene Handlungen ohne Rücksicht auf Verschulden oder für die Handlungen eines Dritten einzustehen hat.; Looschelders 1999, p. 33; Jansen 2007, p. 707. 
of this change. ${ }^{180}$ The change can be considered a commitment to the judicial practice of the gemeine Recht, yet at the same time one opposed to the doctrine of Windscheid that not all degrees of contributory negligence had to cancel out the injured party's right to claim compensation in total. § 217 Entwurf II was in the first place understood as a corrective to the general principle of total compensation. ${ }^{181}$ The fluctuation between weighing of fault and weighing of causation in Entwurf I and II is characteristic for the dilemma caused by the sharp separation between basis of liability and extent of liability. In § 254 BGB no break with the judicial practice of the gemeine Recht was intended; a mitigation of damage as a legal consequence of $\S 254$ BGB remained possible; in particular the concept of interruption of the causal connection was integrated in this new legal provision. ${ }^{182}$

\subsubsection{The solution of the German Bürgerliche Gesetzbuch (1900)}

In Switzerland, the natural law solution (particularly in Article 51 II of the Schweizerische Obligationenrecht $)^{183}$ had been codified under the influence of the Austrian Allgemeine Bürgerliche Gesetzbuch ${ }^{184}$ as well as the French doctrine. ${ }^{185}$ Eventually, the Swiss code, as to the problem of contributory negligence, was taken as example by the drafters of the German Bürgerliche Gesetzbuch and, also under the influence of case law, the Swiss regulation was taken over in its entirety. ${ }^{186}$ The German provision of $§ 254$ BGB reads as follows: ${ }^{187}$

180 Unless one argues that the weighing of faults regarded the partial consequences; then, the transition to Dernberg's doctrine of preponderant cause was easy to perform; see Honsell 1977, p. 80.

181 Honsell 1977, p. 83f.

182 ibid., p. 86.

183 On Art. 51 II Schw. OR 1881, Art. 44 I Schw. OR 1911, and more in general on the Schweizerische Obligationenrecht, see Aumann 1964, p. 199f.; Looschelders 1999, p. 74ff.; - According to Stoll 1972, p. 139, the Continental legal theory of the 19th century went beyond the natural law system of fixed levels of liability and developed the general principle that an equitable balance must exist between culpability and loss compensation. Apparently, the Swiss legal scholar Bluntschli was the first to articulate this axiom (see Bluntschli 1855, p. 69), and thereafter the same doctrine was advocated in other countries by scholars such as Jhering, Pfaff, Larombière and Laurent; see Stoll 1972, p. 139, for the relevant references.

184 The Austrian OGH almost always came to an apportionment in halves in the second half of the 19th century; it was only in 1896 that a division of the damage into thirds was applied. The Austrian case law was cautious in applying a partition of damage going further than a halving; see Honsell 1977, p. 73.

185 See Aumann 1964, p. 161ff., p. 164ff.; on this topic also the 'Motive' in Mugdan 1899 (reprint 1979), II, p. 13.

186 Luig 1969, p. 235; see also Aumann 1964, p. 175-190.

187 On contributory negligence and the provision of $\S 278$, see, e.g., Looschelders 1999, p. 502ff.; Weyts 2003, p. 227 with references, Fedtke \& Magnus 2004, p. 86f., 88f.; Jansen 2007, p. 704ff. Therefore, the Mitverantwortlichkeit des Geschädigten does not cover only the possible negligence of the injured party himself but also the imputability of acts of third parties and also the question whether an increase in the risk must be imputed to the victim; see Jansen 2007, p. 656. 
$\S 254$ BGB: (1) Hat bei der Entstehung des Schadens ein Verschulden des Beschädigten mitgewirkt, so hängt die Verpflichtung zum Ersatz sowie der Umfang des zu leistenden Ersatzes von den Umständen, insbesondere davon ab, inwieweit der Schaden vorwiegend von dem einen oder dem anderen Teil verursacht worden ist. (2) Dies gilt auch dann, wenn sich das Verschulden des Beschädigten darauf beschränkt, dass er unterlassen hat, den Schuldner auf die Gefahr eines ungewöhnlich hohen Schadens aufmerksam zu machen, die der Schuldner weder kannte noch kennen musste, oder dass er unterlassen hat, den Schaden abzuwenden oder zu mindern. Die Vorschrift des $\$ 278$ findet entsprechende Anwendung. ${ }^{188}$

The development after the enactment of this article did not immediately lead to a break with the practice influenced by Pandectism; instead of that, $\S 254 \mathrm{BGB}$ is also at a minimum to be regarded as an expression of the rule of D. 50.17.203. ${ }^{189}$ After all, some authors explicitly come to a limitation of the amount of compensation from the point of view of an interruption of the causal connection. ${ }^{190}$ Also, the case law of the Reichsgericht seems to have used $\S 254$ BGB to limit the amount of damage without applying a distribution (of damage) in the form of quotas. ${ }^{191}$

188 An English translation can be found in the edn. of Kiiver \& Kornet 2010, p. 281: (1) If fault on the part of the injured person contributed to the occurrence of the damage, the duty to compensate as well as the extent of compensation to be made will depend on the circumstances, in particular to what extent the damage is caused predominantly by one or the other party. (2) This also applies if the fault of the injured person is limited to the fact that he failed to draw to the attention of the debtor to $[\mathrm{sic}]$ the risk of unusually extensive damage, where the debtor neither was nor ought to have been aware of the risk, or he failed to avert or reduce the damage. The provision of $\S 278$ applies mutatis mutandis.

189 See Honsell 1977, p. 88; - In certain cases legal provisions still include the all-or-nothing approach in the event of (culpable) Mitverursachung, in the Bürgerliche Gesetzbuch as well as in other special laws; see Looschelders 1999, p. 48ff., 61f. According to this scholar, these provisions are not based on a consistent basic idea, and furthermore, none of these rules was based on the principle of culpae compensatio. Unfortunately, a further investigation into this topic falls outside the ambit of this study.

190 See Honsell 1977, p. 88f.; - The provision seems to mix two thoughts, namely that of the interruption of the causal connection and that of the compensation of fault (Kulpakompensation); see also Jansen 2007, p. 679 with references, who also stated that part of the doctrine and case law initially resorted to the doctrine of the individual imputation of certain parts of the loss resulting from the damaging event based on the criterion of preponderant causation.

191 See Honsell 1977, p. 91f., with reference to RG, 9 May 1900, RGZ 46, 203, 207 (application theory of interruption of causal connection, and application of D. 50.17.203 and $\S 254$ Abs. II to exclude consequential damages) and RG, 13 February 1905, RGZ 60, 149 and RG, 11 May 1908, RGZ 68, 353. However, a more nuanced view is necessary here. The Reichsgericht already early on considered $\S 254$ BGB as an authorisation to a partition of damages in the form of quota; see Jansen 2007, p. 680 with reference to RG, 12 February 1903, RGZ 53, 394, 399f., RG, 21 January 1905, RGZ 60, 33, 34, 36 and RG, 21 November 1907, RGZ 67, 120, 123. Explicitly, the Reichsgericht called it a partition of damages in the form of quota in RG, 11 December 1905, RGZ 62, 145, 148. However, it must be admitted that the courts also initially held to the possibility to focus on the causality of each individual consequential damage and equally related oneself to $§ 254 \mathrm{BGB}$. See RG, 13 February 1905, RGZ 60, 147, 150f. and RG, 11 May 1908, RGZ 68, 352, 353f. However, the idea 
The provision of $\S 254$ BGB as well as the original 222 Entwurf I did not contain an explicit disposition of a distribution of damages in the form of quotas. The purpose of the historical legislator is still disputed (Was the provision meant to assign individual consequential damages to the parties involved or was it meant to partition damages in the form of quotas?). The only certainty is that the rigid, dominant theory of the later ius commune tradition was left behind in favour of a more flexible division of damages, as was already the case in neighbouring jurisdictions such as Austria, France and Switzerland. ${ }^{192}$ With $§ 254$ BGB, the all-or-nothing approach (and the theory of culpae compensatio) was abolished for the general provision on contributory negligence; ${ }^{193}$ contributory fault of the injured party now constitutes an exception to the principle of full compensation. ${ }^{194}$ The provision of $\S 254 \mathrm{BGB}^{195}$ is applicable to both contractual and delictual liability. ${ }^{196}$ Systematically, contributory negligence in $\S 254$ BGB is important both as a factor which can exclude liability as well as a method to determine the reduction of damages. ${ }^{197}$ Liability can thus range between 0 and 100 per cent; the defence of contributory negligence must be pleaded and proved by the person provoking it. ${ }^{198}$ According to $\S 254 \mathrm{BGB}$, the total damage is apportioned between the litigating parties concerned, depending on the circumstances, especially upon how far the injury has been caused predominantly by one or the other party; ${ }^{199}$ however, this has to be interpreted as 'in proportion to their respective degrees of causation and negligence'. ${ }^{200}$ The primary measure seems to be causality, buwt the judge can take into account

of an individual attribution of certain consequential damages was increasingly considered to be foreign and adverse to the system; see Jansen 2007, p. 680, who referred to RG, 09 December 1909, JW 1910, 65f.

192 Jansen 2007, p. 678.

193 See also Wester 1976, p. 2.

194 Also Gerven, Lever \& Larouche 2000, p. 703.

195 An extensive commentary on § 254 BGB can be found, e.g., in Lange 1979, p. 333ff.; Soergel/Mertens 1986, p. 346ff.; MünchKommentar BGB/Oetker §254 (2007); Jansen 2007, p. 677ff.; Erman/Ebert 2008, p. $955 \mathrm{ff}$.

196 See also, e.g., Lange 1979, p. 336; - On contributory negligence and strict liability, see, e.g., Fedtke \& Magnus 2004, p. 84f.

197 Fedtke \& Magnus 2004, p. 75.

198 ibid., p. 76.

199 According to Enneccerus-Lehmann 1958, p. 81 n. 11, the replacement of the criterion of fault in the first draft of the BGB by the causal test in the second was merely intended to generalise (and not to change the essence of) the principle of partition of damages; not only the faults of the parties involved but also - in the event of liability without fault - other grounds for liability or for relief of liability should be balanced against each other. See also Honoré 1983, p. 122; - For the procedural aspects as to the problem of Mitverschulden, see, e.g., Geigel/Rixecker 2001, p. 62f.

200 Wacke 1977, p. 11; 1979, p. 276; Gerven, Lever \& Larouche 2000, p. 703; - An older discussion of the requirements of Verursachung and Verschulden can be found with Rother 1965, p. 42ff. (with enumeration of various views in scholarly literature); Wester 1976, p. 252ff.; Jansen 2007, p. 707ff. The concept of (eigenes) Verschulden is also extensively discussed by Adriani 1939. 
other concrete factors in the apportionment of damage, e.g. the nature of the faults, the social and economic relation between the litigating parties, including a possible insurance agreement, the personal relationship between the parties, the nature of the damage, etc. ${ }^{201}$ The defence of contributory negligence can also be taken into account against a wrongdoer who is strictly liable. ${ }^{202}$

In Germany, contributory negligence, i.e. Mitverschulden ${ }^{203}$ in the sense of $\S$ 254 BGB, applies when the plaintiff acts negligently as regards his own interests. ${ }^{204}$ In the past, various dogmatic solutions were given in doctrine as to the legal basis for this rule of Mitverschulden. ${ }^{205}$ None of these theories seem to explain the Verschulden in $§ 254$ in a satisfying and in all the facts comprehensive manner. ${ }^{206}$ Today two approaches have established themselves. ${ }^{207}$ Some scholars justify contributory negligence by the prohibition of self-contradictory or inconsistent behaviour (venire contra factum proprium), and this idea is thus closely related to the idea of loyalty, equity and good faith (i.e. Treu und Glauben) codified in $\S 242$ BGB. ${ }^{208}$ If an injured party demands full compensation although he partly caused his damage, the claim is regarded as being against good faith. ${ }^{209}$ Other scholars trace $§ 254$ BGB back to the principle of responsibility (Verantwortlichkeitprinzip), ${ }^{210}$ included in $\S 840$ BGB that each

201 Weyts 2003, p. 470 with references.

202 For the first time decided by the Reichsgericht in the event of liability of an animal keeper ( $\$ 833$ BGB); see RG, 5 May 1902, RGZ 51, 275, 277 and Looschelders 1999, p. 254.

203 On this term see, e.g., Von Bar 2000, p. 544; contributory negligence is viewed by reference to an objective standard, which is determined by the standard of conduct by one's peers; see Von Bar 2000, p. 560; - Various dogmatic bases are provided for Mitverschulden; these can already be found with Wester 1976, p. 4ff. On the various views on the Verschuldensbegriff and on the Sorgfaltmaßstab, see also the same Wester 1976, p. 128f., p. $129 \mathrm{ff}$.

204 Van Dam 2006, p. 335; see also Geigel/Rixecker 2001, p. 48: 'vorwerfbar gegen seine eigenen Interessen verhalten hat'; - If an operational risk or inherent danger in tangible property of the injured party contributed to the cause of the damage, this in principle leads to a reduction in the amount of compensation. See also, including exceptions to this rule, Von Bar \& Clive 2009, p. 3653, who gave a summary of some leading cases (case law) on this topic.

205 See, e.g., Rother 1965, p. 80ff; Schäfer 1969; recently Jansen 2007, p. 689, 690ff. Various views can be distinguished: that $\S 254$ BGB regards real negligence, the theories of Verschulden ohne Rechtswidrigkeit, Verschulden gegen sich selbst, § 254 BGB as an expression of Treu und Glauben, the doctrine of Obliegenheitsverletzung, the idea of a violation of a genuine legal obligation, or the legal duty to the nation as a whole, the doctrine of the sozialen Pflicht, and considering the standards of conduct as hypothetical imperatives in the sense of the Kantian deontology.

206 In the same sense Lange 1979, p. 346.

207 See Wurmnest 2003, p. 304.

208 Fedtke \& Magnus 2004, p. 76f., also including other views of academics on this topic; on the latter principle, see Adriani 1938, esp. p. 23ff., also on the idea of venire contra factum proprium. See also Jansen 2007, p. 692.

209 See, e.g., Weyts 2003, p. 347f. with references; Wurmnest 2003, p. 304; Fedtke \& Magnus 2004, p. 76.

210 See, e.g., Looschelders 1999, p. 118 with references. 
wrongdoer - according to his responsibility - has to pay for the damage. ${ }^{211}$ In that case, § 254 BGB regulates damage that falls within the area of the common responsibility of wrongdoer and injured party. ${ }^{212}$ The author of $\S 254$ BGB principally chose for the equal treatment of wrongdoer and injured party. ${ }^{213}$

Before the conditions for a partial reduction due to contributory negligence can be considered there has to be a right of compensation of the injured party against the wrongdoer. The act of the injured party must be contrary to law; § 254 (1) BGB preconceives the objective fault requirement that is filled on the basis of $\S 276 \mathrm{BGB},{ }^{214}$ i.e. there is a fault of the injured party if he acts intentionally or if he in a careless manner forsakes to take the care which he owed with regard to his own interests. ${ }^{215}$ Apart from this infringement of the duty of care (Sorgfaltsverletzung), for $\S 254$ BGB to become applicable his conduct must be imputable to the victim (delictual capacity as defined by $\S \S 827 / 828$ BGB) and there must be a causal link between his conduct and the injury. ${ }^{216}$ In principle, an objective test is applied to the victim's conduct, i.e. the conduct of a careful person of average circumspection and capability is decisive. ${ }^{217}$

211 Wurmnest 2003, p. 304.

212 See also Jansen 2009, p. 1080; - While the (medieval) Roman law solution presupposes a strict separation of the responsibilities of the parties involved, as according to this solution the responsibility of the wrongdoer ends where that of the injured party begins - to which the all-or-nothing approach is the only thinkable model - the modern acknowledgment of the overlapping responsibilities of both parties does not lead to the all-or-nothing approach as the only thinkable solution. The latter lends itself more to a partition of damages based on the respective responsibilities. See Looschelders 1999, p. $12 \mathrm{f}$.

213 Looschelders 1999, p. 127.

214 Although the fault as required by $\S 254$ BGB is, however, not (really) comparable to the general standard as defined in $§ 276$ BGB since contributory negligence constitutes the neglect of one's own interests, while the general standard considers the infringement of someone else's interests; see Fedtke \& Magnus 2004, p. 80.

215 Haas \& Hartlief 1998, p. 92; Weyts 2003, p. 19f.; - It is generally accepted that the German rules on the ability of minors to be negligent can also be applied to injured parties; $§ 254$ BGB contains a specific rule which applies in the event of contributory negligence of the injured party, but the application of $\S 828$ BGB on this article is generally accepted. See Weyts 2003, p. 89. According to Van Dam 2006, p. 340, unconscious and mentally disabled persons cannot be contributorialy negligent ( $§ 827$ jo. $\S 254 \mathrm{BGB}$ ), provided they are not able to understand the negligence of their conduct or to act accordingly. According to $§ 829 \mathrm{BGB}$, despite the lack of accountability, children or handicapped persons can be contributorily negligent if equity demands so.

216 Gerven, Lever \& Larouche 2000, p. 703ff., also for a discussion of the prevalent theories of causation under German law.

217 Van Dam 2006, p. 335; on the 'Mitwirkende Betriebs- und Sachgefahren', see, e.g., Lange 1979, p. 350ff., 388f.; Fedtke \& Magnus 2004, p. 82; - According to German law, contributory negligence can also contain undertaking or accepting an activity or situation involving an unusually high amount of danger; see Fedtke \& Magnus 2004, p. 81. 
The outcome of the damage partition is determined by judicial discretion. According to $\S 254 \mathrm{BGB}$, the duty to compensate as well as the amount of compensation depend on the circumstances, especially on the extent to which the injury was caused predominantly by one or the other party ('vorwiegende Verursachung'). The causative potency of the victim's conduct in producing the damage will thus be the vital, although not the unique factor, to take into account. ${ }^{218}$ In the solution provided in the Bürgerliche Gesetzbuch, contributory negligence (so-called 'Mitverschulden') seems to be considered primarily from the perspective of preponderant causation, the proximate or near cause (causa proxima or propinqua ${ }_{.}{ }^{219}$ This change led to considerable concern in the literature. However, although the new criterion that the duty to compensate as well as the amount of compensation depend on the circumstances, especially on the extent to which the injury was caused predominantly by one or the other party ('vorwiegende Verursachung') was codified, the Reichsgericht continued to apply its old view, ${ }^{220}$ and kept searching for the main fault. Also in legal doctrine, the view that the new criterion that the duty to compensate as well as the amount of compensation depend on the circumstances, especially on the extent to which the injury was caused predominantly by one or the other party ('vorwiegende Verursachung') had to be understood as 'especially on the question of which of the parties' negligence was preponderant/predominant' ('überwiegendes Verschulden'), gradually prevailed. ${ }^{221}$ In conclusion, two principles can be seen in the contemporary solution in the Bürgerliche Gesetzbuch: the assessment/ weighing (Abwägung) of the negligence of the contributions of both parties with regard to the occurrence of the damage (gradually worked out in usus modernus and from Wolff onwards as part of general theory and practice in ius commune), and the idea of the divisibility of the damage-in-total (Wolff's idea ${ }^{222}$ ), in order

218 Markesinis \& Unberath 2002, p. 110, who refer to the view of the Bundesgerichtshof that 'Vorwiegend verursacht hat einen Schaden derjenige, der dessen Eintritt nicht nur objektive ermöglicht, sondern darüber hinaus einem höheren Maße wahrscheinlich gemacht hat als der anderen Beteiligte.' See BGH, 8 February 1952, NJW 1952, 537; BGH, 29 January 1969, NJW 1969, 789, and also Nieuwenhuis 1997, p. 82 nt. 10; Geigel/Rixecker 2001, p. 55.

219 Wacke 1977, p. 12, who stated that in the second place, case law seems to apply Mitverschulden in the weighing. See also Venzmer 1960, p. 134 (case law), p. 139 (legislator); Soergel/Mertens 1986, Rdnr. 112, p. 385; Looschelders 1999, p.568ff., 581ff.; the latter mentioned Sach- und Betriebsgefahr as a third factor and with regard to the applicability of 829 BGB the 'Billigkeitsrelevante Umstände'.

220 That the Reichsgericht remained making the partition based on the gravity of faults can also be deduced from RG, 14 February 1903, RGZ 54, 13-15, stating that the question of the respective negligence of both parties coincides in the rule with the question of the gravity of faults (Guex 1904, p. 166f.)

221 Von Leyden 1902, p. 50; Van Nierop 1905, p. 61f.

222 According to Lorenz 1979, p. 37, 58, the legislator of $§ 254$ BGB did not give up Wolff's concept of contributory negligence - i.e. the concept of Gesamtschuld - but only simplified it, so that one could, in case of questions of doubt, go back to this concept. However, it is doubtful 
to assign a certain part of the damage to each party, according to the extent of their negligence. ${ }^{223}$

\subsection{MODERN CONTEMPORARY SOLUTIONS TO THE PROBLEM \\ OF CONTRIBUTORY NEGLIGENCE}

\subsubsection{The Netherlands}

\subsubsection{New directions in Dutch case law and literature in the twentieth century}

As just described, in the Netherlands the all-or-nothing approach continued to be applied since there was no explicit legal provision on contributory negligence in the Burgerlijk Wetboek of 1838. With the judgment of the Hoge Raad in 1916, ${ }^{224}$ this, however, changed. ${ }^{225}$ According to the Hoge Raad, the duty to

whether - from an historical view - this was indeed the concept which was codified, as the idea of proportional settlement within joint and several liability only enforced itself after the coming into force of the BGB. See Looschelders 1999, p. 144, who refers to the fundamental decision of the RG, 22 December 1910, RGZ 75, 251, 256. However, any (direct) influence of Wolff's concept on the rule of $\S 254$ BGB cannot be proven; see Looschelders 1999, p. 144.

223 Luig 1969, p. 237f.; if the injured party self-inflicted damage intentionally, usually there is no right to claim against the other party; see Wester 1976, p. 225. If the injured party merely acted negligently, while the wrongdoer acted intentionally, no partition of damages would take place, according to case law, as the wrongdoer could not invoke the injured party's contributory negligence in that case; see Wester 1976, p. 225, with reference to case law (not in the case of $\S$ 254 II; see Enneccerus-Lehmann 1958, p. 81); see also recently on this topic (with exceptions to the rules stated above and with refinements to it) Soergel/Mertens 1986, Rdnr. 116, p. 386f.; MünchKommentar BGB/Oetker § 254 (2007), Rdnr. 11, p. 499, Rdnr. 112, p. 527; Erman/Ebert 2008, p. $975 f$.

224 HR, 4 February 1916, NJ 1916, 450; on this case, see, e.g., Van Wassenaer van Catwijck 1971, p. 20; Schut 1990, p. 184f.; Smits 1997, p. 214f.; Jansen 2002a, p. 107f.; 2002b, p. 206f.; Keirse 2003, p. 28f.; 2005b, p. 5 .

225 See also Maeijer 1962, p. 196; Van Boom 2004, p. 132; - Nevertheless, in Ktg. Den Helder, 3 September 1936, NJ 1937, 138, the plaintiff-driver's contributory negligence contributed to the occurrence of the accident and therefore the Kantongerecht denied his claim for damages; this view, as Ekering 1941, p. 144, rightly argued, resembles the view which prevailed before 1916 (allor-nothing); - Except for certain cases in which legal provisions including the all-or-nothing approach were available, this principle was applied even longer. See Van Wassenaer van Catwijck 1971, p. 15f., 30, particularly in cases of commercial law and labour law. A recent discussion on special provisions on contributory negligence can be found in Keirse 2003, p. $57 \mathrm{ff}$.; Van Boom 2004, p. 133. As was already the case with Art. 1638x lid 2 (old) BW, Art. 7:658 lid 2 BW still continues to apply the all-or-nothing approach in the event of negligence in labour accidents (Keirse 2003, p. 59; 2005b, p. 5): the defence of contributory negligence only succeeds if his intentional act or wilful reckless act substantially contributed to his injury of the employee; see also already HR, 27 March 1992, NJ 1992, 496, where the Hoge Raad decided that gross negligence in Art. 1638x lid 2 BW is to be understood as intent or conscious recklessness; see also Hartlief 1997a, p. 131; Bouman 1997, p. 29; Frenk 2006a, p. 50. Art. 7:952 NBW (non-mandatory rule), still providing an all-or-nothing approach is also of particular interest for my argument: when the injured is to blame to a certain extent (intent or recklessness), or - as this is only a nonmandatory rule - the gradations of negligence as written down in the policy are exceeded, he will not receive any compensation, otherwise he will be entitled to total compensation. See, e.g., Frenk 2006a, p. 24, 52. 
compensate has to be measured based on the extent to which the negligence of both parties has contributed to the damage. ${ }^{226}$ It is remarkable that the Hoge Raad decided in a contributory negligence case that the case concerned wrongful acts of several persons. ${ }^{227}$ Then, despite there having been multiple wrongful acts, no full compensation was put on each of the wrongdoers, but the degree of compensation was measured based on the extent to which everybody's fault contributed to the cause of the damage. ${ }^{228}$ A motivation is totally missing: namely, a motivation for the line of thought of the Hoge Raad which provides insight into how one goes from a situation of shared liability (more persons are liable towards one injured party) to a situation of reduced liability of the injured party; this led to the appearance of the phenomenon of partial compensation in cases where contributory negligence of the injured party was decided. This possibility just appeared, meaning that lower courts did not elaborate any further on a case in the event of reduced liability; normally they noted that for that reason (i.e. due to contributory negligence) the damage should be divided between the parties involved. ${ }^{229}$

Since then, i.e. the judgment of the Hoge Raad of 1916, it has generally been accepted that contributory negligence of the injured party can lead to a diminishment of the liability of the wrongdoer. However, it still often occurred in case law after 1916 that in the event of contributory negligence of the injured party, that party was not able to recover his damages, and - due to the existence of contributory negligence - no action was granted (all-or-nothing

226 On case law applying this new approach after 1916, see Keirse 2005, p. 4f.

227 However, the original concept of this decision written by justice B.C.J. Loder (18491935) as found in Nationaal Archief, Den Haag, Hoge Raad der Nederlanden, 1838-1939, 2.09.28, inv.nr. 130, was as follows '... dat art. 1401 BW aan hem door wiens schuld schade is veroorzaakt den plicht tot vergoeding daarvan oplegt, welk wetsvoorschrift den rechter die over de feiten oordeelt niet verbiedt doch veeleer noopt, om in geval van door onrechtmatige daad ontstane schade den vergoedingsplicht af te meten naar de mate waarin ieders schuld heeft medegewerkt tot het veroorzaken diens schade.' This made more sense: if a wrongdoer unlawfully inflicted damage, the amount of damages should be measured/proportioned based on the degree to which each party's fault contributed to the damage that occurred. First, one justice tried to change this into 'of more persons' (van meerdere personen), probably justice J.A.A. Bosch (18551937), but ultimately this is also deleted/crossed out and a justice with siglum $\mathrm{N}$ (probably justice A.P.L. Nelissen (1851-1921)) changed it into the sentence that became the final form: 'schade is ontstaan door onrechtmatige daden (verzuimen) van meerdere personen'.

228 HR, 4 February 1916, NJ 1916, 450; Ekering 1941, p. 139; see also A-Rb. Amsterdam, 16 October 1925, NJ 1926, 996, where the court decided that in that case each of the parties (plaintiff and defendant) could be held liable for a portion of the damage. The court states that in general, the obligation to compensate loss due to wrongful acts is indivisible. However, an exception had to be made in this case, as the damage was caused due to several people, the one who compensated the damage has a right of recourse against the joint wrongdoer(s) for a proportionate part. In this case, as the defendant would have had a right of recourse against the plaintiff of a proportionate part, the court decided to shed more light on this matter and let both parties carry half of the damages.

229 Ekering 1941, p. 139. 
approach); ${ }^{230}$ it is likely that the lack of a legal basis for a proportional partition of damages based on the extent of negligence of each party has contributed to this denial of action. ${ }^{231}$ Another question was the basis for reduction of the damages award. The Hoge Raad in 1916, as discussed above, did not explain this basis very clearly. Lower courts often did not partition based on the causal impact of the fault of each party, but often they balanced the faults, the degree of faults. ${ }^{232}$ In the decennia after this judgment, the decisions of the Hoge Raad on contributory negligence, when taken altogether, suggest that the measure with which one had to partition the damage was no separate consideration, and that a variety of measures (and not just one measure) was used until the late 1980s when the Hoge Raad started to anticipate the new Article 6:101 BW. ${ }^{233}$

We see various arguments in the literature raised to support the idea of reducing the (amount of) damages. ${ }^{234}$ Scholten believed that it was indecent to bring a claim for total compensation for damages when the plaintiff himself had acted negligently and so contributed to causing the damage. ${ }^{235}$ The majority of the Dutch scholars refer to fairness/equity as basis. ${ }^{236}$ However, some authors argue that only equity as a basis is insufficient; and that the legal basis has to be found in the balance/compromise between the viewpoints 'everyone suffers his own loss' (casum sentit dominus) and 'do not cause harm to others' (alterum non laedere) ${ }^{237}$ In the event of a violation of the duty to mitigate the harm (see also section 5.7), the legal basis can be found in the fact that due to circumstances on the side of the injured party, the legal basis for shifting the damage is only present at a reduced level. ${ }^{238}$

Under the regime of the Burgerlijk Wetboek of 1838, three cases existed in which contributory negligence of the injured party still resulted in the refusal of a claim for damages. 1. This applied, according to doctrine and case law, if a

230 Polak 1949, p. 55; - According to Schut 1990, p. 185, only when contributory negligence was that small in comparison to the negligence of the wrongdoer that it can be neglected, will the wrongdoer be fully liable.

231 Jansen 2002a, p. 108; 2002b, p. 207.

232 Ekering 1941, p. 139f.

233 Keirse 2003, p. $196 f$.

234 Van Wassenaer van Catwijck provided eleven grounds for justification in his dissertation of 1971 (p. 19ff.); a more recent discussion on the doctrinal views concerning the legal basis of the partition of damages in case of contributory negligence can be found with Keirse 2003, p. 64ff.

235 Scholten 1921a, p. 35; 1921b, p. 45f.; Jansen 2002a, p. 109; 2002b, p. 207; Keirse 2003, p. 68.

236 See also later Bloembergen 1997, p. 7f. with references, also including other - according to Bloembergen - more in-depth explanations; - Further references can be found in Hartlief 1997a, p. 130; Jansen 2002a, p. 109 nt. 23; 2002b, p. 207, nt. 24.

237 See also Weyts 2003, p. 324.

238 Keirse 2003, p. 69ff., 79. 
victim deliberately underwent the damage inflicted on him. An exception was made (a.) if there was intent, conditional intent or gross recklessness of the wrongdoer, or (b.) if the injured party acted with the intent to save his own or someone else's property or life, ${ }^{239}$ or (c.) in case of the imputation of someone else's blame as contributory negligence of the injured party. 2. Furthermore, this applied when the fault of the victim outweighed the fault of the wrongdoer, and the fault of the latter fell into insignificance. ${ }^{240} 3$. Finally, this applied based on circumstances on the side of the victim: when it could be assumed that the victim accepted the risk that the damage would occur, or consented to the occurrence of the damage. ${ }^{241}$

The reverse situation was also possible (i.e. a total claim in spite of contributory negligence): when intent or gross negligence absorbed a minor negligence from the side of the victim, the total claim for damages had to be paid (no reduction of the amount of damages). ${ }^{242}$ Such a situation occurs when the wrongdoer acts with intent and his intentional behaviour is favoured by acts of the injured party or when the negligence of the injured party is insignificant compared to that of the wrongdoer. ${ }^{243}$ However, this last case, in which someone can pass on the damage to someone else, is an exception. The main rule is that the person who suffers damage has to bear it himself. ${ }^{244}$ According to Van

239 In this study rescue cases are not discussed further.

240 See also HR, 4 November 1977, NJ 1978, 146; Van Wassenaer van Catwijck \& Jongeneel 1995, p. 12; Boonekamp aant. 17.7 ad Art. 6:101 BW; Keirse 2003, p. 227ff.; this did not change under the NBW; see Asser/Hartkamp 2004 (IV-I), nr. 452, p. 408. See also HR, 31 March 1995, NJ 1997, 592.

241 Van Wassenaer van Catwijck 1971, p. 30ff.

242 To the rule that intent or gross negligence of the wrongdoer absorbed a minor negligence of the injured party, and so did not lead to any reduction of the amount of damages, there are some exceptions. A discussion of these exceptions can be found in Van Wassenaer van Catwijck 1971, p. 35ff.; on risk or presumption of negligence and contributory negligence, see Van Wassenaer van Catwijck 1971, p. 162ff. This topic will not be discussed here.

243 Van Wassenaer van Catwijck 1971, p. 35; on the final situation, in the era of Burgerlijk Wetboek of 1992, see Keirse 2003, p. 229f.

244 The question of liability is answered by balancing two viewpoints in the law of delicts: each party carries his own loss (it concerns the adage casum sentit dominus; see Gai. Inst. 3.211; D. 50.17.23; C. 4.24.9; a variant is res perit domino), and: cause no damage to another (Alterum non laedere, D. 1.1.10.1; Jansen 2009, p. 231). A discussion of these points of view can be found, e.g., with Hartlief 1997a, p. 129; 1997b (esp. on the first viewpoint); Keirse 2003, p. 13ff.; Weyts 2003, p. 1ff., 121, 323f. The balance will be tipped in favour of the adage 'each carries his own loss' when the act that caused the damage was not unlawful; see Chao-Duivis 2005, p. 5. According to Jansen 2009, p. 231, the purpose of the law of delicts is to establish in which case a delict is the basis of an eventual liability in order to shift the damage from the injured party to the wrongdoer. Sieburgh 2000, p. 1f., 9ff., talks about finding a balance, depending on the weight awarded to each of these two points of view. See also Asser/Hartkamp 2006 (IV-III), nr. 12ff., p. 16f.; - With regard to the injured party, related points of view are relevant: when someone suffers damage because of his own negligence, he is not considered to have suffered any damage (rule of D. 50.17.203); and the rule that everyone is lord and master in his own sphere of law; on these points of view, see Keirse 2003, p. 16f. 
Wassenaer van Catwijck in his dissertation (1971), therefore, judges (in general) should be very reluctant in deciding that the careless act of the injured party was considered of so little weight that it had no effect on his claim for compensation; they had to assign more weight to the fault of the injured party and decide sooner to deny a claim. ${ }^{245}$ Notice that if one decides that contributory negligence of the injured party has so little weight that it has no effect on his claim for damages, one in fact puts all the burden/all the damage on the side of the wrongdoer. Thereby, one departs from the main rule mentioned above, namely that the person who suffers damage has to bear it himself.

Another question is how the partition of damages should be made. Various standards are mentioned and discussed in Van Wassenaer van Catwijck's dissertation; ${ }^{246}$ the most often mentioned by scholars are the degree of causation of both parties and the degree of negligence of both parties. Van Wassenaer van Catwijck believed that in many cases causation was the most important standard, but in some cases a correction of this standard was required by using other standards. ${ }^{247}$

\subsubsection{Recent codification: The Dutch Burgerlijk Wetboek of 1992}

Before reaching the rule of Article 6:101 of the Burgerlijk Wetboek of 1992 (BW), it has to be noted that in some cases the contributory negligence of the injured party may be of overwhelming preponderance, and so, according to Article 6:98 BW, ${ }^{248}$ the necessary causal nexus between the conduct of the defendant and the damage is absent, ${ }^{249}$ and the requisites to apply Article 6:98 BW (the doctrine of attribution according to reasonableness) are not met.

245 Van Wassenaer van Catwijck 1971, p. 35.

246 See Van Wassenaer van Catwijck 1971, p. 226ff., 238ff.

247 ibid., p. 244; - According to Asser/ Hartkamp 2004 (IV-I), nr. 450, p. 403, the main rule of Art. 6:101 BW (weighing of causality) as well as the exception (correction based on equity) were already accepted by the Hoge Raad under the regime of the OBW, and therefore the case law of that period retains its significance.

248 According to Art. 6:98 BW, the judge has to constitute the causal connection taking into account the nature of the liability and of the damage, but also other factors of assessment are possible, such as the foreseeability of the damage, the expertise of the defendant, the nature of the fault, the existence of an insurance agreement; see Weyts 2003, p. 465 with references, who calls it a multifactor approach. This term is used firstly by Schut, 1990, p. 89.

249 See also Keirse 2003, p. 11; Von Bar \& Clive 2009, p. 3638. 
The principle of contributory negligence is codified in Article 6:101 BW, ${ }^{250}$ which provision reads as follows:

\begin{abstract}
1. Wanneer de schade mede een gevolg is van een omstandigheid die aan de benadeelde kan worden toegerekend, wordt de vergoedingsplicht verminderd door de schade over de benadeelde en de vergoedingsplichtige te verdelen in evenredigheid met de mate waarin de aan ieder toe te rekenen omstandigheden tot de schade hebben bijgedragen, met dien verstande dat een andere verdeling plaatsvindt of de vergoedingsplicht geheel vervalt of in stand blijft, indien de billijkheid dit wegens de uiteenlopende ernst van de gemaakte fouten of andere omstandigheden van het geval eist.
\end{abstract}

2. Betreft de vergoedingsplicht schade, toegebracht aan een zaak die een derde voor de benadeelde in zijn macht had, dan worden bij toepassing van het vorige lid omstandigheden die aan de derde toegerekend kunnen worden, toegerekend aan de benadeelde. ${ }^{251}$

This legal provision can be applied in cases of fault liability as well as in cases of strict liability. The burden of proof of 'contributory negligence' of the injured party in principle rests on the party that invokes contributory negligence of his opponent ( $c f$. Article 149 of the Wetboek van Burgerlijke Rechtsvordering (Code of Civil Procedure, Rv)). ${ }^{252}$ In the event of contributory negligence, ${ }^{253}$

250 Apart from the possible applicability of Article 6:101 BW in delictual liability cases, it can also be applicable for the duty to provide compensation due to a culpable breach of contract; on this topic, see, e.g., Jansen 1997, p. 31ff.

251 An English translation of this provision can be found in the edn. of Kiiver \& Kornet 2010, p. 330: Article 6:101. (1). Where the damage is partly a consequence of a circumstance that can be attributed to the prejudiced person [benadeelde], the duty to compensate is reduced by dividing the damage among the prejudiced person and he who has a duty to compensate in porportion to the extent to which the circumstances attributable to each have contributed to the damage, provided that a different division shall take place or the duty to compensate lapses or remains in its entirety, where fairness [billijkheid] so demands given the discrepancy between de $[=$ the, EvD] severity of the errors made or other circumstances of the case. (2) Where the duty to compensate concerns damage inflicted to an object which a third party kept for the aggrieved party, circumstances that can be attributed to the third party shall be attributed to the prejudiced person when applying the previous paragraph.

252 HR, 11 June 2010, NJ 2010, 333; HR, 8 July 2011, NJ 2011, 307 (the obligation to furnish the facts and the burden of proof of the factual basis of the defence of contributory negligence lies with the defendant); see also HR, 17 November 2006, RvdW2006, 1076; see also HR, 22 April 2005, NJ 2006, 20). See also Keirse 2003, p. 112 with reference to older case law.

253 This implies that, in the circumstances of the case, the victim failed to deal carefully with his own interests (he acted differently than a careful, reasonably acting person would have done in the given circumstances); see Parliamentary History of book 6 (PG Boek 6, p. 351); Spier 1992, p. 3; Asser/Hartkamp 2004 (IV-I), nr. 448, p. 399; Von Bar \& Clive 2009, p. 3638; - The term 'eigen schuld' is somewhat misleading and too narrow; Art. 6:101 BW covers a broader area: not only acts of the injured party itself are relevant, but also faulty acts and circumstances which belong to the sphere of risk of the injured party. Furthermore, also acts of others can belong to his sphere of risk; see, e.g., Van Wassenaer van Catwijck \& Jongeneel 1995, p. 3; Boonekamp aant. 2 ad Art. 6:101 BW. 
a diminished duty to compensate follows by dividing the damage between the injured party and the wrongdoer in proportion to the extent to which the circumstances attributable to each party have contributed to the damage. After the partition of the damage, the injured party carries (that proportion of) his own loss that he ought to carry (see also the above-mentioned principle). ${ }^{254}$ This damage is caused by the injured party himself; at least he is held accountable for his damage, since it is attributed to circumstances that lie in his sphere of risk (idea of so-called equity ('billijkheid')). ${ }^{255}$

Article 6:101 BW is very broad as it covers situations in which the injured party contributed to the occurrence of the damage as well as situations in which the injured party contributed (in a negative sense) to the extent of the damage. In this latter sense, the (violation of the) duty to limit the damage (implicitly) found its way into this article. ${ }^{256}$ In addition, not only the injured party's own behaviour can constitute contributory negligence, but also the acts of persons for whom the person bears (vicarious) responsibility; furthermore, the person also bears the risk for strict liabilities - damage done by an animal or by tangible objects in his possession. ${ }^{257}$ The part of the damage that cannot be recovered is imputed to the injured party, according to the general rules of Article 6:162 (1) and (3) and 6:163 BW; therefore, the injured party must have been at fault or the cause must have been encompassed in his sphere of risk according to the law or to social conventions. ${ }^{258}$

Article 6:101 BW has two standards: ${ }^{259}$ the primary apportionment made by a correlative balancing of causes, ${ }^{260}$ and, secondarily, an equitable adjustment of the outcome of the primary apportionment (the so-called

254 It seems that recent developments in the area of legal provisions on traffic accidents and on the liability of employers do not do justice to this principle, in this sense Jansen 2002b, p. 209; see also Hartlief 2002 b, p. $17 \mathrm{ff}$, who states that in these cases the wrongdoer has to compensate more than he caused.

255 Hartlief 2002b, p. 13.

256 Spier et al. 2000, p. 218; Hartlief 2002b, p. $13 f$.

257 On this point, see Hartlief 2002b, p. 14, also on reflexwerking and the special legal provisions regarding traffic accidents; on the reflexwerking and Art. $185 \mathrm{WVW}$ see also, e.g., Hartlief 2001, p. 73ff. Unmotorised traffic participants are also protected if they collide with a motorised vehicle and damage the latter. If they are sued because of injuries or damage to property, the protective standard of Art. $185 \mathrm{WVW}$ still applies: the motorised partly has to bear his own damage, as far as he cannot prove force majeure or at least fails to prove the contribution of the unmotorised party. See Engelhard \& Van Maanen 1998, p. 20f.; Hartlief 2001, p. 73.

258 Von Bar \& Clive 2009, p. 3639.

259 A discussion of these standards can be found, e.g., with Barendrecht 1997b, p. 153ff., esp. 165ff.; - Art. 6:101 (subsections 1 and 2) were already accepted by case law under the regime of the former Dutch Civil Code (Burgerlijk Wetboek of 1838); see Spier 1992, p. 3.

260 Van Boom 2004, p. 134. 
billijkheidscorrectie). ${ }^{261}$ The first standard ${ }^{262}$ assumes that the damage is causally linked with the act of the wrongdoer as well as with the circumstances on the side of the injured party. ${ }^{263}$ These circumstances must be imputable to the injured party, i.e. when the victim acted with negligence or when the circumstances are at his risk, based on statutory provisions, juridical act or social conventions (de in het verkeer geldende opvattingen ). ${ }^{264}$ The weighing of causal factors ${ }^{265}$ leads to a partition of damage; this partition can be adjusted based on equity, e.g. reasons can be found in the diverging severity of the faults ${ }^{266}$ of the parties involved or in other circumstances (e.g. the age of the victim). ${ }^{267}$ The estimation of the faults on either side to an important extent is based on the intuitive insights of the judge and therefore the motivation required in this respect is limited. ${ }^{268}$ According to the Hoge Raad, the judge should make explicit

261 There seems to be no profound dogmatic thought behind this choice. From the Parliamentary History of book 6 (PG Boek 6, p. 352), one can deduce that it was only because of a question of the (Committee of Justice of the) Second Chamber of the Parliament (House of Representatives) whether one could give more concrete shape for the standard of reasonableness to the judgment of the judge; see also Nieuwenhuis 1997, p. 80f., and Tjong Tjin Tai 2006, p. 27f.; according to the latter the partition in two stadia is somewhat artificial and in practice not always good to realise. On the equitable adjustment, see, e.g., Bouman 1997, p. 25ff. According to Hijma's annotation to HR, 5 December 1997, NJ 1998, 402, the order of the standards in Art. 6:101 is not so much based on substantive considerations, but on generic legal-systematic ones (in many grounds for liability, culpability (verwijtbaarheid) is not a requirement for liability; see the Memorandum of Reply (MvA II in: PG Boek 6, p. 352)).

262 On this standard see, e.g., Spier 1997, p. 15ff. This author argued - see Spier 1997, p. $20 \mathrm{f}$. - that judges find it difficult to apply this standard. Their decision-making should not be based on intuition; possibly experts could better indicate how the various causes contributed to the damage.

263 Spier et al. 2000, p. 218; Asser-Hartkamp 2004 (IV-I), nr. 448a, p. 400.

264 Sterk 1994, p. 245.

265 There seems to be no unanimity on the criterion (see Boonekamp aant. 16 ad Art. 6:101 BW); according to Nieuwenhuis 1997, p. 82, the determining factor is the probability that the circumstances attributable to wrongdoer and injured party would lead to the occurrence of the damage; see also Barendrecht 1997a, p. 13; 1997b, p. 166f. (in any case for traffic cases); according to Weyts 2003, p. 413, the Dutch Hoge Raad considers decisive the extent to which the conduct of the parties on either side have created the danger.

266 It is often assumed that the contributory negligence of the injured party may be disregarded if the wrongdoer acted intentionally, while on the other hand, there is no right to recovery if the injured party acted intentionally. See Spier 1992, p. 10 with references. If the negligence of the injured party is so small that it becomes insignificant compared to the negligence of the wrongdoer, one often disregards the contributory negligence of the injured party; see also Spier 1992, p. 10.

267 Spier et al. 2000, p. 219, 221; Hartlief 2002b, p. 15. In particular, the seriousness of the faults of both parties, and the degree of culpability of each party; see HR, 5 December 1997, NJ 1998,400 , and the question of whether the driver/owner and the cyclist/pedestrian who is held liable are insured; see HR, 4 May 2001, NJ 2002, 214; or the severity of the injury; see HR, 22 April 2005, NJ 2006, 20. On the influence of insurance on the equity correction, see, e.g., Hartlief \& Tjittes 1999, p. $40 \mathrm{ff}$.

268 HR, 8 July 2011, NJ 2011, 307; also Bouman 1997, p. 26 and Tjong Tjin Tai 2005, p. 187, seem to argue that the weighing and partition of Art. 6:101 BW is largely an intuitive assessment. Critical on this point is Barendrecht 1997b, p. $169 \mathrm{f}$. 
to which result (to which kind of partition) the first standard leads as to the weighing of causality, and on what ground that result needs correction. ${ }^{269}$ This is different if the judge decides that because of the divergent seriousness of the faults, the duty to compensate should be 100 per cent (or nil ${ }^{270}$ ); in principle he does not have to indicate exactly to what extent circumstances attributable to each of the parties contributed to the damage in that case. However, such a decision, to be understandable, generally, should be based on a statement of those circumstances; and such a decision, when these circumstances at first sight seem to imply that the duty to compensate would be totally or partially annulled, requires a higher level of motivation. ${ }^{271}$

Recently, it has been argued that Article 6:101 BW should be subdivided into four phases, which follow from the text and the structure of the legal text itself, ${ }^{272}$ after the fulfilment of the general requirement, namely that liability of the wrongdoer is established in a certain case. ${ }^{273}$ The first two phases concern the founding of co-responsibility. The first phase is to investigate whether there is a sufficient causal link between the behaviour of the injured party and the damage, ${ }^{274}$ secondly, this causal contribution must be attributable to the injured party. Subsequently, in the third and fourth phases, the consequences of the (now) established 'contributory negligence' can be further investigated. They contain a twofold standard for dividing the damages in the event of contributory negligence. In the third phase, the damage is partitioned according to the degree in which the circumstances attributable to each party contributed to the damage (measure of causality); and fourthly, a different partition will be made when equiry so requires because of the different severity of the faults or other circumstances of the case. ${ }^{275}$

269 Asser/Hartkamp 2004 (IV-1), nr. 452a, p. 410; - See recently HR, 13 January 2006, NJ 2006, 59, on this judgment, see also Tjong Tjin Tai 2006, p. 27f.; Keirse 2006, p. 188f.; - The correction based on equity ought to be applied by the judge by virtue of his office (ex officio), i.e. without the need of invocation by one of the parties; see on this topic Van Wassenaer van Catwijck \& Jongeneel 1995, p. 141ff.

270 See Tjong Tjin Tai 2006, p. 28 with case law.

271 HR, 3 June 2005, NJ 2005, 286; see also Tjong Tjin Tai 2005, p. 189f.; Keirse 2006, p. $189 f$.

272 Keirse 2003, p. 83ff.; 2006, p. 186; see also Asser/Hartkamp 2004 (IV-I), nr. 450, p. 403; Frenk 2006a, p. 25; differently Van Boom 2004, p. 134.

273 Keirse 2003, p. 84.

274 Often a necessary, but not sufficient, condition will be the condicio sine qua non test/ principle, that is, that without the act of the injured party, the damage would not have occurred; Art. 6:98 of the Burgerlijk Wetboek can serve as a guide here; see also Keirse 2003, esp. p. 90, 115 .

275 Keirse 2003, p. 83ff., 115f.; Knapen 2004, p. 6; - On these phases, see Keirse 2006, p. $186 \mathrm{ff}$., also on the question as to what extent the Hoge Raad can examine the decisions in the distinct four phases, see Keirse 2003, p. 238ff.; 2006, p. $190 \mathrm{f}$. 


\subsubsection{France}

\subsubsection{Contemporary solution in France}

Of course before one could consider whether contributory negligence was present, also in France, there had to be a right to claim compensation against the wrongdoer. ${ }^{276}$ To have legally any influence on his right to damages, a victim has to commit a faute that was one of the causes of the damage. The faute de la victime $^{277}$ even has to constitute a necessary antecedent of the damage and to make the damage objectively possible. ${ }^{278}$ As soon as the judge decides the faute de la victime was a cause of the damage, the division of damage claimed is applied not, however, according to the relative decisiveness of the parties' conduct in producing the damage, but according to the relative gravity of their faults. ${ }^{279}$

The fault of the injured party (faute de la victime) leads to the (total or partial) elimination of the required causal connection between the faute $e^{280}$ of the wrongdoer and the damage. ${ }^{281}$ Presently, the consequence of a victim's

276 Of course, in a concrete case the unlawful act can be justified. Examples are: permission or risk acceptance by the victim. Interestingly, with regard to risk acceptance, it cannot regard any possible risk, but at the utmost normal and frequently occurring risks. When risks above average are concerned, case law normally opts for partial liability, as when someone accompanies a drunken car driver: the acceptance of risk is then negotiated as a percentage of contributory negligence; see Van Dam 2000a, p. 29. An extensive (comparative) work on the 'Handeln auf eigene Gefahr' is provided by Stoll 1961, and on consent and risk assumption, see also Honoré 1983, p. 112ff.

277 Extensively on the topic of fait/faute de la victime, Mazeaud \& Mazeaud 1970, p. 540ff.; in the event in which the fault of one party is the consequence of or is logically entailed by the fault of the other, see Honoré 1983, p. 118f. See on the legal nature of the 'faute' of the victim the overview provided by Neumann-Schniedewind 1969, p. 996.

278 Deschizeaux 1934, esp. p. 9f.; - With regard to the requirement of causal connection (lien de causalité), case law seems to have applied the theory of adequate cause; see Deschizeaux 1934, p. 45ff., who discusses the case law of the 19th and early 20th centuries; differently, Terlez 1938, p. 16 (equivalence theory). Extensively on the requirement of causal connection in legal doctrine and case law, see also Neumann-Schniedewind 1969, p. 80ff., esp. p. $89 \mathrm{ff}$.

279 Lawson 1968, p. 63f. (critically); Wurmnest 2003, p. 310f.; - Also Deschizeaux 1934 p. 52ff., 110, 166, who argued that there are disadvantages to this method, and he suggested apportioning responsibility on the basis of the objective possibility of both parties to cause damage; - However, due to their inviolable discretion, the judges who decide on the questions of fact de facto use various criteria: they often partition the damage based on the causal contributions of each of the parties; see Weyts 2003, p. 388 with references; Deschizeaux suggested a practical plan of action: the judge has to determine and value the respective faults of both parties, e.g. three to the wrongdoer and five to the victim, in which case the wrongdoer has to pay $3 / 8$ of the victim's damage. See Deschizeaux 1934, p. 110.

280 On the definition of faute in doctrine and in general in the Avant-projet de réforme, see recently Borghetti 2009, esp. p. 278f.; - Art. 1352(2) of the Avant-projet defines faute as a breach of a rule of conduct imposed by legislation or regulation, or failure to conform to a general duty of care and diligence (Borghetti 2009, p. 279).

281 Josserand 1939, p. 265ff.; Kontogianni 2003, p. 164; Tourneau 2004, nr. 1796, p. 423; nr. 1799, p. 424. 
negligence is that he cannot claim compensation for the full loss suffered. The court will reduce the damage amount. In French law the concept of fault is broadly construed. ${ }^{282}$ The fault of the injured party can give rise to a partial exoneration of the defendant. It can even leave the victim with empty hands if the defendant can prove that the victim's conduct qualifies as an extraneous cause (cause étrangère), which means that it must have been unforeseeable and unavoidable (imprévisible et irrésistible) for the defendant, and constitutes the sole cause of the damage. ${ }^{283}$ Generally, an objective test of the victim's conduct applies. ${ }^{284}$ Not only a violation of a rule of conduct imposed by statute, but also a breach of a 'general duty to protect oneself' by a 'victim' is considered a faute. ${ }^{285}$

In most cases accidents are partly due to the fault of the defendant and partly to the plaintiff's own act. According to French law, the apportionment of damages must be made based on the principle that the defendant does not have to pay reparation for damages in excess of the damage he caused himself. ${ }^{286}$ The proportion the wrongdoer has to bear, despite the required faute de la victime, is determined by comparing the seriousness of the fautes on either side. ${ }^{287}$

282 See Van Gerven, Lever \& Larouche 2000, p. 693ff.; according to these authors (p. 694f.), the apparent symmetry between the wrongdoer and the injured party is warped by the play of a third party or by liability insurance to the benefit of the defendant (wrongdoer), and the only person who ultimately pays for his fault often is the victim. Therefore, a proposal has been made to only hold a serious or inexcusable fault against the injured party, and to leave intact his right for compensation at least in cases in which the liability of the wrongdoer is covered by his insurance. The Loi Badinter makes a step in that direction with regard to victims of motor vehicle accidents (see section 5.6.1).

283 Le Tourneau 2004, nr. 1863, p. 441; nr. 1889, p. 447; see also Colin-Capitant-La Morandière 1948, p. 228, 268; Planiol-Ripert-Esmein 1952, p. 788; Amos/Walton 1967, p. 215; Mazeaud \& Mazeaud 1970, p. 551ff.; Van Gerven, Larouche \& Lever 2000, p. 692; Van Dam 2006, p. 335.

284 Van Dam 2006, p. 335; Le Tourneau 2004, nr. 1882, p. 446 (but 'l'application de ce critère de partage implique l'appréciation in concreto'); - Another issue is the question of whether a young victim can be contributorily negligent. In answering this question, French case law compares the conduct of the child-victim to that of the bon père de famille just as in the case where the child causes the damage himself; see Van Dam 2006, p. 340 and cited case law; this opinion has been criticised in the literature because it establishes the child's contributory negligence too easily, meaning that the child can get compensation only for part of the damage. However, the Cour de cassation does not seem to be inclined to change its view; see Van Dam 2006, p. 340f. and cited case law.

285 See Cass. civ. 2e, 8 March 1995, Bull. Civ. 1995.II.82, p. 47; also Van Gerven, Lever \& Larouche 2000 , p. 694; Weyts 2003, p. 348f. (also on the views on the legal basis of the partition of damages); Le Tourneau 2004, nr. 1871, p. 443.

286 Amos/Walton 1967, p. 216.

287 Josserand 1939, p. 267, mentions the view that a fault of the injured, less serious than that of the wrongdoer, could annul the liability of the latter. Apparently, and Josserand sustains this by referring to various examples of case law, this view was sometimes held by judges in the 1840s, but no longer in Josserand's time ('l'effet ne doit pas dépasser la cause et la concurrence des fautes détermine non un déplacement de la responsabilité, mais seulement sa modération; à chacun selon la part prise dans le dommage'). 
The sovereign power granted to the trial judges gives plenty of room to consider other factors, especially the causal involvement of the injured versus that of the wrongdoer or to consider only the faute de la victime, regardless of the defendant's conduct. ${ }^{288}$ A total exoneration of liability is exceptional, and seems to be applied only if the injured party's negligence greatly exceeds the wrongdoer's misconduct, namely when the injured commits an intentional fault, ${ }^{289}$ provokes the wrongdoer ${ }^{290}$ or acts with the consent of the injured party. ${ }^{291}$

288 Viney-Jourdain 2006, p. 340.

289 See, e.g., Haller 1926, p. 40ff.

290 Viney-Jourdain 2006, p. 340f.; when the wrongdoer acted intentionally, and the injured was merely negligent or imprudent, the wrongdoer was held solely responsible; see, e.g., Haller 1926, p. 92; Honoré 1983, p. 110, also including a discussion of the (possible) justifications for this rule.

291 Honoré 1983, p. 111; - In that respect, see also Art. 1350 of the Avant-projet Catala, according to which the victim is deprived of any compensation if he deliberately (volontairement) sought the harm - see also Article 26 projet Terré (2011; the victim is not entitled to compensation when he voluntarily sought the damages he suffered).

Also interesting are Art. 1386-58 of the reform proposal of 2010 (in personal injury cases in traffic accidents, contributory negligence does not lead to a reduction in the amount of damages except for the case in which the fault of the injured party was inexcusable and this fault was the exclusive cause of the accident) and Art. 1351 of the Avant-projet, according to which a fault of the victim of personal injury only provides a partial defence to the liability of the person responsible for that personal injury when the fault is serious (une faute grave). See Cartwright, Vogenauer \& Whittaker 2009, p. 842f.; according to Cartwright, Vogenauer \& Whittaker 2009, p. 842, footnote 2, this solution at present is not accepted in the law as it stands, and is a manifestation of a special treatment of victims of personal injuries. With regard to the 'right to compensation' of a victim of a personal injury, the victim's fault may not be taken into account unless it is of a certain degree, i.e. a 'serious fault' (the definition of a serious fault remains to be established in practice); see Rémy-Corlay 2009, p. 308. The Avant-projet seems to aim to further protect the victim's interests, since any fault on his part has to be serious in order to deprive him of his damage claim and, according to the literature, courts will undoubtedly be less inclined to rule in that sense when a victim is seriously injured; see Rémy-Corlay 2009, p. 315f.; nevertheless, according to this author, to the extent the defendant can incur liability without his fault, it can be considered unfair that he has to bear the burden of reparation for all physical harm suffered by a victim who contributed to the occurrence. According to the author, this is explicable only by reference to insurance law. However, this solution is currently adopted in relation to traffic accidents; see Art. 3 Loi Badinter. As will be shown below, the victim's own fault is not sufficient to successfully ward off a claim for damages; the victim's fault has to be inexcusable and the sole cause of the accident. The proposed Art. 1379 Avant-projet is less severe in that sense. Furthermore, according to Art. 4 of the Loi Badinter, only against an injured party/ victim, who is a driver, can his fault be invoked as a general defence. In the Avant-projet the victim-driver would be assimilated to other victims. See Rémy-Corlay 2009, p. 316.

Also interesting is the Proposition de loi no. 657 (2009-2010) déposée le 9 juillet 2010 par L. Béteille, esp. Art. 1386, according to which damage which is a result of an act of God cannot be repaired if this resulted from the act of the victim or of a third party, when such events are unforeseeable and irresistible for the wrongdoer. Furthermore, damage voluntarily provoked by the victim can in principle not be repaired. And esp. Art. 1386-1, according to which the partial exemption of the wrongdoer can only result from a fault of the victim who contributed to the production of damage. In case of violation of physical integrity, only a serious fault (faute grave) may result in partial exemption.

In the title on damage caused by motor vehicles, Art. 26 projet Terré (2011) states that a fault of the victim in cases of injuries to the physical or mental states (i.e. a change, instead of 'personal injury') has no influence on the amount of recovery, unless the fault was inexcusable 
Apart from the gravity of faults, also other circumstances can be considered, particularly the causal impact of the respective conduct of the parties. ${ }^{292}$

An almost opposite situation to that in France before the last quarter of the nineteenth century was reached by the end of the twentieth century, when in certain circumstances the claimant's negligent conduct did not even lead to a reduction of his right to compensation. As will be shown below, particularly in France (and Germany) victims of road traffic accidents are strongly protected against the consequences of their own mistakes. This change of view reflects the compensation function the law of delict has increasingly gained in the course of recent decades. ${ }^{293}$

\subsubsection{Contributory negligence in the context of liability without fault}

Up to now, my exposé concerned the responsibility for one's own acts (responsabilité du fait personnel, Articles 1382 and 1383 Code civil). However, one has to realise that the overall picture of this subject in the French law of delict is also dictated by various sorts of strict liability.

In this respect, mainly Article 1384 Code civil, which regards the liability for damage caused by objects (fait de la chose), is relevant and in that sense it constitutes a strict liability for the keeper (gardien) of the object. In earlier case law of the Cour de cassation (i.e. until 1934), exoneration from liability based on Article 1384 al. 1 Code civil was only possible because of an external cause (une cause étrangère), e.g. because of contributory negligence of the injured party. If contributory negligence of the injured party was proven, the wrongdoer was not liable at all - in that sense French law still applied the all-or-nothing approach. In that case, the behaviour of the victim had to be an external cause, unforeseeable (imprévisible) and unavoidable (insurmontable). ${ }^{294}$ In such a

and the only cause of the accident; in easing the thresholds beyond which the inexcusable fault does not effect his right to recovery, no specific ages are proposed (as is currently done in Art. 3 of the Loi Badinter), but the choice is made to let the judge decide to have regard to the age and the physical and mental condidition of the victim. See also Borghetti 2011, p. 181. In all other cases, the fault of the victim (or someone for whom the victim must answer for) leads to a partial exoneration when this fault contributed to the realisation of the damage.

In the title on the causes of exclusion or exoneration of liability, Art. 46 projet Terré states that conduct of the injured party can lead to a total exoneration if it meets the requirements of force majeure. cf. Art. 47 projet Terré the faute de la victime in principle leads to a partial exoneration if the fault of the victim contributed to the occurrence of the damage. See elaborately Grare-Didier 2011, p. $187 \mathrm{ff}$.

292 Van Gerven, Larouche \& Lever 2000, p. 692.

293 Van Dam 2006, p. 339.

294 Lebreton 1941, p. 24ff.; Terré-Simler-Lequette 2002, nr. 802, p. 761. See also Esmein 1934, p. $985 f f .$, esp. p. 988 . A different situation occurs when a person against whom a presumption of 
case only an external cause could fully exonerate the wrongdoer from liability (Jand'heur judgment). ${ }^{295}$

The Chambre des requêtes adopted a different, more balanced approach from 1904 onwards, reaffirmed in 1934, ${ }^{296}$ holding that the liability of the wrongdoer can be reduced in proportion to the degree of fault of the victim. ${ }^{297}$ An apportionment of liability thus became possible and courts became very generous towards the keeper (gardien), and even partially exonerated him when no fault of the victim could be proven. ${ }^{298}$ The partial exoneration was first established in 1934.

Moreover, this possibility of partial exoneration of the wrongdoer in strict liability cases was curtailed by the Cour de cassation in the case of Desmares (1982). ${ }^{299}$ The possibility of partial exoneration was eliminated, and a total exoneration was only possible in case of force majeure (or an external cause), if the victim's fault was unforeseeable and unavoidable to the keeper (gardien) (return to the all-or-nothing approach). ${ }^{300}$ Shortly after a reform by the Loi Badinter (see section 5.6.1), in 1987, the Cour de cassation overturned the Desmares judgment and re-introduced the principle that the keeper (gardien) of an object is partially exonerated when the victim's fault contributed to the occurrence of the damage caused by the object (for cases not falling under the Loi Badinter $).{ }^{301}$ When the victim's fault can be characterised as an external cause leading to force majeure, of course a total dismissal of the claim will follow.

responsibility rests (and who is in effect strictly liable) is damaged by someone who has been at fault; in that case it is held that the former may recover his damages in full; see Honoré 1983, p. 127.

295 Cass. ch. réun., 13 February 1930, D.P. 1930.I.57; Van Gerven, Larouche \& Lever 2000, p. 696.

296 Honoré 1983, p. 120; according to Honoré, in 1936 the Chambre civile settled the law in the sense that the presumption of responsibility of the keeper (gardien) cannot be totally displaced unless it is shown that the fault of the injured party has been the sole cause of the damage.

297 See Req. 13 April 1934, D.P. 1934. I. 41.

298 Van Gerven, Lever \& Larouche 2000, p. 696.

299 See also Van Gerven, Lever \& Larouche 2000, p. 693.

300 Cass. civ. $2^{\text {e }}, 21$ July 1982, D. 1982. 449ff., with note by Larroumet (p. 452-455) and see also note F. Chabas in JCP 1982, II, nr. 19861, and observations of G. Durry in RTD civ. 1982, 606. See also Engelhard \& Van Maanen 1998, p. 2lf.; Van Gerven, Larouche \& Lever 2000, p. 696f.; Terré-Simler-Lequette 2002, nr. 803, p. 762; Weyts 2003, p. 133, 437.

301 See Cass. civ. $2^{\text {e }}, 6$ April 1987, D. 1988.32, with note by C. Mouly, JCP 1987.II.20828, nt. F. Chabas, RTD civ. 1987.767, with note by J. Huet; Van Gerven, Larouche \& Lever 2000, p. 695f.; Terré-Simmler-Lequette 2002, nr. 803, p. 762f.; Weyts 2003, p. 138; - The partition of damages has to be made by a comparison of the (faultive character of the) acts of both parties; see Weyts 2003 , p. 402f. with references. However, as Weyts correctly stated, it is impossible to assess the fault of a strictly liable person. 


\subsection{TRAFFIC ACCIDENTS: RISE AND FALL OF THE ALL-OR-NOTHING APPROACH?}

\subsubsection{Traffic accidents: France ${ }^{302}$}

At the beginning of the twentieth century, when contributory negligence of the injured occurred in a traffic accident, it led to a partition, in fractions, of damages according to the degree of gravity of faults. ${ }^{303} \mathrm{~A}$ recent development in France is the enactment of the statute on traffic accidents, the so-called Loi Badinter. ${ }^{304}$ This statute is the result of a compromise. ${ }^{305}$ The law covers and protects unmotorised traffic participants, passengers and drivers. ${ }^{306}$ The mere fact that an unmotorised person is hurt by a motorised vehicle or even that a motorised vehicle is involved (requirement of involvement (implication); see Article 1$)^{307}$ in an accident in principle is sufficient to establish a 100 per cent liability for personal injuries for the owner or the 'keeper' (or the liability insurance) of the motorised vehicle ${ }^{308}$ Force majeure or co-liability of a third party does not lead to any reduction or exclusion of the right for reimbursement. ${ }^{309}$

302 Apart from the literature and case law mentioned in this subsection, this brief overview is also based on Van Dam 2000, p. 43ff.

303 Lebreton 1941, p. 6f.; Mazeaud \& Mazeaud 1970, p. 625.

304 Loi $n^{\circ 85-677}$ du 5 juillet 1985 tendant à l'amélioration de la situation des victimes d'accidents de la circulation et à l'accélération des procédures d'indemnisation. On this law, and on the 'droit des accidents de la circulation' after the reform of 5 July 1985, see Chabas 1988; Haas \& Hartlief 1998, p. 27ff.; Viney 1992, with an overview of the literature on this topic; Engelhard \& Van Maanen 1998, p. 26f.; Viney-Jourdain 2006, p. 135f., nr. 431; - The most relevant articles, Arts. 3-5, are extensively discussed by Viney 1992, p. 35ff. with the relevant literature and case law.

305 Tunc 1994, p. 325; according to Tunc, this law was accepted after fierce resistance and attacks, and it is often regretted that the law does not give a better protection to drivers. Apparently, the number of victims who receive compensation has increased; the time to reach a settlement and overall litigation has been substantially reduced; - On the twofold objective of this law, see, e.g., Engelhard \& Van Maanen 1998, p. $26 f$.

306 Engelhard \& Van Maanen 1998, p. 29.

307 On the requirement of implication, see, e.g., Viney 1992, p. 22ff.; Sterk 1994, p. 51ff.; Haas \& Hartlief 1998, p. 30f.; Engelhard \& Van Maanen 1998, p. 30f. In fact this is a foundation of a strict liability of the driver who is compulsorily insured for traffic accidents against pedestrians and cyclists (third-party insurance).

308 With regard to damage to objects (dommages aux biens), Arts. 2 \& 5 Loi Badinter are relevant. With regard to damage to objects, the law protects motorised and unmotorised traffic participants in the same manner. The general rule is that the injured party has a right to total compensation, and that appeal to force majeure is excluded. The defence of contributory negligence is similar to that in common French law of delict, and can be invoked against every victim. When proven, the duty to compensate is diminished in proportion to the contributory negligence (no all-or-nothing approach as in cases of personal injuries). See Engelhard \& Van Maanen 1998, p. 43.

309 See Art. 2 Loi Badinter; - According to Van Dam 2006, p. 367, the development of liability caused by motor vehicles cannot be understood without taking into account the fact that there is compulsory insurance for damage caused by motor vehicles throughout Europe. The focus seems more on the distributive than on the corrective justice and the goals seem 
There are, however, two exceptions to the general rule of 100 per cent compensation. These rules regarding 'contributory negligence', as written in Articles 3 and 4 of the Loi Badinter, are very different from the normal rules of contributory negligence in the French law of delict. The first exception, leading to non-compensation, applies to both categories described below when an injured person voluntarily sought the damage. ${ }^{310}$ The second exception is when the fault of the injured party was inexcusable (faute inexcusable) $)^{311}$ and this fault was the exclusive cause of the accident (cause exclusive de l'accident); ${ }^{312}$ also in such a case the victim has no right to claim any damages (Article 3 Loi Badinter) ${ }^{313}$ In this sense, French law still applies an all-or-nothing approach in these cases. ${ }^{314}$ Moreover, if the injured belongs to a special category of protected persons (children under 16 years of age, persons older than 70 or persons with a permanent incapacity or a disability of 80 per cent or more), they will always receive full compensation for damages suffered. ${ }^{315}$ Only the first exception applies to persons belonging to this category, i.e. in the event they act intentionally. From the above it becomes clear that a defence invoking contributory negligence of children in cases of road traffic accidents is almost completely excluded; apart from children under 16 , this also applies to persons over 70 and the handicapped (over 80 per cent), provided they are not driving a motor vehicle. ${ }^{316}$

A totally different situation occurs when two motorised vehicles are involved in an accident. Persons who suffer damage in principle can claim

to be to provide compensation to victims of traffic accidents for the loss they suffered due to the accidents. In that sense the rules are instrumental for that goal; indeed this seems relevant as to the French situation as the mere fact of 'implication' leads to liability, and the defence of contributory negligence is more or less minimised regarding personal injury cases in traffic accidents. Van Dam rightly argued that compulsory insurance of liability for damage caused by motor vehicles in fact attributes damage to the risk community of the insured rather than to the wrongdoer personally.

310 Art. 3 Loi Badinter. See, e.g., Cass. civ., 21 July 1992, D. 1993, 212 (intention sü̈cidiaire); see also Viney 1992, p. 44; Van Dam 2000a, p. 45; 2000b, p. 545; Le Tourneau \& Cadiet 2003, p. 499, nr. 1877; - Of course, if the wrongdoer has acted intentionally, he will generally not be allowed to invoke a contributory negligence defence. According to Crim., 4 October 1990, D. 1990. IR. 284 and Crim., 16 May 1991, D. 1991. IR. 220 the duty of the wrongdoer to compensate the victim is not reduced because of contributory negligence, if he acted intentionally; see also Viney-Jourdain 1998, p. 335, nr. 430; Le Tourneau \& Cadiet 2003, p. 498, nr. 1873; Le Tourneau 2004, nr. 1873, p. 444; nr. 1877, p. 445.

311 This term is interpreted very restrictedly by the Cour de cassation; see, e.g., Haas \& Hartlief 1998, p. 34; Weyts 2003, p. 145f.; see also Engelhard \& Van Maanen 1998, p. 35ff.

312 On this requirement, see, e.g., Weyts 2003, p. 150 with references.

313 See Chabas 1988, p. 165ff.; Viney 1992, p. 44ff., 47f.; Haas \& Hartlief 1998, p. 33f.; Van Dam 2000b, p. 552.

314 See Sterk 1994, p. 60; Haas \& Hartlief 1998, p. 33.

315 See Chabas 1988, p. 174f.; see also Weyts 2003, p. $143 f$.

316 Van Dam 2006, p. 341. 
compensation for damage to their belongings, unless they commit a faute that contributed to the occurrence of their damage. ${ }^{317}$ The compensation is limited or excluded if a faute of the driver (conducteur) can be proven (see Article 4 Loi Badinter $).{ }^{318}$ The judge who decides on the facts has to decide whether the faute is of such a nature that the compensation should be diminished or excluded. ${ }^{319}$

A final situation that can occur is where a motorised vehicle is damaged by a pedestrian or cyclist. In that case, the common rules of the French law of delict apply and the driver of the motorised vehicle can claim damages based on Article 1382 (pedestrian) or 1384 al. 1 Code civil (cyclist); in that case it does not matter whether the cyclist or the pedestrian was also hurt. The pedestrian or cyclist can defend himself invoking force majeure or contributory negligence of the driver. ${ }^{320}$

To conclude, the compensation of drivers is left under the fault regime. Other victims, i.e. pedestrians, cyclists and passengers of motor vehicles, benefit from a quasi no-fault compensation regime. ${ }^{321}$ These victims are entitled to compensation, unless they are between 16 and 70 years of age and have committed an inexcusable fault that was the only cause of the accident.

\subsubsection{Traffic accidents: Germany}

Until 1909 traffic accidents had to be solved by the rules of the Bürgerliche Gesetzbuch; in that year, the Kraftfahrzeuggesetz took effect and remained in force until 1952 when it was replaced by the Straßenverkehrsgesetz (Road Traffic Act, StVG; into force on 23/1/1953). A distinction is made between strict liability for 'keepers ${ }^{\prime 32}$ or 'holders' (Halter; $\$ 7$ (1) StVG) and prima facie liability for drivers ( $§ 18 \mathrm{StVG}) .{ }^{323}$ According to $\S 7 \mathrm{StVG}$, the holder must compensate all damages caused during the use of the motor vehicle if the damage occurred in the course of the operation (running) of the car (causal connection).${ }^{324}$ Liability will be excluded if the defendant succeeds in proving that the accident was caused by an unavoidable event (see $§ 7$ (2) StVG). Furthermore, according to

317 See Engelhard \& Van Maanen 1998, p. 52f. and case law mentioned.

318 See also on this topic Engelhard \& Van Maanen 1998, p. $50 \mathrm{ff}$.

319 Engelhard \& Van Maanen 1998, p. 53.

320 ibid., p. 55.

321 Tunc 1994, p. 325.

322 The keeper is the person who uses the car at his own expense and who has the power of disposal that goes with such use; see Markesinis \& Unberath 2002, p. 733f.

323 Markesinis \& Unberath 2002, p. 734: the driver can rebut by proving that he was not negligent when driving the car.

324 Weyts 2003, p. 131 with references; another situation occurs when a person with an operational risk (Betriebsgefahr) is injured by a wrongdoer who was at fault. On that situation, see, e.g., Honoré 1983, p. 127. 
$\S 18$ StVG, the driver is liable in the event of a fault, but with a reversal of the burden of proof.

The apportionment principle contained in $\S 254$ BGB is also incorporated in $\S 9$ StVG: $:^{325}$ if the fault of the injured party (not being a holder or driver of a motor vehicle) has contributed to the occurrence of the damage, $\S 254$ BGB applies. ${ }^{326}$ If the victim of a road traffic accident does not observe traffic regulations or if he was responsible for operating a vehicle with an inherent danger, the rule of $\S 254$ (1) BGB applies (to the detriment of the victim). ${ }^{327}$

In the event in which the damage is caused by more than one vehicle or in the event the keeper of one vehicle sustains loss caused by the other party, the provision of $\S 17$ (1) StVG becomes applicable, which position does not differ from $\S 254(1):{ }^{328}$ apportionment is made where both are liable for a creation of risk, depending on the extent to which the injury was caused predominantly by one or the other of the parties. However, the nature of liability changes: it is not necessary for the defendant to invoke or establish the fault of the other driver or keeper; the risk inherent to the respective vehicle in the given circumstances is decisive. ${ }^{329}$

\subsubsection{Traffic accidents: The Netherlands}

In traffic accidents, ${ }^{330}$ the appeal to contributory negligence with regard to children younger than 14 and also older unmotorised traffic participants is restricted, as decided by the Hoge Raad in case law on Article 31 (old) Wegenverkeerswet of $1935^{331}$ (Road Traffic Act, WVW; at present Article 185 Wegenverkeerswet 1994,

325 On the latter legal provision, see extensively Hentschel/König/Dauer 2001, p. 163ff.; Other legal provisions as to the Haftpflichtrecht, such as e.g. § $34 \mathrm{LuftVG}$ and $\S 28$ AtomG, will not be discussed here.

326 When the victim is a child or mentally disabled, the normal rules of $\S \S 827-829$ apply.

327 See Erman/Egbert 2008, p. 961f.; Van Dam \& Clive 2009, p. 3648; see BGH, 9 January 1959, BGHZ 29, 163-171; BGH, 30 January 1979, NJW 1979, 980; - No compensation is provided if the contributory negligence of the injured party outweighs the negligence of the wrongdoer in such a way that the cause (Ursache) of the wrongdoer completely withdraws; see Hentschel/ König/Dauer 2001, p. 165.

328 Van Dam \& Clive 2009, p. 3648.

329 Markesinis \& Unberath 2002, p. 736.

330 In general, railway accidents with passengers are not dealt with any further in this study; the legislative developments and case law in the nineteenth century, and also the contemporary statutory provisions such as Art. 8:109 BW (the carrier can invoke contributory negligence when the behaviour of the passenger was (in part) the cause of the damage), are elaborately discussed by Van Dam \& Van Maanen 2010, p. 112ff.

331 Under a predecessor of this article, i.e. Art. 25 Motor-en Rijwielwet of 1905 (Motor Vehicles and Cyclists Act, MRW; Art. 25 was only inserted in 1924), the case law on this article showed more and more a reduction of the extent of liability in cases of contributory negligence of the injured party. See Star Busmann 1924, p. 55. On the basis for the liability rule of Art. 25 see also Van Dam \& Van Maanen 2010, p. 136f. 
WVW 1994), with a 100 per cent and 50 per cent rule. ${ }^{332}$ These rules are based on the aforementioned equitable correction. ${ }^{333}$ Overall, the Hoge Raad has greatly restricted the possibility of an appeal to contributory negligence in its judgments. ${ }^{334}$ In case law Article 185 WVW 1994 is interpreted to contain an operational risk (so-called Betriebsgefahr), meaning that motorised vehicles represent a more serious danger in traffic and the motorised road users are therefore held liable more easily when colliding with unmotorised traffic participants - and that they are therefore liable for a large share of the damage - than in case of collisions between 'equal' traffic participants. ${ }^{335}$

Article 185 (1) WVW 1994 makes the owner or holder of a motor vehicle liable, unless he can prove force majeure. The latter exception is interpreted very restrictedly. For car accidents, where there are physical injuries, ${ }^{336}$ the Hoge Raad has formulated some rules on the basis of the second standard of Article 6:101 BW, the correction based on equity. If the victim of the car accident (collision) is under 14 (a pedestrian or a cyclist), only intentional or reckless acts of the victim can be taken into account for the division of damages. ${ }^{337}$ Furthermore, the driver will only be exempted from his liability if the sole cause of the accident is an intentional or reckless, bordering on intentional, act of the victim under $14 .{ }^{338}$ When someone is liable based on Article $185 \mathrm{WVW}$, since he could not prove force majeure, ${ }^{339}$ but there is a fault

332 These rules can be regarded as compulsory rules for the outcome of the equity correction, regardless of the outcome of the assessment of the standard of causality; see also Tjong Tjin Tai 2005, p. 188; in general, on the (conditions for) liability based on Art. 31 (old) WVW, see Sterk 1994, p. 248ff. with literature references. According to Haas \& Hartlief 1998, p. 203, based on the motivation by the Hoge Raad, the background of these rules made by the latter is formed by the purpose of Art. $31 \mathrm{WVW}$ (protection of victims), the nature and the severity of the damage (often bodily injuries) and the compulsory WAM (liability) insurance; - The rules are also called: the 100\%-rule and the 50\%-rule by the Hoge Raad; see HR, 2 June 1995, NJ 1997, 700.

333 Hartlief 2002b, p. 16.

334 Also with regard to Art. 7A: 1638x (old) BW/Art. 7:658 BW there is great restraint with regard to contributory negligence. In traffic accidents, the background of the restraint can be explained by the need to protect people from certain risks; the widespread WA-coverage makes such restraining course possible; see Hartlief \& Tjittes 1999, p. 42; the authors wrote that eventually one can probably speak about restraint/reserve in case of violation of traffic and safety norms in general. See also Boonekamp aant. 17.4 ad Art. 6:101 BW (tendency towards reduction of contributory negligence in the event of violation of traffic and safety norms).

335 Tjong Tjin Tai 2005, p. 188.

336 The rules also apply to damage to objects, but the reimbursement based on Art. 185 is limited (Engelhard \& Van Maanen 1998, p. 18).

337 Tunc 1994, p. 326; Spier et al. 2000, p. 221f.; Tjong Tjin Tai 2005, p. 188.

338 HR, 1 June 1990, NJ 1991, 720; HR, 31 May 1991, NJ 1991, 721; see also Hartlief 1997a, p. 132; Engelhard \& Van Maanen 1998, p. 18; Haas \& Hartlief 1998, p. 202f.; Keirse 2003, p. 32, 232f.; Frenk 2006a, p. 29, 50f.

339 It would have been force majeure if he could prove that the collision was exclusively the result of faults of another person (and that he, therefore, had no blame at all), so unlikely for him that he, in determining his driver's behaviour, reasonably did not have to take this possibility into consideration; see, e.g., Nieuwenhuis 1999, p. 357 and HR, 22 May 1992, NJ 1992, 527. See also Van 
of the injured pedestrian or cyclist older than 14 years, the following rule applies: if the victim is older than 14, unless he acted intentionally or recklessly, bordering on intention, a minimum of 50 per cent of the damages will always be imputed to the driver-wrongdoer. ${ }^{340}$ Whether more than 50 per cent of the damages can be imputed to the driver is determined according to the general rule (i.e. the double standard) ${ }^{341}$ of Article 6:101 BW (primary apportionment made by a correlative balancing of causes and secondary apportionment by an equitable adjustment of the outcome of the primary apportionment. ${ }^{342}$ When an insurer of the victim takes action against the driver, the general rule of Article 6:101 applies, and he cannot profit from these (50/100\%) rules based on equity. ${ }^{343}$ In such a case the Betriebsgefahr can be taken into consideration in the correction, based on equity ('normally' this is already included in the 50 per cent rule and of course it cannot be taken into consideration twice). ${ }^{344}$ The differentiation in types of plaintiffs is underpinned by effective victim protection. ${ }^{345}$ Furthermore, the rule of Article 6:101 BW can still be applied in cases of accidents of cars and in situations in which occupants of motor vehicles are injured.

\subsection{Contributory Negligence After the damaging EVENT}

A connected problem is contributory negligence after the damaging event or as it is often brought forward - the question of the injured party's duty to limit

Dam \& Van Maanen 2010, p. $137 \mathrm{ff}$.

340 Tunc 1994, p. 326; see also Spier et al. 2000, p. 222; Keirse 2003, p. 32, 236; Frenk 2006a, p. 51.

341 Differently Van Dam \& Van Maanen 2010, p. 144: 'Whether the owner or keeper can be obliged to pay more depends on the mutual causal contributions to the damage.'

342 HR, 28 February 1992, NJ 1993, 566; HR, 24 December 1993, NJ 1995, 236. See also Stolker 1994, p. 9ff.; Engelhard \& Van Maanen 1998, p. 18; Haas \& Hartlief 1998, p. 165; Keirse 2003, p. 237; Weyts 2003, p. 135f.; Tjong Tjin Tai 2005, p. 188. With regard to the first standard, it becomes clear from HR, 2 June 1995, NJ 1997, 700-702, that the causal partition requires an objective weighing of endangering behaviour, where one abstracts from age and other subjective circumstances; in this sense Haas \& Hartlief 1998, p. 165f., who also write that with regard to the second standard, the Hoge Raad gives the example of a child who is behind in his or her physical and mental development as a case that could lead to an extra correction based on equity (HR, 24 December 1993, NJ 1995, 236) and also the example of the (diverging) degree of culpability of traffic behaviour (see HR, 2 June 1995, NJ 1997, 700-702).

343 Tunc 1994, p. 326f.; Engelhard \& Van Maanen 1998, p. 18f., 61; Haas \& Hartlief 1998, p. 167; Keirse 2003, p. 234, 237f.; Van Boom 2004, p. 144; Tjong Tjin Tai 2005, p. 188; Boonekamp aant. 17.5 ad Art. 6:101 BW; - The advantages of more stringent requirements to the defence of force majeure do apply as does also the reversal of the burden of proof; see, e.g., Engelhard \& Van Maanen 1998, p. 61.

344 HR, 10 November 2000, NJ 2000, 718; HR, 3 June 2005, NJ 2005, 286; Tjong Tjin Tai 2005, p. 190.

345 Engelhard \& Van Maanen 1998, p. 19; see also Hijma's annotation to HR, 5 December 1997, NJ 1998, 402. 
his loss. ${ }^{346}$ In France, since no provision in the Code civil expressly mentions a failure to avert or minimise harm, ${ }^{347}$ this problem is dealt with in case law and doctrine. ${ }^{348}$ Generally, the claimant has a duty to restrict the damage as far as this can be reasonably expected from him. ${ }^{349}$ What can be reasonably expected from a victim will depend on the circumstances of the case. ${ }^{350}$ Therefore, the duty to take adequate measures to mitigate the loss under the circumstances can be attributed to the victim as blameworthy negligence. ${ }^{351}$

French (and Belgian) scholarly doctrine considers the breach of such a duty a species of the genus contributory negligence. ${ }^{352}$ The consequences of such neglect (and thus fault) have to be dealt with in the same manner as in the case of any other concurrence of fault of the wrongdoer and negligence of the injured party, i.e. by dividing the damage between both parties. ${ }^{353}$ Most scholars (of these countries) argue that the extra damage the injured suffers as a consequence of his neglect to limit his damage ${ }^{354}$ cannot be claimed from the wrongdoer and has to be borne by the victim. ${ }^{355}$ Some argue that this extra damage can possibly still be divided between the wrongdoer and the injured party. ${ }^{356}$

346 Strictly speaking, the term 'duty to mitigate the loss' is incorrect, since no such duty exists. See, e.g., Keirse 2003, p. 72; Frenk 2006a, p. 2. It expresses the thought that someone who has not restricted the damage, when he should have done so, the damage totally or partially is at his own expense (also Keirse 2003, p. 79). On this topic, see also Van Dam 2006, p. 337. As the term 'duty to limit the damage' is quite common, I will use it here for the sake of convenience. On the failure to avert or minimise the harm, see for a comparative perspective, Honoré 1983, p. 101ff.; - On the topic of the legal unification as to duty to mitigate the loss, see, e.g., Jansen 2009, p. 1082f.; 2012, p. 403.

347 Honoré 1983, p. 101.

348 Keirse 2005, p. 9; the same applies for Belgium.

349 Van Dam 2006, p. 338. If he negligently fails to take reasonable steps to get medical aid, to follow medical instructions, to look for work, or to follow courses to increase his opportunities, he will lose his right to claim full compensation for his damage; see Van Dam 2006, p. 338. On the right of the patient to refuse medical treatment in Belgian and French law, see Weyts 2003, p. 56ff.; - According to Art. 1373 of the Avant-projet, a victim's duty to mitigate his own harm ceases when the steps to be taken are of such a nature that they would compromise the victim's physical integrity; see Rémy-Corlay 2009, p. 308.

350 See Honoré 1983, p. 102.

351 Keirse 2005, p. 9; the same applies for Belgium.

352 See (implicitly) Kallen 1932, p. 452 with references; Van Oevelen 1993/1994, p. 1396; Dirix 1984, p. 56; Ronse 1984, p. 325; Simoens 1999, p. 86; Weyts 2003, p. 51, 67; Keirse 2003, p. 258; 2005, p. 9; see also Cousy \& Droshout 2004, p. 29.

353 Dirix 1980, col. 2924; 1984, p. 56; Honoré 1983, p. 101; Ronse 1984, p. 332; Van Oevelen 1994, p. 1396; Simoens 1999, p. 89; see also Keirse 2003, p. 258; 2005, p. 5.

354 In Belgium, the Hof van Cassatie decided in Cass. 14 May 1992, R.W. 1993/1994, 1395, that the injured party is not obliged to limit the damage as much as possible, but only to take those measures to limit the disadvantage if that is consistent with the attitude of a reasonable and prudent person (comp. bonus pater familias).

355 Demogue 1924, p. 130, 516ff.; Ripert 1933, p. 116f.; Ronse 1984, p. 332; Kruithof 1989, p. 53; Van Oevelen 1994, p. 1396; Simoens 1999, p. 89; Weyts 2003, p. 66; see also Keirse 2003, p. 258.

356 Keirse 2003, p. 258; 2005b, p. 9; see also Dirix 1980, col. 2924; 1984, p. 56. 
In Germany, from $§ 254$ (2) BGB three duties to take positive action are imposed on the injured party: to warn, to avoid damage and to take appropriate measures to reduce the extent of the damage. ${ }^{357}$ Contributory negligence is attributed to the injured party if he fails to act in good faith by not taking the measures an ordinarily careful and reasonable person would take in order to safeguard his own interests. ${ }^{358}$ In Germany, various views are taken in this respect: some defend a total denial of the extra damage, others argue that under certain circumstances it can be just to leave the extra damage in total with the injured party, while also the view that the extra damage should be partitioned between wrongdoer and injured party has been defended. ${ }^{359}$ The Bundesgerichtshofdecided that the view that the extra damage should always be borne by the injured party in total is not compatible with the wording of the provision of $\S 254$. $^{360}$

The central question in the event of the duty to minimise the harm is: did someone act differently than a reasonable person would have done in the circumstances of the case? As comparative standard the reasonable man (diligens paterfamilias) is taken. The reasonableness is decisive in this assessment, and thereby the concrete circumstances of the case are a major determinant. ${ }^{361}$ Although the all-or-nothing approach in cases of contributory negligence ${ }^{362}$ was abandoned after 1916 in the Netherlands, this was not the case in the Netherlands with regard to the extra damage suffered because of the breach of the obligation to limit the damage. The extra damage was not compensated; this was based on the assumption that the causal link was missing when the liability was based on and the extra damage partly caused by the breach of the duty to limit the damage. ${ }^{363}$ This approach was already criticised in the early

357 See also Keirse 2003, p. 259; Fedtke \& Magnus 2004, p. 78; Von Bar \& Clive 2009, p. 3643; - If the injured party made expenditures to fulfil his duties, the wrongdoer must compensate them; see BGH, 1 April 1993, NJW1993, 2685, 2687.

358 BGH, 13 December 1951, NJW 1952, 299, 300. It is for the judge to assess in each case what measures were advisable to avert or minimise the harm; see Ennecerus \& Lehmann 1958, p. 78; Honoré 1983, p. 101.

359 Keirse 2003, p. 259; 2005b, p. 10. On the latter view, see Venzmer 1960, p. 193f. See also Jansen 2007, p. 710f. with references.

360 BGH 24 July 2001, NJW 2001, 3257-3258; - On the topic of the duty/Obliegenheit to prevent or minimise the damage, see also, e.g., Lange 1979, p. 362ff.; Geigel/Rixecker 2001, p. 49ff.; MünchKommentar BGB/Oetker §254 (2007), Rdnr. 68ff., p. 516ff.; Erman/Elbert 2008, p. $968 f f$.

361 Keirse 2003, p. 160.

362 On the various views on the contents of the legal expression 'contributory negligence' in Dutch (eigen schuld), see, e.g., Keirse 2003, p. $73 f$.

363 See Keirse 2003, p. 44, 71, 249ff., 262; 2005b, p. 6, with the literature mentioned there; - An alternative system to obtain compensation is insurance, which is gaining popularity; the consequences of a move from liability law to an insurance system for the problem of contributory negligence and for the duty to mitigate the loss are discussed by Frenk 2006a; 2006b, p. 41ff. This topic is beyond the scope of this study. 
twentieth century, as a partition of the extra damage was defended. ${ }^{364}$ With the (new) Dutch Burgerlijk Wetboek of 1992, the duty to limit the damage is considered a species of the genus contributory negligence. ${ }^{365}$ Therefore, Article 6:101 BW became the basis for the doctrine on the duty to limit the damage, and not the break in the causal connection. ${ }^{366}$ Some authors still argue that the extra damage has to be attributed to the injured party, and this view was also applied in the case law of lower courts. ${ }^{367}$ Recently, it has been - in my view rightly - defended that it is preferable to apply the two criteria of Article 6:101 of the Burgerlijk Wetboek to the breach of the duty to limit the damage, and so to partition the extra damage in proportion to these criteria. ${ }^{368}$ The criterion of causality developed into determining and weighing the degree of the mutual probability of causation; ${ }^{369}$ the second criterion is corrective, namely an equity correction where a lot of factors could be weighed, such as the seriousness of the mutual violation of legal provisions, the degree of culpability, the nature of the liability of the wrongdoer, the type and gravity of the damage incurred, personal circumstances, financial capacity of the injured party, insurance positions ${ }^{370}$ and the level of the costs to mitigate the damage, etc. ${ }^{371}$

364 See Ribbius 1906, p. 194ff.; recently also Keirse 2003, p. 45, 262 with references and Knapen 2004, p. 6.

365 According to Art. 6:96 (2) NBW, the injured party is entitled to a claim for expenditures incurred in his attempt to avert or minimise the loss. See also Van Bar \& Clive 2009, p. 3645; extensively on the topic of the compensation for expenditures made to limit the damage, Keirse 2003, p. $280 \mathrm{ff}$.

366 Keirse 2003, p. 262f.; 2005b, p. 7.

367 See Keirse 2005, p. $7 f$.

368 Van Wassenaer van Catwijck \& Jongeneel 1995, p. 55, 130; Keirse 2003, p. 269ff.; 2005, esp. p. 11f.; see also Asser/Hartkamp 2004 (IV-I), nr. 453a, p. 412f.; Frenk 2006a, p. $86 f$.

369 The extent to which circumstances on either side brought into existence the damage risk.

370 See also HR, 4 May 2001, NJ 2002, 214; - According to Hartlief \& Tjittes 1999, p 41, if the wrongdoer is compulsorily insured against liability, it could/would be fair to limit the appeal on contributory negligence or make an appeal on it less easy; in the opposite situation, where it is the injured party who is insured for losses, it would be possible that one more easily and/ or more extensively adopt the defence of contributory negligence. However, it is also argued that restraint is required. The question of who is insured in the concrete case should not answer the question of whether the injured party is contributorily negligent. Further arguments can be found in Hartlief \& Tjittes 1999, p. 41f. (with further references). Less restraint is needed, according to these authors, in the context of a realisation of a collectivist point of view, as, e.g., the great restraint as to contributory negligence in the application of Art. 185 WVW, Art. 7:658 BW and probably in cases of violation of traffic and safety norms in general - situations in which there is need to protect certain people against certain risks; - Critical are Brunner, see his objections in his note to HR, 4 May 2001, NJ 2002, 214 and Van Dam 2001, p. 352. See also, e.g., Keirse 2003, p. $222 \mathrm{ff}$.

371 Keirse 2005, p. 14f.; 2006, p. 187; an extensive discussion of various factors can be found with Keirse 2003, p. 213ff. 


\subsection{HARMONISATION: RULES FOR THE FUTURE?}

This chapter examined the question of whether damages can be awarded to the injured party in case of contributory negligence - assuming that the wrongdoer is in principle liable for the damages, of course. In most of the contemporary continental European law systems, in the event of contributory negligence, the wrongdoer is liable only for part of the damage (' $\$ 254$ of the Bürgerliche Gesetzbuch, §1304 of the Allgemeine Bürgerliche Gesetzbuch, Article 51 II of the Schweizerische Obligationenrecht of 1881, Article 44 of the Schweizerische Obligationenrecht of 1911, Article 6:101 of the BurgerlijkWetboek'). The proportional apportionment of damages as legal consequence of the contributory negligence of the injured party seems to be 'contemporary common European law'. ${ }^{372}$

To achieve a common European law in the area of private law, one would aim at harmonisation. ${ }^{373}$ However, this could lead to the inevitability of considering whether other doctrines (among which causality) have to be adjusted as well as of realising the application of one liability law in Europe. ${ }^{374}$ In any case, the adoption of a common 'European' terminology is necessary to counteract the traditional national notions of the law, which can give rise to ambiguities and misunderstandings. ${ }^{375}$

The method of comparative law can provide valuable insights of course but, in case of differences between private law rules in various countries, it is

372 Also Jansen 2007, p. 677. See also Jansen 2009, p. 1082; 2012, p. 402; - See also for the acknowledgment of the solution of proportional apportionment of damages in non-contractual liability cases in European law, the leading case C-145/83, Adams v Commission [1985] ECR 3539, 3592, esp. nr. 53. In this case the amount of damages, which the Commission had to pay, was diminished due to the contributory negligence of the injured party. As the injured party contributed significantly to the damage, which he suffered, and in assessing the conduct of the Commission (wrongdoer) on the one hand and that of the injured party on the other hand, the Court decided that it was equitable to apportion the responsibility for the damage equally between the two parties (i.e. 50/50). See on this case elaborately Wurmnest 2003, p. 312ff.; see also Article 8(2) Directive 1985/374/EEC, [1985] OJ L 210/29 concerning liability for defective products, which states that the liability of the producer may be reduced or disallowed when, having regard to all the circumstances, the damage is caused both by the defect in the product and by the injured party's fault or the fault of any other person for whom the injured party is responsible.

373 One could question, however, whether a (further) harmonisation of liability law should be endeavoured and whether national preferences in this area should be given up. On the topic of (European) harmonisation of liability law and an (negative) assessment of the arguments in favour of such harmonisation, see Hartlief 2002a.; - However, it has been argued that the doctrine of contributory negligence is one of the factors that make unification difficult, see Weyts 2003, p. 6f., 515; differently, Kontogianni 2003, p. 176; - See also Hartlief 2002a, p. 946 , who points out that with regard to contributory negligence of the injured party, there are important differences in various European countries in general, but in particular in the area of traffic liability.

374 See Weyts 2003, p. 515.

375 See Kontogianni 2003, p. $176 f$. 
difficult to say which rule has to be chosen. By adding the historical component, by looking at the common foundations of private law in Europe, a private law that became fragmented after the period of ius commune, the insights received from the comparative law perspective can be deepened; the historical study can provide insight into the arguments chosen for certain models (and the advantages and disadvantages). In this way, the discussion can become more fundamental. There are some initiatives to come to a basis for harmonisation of extra-contractual liability law, and I would like to discuss two of them. Firstly, the European Group on Tort Law (EGTL) that published their Principles of European Tort ${ }^{376}$ Law (PETL) in 2005 and, secondly, the Study Group on a European Civil Code (SGECC), that, together with the Research Group on EC Private Law (Acquis Group), published their Draft Common Frame of Reference in 2008. ${ }^{377}$

The PETL are meant to reveal the common foundations of the various national legal systems and to offer a basis for discussion for a future European law of delict. Moreover, already now the Principles are expected to have some sort of harmonising effect. ${ }^{378}$ On our topic, Article 8:101 PETL is the most relevant provision: contributory conduct or activity of the victim. The expression 'contributory conduct or activity' is chosen instead of the terminologies used in all current national legal systems. The aim was to overcome the shortcomings arising not only from the widely diverging terminology but, according to Martín-Casals, also from the misleading idea arising from the traditional labelling of the conduct of the victim as negligence or culpa. ${ }^{379}$ The original expression used by the Group was 'contributory negligence', being aware of the meaning of contributory negligence in common law, just as culpae compensatio

376 While 'tort law' is the common law term, in this study, the term 'law of delict(s)' - the civil law term - is used.

377 As regarding contributory negligence of the injured party/creditor in initiatives of European contract law, see, firstly, the Principles of European Contract Law, 9:504 PECL. Remarkably, this article in fact applies the all-or-nothing approach. Differently, Article 9:505 PECL which does apply the option of a reduction of loss, but this article only applies in the event of a violation of the duty to minimise or avoid the damage; see also Kontogianni 2003, p. 173ff. See also, secondly, Article 7.4.7 UNIDROIT PICC, including a reduction of the amount of damages in the event harm is in part due to the (conduct of the) aggrieved party, and, thirdly, Article 8:403 Acquis principles, which includes the possibility of a reduction or exclusion of damages to the extent that the creditor wilfully or negligently contributed to the effect of the non-performance or could have reduced the loss by taking reasonable steps. See, finally, Article 77 of the United Convention on Contracts for the International Sale of Goods (CISG), according to which a party that relies on a breach of contract must take such measures as are reasonable in the circumstances to mitigate the loss, including loss of profit, resulting from the breach. If he fails to take such measures, the party in breach may claim a reduction in the damages in the amount by which the loss should have been mitigated.

378 Koziol 2004, p. 234; Van Boom \& Giesen 2004, p. 517 f.

379 Martín-Casals 2005, p. $130 f$. 
in 'old' Continental law, as an all-or-nothing rule, in the sense that the victim's negligence excludes compensation. ${ }^{380}$ Furthermore, the Group rightly stated that all European systems now follow a more flexible approach leading to a partition of damages within the range from 0 to 100 per cent, which only results in exclusion of a claim if the damage is solely due to the conduct or the activity of the victim. ${ }^{381}$ The Group thought the term negligence misleading since in a strict technical sense the conduct of the injured cannot properly be qualified as fault or negligence. Firstly, no one has a legal duty to not cause damage to his or her own sphere. Secondly, in some cases, the operational risks embedded in the activity carried out by the victim can also contribute to the damage. ${ }^{382}$ The consequences of contributory conduct or activity of the victim could lead to a reduction of the amount of damages. The normal apportionment procedure is to establish the amount of the victim's full damage and then reduce it in proportion to the victim's contribution. ${ }^{383}$ The contributory conduct or activity has no effect if the wrongdoer acted intentionally, except in the event of provocation by the victim. ${ }^{384}$ Intent on the side of the victim normally leads to a denial of claim, unless the wrongdoer has a specific obligation to prevent the victim from damaging himself or herself. ${ }^{385}$

It is highlighted by its drafters that the DCFR promotes knowledge of private law in the jurisdictions of the European Union and will, in particular, help to show how much national private laws resemble one another and have provided mutual stimulus for development - and indeed how much those laws may be regarded as regional manifestations of an overall common European legacy. ${ }^{386}$ The drafters of the DCFR nurture the hope that it will be seen also outside the academic world as a text from which inspiration can be gained for suitable solutions for private law questions. ${ }^{387}$ Although the provisions of the DCFR were based on a comparative analysis of the law of the Member States and the applicable European law, this method is not convincing if one does not know how this method was applied. It is not clear whether one looked at the common denominator of the involved jurisdictions or whether one chose the 'better' solution. ${ }^{388}$

380 Contributory negligence was also understood in this sense in the United States, but the rule has been progressively abandoned and is substituted by 'comparative negligence'; see Martín-Casals 2005, p. 131.

381 Martín-Casals 2005, p. 131.

382 ibid., p. 131f.

383 ibid., p. 134.

384 See also Van Dam 2006, p. 339.

385 Martín-Casals 2005, p. 135.

386 Draft-CFR (edn. Von Bar \& Clive 2009, p. 4), nr. 7.

387 Draft-CFR (edn. Von Bar \& Clive 2009, p. 4), nr. 8.

388 See Smits 2008, p. $278 f$. 
Article VI.-5:102 (1) DCFR concerns the situation in which the personal contributory fault of the injured party ${ }^{389}$ contributed to the occurrence or the extent $^{390}$ of the legally relevant damage. In this article, two requirements are included: the causal connection of the injured party's act to the materialisation or the extent of the damage; and fault in the broad sense of negligent and intentional harm to one's own interests. Besides liability based on negligence or intention, this rule of contributory negligence also applies to strict liability. This article is, in essence, based on the so-called mirror principle: everything which can support accountability and liability for legally relevant damage can wholly or partially reduce liability when the roles are reversed and the injured party's conduct or source of danger is concerned. ${ }^{391}$

In principle, as a result of contributory negligence the claim for damages is reduced according to the degree of contributory negligence. The result is mostly a division of liability (the proportions will depend on the circumstances); this can even lead to a denial of the injured party's right to recovery, if his contributory negligence outweighs the wrongdoer's responsibility to such an extent that there is no room left for liability. When the injured party intentionally caused the accident, he will usually get no compensation at all (it is by no means rare that the same applies in case of gross fault); a reduction of the victim's claim in the event of intentional contributory fault mostly emerges in cases in which someone intentionally and unreasonably refuses to minimise the harm that already occurred. ${ }^{392}$

There are some cases in which no regard is taken with respect to contributory fault, namely, first, in case of a very minimal contributory fault of the injured party, as in that case 100 per cent compensation will be granted (usually the minimum threshold is set at 10 per cent), ${ }^{393}$ second, in cases of an insignificant (negligibly low) causal contribution, and, third, in case of a special rule for traffic accidents (in cases of bodily injury contributory fault only gives cause for a reduction of the claim for damages in cases of gross

389 According to Von Bar \& Clive 2009, p. 3628, who prefer to speak of 'contributory fault' instead of 'contributory negligence', as the injured party does not cause harm to someone else, and 'contributory fault' better reflects why the claim is to be reduced, namely the adoption of a personally neglectful position towards his own interests.

390 According to Von Bar \& Clive 2009, p. 3630, this also relates to the minimisation of patrimonial consequences of a bodily injury; it is only required to take or permit reasonable measures.

391 Von Bar \& Clive 2009, p. 3628, where also exceptions to this principle are mentioned.

392 ibid., p. 3630.

393 Von Bar 1999, p. 554, and see already Wester 1976, p. 251 (with regard to the situation in German case law); see Von Bar \& Clive 2009, p. 3631, according to whom, this corresponds with court practice, saves work for the judiciary, is in line with the considerations that support the defence of contributory fault and reflects in this area the rule of liability in VI.-6:102 (De minimis rule). 
disregard of the injured party's own safety). In these cases, when someone suffered bodily injury, only gross disregard of one's own safety could give cause to a reduction of his claim. In this way, the more general European tendency to specially protect victims of car accidents is reflected. Road traffic leads to high risks; furthermore, the originator of the damage is normally insured against liability, while pedestrians or cyclists usually are not. This lack of balance is, at least partially, remedied by the special rule of paragraph $(2)(\mathrm{c})$ : assuming that there is a contributory fault in the occurrence of the damage (not a failure to minimise the damage), and that the traffic accident is caused by a motor vehicle. ${ }^{394}$

In general, Article VI.-5:102 DCFR does not distinguish a difference in the types of legally relevant damage, except for the rule contained in paragraph (2)(c), a special rule regarding bodily injury resulting from traffic accidents. In the latter category, one has to make a distinction between personal injuries and damage to objects (property damage). In the event of damage to property, the usual care in dealing with one's own goods can also be required where traffic is concerned, and a partition of damage is possible. In the category of personal injuries, a further distinction between categories of persons is not made, since everyone is affected in a special way and is subject to the dangers of road traffic. According to paragraph (2)(c), no regard is to be had to the injured person's want of care contributing to that person's personal injury caused by a motor vehicle in a traffic accident, unless that want of care constituted profound failure to take such care as was manifestly required in the circumstances. Therefore, when the injured party acts in a grossly negligent manner, the claim will be reduced or totally denied. Such gross negligence, i.e. a profound failure to take care as manifestly required in certain circumstances, occurs for example in the situation of drunken driving. ${ }^{395}$

Paragraphs (3) and (4) contain extensions of the mirror principle to strict liability: paragraph (3) concerns the case where damage is caused to an employer by a third party, but where the damage has also occurred (or has been increased) due to the contributory fault of his employee; in legal proceedings, where a claim is brought for damages, the claim will be reduced due to contributory fault of his employee (the same applies in case of a representative). And paragraph (4) relates to the circumstances in which compensation is reduced because of the injured person's own responsibility for a contributory source of danger. ${ }^{396}$

394 See also Von Bar 2000, p. 548; Von Bar \& Clive 2009, p. 3631 .

395 Von Bar \& Clive 2009, p. 3632.

396 ibid., p. 3627. 


\section{$5 \cdot 9$ Concluding Remarks}

\subsubsection{The concept of contributory negligence in the nineteenth century}

In French law, the Code civil of 1804 did not contain a general rule on contributory negligence; the topic was dealt with in case law and in particular by the Cour de cassation. In case law the concept of faute de la victime was developed. The legal situation with regard to contributory negligence in the first half of the nineteenth century is not quite clear. It has been argued in scholarly studies that a partition was made based on the faults of both parties, while others say that the all-or-nothing approach was still applied. A more profound study of case law seems to be necessary here. At the end of the nineteenth century, the situation in which the injured party and the wrongdoer were at fault was characterised as faute commune, and a partition of damages was applied, proportionate to the gravity of faults on either side. ${ }^{397}$ This solution was not exactly the same as that proposed by Chr. Wolff, but the legal consequences were more or less the same. The development in France was initiated by the acceptance of judicial discretion when assessing the question of whether negligence (in cases in which both parties were at fault) would give rise to liability and when determining the part of the total damages which the wrongdoer had to pay. The partition made based on the gravity of faults was accepted by the majority of legal scholars and judges who initially stuck to the application of D. 50.17.203, leading to a denial of claim. Later, the all-or-nothing approach was abandoned as in the last quarter of the nineteenth century case law began to apply the theory of partition according to the gravity of faults.

The partition of damages as proposed by Wolff seems to have had its first codification in $§ 1304$ of the Austrian Allgemeine Bürgerliche Gesetzbuch, in which one can also find judicial discretion as regards the consequences of contributory negligence. The situation in nineteenth-century Germany was different. The Historical School just reproduced Roman law texts, and defended the view that no compensation had to be provided if the injured party had (any) contributory negligence. However, the more practical-oriented literature applied the maior culpa doctrine. As to the all-or-nothing approach, however, an adjustment was made in this literary genre. It was generally stated that according to the

397 The term faute commune can already be found in maritime cases, where one can find a subsidiary solution of division in halves, which can also be found in old French law and which is called judicium rusticorum (see also Solomon's judgment in 1 Kings 3:16-28); it has found its way into § 407 Code de commerce, and later into Loi relative aux événements de mer (1967). 
principles in D. 19.1.11.12 and D. 19.1.45.1 the individual consequential losses, for which the injured was responsible, could not be imputed to the wrongdoer. This was in fact a first attempt to escape the all-or-nothing approach (and the tradition of ius commune). Nevertheless, the maior culpa doctrine survived in the nineteenth-century German usus modernus. The Pandectists tried to find new dogmatic reasons to justify the denial of claim in the event of contributory negligence. Their theories were mainly causation theories based on the thought of an interruption of the causal connection in case of contributory negligence. An (often) connected theory was that of culpae compensatio, based on the rule of D. 50.17.203. In the end, the prevailing view held that equity must be the dogmatic basis of the rule of fault compensation. In practice, a small contributory negligence already led to a denial of claim. However, to avoid unfair solutions, to an increasing extent practice opposed this approach; legal practice may have turned to the preponderant responsibility of one of the parties, following also the doctrine of maior culpa. Already the Reichsoberhandelsgericht in some cases ruled that a small contributory negligence of the injured party did not lead to the denial of a claim. A reduction of the compensation amount in case of contributory negligence was accepted for the first time by the Reichsgericht in 1883. The principle of judicial estimation of damages according to $\S 260$ Reichscivilprozessordnung of 1877 (now § $287 \mathrm{ZPO}$ ) allowed the Reichsgericht to apply the natural law rule in its practical consequence in totality.

In the Netherlands, the Burgerlijk wetboek of 1838 contained no explicit rule on contributory negligence. From the thesis of Van Nierop (1905), one can deduce that in the event of a small contributory negligence, no weighing of causality was applied, but of negligence; the 'main fault' is aimed at. Only when the contributory negligence of the injured party was less than the negligence of the wrongdoer did he have a right to claim damages, i.e. 100 per cent of the damages. There was still an all-or-nothing approach, based on the maior culpa variant of the culpae compensatio doctrine. The all-or-nothing approach in cases of contributory negligence ended with the judgment of the Dutch Hoge Raad in 1916, when the Hoge Raad decided that the duty to compensate had to be measured based on the extent to which the negligence of both parties contributed to the damage. Although the legal basis remained disputed throughout the twentieth century, the majority view came to hold that the reduction of liability was based on equity. 


\subsubsection{The concept of contributory negligence in codes and in contemporary law}

In France, a partition was made based on the gravity of the parties' faults. Contributory negligence seems to have (totally or partially) broken the causal connection. In principle, faute de la victime led to a partial compensation. A denial of claim was only provided if the faute de la victime was regarded as an external cause (cause étrangère), which was unforeseeable (imprévisible) and unavoidable (irrésistible), and the sole cause of the damage. A total denial of claim was only provided if the injured party's faute greatly exceeded the wrongdoers' conduct, i.e. in the case of an intentional fault, a provocation or consent of the victim. Next to the gravity of faults also other circumstances can be taken into account in the assessment, e.g. the causal impact.

With regard to the strict liability based on Article 1384 of the Code civil, a total exoneration of the wrongdoer was only possible in the event of an external cause, e.g. an act of the victim that was unforeseeable and insurmountable. ${ }^{398}$ From 1934 onwards a reduction was possible in the event of contributory negligence based on the gravity of faults, until 1982 when the Cour de cassation decided that such a partition was not possible anymore in the case of contributory negligence (Desmares case); this was in fact a return to the all-or-nothing approach. However, the possibility of a partition of damages in the event of contributory negligence was re-introduced in 1987 by the Cour de cassation. With regard to traffic accidents, the Loi Badinter (1985) gave a general rule in principle of 100 per cent liability for personal injuries for the owner or the keeper (gardien) (or the liability insurance) of motorised vehicles. The rules regarding 'contributory negligence' are written in Article 3 and 4 of the Loi Badinter and are very different from the normal rules of contributory negligence in the French law of delict. The first exception applies when an injured person has voluntarily sought the damage, because in that case no recovery has to be paid. The second exception is when the fault of the injured party was inexcusable and this fault was the exclusive cause of the accident; also in such a case the victim has no right to claim any compensation (Article 3 Loi Badinter). In this sense, French law still applies an all-or-nothing approach in these cases (i.e. to victims aged between 15 and 71 years with no permanent incapacity or a disability of 80 per cent or more). Moreover, if the injured party belongs to a special category of protected persons (children under 16, persons older than 70 or persons with a permanent incapacity or a disability of 80 per cent or

398 See Cass. ch. réun. 13 February 1930, D.P. 1930.I.57 (Jand'heur). 
more), they will always receive compensation for damages suffered. Only the first exception applies to persons belonging to this category, i.e. in case they act intentionally. So a defence invoking contributory negligence of children in cases of road traffic accidents is almost completely excluded; apart from children under 16, this also applies to persons over 70 and the handicapped (over 80 per cent), provided they are not driving a motor vehicle.

In Germany at the beginning of the twentieth century, the concept of Mitverschulden - influenced by the Swiss OR, the French doctrine and the Austrian Allgemeine Bürgerliche Gesetzbuch (1811) - was codified in $§ 254$ of the Bürgerliche Gesetzbuch. This concept of Mitverschulden is considered a rule of equity; in this case an apportionment has to be made, based on the circumstances of the case, with an emphasis on preponderant causation. Although the primary standard was causation, the secondary standard was a review of other circumstances (such as negligence). With the codification in $\S 254$ BGB, the doctrine of fault compensation was dismissed. Shortly before, the Reichsgericht still applied this doctrine in 1891, making only an exception when the contributory negligence was insignificant. Just as $§ 1304$ of the Austrian Allgemeine Bürgerliche Gesetzbuch, § 254 of the Bürgerliche Gesetzbuch contained the rule of judicial discretion. $\S 254$ BGB aimed at the predominant causation (vorwiegende Verursachung), which seems like the doctrine of proximate or near cause (causa proxima or propinqua). However, the Reichsgericht kept searching for the main fault, and therefore the predominant causation (vorwiegende Verursachung) seems to have been interpreted already from the start of the twentieth century as überwiegende Verschulden. One can conclude that the contemporary weighing of faults is an idea already present in the period of usus modernus combined with Wolff's theory, the latter theory also coming back in the partition of damage based on the respective faults.

In the Netherlands, according to Article 6:101 of the (new) Burgerlijk Wetboek of 1992, a reduction of the amount of damages is given in the event of contributory negligence, based on the circumstances that can be attributed to the parties that contributed to the occurrence of the damage. Two standards are provided: probability of causation and the correction based on equity, including the faults of the parties, etc. Recently, Keirse (2003 et al.) defended that it is preferable to distinguish four phases in this article (see above). In traffic accidents, when a motor vehicle collides with a pedestrian or cyclist, Article 31 Wegenverkeerswet of 1935 (at present Article 185 Wegenverkeerswet of 1994) and case law developed for that particular situation are applied. The second standard of Article 6:101 of the Burgerlijk Wetboek of 1992 is given further form 
in a special way, namely by the 100 per cent and 50 per cent rules developed by Dutch case law. In that respect one can argue that an all-or-nothing approach was re-introduced, and the wrongdoer can only be relieved when the injured party acted intentionally or recklessly, bordering on intention, in which case no compensation will be provided at all; out of this exception, in cases where the injured party is younger than 14 years old, 100 per cent of his damage will be compensated and in cases where the injured party is older than 14, still a minimum of 50 per cent will always be compensated.

Some final remarks on the concept of contributory negligence at the outset of the twenty-first century have to be made. The rule of Article 8:101 PETL gives the possibility of a reduction or a total dismissal of the amount/claim of damages in the event of contributory negligence, which possibility can indeed be qualified as a common rule of the various legal systems. Article VI.-5:102 (1) DCFR is more elaborate and concerns the situation in which the personal contributory fault of the injured party contributed to the occurrence or to the extent of the legally relevant damage. In this article, two requirements are included: causal connection of the injured party's act to the materialisation or the extent of the damage; and fault in the broad sense - negligent and intentional harm to one's own interests. In principle, the consequence of contributory negligence is a reduction according to the degree of fault. ${ }^{399}$ To this rule of personal contributory fault there are some exceptions: in the event of a very minimal contributory fault of the injured party, because in that case a 100 per cent compensation will be granted (usually the minimum threshold is set at 10 per cent); insignificant (negligibly low) causal contribution; and there are special rules in case of traffic accidents. In these cases, when someone suffered bodily injury, only (surprisingly) gross disregard of one's own safety could give rise to a reduction of the victim's claim. In this way, the more general European tendency to especially protect victims of car accidents is reflected. The special rule of paragraph $(2)(\mathrm{c})$ as regards bodily injury resulting from traffic accidents makes no distinction between different categories of persons (as the aforementioned legal provisions in various countries did).

399 This can even lead to a denial of his right to compensation, if his contributory negligence outweighs the wrongdoer's responsibility to such an extent that there is no room left for liability. When the injured party intentionally caused the accident, he will usually get no compensation at all (it is by no means rare that the same applies in case of gross fault); a reduction of the victim's claim in the event of intentional contributory fault mostly emerges in cases in which someone intentionally and unreasonably refuses to minimise the harm that already occurred. 


\subsubsection{Contributory negligence after the damaging event}

The duty to limit the damage is considered as a species of the genus contributory negligence in France; there is no unanimity on the question as to what to do with the additional damages: some argue that these cannot be claimed by the injured party, while others argue that they can be split. In Germany, § 254 (2) BGB gives the rule on the duty to limit the damage. As to the consequences to be given in case of non-fulfilment hereof, the same difference of opinion exists as in France. However, the Bundesgerichtshof decided that the first view was not compatible with $\S 254$ BGB. Also in the Netherlands, the additional damage was not compensated (nor after the decision of the Dutch Hoge Raad in 1916). The basis for such denial was found in the missing causal link. Already in the early twentieth century, Ribbius defended a partition of the additional damage. In 1992, the duty to limit the damage was considered a species of the genus contributory negligence; Article 6:101 of the (new) Burgerlijk Wetboek became the basis for the doctrine on the duty to limit the damage, and not a break in the causal connection. Although some authors still argue that the extra damage has to be attributed to the injured party, it has recently been defended that the criteria of Article 6:101 of the Burgerlijk Wetboek of 1992 have to be applied to the duty to limit the damage, and as a consequence the extra damage should be partitioned accordingly. 


\section{CHAPTER SIX}

\section{SUMMARY AND CONCLUDING REMARKS}

\subsection{INTRODUCTION}

This study has shown how from Antiquity to today the fault of the injured party influenced claims for damages based on delictual liability and evolved into the modern concept of contributory negligence. This study mainly addressed the following two central questions. Firstly, what was the historical development as to the solutions provided to the problem of contributory negligence in the event of delictual liability? Secondly, what was the influence of the solutions found in Roman law, canon law and indigenous law on later and present-day doctrines and codes?

For the purpose of my study it appeared necessary to start with the answer to the first question in order to be able to provide an answer to the second question; the second part of the study can be regarded as pulling together various views and solutions provided in various periods in legal history. This main query gave rise to several (sub)questions upon which I concentrated: what were the views of classical Roman jurists as regards contributory negligence, how was the topic of contributory negligence treated in Justinian law, what were the views on contributory negligence in the medieval ius commune, what was the development of the topic of contributory negligence from the reception of Roman law up to the codifications (in the eighteenth to the twentieth century) and, finally, how do contemporary jurists in European countries (particularly France, Germany and the Netherlands) deal with the problem of contributory negligence?

In the discussion of these modern codifications (and the preceding nineteenth-century development), particular emphasis has been laid on the extent to which these legal systems were influenced by ius commune approaches to contributory negligence, theories of Natural Law and the German Pandectists and also on the extent to which these legal systems have developed their own unique approach to the concept of contributory negligence. Special attention was also given to the effect of contributory negligence. Theoretically, two solu- 
tions appear possible to the problem: all-or-nothing or an apportionment of damages between wrongdoer and injured party. Which solution was chosen in different periods in time, and what were the dogmatic reasons jurists gave for the solution they chose?

The answers to these questions as well as the main findings of this study are summarised below.

\subsection{ROMAN LAW IN ANTIQUity}

In the second chapter of this study, Roman law in Antiquity was studied whereby a distinction was made between classical Roman law and Justinianic law. Both approaches to the Corpus Iuris are important as points of view. The study of the approach of classical Roman jurists to the problem of contributory negligence is interesting from a comparative perspective (compared to the later development of contributory negligence), and also necessary in order to be able to understand the later views of the humanists and twentieth-century scholarly (Romanistic) studies. In particular, to understand the views of the humanists, the point of view of classical Roman law has to be kept in mind. Although I only studied one particular problem, i.e. the problem of contributory negligence, the results question certain clichés regarding that matter as the humanists appear to have been more rooted in practice than often is assumed. On the other hand, in order to understand the medieval and later development of the problem of contributory negligence, the point of view in Justinian law had to be taken as a starting point.

What were the consequences of the conduct of the injured party for the liability of the wrongdoer? The conclusion for Roman law that the injured party could not recover any damages if his negligence contributed to the occurrence of the damage is erroneous. The rule of D. 50.17 .203 cannot be understood as a general rule applied in classical Roman law. However, due to the fact that the compilers made it a general rule by placing it into the title De diversis regulis iuris antiqui, it could become one of the starting points for the (medieval) theory of contributory negligence. Furthermore, in (post)classical Roman law a specific legal notion of contributory negligence as we know it today did not exist.

The Roman jurists merely enquired whether the injury, considering the circumstances, was due to the negligence of the wrongdoer or not. The application of the doctrine of culpae compensatio to texts of the Digest has to be regarded as being anachronistic as the theory originated in medieval times. Certain Digest texts, such as the text of the javelin thrower (D. 9.2.9.4), show that Roman jurists approached the culpa requirement in a casuistic manner. 
Often they approached the matter by using the status theory of Hermagoras of Temnos, which allowed them to argue more precisely on the legal problem at stake. The examples of the Digest show that technical (dogmatic) theories could often not be found in responsa of classical jurists.

Due to the penal character and to the wording of the lex Aquilia the only and final question in classical Roman law was whether the wrongdoer had been at fault or not. In the formulary procedure, the iudex's only possibility was to condemn the defendant to pay the poena if he was convinced that the requirements of the formula were fulfilled, otherwise he had to absolve the defendant. The possibility to reduce the poena - due to the negligence of the injured party - did not exist. This important characteristic, the all-or-nothing approach, was retained in Justinian law and enforced until the lex Aquilia lost its penal character (only in early modern times).

For the study of Justinian law, the fragments concerning the lex Aquilia written by various Roman jurists could be read in relation to each other, ${ }^{1}$ as they were promulgated by Justinian as being part of one and the same title. Furthermore, they could be read in relation to other texts of Justinian's compilation, such as D. 50.17.203, which rule was regarded as a general principle from that time on. This latter approach particularly makes sense when studying the last phrase of D. 9.2.11pr and also D. 9.2.9.4. The conclusion for Roman law that the injured party could not recover any damages if his negligence contributed to the occurrence of the damage is only right if Roman law is understood as Justinian law.

It was not possible to claim recovery if the victim caused his injury by his own fault. Such an attitude would lead to the unreasonableness of punishing a wrongdoer. Formally, an action was only denied due to the insufficiency in the requirements of the lex Aquilia. In that respect another remark is important, namely, that in classical Roman law no balancing of culpable behaviour of the two parties was possible, but only an assessment of the culpable behaviour of the wrongdoer. Still, the concept of culpae compensatio probably did not develop in Justinian law, but came to be a novelty introduced in medieval legal scholarship only. A balancing of faults did not take place. A few scattered texts in the Digest, outside the law of delicts, could indicate that the liability of the wrongdoer could be restricted. In those cases, consequential losses were concerned, only caused by wrong behaviour of the injured party. ${ }^{2}$ However, these exceptional casuistic decisions do not provide sufficient proof to assume

1 How one reads a (Digest) text depends on how one reads another text; until that time (i.e. during the period of classical Roman law) these texts were disjointed.

2 I.e. Neratius D. 19.1.11.12 and Paul. D. 19.1.45.1. 
a general rule, implying a restriction of the range of compensation, and surely this was not the case in the classical period. However, these texts appear to be important, as they were used in later periods.

\subsection{Medieval iUs COMMUNE}

\subsubsection{Medieval Roman legal scholarship}

The question of how to qualify the act of the injured party in legal terms was first explicitly discussed in medieval times when also for the first time a discussion of the acts of both parties concerned can be observed. In medieval Roman legal scholarship, contributory negligence of the injured party seems to have been regarded as reproachable misconduct to be sanctioned by a refusal of any claim for damages. Thus contributory negligence of the injured party came to be considered a possible legal problem. Two starting points for the problem of contributory negligence in the medieval period were identified in this study. The first starting point is the doctrine of culpae compensatio; the second starting point is identified in the rule laid down in D. 50.17.203.

As to the doctrine of culpae compensatio: the Glossators did take the respective negligence of both parties into account. They applied this doctrine to situations in which both parties acted with negligence of the same sort or were negligent to the same degree. The Gloss does not provide explicit proof whether or not the Glossators believed that culpae compensatio could only be applied to cases of contributory negligence in which both parties had been negligent to the same degree or whether it also applied to cases in which the degree of negligence was not identical. Therefore, all kinds of contributory negligence of the injured party, as long as it could be qualified as culpa, cancelled out all liability of the wrongdoer. A comparison of the amount of negligence, and a refinement in the sense that a small degree of contributory negligence would not lead to compensatio and thus to the deprivation of the possibility to claim compensation for damages/fine, was probably made by the successors to the Glossators at the instigation of the canonists. Some medieval Roman legal scholars used this doctrine of culpae compensatio to solve problems of contributory negligence in cases of damnum iniuria datum, especially Paulus de Castro.

As to the second starting point, Accursius linked D. 50.17.203 to the law of delicts. ${ }^{3}$ According to Accursius, an injured party's own negligence prevented

3 See gloss Quod quis ad D. 50.17.203. 
him from claiming damages from someone else. D. 50.17.203 indeed can be understood in the sense that it only concerns negligence of the injured party. However, Accursius understood it not to concern only cases in which negligence of the wrongdoer was not at all in discussion. It is rather strange that the examples of this maxim mentioned later by the Commentators ${ }^{4}$ all concern cases in which only negligence on the side of the injured party occurred, not contributory negligence, since Accursius opened the door to such an approach.

A final remark to be made regards the exact dogmatic foundation of the denial of claim in the event of contributory negligence. In medieval Roman legal scholarship, various opinions - the same as those in later developments in history ( see below) - can be found. In the first approach, the behaviour of the injured party was taken into consideration when determining the culpability of the wrongdoer's act. In the kinds of cases in which this approach was followed, therefore, the act of the injured party cannot really be considered as contributory negligence. In the second approach, the act of the injured party was regarded as his own responsibility, which led to the non-responsibility and non-liability of the wrongdoer. In the third approach, due to the fact that an injured party exposed himself to danger, he was considered to have caused the injury himself and thus his claim for recovery was denied.

\subsubsection{Medieval canon law}

According to canon law, contributory negligence of the injured party can be seen as contributory causation (co-causation) and therefore in such cases it had to be established whether the wrongdoer or the injured party produced the proximate cause (causa proxima). It seems that the causational contributions of both parties were compared. However, causation and fault seem not to have been separated in this period. Furthermore, the canonists also embraced the theory of culpae compensatio, in various areas of law, although rarely in cases of the law of delicts, unless both persons in the case were laymen. However, with regard to the question of whether a cleric could be granted a higher ordination, this was different, according to the commentary of Animal on D.50 c.50, because in that case culpa could never be compensated by culpa. The author of the Animal also stated that when the wrongdoer and the person killed both acted culpably, even if the culpability of the first was less serious, the cleric could never be promoted to a higher rank.

Two canonists explicitly commented on the position of the injured party. With regard to X 5.12.9, Bernardus Parmensis argued that the killing was

4 And on its counterpart - VI 5.12.86 - by the canonists. 
due to the negligence (culpa) of the injured party (who threw the other on the ground). One has to keep in mind that the question in this case before the Pope was only whether the cleric did or did not act with negligence and whether the cleric could or could not be promoted (and if dispensation was necessary). The conclusion that due to the lack of a possibility to distribute the damages over both parties in case of contributory negligence (which was not at all at stake here) the jurists tended to attribute the 'sole guilt' to the party that acted with the highest degree of negligence can only be taken with care (analogous interpretation).

Hostiensis argued that the other cleric should have been aware that wearing a knife attached to a belt was customary, and therefore he should have been careful. It seems that therefore the 'contributory negligence' led to the sole guilt on the side of the injured party. One could argue, as some modern scholars do, that the liability of the tortfeasor in question is cancelled out because of the preponderant contributory negligence of the injured party. Although the question of liability was not at all at stake in the legal case brought before the Pope if one looked at it from that modern perspective; the majority of the commentaries of the decretalists I consulted do not follow such a theory. However, the just-mentioned comments of Bernardus Parmensis and Hostiensis, who were two influential persons, could indeed indicate that this theory was applied.

Furthermore, towards the end of the medieval period, mainly in consilia literature, the term culpa admixta (literally 'mixed fault') was used to qualify the behaviour of the injured party in a way that led to the exclusion of liability of the wrongdoer. In this way contributory negligence led to a denial of claim without a discussion of the degree of the negligence of each party. The use of the term culpa admixta (or culpa communis) shows that the occurring damage was considered the common responsibility of both parties.

\subsubsection{Some final words on medieval ius commune}

An all-or-nothing approach in the event of 'contributory negligence' was also present in some other medieval sources outside the Roman-canonical tradition (iura propria - indigenous laws). In some other old medieval traditions (e.g. medieval Irish law), this idea of a division of damages can be found in some cases. Contributory negligence of the injured party could lead to partial compensation, the so-called judicium rusticorum, or to a reduction of damages to the amount of two-thirds. Thisjudicium rusticorum is interesting as it appeared again in later periods of legal history, such as in Roman-Dutch law. 


\subsection{THE HUMANISTIC CONTRIBUTION}

Although the humanists tried to resituate D. 50.17.203 in its original classical context (law of legacies), the examples of this rule given by the humanists are mainly the same as those given in the medieval period. Furthermore, without looking at the different palingenetical contexts, the humanists connected the rule of D. 50.17.203 to the cases of D. 9.2.52.1, D.9.2.9.4 and D. 9.2.11pr. Note that it is explicitly stated that these cases concern events in which the injured party acted negligently. Furthermore, the connection of D. 9.2.9.4 with D. 9.2.10, as assumed by the humanists, is not palingenetically defendable, as it is the fact that D. 9.2.9.4 and D. 9.2.11pr. are considered examples of the situation in which both parties acted negligently. Furthermore, it also appears that some humanists on the substantive level sometimes remained strong in the tradition of ius italicus; thus some considered D. 9.2.52.1 as an example of compensation of unlawfulness, or as an example of self-defence.

However, only by stating that D. 9.2.9.4 and D. 9.2.11pr. in fact are examples of the situation in which both parties acted negligently could the negligent acts be compared and could theories develop. One of those theories concerns the continuation of the application of the culpae compensatio, and also the first traces of the theory of gravior culpa (A. Faber) or maior culpa (M. Freher and G. Noodt) appeared. The last new development of major importance is that H. Donellus arguably, but surely P. Faber and J. de Sande, envisaged the possibility of a partial compensation for the first time in the continental Roman law tradition.

\subsection{Reception, Roman-Dutch LAW AND usus MODERNuS}

My study of the question of why the injured party had no right to claim damages proceeded from the hypothesis that the approach to recovery based on the actio de damno dato was still all-or-nothing. The source materials investigated confirmed that this hypothesis was correct. As was put forward first and foremost, in this period a general action for damage done unlawfully was provided, an action that was only Roman in its name (see section 4.3.2). In this early modern period, the idea that an equal or preponderant contributory negligence (maior culpa) excluded the right to claim compensation began to gain acceptance. However, not all jurists used this idea of the maior culpa variant of the culpae compensatio doctrine to solve the problem of contributory negligence; others took different paths in their approach to solving this problem. 
Some Roman-Dutch scholars continued to explain the sedes materiae in the same way as it was done in the Middle Ages, but they tried to situate them in their own time. Others applied the maior culpa theory, e.g. Voet. In RomanDutch law, ship-collision cases are particularly interesting. In these cases a different starting point was applied compared to Roman law. If ship A, without being negligent, hit ship B, ship A still had to pay 50 per cent of the damage. But when two ships collided and both acted negligently, there were two main views on what the law dictated: (1) If the negligence was equal on both sides, the damage had to be regarded as common and both parties had to bear the damage in equal proportions (the view of the Hoge Raadvan Holland, Zeeland en West-Friesland); (2) Each party should carry its own loss, because whoever had been negligent could not bring an action and the damage that occurred was not regarded as damage $c f$. D. 50.17.203 (the view of Van Bijnkershoek and Van der Keessel). Another problem was to determine what the law dictated in case a stationary ship was hit by a moving ship. Van der Keessel considered the negligence of the latter as more serious, and therefore no culpae compensatio could take place (mark the application of the ius commune theory) Thus one ship had to bear 50 per cent of the damage of the other ship, and so something quite similar to the idea of division of damage occurred. Compare the old tradition of judicium rusticorum, with one renewal, namely, that in case of culpa maior 50 per cent of the damage of the other party had to be paid.

Several doctrinal starting points are present in the usus modernus in Germany to solve the problem of contributory negligence. Firstly, the role of the injured party was considered a problem of causality. Secondly, the role of the injured party was considered a question of negligence, and in that respect it was considered a question of concurrence of faults. Several variants of the application of the culpae compensatio doctrine were found, among which the variant in which the mere existence of contributory negligence - even a very small degree of contributory negligence - led to the deprivation of the possibility to obtain compensation, and the opposite situation, namely that only (equal or) preponderant contributory negligence should exclude liability (maior culpa theory). Another solution was to solve the problem of contributory negligence without any reference to the contributory negligence of the injured party. In this variant, the negligence of the wrongdoer was the only relevant factor, and the contributory negligence of the injured party was not considered as a separate legal issue. A last solution was provided by the use of the criterion of the auctor rixae as an alternative way to solve the problem of contributory negligence. The initiator of a fight could not claim damages for injuries suffered during the fight, unless the other party acted excessively in self-defence. 
In Italy, the criterion of auctor rixae was connected with the concept of culpa admixta. If someone started a fight or provoked a fight (the so-called auctor rixae), his negligent behaviour was qualified as culpa admixta, leading to a denial of his claim in totality. The Rota Romana sometimes held the view that contributory negligence, however small, led to a denial of claim, while in another case it seemed to require culpa maior on the side of the injured party, the view which was also held by De Luca.

Apparently, in the early modern period there was discussion on the question as to what sort of damages had to be compensated, and especially whether immaterial damages had to be compensated or not. In the event of quarrels, if the reaction by the provoked party was excessive, the provoker could only claim medical costs, no immaterial damages were granted. In two cases a small amount of negligence of the injured party did not exclude the victim's compensation claim, but was taken into account in order to determine the amount of damages to be paid. However, these examples concern the non-compensation of certain types of damages. No reduction of the total damage occurred and the all-or-nothing approach is to be considered as being still intact in the early modern period.

\subsection{THE NORTHERN NATURAL LAW SCHOOL}

Some scholars followed the 'old' ius commune approach: in the event of contributory negligence of the injured party, they just applied the rule of D. 50.17.203. In such case the application of that rule led to a total denial of a claim for damages. Possibly Grotius but certainly Domat and Pothier followed this approach. Others applied the doctrine of culpa maior, such as Pufendorf and Thomasius. In both approaches the legal consequence was the same: if the injured party was contributorily negligent respectively if his negligence was more serious than that of the wrongdoer, his claim for damages was denied. In that sense the all-or-nothing approach was still followed.

The possible attribution of damage both to the wrongdoer and to the injured party (according to the resp. faults or causal contributions) had its origin in the 'Aufklärungstheorie' of Christian Wolff5 and is therefore a relatively recent phenomenon. But the assessment and balancing of the respective gradations of negligence of both parties was already a step in that direction. So, although Wolff was the first legal scholar who turned away from the 'all-or-nothing principle', his theory can also be considered a continuation of the preceding development.

5 He argued that when both the wrongdoer and the injured party acted negligently, the damages should be borne by both parties according to the extent of their individual negligence. 
Wolff did not treat the matter of contributory negligence in an abstract way, but only for some concrete cases. In particular, no remarks are found as to the relation with the delictual obligation to pay damages. In that respect, the aforementioned example included in the Selectae decisiones of Schoepff, of an earlier date than the work of Wolff, is a much clearer example of a partial compensation of damages in the area of liability for damages, in the sense that certain specific sorts of damages (amount for maintenance expenses) were not recoverable due to the contributory negligence of the injured party.

\subsection{THE CONCEPT OF CONTRIBUTORY NEGLIGENCE IN THE NINETEENTH CENTURY}

In French law, the Code civil of 1804 did not contain a general rule on contributory negligence. The topic has been dealt with in case law and in particular by the Cour de cassation. At the end of the nineteenth century, the situation in which the injured party and the wrongdoer were at fault (characterised as faute commune) led to a partition of damages proportionate to the gravity of the faults on each side. The development in France was initiated by the acceptance of judicial discretion in assessing the question whether negligence (in cases in which both parties were at fault) would give rise to liability and when determining each party's share of compensation. The partition, made on the basis of the gravity of faults, was accepted by the majority of legal scholars and judges who initially stuck to the application of the principle of D. 50.17.203 (although the Digest was not a formal source of law anymore - thus I have not found a direct reference to D. 50.17.203), which led to a denial of claim. Although no (direct) reference to the work of the natural law scholar Wolff can be found in France, it is possible that, taking into consideration the probable familiarity of the jurists with the works of Wolff, that his ideas could have played a role in the intellectual luggage of the jurists. Thus the solution proposed by French doctrine was not exactly the same as that proposed by Chr. Wolff, but the legal consequences were more or less the same. Wolff's doctrine seems to have been codified for the first time in $\S 1304$ of the Austrian Allgemeine Bürgerliche Gesetzbuch (1811), the article also in which judicial discretion is provided as to the consequences of contributory negligence.

The situation in nineteenth-century Germany was different. The Historical School just reproduced Roman law texts, and defended the view that no compensation had to be provided if the injured party had committed (any) contributory negligence. However, the more practical-oriented literature applied the maior culpa doctrine. As to the all-or-nothing approach, however, 
an adjustment was made in this literary genre. It was generally stated that according to the principles in D. 19.1.11.12 and D. 19.1.45.1 the individual consequential losses, for which the injured was responsible, could not be imputed to the wrongdoer. This was in fact a first attempt to escape the all-or-nothing approach (and the tradition of ius commune). Nevertheless, the maior culpa doctrine survived in the German usus modernus in the nineteenth century. The Pandectists tried to find new dogmatic reasons to justify the denial of claim in the event of contributory negligence. Their theories were mainly causation theories, based on the thought of an interruption of the causal connection in the case of contributory negligence. A theory (often) connected to this was the culpae compensatio theory, based on the rule of D. 50.17.203. Later, equity was regarded as the foundation of the rule of D. 50.17.203. In legal practice, a small degree of contributory negligence already led to a denial of claim. However, to avoid unfair solutions, this approach was increasingly opposed in legal practice. A reduction of the amount of damages in the event of contributory negligence was accepted for the first time by the German Reichsgericht in 1883. In Switzerland, somewhat earlier, the natural law solution (particularly in Article 51 II of the Schweizerische Obligationenrecht 1881) had been codified under the influence of the Austrian Allgemeine Bürgerliche Gesetzbuch as well as the French doctrine. Eventually, the Swiss code, as to the problem of contributory negligence, was taken as example by the drafters of the German Bürgerliche Gesetzbuch (1900) and, also under the influence of case law, the Swiss regulation was taken over in its entirety.

In the Netherlands, the Burgerlijk Wetboek of 1838 contained no explicit rule on contributory negligence. Until the beginning of the twentieth century, in the event of a small degree of contributory negligence, an assessment of negligence of the parties involved was applied in the sense that the 'main fault' was decisive. Only when the contributory negligence of the injured party was less than the negligence of the wrongdoer did the injured party have a right to claim damages, i.e. 100 per cent (of the damages). There was still an all-or-nothing approach, based on the maior culpa variant of the culpae compensatio doctrine. The legal basis of the denial of damages to the injured party in the event his act contributed to his own damage remained disputed throughout the twentieth century, although the majority view became that equity demanded the denial of claim and that the damage should be imputed to the victim if he could have prevented the accident from occurring. The all-or-nothing approach ended with the judgement of the Dutch Hoge Raad in 1916, in which the Hoge Raad decided that the duty to compensate had to be measured, based on the extent to which the negligence of both parties contributed to the damage. 


\subsection{THE CONCEPT OF CONTRIBUTORY NEGLIGENCE IN MODERN}

AND CONTEMPORARY LAW

In France, a partition of damages is made based on the gravity of the parties' faults. Contributory negligence seems to have (totally or partially) broken the causal connection. In principle, faute de la victime led to a partial compensation. A denial of claim was only provided if the faute de la victime was regarded as an external cause, which was unforeseeable and unavoidable, and the sole cause of the damage. Next to the gravity of the faults also other circumstances were taken into account in the balancing, e.g. the causal impact. Furthermore, if the injured party's faute greatly exceeded the wrongdoer's conduct, i.e. in the case of intentional misconduct, provocation or consent of the victim, no damages have to be paid.

With regard to the strict liability mentioned in Article 1384 Code civil - at first - a total exoneration of the wrongdoer was only possible in the event of an external cause, e.g. a fait de la victime which was unforeseeable and insurmountable. From 1934 onwards, a reduction was possible in the event of contributory negligence based on the gravity of the faults, until 1982 when the Cour de cassation decided that such a partition was not possible anymore in the case of contributory negligence (Desmares case), which in fact meant a return to the all-or-nothing approach. Shortly after a reform by the Loi Badinter, in 1987, the Cour de cassation overturned the Desmares judgment and re-introduced the principle that the keeper (gardien) of an object is partially exonerated when the victim's fault contributed to the occurrence of the damage caused by the object (for cases not falling under the Loi Badinter). When the victim's fault can be characterised as an external cause leading to force majeure, of course a total dismissal of the claim will follow.

With regard to traffic accidents, in France, the Loi Badinter (1985) gave a general rule of 100 per cent liability (in principle) in case of personal injuries to the owner or the 'keeper' (or the liability insurance) of motorised vehicles. The rules regarding 'contributory negligence' can be found in Articles 3 and 4 of the Loi Badinter. They are very different from the normal rules of contributory negligence in the French law of delict. French law still applies an all-or-nothing approach here for victims not driving a motor vehicle. Victims between 15 and 71 years of age with no permanent incapacity or a disability of 80 per cent or more are granted 100 per cent of their damages, unless the fault of the injured party is inexcusable and that fault was the exclusive cause of the accident or if the victim voluntarily sought the damage, i.e. in case he acted intentionally, in which case the victim has no right to claim any compensation. Moreover, if the injured person belongs to a special category of protected persons (children 
under 16, persons older than 70 years of age or persons with a permanent incapacity or a disability of 80 per cent or more), he or she will always receive compensation for damages suffered. Only when an injured person belonging to this category has voluntarily sought the damage, i.e. in the event that he acted intentionally, can he not claim damages.

In Germany, the concept of Mitverschulden was codified in $\S 254$ of the Bürgerliche Gesetzbuch (1900). This application of the concept of Mitverschulden - whose legal doctrinal basis is much debated - leads to an apportionment based on the circumstances of the case, with an emphasis on the preponderant causation. Although the primary standard is causation, the secondary standard is a review of the other circumstances (among which negligence). With the codification in $§ 254$ of the Bürgerliche Gesetzbuch, the doctrine of culpae compensatio was dismissed. Shortly before, the Reichsgericht still applied this doctrine in 1891, making only an exception in the event that the contributory negligence was insignificant. Just like $\S 1304$ of the Austrian Allgemeine Bürgerliche Gesetzbuch, § 254 of the German Bürgerliche Gesetzbuch gave the judge judicial discretion. Although $§ 254$ aimed at the predominant causation (vorwiegende Verursachung), the Reichsgericht continued to apply the doctrine of the main fault, and that means that the predominant causation seems to have been interpreted already from the start of the twentieth century as überwiegende Verschulden. In Germany, the apportionment principle contained in $\S 254$ BGB is also incorporated in $§ 9$ StVG: if the fault of the injured party (not being a holder or driver of a motor vehicle) has contributed to the occurrence of the damage, § 254 BGB applies.

In the Netherlands, Article 6:101 BW (of 1992) provides a reduction of the amount of damages in the event of contributory negligence, based on the circumstances that contributed to the occurrence of the damage and that can be attributed to the parties. Two standards are provided: firstly, causal connection probability (veroorzakingswaarschijnlijkheid) and, secondly, a correction based upon equity, considering the faults of the parties, etc. When a motor vehicle hits with a pedestrian or a cyclist in traffic accidents, Article 31 (old) WVW of 1935 (at present Article 185 WVW 1994) and the case law for that particular situation are applied, meaning that the second standard of Article 6:101 BW is filled in by 100 per cent and 50 per cent rules developed in Dutch case law. In that respect one can argue that an all-or-nothing approach has been reintroduced - at least for the 100 per cent rule,$-{ }^{6}$ and the wrongdoer can now

6 This also applies in cases of employers: as was already the case with Art. 1638x lid 2 (old) Burgerlijk Wetboek of 1838, Art. 7:658 lid 2 of the (new) Burgerlijk Wetboek still continues to apply the all-or-nothing approach in the event of negligence in labour cases: the defence of contributory negligence only succeeds if the intentional or wilful reckless act of the employee 
only be relieved inthe event that the injured party has acted intentionally or recklessly, bordering on intention, in which case no compensation will be provided. If the injured person is younger than 14 years old, 100 per cent of his damage will be compensated, and to persons older than 14, a minimum compensation of 50 per cent of the damage is granted.

\subsection{TO CONCLUDE}

Some systematic final remarks have to be made. What were the solutions taken to the problem of contributory negligence in legal history? Before making a first distinction in formulating an answer to this question, it has to be stated that the role of the injured party's conduct was sometimes taken into account when determining whether the wrongdoer acted with negligence and/or whether the act could be imputed to the wrongdoer. Furthermore, I found cases that in fact dealt with the opposite situation; in some cases the damage suffered by the injured party was only caused by himself, and no negligence could be imputed to another person. Both of these situations cannot, in a strict sense, be called contributory negligence.

As to the situation in which the injured party contributed to the occurrence of the damage, and so there is also a tortfeasor, two main solutions have been found: all-or-nothing (I) or a partition of damages (II). The all-or-nothing approach (I) had several variants: when the injured party was considered negligent (which in fact would mean that this would apply already in case of a small degree of negligence), ${ }^{7}$ only when the victim's negligence was equal or preponderant to that of the wrongdoer ${ }^{8}$ or only when his negligence was gross or wilful was his claim denied. ${ }^{9}$ Throughout legal history, the denial of claim was caused by and/or dogmatically founded in different ways: sometimes it was caused by the legal procedure and/or the penal character of the civil liability, sometimes it was due to the strict application of Roman law rules,

substantially contributed to his injury.

7 Applied in medieval Roman legal scholarship, by most decretalists, by some jurists in the early modern period and by some natural law scholars. This can also be said for various 19th century Pandectist School scholars, and can be found in 19th century German case law as well as in French case law at the beginning of the 19th century.

8 The culpa maior theory is present not only in the works of various jurists in the early modern period, but also in the commentary Animal est substantia (and possibly with some decretalists), with some humanists, and with various natural law scholars. It is also present in 19th-century Dutch case law and scholarly literature, 19th-century German practical literature and later in 19th-century German case law.

9 This latter solution can be found in modern French and Dutch law regarding personal injury cases in traffic accidents. 
based on or linked to causation theories (interruption of causal connection), or based on the theory of culpae compensatio, and in other cases it was due to socio-political reasons (e.g. an operational risk, so-called Betriebsgefahr) which were codified in various legislative provisions. Another possibility was to compare causal contributions, denying a claim if the injured party's act was the proximate cause (causa proxima) for the damage. ${ }^{10}$

The approach in which a partition is possible (II) can mainly be divided into two groups: a division between the parties of some kind of (consequential) damages to the parties in question, ${ }^{11}$ or a division of the total amount of damage. ${ }^{12}$ Although the possibility of partition was proposed and defended by Christian Wolff, his proposal did not - as one might expect - conquer the legal area immediately. ${ }^{13}$

In the event of a partition of damages, the apportionment can take place based on one or more of the following criteria: the degree of fault of both parties, ${ }^{14}$ their causal contribution to the damage ${ }^{15}$ and equity reasons. ${ }^{16}$ The emphasis was put differently in various times and places; sometimes some of these criteria were considered equal, and sometimes a criterion was used as a corrective. The partition could lead to percentages or quota. Normally percentages between 0 and 100 per cent were possible, although minor segments at either extreme were normally not granted. A 50/50 partition is also applied, ${ }^{17}$ sometimes as the outcome of a partition in percentages/quota, sometimes as an alternative solution (subsidiary solution), sometimes as the standard solution.

10 This approach is found in canon law.

11 As applied in Justinian law in some cases outside the area of the law of delicts, and later in the early modern period in cases of quarrels where, in particular, immaterial damages were sometimes regarded as being non-compensable, due to the fact that the injured party started the fight.

12 I found such partition already in the medieval period in some traditions outside the tradition of ius commune (leading to a 50/50 partition or $1 / 3-2 / 3$ ); in the latter tradition the allor-nothing approach remained the prevailing one until the end of the early modern period, and even to a certain extent in the 19th century.

13 The first traces of consideration of such a partial compensation can already be found with the humanists, as discussed before.

14 As Christian Wolff proposed (although it is generally accepted that this requirement included causation in his theory); it is the solution codified in $\S 1304$ ABGB, as accepted in French case law and doctrine in the 19th century, applied by the Reichsgericht in Germany at the end of the 19th century (1883; even after the codification of the new emphasis in $\S 254$ BGB this remained the focus of the Reichsgericht), and was accepted by the Dutch Hoge Raad in 1916.

15 Codified in Germany in $§ 254$ BGB and as first criterion in the Dutch Art. 6:101 BW (1992).

16 See the second (corrective) criterion codified in the Dutch Art. 6:101 BW.

17 The solution of judicium rusticorum; in collision cases in Roman-Dutch law, Van der Keessel defended the solution that in case one of the colliding party's negligence was greater (quantitatively) than that of the other party, the colliding party had to bear half of the damages of the other party. 
Although in the event of contributory negligence an apportionment of damages is commonly applied in Western Europe today, apportionment has had a short history. Furthermore, this concept - at first proposed by Wolff - has not been received throughout Europe with open arms, but has been consolidated only after a difficult struggle. The solution in Roman law, all-or-nothing, common to various countries in Western Europe, is indeed a common foundation and it has not been easy to set this concept, which survived many centuries, aside.

This study cannot give a normative answer on which solution would be best. Legal scholars and/or comparatists will have to consider other perspectives, such as philosophical, economic, social, etc. Common concepts are also those taken from Roman law, which survived and were handed on to us over the course of many centuries. Fault and causation came more and more to be considered communicating vessels. The emphasis sometimes lies on fault, other times on causation. In this respect, different choices have been made in various codes in force in European countries today. Although the partition of damages between parties seems to be in accordance with equity, it is not at all clear what the standards have to be, and when clear standards are established, what the exact apportionment should be, and so the study of this issue remains of great interest. Furthermore, the historical development of contributory negligence, i.e. the way in which this legal issue was dealt with, is even more interesting - as a source of inspiration - since recently the all-or-nothing approach has regained acceptance again (e.g. in cases of traffic accidents; see chapter five) as to the legal issue of contributory negligence of the injured party. 


\section{BIBLIOGRAPHY}

\section{TEXT EDITIONS ROMAN LAW}

M. Avenarius (ed. and transl.), Die pseudo-ulpianische Einzelschrift der Rechtsregeln (liber singularis regularum), Göttingen 2005.

P. Bonfante et al., Digesta Iustiniani Augusti, Milan 1931 (reprint 1960).

F.P. Bremer (ed.), Jurisprudentiae antehadrianae quae supersunt, Leipzig 1985.

A. Corbino \& B. Santalucia (eds.), Justiniani Augusti Digestorum seu Pandectarum Codex Florentinus, Rome 1902-1910 (fotomech. reprint Firenze 1988).

Fontes iuris romani antejustiniani, S. Riccobono (ed.), I. Leges, Florence 1941, J. Baviera \& J. Furlani (eds.), II. Auctores, Florence 1940, V. Arangio-Ruiz (ed.), III. Negoria, Florence: 1943-XXI.

G.C. Gebauer \& G.A. Spangenberg, Corpus iuris civilis, codicibus veteribus manuscriptis et optimis quibusqve editionibus collatis, Göttingen 1776.

C.J.A. Kriegel \& M. Kriegel (eds.), Corpus juris civilis, I-II, Leipzig 1844.

- Corpus juris civilis. Impressio septima decima. Pars II. Codex, continued by Ae. Herrmann, Leipzig 1887.

Th. Mommsen \& P. Krüger (eds.), Corpus iuris civilis, I, Berlin 1882 (reprint 1963) (referred to as Mommsen \& Krüger 1963a).

—.Digesta Iustiniani Augusti, I-II, Berlin 1868-1870 (reprint 1962-1963) (referred to as Mommsen \& Krüger 1963b).

R. Schoell \& G. Kroll (eds.), Corpus Iuris Civilis. Vol. III:Novellae, 8th edn., Berlin 1963 (reprint Hildesheim 1988).

\section{BYZANTINE LAW}

G. Dittenberger, Sylloge Inscriptionum Graecarum, I, 3rd edn., Leipzig 1915. 'Epitome legum', eds. C.E. Zachariae A. Lingenthal, in: Zepos, IGR IV, Athens 1931 (reprint Aalen 1962), p. 276-585.

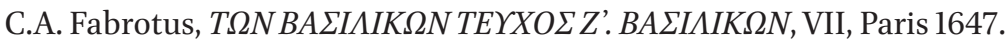

C. Harmenopulos, Manuale legum sive Hexabiblos, ed. G.E. Heimbach, Leipzig 1851 (reprint Aalen 1969).

G.E. Heimbach \& C.G.E. Heimbach (eds.), Basilicorum Libri LX, 6 vol., Leipzig 1833-1870. 
I. Leunclavius (ed.), LX librorum BA $\Sigma I \Lambda I K \Omega N$, Basle 1575.

Photius, Nomocanon, with commentary of Th. Balsamon, Paris 1615.

H.J. Scheltema, D. Holwerda \& N. van der Wal, Basilicorum Libri LX, Series A (textus) I-VII, B (scholia) I-IX, Groningen (et al.) 1953-1988.

'Synopsis (Maior) Basilicorum', edn. C.E. Zachariae A. Lingenthal, in: Zepos, IGR V, Athens 1931 (reprint Aalen 1962), p. 13-598.

Theophilus, Paraphrasis Institutionum, eds. J.H.A. Lokin et al., with translation by A.F. Murison, Groningen 2010.

\section{LITERARY SOURCES}

Ammianus Marcellinus, Rerum gestarum qui de XXXI supersunt libri XVIII, ed. H. Valesius, Paris 1636.

—. Rerum Gestarum qui de XXXI supersunt libriXVIII, ed.J. Gronovius, Lyon 1693. Antiphon, Orationes et fragmenta, ed. Fr. Blass \& Th. Thalheim, Leipzig 1914. Joannes Chrysostomos, Opera omnia, ed. B. de Montfaucon, Paris 1734.

—. Opera omnia, XI, ed. B. de Montfaucon, Paris 1838.

Caecilius Cyprianus, Opera Omnia, Paris 1836.

Théodoret de Cyr, Histoire ecclésiastique, II, ed. P. Canivet et al., Paris 2009.

T.C. Donatus, 'Vitae Vergilianae', ed. J. Brummer, Leipzig 1912 reproduced in

H. Georgius (ed.), Tiberius Claudius Donatus, Interpretationes Vergilianae, II, Stuttgart 1969.

A. Gellius, Noctes Atticae, I-II, ed. P.K. Marshall, Oxford 1968.

Grammaticae Romanae Fragmenta, ed. H. Funaioli, Stuttgart 1907 (reprint 1969). Hesychius Alexandrinus, Lexicon, I, ed. J. Alberti, Leiden 1746.

'Historia Miscella' in: L.A. Muratori (ed.), Rerum Italicarum scriptores, I, Milan 1723. Isidorus Hispalensis, Etymologiarum sive originum. Librixx, II, ed. W.M. Lindsay, Oxford 1911.

T.C. Silius Italicus, Punica, I, ed. G.A. Ruperti, Göttingen 1795.

T. Livius, Historiarum ab urbe condita, IV, ed. A. Drakenborch, Amsterdam/ Leiden 1741.

Nonius Marcellus, De compendiosa doctrina, ed. W.M. Lindsay, Leipzig 1903 (reprograph. reprint Hildesheim 1964).

J.B.P. de Molière, George Dandin, ou le mari confondu, Amsterdam 1693.

P. Porphyrio, Commentum in Horatium Flaccum, ed. A. Holder, Innsbruck 1894 (reprint Hildesheim 1967).

M.F. Quintilianus, Declamationes XIX Majores, ed. P. Burmann, Leiden 1720; ed. G. Lehnert, Leipzig 1905; ed. L. Håkanson, Stuttgart 1982.

P. Terentius et al., Comoediae, Andria, Eunuchus, Heautontimorumenos, Adelphi, Hecyra, Phormio, Paris 1552. 
Theodoretus Cyrensis, Historia ecclesiastica, ed. Henricus Valesius, Paris/ Mainz 1679.

A. Turnebus, Adversariorum tomi III, Strasbourg 1599-1600.

Servius Grammaticus, Commentarii in Vergilii Carmina Aeneidos libros, II, eds. G. Thilo \& H. Hagen, Leipzig 1884 (fotomechanical reprint Hildesheim 1961).

P. Vegetius Renatus, Epitoma rei militaris, ed. M.D. Reeve, Oxford 2004.

P. Vergilius Maro, Aeneis, with argumenta (comm. Servius, revised by $\mathrm{Ph}$. Beroaldus, and Badius), Paris 1501.

- Varietate lectionis et perpetua adnotatione, III, ed. C.G. Heyne, 3rd edn., Leipzig 1803; ed. C.G. Heyne, 4th edn. revised by G.P.E. Wagner, Leipzig/ London 1833.

\section{MEDIEVAL IUS COMMUNE}

\section{GLOSSATORS}

\section{Manuscripts}

Bamberg, Jur. 11.

Bamberg, Jur. 12.

Johannes Bassianus, Glossa in Institutiones, Ms Leiden ABL 3.

Biblioteca Vaticana, Barb. lat. 1459.

Biblioteca Vaticana, Borgh. 225.

Biblioteca Vaticana, Ottobon. lat. 1605.

Biblioteca Vaticana, Palat. lat. 737.

Biblioteca Vaticana, Palat. lat. 1408.

Biblioteca Vaticana, Palat. lat. 2512.

Biblioteca Vaticana, vat. lat. 1405.

Biblioteca Vaticana, vat. lat. 1406.

Biblioteca Vaticana, vat. lat. 2511.

Leipzig, Universitätsbibliothek, 873.

Leipzig, Universitätsbibliothek, 877.

London, British Museum, Royal 11 C. III.

München, Bayerische Staatsbibliothek, Clm. 3887.

Padova BU, 941.

Paris BN, lat. 4450.

Paris BN, lat. 4451.

Paris BN, lat. 4458. 
Paris BN, lat. 4459.

Paris BN, lat. 4461.

Stockholm KB, B 680.

Torino BN, E.I.4.

Trier, Stadtbibliothek, 838/1634.

Troyes, Bibliothèque Municipale, 135.

Wroclaw BU, Rehd. 289.

\section{Printed editions}

F. Accursius, Glossa in Digestum Vetus; Infortiatum; Novum; Volumen, Venice 1487-1489 (reprint Corpus glossatorum iuris civilis, VII-XII, Turin 1968/1969).

- Pandectarum seu digestum vetus iuris civilis, I, ed. A. Persius, Venice 1581.

—.Digestum vetus: digestorum seu pandectarum iuris, I, ed. H. a Porta, Lyon 1551; edn. Th. de Iuges, Geneva 1625.

—.Digestum novum seu Pandectarum iuris civilis, III, ed. of H. Cardon, Lyon 1618. Azo Porcius, Brocardica Aurea, Naples 1568 (reprint Corpus glossatorum iuris civilis, IV, Turin 1967).

—.Summa super Codicem, Pavia 1506 (reprint Corpus glossatorum iuris civilis, II, Turin 1966).

—. Summa Aurea, Lyon 1557 (reprint Frankfurt am Main 1968).

I. Bassianus, 'Apparatus ad titulum De diversis regulis iuris antiqui', ed. S. Caprioli, 'Quem Cuiacius Iohanni tribuerat', Annali di storia del diritto: rassegna internazionale 1963, p. 131-248.

Bulgarus, De diversis regulis iuris antiqui commentarius, with additions of Placentinus, ed.F.G.C. Beckhaus, Bonn 1856 (reprint Frankfurt am Main 1967).

Bertrandus Metensis, De regulis iuris, ed. S. Caprioli, Perugia 1981.

W. de Cabriano, Casus Codicis, ed. T. Wallinga, Frankfurt am Main 2005.

Corpus legum Brachylogus iuris civilis, ed. E. Böcking, Berlin 1829.

Irnerius, 'Glosses on Digestum Vetus', ed. E. Besta, L'Opera d'Irnerio (contributo alla storia del diritto Italiano). Vol. II. Glosse d'Irnerio al Digestum Vetus, Turin 1896 (reprint Bologna 1980).

Irnerius, Summa Codicis, ed. H. Fitting, Berlin 1894 (reprint Frankfurt 1971).

Odofredus, Lectura super Digesto Novo, Lyon 1552 (reprint Opera iuridica rariora $\mathrm{IV}$, Bologna 1968).

—. Lectura super Digesto Veteri, I/II, Lyon 1550/1552 (reprint Opera iuridica rariora II.1, Bologna 1967/1968).

Petrus, 'Exceptiones legum romanorum', in: F.K. von Savigny, Storia del diritto romano nel medio evo, trad. it. a cura di E. Bollati, III, Turin 1857. 
Placentinus, Summa Codicis, Mainz 1536 (reprint of F. Calasso (ed.), Turin 1962). Quaestiones Dominorum Bononiensium. Collectio Gratianopolitana, ed. G.B. Palmieri, in: Scripta Anecdota Glossatorum [=Bibliotheca Iuridica Medii Aevi]. Vol. I, Bologna 1913.

Rogerius, Summa Codicis, ed. G.B. Palmieri, in: Scripta Anecdota Glossatorum [=Bibliotheca Iuridica Medii Aevi]. Vol. I, Bologna 1914.

Summa 'Institutionum Iustiniani est in hoc opere,' ed. P. Legendre, Frankfurt am Main 1973.

Summa Vindobonensis, ed. G.B. Palmieri, in: Scripta Anecdota Glossatorum [=Bibliotheca Iuridica Medii Aevi]. Vol. I, Bologna 1914.

Vivianus Tuscus, 'Casus', in: Corpus Juris Civilis cum glossis et indice Daoyz, I, Lyon 1618.

\section{Commentators}

Angelus de Ubaldis/Perusio, Consilia seu responsa, Lyon 1539.

Baldus de Ubaldis, Consilia sive responsa, II, Venice 1575.

-. Commentaria in primam Digesti veteris partem, Venice 1577.

—. Commentaria in secundam Digesti veteris partem, Venice 1577.

—. In primam et secundam Infortiati partem, Venice 1577.

—.In quartum et quintum Codicis libros commentaria, Venice 1577.

Bartolus de Saxoferrato, Commentaria in primam partem Digesti Veteris, Turin 1574.

—. Super Authenticis et Institutionibus, Basel 1588.

—.Commentarius in secundam partem Digesti Novi, Turin 1574.

P. de Bellapertica, Lectura Institutionum, Lyon 1536 (reprint Opera iuridica rariora VII, Bologna 1972).

J. Bertachinus, Repertorium juris, Lyon 1499.

—. Repertorium juris iutriusque, I-III, Venice 1507-1508.

I. Butrigarius, In primam et secundam veteris Digesti partem (commentaria), I-II, Rome 1606 (reprint Opera Iuridica Rariora XIV, Bologna 1978).

P. de Castro, Auenionicae Praelectiones, Venice 1582.

Cinus de Pistoia, In Digestiveteris libros commentaria, Lyon 1547.

Contius (ed.), Digestum Vetus, seu pandectarum iuris civilis tomus primus. Ex pandectis Florentinis nuper in lucem emissis, quoad eius fieri potuit, repraesentatus: commentariis Accursii, et scholiis Contii, et paratitlis Cuiacii, necnon multorum aliorum doctorum virorum observationibus illustratus, Paris 1576.

A. Cravetta, Consilia siue Responsa, Frankfurt am Main 1611.

Daoyz, 'Index', in: Corpus Juris CivilisJustinianei, cum Accursii; praeter rubricas legum et titulorum Ant. Contii, I, Lyon 1618. 
Ph. Decius, In tit.ff. de regulis iuris, Venice 1564.

I. Faber, In Institutionis commentarii autographo collati, Lyon 1557.

Florianus de Sancto Petro, Supernono libro Digestiveteris, Naples 1471 [Mfiche.182].

R. de Forlivio, Lectura super Digesto Novo, Lyon 1523 (reprint Opera juridica rariora IX, Bologna 1968).

R. Fulgosius, In primam Pandectarum partem Commentariorum, Lyon 1544.

A. Gambilioni, In quattuor Institutionum Iustiniani libros commentaria, Venice 1609.

A. Gandinus, 'Tractatus de maleficiis', ed. Kantorowicz, Albertus Gandinus und das Strafrecht der Scholastik, Berlin/Leipzig 1926.

A. de Imola, Consilia seu responsa, Lyon 1549.

Lo Codi, ed. H. Fitting \& H. Suchier, Lo Codi. Eine Summa Codicis in provenzalischer Sprache aus der Mitte des XII. Jahrhunderts. Erster, einziger Teil. Lo Codi in der Lateinischen Übersetzung des Ricardus Pisanus, Halle 1906 (reprint Aalen 1968).

D. de Mugello, Preclarus et insignis tractatus allegabilis et quotidianus de regulis iuris, with additions of N. Boerius, Pavia 1518.

Nicasius de Voerda, Super Institutionibus, Leipzig 1541.

Ludovicus Pontanus, Singularia, Frankfurt 1596.

H. de Pyro, Super Institutis, Cologne ca. 1482.

A. de Rosate, Commentarii in primam Digestiveteris partem, Venice 1585 (reprint Opera iuridica rariora XXI, Bologna 1974).

—.Commentarii in secundam Digestiveteris partem, Venice 1585 (reprint Opera iuridica rariora XXII, Bologna 1977).

—.Commentarii in primam Infortiatipartem, Venice 1585 (reprint Opera iuridica rariora XXIII, Bologna 1978).

-. Commentarii in secundam Digesti Novi partem, Venice 1585 (reprint Opera iuridica rariora XXVI, Bologna 1982).

—. Dictionarium iuris, tam civilis, quam canonici, Venice 1601.

J. de Ravanis, Lectura super Codicem, Paris 1519 (reprint Opera iuridica rariora I, Bologna 1967).

B. de Salyceto, In secundum Digestiveteris partem commentaria, Venice 1586.

M. Socinus \& B. Socinus, Consilia, II, Venice 1579.

B. Socinus, Commentaria in Digestinovi, ac Infortiati commentaria, Venice 1605.

Bonifacius de Vitalinis, Tractatus de maleficiis, Venice 1598. 


\section{CANonists}

\section{Manuscripts}

Animal est substantia, apparatus (1206-1210), ed. E.C. Coppens, based on Mss. Luik, Bibliothèque de l'Université 127 E; Bamberg Staatsbibliothek, 42; Luxemburg Bibliothèque Nationale, BN 139 (originally in Echternach) and Nosocomium Sancti Nicolai - Sankt Nikolaus Spital, 223, available at www.medcanonlaw.nl/Animal_est_substantia.

L. Hispanus, Apparatus glossarum in compilationem tertiam, in: B.J. McManus, The ecclesiology of Laurentius Hispanus (c. 1180-1248) and his contribution to the romanization of canon law jurisprudence, with an edition of the Apparatus glossarum Laurentii Hispanii in compilationem tertiam, unpublished diss. Syracuse 1991 (microfiches Universitätsbibliothek Tübingen).

J. Teutonicus, Apparatus glossarum in Compilationem tertiam, ed. K. Pennington, based on Ms Admont, Stiftsbibliothek 22, available at http://faculty.cua.edu/ Pennington.

\section{Printed editions}

J. Andreae, In I-Vdecretalium librum Novella commentaria, Venice 1581 (reprint Turin 1963).

—. Novella super sexto Decretalium, Venice 1499.

Th. Aquinas, Opera omnia iussu impensaque leonis XIII P.M. edita, Tomus IX, Secunda secundae Summae theologiae. A quaestione LVII ad quaestionem CXXII, Rome 1897.

—. Summa Theologiae, Rome 1962.

Bernardus Papiensis, Summa Decretalium, ed. E.A.Th. Laspeyres, Regenburg 1860 (reprint Graz 1956).

Bonifacius VIII, Liber sextus decretalium, Straatsburg 1491.

J. de Breitenbach, Repetitio capituli Lator praesentium. De homicidio, Leipzig 1498.

A. a Butrio, In librum quintum Decretalium commentarii, Venice 1578 (reprint Turin 1967).

Corpus juris canonici emendatum et notis illustratum. Gregorii XIII. pont. max. iussu editum, 4 vol., Rome 1582.

Corpus Iuris Canonici, ed. E.A. Friedberg, 2 vols., Leipzig 1879-1881.

D. de Covarruvias (a Leyva), Opera omnia, Antwerp 1638.

W. Durantis, Speculum iudiciale, Basle 1574 (reprint Aalen 1975).

—. Speculum iuris, Venice 1576; Frankfurt 1668. 
Dynus de Mugello, Commentarius in regulas iuris pontificii, Lyon 1548.

Goffredus Tranensis, Summa super titulis decretalium, Lyon 1519 (reprint Aalen 1968).

A. Gomez, Commentariorum variarumque resolutionum iuris civilis, communis et regii tomi tres, with notes of E. Soarez a Ribeira, Frankfurt 1616.

[Gratianus,] Decretum Gratiani seu Concordandia discordantium canonum, Paris 1561.

Gregorius IX, Decretales cum glossa ordinaria Bernardi Parmensis, Venice 1491.

-. Decretales. Suae integritati una cum glossis restitutae, Lyon 1613.

- Decretales cum glossis diuersorum, veterum et authenticorum codicum ope redintegratae, Lyon 1618.

Innocentius IV, Apparatus super Vlibris Decretalium, Lyon 1543.

Johannes Monachus Picardus, Glossa aurea, Paris 1535 (reprint Aalen 1968).

S. de Prierio, Summa Sylvestrinae, I, Antwerpen 1581.

Quinque compilationes antiquae, ed. A. Friedberg, Leipzig 1882.

Roffredus Beneventanus, Libelli iuris civilis. Libelli iuris canonici. Quaestiones sabbatinae, Avignon 1500 (reprint Corpus Glossatorum Juris Civilis VI, Turin 1968).

F. Sandeus, Commentaria in V libros Decretalium, III, Lyon 1514.

H. de Segusio, Summa aurea, Lyon 1537 (reprint Aalen 1962).

—.In quintum Decretalium librum commentaria, Venice 1581 (reprint Turin 1965).

Tancredus, Summa de matrimonio, ed. A Wunderlich, Göttingen 1841.

N. de Tudeschis, Commentaria in primum decretalium librum, Venice 1582; Venice [1591-1592].

—. Commentaria in quartum, et quintum decretalium libros, Venice 1582.

\section{REMAINING MEDIEVAL LEGAL SOURCES}

Fr. Beyerle (ed.), Die Gesetze der Langobarden, Weimar 1947.

H. Böhlau (ed.), Die Blume von Magdeburg, Weimar 1868.

S. Brant, Der Richterlich Clagspiegel, Straßburg 1516.

M. Dobozy (transl.), The Saxon Mirror. A Sachsenspiegel of the Fourteenth Century, Philadelphia 1999.

Eykens von Repgow, Sachsenspiegel, oder Das Sächsische Land-Recht, Leipzig 1732.

M. Normann, Wendisch-Rügianischer Landgebrauch, ausverschiedenen Handschriften berichtiget und herausgegeben von T.H. Gadebusch, Stralsund/ Leipzig 1777.

K. Zeumer (ed.), Leges Visigothorum, Hannover/Leipzig 1902 [MGH, legum sectio I, tom. I] (reprint Hannover 1973). 


\section{EARLY MODERN PERIOD}

\section{HUMANISM}

A. Agustín (ed.), Digestorum seu Pandectarum, I, Paris 1548.

P.P. de Ayala, 'Commentaria in tit. D. et C. de Aleatoribus', in: E. Otto, Thesaurus juris Romani, IV, 2nd edn., Utrecht 1733.

A. Alciatus, Opera Omnia, III, Basel 1551.

Alexander ab Alexandro, Genialium dierum libri sex, I, Leiden 1673.

A. Augustinus, Emendationum, et opinionum, libri quatuor, Lyon 1544.

-. Opera Omnia, II, Lucca 1766.

I.A. Bachius, Historia iurisprudentiae Romanae. Quatuor libris comprehensa, 4th edn., Leipzig 1782.

G. Budaeus, Opera Omnia, III, Basel 1557.

H. Cagnolus, Commentarij in titulum ff. de regulis iuris, Cologne 1585.

I. Cuiacius, Opera Omnia, IV, Paris 1658.

-. Opera Omnia, V, Paris 1658.

—.Paratitla in libros IX Codicis Iustiniani, ed. C.A. Fabrotus, I, Naples 1751.

H. Donellus, Commentarii iuris civilis, in: Opera Omnia, IV, Leiden 1764.

-. Opera Omnia. Tomus nonus et Commentariorum in Codicem Justiniani, III, edn. Macerata 1832/edn. Florence 1846.

-. Opera Omnia. Tomus decimus. Et Commentariorum in selectos quosdam titulos Digestorum, I, Florence 1847.

A. Faber, Rationalia in Pandectas, Lyon 1659-1663.

B. Faber et al., Thesaurus eruditionis scholasticae, Leipzig 1692.

P. Faber, Agonisticon, Lyon 1595.

—. Commentarius ad titulum de diversis Regulis Iuris antiqui, Geneva 1618.

Marquard Freher, Verisimilium libri duo, Nürnberg 1628.

J. Gothofredus, Novus in titulum Pandectarum de diversis Regulis iuris antiqui commentarius, Geneva 1653.

-. Operajuridica minora, Leiden 1733.

G. Haloander \& J. de Vintimille, Digestorum seu Pandectarum iuris civilis libri quinquaginta, nunc primum ad fidem Pandectarum Florentinarum sexcentis locis emendati, supra Gregorii Haloandri editionem, Paris 1550.

D. Heraldus, Quaestionum quotidianarum tractatus eiusdem observationes ad ius atticum et romanum in quibus Claudii Salmasii miscellae deffensiones, eiusque specimen expenditur, Paris 1650.

F. Hotman, Opera, I/II, Geneva 1599.

S.R. Jauchius, Meditationes criticae de negationibus, Amsterdam 1728. 
Constantius Landus, 'Ad titulum Pandectarum, de justitia et iure ennarationes', E. Otto, Thesaurus juris Romani, III, 2nd edn., Utrecht 1733.

S. van Leeuwen (ed.), CorpusJuris Civilis, Pandectis ad Florentinum archetypum expressis, Institutionibus, Codice et Novellis. Cum notis integris, repetitae quitum praelectionis, Dionysii Gothofredi, Amsterdam/Leiden 1663.

G. Maiansius, Ad triginta jurisconsultorum omnia fragmenta quae estant in juris civilis corpore commentarii, I, Geneva 1764.

J. Suarez de Mendoza, 'Commentarius ad Legem Aquiliam', in: G. Meerman, Novus Thesaurus Juris Civilis et Canonici, II, The Hague 1751.

C. Molinaeus, Omnia quae extant opera, II, Paris 1612.

G. Pancirolus, Thesaurus variarum lectionum utriusque iuris, Venice 1610.

Pardulphus Pratejus, 'Jurisprudentiae Mediae libri IV', in: E. Otto, Thesaurus juris Romani, III, 2nd edn., Utrecht 1733.

I.L.E. Püttmann, Interpretationum et Observationum. Liber singularis, Leipzig 1763.

- Adversariorum iuris universi. Liber primus, Leipzig 1775.

I. Raevardus, Ad titulum Pandandectarum De diversis Regulis Iuris Antiqui commentarius, Antwerpen 1568.

Th. Reinesius, Variarum lectionum libri tres priores, Altenburg 1640.

L. Taurellius, Digestorum seu Pandectarum libri quinquaginta ex Florentinis Pandectis repraesentati, Florence 1553.

U. Zasius (Zäsy), Opera Omnia, Lyon 1550 (reprint Aalen 1964).

\section{COLLECTIONS OF CONSILIA OF EARLY MODERN PERIOD}

Chr. Besold, Consiliorum Tubingensium, VI, Tübingen 1661.

J. Brunnemann, Consilia sive responsa academica, revised ed. by S. Stryk, 2nd edn., Frankfurt an der Oder 1704.

J.G. Cotta et al., Collectionis novae consiliorum juridicorum Tubingensium, 9 Bde., ... Inclytae Facultatis Juridicae Tubingensis, Tübingen, Frankfurt \& Giessen 1731ff.

H. de Marsiliis, Consilia, Venice 1585.

Modestinus Pistoris, Consilia sive responsa, II, Leipzig 1588.

P.P. Parisius, Consilia, pars quarta, Frankfurt am Main 1590.

C. Rittershusius, Consilia sive responsa iuris Altdorfina, Nuremberg 1702.

J. Stucke, Consilia sive responsa, ed. J.J. Stucke \& Chr.D. Stucke, Frankfurt am Main 1666.

I. Wamesius, Responsa sive consilia, Antwerp 1639. 


\section{Dutch Elegant School}

G. d'Arnaud, Variarum coniecturarum libri duo, Franeker 1738.

G.C.J.J. van den Bergh \& B.H. Stolte Jr. (eds.), 'Digestorum Iustiniani Augusti titulus Ad legem Aquiliam [IX, 2] secundum editionem Taurellianam in quam Henrici Brenkman additiones mutationesque insertae eiusdem notis criticis instructus', in: G.C.J.J. van den Bergh \& B.H. Stolte Jr., 'The Unfinished Digest edition of Henrik Brenkman (1681-1736). A Pilot-Survey and Edition of Digest 9.2 ad legem Aquiliam', TvR 45 (1977), p. 250-305.

H. Brenkman, Historia Pandectarum, seu Fatum exemplaris Florentini, Utrecht 1722 (reprint Frankfurt am Main 2004 together with Narratio de Henrico Brenkmanno of G.C. Gebauer, with introduction by B.H. Stolte).

E. Bronchorst, Commentarius in titulum Digestorum de [diversis] regulis iuris Antiqui, Amsterdam 1665.

P. Burmann, Phaedri Augusti Liberti Fabularum Aesopiarum libri V. cum integris commentariis M. Gudii, C. Rittershusii, N. Rigaltii, N. Heinsii, J. Schefferi, J.L. Praschii, et excerptis aliorum, Amsterdam 1698.

H. Cannegieter, Commentarius ad Fragmenta veterisjurisprudentiae, Franeker 1765.

A.J.F. Corvinus, Digesta per aphorismos. Strictim explicata, Amsterdam $1642 / 1656$.

P.I. de Fremery, Specimen juridicum inaugurale sive Exercitationes quaedam de Rationibus veterum jurisconsultorum, Leiden 1801.

D. Gothofredus (ed.), Corpus Iuris Civilis, 3rd edn., Saint-Gervais 1602.

J.G. Hoffmannus, Meletematum academicorum ad Pandectas semestria duo, Frankfurt an der Oder 1735.

G.A. ab Hoogeveen \& A. Schulting, Disputatio juridica inauguralis ad tit. instit. de lege Aquilia ex auctoritate Antonii Schultingii eruditorum examini submittit Gerardus Aemilius ab Hoogeveen, Leiden 1718.

U. Huber, Praelectiones juris civilis, $3^{\text {rd }}$ edn., II, Utrecht 1711.

-.Eunomia Romana sive Censura censurae juris Justinianaei, Amsterdam 1724.

J.G. Marckart, Probabilia receptarum lectionum juris civilis, Utrecht 1737.

G. Noodt, Opera Omnia, Leiden 1767.

E. Otto, De vita, studiis, scriptis et honoribus Servii Sulpicii, Lemonia, Rufi, jurisconsultorum principis, liber singularis ejusdem P. Alfenus Varus, ab injuriis veterum et recentiorum liberatus, Utrecht 1737.

A. Schulting, Thesium controversarum juxta seriem Digestorum decades centum, Leiden 1762.

- Notae ad titulos Digestorum De verborum significatione et Regulis iuris, ed. N. Smallenburg, Leiden 1798. 
—. Notae ad Digesta seu Pandectas, ed. N. Smallenburg, II, Leiden 1809; VII, Leiden 1835.

G. a Teisterbant (dict. Bilderdyk), Observationum et Emendationum. Liberunus, Leiden 1819.

J. Voorda, Electorum liber singularis, Utrecht 1749.

J.J. Wissenbach, In extremum pandectarum titulum, de diversis regulis iuris antiqui, exercitationes cathedrariae, Franeker 1656.

\section{ROMAN-DUTCH LAW (AUTHORS)}

C. van Bijnkershoek, Observationes Tumultuariae (E.M. Meijers et al. [eds.]), I/II, Haarlem 1926/1934.

-. Quaestiones juris privati, Leiden 1744.

—.Verhandelingen over burgerlijke rechts-zaaken, in IVBoeken, II, Amsterdam 1747.

—. Opera Omnia, II, Leiden 1767.

C. van Bijnkershoek \& W. Pauw, Index in Observationes tumultuarias, naar het handschrift uitgegeven door A.J.B. Sirks, The Hague 2005.

J. de Damhouder, Practycke in criminele saken, Rotterdam 1660.

I. Eekma, Dissertatio iuridica inauguralis, de Iniuriis, praecipue de illarum poenis (diss. Franeker), Groningen 1809.

Genootschap van rechtsgeleerden, Rechtsgeleerde Observatien, dienende tot opheldering van verscheide duistere, en tot nog toe voor het grootste gedeelte onbewezene passagien uyt De Inleidinge tot de Hollandsche Rechtsgel. van Hugo de Groot. Derde deel, The Hague 1778.

S. van Groenewegen van der Made, Tractatus de legibus abrogatis et inusitatis in Hollandia vicinisque regionibus, Amsterdam 1669 (and edn. B. Beinart 1974, vol. I, with English transl.).

H. Grotius, Inleydinge tot de Hollandse regts-geleertheyt, mitsgaders eenige byvoegsels en aanmerkingen op de selve, door S. van Groenewegen van der Made, Amsterdam 1692.

-. Inleidinge tot de Hollandsche rechts-geleerdheid, met aanteekeningen van S.J. Fockema Andreae, 2nd edn., I-II, Arnhem 1910.

- Inleidinge tot de Hollandsche rechts-geleerdheid. Met de te Lund teruggevonden verbeteringen, aanvullingen en opmerkingen van den schrijver en met verwijzingen naar zijn andere geschriften uitgegeven en van aantekeningen en bijlagen voorzien, edn. F. Dovring, H.F.W.D. Fischer \& E.M. Meijers, Leiden 1952.

U. Huber, Heedendaegse rechtsgeleertheyt, soo elders, als in Frieslandt gebruikelijk, 4th edn., Amsterdam 1742, and English translation (from the fifth edn.), P. Gane, The Jurisprudence of My Time, 2 vol., Durban 1939. 
D.G. van der Keessel, Theses selectae juris Hollandici et Zelandici, ad supplendam Hugonis Grotii Introductionem ad jurisprudentiam Hollandicam, Amsterdam 1860.

-.Praelectiones iuris hodierni ad Hugonis Grotii Introductionem ad iurisprudentiam Hollandicam, ed. P. van Warmelo et al., V, Amsterdam/Kaapstad 1967.

S. van Leeuwen, Het Rooms-Hollands regt, 8th impr., Amsterdam 1708.

- Censura forensis theoretica-practica, 4th edn., rev. and annotated by G. de Haas, Leiden 1741; and also the English translation of Part I, book V, by M. Hewett, Pretoria 1991.

J. van der Linden, Regtsgeleerd, practicaal, en koopmans handboek: ten dienste van regters, practizijns, kooplieden en allen, die een algemeen overzicht van regtskennis verlangen, Amsterdam 1806.

—. 'Supplementum', in:Johannes Voet, Commentarius ad Pandectas, III, Utrecht 1793 (an English translation can be found in the edn. of Gane; see J. Voet, Commentarius ad Pandectas, below).

A. Matthaeus, De criminibus ad Lib. XLVII et XLVIII. Dig. commentarius, Utrecht 1644.

W. Pauw, Observationes Tumultuariae Novae, II, ed. R. Feenstra et al., Haarlem 1967.

J.P. Taunay, Disputatio juridica inauguralis an et quousque exercitores navium ex magistrorum factis obligentur, Leiden 1802.

A. Verwer, Nederlants see-rechten; avaryen; en bodemeryen: begrepen in de gemeene costumen van der See: de placcaten van keiser Karel den Vijfden, 1551; en koning Filips den II. 1563: 't tractaet van Mr. Quintijn Weijtsen van de Nederlantsche avarijen, ende daerenboven in eene Verhandelinge nopende het recht der Hollantsche bodemeryen, 4th edn., Amsterdam 1764.

A. Vinnius, In quattuor libros Institutionum imperalium commentarius academicus et forensis, ed. J.G. Heineccius, Leiden 1726; with German translation by K. Wille, Institutionenkommentar Schuldrecht [Latin text and German translation], Heidelberg 2005.

J. Voorda, Dictata ad ius hodiernum, based on Ms Leeuwarden P.B.F., Hof 33, edn. M. Hewett (ed.), Jacobus Voorda Dictata ad ius hodiernum, lectures on the contemporary law given by Jacobus Voorda (1698-1768) at the University of Utrecht [Latin text and English translation], I, Amsterdam 2005.

J. van de Water, Annotationes ad Pandectas, handwriting in the edition of Gothofredus/Van Leeuwen of 1663; a copy with signature 759 A 36 in the University Library of Leiden has been consulted.

M. Wesenbecius, Pandectas iuris civilis commentarii olim Paratitla dicti, I, Basel 1589. 


\section{ROMAN-DUTCH LAW (SOURCES)}

C. Cau (ed.), Groot placaet-boeck, vervattende placaten, ordonnantien en de edicten van de doorluchtige, hooghmogende heeren Staten Generael der Vereenighde Nederlanden: ende van de edele grootmogende heeren Staten van Hollandt en West-Vrieslandt, mitsgaders vande ed. mog. heeren Staten van Zeelandt, I/II, The Hague 1658/1664.

J. Cooren, Observationes rerum in eodem senatu iudicatarum, The Hague 1642 (reprint Amsterdam 1661).

H.C. Gall (ed.), Regtsgeleerde decisien. Aan de raadsheer Pieter Ockers toegeschreven aantekeningen betreffende uitspraken van het Hof (1656-1669) en de Hoge Raad (1669-1678) van Holland, Zeeland en West-Friesland, Amsterdam 2002.

Instructie voor schepenen van 't watergerecht, en ordonnantie op het stuk van assurantie en avarye, mitsgaders van zeezaken en de manier van procederen ontrent dezelve, Dordrecht 1775.

A. Kaufmann (ed.), Die Peinliche Gerichtsordnung Kaiser Karls V.von 1532 (Carolina), 4th edn., herausgegeben und erläutertvon G. Radbruch, Stuttgart 1978.

F. van Mieris, Handvesten, privilegien, octroyen, rechten, en vrijheden, mitsgaders ordonnantien, resolutien, plakkaaten, verbintenissen, costumen, instructien, en handelingen der stad Leyden, Leiden 1759.

C. van Nieustad (Neostadius), Utriusque Hollandiae Zelandiae Frisiaeque curiae decisiones, The Hague 1667.

C. van Nieustad \& J. Kooren, Hollandse praktijk in rechten, bestaande in vonnissen, observantien van oordelen en consultatien, transl. from the Latin by A. van Nispen, Rotterdam 1655.

Ordonnantie op het stukvan asseurantie ende van avarye: mitsgaders zee-zaken, 1721 (reprint Rotterdam 1748).

G. Remus, Nemesis Karulina:D. Karuli V. imp. Leges capitales, Nassau 1594.

J.F. von Schwarzenberg, Bambergische Peinliche Halsgerichtsordnung, Bamberg 1507.

F. Wielant, Corte instructie in materie criminele, ed. J. Monballyu, Filips Wielant. Verzameld werk. I. Corte instructie in materie criminele, Brussels 1995.

'Zee-Rechten, dat is: dat hooghste ende oudtste Gotlandtsche water-recht, dat de gemeene Coop-lieden ende Schippers geordineert ende gemaeckt hebben tot Wisbuy', Middelburg 1660 in: 't Boeck der zee-rechten. Inhoudende dat hooghste ende oudtste Gotlantsche waterrecht, dat de gemeene koop-lieden ende schippers geordineert ende gemaeckt hebben, tot Wisbuy. De zee-rechten gemaeckt by keyser Karel: mitsgaders de schips-rechten ghemaeckt by de oude Hanze-steden, Middelburg 1664. 


\section{USUS MODERNUS PANDECTARUM}

J. Ayrerus, Tractatus methodicus \& accuratissimus de triplicigenere homocidiorum: necessarii, voluntarii seu culposi, \& involuntarii seu casualis, Frankfurt 1647.

P. Barbosa, De matrimonio et pluribus aliis materibus, in tit.ff. soluto matrimonio, II, Lyon 1668.

C. Bargalius, Tractatus de dolo, Hanau 1604.

G.C. Bastineller, Dissertatio inauguralis iuridica de pariturpitudine, Wittenberg 1734.

J.H. von Berger, Resolutiones legum obstantium, quae in Compendiojuris Lauterbachiano expromuntur, 3rd edn., Wittenberg 1716.

-. Electa iurisprudentiae criminalis variis consultationibus, quaesitis, responsis ac praeiudiciis illustrata, 3rd edn., Supplementa pars I. T. I, Leipzig 1737.

—. Oeconomia iuris ad usum hodiernum accomodati, 6th edn., Leipzig 1755.

I.H. Böhmer, Doctrina de actionibus, Frankfurt am Main 1738.

H. Bonacossa, Quaestiones criminales, Venice 1573.

J. Brunnemann, Commentarius in quinquaginta libros Pandectarum, 3rd edn., ed. S. Stryk, Leipzig 1683.

-. Commentarius in quinquaginta libros Pandectarum, ed. S. Stryk, Lyon 1714.

L. Carerius, Practica causarum criminalium, Frankfurt 1600.

B. Carpzov, Opus definitionum forensium ad Constitutiones Electorales Saxonicas, Frankfurt/Leipzig 1650.

-. Practica nova imperialis Saxonicae rerum criminalium, Wittenberg/Frankfurt 1684; Leipzig 1703.

S. de Coccejus, Jus civile controversum, Frankfurt/Leipzig 1740.

J.U. Cramer, Wetzlarische Beyträge aus der Reichs-Praxi dasigen höchsten Reichts-Gerichts, Wetzlar 1763.

F.N. Cyriacus, Controversiarum forensium, I, Venice 1644.

P. Farinacius, Praxis et theoricae criminalis, pars secundae, tomus secundus, Venice 1609.

-. Praxis et theoricae criminalis amplissimae, pars quidem quarta: ast Operum Criminalium Pars Quinta, 2nd edn., Nürnberg 1676.

P. Favre, Commentarius ad tit. de diversis regulis iuris antiqui, ex libro Pandectarum imperatoris Iustiniani quinquagesimo, Lyon 1590.

A. Gaill, Practicarum observationum tam ad processum judiciarium, praesertim imperialis camerae, quam causarum decisiones pertinentium, libri duo, Cologne 1626.

A. Gilmannus, Decisionem sive rerum in Camera Imperiali iudicatarum libri duo, Frankfurt 1602-1603. 
M. Grass, Collectionis novae consiliorum juridicorum Tubingensium, V, Tübingen, Frankfurt \& Giessen 1733.

P. Gudelinus, Commentariorum de jure novissimo libri sex, Arnhem 1643.

[F.-C. Harpprecht,] Consiliorum Tubingensium Volumen VI. quod, potissimam partem, nomine amplissimae facultatis juridicae, in per-antiqua eberhardina, conscripsit F.-C. Harpprecht, Tübingen 1699.

—. Responsa iuris, criminalia et civilia, IV, Tübingen 1706.

J. Heeser, Loci communes juris practici de rationibus reddendis eorumque, Cologne 1708.

J.G. Heineccius, Recitationis in elementa juris civilis secundum ordinem Institutionum, II, Venice 1824.

J.N. Hertius, Responsa et consilia, coll., rev. and ed. J.J. Hertius, Frankfurt am Main 1729.

C.F. Hommel, Rhapsodia quaestionum in foro quotidie obvenientium neque tarnen legibus decisarum, II/III, 3rd edn., Bayreuth 1769; VI, 4th edn., Bayreuth 1785.

S.J. Kapff \& J.F. Eisenbach, De compensatione circa maleficia vel quasioccasione legis XXXVI. Dig. de dolo malo (diss. Tübingen), [Präses:] S.J. Kapff. [Respondent:] J. Fr. Eisenbach, Tübingen 1778.

G.A. Kleinschrod, Doctrina de reparatione damni delicto dati ex natura rei iureque positivo deducta et ad omnes criminum classes applicata. Spec. I: Principia huius doctrinae generalia, Würzburg 1798.

-. Systematische Entwicklung der Grundbegriffe und Grundwahrheiten des peinlichen Rechts nach der Natur der Sache und der positiven Gesetzgebung, 3rd edn., Erlangen 1805.

-. Abhandlungen aus dem peinlichen Rechte und dem peinlichen Processe, III, 2nd edn., Erlangen 1806.

W.A. Lauterbach, Collectionis novae consiliorum juridicorum Tubingensium, II/ III, Tübingen, Frankfurt \& Giessen 1731/1732.

—.Collegium theoretico-practicum Pandectarum, I, Tübingen 1707/6th edn. 1784.

W.A. Lauterbach \& J. Helm, Conclusionum forensium, Exercitatio XIX. Ad libr. IX. Digest., [Präses:] W.-A. Lauterbach. [Respondent:] J. Helm, Tübingen 1664.

M.F. Lederer, De jure belli privati, libri duo, Wittenberg 1668.

A. von Leyser, Meditationes ad Pandectas, II, 3rd edn., Leipzig 1742.

J. Baptista de Luca, Theatrum veritatis et iustitiae, lib. VIII. De credito et debito, creditore et debitore, Naples 1758.

N.C. von Lyncker, Rerum in sseren. ducum Saxoniae dicasteriis Jenensibus decisarum centuriae quinque, III, Jena 1701.

Sebastianus Medicus, 'Tractatus de compensationibus', in: Tractatus universi iuris, VI.2, Venice 1584. 
G.J.F. Meister, Principia iuris criminalis Germaniae communis, 6th edn., Göttingen 1819.

I. Menochius, De arbitrariis iudicium quaestionibus et causis, Cologne 1615.

D. Mevius, Decisiones super causis praecipuis ad praedictum Tribunal Regium delatis, Frankfurt am Main 1740.

J.E.J. Müller, Promtuarium juris novum, 2nd edn., Leipzig 1792.

B. Olivatius, Decisiones Sacrae Rotae Romanae, III, Rome 1784.

F. Pacianus, De probationibus libri duo in quibus fuse ac erudite exponitur materia cui incumbat onus probandi, Frankfurt/Leipzig 1703.

J.P. Plotus, Tractatus singularis de in litem jurando, Osnabrück 1676.

Cyprianus Regnerus ab Oosterga, Censura Belgica, Utrecht 1648.

J.Ch. von Quistorp, Grundsätze des deutschen Peinlichen Rechts, 5th edn., I, Rostock/Leipzig 1794.

C. Rezzonico, Decisiones Sacrae Rotae Romanae, III, Roma 1762.

C. Rittershusius, Commentarius novus, in quatuor libros institutionum imperialium divi Iustiniani, Strasbourg 1649.

J. a Sande, De diversis regulis iuris antiqui commentarius, Groningen 1681.

W.A. Schoepff, Selectae decisiones et resolutiones Tubingenses, Tübingen 1726.

L. Schrader, Tractatus feudalis, I, Frankfurt 1594.

G. Schweder, Inclytae facultatis iuridicae Tubingensis quotquot a centum et pluribus annis hucusque conscripta colligi potuere, consilia et responsa praecipua omnia, I, Tübingen 1731.

D.G. Strube, Rechtliche Bedenken, III, Hannover 1792 (3rd edn.); IV, 1783 (2nd edn.).

S. Stryk, Specimen usus moderni pandectarum, Halle an der Saale 1730.

-. Continuatio usus moderni Pandectarum a libro VI. usque ad XII, 6th edn., Halle an der Saale 1729.

S. Stryk \& Chr. Seidel, De alapa (diss. Frankfurt an der Oder 1675), [Präses:] S. Stryk. [Respondent:] Chr. Seidel, Frankfurt an der Oder 1683.

A. Tiraquellus, De poenis legum, ac consuetudinem, statutarumque temperandis, aut etiam remittendis, et id quibus quotque ex causis, Lyon 1559.

C.A.Tittmann, Handbuch des gemeinen deutschen Peinlichen Rechts, I, Halle 1806.

D. Tuscus, Practica conclusiones iuris in omni foro frequentes, V, Frankfurt 1621. Tyndarus Alphanus, 'Tractatus de compensationibus', in: Tractatus illustrium, Tomus VI, Pars II, Venetiis 1584.

M. Venturini, Decisiones Rotae Florentinae, Florence 1709.

G. Vernaccini, Collezione completa delle decisioni, II, Firenze 1824.

J. Voet, Commentarius ad Pandectas, I, Geneva 1778; and English translation (of edn. of 1829) by P. Gane, The selective Voet being the Commentary on the Pandects [Paris Edition of 1829] by Johannes Voet [1647-1713] and the Supplement to that Work by Johannes van der Linden [1756-1835], translated with Explanatory 
Notes and Notes of all South African reported Cases by P. Gane, II/III, Durban $1955 / 1956$.

P. Voet, In quatuor libros Institutionum imperialium commentarius, pars posterior, Utrecht 1668.

I.B. Wernher, Selectarum observationum forensium, I, Jena/Leipzig 1756.

Chr. Wildvogel \& J.H. Böhmer, De imputatione culpae (diss. Jena 1695), [Präses:]

Chr. Wildvogel. [Respondent:] J.H. Böhmer, Jena 1695.

J. Zanger, Tractatus de exceptionibus, Frankfurt am Main 1598.

\section{OLD FRENCH LAW FROM PRE-CODIFICATION ERA}

F. Bourjon, Le droit commun de la France et la Coutume de Paris, II, Paris 1770. J. Domat, Les loix civiles dans leur ordre naturel, le proit public, et legum delectus, I, Paris 1777.

M. Guy du Rousseaud de la Combe, Recueil de jurisprudence du pays de droit écrit, et coutumier, par ordre Alphabetique, Paris 1736/1746/4th edn. 1769.

\section{NATURAL LAW}

C.H. Eckhard, Hermeneutica iuris, edited by C.F. Walch, new edn. by C.W. Walch, Leipzig 1802.

H. Grotius, Le droit de la guerre, et de la paix. Nouvelle traduction, parJ. Barbeyrac. Avec les notes de l'auteur même, qui n'avoient point encore paru en François; et de nouvelles notes du traducteur, II, Basle 1746.

-. De iure belli ac pacis libri tres, cum adnotationibus selectis J.F. Gronovii et auctioribus Ioannis Barbeyracii ..., I, Utrecht 1773.

—. De iure belliac pacis, eds. J. Barents \& A.J.S. Douma, with an extract by B.M. Telders, and a preface by W.J.M. van Eysinga, The Hague 1948.

—. De iure belli ac pacis libri tres, ed. B.J.A. de Kanter - van Hettinga Tromp, Leiden 1939 (reprint with additions Aalen 1993).

L. Lessius, De iustitia et iure, ceterisque virtutibus cardinalibus, libri quatuor...., Lyon 1653.

L. de Molina, De iustitia et iure, Cologne 1614.

R.J. Pothier, Pandectae Justinianeae, in novum ordinem Digestae, I/III, Lyon 1782. F.E. Pufendorf, De culpa commentatio juris naturalis et civilis, Lemgo 1741.

S. Pufendorf, De jure naturae et gentium, libri octo, I-II, Amsterdam 1688 (reprint Oxford 1934). 
Chr. Thomasius, Institutionum jurisprudentiae divinae libri tres, Halle 1730.

—. Larva legis Aquiliae, edited and translated from the Latin by M. Hewett under the title 'The Mask of the lex Aquilia torn off the Action for Damage done. A Legal Treatise by Christian Thomasius (1655-1728)', with an Essay 'Christian Thomasius, the Reception of Roman Law and the History of the Lex Aquilia' by R. Zimmermann, Oxford/Portland, Oregon 2000.

Ph.R. Vitriarius, Institutiones juris naturae et gentium in usum, Leiden 1734.

Chr. Wolff, Grundsätze des Natur- und Völkerrechts, ed. M. Thomann, Halle 1754 (reprint Hildesheim 1980).

—.Institutiones juris naturae et gentium, ed. M. Thomann, Halle 1750 (reprint Hildesheim [etc.] 1969).

- Jus naturae methodo scientifica pertratatum, II, Halle 1742.

—. 'Jus naturae', IV, in: Chr. Wolff, Gesammelte Werke, II, 20, Halle 1740-1748 (reprint Hildesheim 1968).

\section{LEGISLATION}

\section{Early modern period}

[Alfonso X the Learned, King of Castile], Las Siete Partidas, transl. by S.P. Scott; ed. by R.I. Burns, I, Philadelphia 2001.

J.S. von Brandenburg, Jus provinciale Ducatus Prussiae, publicatum 1620, edn. Rostock 1623/1624.

[Cleirac,] Us, et coustumes de la mer. Divisées en trois parties. I. De la navigation. II. Du commerce naval, et contracts maritimes. III. De la iurisdiction de la marine. Avec un traité des termes de marine, et, reglemens de la navigation des fleuves et rivieres, Bourdeaux 1647; and under the same name with addition 'Et les nouveaux edits, reglemens, arrests et iugemens rendus fur le fait de commerce de la mer', edn. Rouen 1671.

Das Bayerische Landrecht (Codex Maximilianeus Bavaricus civilis) vom Jahre 1756 in seiner heutigen Geltung, Text mit Anmerkungen und Sachregister herausg. von M. Danzer, München 1894.

Die peinliche Gerichtsordnung Kaiser Karls V, ed. H. Zoepfl, 3rd edn., Leipzig/ Heidelberg 1883.

S.S. Jados, Consulate of the Sea and Related Documents, Tuscaloosa 1975.

Los Códigos Españoles concordados y anotados, XI. Leyes de la nueva recopilacion que no han sido comprendidas en la Novisima, 2nd edn., Madrid 1873.

G. Martínez Diez (ed.), Leyes de Alfonso X, II. Fuero Real. Edición y análisis critico, Ávila 1988. 
Novísima Recopilación de las Leyes de España, V, Madrid 1805.

Ordonnance de la Marine. Du mois d'août 1681. Commentée et conferée sur Les anciennes Ordonnances, le Droit Romain, et les nou.veaux Reglemens, Paris 1756.

\section{LITERATURE OF THE NINETEENTH, TWENTIETH AND TWENTY-FIRST CENTURIES}

$\underline{\mathrm{A}}$

A. Adler (ed.), Lexicographi Graeci. Vol. I. Suidae Lexicon. A-S. Index. Pars II. $\Delta-\Theta$, Leipzig 1931 (reprint Stuttgart 1967).

H. Adriani, Der Schuldbegriff in \$254 BGB, Leipzig 1939.

M.J.A.M. Ahsmann, Collegia en colleges. Juridisch onderwijs aan de Leidse Universiteit 1575-1630, in het bijzonder het disputeren (diss. Leiden), Groningen 1990.

—. 'Voet, Johannes (1647-1713)', in: M. Stolleis (ed.), Juristen. Ein biographisches Lexikon. Von der Antike bis zum 20. Jahrhundert, 2. Aufl., München 2001, p. 656.

M. Ahsmann \& R. Feenstra, Bibliografie van hoogleraren in de Rechten aan de Leidse Universiteit tot 1811, met medewerking van R. Starink, Amsterdam/ Oxford/New York 1984.

B. Albanese, 'Studi sulla legge Aquilia', Annali del Seminario Giuridico della Università di Palermo 21 (1950), p. 5-349.

J. Alberigo \& H. Jedin (eds.), Conciliorum oecumenicorum decreta, 3rd edn., Bologna 1973.

E. Albertario, 'Le fonti delle obbligazioni e la genesi dell'art. 1097 del Codice Civile', Rivista del diritto commerciale e del diritto generale delle obligazioni 21 (1923), p. 493-512.

-. Studi di diritto romano, III, Milan 1936.

J. Alvarado, 'Gregorio Mayans y Siscar (1699-1781)', in: R. Domingo (ed.), Juristas universales. Volumen II. Juristas modernos. Siglos XVI al XVIII: de Zasio a Savigny, Madrid/Barcelona 2004, p. 589-592.

V.M. Amaya García, Coautoriay complicidad: studio historico y jurisprudencial, Madrid 1993.

K. v. Amira, Nordgermanisches Obligationenrecht. II. Westnordisches Obligationenrecht, Leipzig 1895.

J.A. Ankum, 'Dogmatische, sociologische en historische rechtsbeoefening', $A A$ VI (1956-1957), p. 125-132. 
—. 'Towards a Rehabilitation of Pomponius', in: A. Watson (ed.), Daube Noster. Essays in Legal History for David Daube, Edinburgh 1974, p. 1-13.

- 'Actions by which we claim a Thing (res) and a Penalty (poena) in Classical Roman Law', BIDR 24 (1982), p. 15-39.

- 'Gaius, Theophilus and Tribonian and the Actiones Mixtae', in: P.G. Stein \& A.D.E. Lewis (eds.), Studies in Justinian's Institutes in memory of J.A.C. Thomas, London 1983, p. 4-17.

—. 'El carácter jurídico de la actio legis Aquiliae en el derecho romano clásico', in: H. Ankum, Extravagantes. Scritti sparsi sul diritto romano, con una nota introduttiva, un supplemento biografico e un indice della fonti di J.E. Spruit, Naples 2007, p. 99-112 (originally in: Revista Jurídica de Asturias 10-11 (19871988), p. 3-16).

—. 'Was Justinian's Corpus iuris civilis a codification?', in: H. Ankum, Extravagantes. Scritti sparsi sul diritto romano, con una nota introduttiva, un supplemento biografico e un indice della fonti diJ.E. Spruit, Naples 2007, p. 399-412 (originally in: Zbornik. Pravnog Fakulteta u Podgorici 32 (2001), p. 9-22).

L.J.van Apeldoorn (ed.), Uit de practijkvan het Hof van Holland in de tweede helft van de zestiende eeuw. Een handschrift [Oud-Vaderlandsche rechtsbronnen, $3^{\mathrm{e}}$ reeks, VII], Utrecht 1938.

H. Appleton, Des interpolations dans les Pandectes et des méthodes propres a les découvrir, Paris 1895 (anast. reprint Roma 1967).

Aquarius, 'Causation and Legal Responsibility', The South African Law Journal 1941 (vol. 58), p. 232-263.

V. Arangio-Ruiz, Responsabilità contrattuale in diritto romano, reprint of 2nd edn., Naples 1958.

A.-J. Arnaud, Les origines doctrinales du code cvil français, préface de M. Villey, Paris 1969 [Vol. IX of Bibliothèque de philosophie du droit sous la direction de Ch. Eisenmann, H. Batiffol \& M. Villey].

K.L. Arndts von Arnesberg, Lehrbuch der Pandekten, 14th edn., eds. L. Pfaff \& F. Hofmann, Stuttgart 1889.

C. Arnò, 'Ars aequi et boni', Atti della reale accademia delle science di Torino. Classe di scienze morali, storiche e filologiche, Bd. 75 (1939/1940), p. 36-88.

M. Artigot i Golobardes \& F. Gómez Pomar, 'Contributory negligence and comparative negligence in the law and economic literature', in: M. Faure (ed.), Tort Law and Economics [Encyclopedia of law and economics, 2nd edn.], Northampton Mass. 2009, p. 46-79.

W. Ashburner, Nomos Rodion Nautikos: The Rhodian Sea-Law, edited from the manuscripts, Oxford 1909 (reprint Aalen 1976).

C.D. Asser et al., Wetboek van Koophandel, met Aantekeningen, 2nd edn., Amsterdam 1873. 
G. Astuti, Mos italicus e mos gallicus neidialoghi 'de iuris interpretibus'di Alberico Gentili, Bologna 1937.

C. Aubry \& C. Rau, Cours de droit civil français d'après la méthode de Zachariae, IV, 4th edn., Paris 1871.

—. Droit civil français, VI, 6th edn. by P. Esmein, Paris 1951.

P. Aumann, Das mitwirkende Verschulden in der neueren juristischen Dogmengeschichte (diss. Universität Hamburg), Hamburg 1964.

B. Auzary-Schmaltz, 'Liability in Tort in France before the Code Civil:The Origins of Art. 1382 ff. Code Civil', in: E.J.H. Schrage, Negligence. The Comparative Legal History of the Law of Torts, Berlin 2001, p. 309-339.

B

E. Badian \& T. Honoré, 'Alfenus Varus, Publius', in: S. Hornblower \& T. Spawforth (eds.), Who is Who in the Classical World, Oxford (etc.) 2000, available at www.oxfordreference.com.

C.L. von Bar, Die Lehre vom Causalzusammenhang im Recht, besonders im Strafrecht, Leipzig 1871 (reprint Aalen 1971).

C. von Bar, Gemeineuropaïsches Deliktsrecht, II, München 1999.

- The Common European Law of Torts, II, Oxford 2000.

C. von Bar \& E. Clive (eds.), Principles, Definitions and Model Rules of European Private Law: Draft Common Frame of Reference (DCFR). Full Edition, I/IV, Munich 2009.

Chr. von Bar \& H.P. Dopffel, Deutsches internationales Privatrecht im 16. und 17. Jahrhundert. Materialen, Übersetzungen, Anmerkungen. Erster Band, unter Mitwirkung insbesondere von D. Effertz, F. Nieper \& T. Stäcker, Tübingen 1995.

J.M. Barendrecht, 'Inleiding', in: W.H. van Boom, C.E.C. Jansen \& J.G.A. Linssen (eds.), Tussen 'Alles' en 'Niets'. Van toedeling naar verdeling van nadeel, Deventer 1997, p. 1-14 (1997a).

—. 'Eigen schuld: consistentie en verdelingsmaatstaven', in: W.H. van Boom, C.E.C. Jansen \& J.G.A. Linssen (eds.), Tussen 'Alles' en 'Niets'. Van toedeling naarverdeling van nadeel, Deventer 1997, p. 153-186 (1997b).

S.A. Barney et al., The Etymologies of Isidore of Seville, Cambridge 2006.

B. Baudelot, Un grand jurisconsulte du XVIIe siècle: Jean Domat (diss. Paris), Paris 1938.

R.A. Bauman, Lawyers in Roman Republican Politics. A Study of the RomanJurists in their Political Setting, 316-82 BC, München 1983.

- Lawyers in Roman Transitional Politics. A Study of the Roman Jurists in their Political Setting in the Late Republic and Triumvirate, München 1985.

G. Baviera, Le due scuole dei giureconsulti romani, Firenze 1898 (anast. repr. Rome 1970). 
O. Behrends, Die Wissenschafslehre im Zivilrecht des Q. Mucius Scaevola pontifex, Göttingen 1976.

- Review of 'Richard A. Bauman, Lawyers in Roman Republican Politics. A Study of the Roman Jurists in their Political Setting, 316-82 BC (=Münchener Beiträge zur Papyrusforschung und Antiken Rechtsgeschichte, Heft 75), Beck, München 1983. XXII, 453 S.' \& 'Ders., Lawyers in Roman Transitional Politics. A Study of the Roman Jurists in their Political Setting in the Late Republic and Triumvirate (Münchener Beiträge, Heft 79). Beck, München 1985. 148 S.,' ZSS RA 107 (1990), p. 585-610.

B. Beinart, 'The relationship of iniuria and culpa in the lex Aquilia', in: Studi in onore di Vincenzo Arangio-ruiz nel XLV anno del suo insegnamento. I, Naples 1953, p. 279-303.

E.I. Bekker, Die Aktionen des römischen Privatrechts. I. Ius Civile, Berlin 1871.

R. Bellini, 'Il vino nelle leggi della Chiesa', in: G. Archetti (ed.), La civiltà del vino. Fonti, temi e produzioni vitivinicole dal Medioevo al Novecento (Atti del convegno, Monticelli Brusati - Antica Fratta, 5-6 ottobre 2001), Brescia 2003, p. 365-420.

M. Bellomo, The Common Legal Past of Europe 1000-1800, Washington 1995 [translation of L'Europa del diritto comune, by L.G. Cochrane].

A. Berger, 'Peira', in: Encyclopedic Dictionary of Roman Law, vol. 43, 2, 1953, p. 625. G.C.J.J. van den Bergh, 'Gerard Noodt (1647-1725); in: T.J.Veen \& P.C. Kop (eds.), Zestig juristen. Bijdragen tot ene beeld van de geschiedenis der Nederlandse rechtswetenschap, m.m.v. C.H.N. Kwanten, Zwolle 1987, p. 135-140.

- . The Life and Work of Gerard Noodt (1647-1725). Dutch Legal Scholarship Between Humanism and Enlightenment, Oxford 1988.

- Geleerd recht. Een geschiedenis van de Europese rechtswetenschap in vogelvlucht, 3rd edn., Deventer 1994.

—. 'Der Präsident. Cornelis van Bijnkershoek, seine Bedeutung und sein Nachruhm', ZEuP 3 (1995), p. 423-437.

- Die holländische elegante Schule. Ein Beitrag zur Geschichte von Humanismus und Rechtswissenschaft in den Niederlanden 1500-1800, Frankfurt am Main 2002.

G.C.J.J.van den Bergh \& B.H. Stolte Jr., 'The Unfinished Digest Edition of Henrik Brenkman (1681-1736). A Pilot-Survey and Edition of Digest 9.2 ad legem Aquiliam', TvR 45 (1977), p. 227-305.

G. von Beseler, Beiträge zur Kritik der römischen Rechtsquellen, III, Tübingen 1913.

—. 'Einzelne Stellen', ZSS RA 43 (1922), p. 535-556.

—. 'Romanistische Studien', ZSS RA 50 (1930), p. 18-77.

—. 'Beiträge zur Kritik der römischen Rechtsquellen', ZSS RA 66 (1948), p. 265-393.

E. Bethe (ed.), Lexicographi Graeci. Vol. IX. Pollucis Onomasticon. Libri I-X. Index, Stuttgart 1967. 
Ch. Beudant, Cours de droit civil français, 2nd edn. publié par R. Beudant et P. Lerebours-Pigeonnière, IXbis (Les contrats et les obligations), avec le concours de R. Rodière, Paris 1952.

K. Bezemer, What Jacques saw. Thirteenth Century France through the Eyes of Jacques de Revigny, Professor of Law at Orleans, Frankfurt am Main 1997.

Biblioteca Iuris Antiqui (BIA), CD-ROM consulted at Universiteit Utrecht.

Biographisch-Bibliographisches Kirchenlexikon, Hamm, Herzberg-Nordhausen, 1975-2003, 22 dln, available at www.bautz.de.

B. Biondi, Successione testamentaria e donazioni, 2nd rev. edn., Milan 1955.

H. Blanck, Einführung in das Privatleben der Griechen und Römer, 2nd edn., Darmstadt 1996.

F. Blass, Die Attische Beredsamkeit. I. Von Gorgias bis zu Lysias, 2nd edn., Leipzig 1887.

A.R. Bloembergen, 'Eigen schuld bij letselschade: een verweer op zijn retour', in: A.J.O. baron van Wassenaer van Catwijck et al., Eigen schuld bij onrechtmatige daad. De verdeelsleutel zoals neergelegd in art. 6:101 BW. Inleidingen, gehouden op het symposion van de Vereniging van Letselschade Advocaten 1997, Lelystad 1997, p. 5-13.

J.C. Bluntschli, Privatrechtliches Gesetzbuch für den Kanton Zürich, III, Zürich 1855.

M. Bogdan, Comparative Law, Goteborg 1994.

P. Bonfante, Istituzioni di diritto Romano, reprint of 10th edn., Turin 1946.

W.H. van Boom, 'Contributory Negligence under Dutch Law', in: U. Magnus \& M. Martín-Casals (eds.), Unification of Tort Law: Contributory Negligence, The Hague/London/New York 2004, p. 129-147.

W.H. van Boom \& I. Giesen, 'Van Nederlands naar 'Europees' onrechtmatige daadsrecht', NTBR 2004/10, p. 515-523.

R.J.B. Boonekamp, BurgerlijkWetboek Boek 6, Artikel 101 [Eigen schuld benadeelde] (01-01-1992 tot --), in: A. T. Bolt. (ed.), Schadevergoeding, Deventer losbladig bijgewerkt tot 21-03-2011.

J.-S. Borghetti, 'The Definition of la faute in the Avant-projet de réforme', in: J. Cartwright, S. Vogenauer \& S. Whittaker, Reforming the French Law of Obligations. Comparative Reflections on the Avant-projet de réforme du droit des obligations et de la prescription ('the Avant-projet Catala'), Oxford/Portland 2009, p. 271-288.

—. 'Des principaux délits spéciaux', in: F. Terré (dir.), Pour une réforme du droit de la responsabilité civile, Paris 2011, p. 163-183.

B. Bouckaert, De exegetische school. Een kritische studie van de rechtsbronnen-en interpretatieleer bij de 19de eeuwse commentatoren van de Code Civil (diss. Gent), Antwerpen 1981.

A. Boudinhon, 'Minor', The Catholic Encyclopedia, vol.10 (edn. 1913), p. 331-332. 
L.J.H. Bouman, Dissertatio juridica inauguralis de collisione navium/Proeve over collisievan schepen (diss. Leiden), Rotterdam 1855.

H.A. Bouman, 'De billijkheidscorrectie tegen het licht of Het betere, de billijkheidscorrectie, is de vrijand van het goede, de rechtszekerheid', in: A.J.O. baron van Wassenaer van Catwijck et al., Eigen schuld bij onrechtmatige daad. De verdeelsleutel zoals neergelegd in art. 6:101 BW. Inleidingen, gehouden op het symposion van de Vereniging van Letselschade Advocaten 1997, Lelystad 1997, p. 25-56.

A. Braet, De redelijkheid van de klassieke retorica. De bijdrage van klassieke retoriciaan de argumentatietheorie, Leiden 2007.

F. Brandsma, Dorotheus and his Digest Translation, Groningen 1996.

Brassloff, 'Fabius Mela', in: RE VI (1909), column 1830-1831.

A. Brinz, Lehrbuch der Pandekten, $2^{\text {nd }}$ edn., II, 1, Erlangen 1879.

E.H. Brewster, Roman Craftsmen and Tradesmen of the Early Empire, Menasha, Wis. 1917.

E.J.M.F.C. Broers, Beledigingszaken voor de Staatse Raad van Brabant 1586-1795 [Brabantse Rechtshistorische Reeks, nr. 9], Assen 1996.

-.Van plakkaat tot praktijk. Strafrecht in Staats-Brabant in de zeventiende en achttiende eeuw, Nijmegen 2003.

-. Geschiedenis van het straf-en schadevergoedingsrecht. Een inleiding, Apeldoorn/Antwerpen 2012.

Chr. Brom, Urteilsbegründungen im « Hoge Raad van Holland, Zeeland en West-Friesland» am Beispiel des Kaufsrechts im Zeitraum 1704-1787, [Rechtshistorische Reihe, 377], Frankfurt 2008.

E. Bruck \& H. Möller, Kommentar zum Versicherungsvertragsgesetz und zu den allgemeinen Versicherungsbedingungen unter Einfluss des Versicherungsvermittlerrechtes, 8th edn., II. \$\$ 49-80 VVG, Berlin/New York 1980.

E. Brunnenmeister, Die Quellen der Bambergensis. Ein Beitrag zur Geschichte des deutschen Strafrechts, Leipzig 1879.

C.J.H. Brunner, Note to HR, 4 May 2001, NJ 2002, 214.

W.H. Bryson, Dictionary of Sigla and Abbreviations to and in Law Books before 1607, 2nd printing with corrections, Buffalo/New York 1996.

W.W. Buckland, A Text-Book of Roman Law from Augustus to Justinian, revised by P. Stein, 3rd edn., digitally printed edn., Cambridge 2007.

W.W. Buckland \& A.D. McNair, Roman Law and Common Law. A Comparison in Outline, revised by F.H. Lawson, 2nd edn., reprint, Cambridge 1974.

H. Bull, B. Kingsbury \& A. Roberts (eds.), Hugo Grotius and International Relations, Oxford 1990.

C.C. Burckhardt, Sinn und Umfang der Gleichstellung von dolus und lata culpa im Römischen Recht (diss. Göttingen), Göttingen 1885. 
L. Burgmann et al., Repertorium der Handschriften des byzantinischen Rechts. Teil I. Die Handschriften des weltlichen Rechts (Nr. 1-327), Frankfurt am Main 1995.

Y. Buruma, 'Noodweer in de bus' (noot bij HR 11 juni 2002, zaaknr. 00528/01, NJ 2002, 467), $A A 52$ (2003) 2, p. 113-117.

E. Bussi, La formazione dei dogmi di diritto privato nel diritto comune (diritti reali e diritti di obbligazione), Padova 1937.

$\underline{\mathrm{C}}$

J. Carcopino, Het dagelijks leven in het oude Rome, 5th edn., Utrecht 2002 (translation of: La vie quotidienne à Rome, Paris 1939).

Du Cange, et al., Glossarium mediae et infimae latinitatis, Niort 1883-1887.

C.A. Cannata, Ricerche sulla responsabilità contrattuale nel diritto Romano. I, Milan 1966.

—. 'Genesi e vicende della colpa Aquiliana', Labeo 17 (1971), p. 64-84.

—. 'Sul testo della lex Aquilia e la sua portata originaria', in: L. Vacca, $L a$ responsabilità civile da atto illecito nella prospettiva storio-comparatistica, I Congresso internazionale ARISTEC. Madrid, 7 - 10 ottobre 1993, Turin 1995, p. 25-57.

A. Capelli, Lexicon abbreviaturarum. Dizionario diabbreviature latine ed italiane, 6th edn., reprint Milan 2006.

J. Cartwright, S. Vogenauer \& S. Whittaker, Reforming the French Law of Obligations. Comparative Reflections on the Avant-projet de réforme du droit des obligations et de la prescription ('the Avant-projet Catala'), Oxford/Portland 2009.

M.S. del Castillo Santana, Estudio sobre la casuistica de las lesiones en la jurisprudencia Romana, Madrid 1994.

A. Castresana, Nuevas lecturas de la responsabilidad Aquiliana, Salamanca 2001.

P. Cerami, 'La responsabilità extracontrattuale dalla compilazione di Giustiniano ad Ugo Grozio', in: L. Vacca, La responsabilità civile da atto illecito nella prospettiva storio-comparatistica, ICongresso Internazionale ARISTEC. Madrid, 7 - 10 ottobre 1993, Turin 1995, p. 103-122.

F. Chabas, Le droit des accidents de la circulation (après la réforme du 5 juillet 1985), 2nd edn., Paris 1988.

M. Chao-Duivis, Causaliteit als bron van verbintenissen (intreerede TU Delft), The Hague 2005.

J.M.J. Chorus, Privaatrechtvoor rovers en moordenaars. Historisch-kritische kanttekeningen bij artikel 6:211 BW (afscheidscollege RU Leiden), Leiden 1993.

A.B. Cobban, English University Life in the Middle Ages, London 1999.

B. Cohen, 'The Principle of Causation in the Jewish and the Roman Law of Damages', in: Studi in onore di Pietro de Francisci, 1, Milan 1956, p. 305-336.

R. Cohnfeldt, Die Lehre vom Interesse nach römischem Recht mit Rücksicht auf neuere Gesetzgebung, Leipzig 1865 (reprint Rome 1971). 
H. Coing (ed.), Handbuch der Quellen und Literatur der neueren europäischen Privatrechtsgeschichte, I. Mittelalter (1100-1500). Die gelehrten Rechte und die Gesetzgebung, München 1973.

—. 'Die juristische Fakultät und ihr Lehrprogramm', in: H. Coing (ed.), Handbuch der Quellen und Literatur der neueren europäischen Privatrechtsgeschichte, II/1 Wissenschaft, München 1977, p. 3-102.

—.Europäische Privatrecht, I. Älteres gemeines Recht (1500 bis 1800), München 1985.

A. Colin, H. Capitant \& J. de La Morandière, Cours élémentaire de droit civil Francais, X, 10th edn., Paris 1948.

S. Condanari-Michler, 'Über Schuld und Schaden in der Antike', in: Scritti in onore di Contardo Ferrini. Publicati in occazione della sua beatificazione, III, Milan 1948, p. 28-108.

H. Conrad, Deutsche Rechtsgeschichte. I: Frühzeit und Mittelalter, 2nd edn., Karlsruhe 1962; II: Neuzeit bis 1806, Karlsruhe 1966.

P. Coppa-Zuccari, La 'compensazione delle colpe', Modena 1909.

A. Corbino, Il danno qualificato e la Lex Aquilia. Corso di diritto romano, 2nd edn., Padova 2008.

-. 'Actio in factum adversus confitentem. Quint., Declam. maior XIII', in: Studi in onore di Antonino Metro. Tomo I, a cura di C. Russo Ruggeri, 2009, p. 511-524 (Corbino 2009a).

- . 'Antigiuridicità e colpevolezza nella previsione del plebiscito Aquiliano', SDHI 2009, p. 77-111 (Corbino 2009b).

E. Cortese, Il diritto nella storia medievale. II. Il basso Medioevo, Roma 1995.

H. Cousy \& D. Droshout, 'Contributory Negligence under Belgian Law', in: U. Magnus \& M. Martín-Casals (eds.), Unification of Tort Law: Contributory Negligence, The Hague/London/New York 2004, p. 25-46.

G.R. Crane, Perseus Digital Library, Tufs University, available at http://www. perseus.tufts.edu/.

G. Crifò, 'Ulpiano. Esperienze e responsabilità del giurista', ANRW II.15 (1976), p. 708-789.

J.A. Crook, 'Lex Aquilia', Athenaeum 62 (1984), p. 67-77.

M.F. Cursi, Danno e responsabilità extracontrattuale nella storia del diritto privato, Naples 2010.

A. de Curzon, 'L'enseignement du droit français dans les Universités de France aux XVIIe et XVIIIe siècles', Nouvelle revue historique de droit français et étranger XLIII (1919), p. 209-269, 305-364.

$\underline{\mathrm{D}}$

G. Dahm, Das Strafrecht Italiens im ausgehenden Mittelalter: Untersuchungen über die Beziehungen zwischen Theorie und Praxis im Strafrecht des Spätmittelalters namentlich im XIV.Jahrhunderts, Berlin 1931. 
C.C. van Dam, Aansprakelijkheidsrecht. Een grensoverschrijdend handboek, Den Haag 2000.

-. 'Reflexwerking volgens de Hoge Raad. Over de spiegel en de raadselen', Verkeersrecht 49 (2001), 11, p. 349-352.

-. European Tort Law, Oxford 2006.

-. Aansprakelijkheidsrecht. Een grensoverschrijdend handboek, Den Haag 2000.

C. van Dam \& G. van Maanen, 'The Development of Traffic Liability in the Netherlands', in:W. Ernst (ed.), The Development of Traffic Liability, Cambridge 2010, p. 112-150.

D. Daube, 'On the Use of the Term Damnum', in: Studi in onore di Siro solazzi. Nel cinquantesimo anniversario del suo insegnamento universitario (1899-1948), Naples 1948, p. 93-156.

—. Roman law. Linguistic, Social and Philosophical Aspects, Edinburgh 1969.

J. Declareuil, Histoire du droit français des origines à 1789: à l'usage des étudiants des facultés de droit, Paris 1925.

W. Decock, Theologians and Contract Law. The Moral Transformation of the ius commune (ca.1500-1650) (diss. K.U. Leuven/Università Roma Tre), Leuven 2011.

G. Demelius, 'Über Kompensation der culpa', Jahrbücher für die Dogmatik des heutigen römischen und deutschen Privatrechts 1861, p. 52-87.

J. Demey, De la faute commune specialement en matière maritime (diss. Paris), Paris 1906.

R. Demogue, Traité des obligations en général. I. Sources des obligations, IV, Paris 1924.

H. Dernburg, Pandekten, II, Berlin 1886.

O. Descamps, Les origines de la responsabilité pour faute personnelle dans le Code Civil de 1840, préf. A. Lefebvre-Teillard, Paris 2005.

J. Deschizeaux, Influence du fait de la victime sur la responsabilité civile délictuelle (diss. Grenoble), Grenoble 1934.

G. Diephuis, Het Nederlandsch burgerlijk regt, elfde deel, Groningen 1888.

D. Dimitrakos, Mega lexikon ellinikis glossis Dimitrakou (Great Dictionary of the Greek Language), Domi 1951.

G. Diósdi, 'Vim vi repellere licet (A Contribution to the Study on the Question of Self-defence in Roman law)', Acta Universitatis Wratislaviensis. Antiquitas 1963, p. 187-199.

E. Döhring, 'Cocceji, Samuel Freiherr von (seit 1749)', in: NDB 3 (1957), p. 301-302 (Döhring 1957a).

—. 'Cramer (Kramer), Johann Ulrich', in: NDB3 (1957), p. 391 (Döhring 1957b).

G. Dolezalek, Verzeichnis der Handschriften zum römischen Recht bis 1600, I-IV, Frankfurt am Main 1972.

R. Domingo (ed.), Juristas Universales. Volumen II.Juristas Modernos. Siglos XVI al XVIII: de Zasio a Savigny, Madrid/Barcelona 2004. 
C. Donahue (jr.), Law, Marriage, and Society in the Later Middle Ages. Arguments about Marriage in Five Courts, 2007.

J. H. Dondorp, 'Ius ad rem als Recht, Einsetzung in ein Amt zu verlangen', TvR 59 (1991), p. 285-318.

—. 'Zum Begriff Ius ad rem bei Innocenz IV', in: P. Landau (ed.), Proceedings of the ninth International congress of medieval canon law, Munich, 13-18 July 1992, Città del Vaticano 1997, p. 553-574.

-. Schuld en boete. Enige grepen uit de geschiedenis van de onrechtmatige daad, met medewerking van J. Hallebeek, Amsterdam 1998.

- . 'Crime and Punishment. Negligentia for the Canonists and Moral Theologians', in: E.J.H. Schrage (ed.), Negligence. The Comparative Legal History of the Law of Torts, Berlin 2001, p. 101-128.

H. Dondorp \& E.J.H. Schrage, The Sources of Medieval Learned Law, in: J.W. Cairns \& P.J. du Plessis (eds.), The Creation of the ius commune. From casus to regula [Edinburgh studies in law 6], Edinburgh 2010, p. 7-56.

E. van Dongen, 'Alfenus D. 9.2.52.1 geanalyseerd vanuit het perspectief van de retorica', in: D. Heirbaut, X. Rousseaux \& A. Wijffels, Histoire du droit et de la justice, Louvain 2009, p. 163-176.

J.J. Donovan, 'The origins and development of limitation of shipowners's liability', Tulane Law Review 53 (1978-1979), p. 999-1045.

C. Demolombe, Traité des engagements qui se forment sans convention. Des contrats ou des obligations conventionelles en général, VIII, Paris 1882.

E. Dirix, 'Schadebeperkingsplicht van de benadeelde (annotatie bij Rb hasselt 26 febr. 1979)', Rechtskundig Weekblad 1979/1980-43, col. 2921-2929.

-. Het begrip schade, Antwerpen/Apeldoorn 1984.

M. Duijnstee, L'enseignement du droit civil à l'université d'Orléans du début de la guerre de cent ans (1337) au siège de la ville (1528), Frankfurt am Main 2010.

M. Dupin, Dissertation sur la vie et les ouvrages de Pothier, Paris 1825.

$\underline{E}$

I. Ebert, '§254. Mitverschulden,' in: H. Westermann (ed.), Erman:Burgerliches Gesetzbuch, I, 12th edn., Köln 2008, p. 955-979.

C.S. Edwards, Hugo Grotius: The Miracle of Holland, Chicago 1981.

W.S. van Egmond \& M. Mostert (eds.), Spelen in de Middeleeuwen: over schaken, dammen, dobbelen en kaarten, Hilversum 2001.

F. Eisele, 'Beiträge zur Erkenntnis der Digesteninterpolationen. Erster Beitrag', ZSS RA 10 (1889), p. 296-322.

J.A.R. von Eisenhart, 'Lauterbach, Wolfgang Adam', in: $A D B 18$ (1883), p. 75-78.

—. 'Schoepf, Wolfgang Adam', in: $A D B 32$ (1891), p. 358.

—. 'Voerda, Nicasius von' in: $A D B 40$ (1896), p. 91-92. 
J.H.Ekering, Motorrijtuig en aansprakelijkheid naar Nederlands burgerlijk recht (diss. UvA Amsterdam), Amsterdam 1941.

C. Elliott \& F. Quinn, Tort Law, 2nd edn., London 1999.

W. Endemann (ed.), Handbuch des deutschen Handels-, See- und Wechselrechts, IV/1 Das Seerecht, Leipzig 1884.

—.Irrtum und Schuld nach der italienischen Lehre und Praxis des Mittelalters, Berlin 1922.

F. Endemann, Die Rechtswirkungen der Ablehnung einer Operation seitens des körperlich Verletzten. Ein Beitrag zur Lehre von der civilrechtlichen Haftung aus Körperverletzungen und zur Auslegung der Reichsversicherungsgesetze, Berlin 1893.

W. Enfield, 'Alexander ab Alexandro, in: J. Aikin \& W. Enfield, General Biography; or Lives, Critical and Historical, of the Most Eminent Persons of all Ages, Countries, Conditions, and Professions, arranged according to Alphabetical Order, Vol. I, London 1799.

E.F.D. Engelhard \& G.E. van Maanen, Aansprakelijkheid voorverkeersongevallen, Nijmegen 1998.

W. Engelmann, Die Schuldlehre der Postglossatoren und ihre Fortentwicklung. Eine historisch-dogmatische Darstellung der kriminellen Schuldlehre der italienischen Juristen des Mittelalters seit Accursius, 2nd revised edition, Aalen 1965.

J. Erdmann, 'Quod est in actis, non est in mundo'. Päpstliche Benefizialpolitik im sacrum imperium des 14. Jahrhunderts, Tübingen 2006.

P. Esmein, 'La faute de la victime exclut-elle la présomption de responsabilité?', Revue générale des assurances terrestes, 1934, p. 985-1004.

E. Ewig, 'Bertram', NDB 1955, p. 168.

M.A.P.Th. Eyssell, Doneau. Sa vie et ses ouvrages, translated (from the Latin) by M.J. Simonnet, Dijon-Parijs-Rotterdam 1860.

$\underline{F}$

G.L. Falchi, Le controverse tra Sabiniani e Proculiani, Milan 1981.

G. Falcone, Recension of 'Piro I., Damnum 'corpore suo' dare. Rem 'corpore' possidere. L'oggettiva riferibilità del comportamento lesivo e della possessio nella riflessione e nel linguaggio dei giuristi romani [Pubblicazioni della facoltà di giurisprudenza dell'Università degli Studi di Catanzaro "Magna Graecia”, 56] (Napoli, Edizioni Scientifiche Italiane 2004), p. 453', IURA: rivista internazionale di diritto romano e antico LV 2004-2005, p. 292-317.

G. Fassò, Storia della filosofia del diritto. II: L'età moderna, Bologna 1968.

M. Faure, 'Economic Analysis of Contributory Negligence', in: U. Magnus \& M. Martín-Casals (eds.), Unification of Tort Law: Contributory Negligence, The Hague/London/New York 2004, p. 233-256. 
J. Fedtke \& U. Magnus, 'Contributory Negligence under German Law', in: U. Magnus \& M. Martín-Casals (eds.), Unification of Tort Law: Contributory Negligence, The Hague/London/New York 2004, p. 75-98.

R. Feenstra, Review of 'Hermann Lange, Schadenersatz und Privatstrafe in der mittelalterlichen Rechtstheorie. Forschungen zur neueren Privatrechtsgeschichte, hrsg. von F. Beyerle und W. Kunkel, Band 2. Münster-Köln, Böhlau, 1955.182 S, ZSS RA 73 (1956), p. 461-474.

—. 'Over de oorsprong van twee omstreden paragrafen uit de Inleidinge van Hugo de Groot (III.33.2 en III.34.2)', Acta juridica 1958, p. 27-42.

—. 'The Historical Development of Delictual Liability for Killing and for the Infliction of Bodily Harm', Acta juridica 1972, p. 227-237.

—. 'Romeins recht en Europese rechtswetenschap', in: J.E. Spruit (ed.), Coniectanea Neerlandica iuris Romani. Inleidende opstellen over Romeins recht, Zwolle 1974, p. 101-137.

—. Ius in re: het begrip zakelijk recht in historisch perspectief, Zwolle 1979.

—. 'Die Glossatoren und die actio legis Aquiliae utilis bei Tötung eines freien Menschen', in: E.J.H. Schrage, Das römische Recht im Mittelalter, Darmstadt 1987, p. 205-232 (translation of French version: 'L'actio legis Aquiliae utilis en cas d'homicide chez les Glossateurs', in:J.E. Spruit, Maior viginti quinque annis, Assen 1979, p. 45-65.) (Feenstra 1987a).

—. 'Bibliografie zum römischen Recht im Mittelalter (1100-1500)', in: E.J.H. Schrage, Das römische Recht im Mittelalter, Darmstadt 1987, p. 299-353. (Feenstra 1987b).

—. 'Hugues Doneau et les juristes Néerlandais du XVIIe siècle: L'influence se son "système" sur l'évolution du droit privé avant le Pandectisme', in: B. Schmidlin \& A. Dufour (eds.), Jacques Godefroy (1587-1652) et l'humanisme juridique à Genève: actes du colloque Jacques Godefroy, Basel 1991, p. 231-243.

—. 'Das Deliktsrecht bei Grotius, insbesondere der Schadensersatz bei Tötung und Körperverletzung', in: R. Feenstra \& R. Zimmermann (eds.), Das Römisch-holländische Recht. Fortschritte des Zivilrechts im 17. und 18. Jahrhundert, Berlin 1992, p. 429-454 (Feenstra 1992a).

—. 'Law', in: R. Jenkyns (ed.), The legacy of Rome: a new appraisal, New York 1992, p. 399-420 (Feenstra 1992b).

—. 'Henricus Brunonis de Piro (†1473). Professeur de droit civil et Chartreux', TvR 64 (1996), p. 3-46.

- 'Grotius' doctrine of Liability for Negligence: its Origin and its Influence in Civil Law Countries until Modern Codifications', in: E.J.H. Schrage (ed.), Negligence. The Comparative Legal History of the Law of Torts, Berlin 2001, p. 129-171.

—. 'Keessel, Dionysius Godefridus van der (1738-1816)', in: M. Stolleis (Hg.), 
Juristen. Ein biographisches Lexikon, von der Antike bis zum 20. Jahrhundert, 2. Aufl., München 2001, p. 353. (Feenstra 2001b).

R. Feenstra \& C.J.D. Waal, Seventeenth-century Leyden Law Professors and their Influence on the Development of the Civil Law. A study of Bronchorst, Vinnius and Voet, Amsterdam/Oxford 1975.

C. Ferrini, 'Ricerche critiche ed esegetiche. Intorno ai Digesti di Alfeno Varo', BIDR 4 (1891), p. 1-15.

H. Fitting, 'Die systematische Lehr- und Handbücher (Summae) des römischen Rechts im Zeilalter der Glossatoren', in: F. Meyer (ed.), Blätter für vergleichende Rechtswissenschaft, 2. Jahrgang, Berlin 1907, col. 87-105.

Ae. Forcellini, J. Facciolati \& J. Furlanetto, Totius latinitatis Lexicon, 3rd edn., Schneeberg 1831-1835; 4th edn. 1864-1926, Padua (reprint Bonn-Padua 1965).

T. Frank, 'Catullus and Horace on Suffenus and Alfenus', The Classical Quaterly 14 (1920), p. 160-162.

N. Frenk, Naar echte eigen schuld? Over Toerekening aan de Benadeelde in het Aansprakelijkheids- en Verzekeringsrecht (rede VU Amsterdam), Amstelveen 2006. (Frenk 2006a).

- - 'Naar echte eigen schuld? Over toerekening aan de benadeelde in het aansprakelijkheids- en verzekeringsrecht', AV\&S 2006, 7, p. 41-47. (Frenk 2006b).

F. Frensdorff, 'Strube, David Georg', in: ADB 36 (1893), p. 635-639.

C. Fried, 'The Lex Aquilia as a Source of Law for Bartolus and Baldus', The American Journal of Legal History 4 (1960), p. 142-172.

B.W. Frier, 'Why Did the Jurists change Roman Law? Bees and Lawyers revisited', Index: quaderni camerti di studi romanistici, 1994, p. 135-149.

$\underline{G}$

M. Gagarin (ed.), Antiphon: the Speeches, Cambridge 1997.

-. Antiphon the Athenian: Oratory, Law and Justice in the Age of the Sophists, Austin 2002.

-. 'Kata Ton Orthotaton Logon: Correct Argument in the Sophists and Early Orators', www.fks.uoc.gr/conferences/InterfaceOct2004/Gagarin.pdf., 2004, p. 1-6.

G. Galán Vioque, Martial, Book VII. A Commentary, translated by J.J. Zoltowski, Leiden/Boston/Köln 2002.

R. Garraud, Précis de droit driminel, 15th edn., refondue et mise au courant par P. Garraud, Paris 1934.

R.M. Geer, Diodorus of Sicily. In Twelve Volumes. X. Books XIX. 66-110 and XX, Cambridge (Mass.)/London 1954 (reprint 1983).

E. Genzmer, 'Kritische Studien zur Mediaevistik I', ZSS RA 61 (1941), p. 276-354. 
—. 'Talion im klassischen und nachklassischen Recht? Erwägungen über Ursprüng und Grundgedanken des Edikts Quod quisque juris in alterum statuerit, ut ipse eodem jure utatur', ZSS RA 62 (1942), p. 122-142.

—. 'Zur Lebensgeschichte des Accursius', in: Festschrift für Leopold Wenger. Zu seinem 70. Geburtstag dargebrachtvon Freunden, Fachgenossen und Schülern, II, München 1945, p. 223-241.

- . 'Die Justinianische Kodifikation und die Glossatoren', in: E.J.H. Schrage, Das römische Recht im Mittelalter, Darmstadt 1987, p. 5-53.

E. Gerini, Memorie storiche d'illustri scrittori e di uomini insigni dell'antica e moderna Lunigiana, II: Momomie storiche di Lunigiana, Massa 1829.

W. van Gerven, P. Larouche \& J. Lever, Cases, Materials and Text on National, Supranational and International Tort Law, Oxford 2000.

P.G.W. Glare, Oxford Latin Dictionary, Oxford 1982.

C.F. von Glück, Ausführliche Erläuterung der Pandecten nach Hellfeld, 2nd edn., Erlangen 1797-1868.

E. Göller, Die päpstliche Pönitentiarie vor ihrem Ursprung bis zu ihrer Umgestaltung unter Pius V. Erster Band. Die päpstliche Pönitentarie bis Eugen. IV.I. Teil. Darstellung, Rome 1907.

—. Die päpstliche Pönitentiarie vor ihrem Ursprung bis zu ihrer Umgestaltung unter Pius V. Zweiter Band. Die päpstliche Pönitentarie von Eugen. IV bis Pius V. II. Teil. Quellen, Rome 1911.

G.P. Goold (transl.), Manilius Astronomica, LCL, Cambridge, Mass./London 1977.

J. Gordley, The Philosophical Origins of Modern Contract Doctrine, Oxford 1991.

—. 'Tort Law in the Aristotelian Tradition', in: D.G. Owen, Philosophical Foundations of Tort Law, Oxford 1995, p. 131-158.

-. Foundations of Private Law. Property, Tort, Contract, Unjust Enrichment, Oxford 2006.

G. Gorla, 'A decision of the Rota Fiorentina of 1780 on Liability for Damages caused by the "Ball Game”, Tulane Law Review 49 (1974-1975), p. 346-357.

W.P. Gormley, 'The Development of Rhodian-Roman Maritime Law to 1681, with Special Emphasis on the Problem of Collision', Inter-American Law Review 3 (1961), p. 317-345.

A. Gottschalk, Das mitwirkende Verschulden des Beschädigten bei Schadenersatzansprüchen nach dem Bürgerlichen Gesetzbuch, Berlin 1903.

Th. Goudsmit, Geschiedenisvan het Nederlandsche Zeerecht. Inleiding-Geschiedenis der bronnen, The Hague 1882.

O. Gradenwitz et al. (ed.), Vocabularium iurisprudentiae Romanae, I-V, Berlin 1903-.

J.G.Th. Graesse, F. Benedict \& H. Plechl, Orbis Latinus: Lexikon lateinischer geografischer Namen des Mittelalters und Neuzeit, 2nd edn., Braunschweig 1972. 
C. Grare-Didier, 'Des causes d'exclusion ou d'exonération de la responsabilité', in: F. Terré (dir.), Pour une réforme du droit de la responsabilité civile, Paris 2011, p. 185-190.

J.T. Graves, 'Hagiotheodorita', in: W. Smith (ed.), Dictionary of Greek and Roman Biography and Mythology, II, London 1870 on www.ancientlibrary. com/smith-bio/2119.html (last consulted on 1 May 2013).

G. Grosso, I legati nel diritto romano: parte generale, 2nd edn., Turin 1962.

E. Grüber, The Roman Law of Damage to Property being a Commentary on the Title of the Digest Ad legem Aquiliam (IX.2) with an Introduction to the Study of the Corpus iuris civilis, Oxford 1886.

E. Grupe, 'Zur Sprache der Gaianischen Digestenfragmente', ZSS RA 18 (1897), p. 213-223.

G. Gudian, Ingelheimer Recht im 15. Jahrhundert, Aalen 1968.

R. Guex, La relation de cause a effet dans les obligations extracontractuelles, Lausanne 1904.

$\underline{\mathrm{H}}$

S.P. de Haas \& T. Hartlief, Verkeersaansprakelijkheid. Vergoeding van personenschade in Europees perspectief, Deventer 1998.

J. Hallebeek, 'Negligence in Medieval Roman Law', in: E.J.H. Schrage (ed.), Negligence. The Comparative Legal History of the Law of Torts, Berlin 2001, p. 73-100.

- Fons et origo iuris. Een historische inleiding tot het vermogensrecht, Amsterdam 2006.

- 'Noodt, Gerard' in: S.N. Katz (ed.), The Oxford International Encyclopedia of Legal History. Volume 4, Oxford 2009, p. 235-236.

—. 'Specific Performance in Obligations to do according to Early Modern Spanish Doctrine', in:J. Hallebeek \& H. Dondorp (eds.), The Right to Specific Performance. The Historical Development, Antwerp/Oxford/Portland 2010, p. 57-79.

—. 'Recovering Gambling Debts in Classical Canon Law', in: L. Berkvens et al. (eds.), Recto ordine procedit magister. Liber amicorum E.C. Coppens (Iuris Scripta Historica, XXVIII), Brussel 2012, p. 143-159.

J. Hallebeek \& T. Merkel, 'Simon Groenewegen van der Made on the Enforcement of obligationes faciendi', in: J. Hallebeek \& H. Dondorp (eds.), The Right to Specific Performance. The Historical Development, Antwerp-Oxford-Portland 2010, p. 81-96.

M. Haller, Essai sur l'influence du fait et de la faute de la victime sur son droit a réparation, Paris 1926.

J.-L. Halpérin, Histoire du droit privé français depuis 1804, 2nd edn., Paris 2001. 
H. Hälschner, Das preußische Strafrecht, I, Bonn 1855.

O. Hammer, Die Lehre vom Schadensersatze nach dem Sachsenspiegel und den verwandten Rechtsquellen: ein Beitrag zur Geschichte der Schadensersatzverbindlichkeit in Deutschland [Untersuchungen zur deutschen Staats- und Rechtsgeschichte 19], Breslau 1885.

H.A. Harris, Sport in Greece and Rome, London 1972.

-. Greek Athletes and Athletics, Bloomington 1964 (reprint Westport-Connecticut 1979).

A.S. Hartkamp, 'Enkele opmerkingen over Romeins recht aan de hand van een Digestentekst', in: J.E. Spruit, Coniectanea Neerlandica iuris Romani. Inleidende opstellen over Romeins recht, Zwolle 1974, p. 151-166.

-. Mr. C. Asser's Handleiding tot de beoefening van het Nederlands burgerlijk recht. 4. Verbintenissenrecht. DeelI. De verbintenis in het algemeen, Deventer 2004.

-.Mr. C. Asser's Handleiding tot de beoefening van het Nederlands burgerlijk recht. 4. Verbintenissenrecht. Deel III. De verbintenis uit de wet, 12th edn., m.m.v. C.H. Sieburgh, Deventer 2006.

T. Hartlief, 'Eigen schuld en letselschade', in: Miscellanea: jurisconsulto vero dedicata: bundel opstellen aangeboden aan prof. mr. J.M. van Dunné ter gelegenheidvanzijnvïfentwintigjarigjubileum als hoogleraar burgerlijkrecht, handelsrecht en burgerlijk procesrecht aan de Erasmus Universiteit Rotterdam op 1 juni 1997, Deventer 1997, p.129-142. (Hartlief 1997a).

-. Ieder draagt zijn eigen schade. Enige opmerkingen over de fundamenten van en ontwikkelingen in het aansprakelijkheidsrecht (rede RU Leiden), Deventer 1997 (Hartlief 1997b).

—. 'De Hoge Raad en de reflexwerking van art. 185 WVW', AV\&S 2001-3, p. 73-80.

—. 'Op weg naar een Europees aansprakelijkheidsrecht?', TPR 2002, p. 945-953. (Hartlief 2002a).

—. 'Open normen in het schadevergoedingsrecht: de artikelen 6:98, 99 en 101 BW', WPNR 2002, p. 8-19 (Hartlief 2002b).

T. Hartlief \& R.P.J.L. Tjittes, Verzekering en aansprakelijkheid, 2nd rev. ed., Deventer 1999.

C.H. Haskins, The Renaissance of the Twelfth Century, Cambridge 1927.

H. Hausmaninger, Das Schadenersatzrecht der lex Aquilia, 5th edn., Vienna 1996 (Hausmaninger 1996a).

—. 'Das Mitverschulden des Verletzten und die Haftung aus der lex Aquilia', in:W. Ogris \& W.H. Rechberger (eds.), Gedächtnisschrift Herbert Hofmeister, Vienna 1996, p. 235-262 (Hausmaninger 1996b).

F. Haymann, 'Textkritische Studien zum römischen Obligationenrecht', ZSS $R A 42$ (1921), p. 357-393. 
J.W. Hedemann, Die Fortschritte des Zivilrechts im XIXJahrhundert. Ein Überblick über die Entfaltung des Privatrechts in Deutschland, Österreich, Frankreich und der Schweiz. Erster Teil. Die Neuordnung des Verkehrslebens, Berlin 1910 (reprint Frankfurt am Main 1968).

F.P. van den Heever, Aquilian Damages in South African law, I, Cape Town/ Johannesburg 1944.

A. Hegler, Die praktische Thätigkeit der Juristenfakultäten des 17. und 18. Jahrhunderts in ihrem Einfluss auf die Entwicklung des deutschen Strafrechts von Carpzovab, Freiburg i. B. Leipzig/Tübingen, 1899.

E. Heilfron, Römisches Recht (Rechtsgeschichte und System des Privatrechts) als Grundlage des heutigen Rechts, Siebente Auflage der Römischen Rechtsgeschichte (27.-30. Tausend), neubearbeitet von E. Heilfron \&J. Stern, Mannheim/ Berlin/Leipzig 1920.

K. Heinsheimer et al., Die Zivilgesetze der Gegenwart. Band I. Frankreich Code Civil. Erste Hälfte Art. 1-1100, Mannheim/Berlin/Leipzig 1928.

D. Heirbaut, 'Comparative Law and Zimmermann's New ius commune: a Life Line or a Death Sentence for Legal History? Some Reflections on the Use of Legal History for Comparative Law and vice versa', in: R. van den Berg (ed.), Ex iusta causa traditum. Essays in Honour of Eric H. Pool, University of South Africa 2005, p. 136-153.

R.H. Helmholz, Marriage Litigation in Medieval England, Cambridge 1974.

- The Spirit of Classical Canon Law, Athens/London 1996.

H.-E. Henke, 'Mitverursachung und Mitverschulden - Wer den Schaden herausfordert, muß den Schädiger schonen', JuS 1988, p. 753-761.

P. Hentschel, P. König \& P. Dauer, Straßenverkehrsrecht, 41st edn., München 2011.

H. Heumann \& E. Seckel, Handlexikon zu den Quellen des römischen Rechts, Graz 1907 (repr. 1958; 1971).

M.L. Hewett, Ulric Huber (1636-1694). De ratione juris docendiet discendi diatribe per modum dialogi nonnullis aucta ПАРАЯIПOMENOI $\Sigma$ with a Translation and Commentary (diss. UvA, Amsterdam), Nijmegen 2010.

Th. Hinrichs, Die Berücksichtigung des Mitverschuldens bei der Haftung für Personenschäden im französischen und deutschen Recht, Baden-Baden 1991.

K. Hitzbleck, Exekutoren: Die außerordentliche Kollaturvon Benefizien im Pontifikat Johannes'XXII, Tübingen 2009.

W. Holdsworth, A History of English Law, Vol. VIII, 2nd edn., London 1937 (reprint 1966).

A.M. Honoré, Gaius. A Biography, Oxford 1962 (Honoré 1962a).

—. 'Proculus', TvR 30 (1962), p. 472-509 (Honoré 1962b).

- . 'Causation and Remoteness of Damage', in: A. Tunc (ed.), International Encyclopedia of Comparative Law. Volume XI. Torts. Part I, Tübingen/The Hague et al. 1983, p. 3-156. 
—. Ulpian: Pioneer of Human Rights, 2nd edn., Oxford 2002.

T. Honsell, Die Quotenteilung im Schadenersatzrecht. Historische und dogmatische Grundlagen der Lehre vom Mitverschulden, Ebelsbach am Main 1977.

A. van Hove, Prolegomena, Malines/Rome 1945.

A. Hirata, 'Die Vollendung des usus modernus pandectarum: Christian Friedrich von Glück (1755-1831)', ZSS RA 123 (2006), p. 330-343.

E. Holthöfer, 'Hugo Donellus (1527-1591)', in Fränkische Lebensbilder 10 (1982), p. 157-178.J. Hübner, “Schadensverteilung” bei Schäden anläßlich der Verfolgung festzunehmender Personen durch Beamte - eine Wiederkehr der Culpa-Kompensation? OLG Düsseldorf, NJW1973, 1929', JuS 1974, p. 496-502.

P. Huvelin, 'Sur un texte d'Alfenus Varus (Dig., 9,2, fr. 52,1)', in: Mélanges P.F. Girard, I, Paris 1912.

$\underline{I}$

D.J. Ibbetson, A Historical Introduction to the Law of Obligations, Oxford 1999.

-. 'How the Romans Did for Us: Ancient Roots of the Tort of Negligence', University of New South Wales Law Journal 2003, p. 475-514.

- 'Wrongs and Responsability in Pre-Roman Law', The Journal of Legal History 25 (2004), 2, p. 99-127.

- ' 'Historical Reflections on the Compensation Culture', The Journal of Law 1 (2005), p. 1-31, available at www.thejournaloflaw.org.

I

C.M. s'Jacob, Het recht van abandon (diss. Leiden), The Hague 1890.

Ph. Jaffé, Regesta Pontificum Romanorum ab Condita Ecclesia ad Annum post Christum natum 1198, Berlin 1851.

C.E.C. Jansen, 'Toerekening van 'eigen schuld' in het contractenrecht', in: W.H. van Boom, C.E.C. Jansen \& J.G.A. Linssen (eds.), Tussen 'Alles' en 'Niets'. Van toedeling naar verdeling van nadeel, Deventer 1997, p. 31-56.

C.J.H. Jansen, 'Mitverschulden: einige Betrachtungen über D. 9,2,11 pr.', in: L. de Ligt et al. (ed.), Viva vox iuris Romani. Essays in Honour of J.E. Spruit, Amsterdam 2002, p. 103-114 (Jansen 2002a).

—. 'Eigen schuld van de benadeelde: historische wortels en toepassingsbereik van art. 6: $101 \mathrm{BW}$ naar aanleiding van D. 9,2,11,pr', RM Themis 2002, 4, p. 204-209 (Jansen 2002b).

- . 'Noodweer als rechtvaardigingsgrond in het onrechtmatigedaadsrecht: naar aanleiding van D. 9,2,52,1', RM Themis 2004-3, p. 120-126.

—. 'De lex Aquilia en de moderne onrechtmatige daad', in: K.J. Krzeminski \& M.C.A. van den Nieuwenhuijzen, De Digesten en de receptie van het Romeinse recht in het Nederlandse privaatrecht, Nijmegen 2009, p. 231-247. 
N. Jansen, Die Struktur des Haftungsrechts: Geschichte, Theorie und Dogmatik außervertraglicher Ansprüche auf Schadensersatz, Tübingen 2003.

—. 'Duties and Rights in Negligence: A Comparative and Historical Perspective on the European Law of Extracontractual Liability', Oxford Journal of Legal Studies, vol. 24, no. 3 (2004), p. 443-469.

—. '§254. Mitverantwortlichkeit des Geschädigten', in R. Zimmermann(red.), Historisch-kritischer Kommentar zum BGB, Bd. 2: Schuldrecht-Algemeiner Theil, 1. Teilband:vor §241-§304, Tübingen 2007, p. 655-714.

—. 'Mitverschulden (Mitverantwortlichkeit) des Geschädigten', in:J. Basedow, K.J. Hopt \& R. Zimmermann (eds.), Handwörterbuch des Europäischen Privatrechts, met medewerking van M.Illmer, Tübingen 2009, p. 1080-1083.

—. 'Contributory Negligence (Contributory Conduct or Activity)', in:J. Basedow et al. (eds.), Max Planck Encyclopedia of European Private Law. Volume I, Oxford 2012, p. 401-403.

R.C. Jebb (ed.), Selections from the Attic Orators. Antiphon, Andocides, Lysias, Isocrates, Isaeus, 2nd edn., MacMillan 1973.

Chr.G. Jöcher, Allgemeines Gelehrten-Lexicon. Erster Theil. A-C, Leipzig 1750 (reprint 1960).

H.F. Jolowicz \& B. Nicholas, Historical Introduction to the Study of Roman Law, 3rd edn., Cambridge 1972.

H. de Jong, Stephanus en zijn Digestenonderwijs (diss. RU Groningen), The Hague 2008.

P. Jörs, 'P. Alfenus Varus', in: RE I 2 (1894), column 1472-1474.

—.Römisches Recht: Geschichte und System des römischen Privatrechts, Berlin 1927 (appeared as 'Abteilung Rechtswissenschaft' in E. Kohlrausch, W. Kaskel \& A. Spethoff, Enzyklopädie der Rechts- und Staatswissenschaft).

L. Josserand, Cours de droit civil positiffrançais, II. Théorie générale des obligations. Les principaux contrats du droit civil. Les Suretés, 3rd edn., Paris 1939.

$\underline{\mathrm{K}}$

W. Kalb, Roms Juristen nach ihrer Sprache dargestellt, Leipzig 1890.

E.-H. Kaden in: K. Heinsheimer et al., Die Zivilgesetze der Gegenwart. Band I. Frankreich Code Civil, II. Hälfte, Mannheim/Berlin/Leipzig 1932.

C. von Kaltenborn, Grundsätze des praktischen Europäischen Seerechts, II, Berlin 1851.

J.L.J. van de Kamp, Bartolus de Saxoferrato (1313-1357) (diss. UvA Amsterdam), Amsterdam 1936.

B. Kannowski, 'Der Sachsenspiegel im Kontext europaïscher Rechtsgeschichte. "Teutsche" und überregionale Aspekte anhand von Bilderhandschriften und 
Glossen', in: J. Wolff (ed.), Kultur- und rechtshistorische Wurzeln Europas. Arbeitsbuch, Godesberg 2005, p. 139-154.

H.U. Kantorowicz, 'Über die Entstehung der Digestenvulgata', ZSS RA 30 (1909), p. 183-271; 31 (1910), p. 14-88.

—. 'Die Epochen der Rechtswissenschaft', in: H. Coing \& G. Immel (eds.), Rechtshistorische Schriften von H. Kantorowicz, Karlsruhe 1970, p. 1-14 (originally printed in: Die Tat 6 (1914), p. 345-361).

—. 'Die Allegationen im späteren Mittelalter', Archiv für Urkundenforschung 13 (1935), p. 15-29.

H. Kantorowicz \& W.W. Buckland, Studies in the Glossators of the Roman Law, Newly Discovered Writings of the Twelfth Century, Cambridge 1938 (reprint Aalen 1969).

M. Kaser, 'Das legatum sinendi modo in der Geschichte des römischen Vermächtnisrechts', ZSS RA 67 (1950), p. 320-359.

—.Das römische Privatrecht, I, 2nd edn., München 1971; II, 2nd edn., München 1975.

—. Das römische Zivilprocessrecht, 2nd edn. rev. K. Hackl, München 1996.

M. Kaser \& R. Knütel, Römisches Privatrecht, 17th edn., München 2003.

H. Kathe, Die Wittenberger philosophische Fakultät 1502-1817, Köln/Weimar/ Wien 2002.

E. Katz, Ein Grundriss des kanonistischen Strafrechts, Berlin/Leipzig 1881.

D.B. Kaufman, 'Poisons and poisoning among the Romans', Classical philology 1932, p. 156-167.

H. Kaufmann, Rezeption und Usus Modernus der actio legis Aquiliae, Köln/ Graz 1958.

A.P. Kazhdan, 'Hagiotheodoritès', in: A. P. Kazhdan et al. (eds.), The Oxford Dictionary of Byzantium. Volume 2, New York/Oxford 1991, p. 899.

A.L.M. Keirse, Schadebeperkingsplicht. Over eigen schuld aan de omvang van de schade, Deventer 2003.

—. 'Het alles of niets-denken naar de geschiedenis verbannen', AV\&S 2005, 1, p. 3-16.

—. 'Rechterlijke waakzaamheid en het oordeel over eigen schuld', AV\&S 2006, 30, p. 185-192.

—. 'Een sigaar uit eigen doos', in: A.G. Castermans et al. (eds.), Ex libris Hans Nieuwenhuis. Opstellen aangeboden aan prof. Mr.J.H. Nieuwenhuis, hoogleraar burgerlijkrecht aan de Universiteit Leiden, bijzijn emeritaat, Deventer 2009, p. 557-571.

—. 'Golfbewegingen in het verbintenissenrecht', in: J.H.A. Lokin, J.M. Milo \& C.H. van Rhee (eds.), Tweehonderd jaren codificatie van het privaatrecht in Nederland, Groningen 2010, p. 121-128. 
R.G. Kent (transl.), Varro. On the Latin Language. In Two Volumes. I. Books V.-VII, London/Cambridge 1938.

W.C.A. Ker (transl.), Martial. Epigrams. In Two Volumes. I, Cambridge/London 1919 (reprint 1979).

M. Kern, A. Ebenbauer \& S. Krämer-Seifert, Lexikon der antiken Gestalten in den deutschen Texten des Mittelalters, Berlin 2003.

T. Kiefer, Die Aquilische Haftung im 'Allgemeinen Landrecht für die Preußischen Staaten'von 1794 (diss. Passau 1988), Pfaffenweiler 1989.

J.G. Kist, Beginselen van handelsregt volgens de Nederlandsche wet. Vijfde deel. Zee-regt, 2nd edn., The Hague 1889.

A. Kjeldsen, "The Origins and Reception of the "Medical Canons" of the Fourth Lateran Council', 2009, p. 1-11, available on www.voxindeserto.wordpress. com/essays/.

E. Klebs, 'P. Alfenus Varus', in: RE I 2 (1894), column 1472-1473.

G. Kleinheyer/J. Schröder (Hrsg.), Deutsche und europäische Juristen aus neun Jahrhunderten. Ein biographische Einführung in die Geschichte der Rechtswissenschaft, 4th edn., Heidelberg 1996.

M. Knapen, 'Actualiteiten. Advocaten kunnen leerstuk eigen schuld zinvoller gebruiken', Advocatenblad 2004 [discussion of dissertation of A.L.M. Keirse, Schadebeperkingsplicht. Over eigen schuld aan de omvang van de schade, Kluwer Deventer], I, p. 6-7.

E. Klugkist, 'Die Aktenversendung an Juristenfakultäten', JZ 5/6 (1967), p. 155-158.

R. Knütel, 'Zu den Gleichnissen des Art. 146 der peinlichen Gerichtsordnung Kaiser Karls V', in: Festschrift für Gerd Kleinheyer zum 70. Geburtstag, Heidelberg 2001, p. 353-370.

A. Köcher, 'Stucke, Johann St. (Stuckius)', in: ADB 36 (1893), p. 716-717.

R. König, Das allgemeine Schadenersatzrecht im Mittelalter im Anschluss an die lex Aquilia (dissertation Frankfurt am Main), unpublished fotocopy 1954.

A. Kontogianni, 'Gemeinsame Prinzipien des Europäischen Privatrechts zum Mitverschulden des Geschädigten im Schadensersatzrecht. Ein rechtsvergleichender Überblick zum Begriff, den Voraussetzungen und den Rechtsfolgen des Mitverschuldens am Beispiel von Österreich, der Schweiz, Deutschland, Griechenland, Frankreich und England', in: R. Schulze \& G. Ajani (eds.), Gemeinsame Prinzipien des Europäischen Privatrechts/Common Principles of European Private Law, Baden-Baden 2003, p. 145-177.

P.C. Kop, 'Johannes Voet (1647-1713)', in:T.J.Veen \& P.C. Kop (eds.), Zestigjuristen. Bijdragen tot ene beeldvan de geschiedenis der Nederlandse rechtswetenschap, m.m.v. C.H.N. Kwanten, Zwolle 1987, p. 130-134.

P.J.van Koppen \& J. ten Kate, De Hoge Raad in persoon. Benoemingen in de Hoge Raad der Nederlanden 1838-2002, Deventer 2003. 
P. Koschaker, Europa und das römische Recht, 4th edn., München/Berlin 1966. P.J. Kotzé, Die aanspreeklikheid van mededaders en afsonderlike daders (diss. Leiden), Leiden 1953.

H. Koziol, 'Rechtsfolgen der Verletzung einer Schadensminderungspflicht Rückkehr der archaischen Kulpakompensation?' ZEuP6 (1998), p. 593-601.

—. 'Die "Principles of European Tort Law" der "European Group on Tort Law"'. ZEuP 2004, p. 234-259.

C. Krampe, Proculi Epistulae. Eine frühklassische Juristenschrift, Karlsruhe 1970.

—. 'Tabernarius consulebat, Alfenus respondit - D. 9,2,52,1 Alfenus 2 digestorum - ', in: L. de Ligt et al. (eds.), Viva vox iuris romani: essays in honour ofJohannes Emil Spruit, Amsterdam 2002, p. 133-140.

G. Krapinger, [Quintilian] Die Bienen des armen Mannes (Größere Deklamationen, 13) [Latin text with German translation], Cassino 2005.

O.W. Krause, Naturrechtler des sechzehnten Jahrhunderts. Ihre Bedeutung für die Entwicklung eines natürlichen Privatrechts (diss. Universität Göttingen), Göttingen 1949.

W.X.A.F. v. Kreittmayr, Anmerkungen über dem Codicem Maximilianeum bavaricus civilem ..., IV, München 1821.

B. Krikke, 'Rechtshistorische en dogmatische problemen rond het culpa-begrip', in: V.H. Davelaar-van Tongeren, N. Keijzer \& U. van de Pol (eds.), Strafrecht in perspectief. Een bundel bijgedragen op strafrechtelijk gebied ter gelegenheid van het 100-jarig bestaan der Vrije Univeriteitte Amsterdam, Arnhem 1980, p. 197-213.

A. Krikke \& S. Faber, 'Cornelis van Bynkershoek (1673-1743)', in: T.J. Veen \& P.C. Kop (eds.), Zestig juristen. Bijdragen tot ene beeld van de geschiedenis der Nederlandse rechtswetenschap, m.m.v. C.H.N. Kwanten, Zwolle 1987, p. 141-149 (Krikke \& Faber 1987a).

—. 'Dionysius Godefridus van der Keessel (1738-1816)', in: T.J. Veen \& P.C. Kop (eds.),Zestigjuristen. Bijdragen totene beeldvan de geschiedenis der Nederlandse rechtswetenschap, m.m.v. C.H.N. Kwanten, Zwolle 1987, p. 185-189 (Krikke \& Faber 1987b).

A.O. Krug, Die Lehre von der Compensation, Leipzig 1833.

P. Krüger, Geschichte der Quellen und Litteratur des Römischen Rechts, 2nd edn., München/Leipzig 1912.

R. Kruithof, 'L'obligation de la partie lésée de restreindre le dommage', Revue critique de jurisprudence belge 1989, p. 12-55.

B. Kübler, 'Atquin. Kritische Studien zur Interpolationenforschung', ZSS RA 1921, p. 515-542.

—. 'Mucius', in: REXVI 1 (1933), column 442-446.

J. L. Kugel, In Potiphar's House. The Interpretive Life of Biblical Texts, New York 1990.

-. Traditions of the Bible. A Guide to the Bible as it was at the Start of the Common Era, Cambridge/London 1998. 
W. Kunkel, 'Diligentia', ZSS RA 45 (1925), p. 266-351.

—. 'Exegetische Studien zur Aquilischen Haftung', ZSS RA 49 (1929), p. 158-187.

—. Die römischen Juristen. Herkunft und soziale Stellung, 2nd edn., Köln 2001.

K. Kurtz-Eckhardt, Causa proxima und wesentliche Bedingung. Ein Beitrag zur Kausalitätslehre im Zivilrecht (diss. Heidelberg), Bamberg 1977.

S. Kuttner, Kanonistische Schuldlehre von Gratian bis auf die Dekretalen Gregors IX: systematisch auf Grund der handschriftlichen Quellen dargestellt, Città del Vaticano 1935.

-. Repertorium der Kanonistik (1140-1234). Prodromus corporis glossarum. I, Città del Vaticano 1937.

—. 'Bertram of Metz', Traditio 13 (1957), p. 501-505.

- . 'Notes on the Presentation of Text and Apparatus in editing Works of the Decretists and Decretalists', Traditio 15 (1959), p. 452-464 and also S. Kuttner, 'Notes on the Presentation of Text and Apparatus' (Traditio 15 [1959] 452ff.). News on Manuscripts, Traditio 26 (1970), p. 432-433.

—. 'Index titulorum Authentici in novem collationes Digesti', Studi Senesi 75 (1963), p. 191-199.

—. 'The Revival of Jurisprudence', in: R.L. Benson \& G. Constable (eds.), Renaissance and Renewal in the Twelfth Century, Oxford 1982, p. 299-323.

$\underline{L}$

N. Labowsky, Eigenes Verschulden bei Schadenersatz-Ansprüchen nach gemeinem Recht und Bürgerlichen Gesetzbuch (diss. Erlangen), Berlin 1898.

H. Lalou, Traité pratique de la responsabilité civile, 6th edn. by P. Azard, Paris 1962.

P. Landau, 'Zum Ursprung des 'ius ad rem' in der Kanonistik', in: S.G. Kuttner (ed.), Proceedings of the Third International Congress of Medieval Canon Law, Città del Vaticano 1971, p. 81-102.

E. Landsberg, 'Zanger, Johann', in: ADB 44 (1898), p. 685.

J.H. Langbein, Prosecuting Crime in the Renaissance. England, Germany, France, Cambridge, Massachusetts 1974.

H. Lange, Schadenersatz und Privatstrafe in der mittelalterlichen Rechtstheorie, Münster/Köln 1955 [Forschungen zur neueren Privatrechtsgeschichte. Band 2].

—. Schadensersatz, Tübingen 1979 [in: J. Gernhuber (ed.), Handbuch des Schuldrechts. Band 1].

—. Römisches Recht im Mittelalter. Band I. Die Glossatoren, München 1997.

H. Lange \& M. Kriechbaum, Römisches Recht im Mittelalter. Band II. Die Kommentatoren, München 2007.

L. Larombiere, Théorie et pratique des obligations ou commentaire des titres III et IV, libre III, du Code Napoléon art. 1101 à 1386, I, Bruxelles 1862. 
K. Latte, 'Beiträge zum griechischen Strafrecht', p. 263-314, in: E. Berneker, Zur griechischen Rechtsgeschichte, Darmstadt 1968 [Wege der Forschung. Bd. XLV] (reprint from Hermes 66 (1931), p. 30-48, 129-158).

F. Laurent, Principes de droit civil français, XX, 2nd edn., Bruxelles/Paris 1878.

F.H. Lawson, 'The Basilica', LQR 46 (1930), p. 486-501.

—. 'The Basilica - II', LQR 47 (1931), p. 536-556.

-. Negligence in the Civil Law, Oxford 1950 (reprint 1968).

F.H.Lawson, A.E. Anton \& L. Neville Brown (eds.), Amos and Walton's Introduction to French Law, 3rd edn., Oxford 1967.

F.H. Lawson \& B.S. Markesinis, Tortious Liability for Unintentional Harm in the Common Law and the Civil Law, I/II, Cambridge et al. 1982.

J. Lebreton, Le partage de responsabilité dans les accidents d'automobiles (diss. Paris), Paris 1941.

R.W. Lee, An Introduction to Roman-Dutch Law, 5th edn., Oxford 1953.

A.D. Leeman \& A.C. Braet, Klassieke retorica. Haar inhoud, functie en betekenis, Groningen 1987.

T. Leesen, 'Produced and Bottled in Rome - Who Owned the Wine? The Controversy about specificatio', RIDA 2006, p. 265-282.

- Gaius meets Cicero: Law and Rhetoric in the School Controversies (diss. UvT, Tilburg), Nijmegen 2009.

H. Lehmann, Lehrbuch des bürglichen Rechts, Band II, Recht der Schuldverhältnisse. Ein Lehrbuch von L. Enneccerus, 15te Aufl., Tübingen 1958.

O. Lenel, Palingenesia iuris civilis II, Leipzig 1889.

-.Das Edictum Perpetuum. Ein Versuch zu seiner Wiederherstellung, 3rd reprint of 3rd edn., Aalen 1985.

P. Letto-Vanamo, in: P. Letto-Vanamo \& J. Smits (eds.), Coherence and Fragmentation in European Private Law, Munich, p. 151-172.

H. Levison, Über Kompensation der Culpa (diss. Bonn), Siegburg 1891.

E. Levy \& E. Rabel, Index interpolationum quae in Iustiniani Digestis inesse dicuntur. Tomus I. Ad libros digestorum I-XX pertinens, Weimar 1929 (Levy \& Rabel 1929a).

-. Index interpolationum quae in Iustiniani Digestis inesse dicuntur. Supplementum II. Ad libros digestorum I-XII pertinens, Weimar 1929 (Levy \& Rabel 1929b).

—. Index interpolationum quae in Iustiniani Digestis inesse dicuntur. Tomus III. Ad libros digestorum XXXVI-L pertinens, Weimar 1935.

T.L. Lewis \& C.S. Short, A Latin Dictionary founded on Andrew's edition of Freund's Latin Dictionary, 4th edn., Oxford 1980.

Von Leyden, Die sogenannte Culpa-Compensation im Bürgerlichen Gesetzbuch, Berlin 1902. 
W.F. Lichtenauer, Geschiedenis van de wetenschap van het handelsrecht in Nederland tot 1809, Amsterdam 1956.

H.G. Liddell \& R. Scott, A Greek-English Lexicon, Seventh Edition, Revised and Augmented throughout with the cooperation of Professor Drisler, New York 1883.

-. A Greek-English Lexicon, 9th compl. new ed., rev. and augmented throughout by Henry StuartJones; with the assistance of RoderickMcKenzie, Oxford 1940.

R. Lieberwirth, 'Hommel, Karl Ferdinand', in: NDB 9 (1972), p. 592.

D. Liebs, 'Damnum, damnare und damnas. Zur Bedeutungsgeschichte einiger lateinischer Rechtswörter', ZSS RA 85 (1968), p. 173-252.

—. review of Hans-Jörg Roth, Alfeni Digesta. Eine spätrepublikanische Juristenschrift (= Freiburger Rechtsgeschichtliche Abhandlungen 32), Berlin: Duncker \& Humblot 1999. 211 S., ZSS RA 117 (2000), p. 519-525.

—. P. Alfenus Varus - Eine Karriere in Zeiten des Umbruchs, ZSS RA 127 (2010), p. 32-52.

—. 'Rechtsschulen und Rechtsunterricht im Principat', in: ANRW II, 15 (1976), p. 197-286.

—. '\$422. Sex. Pomponius', in: Handbuch der lateinischen Literatur der Antike, herausgegeben von R. Herzog \& P.L. Schmidt. Vierter band. Die Literatur des Umbruchs. Von dem römischen zur christlichen Literatur. 117 bis 284 n. Chr. Herausgegeben von K. Sallmann, München 1997, p. 144-150 (Liebs 1997a).

—. ‘\$424. Domitius Ulpianus', in: Handbuch der lateinischen Literatur der Antike, herausgegeben von R. Herzog \& P.L. Schmidt. Vierter band. Die Literatur des Umbruchs. Von dem römischen zur christlichen Literatur. 117 bis 284 n. Chr. Herausgegeben von K. Sallmann, München 1997, p. 175-187 (Liebs 1997b).

—. '§195.1. Q. Mucius Scaevola (Pontifex) (Scaevola II)', in: W. Suerbaum (herausg.), Die Archaische Literatur. Von den Anfängen bis Sullas Tod. Die vorliterarische Periode und die Zeit von 240 bis 78 v. Chr. ... [in: R. Herzog \& P. Lebrecht Schmidt (herausg.), Handbuch der lateinischen Literatur der Antike. I], München 2002.

H. Liermann, 'Böhmer, Justus (Jobst) Henning', in: NDB 2 (1955), p. 392.

C.S. Lobingier, 'The Maritime Law of Rome', Juridical review 47 (1935), p. 1-32.

E. von Löhr, Die Theorie der Culpa. Eine civilistische Abhandlung, Gießen 1806. J.H.A. Lokin, 'Theophilus antecessor', TvR 44 (1976), p. 337-344.

J.H.A. Lokin \& W.J. Zwalve, Hoofdstukken uit de Europese Codificatiegeschiedenis, 3rd edn., Deventer 2001.

G. Long, 'Mela, Fabius', in: W. Smith (ed.), Dictionary of Greek and Roman Biography and Mythology. Vol. II, 2nd edn., Boston 1870, p. 1011 (Long 1870a).

—. 'Proculus', in: W. Smith (ed.), Dictionary of Greek and Roman Biography and Mythology. Vol. III, Boston 1870, p. 541 (Long 1870b). 
G. Longo, 'Appunti esegetici e note critiche in tema di lex Aquilia', Annali Macerata 22 (1958), p. 49-74.

W.T. Loomis, 'The Nature of Premeditation in Athenian Homicide Law', The Journal of Hellenic Studies 92 (1972), p. 86-95.

D. Looschelders, Die Mitverantwortlichkeit des Geschädigten im Privatrecht, Tübingen 1999.

E. López-Jacoiste Díaz, 'Johannes Voet (1647-1713)', in: R. Domingo (ed.), Juristas universales. Volumen II. Juristas modernos. Siglos XVI al XVIII: de Zasio a Savigny, Madrid/Barcelona 2004, p. 465-467.

E. Lorenz, 'Der Tu-quoque-Einwand beim Rücktritt der selbst vertragsuntreuen Partei wegen Vertragsverletzung des Gegners - BGH, WPM 1970, 1246', Juristische Schulung 1972, p. 311-315.

- Die Lehre von den Haftungs- und Zurechnungseinheiten und die Stellung des Geschädigten in Nebentäterfällen, Karlsruhe 1979.

U. von Lübtow, Untersuchungen zur lex Aquilia de damno iniuria dato, Berlin 1971.

D. de Luca \& R. Farinelli, 'Archi e balestre. Un approccio storico-archeologico alle armi da tiro nella Toscana meriodionale (secc. XIII-XIV)', Archeologia Medievale XXIX (2002), p. 455-487.

K. Luig. 'Überwiegendes Mitverschulden', Ius Commune 2 (1969), p. 187-238.

—.'Universales Recht und particulares Recht in den Meditationes ad Pandectas von Augustin Leyser', in: Diritto comune e diritti locali nella storia dell'Europa: atti del convegno di Varenna (12-15 giugno 1979), Milan 1980, p. 27-48.

—. 'Lauterbach, Wolfgang Adam', in: NDB 13 (1982), p. 736-738.

—. 'Leyser, Augustin Freiherr von', in: NDB 14 (1985), p. 437-439.

—. review of 'G.C.J.J. van den Berg, The Life and Work of Gerard Noodt (1647-1725), Dutch Legal Scholarship between Humanism and Enlightenment, Oxford Clarendon Press, Oxford 1988. XIV + 391S.', TvR 58 (1990), p. 204-209.

—. 'Juristische Methode zwischen Humanismus, Usus modernus und Naturrecht - Gerard Noodt (1647-1725) und die Lehre vom Mitverschulden', Zeitschrift fürneuere Rechtsgeschichte 21 (1999), p. 103-114.

K. Luig, 'Dernburg, Heinrich (1829-1907)', in: M. Stolleis (ed.), Juristen. Ein biographisches Lexikon. Von der Antike bis zum 20. Jahrhundert, 2. Aufl., München 2001, p. 175-176.

\section{$\underline{\mathrm{M}}$}

G.E. van Maanen, De Zutphense juffrouw en de ontrouwe bediende van Lindenbaum, Nijmegen 1995.

G. MacCormack, 'Aquilian Culpa', in: A. Watson (ed.), Daube Noster. Essays in Legal History for D. Daube, Edinburgh-London 1974, p. 201-224.

—. 'Aquilian Studies', SDHI 41 (1975), p. 1-78. 
—. 'Juristic Interpretation of the lex Aquilia', in: Studi in Onore di Cesare Sanfilippo, Vol. I, Milan 1982, p. 255-283.

—. 'Fault and Causation in Early Roman Law: An Anthropological Perspective', RIDA 28 (1991), p. 97-126.

D.M. MacDowell, Athenian Homicide Law in the Age of the Orators, Manchester 1963 (reprint Manchester 1966).

J.M.M. Maeijer, Matiging van schadevergoeding (diss. KUN, Nijmegen), Breda 1962. N. Magens, An Essay on Insurances, vol. I, London 1755. U. Magnus \& M. MartínCasals, 'Comparative conclusions', in U. Magnus \& M. Martín-Casals (eds.), Unification of Tort Law: Contributory Negligence, The Hague/London/New York 2004, p. 259-291.

K.J. Maidment (transl.), Minor Attic Orators (in Two Volumes) I. Antiphon, Andocides, LCL, Cambridge (Mass.)/London 1941 (reprint 1953).

D. Mantovani, 'I giuristi, il retore e le api. Ius controversum e natura nella Declamatio maior XIII', in: D. Mantovani \& A. Schiavone (eds.), Testi e problemi del giurisnaturalismo romano, Pavia 2007, p. 323-385

M. del Mar Agudo Romeo, 'Notas en torno a un juego medieval: Los bohordos', Aragón en la edad media X-XI 10/11 (1993), p. 17-29.

R.G. Marsden, 'Two Points of Admiralty Law', LQR 2 (1886), p. 357-372.

B.S. Markesinis \& H. Unberath, The German Law of Torts. A Comparative Treatise, 4th edn. entirely revised and updated, with a foreword by W. Odersky and the Rt. Hon. Lord Justice Sedley, Oxford and Portland, Oregon 2002.

J. Marquardt, Das Privatleben der Römer, II, 2nd edn., Leizig 1886 (reprografical reprint Darmstadt 1980).

M. Martín-Casals, 'Chapter 8. Contributory Conduct or Activity', in: European Group on Tort Law, Principles of European Tort Law. Text and Commentary, Wien 2005, p. 130-137.

G. Marty \& P. Raynaud, Droit civil, Les obligations, I, Les sources, 2nd edn., Paris 1988.

S. Di Marzo, 'Saggi critici sui libri di Pomponio <<Ad Quintum Mucium>>', Labeo 1961, p. 218-246, 352-383.

R. Maschke, Die Willenslehre im Griechischen Recht, Berlin 1926 (reprint New York 1979).

G.P. Massetto, 'Responsabilità extracontrattuale (dir. interm.)', in: F. Calasso (ed.), Enciclopedia del diritto, Milan 1958, p. 1099-1186.

A. Mau, 'Ballspiel', in: RE 2 (1896), column 2832-2834.

—. 'Barbier' and 'Bart', in: RE 3 (1899), column 3-4, 30-34.

K. Maurer, 'Commonest Abbreviations, Signs etc. used in the Apparatus to a Classical Text', available at www.udallasclassics.org/maurer.html/resources/ EditorsSigla.htm.

Th. Mayer-Maly, 'Proculus', in: RE XXIII 1 (1957), column 1234-1240. 
—. 'Ulpianus', in: RE IX A 1 (1961), column 567-569.

- review of 'Ulrich von Lübtow, Untersuchungen zur lex Aquilia de damno iniuria dato. Berliner Juristische Abhandlungen, band 23. Berlin, Duncker \& Humblot. 1971. 224 S', Göttingische gelehrte Anzeigen 226 (1974), p. 128-137.

—. 'De se queri debere, officia erga se und Verschulden gegen sich selbst', in: D. Medicus \& H.H. Seiler (eds.), Festschrift für Max Kaser zum 70. Geburtstag, München 1976, p. 229-264.

L. Mazeaud et al., Traité théorique et pratique de la responsabilité civile délictuelle et contractuelle, Tome II / avec Jean Mazeaud II, 6th edn., Paris 1970.

W.B. McDaniel, 'Some Passages concerning Ball-Games', Transactions and Proceedings of the American Philological Association 37 (1906), p. 121-134.

[N. McLeod], 'Bloodshed and Compensation in Ancient Ireland. A Public Lecture by Professor Neil McLeod Murdoch University 20 October 1999', Perth 1999.

B.M.E. McMahon \& W. Binchy, Law of Torts, 3rd edn., London 2000.

H.C. Meckbach, Anmerkungen über den Sachsen-Spiegel, Jena 1764.

D. Medicus, Id quod interest. Studien zum römischen Recht des Schadensersatzes, Köln/Graz 1962.

A.T. von Mehren \& J.R. Gordley, The Civil Law System, 2nd edn., Boston/Toronto 1977.

E.M. Meijers, Note to HR, 4 February 1916, NJ 1916, 450 in: WPNR 2425 (1916), p. 301-305.

- 'Uitgegeven en onuitgegeven rechtspraak van den Hoogen Raad en het Hof van Holland, Zeeland en Westfriesland', TvR 1, 1918/1919, p. 400-421 (Meijers 1918/1919a).

—. 'De universiteit van Orleans in de XIIIe eeuw', TvR1 (1918-1919), p. 108-132, 443-488 (Meijers 1918/1919b); 2 (1920-1921), p. 460-518.

H.J. Mertens, ' $\$ 254$ Mitverschulden,' in: H.Th. Soergel (found.), W. Siebert (ed.) \& H.-J. Mertens (ed.), Bürgerliches Gesetzbuch mit Einführungsgesetz und Nebengesetzen. Band 2/1. Schuldrecht I/1 (\$\$ 241-432), 11th edn., Stuttgart et al.1986, p. 346-392.

F. Merzbacher, 'Kleinschrod, Gallus Aloysius Caspar', in: NDB12 (1979), p. 8-9.

C.E. Mesa, C.M.F., 'Juan Suarez de Mendoza. Un gran escritor Novogranatense', Thesaurus. Boletín des Instituto Caro y Cuervo VII (1951), Núms. 1, 2 y 3, p. 280-293.

A. Metro, 'Il “legatum partitionis"', Labeo 9 (1963), p. 291-330.

R. Metz, 'La responsabilité pénale dans le droit canonique médiéval', Annales de la Faculté de droit et des sciences politiques et economiques de Strasbourg 1954 , p. 83-116.

E. Molitor, Grundzüge derneueren Privatrechtsgeschichte, Karlsruhe 1949. 
F. Mommsen, Beiträge zum Obligationenrecht. II, Braunschweig 1853.

—. Zur Lehre von dem Interesse, Braunschweig 1855.

Th. Mommsen, Römisches Strafrecht, Leipzig 1899 (photomechanical reprint Graz 1955).

J. Monballyu (ed.), Filips Wielant. Verzameld werk. I. Corte instructie in materie criminele, Brussels 1995.

C.H. Monro, Digest IX.2. Lex Aquilia. Translated with Notes, Cambridge 1898.

T. Moosheimer, Johannes Voet (1647-1713), in: G. Kleinheyer \& J. Schröder (eds.), Deutsche und Europäische Juristen aus neun Jahrhunderten. Eine biographische Einführung in die Geschichte der Rechtswissenschaft, 4th edn., Heidelberg 1996, p. 440-442.

J.S. Morrison, 'Antiphon', in: R.K. Sprague (ed.), The Older Sophists, Columbia 1972, p. 106-240.

B. Mugdan, Die gesamten Materialien zum Bürglichen Gesetzbuch für das Deutsche Reich, herausgegeben und bearbeitet. II. Recht der Schuldverhältnisse, Berlin 1899 (reprint Aalen 1979).

J. Munniks, Handleiding tot de hedendaagsche rechtsgeleerdheid der Vereenigde Nederlanden, naar den ordervan het Romeinsche recht, Amsterdam 1776.

T. Muther, 'Berger, Johann Heinrich', in:ADB 2 (1875), p. 374-375 (Muther 1875a).

—. 'Besold, Christoph', in: ADB 2 (1875), p. 556-558 (Muther 1875b).

$\underline{\mathrm{N}}$

H. Nellen, Hugo de Groot. Een leven in strijd om de vrede 1583-1645, Amsterdam 2007.

V. Neumann-Schniedewind, Mitverursachung, Mitverschulden. Haftungsausschluß und Schadensteilung im französischen außervertraglichen Schadensersatzrecht (diss. Kiel), Kiel 1969.

U. Nicoloni \& F.S. d'Amico, Indices corporis iuris civilis iuxta vetustiores editiones cum criticis collatas, Milan 1964-1970: I. Index titulorum. - 1964. II. Index legum. (3 vol.). - 1967. III. Index paragraphorum. - 1970.

J.P. van Niekerk, The development of the principles of insurance law in the Netherlands from 1500 to 1800, Volume II, Capetown 1998.

H.A. van Nierop, Eigen schuld van de benadeelde (diss. UvA Amsterdam), Amsterdam 1905.

J.H. Nieuwenhuis, Confrontatie \& compromis. Recht, retoriek en burgerlijke moraal, 2nd edn., Deventer 1997.

—. 'De wet van het uitgesloten midden. De terugkeer van het alles of niets beginsel in het komende verkeersaansprakelijkheidsrecht', RM Themis 1999-10, p. 357-358.

E. Norman Gardiner, 'Throwing the javelin', The Journal of Hellenic Studies 27 (1907), p. 249-273. 
—.Athletics of the Ancient World, Oxford 1930 (reprint Oxford 1955).

D. Nörr, 'Pomponius oder "Zum Geschichtsverständnis der römischen Juristen”', ANRW II, 1976, 15, p. 497-604.

-. Causa mortis. Auf den Spuren einer Redewendung, München 1986.

—. 'Texte zur lex Aquilia', in: Iuris professio, Vienna/Köln/Graz 1986, p. 211-219, reprint in: T.J. Chiusi, W. Kaiser \& H.-D. Spengler (eds.), Historiae iuris antiqui. Gesammelte Schriften. Band 3, Goldbach 2003, p. 1701*-1710*.

—. 'Spruchregel und Generalisierung', SZ 89 (1972), p. 18-93, reprint in: T.J. Chiusi, W. Kaiser \& H.-D. Spengler (eds.), Historiae iuris antiqui. Gesammelte Schriften. Band 2, Goldbach 2003, p. $775^{*}-850^{*}$.

—. 'Zur Formel der actio legis Aquiliae', in: H. Altmeppen, J. Reichard \& M.J. Schermaier (eds.), Festschrift für Rolf Knütelzum 70. Geburtstag, Heidelberg 2009, p. 833-848.

$\underline{\mathrm{O}}$

X. Ochoa \& A. Diez, Indices titulorum et legum Corporis iuris civilis, Rome 1965.

H. Oetker, '§ 254. Mitverschulden', in:W. Krüger (ed.), Münchener Kommentar zum Bürgerlichen Gesetzbuch. Band 2. Schuldrecht Allgemeiner Teil \$\$ 241-432, 5th edn., München 2007, p. 495-557.

A. van Oevelen, 'De zgn. schadebeperkingsverplichting van de benadeelde in het buitenconstractuele aansprakelijkheidsrecht (ann. bij Cass. 14 mei 1992)', Rechtskundig Weekblad 1993/1994-39, p. 1395-1397.

N.J.J. Olivier, Die aksie weens die nalatige veroorsaking van pyn en lyding. 'n regtshistoriese ondersoekmet'n regtsvergelykende ekskursus (diss. Leiden), Leiden 1978.

A.C. Oltmans, De Instituten van Gaius, 3rd edn., Haarlem 1967.

M.S. van Oosten, Systematisch Compendium der Observationes Tumultuariae van Cornelis van Bijnkershoek, Haarlem 1962.

A. d'Ors, Estudios visigóticos. II: El codigo de Eurico, Rome/Madrid 1960.

A. d'Ors, F. Hernandez-Tejero, P. Fuenteseca, M. Garcia-Garrido, J. Burillo, El Digesto de Justiniano I: Constituciones preliminacesy libros 1-19, Pamplona 1968; II: libros 20-36, Pamplona 1972 ; III: libros 37-50, Pamplona 1975.

D.J. Osler, 'Jurisprudentia Elegantior and the Dutch Elegant School', Ius Commune 23 (1996), p. 339-354.

—. 'The Fantasy Men', Rechtsgeschichte 10 (2007), on http://rg.rg.mpg.de (last consulted on 1 May 2013), p. 169-192.

—. 'Legal Humanism', online available at: www.rg.mpg.de (last consulted on 1 May 2013).

G. Otte, Dialektik und Jurisprudenz. Untersuchungen zur Methode der Glossatoren, Frankfurt am Main 1971. 
K.E. Otto, B. Schilling \& C.F.F. Sintenis, Das Corpus iuris civilis (Romani), Bd. 4, Leipzig 1831 (reprint Aalen 1984).

$\underline{\mathrm{P}}$

N. Palazzolo, Bibliotheca Iuris Antiqui, Centro Interuniversitario per l'Informatica Romanistica, CD-Rom, Catania 2000.

G. Paré, A. Brunet \& P. Tremblay, La renaissance du xiie siècle. Les écoles et l'enseignement. Refonte complète de l'ouvrage de G. Robert (1909), Paris \& Ottawa 1933.

F. Parisi, Liability for Negligence and Judicial Discretion, 2nd edn. with foreword by P. Stein, Berkeley 1992.

—. 'Alterum non laedere. An Intellectual History of Civil Liability', Am.J.Juris. 39 (1994), p. 317-551.

P. Paschalidis, 'What did iniuria in the lex Aquilia actually mean?', RIDA 55 (2008), p. 321-363.

P. Pauw, 'Aspects of the Origin of the Action for Pain, Suffering and Disfigurement', Tydskrif vir die Suid-Afrikaanse reg 1977, p. 244-249.

W.M. Peletier, 'Scholten, Paulus', in: J. Charité et al. (eds.), Biografisch woordenboek van Nederland, 's-Gravenhage 1979, p. 536-539.

A. Pelzer, Abbréviations Latines médiévales. Supplément au Dizionario di Abbreviature Latine ed Italiane de Adriano Capelli, 3rd edn., Beauvechain 1995.

M. Pérez Simeón, Nemo pro parte testatus pro parte intestatus decedere potest. El principio de incompatibilidad entra la sucesión testamentariay la intestada en el derecho romano, Madrid/Barcelona 2001.

A. Pernice, Zur Lehre von den Sachbeschädigungen nach römischem Rechte, Weimar 1867.

—.'Parerga', ZSS RA 17 (1896), p. 167-251.

A. Pernice \& M.A. Labeo, Das römische Privatrecht im ersten Jahrhunderte der Kaiserzeit, II Bd.,1. Abt., 2nd edn., Halle 1895.

B. Perrin (transl.), Plutarch's Lives. In Eleven Volumes. X. Agis and Cleomenes, Tiberius and Caius Gracchus. Philopoemen and Flamininus, LCL, London/ Cambridge 1921 (reprint 1968).

L. Pfister, 'Doneau (Donellus) Hugues', in: P. Arabeyre, J.-L. Halpérin, \& J. Krynen (eds.) Dictionnaire historique des juristes français (XIIe-XXe siècle), Paris 2007, p. 256-258.

P. Pic, La loi du 9 avril 1898 sur les accidents du travail, Paris 1898.

E. Picard \& N d'Hoffschmidt (eds.), Pandectes belges. Répertoire général de législation, de doctrine et de jurisprudence Belges, II, Bruxelles 1879.

P. Pichonnaz, 'Da Roma a Bologna: l'evoluzione della nozione di “compensatio ipso iure"', Rivista di diritto romano II (2002), p. 337-350. 
H. Pinkster (ed.), Woordenboek Latijn/Nederlands, Amsterdam 1998.

I. Piro, Damnum 'corpore suo' dare rem 'corpore' possidere. L'oggettiva riferibilità del comportamento lesivo e della possessio nella riflessione e nel linguaggio dei giuristi romani, Napoli 2004.

M. Planiol, Traité élémentaire de droit civil, revu et complété par G. Ripert, avec le concours de J. Boulanger, 3rd edn., II. Obligations - Contrats. Sûretés réelles, Paris 1949.

M. Planiol \& G. Ripert, Traité pratique de droit civil français, 2nd edn., VI. Obligations. première partie par P. Esmein, Paris 1952.

W. Plog, Die sogenannte Kulpakompensation bei Schadenersatzansprüchennach römischem Rechte (diss. Königlichen Universität Greifswald), Greifswald 1896.

M. Pöhls, Darstellung des gemeinen Deutschen und des Hamburgischen Handelsrechts für Juristen und Kaufleute, Bd. 3 Seerecht, Hamburg 1832.

R.J. Polak, Aanspraak en Aansprakelijkheid uit Onrechtmatige Daad, Zwolle 1949.

F. Pollock, The Law of Torts: A Treatise on the Principles of Obligations arising from Civil Wrongs in the Common Law, 13th edn., London 1929.

L.E. del Portillo, 'El farol del posadero', Labeo 29 (1983), p. 157-164.

A. Potthast, Regesta Pontificum Romanorum, I, Berlin 1874 (reprint Graz 1957).

R. Powell, “Novus actus interveniens” in Roman Law', in: G.W. Keeton \& G. Schwarzenberger (eds.), Current Legal Problems. Volume 4, London 1951, p. 197-226.

O. Priester, Compensatio culpae (inaug. diss.), Würzburg 1896.

D. Pugsley, 'Damni iniuria', TvR 36 (1968), p. 371-386.

—. review of 'Responsabilità "ex lege Aquilia": criteri di imputazione e problema della "culpa." By Sandro Schipani [Turin: G. Giappichelli. 1969. XVI and 473 and (index of texts) 20 pp.]', LQR 86 (1970), p. 425-428.

—. 'On the lex Aquilia and culpa', TvR 50 (1982), p. 1-17.

M. Punt, Het vennootschapsrecht van Holland. Het vennootschapsrecht van Holland, Zeeland en West-Friesland in de rechtspraakvan de Hoge Raad van Holland, Zeeland en West-Friesland (diss. Leiden), Deventer 2010.

$\underline{\mathrm{R}}$

C.M. Radding \& A. Ciaralli, The Corpus Iuris Civilis in the Middle Ages. Manuscripts and Transmission from the Sixth Century to the Juristic Revival, Leiden/ Boston 2007.

G. Radke, 'Trigon', in: RE VII A 1 (1939), column 139.

G. Ramires et al., Commento al libro VII dell'Eneide di Virgilio, Bologna 2003.

L. Ramshorn, Dictionary of Latin Synomymes, from the German, by F. Lieber, Boston 1841. 
P. Rasi, 'L'actio legis Aquiliae et la responsabilità extracontrattuale nelle "Glossa", in: G. Rossi (ed.), Atti del convegno internazionale di studiAccursiani, 21-26 ottobre 1963. Vol. II, Milan 1968, p. 725-775.

M. Reinhard (ed.), Early Modern German Literature 1350-1700, IV, Rochester, NY 2007.

T. Reinhardt (transl.), Cicero's Topica, Oxford 2003.

O.W. Reinmuth, 'Ballspiel', KP1 (1964), p. 817-818.

F. Reinoso-Barbero, 'Sobre los precedentes griegos del casus. Un supuesto delictivo idéntico: Protag. en Plut., Per. 36.5 y Ulp. 18 ed., D. 9.2.9.4', Index: quaderni camerti di studi romanistici 21 (1993), p. 489-517.

J.F. Reitemeier, Allgemeines Deutsches Gesetzbuch aus den unveränderten brauchbaren Materialien des gemeinen Rechts in Deutschland, entworfen vom Legationsrathe. Erste Abtheilung. Das Bürgerrecht. Zweiter Band, Frankfurt an der Oder 1802.

P. Rémy-Corlay, 'Damages, Loss and the Quantification of Damages in the Avant-projet de réforme', in: J. Cartwright, S. Vogenauer \& S. Whittaker, Reforming the French Law of Obligations. Comparative Reflections on the Avant-projet de réforme du droit des obligations et de la prescription ('the Avant-projet Catala'), Oxford/Portland 2009, p. 305-324.

H.R. Ribbius, De omvang van de te vergoeden schade bij niet-nakoming van verbintenissen uit onrechtmatige daad (diss. Leiden), Leiden 1906.

S. Riccobono, 'Dalla Communio del diritto quiritario alla Comproprietà moderna', in: P. Vinogradoff (ed.), Essays in Legal History, Oxford (et al.) 1913, p. 33-119.

—. 'Mos italicus e mos gallicus nella interpretazione del Corpus Iuris Civilis', in: Acta congressus iuridici internationalis, Romae 12.-17 novembris 1934, Vol. II, Rome 1935, p. 379-398.

A. Rich, A Dictionary of Roman and Greek Antiquities, London 1860.

K. Richter, 'Rechtsbücher: Sachsenspiegel und Schwabenspiegel', in: J. Wolff (ed.), Kultur-und rechtshistorische Wurzeln Europas. Arbeitsbuch, Godesberg 2005, p. 119-137.

E. Riezler, 'Berufung auf eigenes Unrecht',Jherings Jahrbücher für die Dogmatik des bürgerlichen Rechts 1941, p. 177- 276.

L. Ripert, La réparation du préjudice dans la responsabilitédélictuelle, Paris 1933.

R. Rixecker (bearbeitet), 'Mitverschulden', in: R. Geigel, Der Haftpflichtproze $\beta$ mit Einschluß des materiellen Haftpflichtrechts, 23., völlig neubearbeitete Auflage, München 2001, p. 37-63.

F.M. de Robertis, Damnum iniuria datum. Trattazione sulla responsabilità extra-contrattuale nel diritto romano con particolare riguardo alla lex Aquilia de damno, Bari 2000.

- Damnum iniuria datum. La responsabilità extra-contrattuale nel diritto romano, con particolare riguardo alla lex Aquilia de damno, II, Bari 2002. 
A.A. Roberts, A Guide to Voet, Cambridge 1933.A. Rodger, 'Labeo, Proculus and the Ones that got away', LQR 88 (1972), p. 403-413.

L. Rodriguez-Ennes, 'Notas sobre el elemento subjectivo del <<edictum de effusus vel deiectis >>', IURA 35 (1984), p. 91-98.

C.G. Roelofsen, 'Hugo de Groot (1583-1645)', in: T.J. Veen \& P.C. Kop (eds.), Zestig juristen. Bijdragen tot ene beeld van de geschiedenis der Nederlandse rechtswetenschap, m.m.v. C.H.N. Kwanten, Zwolle 1987, p. 113-119.

J.C. Rolfe (transl.), Ammianus Marcellinus. In Three Volumes. II, Cambridge/London 1940 (repr. 1986); III, rev. and repr., Cambridge/London 1939 (reprint 1972).

—.Suetonius. Volume II, Cambridge/London 1914 (reprint 1997).

J. Ronse, Schade en schadeloosstelling, I, 2nd edn., bewerkt door L. de Wilde, A. Claeys \& I. Mallems, Ghent 1984.

H.J. Rose, A New General Biographical Dictionary. In Twelve Volumes, III, London 1857.

D. Ross (transl. and introd.), The Nicomachean Ethics of Aristotle, London/New York/Toronto 1925 (reprint 1954).

K.F. Roßhirt, Geschichte und System des deutschen Strafrecht, II, Stuttgart 1838.

B.E. Rossi Masella, La Lex Aquilia y la responsabilidad extracontractual en el derecho Romano y su proyeccion en el derecho civil Uruguayo, Montevideo 1951.

H.-J. Roth, Alfeni Digesta. Eine spätrepublikanische Juristenschrift, Berlin 1999.

W. Rother, Haftungsbeschränkung im Schadensrecht, München/Berlin 1965.

G. Rotondi, Scritti giuridici. II. Studi sul diritto Romano delle obbligazioni a cura di Emilio Albertario, Milan 1922.

E. Ruhm, Das eigene verschulden des Verletzten als Grund zur Ausschliessung der Ersatzpflicht im gemeinen Rechte (diss. Königlichen Universität Greifswald), Greifswald 1898.

E. Ruschenbusch, 'Phonos. Zum Recht Drakons und seiner Bedeutung für das Werden des Athenischen Staates', Historia 9 (1960), p. 129-154.

D.A. Russell (transl.), Quintilian. The Orator's Education, I-V, LCL, Cambridge (Mass.)/London 2001.

H. Rushton Fairclough (transl.), Vergil. The Aeneid 7-12. The Minor Poems, Vol. 2, rev. ed., LCL 64, Cambridge, Mass. 1986.

$\underline{S}$

F.J. Säcker (ed.), Münchener Kommentar zum Bürgerlichen Gesetzbuch. Band 1. Allgemeiner Theil. 1. Halbband: §§ 1-240, ProstG, 5th edn., Munich 2006.

E.T. Sage (transl.), Livy. In Thirteen Volumes. X. Books XXXV-XXXVII, London/ Cambridge 1935 (reprint 1984).

B. Saiz Noeda, 'Proofs, Arguments, Places: Argumentation and Rhetorical Theory in the Institutio Oratoria, Book V', in: O.E. Tellegen-Couperus (ed.), 
Quintilian and the Law. The Art of Persuasion in Law and Politics, Leuven 2003, p. 95-110.

K. Salonen, The Penitentiary as a Well of Grace in the Late Middle Ages. The Example of the Province of Uppsala 1448-1527, Helsinki 2001.

M. Salvadore, Concordantia Varroniana. Pars I. Concordantia in M. Terenti Varronis libros de lingua Latina et in fragmenta ceterorum operum. Vol. 1. A-K, Hildesheim/Zürich/New York 1995.

F.D. Sanio, Zur Geschichte der römischen Rechtswissenschaft: ein Prolegomenon, Königsberg 1858.

F.S. l'Hoir, Tragedy, Rhetoric, and the Historiography of Tacitus' Annales, Ann Arbor 2006.

L. de Sarlo, Alfeno Varo e i suoi Digesta, Milan 1940.

S.L. Sass, 'Research in Roman Law; a Guide to the Sources and their English Translations', Law Libr.J. 56 (1963), p. 210-233.

- ' 'Medieval Roman Law: A Guide to the Sources and Literature', Law Libr. J. 58 (1965), p. 130-159.

F.K. von Savigny, Geschichte des römischen Rechts im Mittelalter, 2nd edn., 7 vols., Heidelberg 1834-1851 (reprint Darmstadt 1961/Aalen 1986).

H. Schäfer, Rechtswidrigkeit und Verschulden im Rahmen des $\$ 254$ BGB (diss. Köln), 1969.

H.J. Scheltema, 'L'autorité des Institutes, du Digeste et du Code Justinien', RIDA 13 (1966), p. 344-348.

B. Schilling \& C.F.F. Sintenis, Das Corpus Iuris Canonici in seinen wichtigsten und anwendbarsten Theilen, ins Deutsche übersetzt und systematisch zusammengestellt, II, Leipzig 1837.

S. Schipani, Responsabilità ex lege Aquilia criteri di imputazione e problema della culpa, Turin 1969.

- Justiniani Augusti Digesta seu Pandectae. Digesti o Pandette dell'imperatore Giustiniano: testo e traduzione, Milan 2005.

H. Schlosser, Grundzüge der neueren Privatrechtsgeschichte. Ein Studienbuch, 3., völligüberarbeitete und erweiterte Auflage, des von Dr. Erich Molitorvorm. o. Professor an der Universität Mainz begründetetn Werkes, Heidelberg/Karlsruhe 1979.

J. Schmid, Kirchenlateinisches Wörterbuch, ed. A. Sleumer, Limburg a.d. Lahn 1926.

B. Schmidlin, Die römischen Rechtsregeln. Versuch einer Typologie, Köln/Wien 1970.

E. Schmidt, Einführung in die Geschichte der deutschen Strafrechtspflege, 3rd edn., Göttingen 1965.

W. Schmidt \& O. Stählin, Geschichte der griechischen Literatur. Teil I. Band III.1. Die griechische Literatur zur Zeit der attischen Hegemonie nach dem Eingreifen der Sophistik, München (reprint) 1961. 
H. Schmitt-Lermann, Die Lehre von der Notwehr in der Wissenschaft des gemeinen Strafrechts, Breslau-Neukirch Kurtze 1935.

K. Schneider, 'Sphaeristerium', in: RE III A 2 (1929), column 1680-1682.

—. 'Taberna' in: RE IV A 2 (1932), column 1863-1872.

P. Scholten, 'De causaliteitsvraag in het leerstuk der schadevergoeding buiten contract', in: Rechtsgeleerd Magazijn 21 (1902), p. 265-312, 414-467.

—. De 'schuld' in de leer der onrechtmatige daad, WPNR 2350/1915, p. 17-20.

—. 'Eigen schuld', WPNR 2665/1921, p. 33-35.(1921a).

—. 'Eigen schuld', WPNR 2666/1921, p. 45-47.(1921b).

G.D.J. Schotel, Het maatschappelijkleven onzervaderen in de zeventiende eeuw, Haarlem 1869.

E.J.H. Schrage \& J.H. Dondorp, 'The Sources of Medieval Learned Law', in:J.W. Cairns \& P.J. du Plessis (eds.), The Creation of the ius commune. From casus to regula [Edinburgh studies in law 6], Edinburgh 2010, p. 6-55.

J.F. von Schulte, 'Wamesius, Johann', in: ADB 41 (1896), p. 131-132.

F. Schulz, Die Epitome Ulpiani des Codex Vaticanus Reginae 1128, Bonn 1926.

-.Prinzipien des römischen Rechts, Berlin 1954.

—. Geschichte der römischen Rechtswissenschaft, Weimar 1961.

-. Classical Roman Law, Oxford 1951 (reprint Aalen 1992).

G.H.A. Schut, Onrechtmatige daad volgens BWen NBW, 4th rev. edn., Zwolle 1990.

L. Schütz, Thomas-Lexikon. Sammlung, Übersetzung und Erklärung der in sämtlichen Werken des $h$. Thomas von Aquin vorkommenden Kunstausdrücke und wissenschaftlichen Aussprüche, 2nd edn., Paderborn 1895.

J. Scott, 'Some Reflections on Section 1(1)(a) of the Apportionment of Damages Act 1956 and Contributory Intent', in: J. van der Westhuizen et al. (eds.), Huldigingsbundel Paul van Warmelo, Pretoria 1984, p. 166-178.

L.F. Scott, 'Collisions at sea where both Ships are at Fault', $L Q R$ 1897, p. 17-34, 241-249.

S.P. Scott, The Civil Law, IX, Cincinnati 1932 (photom. repr. New York 1973).

D. Scott Wilson-Okamura (transl.), Aelius Donatus' Life of Virgil, 1996 (revision 2008), www.virgil.org/vitae/a-donatus.htm (last consulted on 1 May 2013).

E. Seckel, 'Paläographie der juristischen Handschriften des 12. bis 15. und der juristischen Druck des 15. und 16. Jahrhunderts', ZSS RA 45 (1925), p. 1-16 (reprint Weimar 1953, p. 54-70).

E. Seidl, 'Proculus als Schueler Labeos', in: Studi in Memoria di Guido Donatuti. III, Milan 1973, p. 1227-1235.

W. Sellert, 'Hert(ius), Johann Nikolaus', in: NDB 8 (1969), p. 700-701.

D.R. Shackleton Bailey (ed. and transl.) Martial. Epigrams. Volume II, Cambridge/ London 1993.

C.P. Sherman, Roman Law in the Modern World, 2nd edn., I, New Haven 1922. 
C.H. Sieburgh, Toerekening van een onrechtmatige daad (diss. Groningen), Den Haag 2000.

D. Simoens, Buitencontractuele aansprakelijkheid, II, Schade en schadeloosstelling in: Beginselen van Belgisch privaatrecht, XI, Antwerpen 1999.

K.W. Simons, 'Contributory Negligence: Conceptual and Normative Issues', in: D.G. Owen (ed.), Philosophical Foundations of Tort Law, Oxford 1995, p. 461-485. (Simons 1995a).

—. 'The Puzzling Doctrine of Contributory Negligence', Cardozo L. Rev. 16 (1995), p. 1693-1747. (Simons 1995b).

A.J.B. Sirks, 'De decisiën van Pieter Ockers (1628-1678)', TvR 71 (2003), p. 197-210.

—. 'The Delictual Origin, Penal Nature and Reipersecutory Object of the actio damni iniuriae legis Aquiliae', TvR 77 (2009), p. 303-353.

J.M. Smits, 'Van risico-aanvaarding en toestemming naar eigen schuld: een ontwikkeling naar billijkheid?', in: W.H. van Boom, C.E.C. Jansen \& J.G.A. Linssen (eds.), Tussen 'Alles' en 'Niets.' Van toedeling naar verdeling van nadeel, Deventer 1997, p. 213-227.

- The Making of European Private Law. Toward a Ius Commune Europaeum as a Mixed Legal System, transl. by N. Kornet, Antwerp/Oxford/New York 2002.

- . 'The Draft-Common Frame of Reference, Methodological Nationalism and the Way Forward', ERCL 3/2008, p. 272-281.

F. de Solá Cañizares, Iniciación al derecho comparado, Barcelona 1954.

A. Söllner, 'Die Literatur zum gemeinen und partikularen Recht in Deutschland, Österreich, den Niederlanden und der Schweiz', in: H. Coing (ed.), Handbuch der Quellen und Literatur der neueren Europäischen Privatrechtsgeschichte. Zweiter Band. Neuere Zeit (1500-1800). Das Zeitalter des gemeinen Rechts. Erster Teilband. Wissenschaft, München 1977, p. 501-614.

J. Spier, Schadevergoeding. Algemeen. Deel 3 [Monografieën nieuw BW. B-Serie 36], Deventer 1992.

—. 'De causale maatstaf van art. 6:101 BW', in: A.J.O. baron van Wassenaer van Catwijck et al., Eigen schuld bij onrechtmatige daad. De verdeelsleutel zoals neergelegd in art. 6:101 BW. Inleidingen, gehouden op het symposion van de Vereniging van Letselschade Advocaten 1997, Lelystad 1997, p. 15-23.

J. Spier et al., Verbintenissen uit de wet en schadevergoeding, 2nd edn., Deventer 2000.

J.E. Spruit, Bibliografie Romeins recht: wegwijzer tot de bronnen, hulpmiddelen en literatuur, Zutphen 1988.

-. Enchiridium. Een geschiedenis van het Romeinse privaatrecht, 4th edn., Deventer 1994.

—. 'Nocturne. Eine Auslegung von Alfenus D. 9,2,52,1 aus Soziologischer Sicht', TvR 63 (1995), p. 247-262; earlier version published in Dutch:J.E. Spruit, 'Nocturne. Een exegese van Alfenus D. 9,2,54,2 vanuit sociologisch perspectief', 
in:J.J.H. Bruggink, et al. (eds.), Rechtsuitgang. Opstellen aangeboden aan prof. mr. N.E. Algra ter gelegenheid van zijn afscheid als hoogleraar, Groningen 1992, p. 312-328.

- Cunabula iuris. Elementen van het Romeinse privaatrecht, 2nd edn., Deventer 2003.

J.E. Spruit et al., Corpus Iuris Civilis. Tekst en vertaling, 8 vols., The Hague/ Zutphen 1993-2007.

J.E. Spruit \& K.E.M. Bongenaar, De Instituten van Gaius [Het erfdeel van de klassieke Romeinse juristen, 1], Zutphen 1982.

-. Ulpianus, Papinianus en kleinere fragmenten [Het erfdeel van de klassieke Romeinse juristen, 3], Zutphen 1986.

C.W. Star Busmann, 'Automobielwetgeving en schadevergoedingsrecht', Vragen des tijds 1924, p. 37-57.

O.W.Star Numan, Cornelis van Bynkershoek. Zijn leven en zijne geschriften (diss. Leiden), Leiden 1869.

G.S. Staring, 'Contribution and Division of Damages in Admiralty and Maritime Cases', California Law Review 45 (1957), p. 304-345.

G.F. Steckley, 'Collisions, Prohibitions, and the Admiralty Court in Seventeenth-Century London', Law and History Review, vol. 21, nr. 1 (2003), p. 41-67.

P. Stein, Regulae iuris. From Juristic Rules to Legal Maxims, Edinburgh 1966.

- 'The Formation of the Gloss 'De regulis iuris' and the Glossators' concept of 'regula', in: G. Rossi (ed.), Attidel convegno internazionale di studi Accursiani, 21-26 ottobre 1963. Vol. II, Milan 1968, p. 699-722.

C.H.W.M. Sterk, Verhoogd gevaar in het aansprakelijkheidsrecht. Een rechtsvergelijkend onderzoek naar aansprakelijkheid voor zaken, stoffen en motorrijtuigen (diss. Tilburg), Deventer 1994.

H. Stiegler, 'Vindicare portionem (D. 30.27)', ZSS RA 84 (1967), p. 357-363.

—. 'partitio legata', in: RE, Suppl. 11(1968), column 1033-1049.

R. Stintzing, Geschichte der populären Literatur des römisch-kanonischen Rechts in Deutschland am Ende des fünfzehnten und im Anfang des sechzehnten Jahrhunderts, Leipzig 1867 (reprint Aalen 1959).

-. Geschichte der Wissenschaften in Deutschland. Neuere Zeit. Achtzehnter Band. 1. Abteilung. Geschichte der deutschen Rechtswissenschaft, München/ Leipzig 1880.

R. von Stintzing \& E. Landsberg, Geschichte der deutschen Rechtswissenschaft, Abt. 1/2, Munich, Leipzig 1880/1884 (reprint Aalen 1978).

O. Stobbe, Geschichte der deutschen Rechtsquellen, II, Braunschweig 1884 (reprint Aalen 1965).

—.Handbuch des deutschen Privatrechts, III, 2nd edn., Berlin 1885.

C.J.J.M. Stolker, 'Verkeer en eigen schuld', Vrb 1994-2, p. 9-11. 
H. Stoll, Das Handeln auf eigene Gefahr. Eine rechtvergleichende Untersuchung, Berlin/Tübingen 1961.

—. 'Consequences of Liability: Remedies', in: A. Tunc (ed.), InternationalEncyclopedia of Comparative Law, Vol. XI. Torts, Part 2, Tübingen et al.1972, p. 1-172.

E. Stolfi, 'Il modello delle scuole in Pomponio e Gaio', SDHI63 (1997), p. 1-106.

M. Stolleis (ed.), Juristen. Ein biographisches Lexikon. Von der Antike bis zum 20. Jahrhundert, 2. Aufl., München 2001.

B.H. Stolte, 'Henrik Brenkman (1681-1736)', in: T.J. Veen \& P.C. Kop (eds.), Zestig juristen. Bijdragen tot ene beeld van de geschiedenis der Nederlandse rechtswetenschap, m.m.v. C.H.N. Kwanten, Zwolle 1987, p. 150-154.

—. 'Balancing Byzantine Law', Fontes minores XI (2005), p. 57-75.(2005a).

—. 'Is Byzantine Law Roman Law?', in: Acta Byzantina Fennica, vol. 2 (20032004), Helsinki 2005, p. 111-126.(2005b).

Th.A. Street, The Theory and Principles of Tort Law, 1906 (reprint Washington D.C. 1999).

H. Südkamp, Johann Stucke - ein europäischer Gelehrter und Politiker. Eine biographische Skizze, Hildesheim/Zurich/New York 2007.

L.A. Sussman, The Major Declamations Ascribed to Quintilian. A Translation, Frankfurt am Main/Bern/New York 1987 [Studien zur klassischen Philologie; Bd. 27].

$\underline{\mathrm{T}}$

M. Talamanca, 'Colpa civile (storia). Sez. II. Diritto intermedio', in: Enciclopedia del diritto. VII (Cir-Compa), Rome 1960, p. 523-534.

R. Tassin, Essai sur la compensation des fautes en droit romain. Suivi d'un aperçu de Législation comparée (diss. Université de Dijon), Paris 1912.

R. Taubenschlag, 'lex Aquilia', in: RE, XII 2 (1925), column 2325-2330.

A. Teichmann, 'Meister, Georg Jacob Friedrich', in: ADB 21 (1885), p. 255-256.

O.E. Tellegen-Couperus, 'Alfeni Digesta. Ein spätrepublikanische Juristenschrift (Review of the book Alfeni Digesta. Ein spätrepublikanische Juristenschrift, 1999)', TvR 69 (2001), 4, p. 382-385.

-. Korte geschiedenis van het Romeinse recht, 4th edn., Amsterdam 2003 (Tellegen-Couperus 2003a).

-. 'Introduction', in: O.E. Tellegen-Couperus (ed.), Quintilian and the Law. The Art of Persuasion in Law and Politics, Leuven 2003, p. 11-28 (TellegenCouperus 2003b).

O. Tellegen-Couperus \& J.W. Tellegen, 'Nihil hoc ad ius ad Ciceronem', RIDA 53 (2006), p. 381-408.

F. Terlez, De la responsabilité en cas de faute partagée dans le droit anglo-saxon et le droit français comparés, Paris 1938. 
F. Terré (dir.), Pour une réforme du droit de la responsabilité civile, Paris 2011.

F. Terré, P. Simler \& Y. Lequette, Droit civil. Les obligations, 8th edn., Paris 2002. Th. Thalheim, 'Antiphon', in: RE I (1894), column 2527-2529.

W. Tetley, 'Chapter 4. Maritime Transportation', in: International Encyclopedia of Comparative Law: VolXII - Law of Transport 2001, p. 3-164.

J.B. Thayer, Lex Aquilia (Digest IX, 2, Ad legem Aquiliam), Text, Translation and Commentary; On Gifts between Husband and Wife (Digest XXIV, 1, De Donationibus inter Virum et uxorem), Cambridge 1929.

Theologische Summavan H. Thomas van Aquino. XV. Over de rechtsvaardigheid. I. (II-II, Q. 57-66), Antwerpen 1940.

M. Thomann, 'Influence du philosophe allemand Christian Wolff (1679-1754) sur l'Encyclopédie et la pensée politique et juridique du XVIII siècle français', Archives de philosophie du droit 13 (1968), p. 233-248.

P.J. Thomas, 'Contributory Fault in Maritime Collisions in the Law of Holland', RIDA 48 (2001), p. 345-360.

T.F.E. Tjong Tjin Tai, 'Verkeersaansprakelijkheid en eigen schuld', Nieuwsbrief bedrijfsjuridische berichten 2005, p. 187-190.

—. 'De motivering van het oordeel over eigen schuld', Nieuwsbrief bedrijfsjuridische berichten 2006, p. 27-28.

C. Torr, Ancient Ships, Cambridge 1894 (reprinted edn. with intr. by A.J. Podlecki, Chicago 1964).

C.B.M. Toullier, Le droit civil français, suivant l'ordre du code, 3rd edn., XI, Bruxelles 1824.

P. le Tourneau, Droit de la responsabilité et des contrats, avec participation de C. Guettier et al., Paris 2004.

P. le Tourneau \& L. Cadiet, Droit de la responsabilité et des contracts, Paris $2002 / 2003$.

P. de Tourtoulon, Placentin. Lavie, les oeuvres, I, Paris 1896 (reprint Glashütten im Taunus 1972).

J. Travis Laster, 'The Role of the Victim's Conduct in Assessing Fault under the lex Aquilia: Insights into the Analytical Methods of Roman Jurists', AngloAmerican Law Review 25 (1996), p. 188-220.

E. Troje, 'Die Literatur des gemeinen Rechts unter dem Einfluß des Humanismus', in: H. Coing (ed.), Handbuch der Quellen und Literatur der neueren Europäischen Privatrechtsgeschichte. Zweiter Band. Neuere Zeit (1500-1800). Das Zeitalter des gemeinen Rechts. Erster Teilband. Wissenschaft, München 1977, p. 615-795.

W. Trusen, 'Strafprozeß und Rezeption. Zu den Entwicklungen im Spätmittelalter und den Grundlagen der Carolina', in: P. Landau \& F.Chr. Schröder (eds.), Strafrecht, Strafprozess und Rezeption. Grundlagen, Entwicklung 
und Wirkung der Constitutio criminalis Carolina, Frankfurt am Main 1984, p. 29-118.

A. Tunc, 'Chapter 18. Traffic Accident Compensation', in: A.S. Hartkamp et al. (eds.), Towards a European Civil Code, Nijmegen et al. 1994, p. 325-332.

$\underline{\mathrm{U}}$

K.A.D. Unterholzner, Unterholzerners quellenmäßige Zusammenstellung der Lehre des römischen Rechts von den Schuldverhälnissen mit Berücksichtigung der heutigen Anwendung, I, Leipzig 1840.

$\underline{\mathrm{V}}$

G. Valditara, 'Damnum iniuria datum', in: A. Biscardi et al., Derecho romano de obligaciones: homenaje al professor José Luis Murga Gener, Madrid 1994, p. 825-885.

T.J. Veen, Recht en nut. Studiën over en naar aanleiding van Ulrik Huber (16361694), Zwolle 1976.

—. 'Ulrik Huber (1636-1694)', in: T.J. Veen \& P.C. Kop (eds.), Zestig juristen. Bijdragen tot ene beeldvan de geschiedenis der Nederlandse rechtswetenschap, m.m.v. C.H.N. Kwanten, Zwolle 1987, p. 120-129.

-.Met dank aan Du Perron. Over terminologie, begripsvorming en hetvermijden van anachronistische redeneringen in het rechtshistorisch bedrijf (rede UvA), Zwolle 1996.

K.J. Venzmer, Mitverursachung und Mitverschulden im Schadensersatzrecht, München/Berlin 1960.

Alejandro Vidal y Diaz, Memoria histórica de la Universidad de Salamanca, Salamanca 1869.

G. Viney, L'indemnisation des victimes d'accidents de la circulation, Paris 1992.

G. Viney \& P. Jourdain, Traité de droit civil. Les conditions de la responsabilité, 3rd edn., Paris 2006.

P. Vinogradoff, Roman Law in Medieval Europe, 3rd edn. with preface by F. Zulueta, Oxford/Hildesheim 1961.

K. Visky, 'La responsabilité dans le droit romain à la fin de la République', RIDA 3 (1949), p. 437-484.

—. 'Die Frage der Kausalität aufgrund des D. 9.2., ad legem Aquiliam', RIDA 26 (1979), p. 476-505.

J.C. Voorduin, Geschiedenis en beginselen der Nederlandsche wetboeken volgens de beraadslagingen deswege gehouden bij de Tweede Kamer derStaten-Generaal uit oorspronkelijke, grootendeels onuitgegeven staatsstukken opgemaakt en aan den koning opgedragen, met voorrede van Jhr. H.M.A.J. van Asch van Wijck, X. Deel. Wetboekvan Koophandel. III. Deel. Art. 453-923, Utrecht 1841. 
P. Voci, Diritto ereditario romano, 2nd edn., I/II, Milan 1963/1967.

R.-F. Voeltzel,Jean Domat (1625-1696). Essai de reconstitution de sa philosophie juridique précédé de la biographie du jurisconsulte, Paris 1936.

H. Vreeland, Hugo Grotius: the Father of the Modern Science of International Law, Littleton, Colorado 1986 (reprint of ed. New York 1917).

M. Vrolijk, Recht door gratie. Gratie bij doodslagen en andere delicten in Vlaanderen, Holland en Zeeland (1531-1567), Hilversum 2004.

\section{W}

A. Wacke, 'Unfälle bei Sport und Spiel nach römischem und geltendem Recht', Stadion III, 1 (1977), p. 4-43.

-. 'Accidents in Sport and Games in Roman and Modern German law', Tydskrif vir hedendaagse Romeins-Hollandse reg 42 (1979), p. 273-287.

—. 'Defence and Necessity in Aquilian Liability', in:J. Roset (ed.), Estudios en homenaje al professor Juan Iglesias, I, Madrid 1988, p. 525-541.

—. 'Notwehr und Notstand bei der aquilischen Haftung. Dogmengeschichtliches über Selbstverteidigung und Aufopferung', ZSS RA 106 (1989), p. 469-501.

- . 'Incidenti nello sport e nel gioco in diritto romano e moderno', Index: quaderni camerti di studi romanistisci 19 (1991), p. 359-378.

H. Wagner, 'Zur wirtschaftlichen und rechtlichen Bedeutung der Tabernen', in: Studi in Onore di Arnaldo Biscardi. III, Milan 1982, p. 391-422.

N. van derWal, Tweetaligheid en recht in het Romeinse keizerrijk (rede Groningen), Groningen 1976.

N. van der Wal \& J.H.A. Lokin, Historiae iuris Graeco-Romani delineatio. Les sources du droit byzantin de 300 à 1453, Groningen 1985.

T. Wallinga, 'Actio legis Aquiliae - Buße oder Schadensersatz?', in: H. Altmeppen, J. Reichard \& M.J. Schermaier (eds.), Festschrift für Rolf Knütel zum 70. Geburtstag, Heidelberg 2009, p. 1385-1399.

P. van Warmelo, 'Noodweer', Acta juridica 1967, p. 5-37.

A.J.O. baron van Wassenaervan Catwijck, Eigen schuld (diss. Leiden), Groningen 1971.

A.J.O. baron van Wassenaer van Catwijck \& R.H.C. Jongeneel, Eigen schuld en mede-aansprakelijkheid, 2nd edn., Zwolle 1995.

A. Watson, 'Two Studies in textual History', TvR 30 (1962), p. 209-242.

—. The Law of Obligations in the later Roman Republic, Oxford 1965 (reprint Aalen 1984).

—. The Digest of Justinian, vol. 1-4, Philadelphia 1985.

—. Studies in Roman Private Law, London/Rio Grande 1991.

B. Wauters, Recht als religie. Canonieke onderbouw van de vroegmoderne staatsvorming in de Zuidelijke Nederlanden, Leuven 2005. 
K. Weinzierl, Die Restitutionslehre der Frühscholastik, München 1936.

-. Die Restitutionslehre der Hochscholastik bis zum hl. Thomas von Aquin, München 1939.

O. Wendt, 'Eigenes Verschulden', Jahrbücher für die Dogmatik des heutigen römischen und deutschen Privatrechts 1892, p. 137-189.

J.N. v. Wening-Ingenheim, Die Lehre vom Schadenersatze nach römischem Rechte. Eine civilistische Abhandlung, Heidelberg 1841.

U. Wesel, Rhetorische Statuslehre und Gesetzeauslegung der römische Juristen, Köln [et al.] 1967.

G. Wesenberg, 'Sextus Pomponius (Jurist)', in: RE 21 (1952), column 2416-2420.

J. Weskett, A Complete Digest of the Theory, Laws, and Practice of Insurance, London 1781.

K. Wester, Mitverschulden im deutschen, englischen und amerikanischen Zivilrecht (diss. Köln), 1976.

B. Weyts, De fout van het slachtoffer in het buitencontractueel aansprakelijkheidsrecht (diss. Antwerpen), trade edn. Antwerpen-Groningen-Oxford 2003.

F. Wieacker, 'Haftungsformen des römischen Gesellschaftsrechts', ZSS RA 54 (1934), p. 35-79.

-. Privatrechtsgeschichte der Neuzeit unter besondere Berücksichtigung der deutschenEntwicklung, 2., neubearbeitete Auflage 5.-10. Tausend, Göttingen 1967.

— . 'Literatur', review of Roland Wittmann, Die Körperverletzung an Freien im klassischen römischen Recht [Münchener Beiträge zur Papyrusforschung und Antiken Rechtsgeschichte, Heft 63], München 1972, 126 pages, ZSS RA 92 (1975), p. 352-357.

—.Römische Rechtsgeschichte: Quellenkunde, Rechtsbildung,Jurisprudenz und Rechtsliteratur, Munchen 1988.

-. A History of Private Law in Europe with Particular Reference to Germany, translated by T. Weir, foreword by R. Zimmermann, Oxford 1995.

F. Wieacker, J.G. Wolf \& U. Manthe, Römische Rechtsgeschichte. Zweiter Abschnitt. Die Jurisprudenz vom frühen Prinzipat bis zum Ausgang der Antike im Weströmischen Reich und die Oströmische Rechtswissenschaft bis zur Justinianischen Gesetgebung. Ein fragment aus dem Nachlass von F. Wieacker herausgegeben von J.G. Wolf mit einer bibliographie von U. Manthe unter Mitarbeit von M. Bolten, München 2006.

C. van der Wiel, Geschiedenis van het kerkelijk recht, 2nd edn., Leuven 2006.

H.J. Wieling, Interesse und Privatstrafe vom Mittelalter bis zum Bürgerlichen Gesetzbuch [Forschungen zur Neueren Privatrechtsgeschichte], Köln/Wien 1970.

B. Windscheid, Lehrbuch des Pandektenrechts, 9th edn., II, ed. by Th. Kipp, Frankfurt am Main 1906. 
C. Witte, Basilicorum titulus. De diversis regulis iuris antiquinunc demum integer, e codice coisliniano edente, Breslau 1826.

R. Wittman, Die Körperverletzung an Freien im klassischen römischen Recht [Münchener Beiträge zur Papyrusforschung und Antiken Rechtsgeschichte, Heft 63], München 1972.

E. Wolf, Grosse Rechtsdenker der deutschen Geistesgeschichte, 4th edn., Tübingen 1963.

C. Wollschläger, 'Das eigene Verschulden des Verletzten im römischen Recht', ZSS RA 93 (1976), p. 115-137.

C.N.S. Woolf, Bartolus of Sassoferrato. His Position in the History of Medieval Political Thought, Cambridge 1913.

U. Wolter, Das Prinzip der Naturalrestitution in \$249 BGB. Herkunft, historische Entwicklung und Bedeutung, Berlin 1985.

W. Wurmnest, Grundzüge eines europäischen Haftungsrechts. Eine rechtsvergleichende Untersuchung des Gemeinschaftsrechts, Tübingen 2003.

\section{$\underline{Z}$}

K.S. Zachariae von Lingenthal \& H.H. Dreyer, Handbuch des französischen Civilrechts, 7th edn., II, Heidelberg 1886.

K.S. Zachariae von Lingenthal \& C. Crome, Handbuch des französischen Civilrechts, 8th edn., II, Freiburg 1894.

J.L. Zamora Manzano, La regulación jurídico-admninistrativa del juego en el derecho romano y su proyección en el derecho moderno, Madrid 2011.

C.J. van Zeben \& J.W. du Pon, Parlementaire geschiedenis van het nieuwe burgerlijk wetboek, Boek 6. Algemeen gedeelte van het verbintenissenrecht, m.m.v. M.M. Olthof, Deventer 1981.

J. Zeylemaker, Geschiedenis van de wetenschap van het burgerlijk procesrecht (praktijkrecht) in Nederland van de aanvang tot 1813 [in: Geschiedenis der Nederlandsche rechtswetenschap. Deel IV, Afl I], Amsterdam 1952.

P. Ziliotto, L'imputazione del danno Aquiliano. Tra iniuria e damnum corpore datum, Padova 2000.

R. Zimmermann, 'Usus modernus legis Aquiliae and Delictual Liability Today', Stellenbosch Law Review 1 (1990), p. 67-93.

—. The Law of Obligations. Roman Foundations of the Civilian Tradition, Oxford 1996.

—. 'Römisch-holländisches Recht - Ein Überblick', in: R. Feenstra \& R. Zimmermann (eds.), Das römisch-holländische Recht. Fortschritte des Zivilrechts im 17. und 18. Jahrhundert, Berlin 1992, p. 9-58.

- 'Christian Thomasius, the Reception of Roman law and the History of the Lex Aquilia', in: M. Hewett (ed.), Larva legis Aquiliae. The Mask of the Lex Aquilia torn off the Action for Damage done. A Legal Treatise by Christian 
Thomasius (1655-1728), edited and translated from the Latin by M. Hewett, Oxford/Portland, Oregon 2002, p. 49-68.

—. 'Arnold Vinnius - Leben, Umfeld, Werk und Wirkung', in: A. Vinnius, Institutionenkommentar Schuldrecht. Text und Übersetzung. Ins Deutschübersetzt von K. Wille. Mit einer Einführung von R. Zimmermann, Heidelberg 2005, p. XI-XXVII.

E. Zitelmann, Digestenexegese: 20 Fälle aus dem römischen Recht, Berlin 1925. H.A. van Zuylen, Veroorzaken van den dood of van lichamelijk letsel door schuld (Art. 307-309 W.v.S.) (diss. VU Amsterdam), Nijmegen 1912.

W.J. Zwalve, Keizers, soldaten en juristen. Vijf Romeinse juridische biografieën, Deventer 1998.

—. 'Het toeschouwersrisico. Enkele opmerkingen over het onderscheid tussen rechtsvragen en vaststellingen van feitelijke aard', in: A.G. Castermans et al. (eds.), De maatman in het burgerlijk recht, Deventer 2008, p. 15-29. 


\section{INDEX OF NAMES}

Abaelardus, Petrus 147

Accursius 108, 117 (n.67, 69), 119, 120 (n.84), 124 (n.113), 127, 129 (n.141), 133 (n.165), 140, 142, 185, 217, 376-377

Africanus 81-82

Alanus 167 (n.372)

Alciatus, Andreas 192

Alexander III, Pope

(Orlando Bandinelli) 156163

Alexander ab Alexandro

(Neapolitanus) 204

Alexander Severus 56

Alfenus Varus, Publius $\quad 30,38-41$, 43, 44-54, 103, 204 (n.67), 205

Andreae, Johannes 151-152, 167, $172,173-174,176$

Antiphon of Ramnus $\quad 66-68,96$, 214 (n.106)

Antoninus Pius 20

Aquinas, Thomas 97 (n.526), 148, 149 (n.262), 225, 239-240, 286

Aristotle 147-148

d'Arnaud, Georgius 19 (n.22)

Augustine (of Hippo; Saint) 147

(n.245), 148-149

Augustus 81

Aumann, Peter $\quad 4,24-25,20,92,252$ (n.330)

Azo 117, 118, 125, 133 (n.165), 134, 174-175, 184, 185, 226 (n.171), 255, 264
Baldus de Ubaldis $113,122,128$, 137, 138, 146 (n.241), 219 (n.133)

Baptista de Sancto Blasio, Ioannes 222 (n.146)

de Barbeyrac, Jean 286, 290 (n.525), 291 (n.539)

Bartolus de Saxoferrato 110, 137-138

Bassianus, Johannes $102,115-117$, 126, 140, 143, 184, 217, 221

Bellapertica, Petrus de 110 (n.22)

Beneventanus, Petrus 165 (n.355)

Berger, Johann 275-276

Beroaldus, Philippus 32

Bertram (Berthold), bishop of Metz 139, 142 (n.224)

Besold, Christoph 265

van Bijnkershoek, Cornelis 206

(n.71), 244, 245, 247-253, 301, 380

Bilderdijk, Willem 31 (n.90), 34

Bloembergen, Auke Reitze 305 (n.10)

Bluntschli, Johann Caspar 333 (n.183)

Bonacossa, Hippolytus 145

Boniface VIII, Pope (Benedetto Gaetani) 176

Bosch, Jacob Anton Albert 340 (n.227)

Brenkman, Henrik 41 (n.164), 79, 207 (n. 77), 219 (n.133)

van Bronckhorst, Everard 33 (n.102), 205 
Brunnemann, Johann 273

de Damhouder, Joost 235 (n.224)

Budaeus (Budé), Guilielmus 32

Darjes, Joachim Georg 291 (n.539)

Bulgarus 139, 142 (n.224), 201

(n.49), 226 (n.171)

Dausque, Claude 34 (n.110)

Decius, Philipphus 142

Burmann, Petrus (the Elder) 22 (n.45)

Butrigarius, Jacobus ～114-115, 141

Demelius, Gustav $\quad 320,325$

Demolombe, Charles $\quad 313-315,316$ (n.69)

Dernburg, Heinrich $\quad 321-322,323$

Cagnolus, Hieronymus $201(n .48)$

Cain 239 (n.254) (n.122), 326

Cannegieter, Hermann 36

Caracalla 55-56

de Castro, Paulus 113 (n.42), 114

(n.50), 122-123, 144, 184, 185, 376

Cato the Elder 268 (n.407)

Cellarius, Christophorus 34 (n.110)

Charles V 235

Chrysostomos, Johannes 58

Cicero 72, 208

Cinus de Pistoia 141 (n.214)

Clement IV, Pope (Guy de Foulques) 142 (n.218)

Cocceji, Samuel 278

Contius, Antonius 32

Corvinus, Arnoldus 135 (n.179)

de Covarrubias (Covarruvias a Leyva),

Diego 149 (n. 262), 164 (n.348)

Diephuis, Ger(h)ardus 325

Domat, Jean 245 (n.285), 286, 287, 290, 320, 313 (n.49, 50), 381

Domitianus 83 (n. 442)

Doneau (Donellus), Hugo 19 (n.23), 20 (n.29) 197-200, 202, 211-212, 298-299, 379

Dorotheus 73 (n.368)

Dumoulin (Molinaeus), Charles 196 (n.28)

Durand (Durantis), Wilhelm 142, 173

Eekma, Idzert 36

von Egloffstein, Leonard 237

Eisenbach, Ioannes Fridericus $\quad 269$ 271,278

Elagabalus 56

Emtinck, Eduardus 232 (n.208)

Engelmann, Woldemar 124 (n.110)

Cravetta, Aymon 137, 144-145, 187,

262, 281-282, 300

Faber, Antonius (Antoine Favre) 36, 204-205, 212-213, 214-215, 240, 265 (n.390), 299, 379

Faber, Johannes (Jean Faure) 121, 136

Faber, Petrus (Pierre du Faur) 196, 199, 201, 202 (n.56), 266 (n.398), 278 (n.470), 299, 379

Farinacius, Prosper 240

Ferrarius, Jacobus $34($ n.110) 
Florianus de Sancto Petro (Sampieri) $122,123,128$

de Forlivio, Rainerius 140 (n.207)

Freher, Marquardt 83 (n.442), 218, 265, 299, 379

Fulgosius, Raphael 123 (n.104), 128-129, 135, 185

Gaius 27-28, 73-74 (n.368), 91

Gallus, Aquilius 81

de Gambilioni, Angelus Aretinus 114 (n.53)

Gandinus, Albertus 151 (n.270)

Gebauer, Georg Christian 32, 79

Gilman, Adrian 262

von Glück, Christian Friedrich 157 (n.305), 199, 270 (n.422)

Goffredus Tranensis 170 (n.386)

Gorla, Gino 285

Gothofredus, Dionysius 32

Gothofredus, Jacobus 199

Grass, Michael 260

Gratian 146, 238

Gregory IX, Pope (Ugolino dei Conti di Segni) 173

van Groenewegen van der Made, Simon 243 (n.274)

Gronovius, Johannes Fredericus 289

de Groot (Grotius), Hugo 225-227, 229-230 (n.192), 242-245, 252 (n.330), 256, 286, 287-289, 294, 302, 381

Gudelinus (Goudelin), Petrus 223

Hagiotheodoritès 178-179

Haloander, Gregor $\quad$ 16-17 (n. 12), $32,78,79$

Heraldus, Desiderius (Didier Herault) 67, 208-209, 214 (n.106) Hermagoras of Temnos 51,375
Hertius, Johann Nikolaus 275

Hippolytus de Marsiliis 142 (n.221)

Hoffmann, Johann Guilielmus 79 (n.404)

Hommel, Karl $\quad$ 267-269, 279, 301

Honorius, Pope 152 (n.277)

van Hoogeveen, Gerardus Aemilius 213 (n.102)

Horace 40

Hotman, François $\quad$ 192, 204, 210-211, 212 (n.97), 214

Huber, Ulrich $\quad 84,206$ (n.71), 220-221, 222, 231, 271 (n.424)

Hugolinus 119

Huguccio 153 (n.283, 285, 286)

Huvelin, Paul 46

Iavolenus 39 (n.142)

Ibbetson, David John 96

de Imola, Alexander 115 (n.57)

Innocent III, Pope

(Lotario dei Conti di Segni)

129 (n.139), 164, 168-169

Innocent IV, Pope

(Sinibaldo dei Fieschi) 160

Irnerius $\quad 105,123$

Isidorus of Sevilla 33

Jansen, Nils 264

von Jhering, Rudolf 333 (n.183)

Justinian 14, 21, 73, 77-79, 75-77, 81, 98-100, 193, 194

van der Keessel, Dionysius Godefridus 229-230 (n.192), 244, 250, 251 (n.327), 253-255, 301-302, 380

Keirse, Anne Lucienne Maria 370

Kleinschrod, Gallus Aloys 271-272

Labeo 81

Lamech 239-240 
Larombière, Léobon Valéry Léon

Jupile 333 (n. 183)

Laurent, François 333 (n.183)

Lauterbach, Wolfgang Adam 263264

van Leeuwen, Simon $\quad 32,191,227$

(n.179), 233-238

Lenel, Otto $\quad$ 19, 21, 25, 26 (n.64), 31 (n.90), 39, 81, 195

Leo the Wise 76

Lessius, Leonardus (Lenaert Leys) 288-289

Levison, Heinrich 332

Leyser, Augustinus $\quad$ 277, 279, 301, 303, 324 (n.128)

van der Linden, Johannes $\quad 250$, 253-254, (n.340)

Liutprand (Lombard King) 180

Loder, Bernardus Cornelis Johannes 340 (n.227)

Looschelders, Dirk 332

de Luca, Giovanni Battista 284 (n.493), 381

Luig, Klaus 4, 155, 219 (n.134), 244 (n.280), 265, 273 (n.436), 275, 289, 292

MacCormack, Geoffrey 61

Macrinus 56

Malumbra, Richardus 138 (n.199)

Marcianus 72

Marckart, Johannes 37

von Martini, Karl Anton Freiherr 298 (n.580), 311-312 (n.42)

Martinus 201 (n.49)

Majansius, Gregorius (Gregorio Mayáns y Siscar) 33 (n.102), 207, 299

Mayer-Maly, Theo 91

Meckbach, Hieronymus Christoph 182
Mela, Fabius $\quad 80-82,85-88,94,96$, 214

Menochius, Jacobus 240

Mevius, David 272-273

Mommsen, Theodor 15 (n.8), 17, 23 (n.52), 31, 54-55 (n.239), 55 (n.245)

Monachus Picardus, Johannes 176 Mucius Scaevola, Quintus 19, 22 (n.46, 47), 23, 28, 138

de Mugello, Dynus 140 (n.207), 141, 174,176

Müller, Johann 267

Nelissen, Antonius Petrus Laurentius 340 (n.227)

Neratius 101

Nerva (filius) 82

Nerva (pater) 82

de Nevo, Alexander 159 (n.316)

Nicasius de Voerda 121

van Niekerk, Johan Petrus 242

van Nierop, Hendrik Abraham 251-252 (n.329), 325-326, 368

van Nieustadt (Neostadius), Cornelis 250

Noodt, Gerard 33 (n.102), 43 (n.181), 84, 190, 206-207, 209210, 215, 218-221, 241, 299, 379 von Normann, Matthäus 183 Noyon, Tarquinius Johannes 329-330

Ockers, Pieter 246-247

Odofredus 120,129-130,133

(n. 165, 169), 141

Olivatius, Bartholomaeus

(Bartholomeo Olivazzi) 283

Osler, Douglas 209 (n.85) 
Pantoja de Ayala/Ajala, Pedro/ Petrus $156(\mathrm{n} .300), 158,165$ (n.357), 216

Papiensis, Bernardus 153-154, 167

Parmensis, Bernardus (Bottono, de Botone) 157 (n.303), 164, $166,168,186,377-378$

Paul 61, 72, 101, 197, 198(n.34), 207, 209

Pericles 69-70

Pfaff, Leopold 333 (183n)

de Piro/Pyro, Henricus Brunonis 121

Pistoris, Modestinus 274 (n.442)

Placentinus 124-125,129(n.142), 134 (n.173), 185

Plutarch 69-70

Polyxenidas 35 (n.117)

Pomponius, Sextus 16-22, 24, 25, 96, 102-103, 197, 251 (n.325)

Porphyrio, Pomponius 40

a Porta, Henricus 78

Pothier, Robert Joseph 245 (n.285), 286, 287, 290-291, 302, 381

Powell, Raphael 63

Prateius, Pardulphus (Pardoux Duprat) 35 (n.118)

da Prierio, Sylvester Mazzolini 159 (n.317), 166 (n.364)

Proculus 80, 82, 88-90, 94, 96, 218, 221

Protagoras 69

Von Pufendorf, Samuel 263 (n.379), 286, 291-292, 294, 302, 381

Püttmann, Jostas Ludwig Ernst 84

Quintilianus, Marcus Fabius 50-53, 204, 206-207, 219, 268 (n.407), 299
Raevardus, Jacobus 20 (n.29), 197

Rehdiger, Thomas 17

von Repgau, Eike 181

de Revigny, Jacques 110 (n.22), 226

di Rezzonico, Carlo della Torre

(Pope Clemens XIII) 283 (n.490)

Ribbius, Hendrik Rudolph 330-331

Rittershusius, Conradus 229 (n.190), 273 (n.436)

Roffredus Beneventanus 118

Rogerius 226 (n.171)

de Rosate, Albericus $\quad 115,123,128$

(n.137), 138 (n.199), 142, 226

du Rousseaud de la Combe, Guy 257 (n.352)

Sabinus $26($ n.64)

de Sande, Johannes $\quad$ 196, 199, 278

(n.470), 299, 379

Schoepff, Wolffgang Adam 279-280, 295, 301, 303, 324 (n.128), 382

Scholten, Paul 330-331,341

Schulting, Antonius 191, 213

(n.102), 232 (n.208)

von Schwarzenberg und Hohenlandsberg, Johann Freiherr 235-237

de Segusio, Henricus (Hostiensis)

160, 167, 168, 175 (n.415), 186, 378

Seneca Maior 268 (n.407)

Servius Honoratus Grammaticus 33

Servius Sulpicius Rufus $\quad 41,43$

(n.180)

Smallenburg, Nicolaas 191

Solomon 318

Socinus, Bartholomaeus $\quad 144,1$

51-152, 187, 262

Socinus, Marianus (the Elder) 144, 151-152, 187, 262

Spangenberg, Georg August 79

Strube, David Georg 266-267

Stryk, Samuel $\quad 189,191$ 
Stucke, Johannes 262

Suárez de Mendoza, Ioannes (Juan)

57-58, 209, 216-217, 221

Teutonicus, Johannes $\quad 165,171(\mathrm{n} .393)$

Theophilus 15, 73 (n.368), 75

Thomasius, Christian $\quad 224,257,291$, 292-294, 302, 381

Tiberius 81

Torelli, Laelio $\quad 16,78,79$

Travis Laster, J. 14 (n.5)

Tribonian 73 (n.368)

de Tudeschis, Nicolaus

(Panormitanus) 135 (n.178), 142, 159, 160, 167

Tuscus, Vivianus 123-124(n.110), 235 (n.228)

Ulpianus, Domitius 54-60,62-63, 64, 68, 72, 73-74 (n.368), 75, 78, 80-81, 85, 89-91, 94-97, 99, 100, $178,207,216,217-221,251$ (n.325) Urban I, Pope 149

Valesius, Hadrianus

(Adrien de Valois) 57

Valesius, Henricus (Henri de Valois) 57

Varro 33

Venturini, Marzio $\quad 262,282,300$

Vergilius 32

Vernaccini, Giuseppe $\quad$ 284-285

Vigilius, Pope 194

Vincentius 167 (n.372)

Vinnius, Arnold $\quad 229,230$

Vitriarius, Philippus Reinhardus 289, 290 (n.525)

Voet, Johannes 205, 219 (n.134), 220, 231-233, 241, 255, 300, 380

Voorda, Jacobus 208 (n.81)
Voorduin, Justinus Cornelius 324$325(\mathrm{n} .131)$

Wamesius, Johann 230-231

Van Wassenaer van Catwijck (baron), Arent Jacob Otto 342-343

van de Water, Johannes 36 (n.123)

von Wening-Ingenheim, Johann Nepomuk $\quad 322,323$ (n.122)

Wernher, Johannes $\quad 276,278$

Wildvogel, Christian $\quad$ 270-271 (n.424)

Windscheid, Bernard 333

Wissenbach, Johannes Jacobus

201

Wolff, Christian $\quad 4$ (n.12), 152 (n.280), 286, 291 (n.539), 295-298, 302, 303-304, 311, 316-317, 324 (n.128), 338-339, 367, 370, 381$382,387,388$

Wollschläger, Christian 26-29

Zanger, Johannes 261

Zasius, Ulrich $\quad 34,208,210,214$, 261-262

von Zeiller, Franz Anton Felix Edler 298 (n.580), 311-312 (n.42) 


\section{INDEX OF SOURCES}

\section{HOLY SCRIPTURE}

Vetus Testamentum

Genesis 4:1 239 (n.254)

Genesis 4:23-24 238 (n.246), 239 (n.254)

Exodus 20:15 148 (n.254)

Exodus 21:19 $275(\mathrm{n} .450)$

Exodus 21:35 162 (n.337), 183

Exodus 21:36 162 (n.337), 183 (n.451)

Deuteronomium

24:19-22 181 (n.443)

1 Kings 3:16-28 183, 318, 367 (n. 397)

ROMAN LEGAL SOURCES

PRE-JUSTINIAN LEGAL SOURCES

Collatio legum Romanarum et

Mosaicarum

7.3.2 $42($ n.175)

Gaius, Institutiones

Gai.Inst. $1.2 \quad 19$ (n.27)

Gai. Inst. 2.254 27, 28

Gai. Inst. 2.254ff. 27 (n.70)

Gai. Inst. 2.257 28

Gai. Inst. 2.258 27 (n.69)
Gai. Inst. 3.149f. 27 (n.69)

Gai. Inst. 3.210ff. 27 (n.69)

Gai. Inst. $3.211 \quad 342(\mathrm{n} .244)$

Gai.Inst. 3.219 87 (n.467)

Gai.Inst. $4.31 \quad 27$ (n.69)

Gai. Inst. 4.37ff. $\quad 27$ (n.69)

Lex XII Tabularum

$8.1242($ n.175)

$8.1342(\mathrm{n} .175)$

8.24a $69(\mathrm{n} .342), 72$

Ulpiani Epitome

XXIV, 2527 (n.71)

CORPUS IURIS CIVILIS

Constitutio Tanta

822 (n.49)

Institutiones (533)

Inst. 1.25.8 218 (n.129), 221

Inst. 2.22.2 197

Inst. 4.3.1 $74(\mathrm{n} .371)$

Inst. 4.3.2 117

Inst. 4.3.3 $74(\mathrm{n} .371)$

Inst. 4.3.4 14, 55 (n. 245), 56

(n.252), 60 (n.276), 62 (n. 288), 63, 71, 73-76, 100, 107 (n. 7), 116-117, 120, 210, 212 (n. 97), 228 (n.184), 229, 230, 257 (n.352), 271 (n. 424)

Inst. 4.3.5 76, 100, 270 


\begin{tabular}{|c|c|c|}
\hline \multicolumn{2}{|c|}{ Inst. 4.3.16 217 (n.126) } & \multirow{2}{*}{$\begin{array}{l}\text { D. 9.2.5pr. } 132 \text { (n.159), } 276 \\
(\text { n.451) }\end{array}$} \\
\hline Inst. 4.6.16-1 & $997($ n.527) & \\
\hline \multirow[t]{2}{*}{ Inst. 4.6.19 } & 97 (n.527) & D.9.2.5.3 \\
\hline & & D.9.2.7pr. 54 \\
\hline \multicolumn{2}{|c|}{ Gloss nulla culpa } & D.9.2.7.1 59 \\
\hline ad Inst. 4.3.4 & $117($ n.66) & $89,128($ n.135) \\
\hline Gloss reus & & 95 (n.519), 201, 276 \\
\hline \multirow[t]{2}{*}{ ad Inst. 4.3.4 } & $117($ n.66) & (n.451), $319($ n.86) \\
\hline & & $\begin{array}{l}\text { D.9.2.8 } 109,117(\mathrm{n} .66) \\
\mathrm{D} 92.9 \mathrm{nr} \quad 132(\mathrm{n} 162)\end{array}$ \\
\hline \multicolumn{2}{|l|}{ Digesta (533) } & \\
\hline D. 1.1.10.1 & $342($ n.244) & D. 9.2.9.4 $14,54-78,81,92$ \\
\hline D. 1.2 .2 .41 & $19(\mathrm{n} .25)$ & (n. 501), 98-100, 107 (n. 7), 109, \\
\hline D. 1.2.2.52 & $82(\mathrm{n} .435,436)$ & 112 (n. 36,39), 115 (n. 58) \\
\hline D. 1.4.4 & $29(\mathrm{n} .81)$ & $117-123,129$ (n. 138), 143, 175 \\
\hline D. 2.7.1.2 & $232($ n.207) & (n. 415), 179 (n. 434), 184, 201, \\
\hline D. 2.7.2 & $232(\mathrm{n} .207)$ & 202 (n. 56), 203, 207-214, 228 \\
\hline D. 2.10.1.2 & $219($ n.130) & (n. 184), 230, 257 (n. 352), 261 \\
\hline D. 2.10.3.3 & 112 & (n. 370), 265 (n. 396), 271 (n. 424), \\
\hline D. 2.13.10.3 & $118(\mathrm{n} .75)$ & 290 (n. 528), 299, 306 (n. 10), 309 \\
\hline D. 2.14.7.10 & 141 & (n. 26), 319 (n. 86), 322 (n. 116), \\
\hline D. 3.3.46.5 & 141, 142 (n.222), 200 & $374,375,379$ \\
\hline D. 3.5.24 & 141 & D. 9.2.10 $58($ n.267), 60-61, \\
\hline D. 4.2.7.1 & $42(\mathrm{n} .175)$ & 72, 77, 117 (n.66), 120, 159 (n.312), \\
\hline D. 4.2.12.4 & $131($ n.153) & 202 (n.56), 207-209, 212, 214, 216, \\
\hline D. 4.2.21pr. & $125(\mathrm{n} .121)$ & 261 (n.370), 271 (n. 424), 299, 319 \\
\hline D. 4.3.36 & 111 (n.31), 112, 113 & $($ n. 86), 379 \\
\hline (n.44), 17 & 2,266 (n.398), 269-270 & D. 9.2.11pr. 14,65 (n.310), \\
\hline D. 4.8.27.2 & 141 & 78-98, 99, 100 (n.539), 112 (n.36), \\
\hline D. 4.9.1.2 & $251(\mathrm{n} .325)$ & 120 (n.87), 122 (n.102), 123-129, \\
\hline D. 5.2.3 & 209 & 136, 155, 175 (n.415), 179 (n.434), \\
\hline D. 5.2 .5 & 209 & 185, 201, 202 (n.56), 203, 207 \\
\hline D. 6.1.15.3 & $218(\mathrm{n} .129)$ & (n.78), 210 (n.89), 212, 214-222, \\
\hline D. 9.1.1.7 & $33(\mathrm{n} .102)$ & 231-232, 237, 241 (n.260), 259 \\
\hline D. 9.1.1.11 & $132(\mathrm{n} .162), 133$ & (n.357), 260 (n.365), 261 (n.370), \\
\hline (n.163), 13 & 38, 166, 205 (n.68), 243 & $265,268,270,271(\mathrm{n} .424), 274$ \\
\hline$(\mathrm{n} .271)$ & & (n.442), 275 (n.448), 285, 290 \\
\hline D. 9.2.2pr. & $55($ n.243), 59 & (n.528), 299, 309 (n.26), 311 \\
\hline (n.268), 8 & $31(\mathrm{n} .423)$ & (n.39), 313 (n.50), 319 (n.86), 322 \\
\hline D. 9.2.2.2 & $37($ n.131) & (n.116), 326 (n.137), 375, 379 \\
\hline D. 9.2.4pr. & 129 (n.142), 130, 201 & D. 9.2.11.1ff. 87 (n.465) \\
\hline D. 9.2.4.1 13 & 32 (n.159), 134 & D. 9.2.11.2 $110(\mathrm{n} .24)$ \\
\hline (n.174), 13 & & D.9.2.13pr. $44,53,226$ (n.171) \\
\hline
\end{tabular}



D. 9.2.15.1 $226(\mathrm{n} .171)$
D. 9.2.27.5 54
D. 9.2.27.11 $89(\mathrm{n} .479)$
D. 9.2.28 14 (n.5), 63 (n.293), 95, $212,228,337$ (n.86)
D. 16.2.10pr. $107,111-112,113,116$
(n.60), 117 (n.68), 126 (n.123), 127 (n.131), 184 (n.456), 265 (n.396), 270 (n.422)
D. 9.2.28.1 116 (n.62), 211, 309 (n.26)
D. 16.3.32 110
D. 17.1.29 200
D. 9.2.29pr. 14 (n.5)
D. 9.2.29.2-5 245
D. 17.2.52.4 291
D. 17.2.52.18 $22(\mathrm{n} .47), 28,139$,
140, 201
D. 9.2.29.7 $319(\mathrm{n} .86)$
D. 9.2.30.3 64 (n.304), 149, 255, 260
D. 9.2.31 14 (n.5), 63 (n.296), 64
(n.304), 65 (n.305), 75, 76, 92
127 (n.127), 140, 142, 185, 211, 265
D. 17.2.55 140, $176(\mathrm{n} .422)$
D. 18.1.57 $102(\mathrm{n} .546)$
D. 18.1.57.3 112, $118(n .72)$
D. 18.1.69 $82(\mathrm{n} .438)$
(n.502), 95 (n.518), 110, 116 (n.62),
D. 18.6.13(12) $232(\mathrm{n} .207)$
D. 18.6.14(13) 232 (n.207)
(n.396), 292, 319 (n.86)
D. 9.2.44pr. 119 (n.79), 257 (n.352)
D. 19.1.11.12 101, 322, 368, 375
D. 9.2.45.3 92, 138, $264(386)$
D. 9.2.45.4 48 (n.215), 131 (n.155),
132 (n.162), 133 (n.169), 276
(n.451), 281 (n.482)
D. 9.2.49pr. 71 (n.353)
(n.2), 383
$\begin{array}{ll}\text { D. 19.1.17.6 } & 81(\mathrm{n} .427) \\ \text { D.19.1.21.3 } & 293(\mathrm{n} .546) \\ \text { D.19.1.45.1 } & 101,203,322,368,\end{array}$
375 (n.2), 383
D. 9.2.52.1 14, 30-54, 68, 98-99, 103, 125 (n.115), 129-132, 134, 137, 201, 202 (n.56), 203, 204-207, 265 (n.396), 270 (n.422), 274, 276 (n.451), 316, 319 (n.86), 379
D. 19.1.51 $273(\mathrm{n} .436)$
D. 19.2.13.4 $87(\mathrm{n} .467)$
D. 21.1.42 226 (n.171)
D. 21.2.17 118 (n.75)
D. 21.2.29.1 200
D. 21.2.55pr. 200
$\begin{array}{ll}\text { D. 9.2.52.2 } & 72 \\ \text { D. 9.2.52.4 } & 14 \text { (n.5), } 37 \text { (n.131), } 83\end{array}$
D. 23.2.43pr. 38 (n.133)
D. 23.3.66 19 (n.23), 198
(n.440), 119 (n.81, 83), 215 (n.112)
D. 9.4 .9201
D. 9.4.17pr. 201
D. 10.2.44.5 176, 200, 201
D. 10.4.7.5 218 (n.129)
D. 11.3.10 204, 205 (n.68)
D. 24.3.39 107, 111-112, 113, 116 (n.60), 118 (n.72), 119 (n.79), 126 (n.123), 171 (n.396), 184 (n.456), 213, 264 (n.386), 265 (n.395), 266 (n.398), 270 (n.422)
D. 11.5.1pr.-2 278-279(n.470)
D. 24.3.47 265 (n.295)
D. 27.1.6.19 $218(\mathrm{n} .129)$
D. 11.5.1.1 219 (n.130)
D. 11.5.2.1 59 (n.272), 165, 217
D. 28.6.39pr. 27 (n.70)
D. 11.5.3 $59(\mathrm{n} .272)$
D. 28.8.5 197
D. 13.6.23 127, 215 (n.112), 266
D. 29.2.77 19 (n.23), 197
D. 30.3726 (n.64) (n.398)
D. 30.39pr.- $\$ 6 \quad 26$ (n.64)
D. 14.3.7.2 176
D. 31.4519 (n.23) 

D. 31.45.1 198
D. 32.29.1 27 (n.70), 28 (n.73)
D. 33.6.16 82
D. 33.7.13 38 (n.133)
D. 33.9.3.10 81 (n.428)
D. 39.2.40.1 111
D. 39.2.44pr. 291 (n.532)
D. 40.1.6 36 (n.123)
D. 41.1.54.1-2 116 (n.62)
D. 41.3.1 201
D. 42.2.8 26 (n.64)
D. 43.16.1.27 131 (n.153), 133 (n.169)
D. 43.16.3.9 133, 205 (n.68)
D. 43.16.9.1 19 (n.23), 197-198
D. 44.4.4.13 171 (n.396), 268
D. 46.3.16 24
D. 46.3.39 81,82
D. 46.3.95.11 139 (n.206)
D. 46.8.22.4 176
D. 47.2.12.1 $276(\mathrm{n} .451)$
D. 47.2.50.4 120 (n.86), 212
D. 47.2.55.2 42 (n.175)
D. 47.7.6pr. 125 (n.116)
D. 47.10.1.1 270 (n.422)
D. 47.10.1.5 280
D. 47.10.1.15 217 (n.126)
D. 47.10.5.1 $31(\mathrm{n} .90)$
D. 47.10.26 217 (n.126)
D. 48.5.2.5 112 (n.38), 173
D. 48.5.14(13).5 $112(\mathrm{n} .38)$
D. 48.10.25 223 (n.156)
D. 48.10.32.1 223 (n.156)
D. 48.19.5pr. 142 (n.217)
D. 48.19.11.2 72, 240 (n.257)
D. 50.15.1pr. 56 (n.247)
D. 50.16.183 38 (n.133)
D. 50.16.207 81
D. 50.17.23 $342(\mathrm{n} .244)$
D. 50.17.151 $274(\mathrm{n} .442)$
D. 50.17.154 112

D. 50.17.155pr. $\quad 198,199$

D. 50.17.173.2 199

D. 50.17.174.1 198 (n.36)

D. 50.17 .19817 (n.12)

D. 50.17.203 14, 16-30, 54, 63, 65 (n.310), 73, 90 (n.485), 94 (n.510), 96, 98-99, 102-103, 108, 110, 111 (n.33), 125 (n.121), 126 (n.122), 139-143, 145, 147, 176, $182,184,185,186,195-203,205$, 206, 212, 214, 228, 231, 241, 248 (n.306), 251 (n.329), 252, 254, 257, 259 (n.357), 260, 262, 263, 264, 271-272, 273 (n.436), 275 (n.448), 278, 280, 281 (n.482), 283 (n.488, 490), 284, 286, 288, 290, 291 (n.532), 298, 299, 300, 301, 302, 311 (n.39), 315 (n.63), 319-320, 325 (n.133), 327, 331, 332, 334, 342 (n.244), 367, 368, 374-377, 379, 380-383

Gloss deteriore

ad D. 2.7.2 112 (n.34)

Gloss quamuis

ad D. 2.10.1.2 111 (n.31)

Gloss dolo compensando ad D. 2.10.3.3 112

Gloss uideantur ad D. 3.5.33 250 (n.321)

Gloss sibi

ad D. 9.1.1.11 138, $264(n .386)$

Gloss glori $(a)$ e causa

ad D.9.2.7.4 226 (n.171)

Gloss sed et siper lusum ad iaculantibus

ad D.9.2.9.4 119-120 
Gloss seruus

ad D. 9.2.9.4 119

Gloss quia non debuit

ad D.9.2.9.4 116 (n.60), 143, 184

Gloss tenebitur

ad D. 9.2.9.4 116, 120 (n.87), 143 (n.226), 174, 264 (n.388), 306 (n.10)

Gloss nam ludus

ad D.9.2.10 119

Gloss teneri

ad D. 9.2.11pr. 124 (n.113)

Gloss queri debere

ad D. 9.2.11pr. 127, 217

Gloss tabernarius

ad D. 9.2.52.1 129 (n.141)

Gloss inerat

ad D. 9.2.52.1 32, 133 (n.165)

Gloss nisi data ad hoc opera

ad D. 9.2.52.1 132-133 (n.163)

Gloss uellet

ad D. 9.2.52.1 134

Gloss rixatus esset

ad D. 9.2.52.1 133 (n.167)

Gloss non repeteret

ad D. 10.2.44.5 $143($ n.225)

Gloss ipso iure

ad D. 16.2.10pr. 112 (n.37, 39), 143

$$
\text { (n.226) }
$$

Gloss culpa tua

ad D. 17.1.26.7 143 (n.226)

Gloss omnimodo

ad D. 19.1.45.1 143 (n.226)

Gloss para enim

ad D. 24.3.39 111-112

Gloss onera

ad D. 39.2.40.1 111

Gloss penali

ad D.48.10.25 223 (n.156)

Gloss condemnatur

ad D. 48.10.32.1 223 (n.156)
Gloss Quod quis

ad D. 50.17.203 140-141, 142-143,

$185,376-377$

Codex (534)

C. 1.3.17 164

Auth. after C. 1.3.17, Interdicimus

158 (n.306), 164

C. 1.27.2.9 58 (n.262)

C. 3.35.5 212

C. 3.43.1 158 (n.306)

C. 3.43.1.4 157, 158 (n.306)

C. $4.24 .9342(\mathrm{n} .244)$

C. 5.27.1pr. 41 (n.167)

C. 6.27 .6141

C. 8.4.1 132, 133 (n.163), 137

C. 8.44(45).8 177 (n.429), 202

C. 8.44(45).9 202-203

C. 9.12 .6133 (n.162)

C. 9.16.1 $75(\mathrm{n} .376)$

Novella

Nov. 72.4 (Coll. 6.2) 117 (n.66)

BYZANTINE LAW

Basilica

B. 2.3.200 (BT 66/10-11) 178

$$
\text { (n.432) }
$$

B. 2.3.203 (BT 66/16-17) 17 (n.16)

B. 60.3.9(.4) (BT 2752/7-9) 77

B. 60.3.10 (BT 2752/10-11) 77

B. 60.3.11(pr.) (BT 2752/12-16)

78, 80 (n.414), 84 (n.449), 220

$$
\text { (n.140) }
$$

B. 60.3.51(.1) (BT 2767/1-5)

$$
38 \text { (n.139), } 42 \text { (n.170), } 48 \text { (n.215) }
$$

Basilica Scholia

BS 3101/12 72 (n.363) 
BS 3101/12-14 77 (n.389, 391)

BS 3101/15-18 77 (n.393)

BS 3101/22-23 77 (n.390)

BS 3104/28-3105/13 178-179

BS 3163/2 38 (n.139)

BS 3163/3-5 48 (n.215)

Epitome legum

$42.34 \quad 48(n .215)$

Scholia Balsamon on Nomocanon of Photius

tit. XIII, cap. $29 \quad 157$ (n.305)

Theophilus, Paraphrasis Institutionum

4.3.4 62 (n.288), 63, 75

\section{(ANCIENT) NON LEGAL SOURCES}

Ammianus Marcellinus, Res gestae

$\begin{array}{lc}\text { XVIII.7 } & 57(\mathrm{n} .257) \\ \text { XX.4 } & 57(\mathrm{n} .259) \\ \text { XX.4.11f. } & 57(\mathrm{n} .258) \\ \text { XX.5.1 } & 57(\mathrm{n} .258) \\ \text { XX.9.6 } & 57(\mathrm{n} .258) \\ \text { XXI.2.1 } & 57(\mathrm{n} .258) \\ \text { XXX.1.21 } & 33(\mathrm{n} .102)\end{array}$

Antiphon, Tetralogiae

II. 256 (n.254)

II.2.8 65 (n.308)

III.2.6 50 (n.221)

III.4.2 \& $4 \quad 50$ (n.221)

III.3.2 $50($ n.221)

Aristoteles, Ethica Nicomachea

II.1 $147-148$

V.4 148 (n.250)

V.8 135 (n.180)

Aristoteles, Physica

II.6 $239(\mathrm{n} .253)$
Artemidorus of Daldis, Oneirocritica

I.58 57 (n.257)

Augustinus, Liber de vera religione

XIV 239 (n.253)

Aulus Gellius, Noctes Atticae

VII.5.1 41

XI.18.6-8 42 (n.175)

Johannes Chrysostomus, Homiliae in 1 Thess.

III.4 $58(\mathrm{n} .265)$

Cicero, De legibus

II.20.50 27 (n.70), 28 (n.73)

Cicero, De officiis

I.103f. 208 (n.79)

Cicero, De oratore

I.57.244 67 (n.326)

I.239-240 $52(\mathrm{n} .231)$

Cicero, In Catilinam

IV.17 42 (n.168)

Cicero, Pro Caecina

IV.12 27 (n.70)

Cicero, Pro Cluentio

VII.21 27 (n.70)

Cicero, Pro Flacco

$1842(n .168)$

Cicero, Topica

10.63-20.64 $72(\mathrm{n} .362)$

$17.64 \quad 72$

$17.6551(\mathrm{n} .228)$

17.6651 (n.228)

$20.58 \quad 72$

$21.8251($ n.225) 


\begin{tabular}{|c|c|}
\hline Cyprianus, Liber de exhortatione & Libanius, Orationes \\
\hline Martyrii & XV.76 57 (n.257) \\
\hline \multicolumn{2}{|l|}{ Praefatio $58(\mathrm{n} .263)$} \\
\hline & Livius, $A b$ urbe condita \\
\hline Diodorus Siculus, Bibliotheca historica & XXXVI.44.2f. 35 (n.114) \\
\hline \multirow[t]{2}{*}{ XX.61.8 $35($ n.116) } & \multirow{2}{*}{$\begin{array}{ll}\text { XXXVI.45.1 } & 35 \\
\text { XXXVII.30.7 } & 35(\text { n.114) }\end{array}$} \\
\hline & \\
\hline \multicolumn{2}{|l|}{ Donatus } \\
\hline on Terentius' Eunuchus & Manilius, Astronomica \\
\hline III.3.9 33 (n.103), 34 (n.110) & IV.227-229 $210(\mathrm{n} .87)$ \\
\hline $\begin{array}{l}\text { Ennodius, Panegyricus Theoderico } \\
\text { dictus }\end{array}$ & Martialis, Epigrammata \\
\hline \multicolumn{2}{|l|}{$1957(\mathrm{n} .257)$} \\
\hline 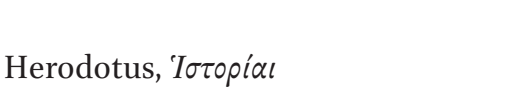 & $\begin{array}{l}\text { Nonius Marcellus, De compendiosa } \\
\text { doctrina }\end{array}$ \\
\hline I.43 $209($ n.84), $240($ n.256) & II.104.28-30 $83(\mathrm{n} .440)$ \\
\hline Hesychius Alexandrinus, Lexicon & $\begin{array}{l}\text { Otfired von Weißenburg, } \\
\text { Evangelienbuch }\end{array}$ \\
\hline s.v. $\Delta \operatorname{tó}^{\prime} \omega \nu \varepsilon \varsigma \quad 33$ (n.102), 34 (n.110) & $\begin{array}{l}\text { Evangelienbuch } \\
\text { (III) }\end{array}$ \\
\hline \multicolumn{2}{|l|}{ Historia miscella } \\
\hline \multirow[t]{2}{*}{ XVII.74 $57($ n.259) } & Ovidius, Ars Amandi \\
\hline & III.382-385 58 (n.266) \\
\hline \multicolumn{2}{|l|}{ Horatius, Epistulae } \\
\hline I.7.50ff. 83 (n.442) & Ovidius, Metamorphoses \\
\hline I.7.88 $26($ n.65) & VII.841 $209(\mathrm{n} .84)$ \\
\hline $26(\mathrm{n} .65)$ & X.174ff, esp. 196ff. $\quad 215$ \\
\hline Horatius, Sermones & Phaedrus, Fabulae Aesopiae \\
\hline I.3.130(ff.) $\quad 40$ & III.6.3 33 (n.106), 34 (n.110) \\
\hline \multicolumn{2}{|l|}{ I.6.126 $83(\mathrm{n} .441)$} \\
\hline II.6.49 $83($ n.441) & Plato, Leges \\
\hline II.3.300 $26(n .65)$ & $869 \mathrm{C} \quad 50($ n.221) \\
\hline Isidorus of Sevilla, Etymologiae & Plautus, Bacchides \\
\hline XVIII.9(.4) $33($ n.103, 107) & III.3 $217(\mathrm{n} .121)$ \\
\hline XIX.3.3 $35(\mathrm{n} .116)$ & \\
\hline & Plutarchus, Pericles \\
\hline Juvenalis, Satires & $36.3 \quad 69-70$ \\
\hline III.287 43 (n.181) & \\
\hline $83(\mathrm{n} .442)$ & \\
\hline
\end{tabular}


Plutarchus, Tiberius Gracchus

X.7 $34(\mathrm{n} .110,111)$

Pollux, Onomasticon

I.91 35 (n.115)

Polybius, Historiae

XVI.15.2 35 (n.116)

Porphyrio

on Horatius' Sermones

I.3.130ff. 40

Procopius, De bello Vandalico

I.17 35 (n.116)

(Pseudo-)Quintilianus, Declamatio

Maior

XIII 22 (n.45), 70-71

XIII.11 206-207

Quintilianus, Institutio Oratoria

III.5.10 51 (n.225)

V.10.38-40 65 (n.306), 85 (n.451)

V.10.58-63 24 (n.55)

V.10.71-72 50-52

V.10.94 $52(\mathrm{n} .232)$

V.11.39 $268($ n.407)

VII.9.15 219, 221

Seneca (Minor), De beneficiis

II.17.3-5 83 (n.440)

II.32 83 (n.440)

V.8.4 83 (n.440)

VII.18 83 (n.440)

Seneca (Minor), Epistulae

$104.3383(\mathrm{n} .441)$
Seneca (Maior), Controversiae

VI.6 268 (n.407)

VII.3.6 268 (n. 407)

Servius Grammaticus, on Vergilius, Aeneis

VII.664 32 (n.96, 97), 33, 34 (n. 110)

Silius Italicus, Punica

III.250 34 (n.110)

Strabo, Geographica

V.3.8 217 (n.122)

Suetonius, Augustus

8357 (n.259)

Suetonius, Claudius

XIII.1 33 (n.102), 34 (n.110)

Suetonius, Domitianus

XVII.1 34 (n.110)

Suetonius, Nero

XXVI.2 43 (n.181)

Tacitus, Historiae

I.64 43 (n.181)

Theodoretus Cyrensis, Historia ecclesiastica IV.26.2 58 (n.264)

Valerius Maximus, Facta et dicta memorabilia I.7 ext. 4209 (n.84)

Varro, De lingua Latina

V.35 41(n.164) 
Vegetius, Epitoma rei militari

II.23 58 (n.262)

Vergilius, Aeneis

VII.162 58 (n.216)

VII.664 32-33

IX.431 $79(\mathrm{n} .404)$

Xenophon, Hellenica

VI.2.27 35 (n.116)

Zosimus, Historia nova

IV.54 57 (n.257)

\section{CANON LAW}

Decretum Gratiani

D.35 c.1 157-158 (n.306)

D.50 c.6 238 (n.249)

D.50 c.37 149, 153, 154 (n.287), 238

D.50 c.39 149 (n.260), 238 (n.249)

D.50 c.43-44 238 (n.249)

D.50 c.50 149, 153 (n.287), 154-155

C.14 q.6 c.1 148

C.15 q.1 p.c. 2238 (n.246)

C.22 q. 2 c.18 164 (n.349)

C.22 q. 4 c. 22 §2 166 (n.370)

C.23 q.4 c.38 176-177

C.23 q.5 c.8 149 (n.258)

C.31 q. 2 c. 4170 (n.388)

C.32 q.4 c.2 164 (n.349)

C.32 q.6 c.1 171 (n.396)

Gloss penitus

ad C.15 q.1 p.c.2 238 (n.248)

Gloss bonum

ad C.23 q.5 c.8 149 (n.262), 150 (n.265)
Quinque compilationes antiquae

1 Comp. 5.10.9 153 (n.287), 154, $155,156,175$

1 Comp. 5.10.10 154, 163, 168

3 Comp. 5.8.1 168

3 Comp. 5.14.4 165 (n.355)

4 Comp. 3.1.4 165

5 Comp. 5.6.2 $152($ n.277)

Decretales Gregorii IX (Liber Extra, 1234)

X 1.41.1 $174(\mathrm{n} .410)$

X2.13.12 129 (n.139), 275 (n.450), 276

X3.1.2 165-166 (n.364)

X3.1.15 165

X 5.12.8 108, 121 (n.95), 147, 153

(n.287), 154, 155, 156-163, 164, 165, 167 (n. 376), 175,

X 5.12.9 108, 147, 154, 156, 163-168, $186,235,377$

X 5.16.6 108, 147, 168-173, 175

$$
\text { (n.416), } 265 \text { (n. 395) }
$$

X 5.16.7 265 (n. 395), 270 (n.422)

X 5.31.11 $165(\mathrm{n} .355)$

$X 5.31 .18 \quad 268$

X 5.36.3 162 (n.337), 183

X 5.36.9 147 (n.243), 223 (n.155)

Gloss dederunt

adX 2.20.9 149 (n.262), 150

$$
\text { (n.265) }
$$

Gloss ludum

adX 5.12.8 159 (n.313)

Gloss eiusdem Diaconi

adX 5.12.8 159 (n.312)

Gloss Romanis Pontificis

adX 5.12.8 159 (n.318), 166, 167 (n.375), 168 
Gloss luderet

ad X 5.12.9 164 (n.349)

Gloss proiecit istum ad terram

ad X 5.12.9 165 (n.359)

Gloss libere

ad X 5.12.9 $167($ n.373, 376)

Gloss spontanea

ad X 5.16.6 170 (n.385)

Gloss euidentiam

ad X 5.16.6 170 (n.387)

Gloss confessionem

ad X 5.16.6 170 (n.388)

Gloss cessante

ad X 5.16.6 171 (n.395)

Gloss mutua compensatione

ad X 5.16.6 172 (n.397)

Gloss alioquin

adX 5.16.6 $170($ n.383)

Liber Sextus Bonifatii VIII (1298)

VI 1.12.1 173, 175 (n.416)

VI 3.4.11 177

VI 5.12.4 148

VI 5.12.65 174

VI 5.12.86 108, 145, 147, 152

(n.279), 175-177, 182 (n.446), 186, 257 (n.352), 262 (n.373, 375), 265 (n.396), 274 (n.442), 283 (n.488), 290

Gloss commentum

ad VI 1.21.1 116 (n.63), 173-174

Gloss damnum

ad VI 5.12.86 116 (n.63), 142

(n.223), 174 (n.411), 176, 177

(n.429)

(MEDIEVAL) INDIGENOUS LAW

Bretha Étgid

§30 182
Codex Euricianus

283180 (n.437)

Klagspiegel, de actione legis aquilie

Blatt XCIXv 179 (n.434)

Leges Frisionum

titulus $22 \quad 34($ n.111)

Leges Visigothorum

III.4.8 $180(\mathrm{n} .435,437)$

V.5.6 $180(\mathrm{n} .436,437)$

VIII.4.18 $180($ n.437)

Liutprandi Leges Anni XXI

cap. $136 \quad$ 180-181

Matthäus von Normann, WendischRügianisches Landgebrauch

tit. 177, al. 4 and 5183

Nicolaus Wurm, Blume von Magdeburg

II.3.98 $181(\mathrm{n} .442)$

Sachsenspiegel

II.48(.2) 181-182

CODES OF MARITIME LAW

Consolato delmare

cap. $33242(\mathrm{n} .263)$

cap. $34242(\mathrm{n} .263)$

cap. 157318 (n.79)

cap. 183242 (n.263)

Rôles d'Oléron

Art. 14246 (n.289), 318 (n.81, 83)

Wisbuische Zee-rechten

Art. $27 \quad 243$ (n.274)

Art. 48243 (n.274), 246 (n.290) 


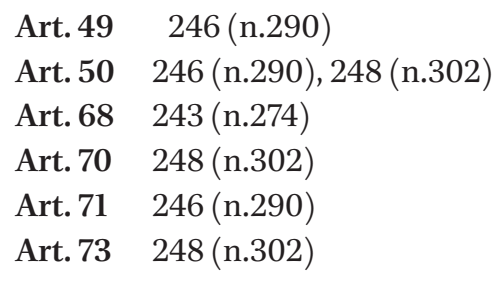

\section{CASTILIAN-SPANISH LEGISLATION}

Siete Partidas

I.6.15 162 (n.333)

Fuero Real

IV.7.7 217 (n.123)

Nueva Recopilacion

VIII.7.8 217 (n.123)

VIII.23.3 217 (n.123)

Novísima Recopilación

XII.23.7 217 (n.123)

XII.21.4 217 (n.123)

\section{AUSTRIAN LAW}

Allgemeines Bürgerliches Gesetzbuch (1811)

§ $1304298,311,312$ (n.42, 43), 317, 362, 367, 370, 382, 385, 387 (n.14)

\section{DUTCH LAW}

Placaet ende Ordonnantie, Op 't stuck vande Zee-Rechten (1551)

Art. 46243 (n.274), 250 (n.315), 253 (n.333)

Art. 48243 (n.274)

Art. 49246 (n.291)
Ordonnantie, Statuyt ende eeuwige

Edict etc. (1563), title 5

Art. 1243 (n.274), 247 (n.298), 250 (n.316), 253 (n.333)

Art. 2250 (n.316)

Art. 3243 (n.274), 250 (n.316), 252-255

Art. 4246 (n.292)

Instructie van den Hoogen Raedt (1582)

§20 249 (n.309)

Ordonnantie of Rotterdam (1721)

Art. $167 \quad 242$ (n.267)

Art. 255250 (n.317)

Art. 262253 (n.338), 254

Instructie of Dordrecht (1775)

Art. $172 \quad 250$ (n.318)

Art. $179 \quad 253$ (n. 338)

Wetboekvan Koophandel (1830)

Art. 413251 (n.329)

Burgerlijk Wetboek (1838)

Art. 1392326 (n.142)

Art. $1401 \quad 328,329$ (n.155), 330

(n.227)

Art. 1402328

Art. (7A:) 1638x 339 (n.225), 357 (n.334), 385 (n. 6)

Wetboekvan Burgerlijke Rechtsvordering (1838)

Art. 149 (2002) 344

Wetboekvan Koophandel (1838)

Art. 276325 (n.131)

Art. $294 \quad 325$ (n.131)

Art. 534ff. 330 (n.166)

Art. 535248 (n.306), 251 (n.329), $325,329,331$ 
Art. $700 \quad 327$

Motor-en Rijwielwet (1905)

Art. 25356 (n.331)

Wegenverkeerswet (1935)

Art. 31 356, 357 (n.332), 370, 385

Burgerlijk Wetboek (1992)

Art. 6:96 361 (n.365)

Art. 6:98 343, 347 (n.274)

Art. 6:101 1, 307 (n.20), 341, 343-347, 358, 361, 362, 370, 372, 385,387 (n.15, 16)

Art. 6:162 345

Art. 6:163 345

Art. 7:658 339 (n.225), 357 (n.334), 361 (n.370), 385 (n.6)

Art. 7:952 339 (n.225)

Art. 8:109 $356($ n.330)

Wegenverkeerswet (1994)

Art. 185345 (n.257), 356-357, 361 (n.370), 370, 385

\section{FRENCH LAW}

Ordonnance de la Marine (1681)

II.8.2 242 (n.267)

III.7.10 $243($ n.273)

Code civil (1804)

Art. 1149310 (n.33)

Art. 1150 310, 312

Art. $1151 \quad 310,312$

Art. 1382310 (n.29), 313, 316, 351, 355

Art. $1383 \quad 313,351$

Art. 1384311 (n.40), 316, 351, 355, 369,384

Art. $1599311($ n.37)
Code de commerce (1807; modification 1915)

Art. 407318 (n. 84), 367 (n.397)

Loi concernant les responsabilités des accidents dont les ouvriers sont victimes dans leur travail (1898)

Art. 20317 (n.75)

Loirelative aux événements de mer (1967)

Art. $4318($ n.84)

Loi tendant à l'amélioration de la situation des victimes d'accidents de la circulation et à l'accélération des procédures d'indemnisation (Loi Badinter; 1985)

Art. 1353

Art. 2353 (n.308, 309)

Art. 3 350-351 (n.291), 354, 369, 384

Art. 4350 (n.291), 354, 355, 369, 384

Art. $5353(\mathrm{n} .308)$

\section{GERMAN LAW}

Halsgerichtsordnung of Bamberg (1507)

Art. $172 \quad 236$

Constitutio Criminalis Carolina (1532)

Art. 146 84, 235-237

Landrecht des Hertogtums Preußen (1620)

Art $4, \S 4$ of title 10, book 6

190 (n.3) 
Art 6, § 2 of title 5, book 6

237-238

Codex Maximilianeus Bavaricus

Civilis (1756)

IV 1 § 20308 (n.23)

IV 2 § 308 (n.23)

IV $3 \S 16308$ (n.23)

Allgemeines Landrecht für die preußischen Staaten (1794)

ALR I.3 §§ 27f. 298 (n.576)

ALR I.6 § 18308 (n.24)

ALR I.6 § 19308 (n.24), 309

ALR I.6 § 20 308-309

ALR I.6 § 21308 (n.24), 309

ALR I.6 § 22248 (n.306), 309 (n.24)

ALR II.8 § $1930 \quad 248$ (n.306)

ALR II.8 §§ 1911f. 309 (n.28)

Allgemeines Deutsches Handelsgesetzbuch (1861)

Art. $737 \quad 321$ (n.105)

Reichscivilprozessordnung (1877)

$\S 260324$ (n. 368)

Zivilprozeßordnung (1900)

$\S 287324,368$

Handelsgesetzbuch (1897)

$\S 736 \quad 321(\mathrm{n} .105)$

Bürgerliches Gesetzbuch (1900)

$\S 242336$

§ 254298,303 (n.2), 321 (n.104), 324 (n.130), 331, 332 (n.174), 333338, 339 (n. 223), 356, 360, 362, $370,372,385,387$ (n. 14, 15)

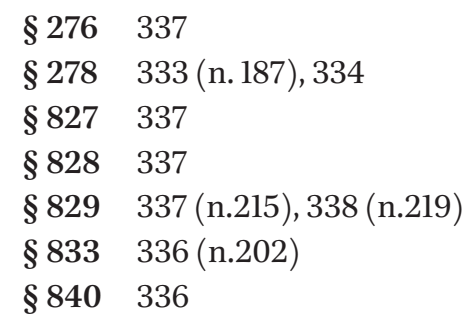

Straßenverkehrsgesetz (1952)

$\S 7355$

$\S 9356,385$

$\S 17 \quad 356$

$\S 18 \quad 356$

Atomgesetz (1959; modification

1964)

$\S 28356($ n.325)

Luftverkehrsgesetz (1968)

$\S 34356$ (n.325)

SOUTH AFRICA

Apportionment of Damages Act

(1956)

Section 1(1)(a) 306 (n.10)

\section{SOVIET UNION LAW}

Civil Code of the Russian Soviet Federative Socialist Republic (1964)

Art. 458305 (n.9)

SWISS LAW

Obligationenrecht (1881)

Art. 51 II 298, 314 (n.59), 331, 333, 362,383 
Obligationenrecht (1911)

Art. 44 (I) 298, 333 (n.183), 362

ITALIAN LAW

Codice Civile (1942)

Art. 1227310 (n.31)

\section{EU DIRECTIVES}

Directive 1985/374/EEC, [1985] OJ L $210 / 29$

Art. 8 (2) 362 (n.372)

INTERNATIONAL TREATIES

Convention for the Unification of Certain Rules of Law with respect to Collisions between vessels (1910) Art. 4 318, 329 (n.155)

United Convention on Contracts for the International Sale of Goods (1980)

Art. 77363 (n.377) 
INDEX OF CASES

HOLY ROMAN EMPIRE

Gilmann, Decisiones

Book 1, dec. 5262 (n.373)

Book 2, dec. $41262($ n.373)

GERMAN TERRITORIES

Württemberg

OTR Stuttgart, 26 February 1875, SeuffA 32, $44 \quad$ 322-322 (n.116)

German Confederation

ROHG, 7 June 1871, ROHGE 20, 40323 (n.123)

ROHG, 9 February 1875, ROHGE 16, 32323 (n.123)

ROHG, 18 March 1876, ROHGE 20, 66323 (n.123)

ROHG, 22 June 1876, ROHGE 20, 99322 (n.116)

German Empire

RG, 25 February 1882, SeuffA 37, 219323 (n.121)

RG, 15 October 1883, RGZ 10, $74 \quad 324,368,383,387$ (n.14)

RG, 25 September 1885, SeuffA 41, 89323

RG, 5 May 1891, SeuffA 48, $30 \quad 323,324$

RG, 9 May 1900, RGZ 46, $203 \quad 334$ (n.191)

RG, 5 May 1902, RGZ 51, 275336 (n.202)

RG, 12 February 1903, RGZ 53, 394334 (n.191)

RG, 14 February 1903, RGZ 54, 13338 (n.220)

RG, 13 February 1905, RGZ 60, 147334 (n.191)

RG, 21 January 1905, RGZ 60, 33334 (n.191)

RG, 11 December 1905, RGZ 62, 145334 (n.191)

RG, 21 November 1907, RGZ 67, 120334 (n.191)

RG, 11 May 1908, RGZ 68, 352334 (n.191)

RG, 09 December 1909, JW 1910, 65335 (n.191)

RG, 22 December 1910, RGZ 75, 251339 (n.222) 
ObLG Bayern, 20 May 1880, SeuffA 35, 285319 (n.92), 323 (n.118), 324 (n.125)

OLG Braunschweig, 21 November 1887, SeuffA 44, 86323 (n.118), 324 (n.125)

OLG Braunschweig, 23 April 1891, SeuffA 47, $28 \quad 324$ (n.130)

Federal Republic of Germany

BGH, 13 December 1951, NJW1952, 299360 (n.358)

BGH, 8 February 1952, NJW1952, 537338 (n.218)

BGH, 9 January 1959, BGHZ 29, 163356 (n.327)

BGH, 29 January 1969, NJW1969, 789338 (n.218)

BGH, 30 January 1979, NJW 1979, 980356 (n.327)

BGH, 1 April 1993, NJW1993, 2685360 (n.357)

BGH, 24 July 2001, NJW 2001, 3257360 (n.360)

\section{ITALY}

Olivatius, Decisiones Sacrae Rotae Romanae

$352 \quad 283-284$

Rezzonico, Decisiones Sacrae Rotae Romanae

III, 325283 (n.490)

Venturini, Decisiones Rotae Florentinae

45 282-283

Vernaccini, Collezione completa delle decisioni

II, $279 \quad$ 284-285

FRANCE

Cass. req., 8 February 1875, DPO 1875.1.320 316 (n.68)

Cass., 20 August 1879, JdP 1880, 123316

Cass. ch. réun., 13 February 1930, D.P. 1930.I.57 351-352, 369 (n.398)

Req., 13 April 1934, D.P. 1934.I.41 352

Cass. civ. 2e, 21 July 1982, D. 1982.449, JCP 1982.II.19861, RTD Civ. 1982.606 $352,369,384$

Cass. civ. 2e, 6 April 1987, D. 1988.32,JCP 1987.II.20828, RTD Civ. 1987.767 352

Crim., 4 October 1990, D. 1990.IR.284 354 (n.310)

Crim., 16 May 1991, D. 1991.IR.220 354 (n.310) 
Cass. civ., 21 July 1992, D. 1993, 212354 (n.310)

Cass. civ. 2e, 8 March 1995, Bull. Civ. 1995.II.82 349 (n.285)

C Lyon, 17 January 1844, S. 1844.2.401 315 (n.64)

C Poitiers, 29 June 1864, D. 1864.2.181 316 (n.68)

C Douai, 14 December 1846,JdP 1848, 492315 (n.64)

C Lyon, 5 May 1865, D. 1866.3.63 316 (n.68)

C Paris, 6 July 1867, D. 1871.5.334 316

CA Paris, 16 November 1871, D. 1871.2.208 316 (n.68)

\section{DUTCH REPUBLIC}

Van Bijnkershoek, Observationes Tumultuariae

1320246 (n.294), 247-248

1689249 (n.311)

$1711[686] \quad 249$

Cooren, Observationes

$40 \quad 248,250$ (n.319)

$41248($ n.305), 250 (n.319)

Neostadius, Decisiones

48243 (n.273), 246 (n.294), 248 (n.305), 250 (n.319)

49243 (n.273), 248 (n.305), 250-251, 253 (n.336)

Ockers, Decisiën

Part I, title 3, dec. $1 \quad$ 246-247

Part I, title 3, dec. 2247 (n.299)

\section{THE NETHERLANDS}

HR, 10 June 1910, W. 9038330 (n.161)

HR, 4 February 1916, NJ 1916, $450 \quad$ 329-330, 339-341, 368, 383

HR, 31 January 1919, NJ 1919, 161330 (n.161)

HR, 30 October 1925, NJ 1926, 157329 (n.155)

HR, 4 November 1977, NJ 1978, 146342 (n.240)

HR, 1 June 1990, NJ1991, 720357 (n.338)

HR, 31 May 1991, NJ 1991, $721 \quad 357$ (n.338)

HR, 28 February 1992, NJ 1993, 566358 (n.342)

HR, 27 March 1992, NJ 1992, 496339 (n.225) 
HR, 22 May 1992, NJ 1992, 527357 (n.339)

HR, 24 December 1993, NJ 1995, 236358 (n.342)

HR, 31 March 1995, NJ 1997, $592 \quad 342$ (n.240), 357 (n.332)

HR, 2 June 1995, NJ 1997, 700-702 358 (n.342)

HR, 5 December 1997, NJ 1998, 400346 (n.267)

HR, 10 November 2000, NJ 2000, 718358 (n.344)

HR, 4 May 2001, NJ 2002, 214346 (n.267), 361 (n.370)

HR, 22 April 2005, NJ 2006, $20 \quad 344$ (n.252), 346 (n.267)

HR, 3 June 2005, NJ 2005, 286347 (n.271), 358 (n.344)

HR, 13 January 2006, NJ 2006, 591 (n.3), 347 (n.269)

HR, 17 November 2006, RvdW 2006, 1076344 (n.252)

HR, 13 April 2007, NJ 2008, 576306 (n.12)

HR, 11 June 2010, NJ 2010, $333 \quad 344$ (n.252)

HR, 8 July 2011, NJ2011, $307 \quad 344$ (n.252), 346 (n.268)

Gh. Amsterdam, 28 January 1910, W. 9066329 (n.154)

Gh. Amsterdam, 31 March 1913, W. 9586327

Gh. Amsterdam, 8 February 1915, NJ 1915, 955329

Gh. Amsterdam, 16 May 1919, NJ 1919, 989327 (n.143)

A-Rb. Rotterdam, 9 December 1896, W. 6910327

A-Rb. Zierikzee, 7 June 1898, W. 7191328 (n.152)

A-Rb. Arnhem, 5 October 1899, W. 7343327 (n.149), 328

A-Rb. Rotterdam, 24 November 1902, W. 7969328 (n.152)

A-Rb. Haarlem, 20 June 1903, W. 8083327 (n.149), 328

A-Rb. Rotterdam, 6 March 1911, NJ 1914, 1223328

A-Rb. Amsterdam, 16 October 1925, NJ 1926, 996340 (n.228)

Ktg. Den Helder, 3 September 1936, NJ 1937, $138 \quad 339$ (n.225)

BELGIUM

Cass. 14 May 1992, R.W. 1993/1994, 1395359 (n.354)

COURT OF JUSTICE OF THE EUROPEAN UNION

C-145/83, Adams v Commission [1985] ECR 3539362 (n.372) 


\title{
SAMENVATTING EN CONCLUSIES
}

\author{
EIGEN SCHULD \\ EEN HISTORISCHE EN RECHTSVERGELIJKENDE STUDIE
}

\section{INLEIDING}

In dit boek wordt de invloed van eigen schuld van de gelaedeerde bij schadevergoedingsvorderingen uit buitencontractuele aansprakelijkheid bestudeerd, en wel vanaf de Oudheid tot op heden. Twee hoofdthema's staan daarbij centraal: (1) de historische ontwikkeling van de rol van eigen schuld bij buitencontractuele aansprakelijkheid, en (2) de invloed van Romeinse, canonieke en inheemse regelingen met betrekking tot eigen schuld bij buitencontractuele aansprakelijkheid op latere doctrines en codificaties.

In het kader van de behandeling van genoemde hoofdthema's, wordt een aantal deelvragen geadresseerd. Voorbeelden van deze deelvragen zijn: Wat was de visie van de Romeinse juristen uit de periode van het (voor)klassieke Romeinse recht op de rol van eigen schuld? Hoe werd het onderwerp 'eigen schuld' behandeld ten tijde van het Justiniaanse recht? Wat waren de opvattingen over eigen schuld in de periode van het middeleeuwse ius commune? Wat was de ontwikkeling van het leerstuk van de eigen schuld vanaf de receptie van het Romeinse recht tot en met de codificaties van de achttiende tot en met de twintigste eeuw? En, ten slotte, hoe gaan hedendaagse Europese juristen om met het leerstuk van de eigen schuld van de gelaedeerde (met name in Frankrijk, Duitsland en Nederland)?

Bij de bespreking van de moderne en hedendaagse codificaties, rechtspraak en doctrine (en de daaraan voorafgaande negentiende-eeuwse ontwikkeling), is bijzondere aandacht besteed aan de mate waarin deze codificaties, rechtspraak en doctrines werden beïnvloed door benaderingen van eigen schuld in het ius commune, het natuurrecht en de Duitse Pandektistiek. Bovendien wordt bezien in welke mate deze rechtssystemen een eigen, unieke benadering ten aanzien van de rol van eigen schuld hebben ontwikkeld. Speciale aandacht wordt ook gegeven aan het rechtsgevolg van eigen schuld: alles-of-niets of een verdeling van de schade tussen laedens en gelaedeerde. Tevens wordt bezien welke oplossingen in verschillende periodes van de (rechts)geschiedenis werden gekozen en wat de dogmatische redenen waren die juristen voor deze 
oplossingen gaven. In het onderstaande worden de belangrijkste bevindingen van dit boek samengevat.

\section{ROMEINSE RECHT IN DE OUDHEID}

Bij de studie van het Romeinse recht in de Oudheid is een onderscheid gemaakt tussen de periode van het klassieke Romeinse recht en het Justiniaanse recht. Beide periodes in de ontwikkeling van het Romeinse recht zijn voor deze studie van belang. De benadering van de klassieke Romeinse juristen van het probleem van eigen schuld is niet alleen interessant vanuit comparatief juridisch perspectief, maar ook om de latere standpunten van de humanisten en twintigste-eeuwse geleerde (Romanistische) studies te kunnen begrijpen en te plaatsen. In het bijzonder dient men, om de visies van de humanisten te kunnen begrijpen, het gezichtspunt van het klassieke Romeinse recht in het hoofd te houden. Hoewel in deze studie slechts één leerstuk is bestudeerd, namelijk de eigen schuld, kan toch reeds worden aangetoond dat bepaalde clichés ter discussie moeten worden gesteld. Zo bleek bijvoorbeeld dat de humanisten meer geworteld waren in de juridische praktijk dan gewoonlijk wordt aangenomen. Om de middeleeuwse en de latere ontwikkeling van het leerstuk van de eigen schuld te kunnen begrijpen, dient het Justiniaanse recht als uitgangspunt te worden genomen.

Wat waren de gevolgen van het gedrag van de gelaedeerde voor de aansprakelijkheid van de laedens? De conclusie voor 'het Romeinse recht' dat de gelaedeerde geen recht op schadevergoeding had indien zijn schuld had bijgedragen aan het ontstaan van de schade, is onjuist. De regel van D. 50.17.203 kan in het klassieke Romeinse recht namelijk niet als algemene regel worden gezien. Slechts omdat de compilatoren van deze tekst er in de Justinaanse codificatie een algemene regel hebben gemaakt, en wel door hem te plaatsen in de titel De diversis regulis iuris antiqui, kon hij een van de uitgangspunten worden voor de (middeleeuwse) theorie over eigen schuld. Overigens bestond er in het (post-)klassieke Romeinse recht geen specifieke juridische notie van 'eigen schuld' zoals wij die tegenwoordig kennen.

De klassieke Romeinse juristen keken slechts of de schade, gezien de omstandigheden van het geval, al dan niet te wijten was aan de schuld van de laedens. De toepassing van de culpae compensatio-leer op teksten uit de Digesten moet als anachronistisch worden bestempeld, aangezien deze leer stamt uit de middeleeuwse periode. Bepaalde Digestenteksten, bijvoorbeeld die over de speerwerpers (D. 9.2.9.4), laten zien dat klassieke Romeinse juristen het culpavereiste op een casuïstische wijze benaderden. Vaak maakten zij gebruik van 
de status-theorie van Hermagoras van Temnos, die het hen mogelijk maakte om het juridische probleem in kwestie nauwkeuriger te beargumenteren. De casus uit de Digesten die in het kader van deze studie zijn bestudeerd, laten zien dat er geen technische (dogmatische) theorieën over eigen schuld in de responsa van de klassieke (Romeinse) juristen zijn te vinden.

Vanwege het poenale karakter van de actio legis Aquiliae en de bewoording(en) van de lex Aquilia was de enige, uiteindelijk te beantwoorden vraag in het klassieke Romeinse recht of de laedens al dan niet culpoos had gehandeld. In het kader van de formula-procedure kon de iudex enkel de aangeklaagde veroordelen tot het betalen van de poena, namelijk indien hij ervan overtuigd was dat de vereisten van de formula vervuld waren, of hij kon hem vrijspreken indien hij niet tot dit laatste oordeel kwam - een tussenoplossing was niet mogelijk. De mogelijkheid om de hoogte van de poena te verminderen op grond van eigen schuld van de gelaedeerde bestond niet. Deze zgn. alles-of-nietsbenadering werd behouden in het Justiniaanse recht en bleef gehandhaafd totdat de lex Aquilia haar poenale karakter in de vroegmoderne tijd verloor.

Voor bestudering van het Justiniaanse recht kunnen de ons overgeleverde fragmenten over de lex Aquilia, hoewel geschreven door verschillende Romeinse juristen, in onderlinge samenhang worden gelezen, aangezien zij als onderdeel van één en dezelfde titel als wetgeving zijn uitgevaardigd door keizer Justinianus. Daarnaast kunnen ze worden gelezen in samenhang met andere teksten uit de compilatie van Justinianus, zoals D. 50.17.203, dat een rechtsregel bevat die vanaf de Justiniaanse tijd wordt beschouwd als een algemeen beginsel. Deze laatste benadering is met name zinvol bij bestudering van D. 9.2.9.4 en het laatste gedeelte van D. 9.2.11pr. De conclusie dat de gelaedeerde naar Romeins recht geen schadevergoeding kon verkrijgen indien zijn gedrag had bijgedragen aan het ontstaan van de schade, is enkel juist indien het Romeinse recht wordt geïnterpreteerd als Justiniaans recht.

Afsluitend kan worden gesteld dat het in de Oudheid niet mogelijk was om (schade)vergoeding te vorderen wanneer de eigen schuld van de gelaedeerde had bijgedragen aan het ontstaan van zijn verwonding of de schade. In dat geval zou het onredelijk zijn om de laedens een straf op te leggen. Formeel werd de actie tot (schade)vergoeding afgewezen vanwege het feit dat de vereisten van de lex Aquilia niet waren vervuld. In dit opzicht is het ook van belang te vermelden dat in het klassieke Romeinse recht geen mogelijkheid tot schuldweging bestond, maar het enkel aankwam op een waardering van het al dan niet schuldige gedrag van de laedens. De culpae compensatio-leer werd vermoedelijk pas geïntroduceerd in de middeleeuwse rechtswetenschap. Een afweging van fouten werd in het Justiniaanse recht naar alle waarschijnlijkheid ook niet gemaakt. Enkele verspreide fragmenten in de Digesten, buiten het 
gebied van de onrechtmatig toegebrachte zaakschade om, zouden een indicatie kunnen geven van een beperking van de aansprakelijkheid van de laedens. In deze gevallen, die gevolgschades betreffen, werd de schade echter louter veroorzaakt door een foute gedraging van de gelaedeerde. De uitzonderlijke, casuïstische beslissingen in deze fragmenten vormen echter geen afdoende bewijs om het bestaan van een algemene regel aan te nemen tot restrictie van de omvang van schadevergoeding in geval van eigen schuld van de gelaedeerde; in elk geval bestond deze restrictie niet in de klassieke periode. Genoemde teksten (D. 19.1.11.12 en D. 19.1.45.1) blijken echter toch relevant omdat ze in latere periodes in de rechtsgeschiedenis werden gebruikt.

\section{HET MIDDELEEUWSE IUS COMMUNE}

\subsection{De MidDELEeUWSE BESTUdERING VAN HET RoMEINSE RECHT}

De vraag hoe men het (eigen) handelen van de gelaedeerde juridisch moet kwalificeren, werd in de middeleeuwse periode voor de eerste keer expliciet gesteld toen de handelingen van beide betrokken partijen naast elkaar werden bediscussieerd. Uit de middeleeuwse interpretaties van teksten uit het Corpus Iuris blijkt dat 'eigen schuld' van de gelaedeerde werd beschouwd als laakbaar wangedrag dat ertoe leidde dat de gelaedeerde (in beginsel) geen schadevergoeding kon verkrijgen. Een gevolg van deze opvatting was dat eigen schuld van de gelaedeerde werd beschouwd als een juridisch probleem. In de middeleeuwse periode kunnen twee uitgangspunten voor het leerstuk van de eigen schuld worden geïdentificeerd. Het eerste uitgangspunt is de leer van de culpae compensatio; het tweede uitgangspunt is vereenzelvigd met de regel zoals neergelegd in D. 50.17.203.

Bij de culpae compensatio-leer namen de glossatoren de schuld van beide partijen in beschouwing. Zij pasten culpae compensatio toe op situaties waarin beide partijen schuld van dezelfde soort of in dezelfde mate hadden. De Glossa Ordinaria verschaft geen expliciet bewijs voor het feit dat de glossatoren van mening waren dat culpae compensatio enkel kon worden toegepast op gevallen waarin beide partijen in dezelfde mate schuld hadden aan het ontstaan van de schade, of ook op gevallen waarin de ernst van de schuld aan weerszijden ongelijk was. Daarom sloot elk soort eigen schuld, zolang deze kon worden gekwalificeerd als culpa, de gehele aansprakelijkheid van de laedens uit. Een vergelijking van de omvang van de schuld van partijen, en een verfijning in de zin dat een zeer geringe mate van eigen schuld niet zou leiden tot compensatio en dus tot het verlies van de mogelijkheid om een schadevergoeding/boete te 
verkrijgen, werden vermoedelijk eerst door de opvolgers van de glossatoren gemaakt op instigatie van de canonisten. Sommige middeleeuwse legisten gebruikten culpae compensatio om problemen van eigen schuld op te lossen in gevallen van damnum iniuria datum, in het bijzonder Paulus de Castro.

Ten aanzien van het tweede uitgangspunt kan worden opgemerkt dat Accursius D. 50.17.203 in verband bracht met het delictenrecht. ${ }^{1}$ Volgens Accursius zal de eigen schuld van de gelaedeerde hem ervan weerhouden om van iemand anders schadevergoeding te vorderen. De tekst van D. 50.17.203 zou kunnen worden opgevat alsof deze uitsluitend betrekking had op de situatie dat er alleen schuld was aan de zijde van de gelaedeerde. Accursius meende echter dat de regel van D. 50.17.203 niet beperkt was tot gevallen waarin enkel de schuld van de laedens buiten twijfel stond. Het is echter vrij opmerkelijk dat de voorbeelden van toepassing van de rechtsregel van D. 50.17.203 die later door de commentatoren werden genoemd uitsluitend gevallen betreffen waarin er enkel aan de zijde van de gelaedeerde sprake was van schuld en derhalve geen sprake kon zijn van medeschuld. Dit is opmerkelijk, aangezien Accursius de deur had opengezet voor een ruimere toepassing van de regel.

Een laatste opmerking dient te worden gemaakt ten aanzien van de precieze dogmatische basis voor de afwijzing van de vordering tot schadevergoeding in het geval van eigen schuld. De middeleeuwse interpretaties van het Romeinse recht laten verschillende benaderingen zien, benaderingen die overigens ook aanwezig waren in de latere rechtsgeschiedenis. De eerste benadering betrok ook het gedrag van de gelaedeerde bij het bepalen van de verwijtbaarheid van de handeling van de laedens. Volgens deze benadering kon de handeling van de gelaedeerde dus niet echt als 'eigen schuld' worden gezien. In de tweede benadering werd gesteld dat de handeling van de gelaedeerde onder zijn eigen verantwoordelijkheid viel en leidde dit tot het ontbreken van verantwoordelijkheid en aansprakelijkheid van de laedens. Volgens de derde benadering werd de gelaedeerde beschouwd zelf zijn schade te hebben veroorzaakt en werd hem de vordering tot schadevergoeding op die grond geweigerd. Hij had zich immers zelf aan gevaar blootgesteld.

1 Zie glosse Quod quis ad D. 50.17.203. 


\subsection{MiddeleEUWS CANONIEK RECHT}

Volgens het canonieke recht kon eigen schuld van de gelaedeerde worden beschouwd als een medeoorzaak van het intreden van de schade. In dergelijke gevallen moest daarom worden onderzocht of de handeling van de laedens dan wel die van de gelaedeerde de meest nabijgelegen oorzaak (causa proxima) van de schade was. Het lijkt erop dat men de causale bijdragen van beide partijen vergeleek. Echter, veroorzaking en schuld schijnen in deze periode niet te worden gescheiden. Bovendien pasten de canonisten culpae compensatio op verschillende terreinen toe, zij het dat het hier zelden ging om het delictenrecht, tenzij het delicten betrof waarbij geen van beide partijen geestelijke was. Bij de vraag of een geestelijke al dan niet een hogere wijding kon worden verleend, was dit echter volgens het commentaar van Animal op D.50 c.50 anders, omdat in dit geval de culpa van de geestelijke nooit kon worden gecompenseerd door de culpa van de gelaedeerde. De schrijver van Animal stelde ook dat de geestelijke nooit kon worden gepromoveerd naar een hogere rang wanneer de laedens en de gedode gelaedeerde beiden schuld hadden aan het feit, zelfs wanneer de verwijtbaarheid van de laedens geringer was dan die van de gelaedeerde.

Twee canonisten hebben zich expliciet uitgelaten over de positie van de gelaedeerde in de casus van X 5.12.9. Met betrekking tot deze casus schreef Bernardus Parmensis dat het erin vervatte dodelijke ongeval toe te schrijven was aan de schuld (culpa) van de gelaedeerde. Men dient hierbij in gedachten te houden, dat de vraag voor de Paus in deze zaak enkel was of de geestelijke wel of niet met schuld gedood had en of de geestelijke derhalve wel of niet kon worden gepromoveerd (en ook of dispensatie noodzakelijk was). Men dient terughoudend te zijn met de conclusie dat de canonisten in geval van 'eigen schuld' (waarvan hier eigenlijk in het geheel geen sprake was) gewoon waren de partij met de grootste schuld als de enige schuldige aan te merken vanwege het ontbreken van de mogelijkheid om de schade tussen partijen te verdelen (analoge interpretatie).

Hostiensis (Henricus de Segusio) was van mening dat in de beschreven casus de gelaedeerde geestelijke zich ervan bewust had moeten zijn dat het gebruikelijk was om een aan een riem bevestigd mes te dragen. Hij had voorzichtig moeten zijn. Het lijkt er daarom op dat 'eigen schuld' leidde tot de vaststelling dat er enkel schuld aanwezig was aan de kant van de gelaedeerde. Men kan, zoals sommige hedendaagse rechtsgeleerden doen, stellen dat de aansprakelijkheid van de laedens in kwestie wegvalt vanwege de zwaarderwegende eigen schuld van de gelaedeerde. Hoewel het in de betreffende rechtszaken voor de Paus in het geheel niet ging om de aansprakelijkheidsvraag, kan, wanneer men deze teksten zou bekijken vanuit een modern perspectief, worden gesteld dat de 
meerderheid van de in het kader van deze studie bestudeerde commentaren van decretalisten deze theorie niet volgen. Enkel de twee zojuist genoemde kanttekeningen van de invloedrijke Bernardus Parmensis en Hostiensis kunnen een indicatie vormen van het feit dat deze theorie werd toegepast.

Later, tegen het einde van de middeleeuwse periode, werd hoofdzakelijk in consilia-literatuur de term culpa admixta (letterlijk 'gemengde schuld') gebruikt om het gedrag van de gelaedeerde te kwalificeren op een manier die leidde tot de uitsluiting van aansprakelijkheid van de laedens. Op deze wijze leidde eigen schuld tot een afwijzing van de vordering van de gelaedeerde zonder discussie over de ernst van ieders schuld. Het gebruik van de term culpa admixta (of culpa communis) laat zien dat de geleden schade werd beschouwd als een gemeenschappelijke verantwoordelijkheid van beide partijen (laedens en gelaedeerde).

\subsection{ENKELE AFSLUiTENDE WOORDEN OVER HET MIDDELEEUWSE IUS COMMUNE}

Een alles-of-niets benadering in het geval van 'eigen schuld' zoals deze hierboven werd beschreven, werd ook gevolgd in enkele middeleeuwse bronnen buiten de romano-canonieke traditie (iura propria-inheems recht). In sommige andere middeleeuwse bronnen (bijvoorbeeld die van het middeleeuwse Ierse recht) kan een verdeling van de schade in sommige gevallen echter wel worden gevonden. Eigen schuld van de gelaedeerde kon dan leiden tot een gedeeltelijke vergoeding, het zogenoemde judicium rusticorum, dat wil zeggen een reductie van de schadevergoeding tot $1 / 3$ van de gehele schade. Dit judicium rusticorum is van belang omdat het in latere periodes in de rechtsgeschiedenis opnieuw voorkomt, zoals bijvoorbeeld in het Rooms-Hollandse recht.

\section{DE HUMANISTISCHE BIJDRAGE}

Hoewel de humanisten het initiatief namen tot de reconstructie van de oorspronkelijke samenhang van de Digestenfragmenten in het klassieke recht en aldus D. 50.17.203 trachtten terug te plaatsen in de oorspronkelijke klassieke context, zijn de voorbeelden van de toepassing van de in deze tekst vervatte regel door humanistische juristen hoofdzakelijk dezelfde als die uit de middeleeuwse periode. Bovendien verbonden de humanisten de regel van D. 50.17.203 met de gevallen van D. 9.2.52.1, D. 9.2.9.4 en D. 9.2.11pr. zonder te kijken naar de verschillende palingenetische contexten. Op te merken valt dat expliciet werd gezegd dat deze laatste teksten gevallen betroffen waarin de 
gelaedeerde met schuld handelde. Daarnaast is het verband tussen D. 9.2.9.4 en D. 9.2.10, zoals aangenomen door de humanisten, palingenetisch niet verdedigbaar, noch het feit dat D. 9.2.9.4 en D. 9.2.10 worden beschouwd als voorbeelden van een situatie waarin beide partijen schuld hebben. Ook bleek dat sommige humanistische juristen op materieelrechtelijk vlak soms sterk in de traditie van het mos italicus bleven staan; zo beschouwden enkelen de rechtsregel in D. 9.2.52.1 als een voorbeeld van een compensatie van onrechtmatigheden, of als een voorbeeld van zelfverdediging.

Enkel door D. 9.2.9.4 en D. 9.2.11pr. te beschouwen als voorbeelden van de situatie waarin beide partijen schuldig waren aan (het ontstaan van) de schade, konden de schuldige handelingen vergeleken worden en kon theorievorming plaatsvinden. Een van de theorieën continueert de toepassing van culpae compensatio. Bovendien treft men in deze theorie de eerste sporen aan van de gravior culpa-benadering (A. Faber) en de maior culpa-benadering (M. Freher en G. Noodt). Een andere, nieuwe ontwikkeling van groot belang was, dat wellicht H. Donellus, maar in ieder geval P. Faber en J. de Sande, voor het eerst in de continentale Romeinsrechtelijke traditie melding maakten van de mogelijkheid van een gedeeltelijke vergoeding van de schade.

\section{RECEPTIE, ROOMS-HOLLANDS RECHT EN USUS MODERNUS}

Mijn onderzoek naar de vraag waarom de gelaedeerde geen recht had om schadevergoeding te vorderen ging uit van de veronderstelling dat de algemene actio de damno data nog altijd was gebaseerd op de alles-of-niets benadering. In de vroegmoderne tijd was een algemene actie voor onrechtmatig toegebrachte schade ontstaan, een actie die nog slechts in naam Romeins was. In deze periode begon ook de gedachte post te vatten, dat alleen als de schuld van de gelaedeerde even groot was als, of groter dan de schuld van de laedens, de aansprakelijkheid van de laedens verviel. Niet alle juristen volgden echter deze culpa maior-variant van de culpae compensatio-leer om het eigenschuldprobleem op te lossen. Bovendien werden andere wegen bewandeld in de benadering van deze problematiek.

Enkele Rooms-Hollandse geleerden bleven de sedes materiae uitleggen op een middeleeuwse manier, maar zij probeerden bovendien de teksten te situeren in hun eigen tijd. Anderen pasten het criterium van de maior culpa toe. Een voorbeeld hiervan vormt Johannes Voet. In het Rooms-Hollands recht zijn in het bijzonder casus van botsingen van schepen interessant. In deze zaken werd een ander uitgangspunt gehanteerd dan in het Romeinse recht. Indien 
schip A schip B zonder schuld geraakt had, moest de eigenaar van schip A nog steeds de helft van de schade betalen. Maar in het geval dat twee schepen tegen elkaar aan botsten en beide schepen hieraan schuld droegen, waren er twee verschillende opvattingen over wat het recht dicteerde: (1) De schade moest aan beide zijden gelijk worden gedragen, aangezien de schuld aan beide zijden gelijk was (dit was de visie van de Hoge Raad van Holland, Zeeland en WestFriesland); (2) De eigen schade diende door elke partij te worden gedragen, omdat iemand die schuld heeft geen actie kan instellen en omdat de schade niet wordt beschouwd als verhaalbare schade, cf. D. 50.17.203 (dit was de visie van Van Bijnkershoek en Van der Keessel). Een ander probleem vormde de vraag wat het recht voorschreef in het geval dat een stilliggend schip werd geraakt door een varend schip. Van der Keessel beschouwde de schuld van het laatstgenoemde schip als zwaarder, en daarom kon volgens hem geen culpae compensatio plaatsvinden (zie hier de toepassing van de ius commune-theorie). Eén schip moest daarom de helft van de schade van het andere schip dragen; dit is vergelijkbaar met de idee van de verdeling van schade en ook met de oude traditie van het judicium rusticorum, maar dan met één vernieuwing, namelijk dat bij culpa maior de helft van de schade van de andere partij moet worden vergoed.

Verscheidene dogmatische uitgangspunten om het probleem van eigen schuld op te lossen kunnen worden gevonden in literatuur uit de periode van de usus modernus in Duitsland. Door sommige usus modernus-auteurs werd de vraag naar het gedrag van de de gelaedeerde beschouwd als een causaliteitsprobleem. Door anderen werd deze vraag beschouwd als een schuldvraag, namelijk als een samenloop van fouten. Ook kunnen verscheidene varianten van culpae compensatio worden gevonden, waaronder de variant waarbij het loutere bestaan van eigen schuld, zelfs in een zeer geringe mate, leidde tot het ontnemen van de mogelijkheid om schadevergoeding te verkrijgen, en de variant waarbij enkel gelijke of zwaarderwegende eigen schuld aansprakelijkheid uitsloot (maior culpa). Nog een andere oplossing was om het eigenschuldprobleem op te lossen zonder enige verwijzing naar de eigen schuld van de gelaedeerde. In deze variant was de schuld van de laedens de enige relevante factor en werd de eigen schuld van de gelaedeerde niet beschouwd als een afzonderlijk juridisch vraagstuk. In een laatste oplossing, een alternatieve manier om het probleem van de eigen schuld op te lossen, werd voorzien door het gebruik van het criterium van de auctor rixae. De aanstichter van een gevecht kon geen vergoeding eisen voor verwondingen, opgelopen tijdens dit gevecht, tenzij de andere partij excessief ter zelfverdediging had gehandeld (noodweerexces). 
In Italië was het criterium van de auctor rixae verbonden met het concept culpa admixta. Indien iemand een gevecht begon of een gevecht provoceerde (de zogenaamde auctor rixae), werd zijn schuldig gedrag gekwalificeerd als culpa admixta, hetgeen leidde tot het geheel afwijzen van zijn vordering tot schadevergoeding. De Rota Romana verkondigde hierbij soms de opvatting dat eigen schuld, hoe gering ook, moest leiden tot afwijzing van de schadevergoedingsvordering, terwijl de Rota in andere gevallen culpa maior aan de zijde van de gelaedeerde leek te vereisen, een visie die ook De Luca aanhing.

Blijkbaar was er in de vroegmoderne tijd een discussie gaande over de vraag welk soort schades vergoed moest worden, en in het bijzonder of immateriële schade wel of niet voor vergoeding in aanmerking kwam. Bij ruzies kon de provocerende partij, als de reactie van de geprovoceerde partij excessief was, enkel vergoeding van medische kosten vorderen, maar - volgens de heersende leer - geen immateriële schadevergoeding. In twee gevallen verhinderde een geringe mate van eigen schuld de vordering van de gelaedeerde tot schadevergoeding niet, maar werd die schuld in aanmerking genomen om de omvang van de schadevergoedingsplicht te bepalen. Deze gevallen betreffen echter het al dan niet vergoeden van bepaalde soorten schades; er vond geen vermindering van de gehele schade plaats. De alles-of-niets-benadering moet dus voor de vroegmoderne periode nog steeds als geldend worden beschouwd.

\section{DE NATUURRECHTSGELEERDEN}

Enkele geleerden bleven de 'oude' ius commune-benadering volgen: bij eigen schuld van de gelaedeerde paste men simpelweg de regel van D. 50.17.203 toe. In dergelijke gevallen leidde de toepassing van deze regel ertoe dat de vordering tot schadevergoeding in haar geheel verviel. Mogelijkerwijze werd deze benadering toegepast door Grotius, maar in ieder geval deden Domat en Pothier dit. Anderen, zoals Pufendorf and Thomasius, pasten het criterium van culpa maior toe. In beide benaderingen was het juridische gevolg hetzelfde: als er eigen schuld was aan de zijde van de gelaedeerde respectievelijk als de eigen schuld van de gelaedeerde zwaarder woog dan de schuld van de laedens, werd de vordering tot schadevergoeding van eerstgenoemde afgewezen. In dit opzicht werd de alles-of-niets-benadering nog steeds toegepast.

De mogelijkheid tot verdeling van schade tussen de laedens en de gelaedeerde (in evenredigheid met de mate van ieders schuld, respectievelijk met de mate van de causale bijdrage van de handeling van elke partij), vindt 
zijn oorsprong in de 'Aufklärungstheorie' van Christian Wolff' en is dan ook een relatief recent fenomeen. Maar de beoordeling en de afweging van de respectieve gradaties van schuld van partijen was reeds een stap in deze richting. Hoewel Wolff het traditionele alles-of-niets-beginsel als eerste opzij heeft gezet, kan zijn benadering dus tevens als voortzetting van de eraan voorafgaande ontwikkeling worden gezien. Wolff behandelde eigen schuld niet op abstracte wijze, maar enkel in verband met concrete gevallen. Hij behandelde de vergoedingsplicht niet in het kader van een gepleegde onrechtmatige daad. In dit verband is het eerdergenoemde en oudere geval, opgenomen in de Selectae decisiones van Schoepff, een veel duidelijker voorbeeld van een gedeeltelijke vergoeding van schade bij aansprakelijkheid voor onrechtmatig toegebrachte schade, in die zin dat bepaalde specifieke soorten schades (namelijk de kosten van levensonderhoud) niet verhaalbaar zijn vanwege de eigen schuld van de gelaedeerde.

\section{HET CONCEPT ‘EIGEN SCHULD’ IN DE NEGENTIENDE EEUW}

De France Code civil (1804) bevat geen algemene bepaling over eigen schuld. Eigen schuld werd wel behandeld in de rechtspraak, in het bijzonder van de Cour de cassation. Aan het einde van de negentiende eeuw leidde de situatie waarin gelaedeerde en laedens beiden schuld hadden aan de schade (dit werd gekarakteriseerd als faute commune) tot een verdeling van de schade in evenredigheid met de omvang van ieders schuld. De ontwikkeling in Frankrijk werd geïnitieerd door de acceptatie van de discretionaire bevoegdheid van de rechter bij de waardering van de vraag of, in gevallen waarin beide partijen schuld hadden aan het ontstaan van de schade, genoemde schuld aanleiding zou geven tot aansprakelijkheid en bij het vaststellen van het door elk der partijen te dragen deel van de schade. Een verdeling op basis van de omvang van ieders schuld werd geaccepteerd door de meerderheid van de rechtsgeleerden en rechters, hoewel die laatsten aanvankelijk vasthielden aan de toepassing van het beginsel zoals neergelegd in D. 50.17.203 (dit hoewel de Digesten geen formele bron van recht vormden - een directe verwijzing naar D. 50.17.203 heb ik dan ook niet gevonden), wat leidde tot de afwijzing van de vordering tot schadevergoeding. Hoewel in Frankrijk geen (directe) verwijzing naar het werk van Wolff kon worden gevonden, is het mogelijk dat zijn ideeën een bestanddeel hebben gevormd van de intellectuele bagage van de negentiende-

2 Hij was van mening dat wanneer zowel laedens als gelaedeerde schuld hadden aan het ontstaan van een schade, die schade moest worden gedragen door beide partijen in evenredigheid met de omvang van ieders schuld. 
eeuwse Franse juristen. De gevolgen van de oplossing die werd geboden door de Franse doctrine waren niet exact hetzelfde als die Wolff voor ogen had, maar de juridische gevolgen waren wel min of meer gelijk. Wolffs opvatting werd overigens gecodificeerd in § 1304 van het Oostenrijkse Allgemeine Bürgerliche Gesetzbuch (1811), in welk wetsartikel tevens discretionaire bevoegdheid aan de rechter werd gegeven ten aanzien van de bepaling van de gevolgen van eigen schuld van de gelaedeerde.

De situatie in het negentiende-eeuwse Duitsland was anders. De juristen van de Historische School reproduceerden enkel Romeinsrechtelijke teksten en verdedigden de opvatting dat er geen aanspraak op schadevergoeding kon bestaan wanneer de gelaedeerde zelf (enige) schuld had aan (het ontstaan van) zijn eigen schade. Daarentegen werd ook in de op de praktijk gerichte literatuur het criterium van de maior culpa toegepast. Ten aanzien van de alles-of-niets-benadering vond er bovendien in dit literaire genre een aanpassing plaats, omdat gesteld werd dat volgens de beginselen, opgenomen in D. 19.1.11.12 en D. 19.1.45.1, de individuele gevolgschades waarvoor de gelaedeerde aansprakelijk was niet konden worden toegeschreven aan de laedens. Dit was in feite een eerste poging om te ontsnappen aan de alles-of-niets-benadering (en dus de ius commune-traditie). Desalniettemin overleefde de maior culpa-variant, en wel in de Duitse usus modernus in de negentiende eeuw. De Pandektisten zochten naar nieuwe dogmatische gronden om de afwijzing van de vordering tot schadevergoeding in het geval van eigen schuld te rechtvaardigen. Hun theorieën waren hoofdzakelijk causaliteitstheorieën, gebaseerd op de gedachte van een verbreking van het causaal verband tussen het gedrag van de laedens en de geleden schade in het geval van eigen schuld van de gelaedeerde. Een leer die hier (vaak) mee verbonden was, was de leer van de schuldcompensatie (culpae compensatio), (nu) gebaseerd op de regel van D. 50.17.203. Later werd de billijkheid beschouwd als de grondslag van de regel van D. 50.17.203. In de rechtspraktijk wezen rechters de vordering van de gelaedeerde reeds af bij een geringe mate van eigen schuld. Ter vermijding van onbillijke uitkomsten, verzette men zich in de rechtspraktijk echter in toenemende mate tegen deze benadering. In 1883 werd een vermindering van de omvang van de vergoedingsplicht in het geval van eigen schuld voor het eerst aanvaard door het Duitse Reichsgericht. In Zwitserland was, net iets eerder, de natuurrechtelijke oplossing (in het bijzonder in artikel 51 II van het Schweizerische Obligationenrecht 1881) gecodificeerd, onder invloed van zowel het Oostenrijkse Allgemeine Bürgerliche Gesetzbuch als ook van de Franse rechtsgeleerde doctrine. Uiteindelijk werd door de samenstellers van het Duitse Bürgerliche Gesetzbuch (1900) ten aanzien van het leerstuk van de eigen schuld de oplossing van het Zwitserse wetboek als voorbeeld genomen 
en werd, ook onder invloed van de rechtspraak, de Zwitserse regeling integraal overgenomen.

In het Nederlandse Burgerlijk Wetboek van 1838 kwam geen algemene bepaling inzake eigen schuld voor. Tot aan het begin van de twintigste eeuw werd een afweging gemaakt van de zwaarte van de wederzijdse fouten van partijen, in die zin dat het beslissend was wie de meest zwaarwegende schuld had. Enkel wanneer de eigen schuld van de gelaedeerde minder ernstig was dan die van de laedens, had de gelaedeerde recht op schadevergoeding, dat wil zeggen op een vergoeding van $100 \%$. De alles-of-niets-benadering, gebaseerd op de maior culpa-variant van de culpae compensatio-doctrine, werd nog steeds gevolgd. De juridische basis voor het ontbreken van een vordering tot schadevergoeding wanneer de eigen schuld van de gelaedeerde had bijgedragen aan het ontstaan van de schade bleef gedurende de hele twintigste eeuw betwist. Volgens de meerderheidsopvattingen was het echter de billijkheid, die tot het ontbreken van de vordering aanleiding gaf. Men stelde dat de schade diende te worden aangerekend aan het slachtoffer indien het had kunnen voorkomen dat het ongeval geschiedde. Er kwam pas een einde aan de alles-of-niets-benadering toen de Hoge Raad in een arrest uit 1916 besliste dat de vergoedingsplicht moet worden afgemeten naar de mate waarin ieders schuld heeft meegewerkt tot het veroorzaken van de schade.

\section{HET LEERSTUK VAN DE 'EIGEN SCHULD' IN HET HEDENDAAGSE RECHT}

Tegenwoordig is in Frankrijk de verdeling van de schade bij buitencontractuele aansprakelijkheid gebaseerd op de ernst van de fouten van partijen. Eigen schuld lijkt (geheel of gedeeltelijk) het causale verband tussen de handeling van de laedens en de schade te hebben verbroken. In beginsel leidt een faute de la victime tot een gedeeltelijke vergoeding van diens schade. De vordering tot schadevergoeding wordt enkel geweigerd indien de faute de la victime kan worden gezien als een externe oorzaak van de schade, die onvoorzienbaar en onvermijdelijk was, en die de enige oorzaak van de schade vormt. Naast de ernst van de fouten worden ook andere omstandigheden in aanmerking genomen bij de afweging, bijvoorbeeld de causale invloed. Bovendien behoeft er, als de faute van de gelaedeerde veel ernstiger is dan die van de laedens, dat wil zeggen bij opzettelijk wangedrag, provocatie of toestemming van de gelaedeerde, geen schadevergoeding te worden betaald.

Met betrekking tot de risicoaansprakelijkheid van art. 1384 Code civil was aanvankelijk een algehele bevrijding van de vergoedingsplicht van de laedens 
enkel mogelijk in het geval van een van buitenaf komende oorzaak, dat wil zeggen een fait de la victime dat onvoorzienbaar en onvermijdbaar was. Vanaf 1934 was een vermindering van de omvang van de vergoedingsplicht bij eigen schuld mogelijk. Deze werd gebaseerd op de ernst van ieders fout en wel tot 1982, toen de Cour de cassation besliste dat een dergelijke verdeling in het geval van eigen schuld niet meer mogelijk was (Desmares zaak), wat in feite een terugkeer naar de alles-of-niets-benadering inhield. Kort na de hervorming door de Loi Badinter in 1987 kwam de Cour de cassation terug op de Desmaresbeslissing en voerde opnieuw het beginsel in, dat de houder (gardien) van een object gedeeltelijk bevrijd is van zijn vergoedingsplicht wanneer de faute van het slachtoffer bijgedragen heeft aan het ontstaan van de schade die veroorzaakt werd door de zaak (voor gevallen die niet vielen onder de Loi Badinter). Indien de eigen schuld van het slachtoffer kan worden gekarakteriseerd als een van buitenaf komende oorzaak die leidt tot force majeure, wordt natuurlijk geen aansprakelijkheid aangenomen.

Met betrekking tot verkeersongevallen hanteert het Franse recht, op grond van de Loi Badinter (1985), een algemene regel tot een in beginsel volledige vergoedingsplicht voor personenschade voor de eigenaar of houder (of de aansprakelijkheidsverzekeraar) van gemotoriseerde voertuigen. De regels over 'eigen schuld' kunnen worden gevonden in art. 3 en 4 van de Loi Badinter. Deze verschillen aanzienlijk van de normale regels over eigen schuld in het Franse onrechtmatigedaadsrecht. Voor ongemotoriseerde verkeersslachtoffers wordt in het Franse recht nog steeds een alles-of-niets-benadering toegepast. Indien het slachtoffer behoort tot een speciale categorie van beschermde personen (kinderen onder de 16 jaar, personen ouder dan 70 jaar of personen met een blijvende invaliditeit van 80 procent of meer), zal steeds volledige schadevergoeding moeten worden betaald. Alleen in geval de tot deze categorie behorende gelaedeerde de schade (vrijwillig) over zich heeft afgeroepen, dat wil zeggen in het geval hij opzettelijk handelde, heeft hij geen recht op schadevergoeding. Voor andere personen - slachtoffers - wordt 100 procent van de schade vergoed, tenzij er sprake is van een onverschoonbare fout van de gelaedeerde en die fout tevens wordt aangemerkt als de uitsluitende oorzaak van de schade. Hetzelfde geldt als het slachtoffer de schade (vrijwillig) over zich heeft afgeroepen, dat wil zeggen in het geval hij opzettelijk handelde. In dit geval heeft het slachtoffer geen enkel recht op schadevergoeding.

In Duitsland werd Mitverschulden gecodificeerd in $§ 254$ van het Bürgerliche Gesetzbuch (1900). De toepassing van dit wetsartikel leidt tot een schadeverdeling die is gebaseerd op de omstandigheden van het geval, en die in het bijzonder afhankelijk is van de vraag in hoeverre de schade overwegend door de ene of de andere partij veroorzaakt is. Hoewel de primaire verdelings- 
maatstaf de causaliteit is, kunnen bij de secundaire verdelingsmaatstaf andere omstandigheden (waaronder schuld) in aanmerking worden genomen. Met $\S 254$ van het Bürgerliche Gesetzbuch is door de Duitse wetgever afstand genomen van de leer van de schuldcompensatie. In 1891, kort voor invoering van dit artikel, had het Reichsgericht genoemde leer nog toegepast, waarbij enkel een uitzondering werd gemaakt voor gevallen waarin de eigen schuld onbetekenend was. Net als in § 1304 van het Oostenrijkse Allgemeine Bürgerliche Gesetzbuch, werd in $§ 254$ van het Duitse Bürgerliche Gesetzbuch de rechter discretionaire bevoegdheid geboden. Hoewel in $\S 254$ het criterium van de vorwiegende Verursachung centraal stond, bleef het Reichsgericht de doctrine van de zogenoemde hoofdschuld toepassen. Dit betekende dat de vraag of de schade overwegend door de ene of door de andere partij veroorzaakt was, reeds vanaf het begin van de twintigste eeuw werd geïnterpreteerd als de vraag welke partij de grootste schuld had (überwiegende Verschulden). In Duitsland is de verdelingsgedachte van $§ 254$ BGB ook overgenomen in $§ 9 \mathrm{StVG}$ : indien de eigen schuld van de gelaedeerde (niet zijnde een houder of een bestuurder van een motorvoertuig) heeft bijgedragen tot het ontstaan van de schade, is $\S 254$ BGB toepasselijk.

In Nederland voorziet art. 6:101 BW (1992) in een vermindering van de omvang van de vergoedingsplicht bij eigen schuld aan de zijde van de gelaedeerde door de schade over gelaedeerde en laedens te verdelen in evenredigheid met de mate waarin de aan elke partij toe te rekenen omstandigheden tot de schade hebben bijgedragen. In art. 6:101 zijn twee maatstaven voor verdeling te vinden: de primaire maatstaf is causaliteit gebaseerd op de veroorzakingswaarschijnlijkheid, en de secundaire maatstaf is de billijkheid, waarbij de uiteenlopende ernst van de gemaakte fouten en eventuele andere omstandigheden van het geval kunnen worden meegewogen. Bij verkeersongevallen tussen een gemotoriseerde verkeersdeelnemer en een ongemotoriseerde verkeersdeelnemer (voetganger of fietser) worden art. 185 WVW 1994 (art. 31 (oud) WVW 1935) en regels uit de rechtspraak over die specifieke situatie toegepast. Dit komt er in de praktijk op neer dat de billijkheidscorrectie van art. 6:101 BW wordt ingevuld door de zogenaamde 100\%- en 50\%-regels die zijn ontwikkeld in de rechtspraak van de Hoge Raad. In dit kader kan men beargumenteren dat de alles-of-niets-benadering opnieuw geïntroduceerd is - in ieder geval bij toepassing van de 100\%-regel ${ }^{3}$ - en de laedens enkel van het geheel van zijn

3 Dit geldt ook voor werkgevers: zoals reeds het geval was met art. 1638x lid 2 (oud) Burgerlijk Wetboek 1838, wordt volgens art. 7:658 lid 2 (nieuw) Burgerlijk Wetboek de allesof-niets-benadering nog steeds toegepast in het geval van eigen schuld bij arbeidsongevallen: het eigenschuldverweer slaagt enkel indien opzettelijke of moedwillige roekeloosheid van de werknemer substantieel heeft bijgedragen aan diens schade. 
vergoedingsplicht kan worden bevrijd wanneer sprake is van opzet of daaraan grenzende roekeloosheid van de gelaedeerde, in welk geval in het geheel geen vergoeding behoeft te worden betaald. Indien het ongemotoriseerde slachtoffer jonger dan 14 jaar is, dient de gehele schade te worden vergoed. Bij een leeftijd van 14 jaar of ouder, komt in beginsel tenminste $50 \%$ van de schade voor vergoeding in aanmerking.

\section{AFSLUITING}

Het is dienstig enkele systematische afsluitende opmerkingen te maken. Een eerste opmerking betreft de vraag welke oplossingen in de rechtsgeschiedenis zijn aangedragen voor het eigenschuldprobleem. Alvorens een eerste onderscheid ter beantwoording van deze vraag te maken, kan worden gesteld dat het gedrag van de gelaedeerde regelmatig in aanmerking werd genomen bij beantwoording van de vraag of de laedens al dan niet met schuld had gehandeld en of de laedens de handeling al dan niet kon worden toegerekend. Ook worden gevallen gevonden waar de door de gelaedeerde geleden schade enkel was veroorzaakt door hemzelf en waarin derhalve geen schuld kon worden toegerekend aan een ander. In beide situaties is, in strikte zin, geen sprake van 'eigen schuld' in de zin van medeschuld.

Voor de situaties waarin het handelen van de gelaedeerde slechts had bijgedragen aan het ontstaan van de schade, worden in de rechtsgeschiedenis twee benaderingen gevonden: alles-of-niets (I) of een verdeling van de schade (II). De alles-of-niets-benadering (I) kende verschillende varianten. De vordering van de gelaedeerde werd afgewezen: (a) wanneer de gelaedeerde enige schuld had, ${ }^{4}$ (b) wanneer de schuld van de gelaedeerde gelijk of groter was dan die van de laedens, ${ }^{5}$ en (c) wanneer de gelaedeerde met grove schuld of opzet had gehandeld. ${ }^{6}$ Gedurende de gehele rechtsgeschiedenis vloeide het afwijzen van een vordering voort uit uiteenlopende oorzaken of werd zij dogmatisch onderbouwd op uiteenlopende wijzen: soms was het een gevolg van

4 Cf. de middeleeuwse legisten, de meeste decretalisten, sommige juristen uit de vroegmoderne tijd, sommige natuurrechtsgeleerden, en verschillende 19de-eeuwse Pandektisten. Zie ook de 19deeeuwse Duitse rechtspraak en de Franse rechtspraak aan het begin van de 19de eeuw.

5 Het criterium van de culpa maior wordt niet alleen in werken van verschillende juristen uit de vroegmoderne periode gevonden, maar ook in het middeleeuwse commentaar Animal est substantia (en mogelijkerwijs tevens in de werken van enkele decretalisten) en in de werken van sommige humanisten en diverse natuurrechtsgeleerden. Het is ook terug te vinden in de 19de-eeuwse Nederlandse rechtspraak en rechtsgeleerde literatuur, in de 19de-eeuwse Duitse praktijkliteratuur en in de latere 19de-eeuwse Duitse rechtspraak.

6 Deze variant kan worden gevonden in het moderne Franse en Nederlandse recht ten aanzien van letselschade bij verkeersongevallen. 
het procesrecht of van het poenale karakter van de civiele aansprakelijkheid, soms ook op een strikte toepassing van regels van Romeinse recht, soms op causaliteitstheorieën (onderbreking causaal verband), soms op de leer der schuldcompensatie (culpae compensatio) en in andere gevallen op sociaalpolitieke gronden (bijvoorbeeld het aan het gemotoriseerd verkeer verbonden gevaar: Betriebsgefahr). Ook werden de (causale) bijdragen aan het ontstaan van de schade van laedens en gelaedeerde met elkaar vergeleken. Wanneer men tot de conclusie kwan dat de handeling van de gelaedeerde was te beschouwen als de meest onmiddellijke oorzaak (causa proxima) van de schade, werd de schadevordering van de gelaedeerde afgewezen. ${ }^{7}$

De tweede benadering, waarbij een verdeling van de schade mogelijk werd geacht (II), valt uiteen in twee subgroepen: (a) een verdeling tussen partijen in die zin dat enkele schadeposten geheel door de gelaedeerde moesten worden gedragen, ${ }^{8}$ of (b) een verdeling van de totale schade tussen laedens en gelaedeerde. ${ }^{9}$ Hoewel de mogelijkheid tot verdeling werd voorgesteld en verdedigd door Wolff, werd zijn voorstel niet meteen in het juridische domein overgenomen. $^{10}$

De verdeling van de gehele schade (b) kan plaatsvinden op grond van een of meer van de volgende criteria: de zwaarte van ieders schuld, ${ }^{11}$ de causale bijdrage van elke partij aan de schade, ${ }^{12}$ en de billijkheid. ${ }^{13}$ De nadruk werd op verschillende plaatsen en op verschillende momenten in de tijd steeds anders gelegd: soms werd (sommige van) genoemde criteria een gelijke waarde toegekend, maar soms ook werd een van genoemde criteria gebruikt als correctief op een van de andere criteria. De verdeling kon leiden tot

7 Deze variant kan worden gevonden in het canonieke recht.

8 Zie het Justiniaanse recht wat betreft enkele gevallen buiten het gebied van de onrechtmatig toegebrachte schade, en de vroegmoderne periode wat betreft gevallen van ruzies waar in het bijzonder immateriële schade soms als niet-compenseerbaar werd beschouwd vanwege het feit dat de gelaedeerde met de ruzie was begonnen.

9 Ik heb de toepassing van een dergelijke verdeling reeds in de middeleeuwse periode aangetroffen, en wel buiten het ius commune (ze leidde tot een verdeling van 50/50 of van 1/3$2 / 3)$; in het ius commune bleef de alles-of-niets-benadering gehandhaafd tot en met het einde van de vroegmoderne periode en tot op zekere hoogte zelfs tot in de 19de eeuw.

10 De eerste sporen van een overweging om de schade te verdelen kunnen al worden gevonden bij de humanisten, zoals hierboven beschreven.

11 Zoals werd voorgesteld door Christian Wolff (hoewel het algemeen geaccepteerd is dat dit vereiste in zijn theorie ook causaliteit omvatte); het is de oplossing die is gecodificeerd in $\$ 1304$ ABGB, geaccepteerd in de Franse jurisprudentie en doctrine in de 19de eeuw, toegepast door het Duitse Reichsgericht aan het einde van de 19de eeuw (1883; zelfs na de codificatie van de nieuwe beslissende maatstaf in $§ 254$ BGB bleef dit de benadering van het Reichsgericht), en geaccepteerd door de Nederlandse Hoge Raad in 1916.

12 Gecodificeerd in Duitsland in $\$ 254$ BGB en als eerste criterium opgenomen in het Nederlandse art. 6:101 BW (1992).

13 Zie het tweede (correctieve) criterium dat is gecodificeerd in het Nederlandse Art. 6:101 BW. 
bepaalde percentages of quota. Normaal gesproken waren percentages tussen 0 en 100 procent mogelijk, hoewel kleine percentages aan een van beide zijden gewoonlijk niet werden toegestaan. Een 50/50-verdeling wordt ook gevonden, ${ }^{14}$ soms als resultante van een verdeling in percentages of quota, soms als alternatieve oplossing (subsidiair), soms als standaardoplossing.

Hoewel tegenwoordig in eigen-schuld-zaken in West-Europa gewoonlijk een verdeling van de schade wordt toegepast, heeft de verdelingsgedachte zoals in deze studie wordt aangetoond pas een korte geschiedenis. Bovendien is deze benadering, nadat zij voor het eerst werd voorgesteld door Wolff, niet meteen met open armen ontvangen in West-Europa, maar heeft zij zich pas geconsolideerd na een lange en lastige strijd. De Romeinsrechtelijke oplossing van alles-of-niets vormde inderdaad een gemeenschappelijke basis voor verschillende WestEuropese landen en het was niet gemakkelijk om de alles-of-niets-benadering, die vele eeuwen heeft overleefd, zomaar opzij te zetten.

Aan de hand van deze studie kan geen normatief antwoord worden gegeven op de vraag welke benadering het beste zou zijn. Rechtsgeleerden en/ of comparatisten zullen deze vraag ook vanuit andere perspectieven moeten bezien, zoals het filosofische, economische en sociale perspectief. Gemeenschappelijke elementen voor de eigenschuldproblematiek zijn overgenomen uit het Romeinse recht. Schuld en causaal verband werden meer en meer beschouwd als communicerende vaten. De nadruk lag soms op de schuld en soms op het causale verband tussen fout en schade. In dit opzicht zijn in de diverse codificaties die in de Europese landen heden ten dage gelden, verschillende keuzes gemaakt. Hoewel de verdeling van de schade tussen de partijen in overeenstemming lijkt te zijn met de billijkheid, is geenszins duidelijk wat precies de maatstaven voor een verdeling zouden moeten zijn. Waar duidelijke maatstaven wel zijn vastgesteld is niet duidelijk tot welke exacte verdeling de afweging zou moeten leiden. Het onderwerp van deze studie is dan ook van blijvend belang. De historische ontwikkeling van de eigenschuldproblematiek heeft bovendien aan belang gewonnen omdat sinds kort de alles-of-nietsgedachte bij eigen schuld van de gelaedeerde weer acceptatie heeft herwonnen (bijvoorbeeld bij verkeersongevallen).

14 Deze verdeling is die van het judicium rusticorum. Ten aanzien van aanvaringszaken verdedigde Van der Keessel voor het Rooms-Hollandse recht de oplossing dat in het geval de schuld van één van de in botsing komende partijen (kwantitatief) groter was dan die van de andere partij, de botsende partij de helft van de schade van de andere partij moest dragen. 


\section{CURRICULUM VITAE}

Emanuel van Dongen (Tilburg, 31 December 1982) received his secondary education in Goirle. He studied Dutch law at Tilburg University, where he received his (first) Master's degree in Law in 2005 (cum laude). His specialisation mainly concerned Roman law, with additional courses in the History of Canon law at the Catholic University (now: Radboud) Nijmegen. Thereafter, he completed a Research Master in Law at Tilburg University and graduated in 2007. During his studies he first worked as a student-assistant in the Department of Criminal Law at Tilburg University and later, from 2006 onwards, he worked as a lecturer in the Department Metajuridica at Maastricht University. During the course of 2007 he became employed as a junior researcher in the Department Metajuridica (now: Department of Foundations and Methods of Law) at Maastricht University. During the period he spent working on his $\mathrm{PhD}$ he regularly attended conferences in the areas of law and legal history and gave lectures in the Netherlands and abroad, wrote an article and contributed to several publications, frequently visited various libraries in the Netherlands and abroad, worked as a Stipendiat at the Max Planck Institute for European Legal History (Frankfurt am Main), co-organised the XVII Annual Forum of Young Legal Historians, taught several legal history courses and accomplished teaching-related tasks. While researching and writing his $\mathrm{PhD}$ dissertation, he was a member of the Ius Commune Research School and, in the period close to the end of his research, he started working as a clerk in the civil law section of the Court of Appeal in 's-Hertogenbosch, the Netherlands. 